UNIVERSIDADE DE SÃO PAULO

FACULDADE DE FILOSOFIA, LETRAS E CIÊNCIAS HUMANAS

DEPARTAMENTO DE GEOGRAFIA

PROGRAMA DE PÓS-GRADUAÇÃO EM GEOGRAFIA HUMANA

\title{
PARI-CACHOEIRA E TRINIDAD: CONVIVÊNCIA E CONSTRUÇÃO DA AUTODETERMINAÇÃO INDÍGENA NA FRONTEIRA BRASIL-COLÔMBIA
}

Dissertação apresentada ao Programa de PósGraduação em Geografia Humana, do Departamento de Geografia da Faculdade de Filosofia, Letras e Ciências Humanas da Universidade de São Paulo para obtenção do Título de Mestre em Geografia.

Área de concentração: Geografia Humana. Orientador: Prof. Dr. Ariovaldo Umbelino de Oliveira.

SÃO PAULO

2008 


\section{FOLHA DE APROVAÇÃO}

\section{Israel Fontes Dutra}

Pari-Cachoeira e Trinidade: convivência e construção da autodeterminação indígena na fronteira Brasil-Colômbia.

Dissertação apresentada à Faculdade de Filosofia, Letras e Ciências Humanas da Universidade de São Paulo para obtenção do título de Mestre em Geografia.

Área de concentração: Geografia Humana

Aprovado em:

Banca Examinadora

Prof. Dr.

Instituição:

Assinatura:

Prof. Dr.

Instituição:

Assinatura:

Prof. Dr.

Instituição:

Assinatura:

Prof. Dr.

Instituição:

Assinatura:

Prof. Dr.

Instituição:

Assinatura: 


\section{DEDICATÓRIA}

Ao Paó, Camilo de Souza Dutra, meu filho tuyukinha, com amor, admiração e gratidão por seu nascimento e crescimento ao longo do período de elaboração deste trabalho.

Ao meu pai, Avelino Dutra, e à minha mãezinha, Maria Olga Alves Fontes.

Aos povos indígenas do alto rio Negro, que lutam pela autodeterminação de nossas comunidades. 


\section{AGRADECIMENTOS}

Ao Instituto Felowship, IFP, pela bolsa de mestrado que proporcionou a realização desta dissertação.

Ao meu orientador Prof. Dr. Ariovaldo Umbelino de Oliveira, pelo acompanhamento, orientação, paciência, compreensão e amizade, que sempre me tratou com muito respeito e consideração por sua erudição, e que valorizou o meu ser indígena e, assim, contribuiu mais uma vez com a luta indígena no Brasil.

Aos professores do Programa de Pós-Graduação em Geografia Humana e Antropologia Social, respectivamente (Professora Dra. Maria Mônica Arroyo, Prof. Dr. Wagner Costa Ribeiro e Profa. Dra. Dominique Tilkins Gallois), que me acolheram e ouviram com amizade e respeito as minhas argüições durante as aulas, e ajudaram na minha formação intelectual.

Agradeço de maneira muito especial aos meus pais Yuhkułó Avelino Dutra e Bussá Maria Olga Alves Fontes, que transmitiram os principais conhecimentos descritos nesta dissertação e, acima de tudo, por serem meus pais.

Ao meu tio Paó, Laureano Dutra, que também transmitiu um dos principais conhecimentos descritos nesta dissertação e acompanhou durante a minha viagem de pesquisa de campo, desde São Gabriel da Cachoeira, Brasil à Trinidad, Colômbia.

À família de meu irmão Henrique Barrera (esposa, filhos, filhas e ele), que acolheram em sua residência com muito carinho e familiaridade.

Aos Tuyuka de Trinidad (Colômbia) e Tukano de Pari-Cachoeira (Brasil) pela amizade e familiaridade.

A cada um dos sujeitos da pesquisa (de Pari-Cachoeira e Trinidad) que me acolheram em suas casas com carinho e consideração. 
Agradeço de maneira especial e cordial à minha esposa Maria Leonilda de Souza Dutra, que enquanto estive na pesquisa de campo, esteve em São Paulo, SP, passando por gravidez de risco do nosso filho, Camilo de Souza Dutra, agüentando as dores de contrações constantes e de repouso absoluto, quando sem a minha presença durante três meses (fevereiro, março e abril) teve que se virar sozinha com risco de até perder o nosso tuyuquinha.

Ao meu filho Paó Camilo de Souza Dutra, que nasceu durante a elaboração da dissertação. O nascimento dele foi o maior evento de nossa [minha esposa e eu; meus pais e minhas irmãs (ãos)] vida e fortaleceu mais ainda para concluir esta dissertação, porque acrediamos que no futuro próximo, ele continuará aprendendo e formalizando as tradições do nosso povo Tuyuka e dos povos indígenas do Uaupés.

Ao amigo Fernando Vicente, do ISA, que emprestou o GPS para que pudesse registrar dados, e cedeu as imagens.

Aos meus amigos Maurício Torres e Malú, que me ensinaram a usar o GPS e que deram dicas de como realizar uma pesquisa de campo.

Ao Programa de Pós-Graduação de Geografia Humana da USP, por ter aprovado a minha entrada no Mestrado e ter contribuído com o crescimento científico e intelectual dos povos indígenas no Brasil. 


\section{RESUMO}

DUTRA, Israel Fontes. Pari-Cachoeira e Trinidad: convivência e construção da autodeterminação indígena na fronteira Brasil-Colômbia. 2008. 317 f. Dissertação (Mestrado) - Faculdade de Filosofia, Letras e Ciências Humanas, Universidade de São Paulo, São Paulo, 2008.

Esta dissertação enfoca as contradições e conflitos da convivência dos Tukano de PariCachoeira (Brasil) e Tuyuka de Trinidad (Colômbia) e a construção da autodeterminação indígena na fronteira Brasil-Colômbia, pois, mesmo depois da demarcação da Terra Indígena Alto Rio Negro em 1998, ficaram entrecortados pela fronteira. Este fato ameaça as relações de diversos matizes entre esses dois grandes povoados, a saber, prejudicam as relações de parentesco e circulação. Pari-Cachoeira é uma comunidade habitada pelo povo Tukano, do subgrupo Pãtẽsi Põłã, localizada no alto rio Tiquié, Uaupés, Brasil. Trinidad é habitada pelo povo Tuyuka, alto Tiquié, na Gran Resguardo Indígena Del Vaupés, Departamento Del Vaupés, Colômbia. No cenário da política indígena do rio Negro, Pari-Cachoeira se destaca por ser o lugar onde se originou o Movimento Indígena do rio Negro, no início da década de 70, que culminou na fundação da Federação das Organizações Indígenas do rio Negro (FOIRN), em 1987. E, Trinidad se destaca por estar situada em uma zona de conflito entre Governo colombiano e as Forças Armada Revolucionária da Colômbia (FARC), que ameaça a circulação e a autonomia indígena em território colombiano. A dissertação está constituída por quatro capítulos. O primeiro capítulo apresenta o contexto histórico dos indígenas do alto rio Negro e o movimento indígena na atualidade. Conjugo informações bibliográficas acadêmicas e as fontes orais dos sujeitos sociais da pesquisa. No segundo capítulo apresentamos uma abordagem teórica dos conceitos selecionados para a pesquisa, baseados em autores da geografia e ciências afins que estudam os povos e comunidades indígenas, soberania e autodeterminação, fronteira e circulação e o paradoxo da política: poder e liberdade, que também constitui o ser indígena. No terceiro capítulo enfatizamos as relações de convivência entre indígenas e não-indígenas - e principalmente de Pari-Cachoeira e Trinidad -, no qual destacamos os aspectos positivos e negativos da presença de missionários, militares e ONGs. No quarto capitulo apresentamos a "fronteira viva", a importância e os desafios das relações de convivência entre indígenas de Pari-Cachoeira e Trinidad, que fortalecem a construção da autodeterminação indígena na faixa de fronteira, onde circulam constantemente para pescar, caçar, trabalhar nas roças, visitar seus parentes, participar de eventos culturais, políticos e esportivos. A análise de convivência e construção da autodeterminação desses povos na faixa de fronteira, tem o objetivo de chamar atenção da política externa brasileira e colombiana, para a necessidade de criar normas de convivência e mobilidade na fronteira entre os dois países - em acordo com as lideranças locais -, garantindo, então, a segurança desses povos para que se sintam livres e vivam de acordo com seus princípios e tradições sem perder a nacionalidade de ambos os países. A dissertação demonstra que a construção de autodeterminação indígena não significa a luta por um Estado independente, mas constitui a lógica de liberdade de gerir seus próprios interesses, de sustentabilidade das comunidades indígenas e de convivência familiar presente no relacionamento familiar entre os grupos; e que a presença indígena na Amazônia e na fronteira representa uma importância geopolítica para o Brasil e Colômbia.

Palavras-chave: povos indígenas, fronteira, autodeterminação indígena, poder e liberdade. 


\begin{abstract}
DUTRA, Israel Fontes. Pari-Cachoeira and Trinidad: coexistence and construction of the self-determination indigenous in the border Brasil-Colômbia. 2008. $318 \mathrm{f}$. Dissertation (Mestrado) - Faculdade de Filosofia, Letras e Ciências Humanas, Universidade de São Paulo, São Paulo, 2008.
\end{abstract}

This work focuses the contradictions and conflicts of the coexistence of Tukano de Pari Cachoeira (Brazil) and Tuyuka of Trinidad (Colombia) and construction of the selfdetermination indigenous in the border Brazil-Colombia, that even with the demarcation of the Indigenous Land Alto Rio Negro in 1998, they were interrupted by the border. This fact threatens the relationships of several shades among those two great towns, to know, the relationship relationships and circulation are harmed. Pari Cachoeira is an inhabited community for the people Tukano, of the subgroup Pãłẽsi Põłã, located in the Alto Rio Tiquié, Uaupés, Brazil. Trinidad is inhabited by the people Tuyuka, Alto Tiquié, in Gran Resguardo Indígena Del Vaupés, Department Del Vaupés, Colombia. In the scenery of the indigenous politics of the Rio Negro, Pari Cachoeira stands out for being the place where arose the Indigenous Movement of the Rio Negro, in the beginning of the decade of 70, that it culminated in the foundation of the Federation of the Indigenous Organizations of the Rio Negro (FOIRN), in 1987; and Trinidad stands out for being placed in a conflict area among Colombian Government and the Armed forces Revolutionary of Colombia (FARC), that threatens the circulation and the autonomy indigenous in Colombian territory. The work is constituted of four chapters. The first chapter presents the natives' of the Alto Rio Negro historical context and the indigenous movement today. I conjugate bibliographical information of the academy and orals of the subject of the research. In the second chapter we turned a theoretical approach of the concepts selected for the research, based on authors of the geography and sciences that study the people and indigenous communities, sovereignty and self-determination, border and circulation and the paradox of the politics: to can and freedom, that also constitutes being indigenous. In the third chapter we emphasized the coexistence relationships among natives and no-indigenous. and mainly of Pari Cachoeira and Trinidad., in which detached the positive and negative aspects of the missionaries' presence, military and ONGs. In the room I surrender presented the "alive border", the importance and the challenges of the coexistence relationships among natives of Pari Cachoeira and Trinidad, that strengthen the construction of the indigenous self-determination in the border strip, where they constantly circulate to fish, to hunt, to work at the countries, to visit their relatives, to participate in events cultural, political and sporting. With the coexistence analysis and construction of the self-determination of those people in the border strip, the objective is to call attention of the Brazilian and Colombian foreign policy, for the need to create coexistence norms and mobility in the border among the two countries - In agreement with the local leaderships - guaranteeing, then, the safety of those people so that if they feel free and live in agreement with their beginnings and traditions without losing the nationality of both countries. The study demonstrates that the construction of indigenous self-determination doesn't mean the fight for an independent State, but it constitutes the logic of freedom of managing their own interests, of the indigenous communities' sustainability and of present family coexistence in the family relationship among the groups; and that the indigenous presence in the Amazonian and border represents an importance geopolitics for Brazil and Colombia.

Keywords: indigenous people, border, sel-determination indigenous, to can and freedom. 


\section{LISTA DE ANEXOS}

ANEXO 1 - Vamos conhecer retrospecto e descobrir novos caminhos.

ANEXO 2 - Relatório da I Assembléia Geral dos Líderes Indígenas do alto rio Negro.

ANEXO 3 - FOIRN e associações filiadas.

ANEXO 4 - Letras de Músicas usadas por indígenas nas eleições municipais de 2004 em São Gabriel da Cachoeira, AM.

ANEXO 5 - Abril a outubro de 1980, em São Francisco, rio Tiquié - alto rio Negro - Am.

ANEXO 6 - Militarização da Amazônia: Calha Norte: Um pesadelo para os povos indígenas do rio Negro. Fonte: Jornal da Manhã, 13 de julho de 1989.

ANEXO 7 - Tukanos ingressam na justiça com uma ação contra o CMA. Fonte: Jornal do Brasil, 23 de maio de 1991.

ANEXO 8 - CMA nada sabe sobre pedido de indenização. Fonte: Jornal $A$ Crítica, 25 de maio de 1991.

ANEXO 9 - Calha Norte já transfere os indígenas.

ANEXO 10 - Carta Aberta: alto rio Negro e dominação militar. Informativo Calha Norte Nov/89.

ANEXO 11 - Militares prendem e torturam índio Baniwa.

ANEXO 12 - Amazônia: Sipam será base para monitoramento internacional da Amazônia. $06 / 06 / 2006$.

ANEXO 13 - Zona perigosa de fronteira está desguarnecida. Fonte: O Globo, 06 de dezembro de 1998.

ANEXO 14 - EUA redesenham sua estratégia militar. Fonte: Folha de São Paulo, 22 de junho de 2003.

ANEXO 15 - Globalização, militarismo norte-americano e Amazônia. Brasília 01 de setembro de 2004.

ANEXO 16 - A Amazônia ameaçada.

ANEXO 17 - América sitiada: bases militares dos EUA na AL.

ANEXO 18 - "Cinturão militar" em volta do Brasil.

ANEXO 19 - Militares planejam defesa da Amazônia. 05 de maio de 2002.

ANEXO 20 - Governo cria brigada em área ameaçada pelas Farc: mais 2.500 homens fiscalizarão fronteira com a Colômbia.

ANEXO 21 - Fronteira com a Colômbia terá reforço militar.

ANEXO 22 - Exército manda mais 3 mil homens à Amazônia em 2004.

ANEXO 23 - 'Economist': Brasil quer minar domínio dos EUA.

ANEXO 24- Operação Colbra. Manobra marca estréia dos Super tucanos na defesa aérea.

Brasil e Colômbia farão ação conjunta.

ANEXO 25 - Milicos na Amazônia: Brasil se reafirma por mais peso na América Latina, diz "El País".

ANEXO 26 - Índias movem 157 ações contra soldados.

ANEXO 27 - Militares do Exército são acusados de agredir índios.

ANEXO 28 - Indígenas del Vaupés fortalecen sus procesos organizativos.

ANEXO 29 - Comunidades indígenas y campesinas del Vaupés confinadas por combates.

ANEXO 30 - Do outro lado da fronteira: El Camino de las Entidades Territoriales Indígenas (ETI's) em la Amazonía Colombiana. 


\section{SUMÁRIO}

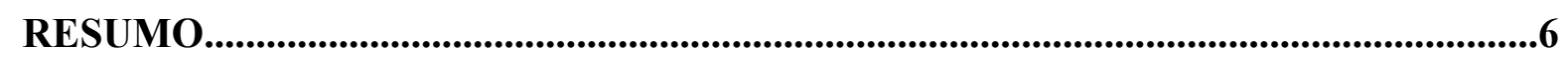

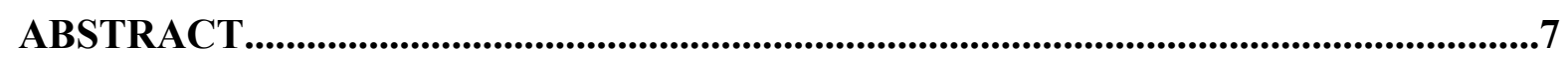

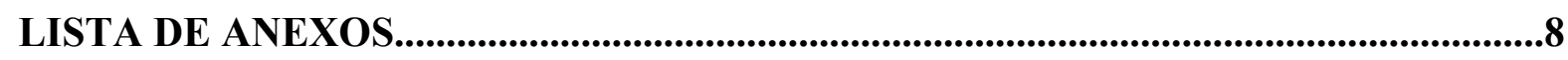

NOTA LINGÜÍSTICA TUYUKA E TUKANO...............................................................11

INTRODUÇÃ

1 INDÍGENAS DO UAUPÉS E MOVIMENTO INDÍGENA DO RIO NEGRO............29

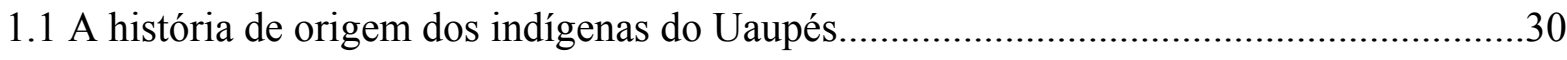

1.2 História do Movimento Indígena do Rio Negro e demarcação de terras.......................... 46

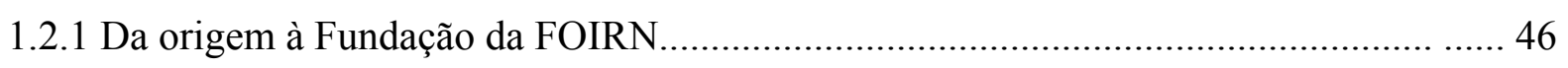

1.2.2 Da demarcação das Terras Indígenas e a construção do projeto sustentável................. 55

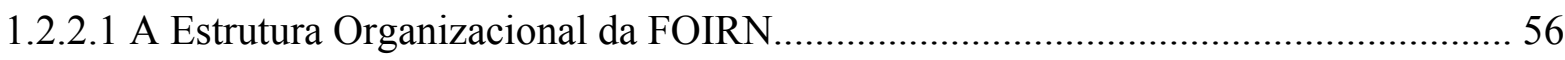

1.2.2.2 Os departamentos e a participação de mulheres indígenas........................................ 61

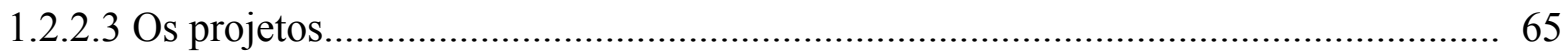

1.2.2.4 A participação indígena na política partidária........................................................ 74

2 AS CONCEPÇÕES NA VISÃO DE DIFERENTES AUTORES............................. 82

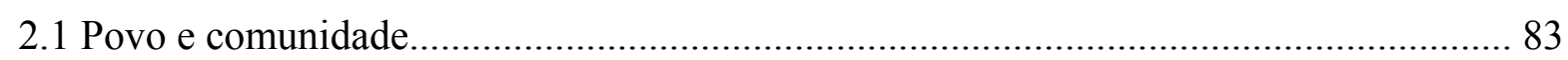

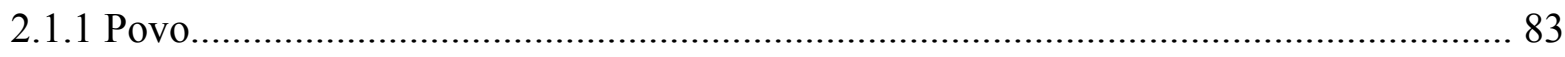

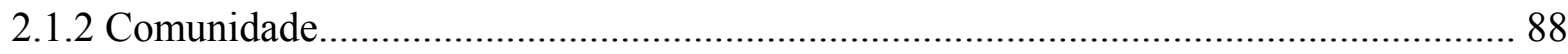

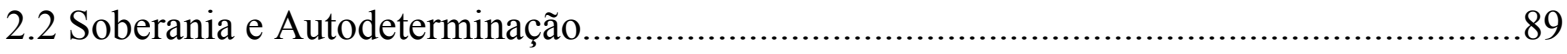

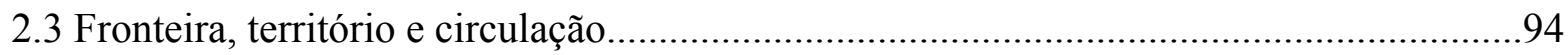

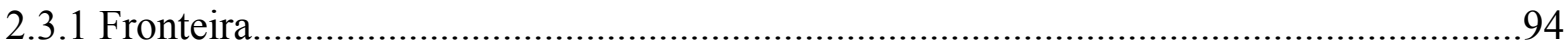

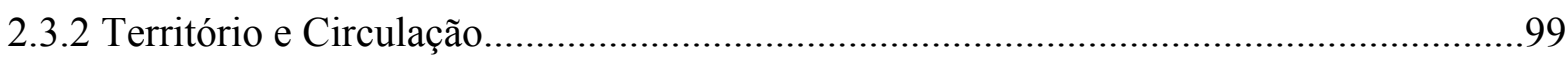

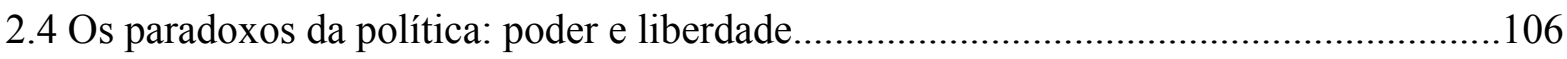

3 A CONVIVÊNCIA ENTRE INDÍGENAS E NÃO-INDÍGENAS NO UAUPÉS........116

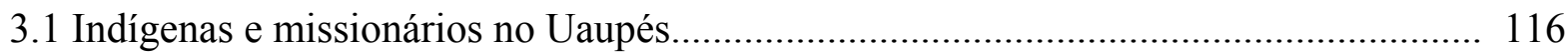

3.1.1 A presença missionária antes de 1998................................................................... 118

3.1.2 A presença missionária depois de 1998 .................................................................. 128

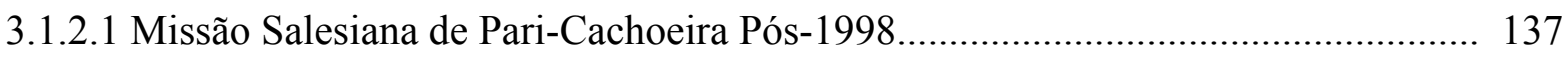

3.1.2.2 Missão Javeriana de Trinidad Pós-2000............................................................. 141

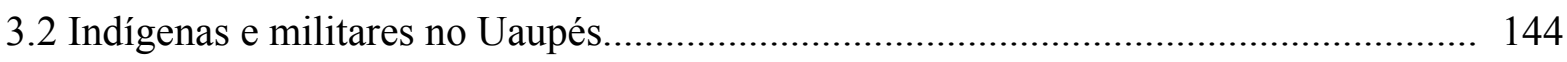

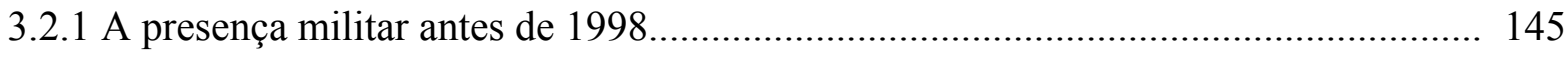

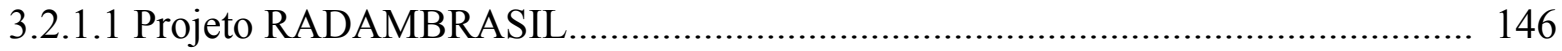


3.2.1.2 Perimetral Norte.

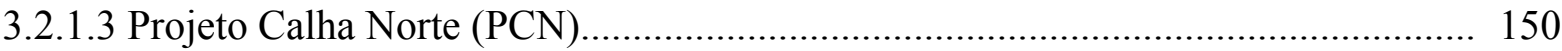

3.2.1.4 Projeto do Sistema de Vigilância da Amazônia (SIVAM)................................... 163

3.2.2 Indígenas e Militares depois de 1998................................................................ 167

3.2.3 Indígenas e militares: acontecimentos e notícias.............................................. 171

3.2.4 Normas de Conduta em Terras Indígenas na Faixa de Fronteira............................. 171

3.2.5 $6^{\circ}$ Pelotão Especial de Fronteira de Pari-Cachoeira.................................................... 177

3.2.6 Indígenas e Militares em Trinidad (Colômbia)........................................................... 182

3.3 A relação de convivência entre indígenas e ONGs.................................................... 184

4 A FRONTEIRA "VIVA": CONVIVÊNCIA ENTRE TUKANO E TUYUKA ........ 191

4.1 Pari-Cachoeira: a comunidade de domínio Tukano.................................................. 191

4.1.1 Quem são os Tukano de Pari-Cachoeira?................................................................ 204

4.1.2 A convivência entre os indígenas de Pari-Cachoeira............................................. 209

4.1.3 A perspectiva da convivência entre os indígenas de Pari-Cachoeira........................ 214

4.2 Trinidad: a comunidade de domínio Tuyuka............................................................ 219

4.2.1 Quem são os Tuyuka de Trinidad?..................................................................... 220

4.2.2 A fronteira: os marcos que dividem Pari-Cachoeira e Trinidad............................... 226

4.3 A importância e o desafio da convivência indígena na fronteira................................ 230

4.4 Jogos do Triângulo Tukano e sua importÂncia............................................................ 233

4.4.1 A história de origem dos Jogos do Triângulo Tukano.............................................. 238

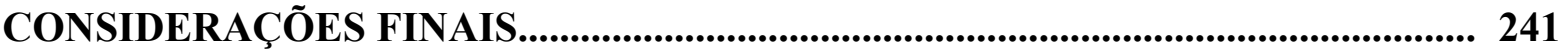

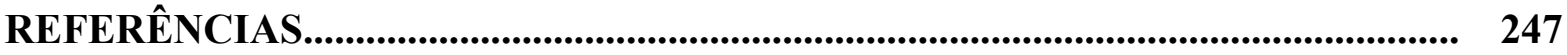

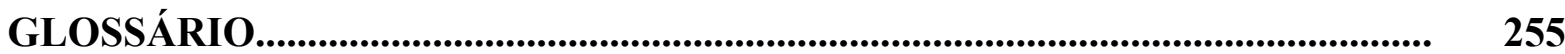

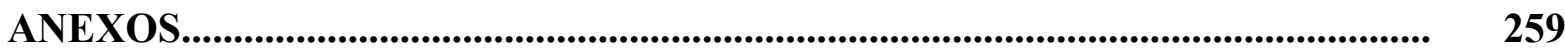




\section{NOTA LINGÜÍSTICA TUYUKA E TUKANO}

O sistema de transcrição da língua Tuyuka adotado nesta dissertação baseia-se parcialmente nas propostas gráficas da língua Tuyuka, utilizada pelos professores Dohkapuala da Escola Municipal Indígena Uhtãpinõponã, no alfabeto usado por Justino Sarmento REZENDE (2007), em sua dissertação de Mestrado e, no entanto, como a grafia atual não constitui o resultado do consenso oficial do grupo Tuyuka, busco acrescentar mais três letras $(\boldsymbol{t}),(\dot{\boldsymbol{g}})$ e $(\mathbf{x})$ que acredito serem importante para um leitor Tuyuka - que não sabe a escrita - e não-Tuyuka; além disso, a acentuação gráfica e a ortografia não segue as regras gramaticais adotadas pelos Tuyuka da Escola São Pedro. E o sistema de transcrição da língua Tukana, será baseado parcialmente nas propostas de Henri RAMIREZ (1997/2001) que, enfim, também adaptarei a escrita conservando a maioria do alfabeto usado nas escolas indígenas do Uaupés.

O alfabeto usado nesta pesquisa compreende 25 letras: $\mathbf{a}, \mathbf{b}, \mathbf{d}, \mathbf{e}, \mathbf{g}, \dot{\mathbf{g}}, \mathbf{h}, \mathbf{i}, \mathbf{j}, \mathbf{k}, \mathbf{l}, \mathbf{m}, \mathbf{n}$, $\tilde{\mathbf{n}}, \mathbf{o}, \breve{\mathbf{o}}, \mathbf{p}, \mathbf{r}, \mathbf{s}, \mathbf{t}, \mathbf{u}, \mathbf{u}, \mathbf{w}, \mathbf{y}, \mathbf{x}$.

O acento agudo (') será muito usado para diferenciar de uma pronúncia fechada e aberta, fraca ou forte constantemente pronunciada em tuyuka. Por exemplo: pahkó (mãe) e dohkapualayo (mulher tuyuka).

O acento til ( ) será usado em $\tilde{\mathbf{n}}(\mathrm{em}$ vez de $n h)$ e nas vogais $\tilde{\mathbf{a}}, \tilde{\mathbf{e}}, \tilde{\mathbf{i}}, \tilde{\mathbf{o}}, \tilde{\mathbf{u}}$ para indicar a nasalidade ou antes de um consoante substituindo am, an, em, em, im, in, om, on, um e um. Por exemplo: Uhtãpinõponã, Wãhtĩ (diabo, demônio, curupira, etc).

A partir de agora detalharei a pronúncia de cada letra na língua Tuyuka, adaptada de Justino Sarmento Rezende:

a, e, i, o, u pronuncia-se como em português;

á, é, í, ó, ú indica o tom alto;

$\tilde{\mathbf{a}}, \tilde{\mathbf{e}}, \tilde{\mathbf{i}}, \tilde{\mathbf{o}}, \tilde{\mathbf{u}}$ indica que a pronúncia é nasal.

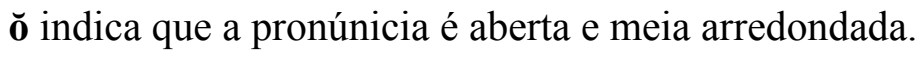

* é uma vogal que pode ser alta ou baixa, indica uma pronúncia fechada, não arredondada. Por exemplo: pahku' $\mathbf{k} \mathbf{k}$ (vovô);

ú é uma vogal que é média, portanto, indica uma pronúncia meia aberta. Por exemplo: aŭhĩrã (....).

b e d pronuncia-se como em português, que varia conforme o contexto nasal ou oral; g pronuncia-se como em português;

ge não se pronuncia como em português. Ela é pronunciada como a palavra distingue;

g indica uma pronúncia nasalada, baixa ou até quase omitida. Por exemplo: manĩg்tti (ele não está presente);

h a pronúncia é diferente de português. Esta letra é usada, nesta dissertação em três eventos: 1) antes de um consoante que indica pronúncia afim da letra $r$ [pahku (pai, vovô)]; 2) antes de um vogal [hoaya (escreva)] tem um som de dois $r r$; 3) é ortografada entre as vogais (aŭhĩrã), onde também é pronunciado como se fosse dois $r r$. Lembrando que esta ortografia não segue a escrita existente em várias bibliografias do povo Tuyuka. A idéia é buscar aproximar o máximo da pronúncia original, através de algumas letras que estão sendo acrescentadas neste trabalho para facilitar a pronuncia dos que não falam o idioma. Quem fala a língua sabe onde tem que ser pronunciada a letra $h$ como se fosse dois $r r$ ou apenas com um $r$, porém, para quem não sabe torna difícil, por isso, utilizo a letra $h$; 
j a pronuncia é diferente de português conforme o contexto oral, quase se omite a letra. Entretanto, todos os autores que até agora tiveram suas publicações acadêmicas omitiram esta letra por acharem que não existe nas línguas das etnias do Uaupés, mas ela existe. Por exemplo: djá (alumiar);

$\mathbf{k}$ pronuncia-se como em português. Assim, aqui não será usada a letra $c$.

l é a nova letra que usarei no meu trabalho em substituição da letra $l$, que normalmente é ortografa por autores que estudam as grupos indígenas do Uaupés. A razão é que, tanto na língua Tuyuka e Tukana, há palavras que não se pronuncia $l$ como em português. A $\mathbf{l}$ é uma vogal balanceada que para pronunciar tem que encostar a língua no palato duro. Por exemplo: ohkoló (chuva);

$\mathbf{m}$ e $\mathbf{n}$ pronuncia-se como em português;

$\tilde{\mathbf{n}}$ é escrita e pronunciada como em espanhol, no lugar de $n h$;

p e $\mathbf{r}$ pronuncia-se como em português. Todos os autores que escrevem sobre os indígenas do alto rio Negro usam a letra $\mathbf{r}$ no lugar de $\mathbf{l}$ criando muitas vezes confusão na hora da pronúncia e, com isso, acabam modificando a pronúncia original da língua. E os indígenas sem saber como modificar, também terminam usando a ortografia ditada por alguns lingüistas externos. Há palavra que deve ser escrita e pronunciada de forma diferenciada. Por exemplo: mãtĩrẽ (para nós); e não mãrĩrẽ ou mãnĩrẽ etc;

s pronuncia-se sempre como dois $s$;

t pronuncia-se como em português;

y pronuncia-se como em inglês payé;

w pronuncia-se como em inglês word.

$\mathbf{x}$, em Tuyuka existe, sim, pronuncia-se como em português, no lugar de ch ou $x$. por exemplo: xiu, significa enxotar e significa $e i$.

Observações:

de, di, te e ti pronuncia-se como em italiano;

ge e gi pronuncia-se como em gueto ou guilda;

r somente esta letra não aparece antes das palavras tuyukas. 


\section{INTRODUÇÃO}

Desde o século XVI, com a chegada dos portugueses e espanhóis na região do alto rio Negro, os povos indígenas resistem e lutam pela sua sobrevivência, e, atualmente as lideranças reivindicam a autodeterminação de seus povos. Atualmente, das centenas de grupos que habitavam desde os tempos imemoriais, restam aproximadamente 23 povos em toda a região. Somente no Uaupés, tanto no território colombiano e como no território brasileiro, vivem aproximadamente 20 a 40 grupos, respectivamente.

O povo Tuyuka (em Nhengatu ou Língua Geral), denominado tradicionalmente de Uhtãpiñ̃ponã e Dohkapuała (em Tuyuka) ou Dikãhãtã (em Tukano), e o povo Tukano (Dahsea), chamado tradicionalmente de Yepamahsã (descendentes de Deus Yepá) vivem na faixa de fronteira entre Brasil e Colômbia. Segundo a sua história de origem, seus ancestrais foram criados por um ser espiritual denominado de Pamutĩ Pinõ, na Casa da Emergência de Ohkó Diawi, no baixo Uaupés, Brasil; depois da criação os Tuyuka emergiram na Casa da Emergência da cachoeira de Jurupari, no alto Uaupés, Departamento del Vaupés, Colômbia; e os Tukano emergiram na Casa da Emergência da cachoeira de Ipanoré, no baixo Uaupés, Brasil. Os grupos são constituídos hierarquicamente; exogâmicos e patrilineares; têm suas próprias línguas; ainda contam com os seus principais yaíwa (pajés), ba'asera (pajés) e bayaroa (mestres de cantos e danças tradicionais); conservam as Bahsawihseri (casas tradicionais, chamadas de "malocas" 1); e, os membros vivem em comunidades com aproximadamente 50 famílias individuais. Em algumas comunidades há escolas até o ensino médio, como por exemplo: Escola Tuyuka da comunidade de São Pedro, alto Tiquié, Brasil; Colégio Indígena Dom Pedro Massa, Pari-Cachoeira, Brasil; Colégio Indígena “São Miguel”, Iauaretê, Brasil; Colégio Indígena "Sagrado Coração de Jesus", Taracuá, Brasil. A maioria dos membros desses povos é poliglota, pois, além do português e castelhano, falam mais duas línguas indígenas.

Os Tuyuka e Tukano fazem parte da complexa "teia" (Clifford GEERTZ, 1978) de parentesco que constitui os grupos do Uaupés e do alto rio $\mathrm{Negro}^{2}$. Os conhecimentos

\footnotetext{
${ }^{1}$ Neste trabalho usarei a palavra Bahsawi ou Bahsariwi (em Tuyuka) para referir à casa tradicional dos povos indígenas do Uaupés e não "maloca", porque "maloca" é palavra composta de mal + oca, portanto, tem uma conotação preconceituosa, por não aceitar a existência desse termo que não usarei.

2 Entre vários livros produzidos pelo ISA (Instituto Socioambiental), destacamos alguns que constituem informações sobre os povos indígenas do rio Negro: Povos Indígenas no Brasil (1990, 1995, 2000, 2005); mapa-livro: Povos Indígenas do Rio Negro: uma introdução à diversidade socioambiental do noroeste da Amazônica brasileira. $3^{\text {a }}$ edição atualizada, 2006.
} 
tradicionais vivenciados pelos dois grupos são compartilhados e circulam entre outros povos da região.

A história de convivência entre indígenas (pohterimahkãtã), missionários (payiá), brasileiros e colombianos na região do alto rio Negro (FARIA: 1997) já revelou várias tentativas da destruição do modo de ser indígena rionegrino. As ações mais violentas que os grupos enfrentaram foram dos antigos padres e freiras da Congregação Salesiana, no período de internatos que funcionou entre 1923 e 1987, em Taracuá (1923-1986), Iauaretê (19271986) e Pari-Cachoeira (1940-1987). Neste período, os meninos e as meninas indígenas foram obrigados a ser internados para estudar sob o sistema preventivo de Dom Bosco, fundamentado no tripé que os salesianos chamam de religião, razão e amorevolezza. Inclusive, as crianças Tukano e Tuyuka colombiano também passaram pelos internatos salesianos.

Atualmente, os maiores desafios que o movimento indígena do rio Negro enfrenta é a lógica da política de soberania e segurança da Amazônia, de desenvolvimento e fronteira adotada pelo Estado brasileiro. E, no território colombiano, os indígenas vivem entre o fogo cruzado dos militares do Governo colombiano e das Forças Revolucionárias da Colômbia (Farc).

É objetivo também desta dissertação mostrar, através de análise da convivência atual dos Tukano de Pari-Cachoeira e os Tuyuka de Trinidad na área de fronteira entre o Brasil e a Colômbia, o processo de construção da autodeterminação indígena. Para isso utilizaremos como base os depoimentos dos sujeitos sociais entrevistados, que exprimem a atuação de agentes externos que tentam apoiar e impedir, sempre em nome de desenvolvimento regional e da soberania nacional. $\mathrm{O}$ fortalecimento político das relações de convivência atual entre os indígenas do alto rio Negro, significa que, na verdade, a luta pela autodeterminação indígena na região de fronteira continua, isto é, os missionários, os militares e alguns outros agentes externos não conseguiram impedir a luta indígena pela demarcação de suas terras, a qual se tornou o passo fundamental para iniciar a construção dessa autodeterminação.

Hoje, as portas e janelas estão "abertas" para que os Tuyuka, Tukano e os demais grupos do Uaupés construam o projeto de autodeterminação que existe entre eles. Ao longo da história de contato dos Tukano e Tuyuka, percebemos que eles sofreram diversas transformações culturais, sociais, políticos e religiosos, porque se apropriaram de novos valores e, portanto, vivem na modernidade. No entanto, algumas tradições são preservadas de forma dinâmica, com tendências a se tornarem mais flexíveis e mais acessíveis às pessoas interessadas da sociedade envolvente, em intercambiar com o mundo indígena. A 
flexibilidade, acessibilidade e intercâmbio significam que, segundo os sujeitos entrevistados, a autodeterminação indígena é um direito milenar de cada povo, porém, hoje, como diversas famílias residem em países diferentes, devem ser respeitadas e valorizadas a nacionalidade de seus membros, mesmo que sejam do mesmo grupo indígena.

Foi a partir da minha vivência direta por 15 anos entre os Tukano de Pari-Cachoeira, da vivência natural entre os Tuyuka de Trinidad, que são membros do povo Tuyuka, do qual sou membro, de observações e participações em eventos e discussões realizados pela Federação das Organizações Indígenas do Rio Negro, a respeito de autodeterminação, da demarcação de terras indígenas do alto rio Negro, do desenvolvimento sustentável de comunidades indígenas, e da verificação de que a conquista desses direitos fortaleceria as relações de convivência e a construção da autodeterminação indígena na faixa de fronteira sem violar os princípios da soberania dos Estados envolvidos, que decidi analisar o problema proposto nesta dissertação sob aportes teóricos da Geografia Humana e Geografia Política

Pari-Cachoeira é a comunidade onde moram alguns membros do povo Tukano, que são meus tios, cunhados, primos, amigos etc. Desde que comecei estudar o ensino fundamental na Missão Salesiana de Pari-Cachoeira, participar indiretamente das Assembléias realizadas pelas lideranças da comunidade para discutir diversas questões referentes à autodeterminação, quando ainda era adolescente, já tinha interesse em um dia ajudar na luta política desse movimento. Participar diretamente da luta significava estar preparado para enfrentar os desafios do mundo moderno. Por esse motivo, para colaborar com mais qualidade, decidi estudar, pois percebi que o estudo representava o único caminho a partir do qual podia qualificar e adquirir novos instrumentos de luta. Assim, no final de 1988, fui selecionado pelos padres salesianos da Missão de Pari-Cachoeira para estudar no seminário salesiano em Manaus. Em 1989, entrei no Centro Vocacional Salesiano (CVS), em Manaus, onde fui estudar para ser padre, porém ao longo dos anos refletia comigo mesmo de como poderia ajudar melhor o movimento indígena do rio Negro. Na minha mente tinha duas perguntas que incomodavam de forma positiva: 1) Ser padre salesiano para lutar ao lado dos indígenas? 2) Sair do seminário para estudar e adquirir outros tipos de conhecimentos?

Apesar da vida religiosa constituir valores humanos e transmitir aos seus formandos a espiritualidade salesiana, decidi sair da congregação, porque percebi que acima de tudo sou um Tuyuka e que apenas os valores religiosos da instituição não corroborariam a minha participação dentro do movimento indígena do rio Negro. Precisava algo a mais, senti a necessidade de estudar e adquirir novos tipos de conhecimentos que possibilitassem acesso a instrumentos acadêmicos que pudessem sustentar a participação mais efetiva dentro do 
movimento. Depois de concluir o ensino médio, ainda com a ajuda dos salesianos, cursei Filosofia (2000), e depois graduei-me na área de Matemática (2005) e, decidi cursar a pósgraduação em Geografia Humana na USP.

Vivi seis anos no seminário em Manaus na capital do Amazonas, onde conheci algumas lideranças Tukano, Desano e Tariano que trabalhavam na Coordenação das Organizações Indígenas da Amazônia Brasileira (COIAB). Conheci outros religiosos e diocesanos indígenas que também estudavam nos seminários de diversas congregações religiosas da cidade. Desse modo, comecei participar de eventos realizados pela COIAB e pelos religiosos indígenas que discutiam sobre a Teologia Índia.

No final de 1997, em Iauaretê, decidi sair da vida religiosa salesiana. Nessa comunidade indígena participei de eventos esportivos, das discussões de professores e ministrei aulas de Filosofia, na Escola Estadual "São Miguel”, que era dirigido pelas irmãs salesianas. Um ano depois fui para a cidade de São Gabriel Cachoeira, sede do município, onde continuei ministrando aulas no Colégio "São Gabriel", também dirigido pelas irmãs salesianas. O motivo que me levou a sair de Iauaretê, foi a possibilidade de continuar os estudos.

O interesse pela questão indígena aumentava, cada vez mais, primeiro pelo fato de ser Tuyuka, e, segundo porque comecei coordenar a Pastoral da Juventude da Diocese de São Gabriel da Cachoeira. Em terceiro lugar, porque senti na pele, o desafio de coordenar o Conselho de Professores Indígenas do Alto Rio Negro. Em quarto, porque tinha um projeto pessoal de desenvolver a valorização das línguas indígenas do alto rio Negro através de músicas. Em função deste projeto comecei participar do maior evento festivo do município de São Gabriel da Cachoeira: o FESTRIBAL. Nele participei como músico e compositor da Agremiação Cultural Rio Negro e da Agremiação Cultural Uaupés no Festribal. Durante essa vivência mais intensa, constatei que chegava a um certo ponto que sentia-me inseguro e incapaz de assumir compromissos que exigiam mais preparo acadêmico ou até experiência de militância, tais como: debates sobre Mineração em Terras Indígenas, o Estatuto do Índio, Desenvolvimento Sustentável etc. Por isso, saí da região para estudar em São Paulo.

Por ser Tuyuka, nascido em Mercês, igarapé Cabari, na região de Pari-Cachoeira, alto Tiquié, sou descendente de milhares de ancestrais indígenas enterrados nas terras amazônicas e, por essa razão, proponho estudar e, em seguida, através da minha qualificação acadêmica, procurarei ajudar o movimento indígena do rio Negro na luta pela autodeterminação dos povos da região, que têm como um dos principais objetivos melhorar a qualidade de vida das comunidades. 
A importância deste tema de pesquisa para os povos indígenas está na reflexão e análise da convivência indígena que vivem na faixa de fronteira entre Brasil e Colômbia e em outras fronteiras da Amazônia. Estes estudos são importantes não só para os indígenas, mas também para a Geografia, porque os povos indígenas das áreas de fronteiras continuaram suas existências históricas. Assim, é necessário que os próprios indígenas mostrem ao mundo, que eles não representam nenhuma ameaça para a soberania dos Estados. Pode ser que a apropriação de conceitos geopolíticos ocidentais como autodeterminação, território e outros não se enquadrem dentro das definições e aportes teóricos que sustentam a formação de um Estado nacional. Por isso, sempre quando necessário e oportuno precisamos mostrar à sociedade não-indígena que os índios que vivem no território brasileiro são brasileiros. Os índios que vivem no território colombiano são colombianos. Porém são parentes e familiares, porque têm a mesma origem histórica, portanto, constituem uma "rede" de famílias que compartilham os mesmos conhecimentos e valores culturais.

Durante a nossa pesquisa de campo, os indígenas do Uaupés (brasileiros e colombianos, lideranças e não-lideranças) com quem conversamos, começavam dizendo que eu tinha sumido da região, perguntavam por onde eu andava e sobre o que estudava. Depois que expliquei os motivos de minha ausência, ficaram felizes, porque sabiam que saí da região para estudar e que depois retornaria mais preparado para ajudá-los na luta por melhoria das condições de vida de suas famílias e na aproximação maior com seus parentes que vivem no território colombiano e território brasileiro. Reconheci criticamente mais uma vez, que estou entre os privilegiados que chegam a uma universidade. Enquanto isso, muitos jovens indígenas são impedidos de continuar seus estudos por condições financeiras de suas famílias e pela falta de apoio político daqueles que assessoram ou lideram o movimento indígena do rio Negro.

Desde a década de 70, com a fundação da Federação das Organizações Indígenas do Rio Negro (FOIRN) em 1987, o objetivo das populações indígenas do alto rio Negro foi lutar pela autodeterminação e, a partir daí, então, buscar proporcionar a melhoria das condições de vida das comunidades. Para que esses objetivos tornassem concretos, as lideranças indígenas iniciaram a luta pela demarcação de suas terras, a qual conquistaram em 1998, com a homologação de cinco Terras Indígenas do alto rio Negro, durante o Governo do Presidente Fernando Henrique Cardoso.

Para refletir as questões referentes à convivência dos indígenas na faixa de fronteira entre Brasil e Colômbia, nesse início do novo milênio - e principalmente após a demarcação de suas terras em 1998 -, torna-se necessário compreender como está o processo de 
construção da autodeterminação indígena na Amazônia em uma área de fronteira cercada de interesses nacionais e internacionais, onde impera os princípios da soberania nacional, como expressaram os militares.

Hoje, as relações de convivência das populações indígenas do alto rio Negro, inclusive dos Tukano de Pari-Cachoeira (Brasil) com seus parentes Tuyuka de Trinidad (Colômbia), no alto Tiquié, e com os agentes externos, requer uma nova reflexão que contribua na busca de novos caminhos que possibilite a construção da autodeterminação indígena, que compreendem: autonomia territorial, autonomia econômica, política, religiosa etc.

Este estudo é uma oportunidade que temos para colocarmos em evidência o pensamento desde os mais simples indígenas até o pensamento de algumas lideranças de PariCachoeira e Trinidad, como vivem e pensam na atualidade, em uma região cobiçada pelos interesses internacionais. As duas comunidades que estudamos estão localizadas uma no Brasil e outra na Colômbia. E nelas, há a presença de instituições religiosas, civis e militares, que convivem diariamente com os indígenas, por isso é o momento de mostrarmos a importância e os desafios da convivência entre indígenas e não-indígenas.

Para a Geografia, a pesquisa vem contribuir para a discussão do conceito de autodeterminação, que já foi refletido por Ivani Ferreira de FARIA (1997), de acordo com o pensamento apresentado pelos indígenas mais velhos e lideranças atuais das duas comunidades.

Segundo FARIA (1997), há vários acadêmicos que referem, em seus estudos, “a questão indígena”, como por exemplo:

o Prof. Dr. ARIOVALDO UMBELINO De OLIVEIRA, em suas obras: "Integrar para não Entregar", 1990; "Amazônia: monopólio, expropriação e conflitos", 1987; BERTA BECKER, em "A Fronteira Amazônica: questões sobre a gestão do território", 1990; MARIA LÚCIA PIRES MENEZES na sua tese de doutorado intitulada "Parque Indígena do Xingu: a construção de um território estatal", defendida em 1990; no Instituto de Geociências da UFRJ, e CARLA GONÇALVES ANTUNHA BARBOSA, na sua dissertação de mestrado intitulada "Trazidos por Tupã", defendida em 1994, no Departamento de Geografia da USP $[\ldots]$.

O tema desse estudo é importante para a Geografia, porque a cada ano que passa, os estudiosos da questão indígena reforçam "[...] uma reciprocidade quanto à importância do tema para a Geografia, assim como desta para o tema". Além disso, através deste estudo será evidenciado a importância geopolítica da presença indígena na área de fronteira, fundamentado em alguns princípios da Geografia. 
Assim, o objetivo geral da pesquisa é mostrar de maneira analítica os aspectos positivos e negativos da convivência entre indígenas e não-indígenas e da construção de autodeterminação indígena na fronteira que envolve o Brasil e a Colômbia. Do ponto de vista histórico dos povos indígenas do Uaupés, a relação entre os dois mundos (indígena e ocidental) sempre esteve marcado por uma relação desigual de poder que processa até os dias atuais. Mas os indígenas de Pari-Cachoeira e Trinidad, divididos por um limite fronteiriço, porém interligados pela lógica familiar, mantêm uma forte relação de parentesco, que fortalece os aspectos político e cultural diante das ações do Estado brasileiro e colombiano. Este fato demonstra que a política de destruição e de integração dos povos indígenas, em ambos os países, não aconteceu. Desse modo, o sonho de autonomia tem sua porta aberta. Por isso, hoje, os indígenas emergem através de suas organizações de base e participação política nas esferas municipal, estadual e federal para fortalecer a luta indígena. Além deste objetivo principal procuraremos também: identificar o fluxo como elemento constitutivo das populações indígenas em seu território e destacar suas manifestações e transformações significativas na dimensão social, política, cultural e religiosa; refletir sobre as concepções de autodeterminação indígena em uma área de fronteira, a partir da lógica das relações familiares e procurar evidenciar fatores que legitimam a sua existência milenar e sua circulação territorial; analisar a relação de convivência entre indígenas e atores externos (missionários, militares e ongs) em Pari-Cachoeira e Trinidad; analisar o caráter político e cultural da convivência entre os indígenas de Pari-Cachoeira e Trinidad, que circulam diariamente, ambos, no território brasileiro e colombiano.

Dessa forma, a análise proposta neste estudo focaliza duas comunidades indígenas, localizadas no alto rio Tiquié, região do Uaupés: Pari-Cahoeira (Brasil) e Trinidad (Colômbia) (ver mapa 01), após a demarcação da TI Alto Rio Negro 1998 a 2007.

A escolha destas comunidades foi estratégica por se tratar da faixa de fronteira, pois permitirá mostrar como uma autodeterminação indígena é fundamental para garantir a sobrevivência de suas gerações futuras e a segurança da Amazônia sem ameaçar a soberania nacional. Assim, procuraremos encontrar respostas para as seguintes questões:

1) O que representa a fronteira entre Brasil-Colômbia para os indígenas de PariCachoeira e Trinidad e quais são os problemas provocados?

2) $\mathrm{O}$ que significa a autodeterminação indígena na faixa de fronteira na concepção indígena?

3) Como se dá à convivência entre indígenas e não-indígenas? 
4) Qual a importância da convivência familiar entre os indígenas brasileiros e colombianos?

As bases teóricas e metodológicas para a realização da pesquisa estão fundadas na a intenção de resgatar quais são os elementos que os indígenas (pohterimahkãtã) de PariCachoeira e Trinidad fundamentam suas concepção de fronteira, autodeterminação e circulação na faixa de fronteira para sua relação de convivência na fronteira Brasil-Colômbia.

Para realizar a análise dessa convivência frente aos desafios da autodeterminação territorial parto das premissas propostas por alguns autores que fazem abordagens conceituais de: povo, autodeterminação e soberania (Marco Antônio BARBOSA, 2001); fronteira (Prof. Dr. André Roberto MARTINS, 1992 e Claude Raffestin, 1980); terra e terra indígena (Carlos Frederico Marés de SOUZA FILHO, 2005); território e circulação, (Friedrich RATZEL, 1914; Claude RAFFESTIN, 1980). Autores que estudam e analisam concepções dos povos indígenas também formam a base de análise desta investigação. Focamos a atenção nos trabalhos realizados com os indígenas do alto rio Negro - e principalmente - das comunidades de Pari-Cachoeira e Trinidad. Assim, foi importante a contribuição de Ivani Ferreira de Faria (1997/2007), que estudou território e territorialidade indígena em sua dissertação de mestrado: Território indígena: direito imemorial e o devir, e em sua tese de doutorado: Ecoturismo Indígena, Território, Sustentabilidade, Multicuturalismo: princípios para a autonomia, onde, mais uma vez, versou sobre algumas concepções sobre autonomia indígena do médio e alto rio Negro. Os livros Povos Indígenas no Brasil, do Instituto Socioambiental (1987-1990, 1991-1995, 1996-2000 e 2001-2005) que contêm informações acuradas sobre a história dos povos indígenas no Brasil também foram utilizados, o mesmo ocorreu com o livro Terras Indígenas \& Unidades de Conservação da natureza (2004), organizado por Fany RICARDO, que traz estudos sobre terra indígena e território indígena de autores de diferentes áreas do conhecimento acadêmico. Obras de alguns padres Salesianos como os artigos das edições do Boletim Salesiano também foram usadas. Será enfatizado também, os estudos de Aloísio CABALZAR (1994-2005), que apresentam diversas informações sobre os Tuyuka e o rio Tiquié, e do Tuyuka, Justino Sarmento REZENDE (2007) que investigou a Educação Escolar Indígena através de sua dissertação de mestrado: Educação Municipal Indígena Uhtãpinõponã - Tuyuka e a Construção da Identidade Tuyuka, e dos depoimentos e os escritos de Álvaro Fernandes Sampaio, Pedro Machado, Benedito Machado e Carlos Machado, líderes indígenas de Pari-Cachoeira e pioneiros do movimento indígena do rio Negro. 
Marcos Antônio BARBOSA é um dos principais acadêmicos brasileiros que vem se dedicando à defesa dos direitos dos povos indígenas do Brasil. Através de seus estudos jurídicos e antropológicos, reflete, acima de tudo, sobre a questão da autodeterminação dos povos autóctones do planeta, inclusive dos grupos indígenas, no contexto do direito internacional, "por seu direito à diferença". Em sua análise, destaca [...] que não há a possibilidade jurídica em direito internacional, de se negar aos povos indígenas o direito a autodeterminação, como é reconhecida a todos os povos da Terra [...]”.

No dia 13 de setembro de 2007, a Organização das Nações Unidas aprova Declaração Universal dos Direitos dos Povos Indígenas, constituindo assim, um importante instrumento para a luta dos povos indígenas pelos seus direitos.

Parte 1

$\S 1$ - Os povos indígenas têm o direito à autodeterminação, de acordo com a lei internacional. Em virtude deste direito, eles determinam livremente sua relação com os Estados nos quais vivem, num espírito de coexistência com outros cidadãos, e livremente procuram seu desenvolvimento econômico, social, cultural e espiritual em condições de liberdade e dignidade.

$\$ 2$ - Os povos indígenas têm o direito ao pleno e efetivo desfrute de todos os direitos humanos e liberdades fundamentais reconhecidos na Carta das Nações Unidas e outros instrumentos internacionais de direitos humanos.

$\S 3$ - O povos indígenas têm o direito de serem livres e iguais a todos os outros seres humanos em dignidade e direitos, e de serem livres de distinção ou discriminação adversa de qualquer tipo baseada em sua identidade indígena

Entretanto, vários povos indígenas que habitam em áreas fronteiriças são vistos como ameaças para a soberania dos Estados onde vivem, porque a autodetrminação como objeto de reivindicação política incomoda os governos destes países. A fronteira, segundo MARTIN (2002), “constitui uma zona, muitas vezes bastante povoada onde os habitantes de Estados vizinhos podem desenvolver intenso intercâmbio, em particular sob a forma de contrabando [...]"3. A região do alto rio Negro, tem características próprias dessa definição, pois é habitada por mais de 23 povos que convivem na faixa de fronteira tanto no território colombiano como território brasileiro.

Carlos Frederico Marés de SOUZA FILHO (2005) destacou que "os europeus, especialmente os portugueses e espanhóis, chegaram na América com se estivessem

\footnotetext{
${ }^{3}$ André Roberto MARTIN, 1992, p. 47.
} 
praticando a expansão de suas fronteiras agrícolas. Foram chegando, extraindo as riquezas, devastando o solo e substituindo a natureza existente por outra. [...]" ${ }^{\prime 4}$ O autor ainda ressaltou:

É claro que a transformação da natureza, forçada antropicamente, altera a cultura, cuja transformação da base alimentar inviabiliza ou desnatura os costumes. Desta forma, os povos e seus costumes também foram alterados. Aos poucos se foi cobrindo as "vergonhas" dos índios, retirando suas armas, branqueando a cor de sua pele e o sentimento de sua religiosidade. A natural nudez virou vergonha, a Religião crença, a Língua dialeto, o Direito costume. ${ }^{5}$

Desse modo, a terra indígena foi substituída por um território dominado pelos conceitos e valores europeus, onde os índios mesmo sabendo que são os habitantes tradicionais têm que lutar para que seus direitos sejam reconhecidos.

Em relação a circulação, Friedrich RATZEL (19980) entendia que "a circulação não se limita a agir sobre os gêneros de vida já existentes para transformá-los, desenvolvê-los ou especializá-los. Ela faz surgir novos gêneros de vida, ligados diretamente à sua existência. Quando pensamos nos grupos humanos cuja atividade está voltada para os transportes, [...]". 6

Claude RAFFESTIN (1980) afirmou que todos os dias, por sermos seres de relações, confrontamos com a idéia de limite, ou seja, marcamos limites ou tocamos em limites. $\mathrm{O}$ fato de sermos seres de relações com outros seres e objetos significa que traçamos limites ou entramos em conflito com limites. Todas as relações de convivência direta e indireta dependem do limite de um campo, de como elas se originam, se realizam e se esgotam. E o limite é sinal utilizado para marcar o território. A fronteira, por sua vez, "é manipulada como um instrumento para comunicar uma ideologia".

A autodeterminação que os indígenas brasileiros, que vivem nas áreas fronteiriças da Amazônia, sonham em conquistar na prática permeia por diferentes paradoxos da política do Estado, entre os quais os conceitos de poder e liberdade que constituem o circuito da "ordem e desordem"7.

Com Michel FOUCAULT ${ }^{8}$, diferente de Sartre nas obras do qual há a valorização do indivíduo em detrimento da estrutura do poder, há o caminho inverso: a valorização da estrutura do poder em detrimento do indivíduo.

No capítulo que trata sobre a Soberania e disciplina, Foucault destaca sua tentativa de investigação de “como o poder” foi polarizado por dois limites: de um lado, as regras do poder

\footnotetext{
${ }^{4}$ Carlos Frederico Marés de SOUZA FILHO, 2005, p. 33.

${ }^{5}$ Ibidem, 2005, p. 33.

${ }^{6}$ Friedrich RATZEL, 1980, p. 116.

${ }^{7}$ Georges BALANDIER, 1997.

${ }^{8}$ FOUCAULT, M. Microfísica do Poder.
} 
e, por outro os efeitos de verdade. A partir daí, então, mostra a relação do triângulo: poder, direito e verdade.

Para autor, independentemente do tipo de sociedade a que pertençamos, somos constantemente submetidos, obrigados, condenados, interrogados a buscar e a produzir a verdade. Assim, ele escreveu, "somos [...] destinados a um certo modo de viver ou morrer em função dos discursos verdadeiros que trazem consigo efeitos específicos de poder".

Um dos principais conceitos da política dos Estados é a soberania. Para Foucault a teoria jurídico-política da soberania "foi o grande instrumento da luta política e teórica em relação aos sistemas de poder dos séculos XVI e XVII”. A partir do século XVIII a teoria da soberania esteve ligada a uma forma de poder que se exerceu muito mais sobre a terra e seus produtos do que sobre os corpos e seus atos. Seria um poder não soberano, em poder disciplinar, que foi uma das grandes invenções da burguesia.

Enfim, o poder da disciplina não pode ser entendida como um discurso do direito, da regra jurídica derivada da soberania, porém o da regra "natural", da norma, do domínio das ciências humanas. Conforme o autor "a sua jurisprudência será a de um saber clínico". É dentro desses limites heterogêneos de soberania e disciplina é que se dá o exercício do poder atual.

No mundo atual em que vivemos não existe apenas um conceito de política e a partir de um grupo humano ou povo. Por isso, é necessário se situar no contexto maior, a partir de um estado transnacional e da pluralidade conceitual que ela nos traz. Desse modo, a política pode ser vista a partir da perspectiva que se baseia no princípio de conflitos. Ou seja, o desaparecimento de tensões e conflitos significaria o desaparecimento da política.

Os conflitos são características de seres humanos, nesse sentido, estão nos indivíduos, nas pessoas, nos povos e nas diferentes sociedades, ou seja, a política se fundamenta a partir do "desentendimento" dos homens, pois de um lado existem os que querem sempre manter o controle do poder em todas as dimensões da vida e, por outro lado, há os dominados que lutam pela liberdade. Segundo Jacques RANCIÈRE (1996) o desentendimento é a chave para entendermos a luta pela palavra e pela razão, crucial na política.

Para Ivani Ferreira de FARIA, "os desencontros de ideologias e de concepções entre indígenas e aparelhos do Estado (forças armadas) dificulta e acirra a luta pelo território do alto rio Negro" e, então, pela autodeterminação. Apesar desses desafios, e do não reconhecimento legal do conceito de autodeterminação indígena e do termo povo para se referir aos povos indígenas, eles sempre estiveram dispostos em dialogar com o Estado brasileiro. Segundo FARIA, para os indígenas o Estado pode utilizar diferentes termos como povos, etnias ou 
grupos, [...], território indígena, como queira, mas esses termos pouco mudam suas concepções, porque "eles têm consciência do que são e do querem". 9

Por isso, nossa intenção é analisar de maneira qualitativa, o problema proposto para a pesquisa, a partir de conceitos que contribuam para a compreensão de concepções indígenas e de autores que estudam os indígenas do alto rio Negro.

$\mathrm{O}$ ambiente no qual os indígenas vivenciavam seus valores e conhecimentos milenares, herdados de seus ancestrais, sofreram intensas transformações a partir do contato com a sociedade envolvente. Cabe destacar a seguir alguns impactos que mais provocaram mudanças na vida desses grupos, por exemplo, no início da década de 20 do século XX, a região do Uaupés foi o palco da ação missionária e de projetos militares que atuaram juntos para integrar as populações indígenas na sociedade nacional, inclusive as duas comunidades indígenas que estudamos foram atingidas diretamente. Trata-se da construção de uma série de internatos pelos missionários salesianos, em parceria com o governo brasileiro, por exemplo: no Uaupés (Pari-Cachoeira, Taracuá e Iauaretê); na área do Içana (Assunção do Içana), no alto rio Negro (Cucuí e São Gabriel da Cachoeira); médio rio Negro (Santa Isabel do Rio Negro); baixo rio Negro (Barcelos), com o objetivo de "civilizar" e "evangelizar" os índios. Esse processo levou à destruição parcial da cultura indígena. A efetivação dessa ação trouxe conseqüências desastrosas, entre outras, ocasionando divisões e conflitos internos, e o desaparecimento de chefes tradicionais e de principais yaíwa (pajés), kumuã, ba'asera (pajés) e bayaroa (mestres de músicas e danças de kapiwayá). E também provocou outras transformações deletérias entre os povos indígenas, como por exemplo, as casas tradicionais foram destruídas e substituídas por igrejas, capelas e catedrais; as aldeias transformadas em distritos que são compostas por vilas; os chefes tradicionais substituídos pelos capitães, novos representantes de comunidades indígenas, indicados pelo Serviço de Proteção ao Índio (S.P.I.) e pelos missionários.

Outros atores externos, tais como os militares, através do Projeto Calha Norte, em meados da década de 80, a presença de Ongs, como Instituto Socioambiental (ISA), que desde 1994 assessora diretamente a FOIRN, a instalação do $6^{\circ}$ PEF, em Pari-Cachoeira (1998), a instalação da $3^{\mathrm{a}}$ Brigada de Infantaria do Exército em São Gabriel da Cachoeira; e a presença da Fundação Gaia e da guerrilha colombiana, em Trinidad, também representaram fatores de transformações sociais e políticas das comunidades indígenas.

\footnotetext{
${ }^{9}$ FARIA, op. cit., 1997.
} 
Será focado com mais veemência na pesquisa, os aspectos referentes a convivência dos indígenas de Pari-Cachoeira e Trinidad, que têm seus desafios no processo de construção da autodeterminação e na convivência com agentes da sociedade envolvente após a demarcação da TI Alto Rio Negro (1998) e o reconhecimento do governo Colombiano de Área de Resguardo das populações indígenas do Departamento Del Vaupés. Foi nesse contexto indígena que os dados foram coletados.

A escolha o problema proposto para o projeto de pesquisa levou-me a trilhar o caminho da dialética. Uma dialética traduzida por Georges BALANDIER (1997), que se fundamenta nas idéias de Karl Marx, expressada em seu livro $A$ desordem: elogio do movimento.

\section{Segundo BALANDIER ${ }^{10}$ :}

A ordem e a desordem são como as duas faces de uma moeda: indissociáveis. São dois aspectos ligados ao real, sendo que um, baseado no senso comum, parece ser o inverso do outro. Em uma sociedade tradicional que se define em termos de equilíbrio, de conformidade, de estabilidade relativa, que se vê como um mundo civilizado, a desordem se torna uma dinâmica negativa que cria um mundo ao contrário. Do mesmo modo ninguém ignora que a inversão da ordem não é seu desmantelamento; pode servir para reforçá-la ou ser um de seus elementos constitutivos sob um novo aspecto [...] Todas as sociedades reservam um lugar para a desordem, mesmo temendo-a; por não terem a capacidade de eliminá-la - o que as levaria a matar o movimento em seu interior e a se degradar até o estado das formas mortas -, é preciso de alguma forma compor-se com ela. Na medida que é irredutível, e mais que isso, necessária, a única saída é transformá-la em instrumento de um trabalho com efeitos positivos, de utilizá-lo no sentido de sua própria e parcial neutralização, ou de convertê-la em fator de ordem.

A presença dos povos indígenas e a demarcação de Terra Indígena na faixa de fronteira sempre representaram para as estratégias geopolíticas dos dois países (Brasil e Colômbia) sinônimos de insegurança e ameaças à soberania nacional. A questão da pesquisa torna-se assim, pertinente, nesses últimos anos, a partir do momento que os indígenas começaram reivindicar cada vez mais a sua autodeterminação. Neste cenário, há instituições da sociedade envolvente que tentam impedir e outras que querem mudar as normas vigentes nos dois países em apoiar a política indígena. É aqui que entra o papel da dialética como método de compreensão do mundo, porque possibilita pensar "as contradições da realidade, o modo de compreendermos a realidade como essencialmente contraditória e em permanente transformação"

O caminho que percorri durante este último período da minha vida (1989-2007) proporcionou observar a partir de novos olhares o movimento indígena no Brasil. Hoje,

\footnotetext{
${ }^{10}$ BALANDIER, op. cit., 1997, p. 121.

${ }^{11}$ Leandro KONDER, 1981, p. 143.
} 
percebo que os povos indígenas estão cada vez mais inseridos no circuito e na rede das relações em diversos matizes que ultrapassam as simples barreiras de limites territoriais e culturais.

Desse modo, acreditamos que não basta ser indígena ou fazer parte de um povo autóctone e, por essa razão, achar que podemos garantir a autodeterminação indígena apenas com a vivência das tradições de nossos antepassados. Mas, ser indígena significa fazer parte de um mundo plural de identidades culturais que direta e indiretamente estão interligados (indígenas e não-indígenas).

A perspectiva de análise qualitativa na pesquisa também ajudou a compreender a crítica e a autocrítica do ser indígena hoje e a concepção de autodeterminação indígena. $\mathrm{O}$ método dialético, diz KONDER, "nos incita a revermos o passado à luz do que está acontecendo no presente; ele questiona o presente em nome do futuro [...]"12. Para Sedi HIRANO (2004: 107), “As informações colhidas sofrem uma análise de conteúdo capaz de fornecer algumas inferências qualitativas"13.

Investigar e analisar a convivência dos próprios familiares, talvez não seja difícil de se realizar, mas também, não é tão fácil, entretanto, se torna necessário. $\mathrm{O}$ risco que se corre é o aprofundar do viés indígena na análise do nosso objeto de pesquisa. Mas, é interessante ver que os indígenas não vivem mais sós, nem mesmo em seus territórios tradicionais. Eles estão em contato constante com diversas instituições governamentais e não-governamentais por isso, de acordo com o objeto de nossa pesquisa, requerem um estudo analítico e crítico.

A coleta de dados foi realizada através de entrevistas informais com indígenas da comunidade de Pari-Cachoeira e Trinidad, que responderam as nossas perguntas nas línguas Tuyuka, Tukano, Barás, Português e Castelhano. Nem todos os indígenas foram entrevistados, porque o universo dos sujeitos pesquisados foi selecionado de acordo com seus conhecimentos e sua representatividade dentro das comunidades. Este procedimento está calcado nos princípios da pesquisa qualitativa.

Assim, a coleta de dados foi realizada no mês de abril de 2007, em Pari-Cachoeira (Brasil), altitude: 109 m, coordenadas N $00^{\circ} 15^{\prime} 09.3^{\prime \prime}$ e W069 $47^{\circ} 25.5^{\prime \prime}$; e no mês de fevereiro a março em Trinidad (Colômbia), altitude: $171 \mathrm{~m}$, coordenadas N 00¹4'01.7" e W 070 10'09.6", na região do alto rio Tiquié. As entrevistas foram feitas com as principais lideranças de comunidades e alguns representantes de Ongs e da Igreja Católica . Durante as entrevistas tivemos que nos comunicar com os indígenas através das línguas Tuyuka e Tukano. Assim, os depoimentos foram feitos e gravados nas línguas indígenas. As entrevistas foram realizadas nas residências dos sujeitos junto com as suas famílias. Quando chegávamos em suas casas, a primeira coisa que faziam era oferecer kinhapira e mujeca com biju, xibé ou

\footnotetext{
${ }^{12}$ Ibidem, 1981, p. 188.

${ }^{13}$ Sedi HIRANO, 2004, p. 107.
} 
frutas, de acordo com o costume indígena. Nunca se começava falando da pesquisa. Pelo contrário, os nossos parentes queriam saber como era a vida em São Paulo, como estava o meu estudo e no final pediam que retornasse para a região do Tiquié e Trinidad para ajudá-los a buscar novos rumos para sua autodeterminação.

Os depoimentos de alguns representantes de Ongs também foram coletados e gravados, como por exemplo, aqueles da Saúde Sem Limite (SSL), que atuam entre as comunidades dos Macu, no médio Tiquié. Não foi possível coletar depoimentos de representantes da Fundação Gaia Amazonas, que atuavam em Trinidad, até em 2005, pois quando chegamos na comunidade seus representantes já não trabalhavam mais entre os Tuyuka, porque haviam sido expulsos pelos líderes Tuyuka. Os representantes do Instituo Socioambiental (ISA) não foram selecionados para entrevistas desta pesquisa, porque não trabalham em Pari-Cachoeira. No entanto, a sua atuação na área será analisada, a partir dos depoimentos indígenas e referências bibliográficas, pois o ISA é o principal parceiro-assessor da Federação das Organizações Indígenas do Rio Negro.

Os missionários católicos que atuam nas duas comunidades também foram entrevistados. Atualmente, em Pari-Cachoeira, só há a presença católica: diocesana e de freiras salesianas. Desde 2000, os padres salesianos não atuam mais na comunidade. No lugar dos salesianos, está um padre indígena diocesano, do povo Tukano do próprio distrito de PariCachoeira. E, em Trinidad, há a presença de missionários católicos que vivem em conflitos com a comunidade.

Entre os instrumentos de coleta de dados, utilizamos o caderno de anotações com questões-problema para serem apresentados por meio de perguntas abertas e informais de modo a não inquiri-los. Usamos também, tecnologia digital: GPS etrex GARMIN, Mp3 Merlin, de 512 mega, máquina fotográfica digital (Sony Cyber-shot 6.0 MEGA PIXELS) e a filmadora-fotográfica digital Sony (Filmadora Sony HC 28 Sony DCR-HC28 MiniDV Handycam Camcorder with 20 x Optical Zoom).

Dessa maneira, tentamos captar as informações históricas, concepções de fronteira, território indígena, autodeterminação territorial e resgatar qualitativamente um pouco da vida dos indígenas de Pari-Cachoeira e Trinidad na faixa de fronteira entre Brasil-Colômbia.

É concebível que atualmente a maioria dos indígenas de Pari-Cachoeira e Trinidad, não tenham visões comuns dos fatos e do momento que vive, porém o que é importante para este estudo é procurar analisar como se dá à convivência entre indígenas e não indígenas frente à sobreposição territorial, na fronteira. Para isso, foram convidados para responder as questões da pesquisa, líderes e não-líderes das vilas (os capitães) e alguns detentores de conhecimentos tradicionais, visto que, de acordo com Georges BALANDIER (1997: 37) "A tradição joga com o movimento":

[...] tradição gera continuidade; exprime a difícil relação com o passado; impõe uma conformidade resultante de um código do sentido, e portanto de valores que 
regem as condutas individuais e coletivas, transmitidos de geração em geração. A tradição é uma herança que define e mantém uma ordem ao apagar a ação transformadora do tempo, só retendo os momentos fundadores dos quais tira sua legitimidade e sua força. Ordena em todos os sentidos da palavra, como enfatizou Marx quando a considerou de "obsessão" que pesa sobre o cérebro humano [...].

Dessa forma, o registro de tradição oral foi uma das bases utilizada para a pesquisa. Em nenhum momento pedimos que os sujeitos entrevistados respondessem as nossas perguntas no papel, porque os indígenas tem mais facilidade de expor as suas idéias oralmente. Ou seja, são povos que transmitem seus conhecimentos e sua cultura pela oralidade.

Depois de feito os levantamentos bibliográficos e a pesquisa de campo, as entrevistas gravadas em fitas MiniDV e em MP3, transcrevemos e traduzimos os depoimentos indígenas para o português; para destacar os depoimentos indígenas e suas respectivas traduções, utilizamos a fonte Century, tamanho da fonte 10. As fotos foram selecionadas e anexadas ao longo da dissertação. Os depoimentos selecionados foram analisados e fundamentados a partir de conceitos que contribuem para o melhor entendimento das informações apresentadas pelos indígenas entrevistados. Para melhor compreender os termos indígenas, escritos na dissertação, elaboramos uma nota lingüística Tuyuka e Tukano e um glossário Tuyuka. Além disso, anexamos mapas que mostram a localização das comunidades indígenas na região do alto rio Negro, onde a pesquisa foi realizada.

Mapa 1. Localização da comunidade de Trinidad (COL) e Pari-Cachoeira (BR) na fronteira Brasil-Colômbia, alto rio Tiquié, AM. 


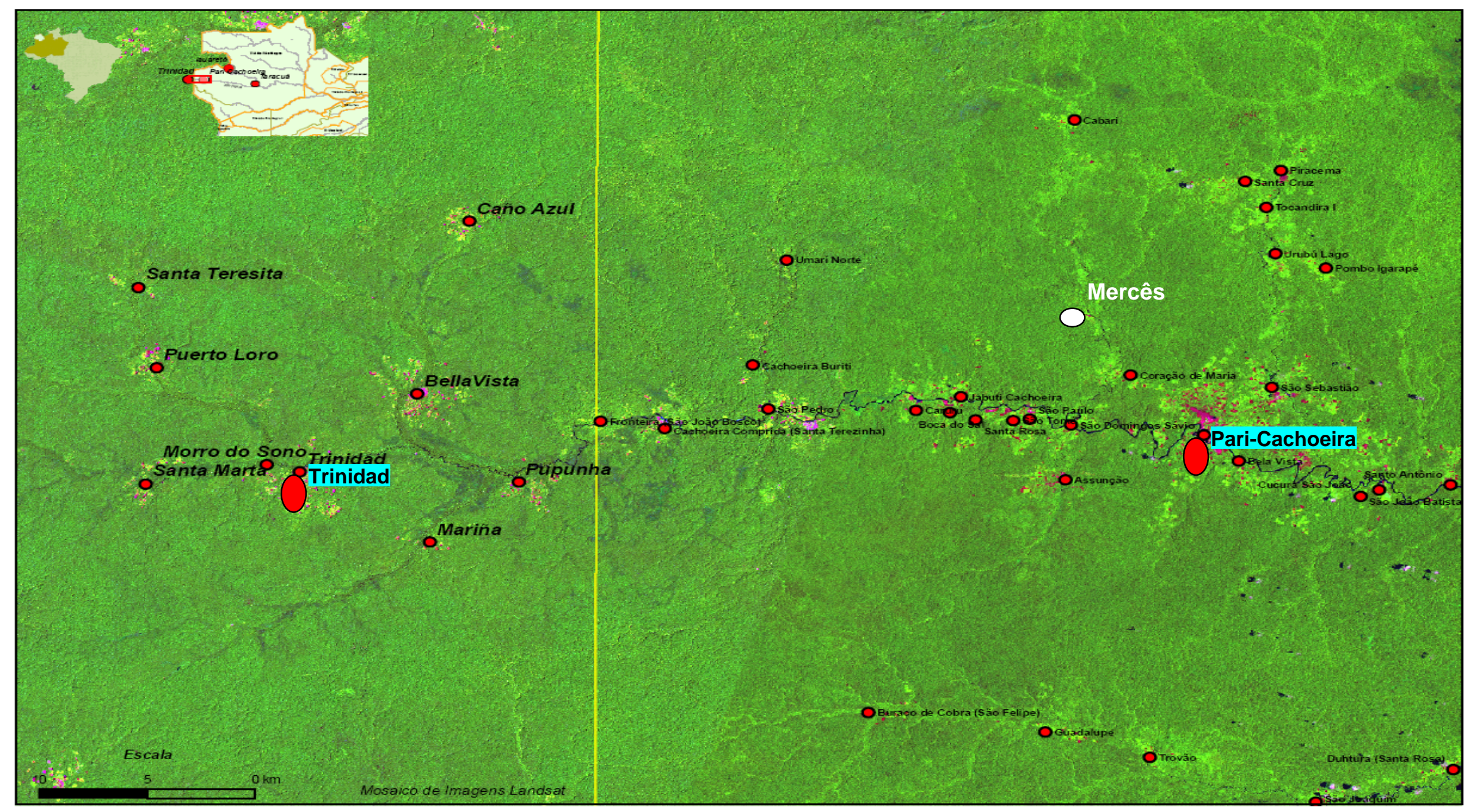

Fonte: adaptada por autor de ISA/GAIA, 2007. 


\section{OS INDÍGENAS DO UAUPÉS E O MOVIMENTO INDÍGENA DO RIO NEGRO}

Mapa 2 - Região do Alto e Méidio Rio Negro: a situação dos povos indígenas.

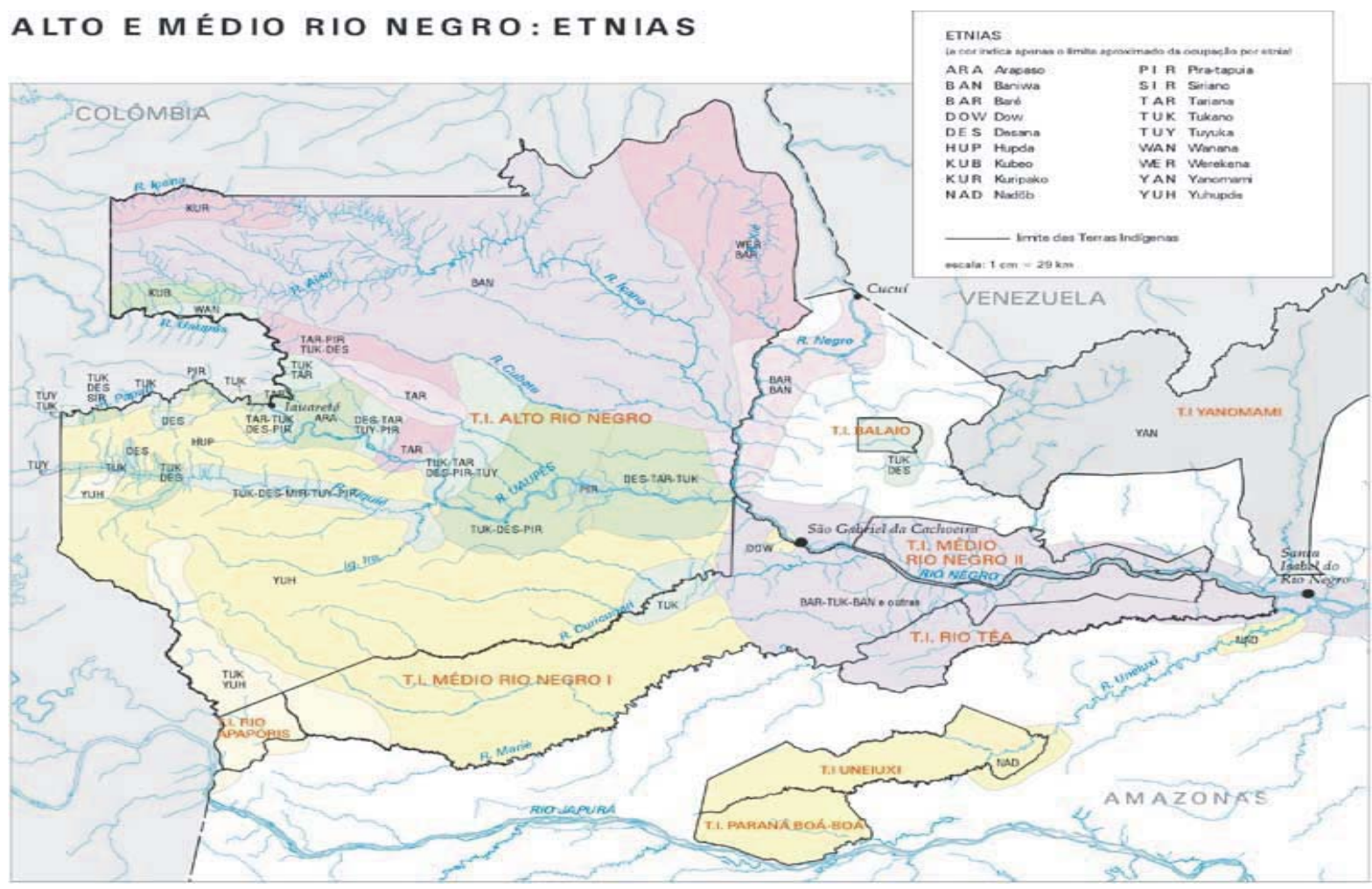

Fonte: ISA/FOIRN, 2006.

\subsection{A história de origem ${ }^{14}$ dos indígenas do Uaupés}

$\mathrm{Na}$ apresentação da história de origem, narrada pelo pajé (Ba'asi) Tuyuka, Yuhkutó Avelino Dutra ${ }^{15}$ (2007), omitiu-se diversos termos referentes os rituais de pajelança e benzimento, porque, por enquanto, não foi possível traduzir para o português, devido a nossa falta de conhecimento mais aprofundado dessa linguagem "clássica", usada apenas por pajés e benzedores dos povos indígenas do Uaupés. Para os pajés e benzedores, a história de origem

\footnotetext{
${ }^{14}$ Vários autores indígenas e não indígenas estudaram e escreveram as histórias tradicionais dos povos do rio Negro e Uaupés. São autores que ajudam a entender um pouco mais sobre a origem dos povos indígenas dessa região, tais como: Marcos FULOP, 1956; Tõrãmt KẼRÍRI (Luiz Gomes Lana), 1995; KISIBI (Dorvalino Moura Fernandes), 1996; Gabriel dos Santos GENTIL, 2000; Pedro GARCIA, 2000; Dorvalino CHAGAS, 2001; Jeferson JUREMA, 2001; Arlindo MAIA, 2004; SSL - Saúde Sem Limites, 2004; AETU, 2005; Cristiane LASMAR, 2005.

${ }^{15}$ Yuhkuló é nome de benzimento Tuyuka de meu pai Avelino Dutra, que é um dos principais pajés do povo Tuyuka, residente na comunidade de Mercês, Igarapé Cabari, Distrito de Pari-Cachoeira, alto Tiquié, Uaupés, AM. A história foi narrada no dia 23 de março de 2007, em Pari-Cachoeira.
} 
constitui o fundamento histórico-cosmológico dos rituais de pajelança e benzimento; constitui uma "história verdadeira""16 , porque comprova a sua existência no planeta Terra e no universo.

As histórias antigas (buthtoá kihti), consideradas tradicionais pelos indígenas ou mitos para os não-indígenas, são "histórias verdadeiras", não são histórias falsas; fazem parte do ser indígena do Uaupés.

A vida e a geografia das populações indígenas do Uaupés se baseiam em suas histórias milenares, onde diversos pontos míticos estão materializados ao longo do continente americano. Para os pajés Tuyuka ${ }^{17}$, a história de origem dos povos do Uaupés, não constitui apenas a criação de grupos humanos, vai além disso, mostra em quais fundamentos os pajés (yaíwa e ba'asera) se baseiam para vivenciar os conhecimentos de seus ancestrais e que tipos de tradições espirituais transmitem aos seus descendentes. E, em quais princípios imemoriais a luta do movimento indígena do rio Negro pela autonomia se fundamenta. Para os indígenas não importa o que alguns estudiosos não-indígenas (pehka'asã, em tuyuka) pensam sobre as histórias que eles narram, pois, o mais importante é que são histórias que constituem a vida deles, fazem parte do seu cotidiano. Assim como os ocidentais têm suas histórias de origem, de migração, de colonização, de invasões e conquistas, com as quais dominaram outros povos, sabem que, hoje, os indígenas do Uaupés, também têm suas bases históricas que legitimam e garantem a sua presença numa área considerada como área de segurança nacional, tanto do lado brasileiro como do lado colombiano.

De acordo com Avelino Dutra (2007), "a nossa história de origem mostra como nós, indígenas do Uaupés, fomos criados e emergimos nesta terra, e como as nossas tradições e os nossos rituais de pajelança e benzimento se originaram”. Essa história de origem apresentada nesta dissertação não detalha a origem do mundo, a criação do mundo e da natureza, dos animais terrestres e aquáticos e nem detalha a história das Casas da Emergência e o

\footnotetext{
${ }^{16}$ Mircea ELIADE, 1963, p. 15-23.

${ }^{17}$ DUHPÓ, Henrique Barrera (2007; PAÓSTU,Laureano Dutra (2007); PÕ€Õ, Antônio Barrera (2007); YUHKUŁÓ, Avelino Dutra (2007).
} 
povoamento de outros grupos da região, porque o nosso objetivo é apresentar a origem dos

povos indígenas do Uaupés e o fundamento dos rituais de pajelança e benzimento. Por isso,

Avelino Dutra apenas destacou questões que se referem a origem dos grupos e dos rituais

espirituais (pajelança e benzimento).

Apresentamos a seguir, a história de origem dos povos do Uaupés:

Aqui é assim, conforme já te contei várias vezes sobre essa história: a Pamulĩ Yohkosoró (Canoa da Emergência), que trouxe os grupos humanos, veio do outro lado do oceano Atlântico. A Canoa veio conduzida por quatro irmãos: Pamtî̃ Pinõ (o chefe, irmão maior), $\tilde{A} h s \tilde{p} p o \tilde{a}$ Nehku (criador de grupos indígenas da região andina), Yałebo (criador de alimentos e bayâ) e Muĩpũfĩ Pinõ. O Muĩpũ̂̃ Pinõ era um ba'asi e mahsãkuła yaí, ou seja, ser espiritual dos rituais de benzimento de habitações e da fertilidade da terra. Foi escolhido por Uhtã Nehku (Avó de Pedras ou Deus do Universo) para ser ba'asi (pajé) desses rituais, que são considerados pelos ba'asera (pajés) do Uaupés, os mais importantes rituais de benzimento. Até aqui ainda não havia divisão e conflito entre os quatro irmãos e nem de grupos humanos. A Canoa que estava no outro lado do oceano Atlântico atravessou e aportou aqui no litoral brasileiro, na primeira Casa da Emergência que se chama Diasihti Mahkãwi (Casa do Sul). Nós, Tuyuka, chamamos essa Casa de Diasihti Mahkãwi, Dia Õhpẽkõ Tałó. Os Tukano a chamam de Diá Ohpẽkõ Tałó.

O ser espiritual que nos trouxe, que conduziu a Canoa da Emergência era chefe dos Dahseá (Tukano) e falava a língua Tukano. Ele se chamava Pamufĩ Pinõ. O Pamufĩ Pinõ ao atravessar o oceano Atlântico, por debaixo da água, aportou com a Canoa da Emergência em uma praia do litoral de São Paulo18. Não sei como é o litoral de São Paulo, se tem praias ou não, não sei. A gente fala aonde fica os lugares históricos, aonde Pamulĩ Pinõ passou com a Canoa da Emergência, no entanto nunca fomos ver. A única certeza que temos é que esses lugares existem.

O Pamłłĩ Pinõ era um deus. Possuía muitos poderes espirituais, com os quais podia realizar diversas criações e enfrentar quaisquer ameaças de outros seres espirituais que já existiam aqui nessas regiões. Por isso, se sentia auto-suficiente, todo poderoso, acreditava que jamais precisaria a colaboração de quaisquer outros seres espirituais, que poderiam ajudar na criação e no povoamento de grupos humanos; e, além disso, nem dava muita atenção aos seus irmãos, que também estavam aí para ajudar, e eram sábios como eles. Quis fazer tudo sozinho.

Naquela hora, até esqueceu que seu Avô (Deus) existia, o mais poderoso entre todos os poderosos do universo. Diante de seu Avô, ele não era nada, apenas mais um neto incumbido para realizar o projeto de criação de novos seres humanos. O modo como pensou em conduzir e criar os humanos não deu certo, porque o seu sentimento de auto-suficiência o dominou e, além do mais, não era tão poderoso como imaginava para enfrentar a força espiritual de seres contrário a criação de humanos no novo continente e da Porta da Emergência de Diasihti Mahkãwi, que era uma porta de pura pedra, onde ninguém podia ultrapassá-la. Era a única porta para Suniã Pãłãmĩ entrar com grupos humanos para depois criar e fazer emergir em diversas Casas da Emergência (Pamulĩ Wihserı).

O primeiro desafio que Pamułĩ Pinõ enfrentou, na Casa da Emergência de Diasihti Mahkãwi, foi a Porta da Emergência. Antes de realizar a primeira tentativa de entrada, adornou a sua cabeça com um suó duhpu (cocá), colocou em sua orelha yohsałipĩ (brinco de ouro), colocou nos seus ouvidos wĩhtôkołí (pequenos objetos com formato de uma flor, que representavam a fonte de sabedoria), em seguida, enfeitou-se com ñahkẽ kałé (peças artesanadas de miçangas). Cada objeto formava o conjunto de seus poderes, depois pegou seu yuhkt behsułé (bastão de poder espiritual), cravou na parte lateral do Portão e tentou abrir.

O Pamulĩ Pinõ queria mostrar aos sábios da Terra, que era poderoso e, portanto, não precisava de quaisquer ajudas externas. Por isso, usou apenas os seus poderes para abrir a Porta da Emergência e, assim, levar grupos humanos para dentro do continente; no entanto, a Porta era

\footnotetext{
${ }^{18}$ Segundo os entrevistasdos da pesquisa, o local, onde a Canoa da Emergência aportou, provavelmente fica em uma das praias do litoral do Estado de São Paulo, em Santos, SP.
} 
muito forte, dura e poderosa; nenhum outro ser espiritual ousou ultrapassá-la, porque sabia de sua força espiritual que a protegia. A porta tinha sido colocada por Deus, ou seja, ela fazia parte do projeto de criação e o povoamento de grupos humanos aqui no continente.

Em seguida, com todos os seus instrumentos e forças espirituais (ktñé baułuká mahkẽ, yuhku behsú ñãpehtì) e com seu bastão de poderes tentou abrir a porta. Até aí ainda não existiam diferentes grupos humanos: Tukano, Desano, Tuyuka, Wanano, Tariano, Miriti-Tapuia, Siriano, Karapanã, Barasano, Makú e todos os outros povos que habitam neste continente. Existia apenas uma só língua. Ninguém dizia que esse ou aquele era Barasano, Tuyuka, Desano, pois não havia diferença de povos.

O Pamulĩ Pinõ queria passar de qualquer jeito pelo Portão da Emergência (Pamulĩ Sohpé de Diasihti Mahkãwi. Como falei para você, essa porta ficava em Diasihti Mahkãwi. Aí era um lugar onde ninguém podia passar. Pamułĩ Sohpé era uma porta de pedra muito dura. Era uma porta projetada pelo Suniã Nehkt para acontecer tudo que ocorreu com o seu neto, que não sabia totalmente o plano de seu Avô. O Suniã Nehkt sabia que seu neto tentaria conduzir os grupos humanos pela Porta da Emergência sem perguntá-lo se isso daria certo ou não, por isso, projetou essa porta para servir um desafio a ser superado.

Antigamente, somente os pajés (yaíwa e ba'asera) que conseguiam ver a força espiritual dessa Porta. Por isso, para os yaíwa e ba'asera Tuyuka a Porta representava pura força espiritual, chamado de: Uhtã Wehtiri Sohpé, Ẽ̃̃̃ Wehtiri Sohpé, Pehká Omẽdá Wehtirisohpé, Yaí Wehteri Sohpé. Hoje, se fôssemos ver Porta da Emergência da Casa do Sul com os nossos olhos humanos, encontraremos apenas uma pequena pedra, com formato de uma porta, que deve estar em algum ponto das montanhas que cercam o litoral paulista.

Para Pamulĩ Pinõ e seus irmãos a porta era bem estreita e alta. Atualmente, quem consegue enxergar a representatividade da força espiritual dessa Porta são apenas os pajés (yaíwa e ba'asera) através dos rituais de pajelança e benzimento, e por meio de sonhos ou sob o efeito da kahpi e wiõ (substância alucinógena). A porta, aparentemente pequena na visão humana, para o Pamutĩ Pinõ e seus irmãos, era muito poderosa e impossível de ultrapassá-la que ao mesmo tempo parecia tão grande que na parte de cima tocava o céu e em baixo da terra chegava até o último lugar que se possa imaginar, e ultrapassava os limites do leste e oeste do planeta Terra. Não tinha como passar. A única maneira de entrar neste continente era no meio da Porta da Emergência. Foi isso que o Pamulĩ Pinõ tentou fazer, no entanto o seu bastão de poderes não agüentou e entortou rapidamente.

Essa era a Porta que o próprio Deus (Suniã Nehkt) colocou para que o seu neto enfrentasse, vencesse e ultrapassasse para poder criar nós, os indígenas, do continente americano. O objetivo de Deus era testar os conhecimentos e os poderes de seu neto, que se considerava auto-suficiente demais. Vendo que seu neto o ignorava e desprezava a ajuda de outros sábios da Terra, Suniã Nehkt, Buhpó Nehkt (Avô do Trovão), Uhtã Nehkt (Avô das pedras), Bułekó Nehku (Deus do Tempo e do Universo), pensou o seguinte: quero ver como o meu neto conduzirá os humanos e seus irmãos. Suniã Nehku era avô de Pamulĩ Pinõ. O Pamulĩ Pinõ também é chamado de Suniã Pãłãmĩ.

O Suniã Pãłãmĩ sentiu que o momento de ultrapassar a porta estava próximo, por isso antes de entrar, fumou tabaco, comeu ipadu e bebeu caxiri; em seguida, com o seu bastão de poderes tento abrir pela primeira vez a Porta, porém a porta era tão forte que em poucos segundos o bastão se entortou. Foi a primeira tentativa que Pamulĩ Pinõ realizou para entrar pela porta, no entanto não conseguiu abrir. Na primeira tentativa, Suniã Pãłãmĩ perdeu o primeiro grupo humano.

Depois de perder o primeiro grupo, parou e pensou por que estava acontecendo isso com ele. Apesar do primeiro fracasso, tentou abrir a porta pela segunda vez, entretanto mais uma vez o bastão amoleceu e a porta se fechou em poucos segundos, foi quando perdeu o segundo grupo humano. Tentou pela terceira vez e, de novo, o bastão amoleceu, a porta se fechou e ele perdeu o terceiro grupo.

O objetivo Pamulĩ Pinõ era levar os futuros humanos para dentro do novo continente para criar e povoar, porém nas três tentativas que fez não conseguiu vencer a Porta da Emergência. Por causa da perda desses grupos humanos, que a Casa da emergência de Diasihti Mahkãwi, a Porta da Emergência se chama Dianuhĩriãwi, em tukano, porque foi a casa e a porta onde o poderoso bastão de Suniã Pãłãmĩ amoleceu ou sucumbiu diante da força da Pamłfĩ Sohpé (Porta da Emergência). Desde aquele tempo essa casa é denominada de Dianuhiriãwi Mihsĩpewi e Kahpi Mihsĩpewi. Para nós, Tuyuka (Dohkapuała), essa casa se chama Diakameñãłiwi. 
Após três tentativas, Suniã Pãłãmĩ parou, pensou e lamentou as perdas e, em seguida, pegou o seu yuhkt behsułé (bastão de poderes) e deixou ao seu lado. Depois, retirou os ornamentos e adornos que colocou em seu corpo, e ficou só com um cocá na cabeça. Fumou e defumou o seu corpo com o tabaco. Pensou. A única coisa que ficou no corpo, além do cocá na cabeça, foi o seu coração.

O Pamulĩ Pinõ estava muito decepcionado e triste consigo mesmo. Pensou melhor e disse: por que tudo isso está acontecendo comigo? Naquele momento, percebeu que fracassou e reconheceu o seu limite e erro por ter negado a ajuda de outros seres espirituais, e de seus irmãos. Em seguida se preparou para ir perto de seu Avô. Olhou para o céu e pensou Nele. Olhou para o oceano Atlântico e pensou na terra de onde saiu com a Canoa da Emergência. Olhou para o norte, para o sul, leste e oeste, e voltou a se indagar e falou consigo mesmo: tentei fazer do meu jeito, mas não consegui. Antes sempre sonhei que poderia criar grupos humanos sozinho, mas não deu certo como planejei. Até agora já perdi três grupos humanos. Isso não é bom, porque se eu continuar fazendo as coisas a só perderei mais pessoas. Por isso, vou atrás do meu Avô para pedir mais poderes para na volta conseguir vencer o Portão da Emergência.

Os três grupos que se perderam na Diasihti Mahkãwi, hoje, são os Waí Mahsã (seres sobrenaturais): dihtá wihseri mahkãłã (espíritos da terra), diyáłi mahkãłã (os espíritos que vivem no mundo aquático), outros são os curupiras etc. Esses se tornaram nossos inimigos e rivais, porque não conseguiram se tornar pessoas como nós, humanos. Por isso, fazem aparecer constantemente diversas doenças pelo mundo. Para demonstrar a raiva que tem contra os humanos, os Waí-Mahsã dizem o seguinte: esses humanos pensam que são gentes, mas nós que éramos os primeiros, os chefes deles, só que para nós não deu certo. Agora que são gentes querem brincar conosco.

Alguns desses espíritos são os que sempre falo para você, tais como: dihtíroa, kayáłoa, yahkominiã, waikułastirá, pusíria, ẽm廿ã, yãmuã, mayaroa, nimayuá, yuhkubuemihsiã, buemihsiãbahsiroa, sẽ, dahsé, nenirõ, wã, konepihkõo, yamiká bałeró, diatuñoã, buá (pombo), watoropoa, ohsó (morcego), ohsó pahku (morcego gigante), muipu durú, ohkõlou, buhpupahkó (coruja). ${ }^{19}$ São espíritos que ficaram no mundo sobrenatural para causar doenças e morte aos humanos. Querem que os humanos também morram como eles, quando se perderam na porta de Diasihti Mahkãwi. Os Waí Mahsã podem causar doença e matar os bebês na hora do parto, como forma de vingança e raiva contra nós. O parto de uma criança tem o mesmo significado da emergência de um grupo humano, isto é, é como se a criança passasse pela Porta da Emergência de Diasihti Mahkãwi sob a proteção de Uhtã Nehkt, que no nosso caso seria sob a proteção dos de um pajé ou benzedor que protege a criança através dos rituais de benzimentos.

Após fumar o tabaco de toasini, Suniã Pãfãmĩ parou e ficou em pé conversando com seus irmãos menores - Áhsĩpoã Yaí, Yałebó, Muipũ Yaí - que estavam junto com ele e perguntou-lhes o seguinte: o que será que vai acontecer agora?

Você que deve saber, respondeu seu irmão Âhsĩpoã Yaí, que também era chamado Ahsĩpoã Nehku.

Enquanto os quatro irmãos discutiam entre si, a Canoa da Emergência estava aportada na praia. Nós, que seríamos humanos, estávamos dentro dessa Canoa, bem guardados e éramos invisíveis aos olhos de outros seres espirituais que já existiam nesta Terra. Estávamos dentro do espírito de patugu (pé de ipadu), de kahpidá (pé de kahpi), de mahsãkula waí koãłĩ (dentro dos "ossos" de pajés). Só os quatro irmãos que sabiam da nossa existência e eram visíveis aos olhos de outras divindades.

No início, os três primeiros grupos que se perderam em Diasihti Mahkãwi também estavam junto conosco. Na tentativa de emergir para este mundo natural que eles se perderam. Mais uma vez, Suniã Pãłãmĩ ficou em pé diante de seus irmãos, pensou consigo mesmo, olhou para o céu, fumou tabaco, comeu ipadu, bebeu caxiri, pensou de novo e olhou para o céu. Em seguida, de repente, partiu djaaaa (como o reflexo da luz), quando entrou no interior do mundo espiritual de uhtã omẽkodá patipu, pehká omẽkodá patipu, ẽ̃̃o omẽkodá patipu, yaí omẽkodá patipu, djaaaa. Depois de alcançar esse mundo, retornou para o lugar onde os seus irmãos e a Canoa da Emergência se encontravam. Era apenas um ensaio, antes de viajar para o céu. $\mathrm{Na}$ volta, viu que estava tudo como era antes, depois decidiu se enfeitar e adornar de novo o seu corpo, usando ñahkẽká kałiré (colares de miçanga), ahsĩpoã pĩrĩrẽ (brincos de ouro), colocou o

${ }^{19}$ Os seres que foram apresentados por meu pai são pássaros. Alguns são da noite e outros do dia. Por enquanto, não dá para nomeá-los em português, porque muitos são desconhecidos pela academia. 
sioduhpu, pôs no seu pescoço os sẽ behtoliré (argolas de metais), a sua uhtãteniã (pedra de quartzo), o seu sẽkułé, waí wałú (essência e poder de peixes); adornou também com o wãniããĩá (corda de quebrar e entortar) e todos kamõkã (adornos tradicionais). Depois disso, estava pronto para partir perto de seu Avô. Olhou para o céu e foi djaaaa. Estava tudo muito lindo. Quando olhou para a casa de Buhpowi (Avô de Trovão), a casa do centro do universo, a casa do céu, percebeu que a porta do céu estava fechada.

Essa casa deve estar bem em cima da Porta da Emergência (Pamutĩ Sohpé). Os pajés dizem que a superfície do planeta Terra fica bem no meio. É nesse meio que Suniã Pãłãmĩ estava querendo fazer emergir os grupos humanos. Aí era o lugar onde os espíritos diziam que ninguém conseguiria emergir, por causa da Porta da Emergência que era muito forte e perigosa.

Olhando mais uma vez para o céu, pensou em seu Avô e disse aos seus irmãos: agora estou pronto para ir perto do nosso Avô. Na véspera de sua partida, realizou o ritual de benzimento do tabaco para tentar convencer ao seu Avô, que o acolhesse em sua casa com cordialidade. Através desse ritual evitou que seu Avô negasse a conceder mais poderes. Depois de se defumar olhou para o céu, sentou e pegou seus principais poderes que possuía, e em seguida guardou dentro do seu corpo.

Aqui está o exemplo para quem escutou e aprendeu os rituais de pajelança e benzimento com seu pai. Um dia uma pessoa sempre se torna órfão. Por isso, depois que um pai morre, um filho obediente e observador de princípios que regem as nossas tradições sempre será considerado sábio pelos outros pajés e pessoas comuns. Esses conhecimentos proporcionarão muita segurança à pessoa se um dia ela decidir discutir e refletir sobre a pajelança e o benzimento com outros pajés, porque saberá como seu pai falava e te ensinava. E quando os outros pajés não quiserem te contar os conhecimentos que não sabe, você saberá fazer perguntas certas e corretas na hora certa.

Depois disso, mais uma vez, Suniã Pãłãmĩ olhou para o céu, comeu ipadu, fumou tabaco, bebeu caxiri e ficou pensativo. Apesar de ele estar entre os seus irmãos, o pensamento de Suniã Pãłãmĩ estava dentro de forças espirituais, que os pajés chamam de: uhtã õmẽkodá patipu, uhtã pehká buhti õmẽkodá, pehká sumeri, pehká ñãbué ômẽkodá, tiyá õmẽkodá patipu, ẽ̃ño ômẽkodá nãbué tiyá õmãkodá patipu e pehká õmẽkodá ñãbué nãatá tiyá õmẽkodá patipu, yaí ómẽkodá ñãbué nałakatú tiyá ómẽkodá patipu. ${ }^{20}$ De repente, djaaaa, como um raio de luz subiu para o céu. O Pamułi Pinõ estava bem enfeitado e ornado, o seu corpo brilhava como uma luz dja, dja, dja, dja, dja, dja, dja, dja...

Em cada lado da porta do céu estavam sentadas duas mulheres, que eram filhas de Deus, as quais costuravam e trançavam cestinhos que, na verdade, criavam seus netos e os animais que causariam doenças aos humanos. As duas eram as seguintes: uma se chamava Ânhã Nẽ hkố, e a outra se chamava Patu Nẽhkõ. A $\tilde{A} n h \tilde{a} \tilde{N} e ̂ h k \tilde{o}$ era a avó de jararacas, cobras, aranhas, de bichos venenosos e peçonhentos. A Patu Ñ̃ehkõ era a avó do ipadu. Quando de repente viraram para um lado perceberam que Pamulĩ Pinõ estava se aproximando da casa de Deus e disseram entre si: olha quem está chegando! É o neto de nosso Pai, que perdeu os grupos humanos.

O Suniã Pãłãmĩ já se aproximava da porta do céu. Rapidamente, chamaram o Pai delas, o Uhtã Nehku: Pai! Você se lembra daquele seu neto, que as pessoas chamam de Pamulĩ Pinõ ou Suniã Pãłãmĩ, que tentou criar os grupos humanos na Terra, achando que podia conseguir somente com seus poderes, mas que no final acabou perdendo três grupos? Ele está chegando aqui. O Suniã Pãłãmĩ que você tanto fala, já vem.

E o velho não respondeu nada. Depois de tentar acordar o pai, as duas mulheres entraram na casa sem recepcionar e acolher o Suniã Pãłãmĩ.

Logo em seguida, Pamutĩ Pinõ chegou na porta do céu e saudou: sooooooo! Depois, tocou o seu bastão de poderes: kiririrı! Kiririrı! Kiririrı! Kiririrı! Kiririrı! Kiririrı! Kiririrı! E nada do Velho responder.

Mesmo assim, insistiu e fez outra saudação: Como vai você Suniã Nehku (meu avô), você Uhtã Nehku,(Avô de Pedras), Bułekó Nehku (Avô do dia e da noite). Sou seu neto, responsável para criar e povoar grupos humanos no novo continente do planeta Terra.

E seu avô não respondeu nada.

${ }^{20}$ Esses termos fazem parte dos rituais de pajelança e benzimento, ou seja, é uma linguagem "clássica" dos pajés. Por isso, nesta dissertação, diversos termos, palavras que constituem os rituais de pajelança e benzimento servirão apenas como ilustrações, pois não será possível traduzir para evitar equívocos e erros de tradução para português. 
O Pamulĩ Pinõ sabia que isso aconteceria, porque tinha errado ao ignorar seu Avô nas três tentativas de criar gentes, porém não desistiu, pelo contrário, insistiu. O que Pamufĩ Pinõ enfrentou naquele momento era o sinal de que no futuro os pajés (yaíwa e ba'asera) enfrentariam os mesmos desafios. Por exemplo, os pajés se depois de realizarem os rituais de pajelança e benzimento e não conseguirem prevenir e curar algumas doenças recorrem aos outros tipos de pajés para perguntar como se benze essas doenças estranhas. Essas coisas são assim. Hoje, muitas vezes é isso que acontece conosco, quando procuramos outros pajés para perguntar como se benze as doenças, porque esses outros conhecem rituais de pajelança e benzimento que nós pajés (individualmente) nem sempre sabemos.

O Pamułĩ Pinõ fez de novo a saudação: sooooooo! Uhtã Nehkt, Bułekó Nehkt. E Deus, pela segunda vez, não respondeu. Suniã Pãłãmĩ saudou de novo: sooooooo! Uhtã Nhehku, Bułekó Nehku. Depois de três saudações, o seu Avô suspirou lá no fundo de seu quarto: huuuuuu. Estava no final de sua casa, atrás de uma parede, em um quarto bem fechado. Estava deitado na rede se esquentando no calor do fogo e dormindo.

Por isso, antigamente, os velhos pajés (yaíwa, ba'asera, kũmũâ), os sábios, após os rituais não saiam para nenhum outro lugar, ficavam em resguardos, ornados, defumavam-se com tabaco benzido para fechar os corpos e seus espíritos, pintavam-se seus corpos com wãłõsoã (carajuru) benzido. Ficavam no quarto durante um dia, dois dias ou até mais, dependendo do tipo de ritual realizado. O Buhpó (Deus do Trovão) estava fazendo o que os pajés humanos fariam no futuro, isto é, era um exemplo do que aconteceria conosco. Por essa razão, atualmente, quem é pajé ainda pratica esse ritual de resguardo para se proteger das doenças espirituais.

Depois, Pamułĩ Pinõ rosnou: heõõô!

Logo em seguida, Suniã Nehku disse-lhe: como vai você, meu neto! Você está aí? Nem sabia que era você que estava na minha porta.

Sim, estou aqui, respondeu Pamłtĩ Pinõ.

Suniã Ñehku perguntou-lhe o seguinte: O que está acontecendo com você meu neto?

O Pamulĩ Pinõ respondeu: É Vovô! Você sabe o que aconteceu comigo. Tentei criar os humanos como me pediu, no entanto tentei criar sozinho, do meu jeito, mas não deu certo. Nessa tentativa perdi três grupos de humanos. No começo não queria ajuda ninguém, nem dos pajés (ba'asera) da porta do norte, do sul, do alto (céu); nem dos que vivem no outro lado do oceano Atlânticos, de onde saí com a Canoa da Emergência, porque pensei que seria capaz de realizar sozinho apenas com os meus poderes, que recebi de Você. Reconheço o meu fracasso e o meu erro. Por isso, acreditando, que só o Uhtã Nehkt, Bułekó Nehkt, quem manda em todas as coisas existentes no universo, decidi vir atrás de Você, meu Avô. Além do mais, sou seu neto incumbido para criar os humanos e não desistirei da minha responsabilidade só porque perdi três grupos, até porque ainda existem outros grupos humanos que devo criar e povoar no planeta, mas para isso preciso emergir na superfície terrestre junto com eles.

O Avô respondeu-lhe: É isso mesmo! Você pensou que estava criando humanos longe do meu alcance ou escondido de mim, entretanto estava aqui bem embaixo de mim, aliás, você sempre está aqui pertinho de mim. Fiquei te observando e me perguntando: esse meu neto Suniã Pãłãmĩ está me ignorando? O que pensa que é? O meu neto sabe tudo, fala de tudo. Ouça bem e preste atenção nas minhas palavras. Quem é sábio deve ouvir o que os outros sábios têm a dizer. Quem é sábio nunca se acha o melhor e/ou máximo, insuperável. Você não fez jus a sua sabedoria, por isso cometeu erros infantis. Olhei para você e pensei: será que o meu neto, acha que é mais poderoso e mais sábio que Eu? Depois que você perdeu três grupos humanos, continuei pensando em você e me perguntando: será que ele vai acabar perdendo todos os demais grupos humanos? Fiquei muito preocupado. Não pense que não estou te observando ou que estou longe de você. Estou constantemente de olho nos seus atos.

Depois de chamar a atenção ao seu neto , Bułekó Nehku estava pronto para concedê-lo mais poderes espirituais. Só falou isso. Para chamar atenção de seu neto e para conceder novos poderes espirituais, Deus (Bułekó Nehkt) não saiu de seu quarto e Suniã Pãłãmĩ nem teve contato direto com seu Avô. Mesmo deitado na sua rede, dentro de seu aposento, começou entregar os poderes materializados nos seguintes instrumentos, que chegaram até nas mãos de Suniã Pãłãmĩ. $1^{\circ}$ entregou o wehti kũmũłõ (banco que Suniã Pãłãmĩ sentaria para benzer breu e tabaco).

O Suniã Pãłãmĩ estava na entrada da porta do céu, quando recebeu os poderes através de sua força espiritual, nem chegou entrar na casa. Os pajés chamam esses instrumentos de: thtã omẽkodá patipu, ẽ̃̃̃ omẽkodá patipu, yaí omẽkodá patipu, pehká omẽkodá patipu, djaaa, głłłł 
(deu estrondo); $2^{\circ}$ entregou o munõ puhti senerõrẽ (suporte de tabaco), que mais uma vez Suniã Pãłãmĩ recebeu através da força de seus poderes de pajelança e benzimento; $3^{\circ}$ entregou os mahsãkułałé (a força espiritual dos pajés mestres dos rituais de Jurupari); $4^{\circ}$ entregou o yuhku behsuhtirigu (bastão de poder e autoridade); $5^{\circ}$ entregou o poasti tirigz (bastão de rituais de benzimento e pajelança). Só era isso.

Após entregar os poderes e os instrumentos, Bułekó Nehku disse-lhe: daqui você desce até aonde você veio, por meio da força espiritual da fumaça de uhtã omẽkodá (fumaça de pedra), toyé uhtã omẽkodá (força espiritual da fumaça branca de pedra), yaí omẽkodá (fumaça de yaî), pehká omẽkodá (fumaça de lenha). Chegando perto de seus irmãos, fume o tabaco, coma o ipadu, beba o caxiri e em seguida olhe para o céu e lembre-se de mim e nas coisas que falei para você. Depois disso, com a força de uhtã omẽkodá, ẽ̃ño omẽkodá, yaí omẽkodá, pehká omẽkodá, defume a Porta da Emergência (Pamułĩ Sohpé) e, em seguida, pegue o seu bastão de poderes (yuhku behsuré) e finque na lateral da Porta para abrir. Seja rápido para que os grupos humanos consigam ultrapassar a Porta, porque a porta se fechará rapidamente, mas você conseguirá ultrapassá-la, é só seguir as minhas orientações. Depois que você fizer isso, todos os grupos passarão: psi, psi, psi, psi, psi...!. Após essa execução pára, fume o tabaco, coma o ipadu, beba o caxiri, olhe para o céu e lembre-se de mim, que estarei te olhando e te acompanhando. Em seguida, defume com breu (wehtê) o caminho aonde os humanos passarão e percorrerão, com a força da fumaça de thtã omẽkodá, ẽ̃̃̃o omẽkodá, yaí omẽkodá, pehká omẽkodá.

Assim, depois de receber mais poderes, Suniã Pãłãmĩ retornou para perto de seus irmãos. Quando chegou, cumpriu todos os passos e as orientações que recebeu de seu Avô. Abriu a Porta da Emergência com seu bastão de poderes, que não se sucumbiu à força da Porta, por isso, rapidamente, fez passar grupos humanos pelo Portão da Emergência (Pamulĩ Sohpé) de Diasihti Mahkãwi, no entanto a Porta era tão poderosa que não ficou aberta por muito tempo. Por isso, Suniã Pãłãmĩ teve que agir rápido, pois a porta se fechou em poucos instantes...tak! Apesar disso, o tempo foi suficiente para que os humanos ultrapassassem, conforme havia dito o seu Avô.

Logo depois que conseguiu concretizar o pedido de seu avô, Suniã Pãłãmĩ parou, fumou o tabaco, comeu o ipadu, bebeu o caxiri, olhou para o céu e agradeceu ao Avô. Em seguida, subiu para ao céu, onde contou ao Avô a sua façanha. Dessa vez, foi recebido rapidamente pelo Bułekó Nehku.

Chegando na porta do céu fez a seguinte saudação: sooooooo! Uhtã Nehku, Bułekó Nehku, você está aí.

O velho não demorou em respondê-lo: Estou aqui Suniã Pãłãmĩ. E perguntou: Como estão se delineando os seus trabalhos?

O seu neto respondeu: Agora está tudo bem, Suniã Nehku.

O Bułekó Nehku disse:-É isso que sempre esperei de você. Daqui em diante as coisas vão ser diferentes e tudo dará certo, Suniã Pãłãmĩ. Antes não deram certo, porque você tentou me ignorar, tentou esquecer que eu existo. Eu não sou qualquer Deus, que você e outros seres podem desrespeitar. Sou seu Avô, Deus do tempo e do universo. Sou um ser que nasceu antes de tudo, antes do universo. Agora, sim, os seus trabalhos e suas criações sempre terão resultados positivos. Por isso, agora, daqui você desce para a terra através da força espiritual da fumaça de $u h t a ̃ a$ omẽkodá, ẽ̃̃õ omẽkodá, yaí omẽkodá, pehká omẽkodá patipu. Chegando na terra envie o seu irmão Ahsipoã Nẽhkt para a porta do norte. É lá que ele criará e povoará outros grupos humanos. Depois envie o seu segundo irmão, o meu neto Yałebo, que irá antes de você para criar as plantas frutíferas, preparar a terra para plantações, criar kirikt (maniva), preparar os kũmũdzhkałi (coxos de caxiri), as stubuhkupału (panelas grande de barro que servem para armazenar caxiri), construir as Bahsawihseri (Casas Tradicionais), aonde criará diferentes povos.

Depois de falar isso, sentiu algo estranho e suspirou: hummmmmm!

O Bułekó Nehkt sentiu que alguma coisa não daria certo para seu neto. E disse-lhe: enquanto o Yałebo estiver construindo as Bahsawihseri, criando as plantas frutíferas, criando maniva e mandioca, preparando o caxiri, envie este seu irmão Muĩpũfĩ Pinõ, que irá em todas as Bahsawihseri construídas até chegar em Ohkó Diawi para realizar os rituais de benzimentos das habitações.

Naquele momento o Błłekó Nehku já sabia o que aconteceria no futuro, na Casa da Emergência de Ohkó Diawi. Teve um pressentimento negativo, por isso, alertou para o Suniã Pãłãmĩ e disse-lhe: uma coisa não dará certo para você. O seu irmão caçula, Muĩpũfĩ Pinõ apesar de ser seu irmão, não te obedecerá, porque depois que você perdeu três grupos humanos ele não confia mais em você, por isso duvidará de sua capacidade e de seus poderes. Ele não sabe que você 
acaba de receber mais poderes e está sob a minha proteção espiritual. Por isso, fique atento e preparado contra as ações dele para que nada de mal ocorra durante a criação de gentes, porque ele tentará destruir o que você e outros seus irmãos construirão na terra.

O Muĩpũfĩ Pinõ também era filho de Deus, portanto era um ser espiritual e sábio como o seu irmão maior, por isso não temia em desobedecê-lo. Era tão poderoso como Suniã Pãłãmĩ. Por causa desse fato milenar e espiritual, hoje, existem entre os Tukano, Tuyuka, Desano, etc., pessoas que se dizem conhecedores dos rituais de pajelança e benzimento, os que se acham sábios quanto aos demais e que não querem ouvir o que os outros têm a dizer. E, às vezes, alguns até dizem o seguinte: eu também sei os rituais de pajelança e benzimento como você; posso benzer sozinho e não preciso de você. Outros falam até contrário e com ironia, dizendo assim: por isso, como não sei as pajelanças e benzimentos, nunca disse a ninguém que vou fazer isso ou aquilo, que um dia irei juntar as pessoas, construir uma Bahsawi ou comunidade. Essas são algumas indiretas maldosas que alguns pajés ou benzedores dizem por aí.

Antes de iniciar a criação dos humanos, Deus pressentiu o conflito que ocorreria em Ohkó Diawi entre Suniã Pãłãmĩ e seu o irmão Muĩpũ̂̃ Pinõ. No futuro, esse conflito seria revivido por nós que somos pajés. Hoje, para quem acredita que nada disso acontecerá, talvez isso não ocorra, mas para quem acredita e vivencia os rituais de pajelança e benzimento os conflitos e as brigas são constantes, criam divisões Tribais, familiares e comunitárias.

Quando o Suniã Pãłãmĩ tentou enviar o seu irmão caçula, Muĩpũ fĩ Pinõ para realizar os rituais de benzimento das habitações, ouviu a seguinte resposta: desde que chegamos aqui, em Diasihti Mahkãwi, vejo que você só faz as coisas sem nos consultar e sem pedir nossas opiniões. Se você conduz as coisas dessa forma é porque sabe o que está fazendo e não precisa de mim. Por isso, digo-te mais: estou cansado de ser a sua sombra. De tanto ficar atrás de você, vi perder três grupos humanos, sem poder interferir para evitar que gentes se perdessem na Porta da Emergência. Agora, não quero ver de novo a mesma história se repetir; nem quero ouvir as pessoas falarem que meu irmão mais uma vez perdeu outros grupos humanos. Por causa dessas perdas de perdido três grupos nas três primeiras tentativas de passar pelo Portão, muitas pessoas por aí comentam sobre o evento triste que ocorreu conosco. Tenho vergonha quando ouço comentários de outros seres espirituais sobre o seu fracasso. Por isso, a minha resposta é não. Não irei. Vai e faça você mesmo.

Ao ouvir a resposta do irmão, Suniã Pãłãmĩ respondeu-lhe: Tudo bem! Faça como quiser.

Suniã Pãłãmĩ sabia que isso aconteceria, porque o seu Avô havia alertado antes de tudo e de todos. Os três irmãos eram todos sábios e poderosos. Eram filhos de Deus. A única diferença é que entre os quatro, o Suniã Pãłãmĩ não era qualquer filho de Deus. Tinha um diferencial entre seus irmãos menores pelo fato de ser irmão maior e por ser o principal responsável para criação e povoamento de grupos humano neste continente. Por isso, era único e incomparável aos seus irmãos menores; era o mais sábio e mais poderoso; era o duhpu (chefe, cabeça, irmão maior); era o irmão que conseguiu chegar perto de Deus (Uhtã Nehkt, Bułekó Nehkt), que recebeu de seu Avô mais bahseré (rituais de pajelança e benzimento).

Deus criou os quatros irmão porque pensou o seguinte: se eu criar apenas um, o trabalho de criação e povoamento dos humanos vai demorar muito. Criarei quatro irmãos, porque assim o trabalho será feito como mais rapidez e segurança.

Por isso, decidiu criar os quatro irmãos. Ao criar os deu poderes suficientes para enfrentar e superar as ameaças de outros seres espirituais da Terra. Os poderes eram seguintes: munõ omẽkodá (a força espiritual de tabaco e sua fumaça), yayałi omẽkodá (a força espiritual do ser yaì), bayiałi omẽkodá (a força espiritual do ser bayá), kũmũã̂̃ omẽkodá (a espiritual do ser kũmû). Com esses poderes, os quatros se tornaram poderosos e sábios.

O Ahsĩpoã Nehkt cumpriu com seus deveres de acordo com a ordem de seu Avô. O Yałebo também cumpriu com seus deveres: criou alimentos, espalhou diversas plantas frutíferas pelo continente; criou a maniva, o ipadu, o tabaco etc. Yałebo era o pai e o ser espiritual dos alimentos, do coração; era o deus que sabia bem os s rituais de pajelança e benzimento para prevenir e curar as doenças de pessoas, das roças, de manivas. Muĩpũ̂fi Pinõ foi o único que não obedeceu às ordens de seu Avô, logo, não cumpriu com sua responsabilidade.

Por essa razão, antigamente, em um grupo ou em uma comunidade sempre havia pajés especialistas para realizar os rituais de benzimento da habitação. Atualmente, com a ausência desses pajés, fica cada vez mais difícil realizar esses tipos de rituais, por isso os conflitos, as brigas e divisões são constantes entre os indígenas do Uaupés. 
Estava se aproximando o tempo de Yałebo construir a Casa da Emergência de Ohkó Diawi. Antes de iniciar a construção dessa Casa, Yałebo já havia construído outras Casas da Emergência espalhadas no território brasileiro. Ao iniciar a construção de Ohkó Diawi, convidou todos os animais terrestres, aquáticos e aves desta região do alto rio Negro para que o ajudassem, tais como: ohkó dahseá (tucanos da água), wayuá (macacos guaribas), yôłoã (inambus), wuaberi buhtoá, kahkałoá, ũmuã (japus), yeá (garças), uhkuãłã (macacos da noite), wĩhsoã (porcosespinho) etc. Cada um desses trazia um tipo de objeto para construção da Bahsawi. Esses seres também eram seres espirituais, não eram simplesmente animais como conhecemos hoje. Aliás, na visão dos pajés, são seres espirituais.

Quando Suniã Pãłãmĩ ainda esteve com seu Avô, O Uhtã Nehku disse-lhe: Depois que seu irmão Yalebo concluir a construção das Bahsawihseri (Casas Tradicionais), antes de viajar com a Canoa da Emergência, passe em todas as casas para realizar os rituais de pajelança e benzimento. Através dos rituais protegerá contra as ações de Waí-Mahsã, de bołi bahsoká (espíritos causadores de doenças, que são os mesmos Waí Mahsã).

Os bołi bahsoká eram das seguintes Casas da Emergência: Diasihti mahku, que fica situada no litoral de São Paulo, provavelmente nas montanhas; Uhtã Tuhtułi mahkũ, situada em Belém, estado do Pará; Dia Duiró Yukawi mahkt, localizada no encontro das águas ente rio Negro e Solimões, Manaus, AM; Temedawi mahkt, situada abaixo de Barcelos, baixo rio Negro, AM; Behkowi mahkz, Tapurucuara, hoje, Santa Isabel do rio Negro, AM; Kanẽpało mahkz, que fica localizada acima de Santa Isabel do rio Negro, AM; Nahpõbowi mahku, em São Gabriel da Cachoeira, AM; Ko'ohtu mahkt, próximo a comunidade da Ilha das Flores, foz do Uaupés, AM; Buhpowi mahkt, hoje, comunidade Trovão, no baixo Uaupés, AM; Õmãwi mahkt, situada acima da comunidade Trovão, baixo Uaupés, AM; Nẽcołołiwi mahkt, situada acima de Õmãwi, baixo Uaupés, AM) e Ohkó Diawi mahku (Ilha de Bela Vista, no Baixo Uaupés, AM).

Depois de cumprir as ordens de seu Avô, após realizar os rituais de benzimentos de habitações para proteger contra os Waí-Mahsã que poderiam vim atrás de Suniã Pãfãmĩ até Ohkó Diawi para empestear de epidemias os humanos, durante e após a criação, porém o Suniã Pãłãmĩ estava pronto para viajar com a Canoa da Emergência, porque o caminho estava protegido. Se ele não benzesse as Casas da Emergência, a sua viagem, com a Canoa da Emergência, tornaria muito perigosa para sobrevivência dos humanos, pois em todas as Casas existiam os Waí-Mahsã prontos para matar quaisquer seres que ousassem impedir suas ações contra os grupos humanos. Mesmo após os rituais, se houvesse qualquer vacilo e desatenção de Pamulĩ Pinõ, os Waí-Mahsã estavam prontos para atacar e matar os humanos. O Pamulĩ Pinõ sabia que os Waí-Mahsã dessas Casas não ousariam atacar os futuros humanos e sua embarcação, porque já havia benzido, por isso saiu de Diasihti Mahkãwi, ao longo do caminho parava, criava e povoava em diversas regiões.

O Suniã Pãłãmĩ viajou com a Canoa da Emergência para criar os humanos porque confiava nas palavras e na proteção de seu Avô. Até chegar em Ohkó Diawi, não foi fácil, porque mesmo assim teve que enfrentar os Waí Mahsã, no entanto como seguiu as orientações de seu Avô não teve tantos problemas. Só faltava uma pessoa para ajudar diretamente na criação dos humanos: o seu irmão Muĩpũ̂ĩ Pinõ. Como te falei anteriormente, tudo que seu Avô pressentiu e previu no começo, estava para acontecer em Ohkó Diawi.

O Muĩpũfĩ Pinõ não veio com seu irmão na Canoa da Emergência. Preferiu ficar em Diasihti Mahkãwi, atrás de Pamulĩ Sohpé(Porta da Emergência). Muĩpũ̃ĩ Pinõ, por ser o pajé dos rituais de benzimento das habitações também era o pai de muhsĩroã (grilos que devoram as folhas de caraná ou palha utilizadas para cobrir as Bahsawihserı). É com os muhsĩroã (grilos) que em poucos segundo devoraria a Bahsawi (Casa Tradicional) de Ohkó Diawi. Ele chegaria na hora que o Pamũfĩ Pinõ começaria beber caxiri e realizar quaisquer rituais de pajelança e benzimento. Esse era o plano de Muĩpũfĩ Pinõ para destruir o projeto de criação dos humanos do Uaupés. Apesar de ser seu irmão, apoderou-se de raiva e ódio, por isso queria acabar com o projeto de criação, que ele fazia parte.

Após longa e dura viagem, enfim, Pamũfĩ Pinõ chegou em Ohkó Diawi. Para ele a distância era mínima, porque era filho de deuses, só demorou um pouco porque teve que parar e entrar em outras Casas da Emergência para criar humanos, distribuir conhecimentos para outros povos. Durante a viagem entrou e passou em todas as Casas da Emergência que o seu irmão Yalebo construiu. Em cada Bahsawi, fechava as portas para que os Waí Mahsã não o seguissem. Depois de tudo isso, conseguiu chegar em Ohkó Diawi. Assim que chegou na Bahsawi, olhou para o céu e pensou em seu Avô, em Uhtã Nehkt, Bułekó Nehkt. Sentiu que estava tudo bem. 
O seu Avô já havia avisado o que aconteceria com ele em Ohkó Diawi. Em seguida, fumou o tabaco, comeu o ipadu e entrou em Ohkó Diawi. Viu que o seu irmão Yalebo, com os seus amigos, já tinham construídos a Pamulĩwi (Casa da Criação, Casa da Emergência), aonde criaria os grupos indígenas do Uaupés, realizaria rituais de pajelança e benzimento, e dividir os povos e as línguas indígenas dessa região. Quando entrou, viu a casa cheia de coxos de caxiri e potes de kahpi. Havia caxiri de todos os tipos: caxiri de milho, caxiri de batatas, caxiri de cará, caxiri de pupunha, caxiri de cana etc. A única coisa que ainda não tinha dentro daquela casa era o Kahpi, mas já tinha os potes preparados para encher a bebida só não tinha a planta e a bebida. Por isso, até naquele momento, o Kahpi ainda não existia. Kahpi só apareceria durante o ritual, no centro da Bahsawi (Casa Tradicional). Logo depois que entrou na casa, começou benzer todas as coisas que tinham sido preparadas pelo seu irmão Yałebo: a Bahsawi, os potes, os cochos, as bebidas, os instrumentos musicais etc. Ao meio dia, todas as bebidas estavam benzidas, porém, até às 15 horas, Pamũfĩ Pinõ ainda não tinha concluído o seu ritual de prevenção e proteção contra as possíveis ações dos Waí-Mahsã e seu irmão caçula, que estava se aproximando para destruir a grande Bahsawiré (Casa Tradicional) e Pamũ̃ĩwiré (Casa da Emergência) de Ohkó Diawi.

De dentro de Ohkó Diawi, Pamũfĩ Pinõ virou a cabeça e olhou até Diasihti Mahkãwi para ver se ocorria algo estranho, quando percebeu, viu que o seu irmão Muĩpũł Piñ vinha rapidamente na direção de Ohkó Diawi. Ele vinha como o vento, estava bem ornado com seus adornos que brilhavam de longe como a luz do sol. Estava muito bonito e brilhava dja, dja, dja, dja, dja, dja... Os demais seres que estavam em Ohkó Diawi também perceberam e viram e, logo, gritaram: o Muĩpũłĩ Pinõ já vem!

E o Pamũfĩ Pinõ nem virou para ver de novo. Só pensou o seguinte: esse meu irmão já vem! A única coisa que me resta é benzer a Casa para proteger de seus malzimentos ("sopros") para que esse louco não destrua a Casa da Emergência de Ohkó Diawi, que o projeto de meu Avô.

Enquanto o Pamũ̃ĩ Pinõ pensava e benzia, Muĩpũ̃ î̃ Pinõ se aproximava de Ñahpõpõ Mahkãwi (Casa da Emergência de São Gabriel da Cachoeira). Quando chegou em Nahpõpõ Mahkãwi, o reflexo de sua luz atingia diretamente aqui em Ohkó Diawi, dja, dja, dja, dja, dja, dja, dja...! Na hora que Suniã Pãfãmĩ viu, o seu irmão voava junto com o vento sem parar em nenhum lugar.

Como eram deuses, para eles, a distância entre Diasihti Mahkãwi até Ohkó Diawi, era como se não existisse, em pouco tempo estavam em lugares diferentes. Por isso, Muĩpũfĩ Pinõ se aproximava rapidamente de Ohkó Diawi. Antes de ele chegar em Ohkó Diawi havia passado em todas as outras Casas da Emergência construídas por Yałebo.

Esse fato pré-anunciava os conflitos, as brigas e as guerras que um dia aconteceria entre os pajés humanos. Nós, Tuyuka, chamamos as bołiwihseri (casas de doenças, dos Waí Mahsâ) de: uhtã wihseri (casas de pedra) buhpó wihseri (casas de trovão), sukałé wihseriré etc. Por exemplo, depois que o ba'asi benze o breu (wehté), benze o tabaco (mtnô) e se não ficar em resguardo (behti tiriri), corre sério risco de ficar doente, ser picado por jararacas, se envenena com o veneno dessas casas e, por isso, morrer. Outro significado desse fato é que os pajés de outros grupos malzeriam seus rivais pajés (yaíwa e ba'asera) para matar.

Essas casas eram cheias de doenças e malzimentos, como por exemplo: bołiti (doenças, tristezas), bołi wai ya (doenças de peixes remosos), bołi numiã numiãti (doenças de mulheres impuras), bołi yałigé (comidas impuras), bołi waikułá (doenças de animais), bołi munõ (tabaco causador de doenças), bołi patu (doenças de ipadu), bołi kahpi (doenças de kahpı), bołi mahsãkuła (seres espirituais inimigos dos humanos). Foi nessas Boli Wihseriré (casas de doenças) que o Muĩpũ̂̃̂ Pinõ entrou e passou, antes de chegar em Ohkó Diawi.

O Suniã Pãłãmĩ viu que seu irmão se aproximava do porto de Ohkó Diawi. Por isso, antes de ele subir até a Bahsawi, enquanto ele estava no porto, rapidamente, defumou a Casa de Ohkó Diawi dentro e fora com o pedaço de breu benzido (wehté bahserikimenâ). Logo depois que Pamũfĩ Pinõ concluiu o ritual de defumação da Casa e deixou o wehteki (pedaço de breu benzido) no centro da Bahsawi, chegou e saudou: sooooooo!

O objetivo de Muĩpũłĩ Pinõ era entrar direto até o final da casa e pegar o pote de kahpi para em seguida oferecer ao seu irmão, entretanto o Pamũfĩ Pinõ o impediu. Quando cortejou, Muĩpũ̂̃ Pinõ disse assim: Está tudo bem entre nós dois, meu irmão maior?

E o Pamũtĩ Pinõ respondeu-lhe: Está tudo bem! Mas você não vai entrar dentro desta casa. Fique na entrada da porta mesmo. Não dê nenhum passo a mais, porque ao contrário terei que agir de outra forma. 
Assim, impediu que entrasse até o final da Bahsawi e que destruísse a Casa. No começo, deixou-lhe ficar na porta em pé e nem convidou para sentar; só depois de algumas conversas que convidou para que sentasse no banco. Como te falei, Muĩpũfĩ Pinõ queria entrar até o final da Casa e pegar a panela de kahpi, que estava no último quarto, para em seguida beber e oferecer ao seu irmão. Se tivesse feito isso, a Casa teria desmoronado em poucos segundos, entretanto Muĩpũfĩ Pinõ estava pronto para destruíla.

O Suniã Pãfãmĩ sabendo das intenções de seu irmão, gritou: para destruir as obras de seus irmãos que, quando pedi que ajudasse na criação de grupos humanos, você desobedeceu? Eu sou seu irmão maior. Você não pode desobedecer ou querer ser maior que eu. Você pensou que eu era um qualquer, um fracassado que perdeu três grupos humanos e que mais uma vez perderia de novo, é isso? Você é o meu irmão caçula, o último. Tem que obedecer. Senta aí na porta. Não entre e nem saia sem a minha permissão. Fique sentado na porta. Aqui, na minha frente, não destruirá nada, porque para isso não têm poderes suficientes. Se tentar destruir essa Bahsawi não conseguirá, porque todas as suas tentativas serão anuladas.

Por isso, meu filho, até hoje existe e aparece muhsĩrõ (grilo) na porta de casas que não foram bem benzidas, que canta de noite: siri, siri, siri, siri, siri, siri, siri. O muhsĩrõ representa o Muĩpũfĩ Pinõ que ficou em pé na porta da Casa de Ohkó Diawi, pronto para destruir a Casa. O grilo significa que a casa e seus habitantes correm o risco de ficarem doentes e morrerem. Quando a gente percebe a presença desse grilo, as pessoas devem procurar o pajé ou um benzedor que conhece o ritual de benzimento para expulsar o grilo e proteger a residência.

Depois dessa ocorrência, em Ohkó Diawi, Suniã Pãłãmĩ se preparava para realizar o ritual da criação de grupos humanos; se preparava para criar nós humanos, criar as mulheres, criar os pajés e bayaroa, dividir as línguas e os grupos, transmitir os rituais de pajelança e benzimento e, no final, enviá-los em diversas regiões do Uaupés para que emergissem na superfície terrestre, em diferentes Casas da Emergência do Uaupés.

Os principais participantes da festa de criação foram todos os seres espirituais que colaboraram com a construção da Bahsawi de Ohkó Diawi, que eram milhares e milhares de seres espirituais. Durante a festa, em primeiro lugar, criou o pé de tabaco (mtnô), constituído de todas as espécies que conhecemos; em seguida criou o pé de kahpi, que também era constituído de várias espécies que conhecemos; criou os mahsãkuła (os pajés e mestre dos rituais de Jurupari); criou uma palmeira cheia de instrumentos de benzimentos (wõ de behsudá), que eram: wãtõsoã behsú wõ (palmeira de carajuru), ewá behsú wõ (...)21, dïi behsú wõ (palmeira de sangue), muhsã behsú wõ (palmeira de urucum). Em uma só palmeira existia tudo isso. Na palmeira de tabaco tinham as seguintes espécies: uma palmeira de saí munõ wõ (tabaco de peixe mandi-piroca), buhsaró munõ wõ (tabaco de peixe piroca), dihké munõ wõ (tabaco de sarapó). Em uma só palmeira existia tudo isso. Kahpidá idem: uhtã kahpida (pé de kahpi de pedra), dïi kahpidá (pé de kahpi de sangue), wãłõsoã kahpidá (pé de kahpi de carajuru), muhsã kahpidá (pe de kahpi de urucum), yãłĩ kahpidá (...), kahpi yãdá (...), kahpi cułidá nimiãtoahsubia (...), wihtõkahpiró (...). Todos esses kahpi estavam em um só pé. Até aí, só isso que fez.

Em seguida se preparava para criar e dividir a gente, dividir as línguas, os rituais de Jurupari e os rituais de pajelança e benzimento, transmitir os conhecimentos musicais e danças,

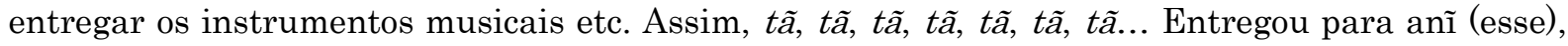
anĩ, anĩ, anĩ, anĩ, anĩ, anĩ... e no final disse o seguinte: vai ser assim.

Depois criou os humanos, porém no começo não nos enviou para emergirmos como humanos. Só tornamos humanos depois que emergimos nesta superfície terrestre. Entregou a gente aos Mahsãkułapułé (pajés e mestres dos rituais de pajelança e banzimento, e rituais de Jurupari), que foram responsáveis para conduzir a nossa emergência e sobrevivência na superfície terrestre. Foi através de Mahsãkuła (pajés, quase espíritos), que Suniã Pãłãmĩ realizou o projeto de criação, divisão e povoamento nesta região do Uaupés.

Nós, humanos, emergimos para este mundo por meio de Mahsãkuła (os ancestrais indígenas). Durante o ritual da criação, primeiro criou o Tukano (Dahseayz, em tuyuka); segundo, criou o Desano (Winãyz, em Tuyuka); terceiro, criou o Tuyuka (Dohkapuałayz); depois foi criando o Waimahku (Pira-tapuyo), Ahkotimahku (Wanano) etc; e por último, criou o Pawałayu (Tariano).

Nesse sentido, digo que o Pamulĩ Pinõ era - e é, sim - o chefe e criador de todos nós. Criou-nos sob a ordem de Deus (Uhtã Nehku) e continua criando através dos rituais de pajelança e benzimento que transmitiu e transmite aos yaíwa e ba'asera.

${ }^{21}$ (...) significa que não tem tradução em português. 
Depois de criar os humanos e escolher os chefes de cada grupo, pegou o pé de tabaco e os dividiu em pedaços: tak, tak, tak, tak, tak, tak, tak! Em seguida pegou o kahpida e também dividiu em pedaços para entregar aos chefes dos grupos: tak, tak, tak, tak, tak, tak, tak! Nós, Tuyuka, pegamos as coisas das pontas, das extremidades. Fez a mesma divisão com o behsu wõ e com o patu: tak, tak, tak, tak, tak, tak, tak! Só isso!

Depois que todos os chefes de grupos indígenas foram criados e escolhidos, que receberam o tabaco e o kahpi e beberam a kahpi, enquanto estavam sob o efeito alucinógeno da bebida se preparou para criar a primeira mulher a partir de um Mahsãkułyu, que se chamava Kahpi Suniã Mahkõ (filha de Kahpı); criar e dividir as línguas e transmitir os conhecimentos tradicionais.

O igarapé Diłiya (igarapé de Sangue) fica localizado abaixo de Mitú, alto Uaupés, Departamento del Vaupés, Colômbia. Foi naquele igarapé que a Kahpi Suniã Mahkõo, depois que foi criada em Ohkó Diawi, permaneceu grávida do filho que seria de Kahpi Suniã, apenas durante o ritual de criação dos humanos. Ela era a filha de Kahpi Suniã. Chamava-se Kahpi Suniã Mahkõ. Enquanto Suniã Pãłãmĩ realizava a festa, a Kahpi Suniã fez o parto. Ela só retornou à Ohkó Diawi, ao meio dia, após o parto.

Na hora do parto, no igarapé Dïia (Sangue), em pouco instante a Casa de Ohkó Diawi ficou inundada de kahpi que, na verdade, era o sangue do parto, porém para os pajés (mahsãkuła) o sangue era a bebida kahpi. Daí em diante, os pajés (yaíwa, ba'asera, mahsãkłła yaíwa), os mestres de músicas e danças tradicionais (bayaroa), e os chefes de grupos indígenas, que naquele momento ainda eram seres sobrenaturais, ficaram embriagados ao beberem kahpi. Apenas o Suniã Pãłãmĩ e seu irmão Yalebo estavam totalmente cientes, porque eram deuses. Foi naquele momento que Suniã Pãfãmĩ dividiu as línguas, criou e dividiu as mulheres para cada grupo.

O parto de Kahpi Suniã Mahkõ foi o primeiro que antecedeu os partos que ocorreriam entre as mulheres indígenas do Uaupés. Até aquele instante, além de Kahpi Suniã Mahkó, não existia nenhuma mulher humana. Só existiam homens. Para criar as mulheres, Suniã Pãłãmĩ escolheu alguns pajés (mahsãkula yaíwa), que estava sob o efeito de kahpi e, em seguida, pegou o munõ puhtiri senerõ (suporte de tabaco), encostou entre as pernas de alguns deles, transformando-os em mulheres. Foi assim que fez a vagina da mulher, da qual serviria para realizar o parto. Assim, aos poucos, enquanto estavam sob o efeito de kahpi, alguns dos mahsãkula yaíwa se transformaram em mulheres, as primeiras mulheres. E através do efeito da bebida de kahpi que os diferentes grupos reconheceram os seus parentes próximos, seus primos e os que seriam seus cunhados.

Essa história imemorial que aconteceu em Ohkó Diawi, prova que os povos indígenas do Uaupés foram criados nesse lugar sagrado. Foi assim que aconteceu a nossa origem indígena, a divisão das línguas, dos rituais de pajelança e benzimento, a divisão e distribuição de ipadu, de tabaco, de kahpi, a divisão dos rituais de Jurupari etc. Todos esses grupos receberam os mesmos conhecimentos tradicionais. Por isso, hoje, ninguém, nem o Tukano, nem o Tuyuka ou de quaisquer outros povos do Uaupés pode dizer que para nós é assim e para vocês não... E não é assim, não para quem é sábio ou que ouviu falar essa história. Antes de falar contrário, é necessário conhecer com profundidade a nossa história de origem, porque ela é o fundamento da nossa existência, dos nossos rituais de pajelança e benzimento e da nossa vida como povos.

A criação dos povos do Uaupés ocorreu para que um dia alguém falasse o seguinte: você acha que é assim mesmo com a sua língua, porque também digo que é a mesma coisa falando com o meu idioma. É aqui que quem não conhece bem essa história de origem, acaba sendo dominado por pessoas que acham que conhecem mais do que o outro ou por quem se consideram chefes. Aí o indivíduo fica com vergonha e com medo, porque não conhece bem a história ou porque também seus pais não eram sábios e, logo, não faz parte de uma linhagem tradicional de pajés, enfim, acaba dizendo assim: Tudo bem! Vocês estão certos. Para vocês deve ser assim mesmo. Para mim, os meus pais não eram sábios como vocês. Eram à-toas. Por isso, não sei direito.

Na hora que você discute com outros sábios, nunca deve demonstrar insegurança e dizer o seguinte: É, eu não sei direito. E nem achar que é melhor que os outros, dizendo assim: ninguém pode me dizer, nem ontem, nem hoje e nem amanhã, que sou assim, sou o melhor, sou chefe, sou o primeiro, sou cabeça, sou o mais importante. Nem o Peogu (Maku). O Peogz também tem a mesma origem, portanto tem a mesma história, o mesmo criador e os mesmos conhecimentos tradicionais. A história é a mesma. A história parece ser diferente, quando as pessoas contam em suas línguas. Até aqui, meu filho, a nossa origem foi assim que aconteceu.

O Pamulĩ Pinõ, depois de Ohkó Diawi, viajou para outras regiões, onde continuaria a criação de novos povos, por exemplo, rumou para o rio Negro, Içana etc. 
Depois que terminou o ritual da criação em Ohkó Diawi, levou os chefes de cada povo para mostrar as Casas da Emergência, no rio Uaupés, Tiquié, Papuri, onde emergiriam com seus grupos. Na volta, entrou na Canoa da Emergência (Pamłtĩ Yohkosoró), deu meia volta na Casa de Ohkó Diawi e partiu para outras regiões.

A Casa da Emergência de Ohkó Diawi, foi o lugar que Suniã Pãłãmĩ projetou para criar e povoar alguns grupos indígenas. Já antes havia planejado o número de povos que povoaria na região do Uaupés. Depois que a Canoa da Emergência foi embora, os grupos humanos também viajaram para emergir em várias Casas da Emergência, as quais estão disseminadas e materializadas ao longo do Uaupés e seus afluentes. Cada povo estava acompanhado por outros povos que seriam seus primos: Desano, Tukano, Bałá, Pãnẽroã, Aůhĩrã, Edułiá, Kawiriá, Yahuana etc. No final, todos os grupos se espalharam [...].

Para nós, Tuyuka (Dohkapuała), o Pamulĩ Pinõ nos levou acompanhado por YUEI YUHKUEÓ (chefe dos Tuyuka) e o BOHTEA (chefe dos Tukano) até à Cachoeira de Suniã Poeá, na região onde habitavam os Wanano, Tariano e outros. Por isso, Aí é a nossa Pamulĩwi (Casa da Emergência), a Cachoeira de Suniã Poeá, também chamada de cachoeira de Jurupari, atualmente localizada no território colombiano. Foi nessa casa, que nós, Tuyuka, emergimos para esta superfície terrestre, isto é, saímos da vida espiritual para este mundo natural com todos os conhecimentos que recebemos de Suniã Pãłãmĩ.

O YUEI YUHKUEÓ era um pajé [mahsãkulayaí e duhpu (chefe)], ser espiritual do povo Tuyuka. O BOHTEA também era um pajé (mahsãkulayai), duhpu (chefe) do povo Tukano. Foram esses que nos conduziram pelo rio Uaupés até a Cachoeira de Suniã Poeá, localizado no alto Uaupés, acima da cidade de Mitú, Departamento del Vaupés, Colômbia. Assim, para nós, Tuyuka (Uhtãpinõponâ), lá é o nosso chão, nossa terra, a nossa Casa. Em Tuyuka se diz: uhtã misá, uhtã pamulĩ yehpá, uhtã pamułĩ kumułĩ, uhtã pamułĩ nuhłĩ, uhtã pamułĩ wiałé.

Aliás, depois da viagem de reconhecimento de lugares da Emergência, Suniã Pãfãmĩ e os chefes dos povos indígenas retornaram à Ohkó Diawi para o ritual de enviou. Após o ritual, aí sim, como já sabiam onde cada povo deveria emergir, partiram rapidamente: dja, dja, dja, dja, dja, dja, dja..., forma embora. Todos se mandaram. Os Desano foram emergir em Buhpó Wi (Casa do Trovão), no igarapé Abiu, afluente do rio Papuri, região do Uaupés; os Barasano viajaram para a cabeceira do Tiquié; os Tukano e Makú viajaram aqui para a cachoeira de Ipanoré (médio Uaupés); e nós, Tuyuka, fomos direto para a Cachoeira de Jurupari, alto Uaupés. Assim, todos os povos se espalharam.

Os Tariano foram os últimos que foram criados e surgiram na terra. Eles não emergiram como os demais povos criados em Ohkó Diawi. Por isso, os Tariano não podem ser considerados como Pamulĩ Mahsã (povo que emergiu), porque não são. Os Tariano são filhos do Trovão, desceram do céu, através do raio de trovão.

Entre a Diasihti Mahkãwi até Ohkó Diawi, nesse pedaço, Pamutĩ Pinõ já havia criado e povoado outros grupos humanos, como por exemplo, na região de São Paulo, Nordeste e outras regiões povoou vários grupos indígenas, por isso, existem diferentes indígenas. Nós fomos uma das últimas criações de Pamułĩ Pinõ. Meu filho, assim é a nossa história de origem.

Depois que chegaram nas Casas da Emergência, cada chefe de grupos, ajudou emergir seus descendentes para este mundo terreno, através da força espiritual e rituais de pajelança e benzimento que recebeu de Suniã Pãłãmĩ. O Suniã Pãłãmĩ, depois de criar e realizar o ritual de envio, ficou em Ohkó Diawi. Não acompanhou mais as viagens dos povos, porque confiava na sabedoria dos chefes que criou, preparou e enviou.

Nós, Tuyuka, também fomos embora direto para a nossa Casa da Emergência, em Suniã Poeá. O nosso chefe, YUEI YUHKUŁÓ, levou-nos dentro de sua força espiritual. Os Tukano emergiu na cachoeira de Ipanoré, localizado no baixo Uaupés, os Desano emergiu na região do Papuri e outros grupos também emergiram em suas Casas da Emergência.

Antes de chegar nas nossas Casas ds Emergência, os grupos já tinham suas divisões hierárquicas: irmãos maiores e menores, chefes e "servos"; cada subgrupo tinha um chefe acompanhado de seus servos. Após a emergência de grupos indígenas, os chefes de todos os povos (Tukano, Desano, Wanano, Tatuyo etc) retornaram para Ohkó Diawi, aonde embarcaram na Canoa da Emergência e foram embora com Suniã Pãłãmĩ, porque eram espíritos e não totalmente humanos, inclusive o nosso chefe, YUEI YUHKUモÓ, também foi embora. 
Nessa história, é interessante entender duas coisas que corroboram para este estudo. A primeira, é que os povos Tuyuka e Tukano estão totalmente interligados com os demais grupos do Uaupés e, por isso, os conhecimentos que vivenciam também são vivenciados pelos demais povos da região. A segunda, é que os indígenas do Uaupés foram criados na Casa da emergência de Ohkó Diawi, no Baixo Uaupés, por Suniã Ñehkt; ${ }^{22}$. O Suniã Pãłãmĩ ou Pamutĩ Pinõ, junto com seus irmãos - Ãhsĩpoã Yuhkt, Yałebo e Muĩpũtĩ Pinõ -, após atravessar o oceano Atlântico na Canoa da Emergência, criou e povoou vários grupos humanos deste continente sob a ordem de Suniã Nehktt. (ver Mapa 2).

Depois da emergência nenhum grupo permaneceu por muito tempo nos lugares de origem e da emergência. A maioria migrou para outras regiões em busca de alimentos (peixes e caças), de terra fértil e de terra alta com belas paisagens. Por exemplo, os Tuyuka migraram da cachoeira de Jurupari, no alto Uaupés, Colômbia, para o alto Tiquié e Caño Inambu (no alto Papuri). E, os Tukano também migraram da cachoeira de Ipanoré, baixo Uaupés, para outras regiões brasileiras e colombianas.

O processo de migração desses povos gerou diversos conflitos intertribais que culminou na extinção de alguns grupos indígenas e línguas. Provocou também, o domínio político e cultural de alguns grupos e subgrupos, e o domínio de territórios "alheios". Assim, atualmente, por exemplo, temos a comunidade de Pari-Cachoeira dominada pelos Tukano, a comunidade de Iauaretê com predomínio Tukano e Tariano, Taracuá dominada pelos Tukano, Trinidad dominada pelos Tuyuka. Segundo Avelino Dutra (2007) e todos os sujeitos da nossa pesquisa, os Tukano e Tuyuka que hoje habitam o Tiquié não são originários desse rio, mas, sim, são originários do Uaupés, porque emergiram nas cachoeiras de Ipanoré e Jurupari, respectivamente, ambos situados ao longo desse rio. Os indígenas que emergiram no Tiquié são outros (ver capítulo 4 desta dissertação).

${ }^{22}$ Hoje, a Casa da Emergência de Ohkó Diawi está materializada numa ilha que se chama em Tuyuka ilha de Ohkó Diawi, situada em frente as comunidades Uriri e São Tomé (baixo Uaupés), ELEV: $70 \mathrm{~m}$ N 00 10'53.3" W $067^{\circ} 57^{\prime} 24.3^{\prime \prime}$. 
Após milhares de anos de presença indígena no Uaupés, os portugueses e espanhóis conquistaram a região sem perguntar se os povos que aí habitavam permitiam ou não a entrada deles. Expulsaram os indígenas e conquistaram a região com a sua força bélica e seus princípios religiosos, e após a invasão tentaram exterminar os grupos e destruir suas tradições, no entanto não conseguiram, porque os indígenas resistiram às matanças e prisões, por isso existem e vivem até hoje, com suas terras demarcadas e reconhecidas pela lei maior da Constituição brasileira. Para conseguir esse reconhecimento legal travaram longas batalhas políticas com o Estado brasileiro, principalmente com os militares, políticos e empresas mineradoras, que tinham interesses em integrar os indígenas na sociedade nacional.

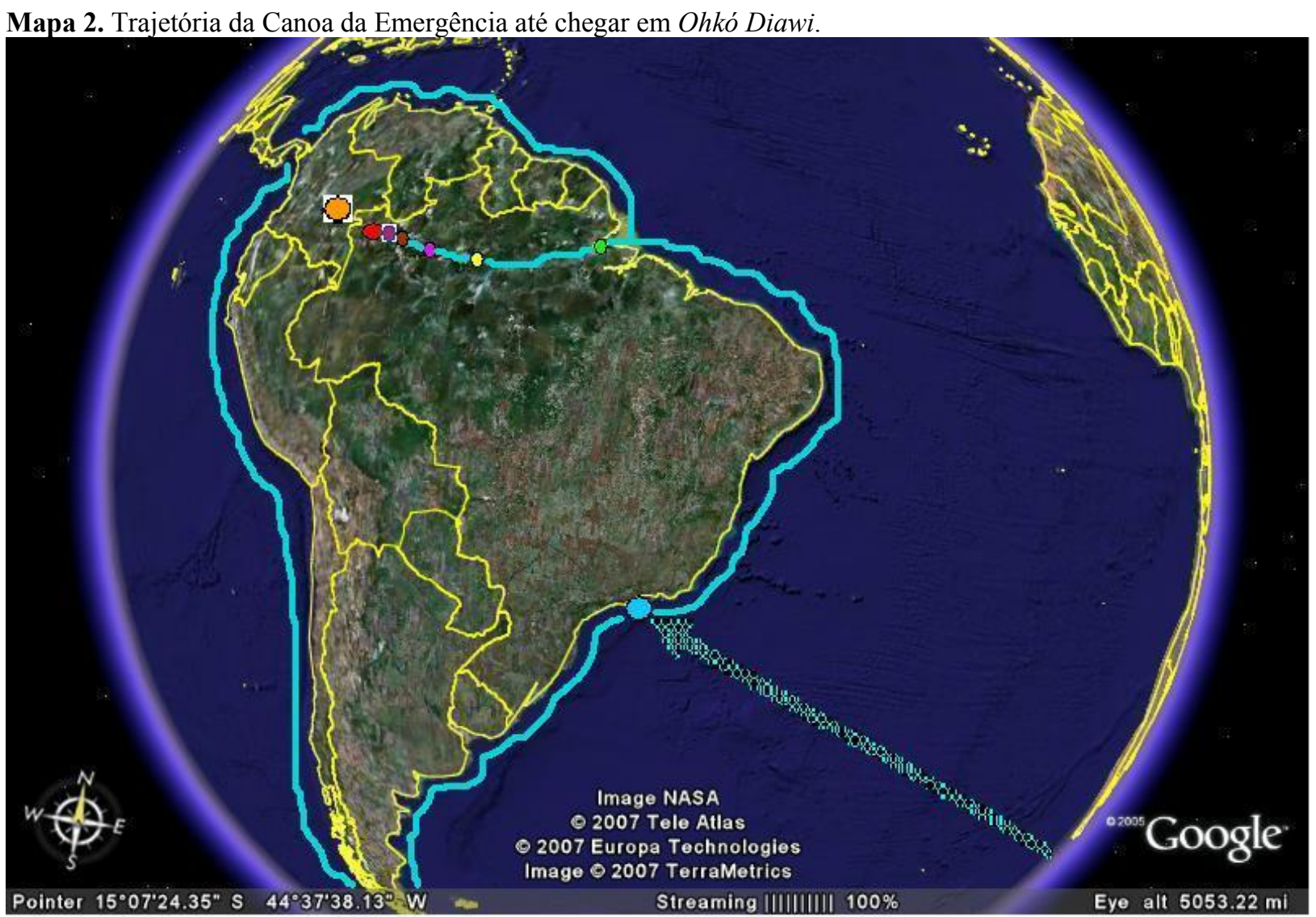

Fonte: adaptado por autor de Imagem NASA/Google Earth, 2007.

- Casa da Emergência de Diasihti Mahkãwi - Casa do Sul, São Paulo, SP

- Casa da Emergência de Uhtãtuhtuwi - Casa de Belém do Pará, PA.

- Casa da Emergência de Dia Yukawi - Casa de Manaus, AM.

- Casa da Emergência de Temẽdawi - Casa situada próximo de Carvoeiro, rio Negrgro, AM.

- Casa da Emergência de Behkowi - Casa de Tapurucuara ou Santa Isabel do Rio Negro, AM.

- Casa da Emergência de Ñãhpõpõwi - Casa de São Gabriel da Cachoeira, AM. 
- Casa da Emergência de Ohkó Diawi - Casa da Ilha de Ohkó Diawi, baixo Uaupés, AM.

- Casa da Emergência de Suniã Poeá - Casa da Emergência do grupo Tuyuka, alto Uaupés, Colômbia.

\subsection{História do Movimento Indígena do Rio Negro e a demarcação de terras}

A história do movimento indígena do rio Negro, iniciou formalmente no início da década de 70, na comunidade indígena de Pari-Cachoeira, através de lideranças Tukano. E, culminou em dois dos principais eventos político para a organização atual do movimento indígena, a saber: em 1987, a fundação da Federação das Organizações Indígenas do Rio Negro; e, em 1998, a demarcação de cinco Terras Indígenas do Alto Rio Negro. A história tem uma trajetória constituída de aspectos positivos e negativos. A pergunta que ajudará a delinear a nossa reflexão geral é a seguinte: Quais foram os principais impactos e os principais efeitos da luta política entre o Estado brasileiro e os indígenas do Uaupés?

Desde o início, o objetivo principal do movimento indígena, foi lutar junto ao governo brasileiro pela demarcação de uma terra indígena contínua, onde pudessem construir a autonomia cultural para fortalecer a rede de relações de convivência familiar com os seus parentes brasileiros e colombianos do Uaupés. Nesse processo de embates políticos com o Governo brasileiro, os indígenas contaram com o apoio de alguns agentes da sociedade envolventes, principalmente Missionários da Igreja Católica, CIMI, FUNAI, ISA etc.

\subsubsection{Da origem à Fundação da FOIRN}

A história indígena do rio Negro pela demarcação das terras ${ }^{23}$, originou-se na comunidade indígena de Pari-Cachoeira, alto Tiquié, Uaupés, no dia 16 de agosto de 1972.

\footnotetext{
${ }^{23}$ Ver Mapa 2.
} 
Antes desse período, entre 1940 a 1970, as comunidades indígenas do Tiquié, assim como as demais localidades do Uaupés e rio Negro, viviam sob o domínio cultural, político e religioso de padres e freiras da Congregação Salesiana ${ }^{24}$. Naquela época, quase todos os missionários salesianos que atuavam nas missões da região, eram italianos, espanhóis, alemães etc. Alguns eram ex-combatentes da Segunda Guerra Mundial ${ }^{25}$.

Entre os missionários salesianos, existiam alguns que não comungavam com as práticas da evangelização e, por isso, tentavam trabalhar de forma diferente, respeitando e valorizando as tradições indígenas ${ }^{26}$. Por exemplo, alguns se destacaram pelas suas iniciativas de terem compostos músicas para celebrações religiosas, que atualmente são entoadas nas missas nas comunidades indígenas do alto rio Negro, onde falam as línguas Tukano e Língua Geral, tais como: Pe. Antônio Scolaro, Pe. Eduardo Lagório (ambos italianos) e Pe. Afonso Casas Nuevas (espanhol). Em Pari-Cachoeira, foi a partir das iniciativas de alguns desses missionários que o movimento indígena se originou. Destacamos, assim, entre os pioneiros missionários salesianos do movimento indígena do rio Negro, que criaram a associação União Familiar Animadora Cristã (UFAC), o Pe. Antônio Sacolaro e Irmã Dirce. ${ }^{27}$

Entretanto, nem todos os missionários católicos (salesianos ou diocesanos) incentivavam a reivindicação indígena para a demarcação das terras indígenas, porque alguns eram amigos de coronéis, brigadeiros e comandantes de militares. Os poucos missionários que tentaram lutar ao lado e pelos interesses dos povos indígenas eram preteridos e mal vistos por outros missionários da mesma congregação e missão, ou diocese. A maioria dos missionários não queria perder amizade com os militares, porque viajavam e transportavam seus mantimentos nas aeronaves com toda liberdade. Naquela época a Funai já existia, porém a sua

\footnotetext{
${ }^{24}$ LANA, Luiz Gomes (1993). Ver anexo 1.

${ }^{25}$ Entrevista concedida por Pedro MACHADO, no dia 23 de agosto de 2004, durante a viagem a Pari-

Cachoeira, no período de campanha eleitoral.

${ }^{26}$ Ibidem, 2004.

${ }^{27}$ Ver Anexo 1.
} 
atuação não respondia os interesses dos indígenas e, sim, os interesses dos Governos militares. $^{28}$

A União das Famílias Cristãs (UFAC), criada em 1972, em Pari-Cachoeira, foi a primeira organização indígena na região do rio Negro. Foi criada para fortalecer os princípios cristãos na região do Tiquié frente a expansão das igrejas evangélicas na região. Os coordenadores e assessores eram os próprios missionários que controlavam e ditavam os objetivos da organização com o apóio de alguns catequistas Tukano de Pari-Cachoeira, principalmente da família Castro, através do Sr. Henrique Castro, que aos poucos foi se destacando como um dos principais líderes da comunidade. ${ }^{29}$

O Sr. Henrique Castro tinha apoio total de missionários salesianos e seus aliados militares para ser chefe da comunidade, no entanto com o passar dos anos, o seu poder político entrou em declínio com o surgimento de quatro irmãos (Pedro Machado, Benedito Machado, Carlos Machado e Cecília Machado) que se destacaram como novos líderes Tukano (também ex-alunos salesianos). Os novos líderes que surgiram eram contrários a interferência de quaisquer padres e de freiras nas questões que se tratavam da vida política, social e cultural dos povos indígenas do Tiquié. Além deles tinha Álvaro Sampaio, que era primo dos quatro, já citados, e que se tornaria o pai do movimento indígena do rio Negro. Os quatros jovens eram descendentes da família Machado, considerada a família nobre dos Tukano de PariCachoeIra. Isso gerou desentendimento entre os próprios Tukanos da comunidade pela disputa do poder político. De um lado os da família Castro, apoiados pelos padres e freiras, e de outro lado, os Machado rotulados como rebeldes e, assim, a UFAC foi extinta ${ }^{30}$.

A existência da UFAC teve aspectos positivo e negativo. Entre os aspectos positivos destacamos quatro pontos que contribuíram para a transformação política, cultural e social dos indígenas de Pari-Cachoeira, tais como: 1) os missionários que decidiram lutar ao lado dos

\footnotetext{
${ }^{28}$ MACHADO, op. cit., 2004.

${ }^{29}$ Ibidem, 2004.

${ }^{30}$ Ibidem, 2004.
} 
indígenas ajudaram a abrir a mente de novas lideranças que organizaram novas associações para melhor se adaptarem às mudanças que começavam atingir diretamente na organização social e política das comunidades indígenas do Tiquié; 2) através de internatos, os missionários contribuíram na formação intelectual de novas lideranças, as quais tiveram novas visões e coragem para lutar pelos direitos indígenas contra os interesses da própria Igreja Católica e do Estado brasileiro; 3) as mulheres indígenas organizaram um clube de mães, através do qual trabalharam o artesanato, corte costura e tecelagem; 4) Em 1979, a parceria entre alguns missionários e lideranças indígenas de Pari-Cachoeira gerou o reconhecimento da FUNAI a "ocupação indígena de três áreas contíguas: Pari-Cachoeira, Iauaretê, Içana-Aiari" e, nesse mesmo ano, os Tukano de Pari-Cachoeira encaminharam ao Governo Federal a "proposta para a delimitação do Alto Rio Negro como área única”.

Entre os aspectos negativos destacamos que os objetivos da UFAC respaldavam mais os interesses e o fortalecimento da presença salesiana em Pari-Cachoeira; por isso, através da UFAC, os missionários conseguiram "controlar" as discussões da política indígena durante uma década, até que o surgimento de novos líderes da comunidade rompessem o domínio religioso.

No dia 04 de abril de 1983, os novos líderes que extinguiram a UFAC, fundaram a União das Comunidades Indígenas do Rio Tiquié (UCIRT), com sede em Pari-Cachoeira. ${ }^{31}$ A nova organização, genuinamente indígena, constituía-se de coordenadores e assessores indígenas que não aceitavam mais a interferência missionária. Muitas vezes, os padres que tentavam participar nas Assembléias Gerais eram expulsos dos eventos. Os indígenas argumentavam que estavam cansados da intromissão dos missionários e não precisavam mais de suas opiniões para deliberar sobre o rumo de Pari-Cachoeira ${ }^{32}$.

\footnotetext{
${ }^{31}$ Ver anexo 1.

${ }^{32}$ Nessa época embora com apenas 9 anos de idade, lembro muito bem das brigas que ocorriam no centro comunitário que se chamava UFAC, quando os padres eram agarrados pelas golas das camisas e empurrados para fora da reunião. Uma vez um padre paulista até falou que quando ele ficava nervoso e bravo, cada mão dele
} 
Outros Tukano (catequistas, aliados de missionários) não aceitaram e nem cederam facilmente a emancipação de novos líderes da comunidade, por isso tentaram por vários anos denegrir as ações de seus parentes que consideravam oponentes políticos. Enquanto que os Tukano se degladiavam para ocupar o poder de chefia do distrito de Pari-Cachoeira, as lideranças de outras comunidades do Tiquié apenas podiam participar de eventos e discutir sobre as questões referentes aos problemas de suas povoações e apoiar os interesses coletivos do distrito. Quando se tratava de ser chefe ou líder Geral de Pari-Cachoeira, não podiam, só podiam ser coadjuvantes, por duas razões: os Tukano não aceitavam que tornassem líderes gerais; os Tukano não aceitavam serem comandados por outros povos, porque se consideravam os mais importantes que os demais.

A extinção da UFAC fortaleceu a liderança de cinco jovens indígenas que transformaram Pari-Cachoeira no principal centro de discussões sobre a política indígena do rio Negro. Além daqueles já citados, também se destacaram outros Tukano, tais como: Manoel Fernandes Moura, Gabriel Gentil, Carlos Eugênio Machado, Alfredo Fontes, Quintino Gentil, Brasilino Barreto etc. Foi através deles que diversas assembléias foram promovidas em Pari-Cachoeira e no alto rio Negro, quando surgiu a idéia de lutar pela demarcação de uma terra indígena contínua que garantisse a sobrevivência de futuras gerações e para a melhoria da qualidade de vida das comunidades indígenas. Enquanto ocorria transformação política em Pari-Cachoeira, os indígenas de Iauaretê, Taracuá, Assunção do Içana e São Gabriel da Cachoeira almejavam o progresso e o desenvolvimento econômico de suas comunidades nos molde do mundo ocidental. Ou seja, "diziam que não eram mais índios, porque estavam virando brancos". 33

Segundo Pedro Machado (2007):

pesava $5 \mathrm{~kg}$, mas, não adiantou nada sua tentativa de intimidar as lideranças indígenas, foi expulso do mesmo jeito.

${ }^{33}$ MACHADO, op. cit. 2004. 
Um dia, o pessoal de Iauaretê soube que, os líderes de Pari-Cachoeira reivindicavam, junto ao Governo Federal, a demarcação de uma terra contínua na região do Uaupés. Sabendo dessa notícia ficaram bravos e ironizaram dizendo o seguinte: Puxa! Como esse pessoal de PariCachoeira querem ser índios. Como eles não têm vergonha. Nós é que não queremos ser mais índios. Agora nós estamos virando brancos. Naquela época os Tariano e os Tukano de Iauaretê não se consideravam mais índios. Falar de índios para eles, era a mesma coisa que insultar. Por isso, no começo os de Iauaretê foram contra a demarcação de uma terra indígena na região, pois acreditavam que essa idéia era retrógrada. Outros povos da região também não conseguiam entender nada o que, nós, de Pari-Cachoeira queríamos. Quase todos os povos do alto rio Negro achavam que éramos doidos e diziam que queríamos vender as terras da região. ${ }^{34}$

A década de 80 foi o período que tivemos transformações políticas intensas na região do alto rio Negro. A semente da luta pela demarcação de uma terra contínua do alto rio Negro estava lançada em Pari-Cachoeira, porém precisava que outros parentes da região do Uaupés participassem e compreendessem a importância dessa luta. Ao longo da década, aos poucos, as lideranças de Iauaretê, Taracua e Içana começaram participar diretamente de eventos, e, com isso, também entender que era necessário lutar em conjunto para garantir a demarcação de suas terras, caso contrário, as gerações futuras corriam o risco de não terem o mesmo usufruto territorial. ${ }^{35}$

Três eventos históricos do movimento indígena do rio Negro marcaram a década de 80: a I Assembléia Geral dos Líderes Indígenas do Alto Rio Negro (1984); a II Assembléia dos Líderes Indígenas do Alto Rio Negro, (1987); e a criação da Federação das Organizações Indígenas do Rio Negro (FOIRN).

A I Assembléia Geral dos Líderes Indígenas do Alto Rio Negro foi realizada no Ginásio das Missões, em São Gabriel da Cachoeira, AM, nos dias 30 de abril a 04 de maio de

\footnotetext{
${ }^{34}$ Ibidem, 2004.

${ }^{35}$ Ibidem, 2004.
} 
1984. A assembléia foi liderada pelos cinco Tukano de Pari-Cachoeira (Álvaro Fernandes Sampaio, Pedro Fernandes Machado, Benedito Fernandes Machado, Carlos Fernandes Machado e Manoel Fernandes Moura). ${ }^{36}$ De acordo como Pedro Machado (2007), "na I Assembléia os Baniwa e os Kuripako não participaram do evento, porque naquela época nem sabiam o que estava acontecendo na região em termo da luta e da política indígena. O pessoal de Iauaretê foi convidado, porém os principais líderes ignoraram a luta, pois diziam que eram brancos e não mais índios, e, para eles, a nossa luta representava atraso em relação ao progresso $^{37}$. Na verdade, foram os padres de Iauaretê que incutiram neles essa idéia de progresso e atraso". Além de alguns indígenas do alto rio Negro, participaram os nãoindígenas convidados, como por exemplo:

"O Comandante da $1^{\text {a }}$ Companhia do $1^{\circ}$ Batalhão de Engenharia e Construção, representado pelo Tenente Veronildo Lemos de Oliveira; Bispo Diocesano Dom Miguel Alagna, representado pelo Pe. Waldecir Vieira; Prefeito Municipal de São Gabriel da Cachoeira, Sr. Antônio Evangelista Batista da Silva; chefe da FUNAI, Sr. José Ribamar Caldas Lima Filho; Presidente da Câmara Municipal, Sr. Manoel Soares; Diretor de Campos Avançado do Projeto Rondon, Dr. Fernando Mota; Agente do IBDF, Vereador Rodolfo Otéro Gonçalves e Sr. Jaime Edward Curtis, Chefe das Missões Novas Tribos [...]". ${ }^{38}$

Os objetivos da assembléia eram os seguintes:

[...] expor na reunião os problemas que afligem o povo indígena da área do Município de São Gabriel da Cachoeira para que juntos, unidos, encontrar soluções; saídas para melhor progredirmos, seja na vida social, econômica, política indígena nacional para irmanarmos humanamente sem choques com a civilização da Sociedade Banca. Fazermos juntos nossos estudos, nossas reivindicações coerentes e conscientes perante as autoridades constituídas para conquistarmos o nosso progresso. Não vamos só pedir, cobrar, exigir, porém, cooperar, retribuir, estudar junto com as autoridades para chegarmos ao único objetivo que é: a promoção humana do povo indígena do Alto Rio Negro e suas adjacências. ${ }^{39}$

A II Assembléia dos Líderes Indígenas do Alto Rio Negro foi realizado em 1987, mais uma vez, no Ginásio das Missões, na cidade de São Gabriel da Cachoeira, AM. O evento foi

\footnotetext{
${ }^{36}$ Ver anexo 2.

${ }^{37}$ MACHADO, op. cit., 2004.

${ }^{38}$ Benedito Fernandes MACHADO, 1984, p. 01.

${ }^{39}$ Ibidem, 1984, p. 01.
} 
coordenado pelos líderes Tukano de Pari-Cachoeira com o apoio financeiro do Conselho de Segurança Nacional (CSN). Desta vez, participaram todos os principais representantes dos distritos (Pari-Cachoeira, Iauaretê, Taracuá, Assunção do Içana, Cucui, Maturacá e os Barés de São Gabriel da Cachoeira). Também participaram vários representantes da sociedade envolvente, de instituições governamentais (CSN, FUNAI, políticos), religiosas (católicas e evangélicas do município de São Gabriel da Cachoeira) e representantes da empresa mineradora Grupo Parapanema. ${ }^{40}$

A Federação das Organizações Indígenas do Rio Negro (FOIRN) foi criada no final do evento da II Assembléia dos Povos Indígenas, em 1987. Segundo Pedro Machado (2007), “a criação de uma Federação não estava nos planos das lideranças. A criação foi decidida antes de encerramento do evento, em cima da hora decidimos criar uma Organização que representasse os interesses de todos os povos indígenas do alto rio Negro: a FOIRN". Ela foi criada para: 1) lutar pela demarcação e homologação de terra indígena contínua do alto rio Negro; 2) melhorar através de projetos econômicos as condições de vida das comunidades indígenas; 3) preparar recursos humanos em diversas áreas acadêmicas para a autonomia territorial e sustentabilidade indígena. ${ }^{41}$

Até o início da II Assembléia não existia nenhuma Ong ou Universidade apoiando as nossas reivindicações indígenas. A primeira Ong que apareceu logo depois que a FOIRN foi criada, foi o Instituto Socioambiental (ISA). Surgiu de uma hora para outra, através do Sr. Carlos Alberto Ricardo que não perdeu tempo em criar parceria junto com a nova organização indígena. Na verdade, ninguém sabia o que era ISA, depois foram chegando outras. Na verdade, o que se sabe é que as Ong perceberam rapidamente que as populações indígenas do

\footnotetext{
${ }^{40}$ Benedito Fernandes MACHADO, 1987, p. 01.

${ }^{41}$ MACHADO, op.cit., 2004.
} 
rio Negro seriam fontes para eles ganharem dinheiro, porque para a opinião pública nacional e internacional tudo isso era uma novidade. ${ }^{42}$

A Assembléia era constituída de dois grupos indígenas: de um lado, as lideranças que eram contra a interferência da Igreja e do outro lado, outras lideranças jovens indígenas que defendiam a atuação da Igreja Católica na política do movimento indígena. Os que defendiam a Igreja eram alunos e ex-alunos salesianos que foram preparados pela Igreja Católica para defenderem os seus interesses e para combaterem a posição de seus opositores. No final, a estratégia da Igreja deu certo, porque quando o encontro terminou a Igreja saiu ganhando, pois conseguiu afastar os pioneiros do movimento indígena, os organizadores e os criadores da FOIRN do poder e da direção do movimento. ${ }^{43}$

A partir daquele evento os líderes Tukano decidiram se afastar do movimento indígena, porque ficaram revoltados com a posição de vários indígenas que defendiam a Igreja, porém a união dos povos para lutar pela demarcação das terras indígenas do alto rio Negro estava decidida. ${ }^{44}$ Nesse aspecto os indígenas da região saíram ganhando, no entanto a partir desse evento resultaram as seguintes marcas que duram até hoje: o afastamento dos primeiros líderes Tukano, a separação entre o movimento indígena do rio Negro e a Igreja, e o domínio de ONGs dentro do movimento.

Depois da II Assembléia, começou a luta direta pela demarcação das terras, que apesar da posição contrária de militares e de mineradoras, as novas lideranças da FOIRN enfrentaram a luta política de forma destemida. Após a desistência da FUNAI para administrar a demarcação, os representantes da FOIRN, que conheciam os membros do ISA, indicaram-no para que administrassem diretamente a demarcação das terras indígenas do alto rio Negro. As lideranças da FOIRN também iniciaram a busca de parcerias internacionais,

\footnotetext{
${ }^{42}$ Entrevista concedida por Pedro Fernandes Machado, no dia 16 de abril de 2007 em São Gabriel da Cachoeria, AM e documentada por autor.

${ }^{43}$ Ibidem, 2007.

${ }^{44}$ Ibidem, 2007.
} 
com objetivo de buscar recursos financeiros para tentar estruturar a Federação. Enfim, no começo da década de 90, iniciou-se com "a consolidação da demarcação e um plano de proteção e fiscalização da área", e, assim, ocrreram as "atividades de demarcação entre abril de 1997 e abril de 1998 " ${ }^{45}$

\subsubsection{A demarcação das Terras Indígenas e a construção do projeto sustentável.}

Em relação a política indígena nacional, a década de 90 caracterizou-se como o período do surgimento de novas "Propostas para uma Nova Política Indigenista", ou seja, "a reestruturação dos serviços públicos relativos à atenção aos povos indígenas”. Entre as comunidades indígenas do alto e médio rio Negro houve o surgimento de dezenas de associações de base que constituiriam a Federação das Organizações Indígenas do Rio Negro.

Para os indígenas do alto rio Negro, o ano de 1998 foi o mais importante da década de 90, porque um de seus principais objetivos de luta, almejado por todos os participantes da II Assembléia Geral de Lideranças Indígenas do rio Negro (1987), tornou-se realidade, a demarcação de cinco Terras Indígenas: Terra Indígena (TI) Alto Rio Negro [Decreto s/n de 14/04/98(DOU, 15/04/98)]; TI Médio Rio Negro I (Decreto s/n. de 14/04/98); TI Médio Rio Negro II [Decreto s/n. de 14/04/98 (DOU, 15/04/98)]; TI Rio Apaporis [Decreto s/n. de 14/04/98 (DOU, 15/04/98)]; TI Rio Téa [Decreto s/n. de 14/04/98, (DOU, 15/04/98)]. No ano anterior havia sido homologada a TI Paraná Boá-Boá (Lago Jutaí) [Decreto, s/n. de 03/11/97 (DOU, 04/11/97)]; ainda, no de 1998 foi homologada a TI Uneiuxi [Decreto s/n de 11/12/98 (DOU, 14/12/98)]. Outras duas TI ficaram na fase de identificação e revisão, a saber: Balaio, Marabitana/Cue-Cue. ${ }^{46}$ No dia 15 de abril de 1998, o ministro da Justiça Renan Calheiros, "entregou às lideranças indígenas os decretos de homologação das cinco terras indígenas demarcadas", durante o evento a VI Assembléia Geral da FOIRN, fato que foi comemorado pelas lideranças presente como uma vitória histórica". 47

\footnotetext{
${ }^{45}$ Beto RICARDO, setembro 2000. Povos Indígenas no Brasil 1996/2000, p. 245-254.

${ }^{46}$ CABALZAR, Aloisio; RICARDO, Beto. Povos Indígenas do alto e médio rio Negro: uma introdução à diversidade cultural e ambiental do noroeste da Amazônia brasileira. $3^{\text {a }}$ edição atualizada. São Paulo: São Gabriel da Cachoeira, ISA/FOIRN, 2006, P. 115-124.

${ }^{47}$ RICARDO, op. cit., 2000.
} 
Em seu discurso durante esta comemoração histórica uma das lideranças indígenas, Braz França (Baré), ex-presidente da FOIRN, destacou que a conquista da demarcação só saiu porque teve o apoio do Governo federal e das ONGs e, ainda, ressaltou:

Queremos que essa terra seja realmente o berço de sustentação econômica, política e administrativa dos povos indígenas. queremos que essa terra, essa população seja sujeito de um progresso que sejam também participantes efetivos do desenvolvimento da nossa própria sociedade, daquilo que tanto ansiamos para nosso futuro, para garantia do nosso futuro. Para tanto, então, não se encerra aqui a luta dos povos indígenas. A luta dos povos indígenas começou, chegou a seu ponto e tem ainda sua longa caminhada para uma verdadeira conquista na área social, na área de segurança realmente dos povos indígenas e da população que dela participa. Para que isso seja possível, [...], é preciso haver uma visão conjunta tanto a nível de governo, como a nível de população e outros setores que sempre vêm apoiando e assessorando o movimento indígena. ${ }^{48}$

Com a demarcação das terras, os indígenas sabiam que o primeiro objetivo tinha sido conquistado, no entanto também sabiam que apenas uma terra demarcada não garantiria outros dois objetivos acordados na II Assembléia Geral, de 1987: a qualidade de vida das famílias indígenas e a autonomia territorial. Por isso, após a homologação das terras, a FOIRN e seus parceiros começaram apoiar e executar diversos projetos de desenvolvimento sustentável das comunidades indígenas em diversas áreas, tais como: Educação, Saúde, Política e Cultural. ${ }^{49}$

\subsubsection{A Estrutura Organizacional da FOIRN}

Antes de iniciar a elaboração e a execução de projetos sustentáveis, internamente, a FOIRN, como instituição indígena, teve que se organizar hierarquicamente, para isso criou diversas instâncias de comando. Os dirigentes dessa época projetaram uma organização que envolvesse a participação de todos os representantes das associações de bases do rio Negro e não de povos indígenas. Por essa razão, os membros de grupos Maku, que não tinham associações de base não participaram das discussões e das deliberações da Federação. Além disso, também não eram convidados para participarem de Assembléias e discussões afins. Outro motivo que impediu a participação dos Maku foi o princípio histórico e tradicional de serem considerados pelos demais povos do rio Negro como pessoas que vieram para este mundo apenas para servirem outros grupos. Assim, diziam todos os outros povos: os Maku

\footnotetext{
${ }^{48}$ Ibidem., 1996/2000, p. 252.

${ }^{49}$ Instituto Socioambiental. Povos Indígenas no Brasil 1996/2000, p. 241-292.
} 
(Peołá) não são gente. Eles são Peołá, estão aqui para nos servir e não para dizer como devemos fazer as coisas. Isto mostra a complexidade das relações entre os povos indígenas.

A organização vigente da Federação tem como objetivo melhorar a "gestão política da instituição" e tem a seguinte estrutura organizacional: Conselho Diretor, Diretoria, Coordenadorias Sub-Regionais e Associações de Base. ${ }^{50}$

O Conselho Diretor é a instância maior da Federação. É composto por delegados escolhidos pelas Coordenadorias em assembléias regionais e suas representatividade no conselho é de quatro anos. Cada coordenadoria tem o limite máximo de indicar até 20 delegados para participarem das Assembléias Gerais e Extraordinárias. O conselho diretor é quem escolhe o presidente da Federação em eleição através do voto secreto e delibera ações e projetos que os diretores da FOIRN deverão cumprir durante os 4 anos de mandato. Caso alguns diretores cometam atos ilícitos após a decisão do Conselho Diretor, o Conselho tem total legitimidade de punir ou excluir o diretor da gestão.

A Diretoria da FOIRN é composta por cinco diretores escolhidos e indicados pelas Coordenadorias Sub-Regionais, ou seja, cada Coordenadoria Sub-Regional escolhe o seu diretor para compor a diretoria da Federação. Dessa forma, todas as regiões do rio Negro têm sua representatividade política. A diretoria tem mandato de no máximo quatro anos, podendo os diretores concorrerem à reeleição. Entre os cinco diretores um é escolhido pelo Conselho Diretor para ser Presidente da Federação. A escolha é realizada através de uma eleição com voto secreto. O mais votado se torna Presidente, o segundo mais votado é declarado o VicePresidente e os demais compõem a diretoria com direito de igualdade para tomada de decisões da instituição.

As Coordenadorias Sub-Regionais são organizações sub-regionais de base que, através de assembléias sub-regionais, indicam os futuros diretores da FOIRN, escolhem os delegados que participam das Assembléias Gerais e Extraordinárias. Atualmente são cinco coordenadorias: Coordenação das Associações Baniwa e Curipaco (CABC), Coordenação das Associações Indígenas do Alto Rio Negro e Xié (CAIARNX), Coordenação das Associações Indígenas do Médio e Baixo Rio Negro (CMBRN), Coordenação das Organizações Indígenas do Distrito de Iauaretê (COIDI) e Coordenação das Organizações Indígenas do Tiquié e Uaupés (COITUA). Essas coordenadorias foram criadas para descentralizar as atividades da FOIRN, na sede; permitir a eleição dos futuros diretores, escolhidos pelas bases, para compor a diretoria da FOIRN; tentar amenizar as tensões de bastidores geradas pela eleição para o

\footnotetext{
${ }^{50}$ FOIRN. Relatório Institucional 2001-2004.
} 
presidente da Federação; permitir que atuem como assessoria direta às associações de base e no futuro próximo garantir que se tornem autônomas para formular seus próprios projetos de sustentabilidade. Com isso a FOIRN pretende "se dedicar por mais tempo para articular recursos para as Coordenações regionais". 51

As Associações de Base constituem o sustento político da FOIRN e das Coordenadorias Sub-Regionais. Destacamos dois aspectos do funcionamento das associações indígenas do rio Negro: o primeiro é a iniciativa e a coragem dos indígenas em se organizarem em associações; o segundo é o fato das associações existirem apenas nos estatutos sem efetividade para a melhoria das comunidades indígenas.

\section{ESTRUTURA ORGANIZACIONAL DA FEDERAÇÃO DAS ORGANIZAÇÕES INDÍGENAS DO RIO NEGRO - FOIRN}

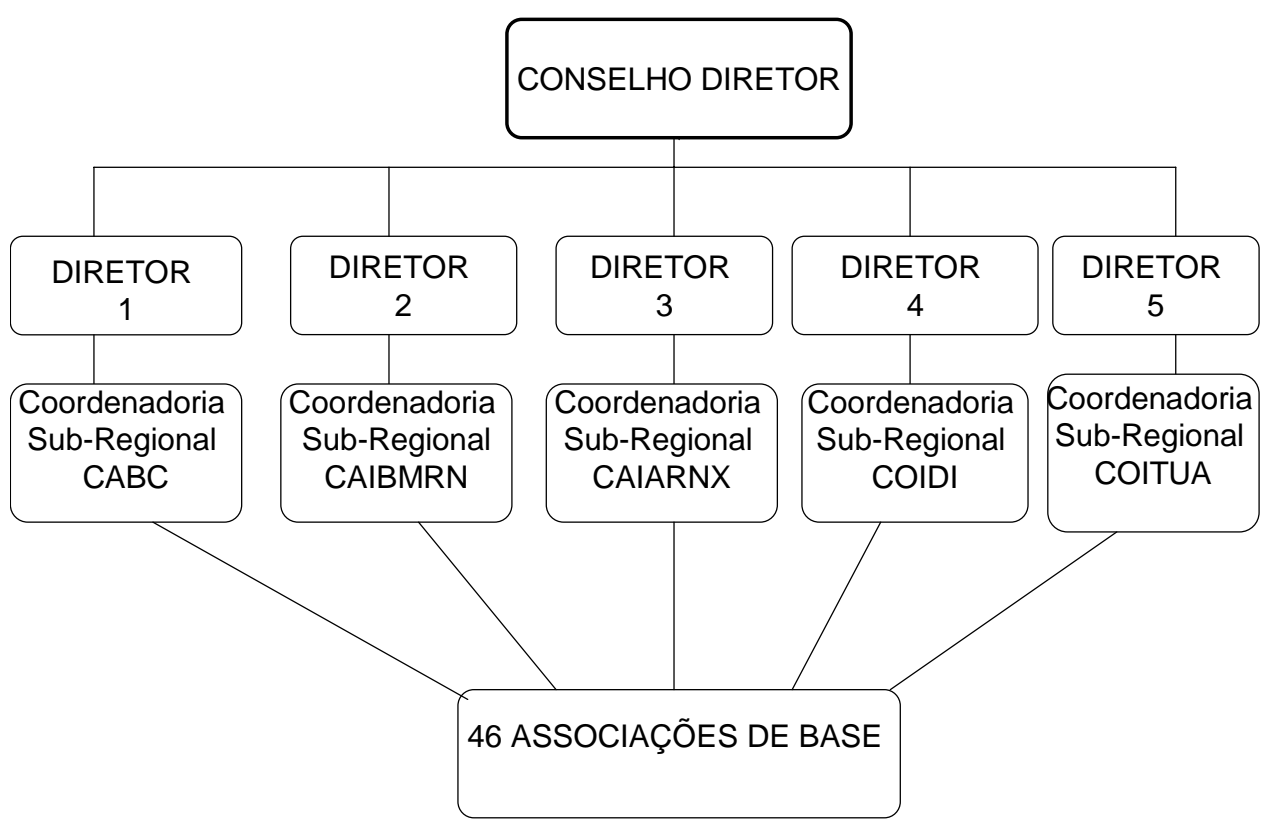

A FOIRN tem mais de 29 organizações de base filiadas, que surgiram antes e após a demarcação das terras indígenas do alto e médio rio Negro ${ }^{52}$. Segundo Felisberto Ascenção Damasceno (1992), o surgimento de dezenas de associações no país é um “[...] fenômeno político que desperta nos que acompanham, apóiam e assessoram os povos indígenas e suas lutas e, entre os próprios índios pelos muitos significados que tem para eles a criação das organizações indígenas" ${ }^{\text {"53 }}$. São associações criadas para reivindicar e propor projetos de

\footnotetext{
${ }^{51}$ Ibidem, 2001-2004.

52 CABALZAR; RICARDO, 2006, op.cit., p. 107. Ver anexo 3.

${ }^{53}$ Felisberto Ascenção DAMASCENO, 1992.
} 
sustentabilidade para as comunidades que compõem, com o objetivo de melhorar a qualidade de vida de suas famílias. Elas elaboram projetos sociais com apoio da FOIRN e conseguem aprovação da instituição e assim obtêm recursos financeiros para executar em suas comunidades; e os representantes das associações participam das Assembléias Gerais e Assembléias Extraordinárias organizadas pela Federação e ajudam a decidir as prioridades para o trabalho da Federação.

Entretanto, muitas associações não têm recursos humanos qualificados para dirigir e executar projetos acordados junto com suas comunidades, por isso só ficam no papel, porque na prática não funcionam. Têm mais de 46 associações, porém, entre elas mais de $70 \%$ não têm maiores significados e efetividade para as comunidades, porque é como se não existissem, pois, não funcionam, só tem nome e coordenadores que não conseguem dinamizar a vida de seus associados. Isso reflete na vida das comunidades, que apesar de terem uma terra demarcada, em muitas localidades as pessoas passam fome, porque apenas com as práticas tradicionais de agricultura, pesca e caça não conseguem mais obter o sustento para suas famílias. Os representantes das associações participam das decisões da FOIRN, porém para a maioria das comunidades indígenas as decisões tomadas na sede da instituição não interferem e nem provoca mudanças em suas vidas.

Outro aspecto interessante que temos dentro da estrutura organizacional da FOIRN, é o processo de escolha para o Presidente da FOIRN e suas conseqüências políticas que interferem diretamente nas relações de convivência entre os povos indígenas do rio Negro.

Nesses últimos anos a disputa para o cargo de Presidente da FOIRN vem se transformando em um "caldeirão político", porque resulta em tensões e divisões nas relações de convivência intercultural entre os povos que participam do movimento indígena. Em princípio, os cinco diretores eleitos pelas Coordenadorias Sub-Regionais disputam eqüitativamente o cargo de Presidente da FOIRN, porém na hora das eleições as coordenadorias que tem maior número de delegados participantes na Assembléia levam vantagem numérica para votar e escolher o futuro presidente de sua região. Muitas vezes, as coordenadorias menores se aliam às coordenadorias maiores para no futuro receberem apoio político do futuro presidente. A estratégia da construção de alianças é feita pelos delgados nos bastidores do encontro. Para isso, não existe hora certa para negociar e tentar conquistar os votos de outras coordenadorias. As coordenadorias mais fortes são do Triângulo Tukano (COITUA e COIDI), da região do Uaupés; e da região do Içana (CABC). Estas duas têm seus diretores como candidatos fortes para ocupar o cargo de presidente da instituição. Apesar de tudo isso, as coordenadorias maiores também cedem oportunidades para os diretores de 
representações menores, porque acreditam que todos têm que ter o mesmo direito de ter o presidente da FOIRN, mas isso depende dos resultados da política partidária e da trajetória pessoal do diretor.

A eleição para o presidente da FOIRN é feita sempre no final das Assembléias Gerias que acontecem de quatro em quatro anos e coincidem com os anos das eleições municipais. Por isso, muitas vezes, a escolha do presidente da FOIRN depende do resultado das eleições municipais, que fortalece ou enfraquece a construção das relações de convivência entre os indígenas da região. Os dirigentes da Federação declaram que seus representantes não podem participar da política partidária, no entanto muitos deles estão engajados e filiados nos partidos políticos do município. Além disso, há outros fatores que criam o "campo político" nas Assembléias da FOIRN, como por exemplo, na Assembléia Geral, em outubro de 2004, quando foi escolhida a nova Diretoria, alguns representantes das coordenadorias tentaram anular a indicação legal de um diretor, que foi escolhido por uma Assembléia Sub-Regional, porque alegaram que a pessoa que havia sido eleito pela base não pertencia a nenhum grupo tradicional da sub-região. Por esse motivo, realizaram outra assembléia com objetivo de anular a legitimidade da escolha anterior e, enfim, escolheram outro diretor, o que ocasionou a existência de dois diretores eleitos: primeiro eleito de forma legal, de acordo com o Estatuto da FOIRN e segundo eleito de forma ilegal, que atendia os interesses de algumas pessoas, sem apoio da FOIRN. Enfim, o segundo diretor tentou justificar a sua indicação para ser o diretor da FOIRN, porém a sua intenção foi abortada pelo Conselho Diretor constituído por 97 delegados. Nessa ocasião, a liderança Tukano, Maximiliano Menezes, ex-diretor da FOIRN, disse o seguinte: "Se este Estatuto da FOIRN não vale mais nada, se ninguém respeita mais nada, se o Conselho Diretor deixar que esse segundo candidato assuma o lugar do primeiro, então, neste momento ... vou rasgar e jogar fora. É isso que vocês querem?",54. Todos os delegados ficaram calados e ninguém falou nada.

Assim como acontece em diversas instituições indígenas e não-indígenas, a FOIRN também corre o risco de se tornar um instrumento político para interesses subjetivos. Não há dúvidas que as lideranças que se tornam dirigentes da FOIRN ou de quaisquer outras instituições governamentais lutam, sim, pelos interesses das comunidades indígenas, porém, como acontece na sociedade envolvente, sempre existem lideranças que entram e sentem o gosto de ter o poder político e financeiro em suas mãos, depois fazem de tudo para nunca

\footnotetext{
${ }^{54}$ Discurso realizado por Sr. Maximiliano Menezes, durante a VI ASSEMBLÉIA GERAL ELETIVA DA FOIRN, 28 a 30 de outubro de 2004, documentado por autor.
} 
mais sair do circuito do poder. Aí surge o conflito entre os que já estão no poder e os que tentam ocupar espaço no movimento indígena. Os que estão no poder, são pessoas mais idosas, sem muita formação acadêmica, porém têm muita experiência da luta indígena e, portanto, conhecem com profundidade a história e as estratégias da luta indígena do rio Negro, e também são apoiados pelas ONGs que assessoram a instituição. Já. os que buscam um espaço no poder, são lideranças mais jovens, que tem uma formação acadêmica mais avançada, no entanto não têm experiência e conhecimento mais profundo da caminhada histórica do movimento indígena no sentido mais amplo, e não tem apoio político das ONGs, porque são consideradas ameaças para o controle das instituições não-governamentais e para as lideranças antigas que podem perder o poder.

A luta pelo poder político não acontece apenas entre as instituições governamentais ou na sociedade envolvente, pois entre os indígenas isso também é uma realidade. Desde os primórdios, quando ainda existia as Casas Tradicionais habitadas por diversas famílias, o chefe da casa se chamava Bayá (Mestre de danças e músicas tradicionais). O Bayá-chefe pertencia o sib considerado chefe, os bayá de sib "servos" não tinha direito de indicarem ou escolherem o chefe das habitações. Hoje, essa forma tradicional de controle do poder político não existe mais entre os indígenas. As populações do rio Negro se apropriam de costumes e instrumentos políticos da sociedade ocidental para se organizarem em associações conquistar os cargos de dirigentes e controlar o poder das instituições que dirigem.

\subsubsection{Os departamentos e a participação de mulheres indígenas}

A Federação das Organizações Indígenas do rio Negro tem dois departamentos que destacamos, porque contribuem diretamente e de forma eficiente o funcionamento da instituição: o Departamento de Comunicação e o Departamento de Mulheres do rio Negro.

a) O Departamento de Comunicação

O departamento de comunicação da FOIRN foi criado desde sua fundação em 1987. A partir de 1998, os dirigentes da instituição investem na formação de recursos humanos e na aquisição de meios de comunicação para o funcionamento mais eficiente do departamento, 
porque sabem que é "um dos departamentos mais estratégicos" da instituição para a articulação entre as comunidades indígenas e a sede. ${ }^{55}$

O objetivo principal do departamento de comunicação é expor formalmente para as comunidades indígenas e para os não-índios os projetos que são desenvolvidos pela Federação, em nível municipal, estadual e federal. Por exemplo, o departamento executa diariamente diversas atividades de articulação e comunicação usando diversos meios, tais como: ${ }^{56}$

a) Programas semanais nas duas Rádios existente no Município: Rádio Novo Milênio (FM) e Rádio Municipal (AM) que abrange o interior do Município com o "PROGRAMA CHAMADO VOZES DO RIO NEGRO".

b) Rádio Fonia: Atualmente a Foirn possui 125 Rádio Fonias, todas adquiridas através de vários projetos. Sendo que nestes últimos 4 anos foram instalados 82 rádios em toda região do alto rio Negro.

c) Também o departamento possui outro veículo de Comunicação chamado "WAYURÍ" que [...] saí de 3 em 3 meses e ainda o INFOIRN, este sai a medida que acontece algum evento importante que a Foirn realiza.

A comunicação entre as comunidades é feita em diversas línguas da região. Por exemplo, os Tuyuka quando se comunicam entre si, através da rádiofonia, falam a língua Tuyuka; os Tukano na língua Tukano; os Tuyuka que se comunicam com os Tukano, falam na língua Tukano, porque a maioria dos Tukano não entende e nem fala a língua Tuyuka; os Baniwa se comunicam através da língua Baniwa ou língua geral; na comunicação entre os indígenas da região do Uaupés, Içana, Xié, rio Negro e as demais comunidades a língua falada é o português. Os não-índios que não entendem e não falam as línguas indígenas da região, principalmente os militares, ficam sem compreeder com o conteúdo da comunicação. Alguns inclusive, acham que os indígenas podem traçar estratégias políticas e sociais que poderão por em risco a soberania nacional e o domínio político dos não-índios na região.

A rádiofonia é o meio de comunicação que trouxe avanços significativos para o fortalecimento da FOIRN e para as relações de convivência das comunidades indígenas da região. É através desse meio de comunicação social que diversas atividades na área de educação, saúde, social, esportiva são articuladas. Por exemplo, quando uma pessoa da comunidade precisa de um socorro médico, usa-se a rádiofonia para avisar a base médica mais próxima da área ou se não tiver uma equipe médica na área comunicam para a sede da FOIRN. A equipe de comunicação da Federação também usa a fonia para se comunicar com

\footnotetext{
${ }^{55}$ FOIRN. Relatório Institucional 2001-2004.

${ }^{56}$ FOIRN, op. cit., 2001-2004.
} 
mais rapidez e eficiência antes de um evento importante na FOIRN ou na cidade de São Gabriel da Cachoeira.

A equipe de comunicação da FOIRN também atua nos programas de rádio da cidade: Rádio FM 104.1, chamada também de Rádio Novo Milênio, dirigida pela Diocese de São Gabriel da Cachoeira; Rádio Municipal de São Gabriel da Cachoeira; e Rádio a Crítica, filiada da Rádio A Crítica de Manaus. O objetivo da equipe é divulgar os valores culturais, difundir as músicas e expor a importância do ser indígena. Por isso, geralmente as músicas tocadas durante os programas são músicas tradicionais ou compostas pelos indígenas da região. Os locutores da equipe são indígenas que se comunicam com o público indígena através de várias línguas Tukano, Nheengatu (ou Língua Geral) e português, que são as línguas mais faladas na região do alto rio negro. Enfim, são programas de comunicação que contribuem e reforçam a a valorização do ser indígena.

Por essas razões, o departamento de comunicação da FOIRN é considerado um dos departamentos mais estratégico da instituição, porque suas ações reforçam o senso de parentesco, de familiaridade das relações interculturais, relações sociais e políticas das comunidades indígenas e da Federação com a base.

\section{b) O Departamento de Mulheres do Rio Negro}

Os povos indígenas do alto rio Negro são patrilineares. Essa tradição coloca as mulheres indígenas como sendo pessoas menos importantes para liderar, tomar decisões e conduzir quaisquer das principais organizações sociais e políticas. AEste é ainda é um aspecto cultural vivenciado em todas as comunidades indígenas da região. É uma tradição observada rigorosamente pelas comunidades. Essa vivência de base reflete no movimento indígena do rio Negro, porque as mulheres têm que reivindicar e brigar pelo seu espaço natural para poder participar diretamente nas deliberações e na administração da Federação, fato que não vem se resolvendo de forma muito fácil.

Por exemplo, até hoje, nenhuma mulher indígena do rio Negro conseguiu ser capitã ou líder de uma comunidade indígena, porque os homens é que ditam as regras e, na maioria das vezes, as mulheres têm que apenas cumprir o que os homens decidem. Esse costume ainda existe. Por isso, geralmente são os homens os líderes comunitários e gerais ou capitães. As mulheres apenas são coadjuvantes das organizações sociais e comunitárias, o máximo que ocupam são os papéis de vices. Outro exemplo é o que ocorre em Pari-Cachoeira, Taracuá e Iauaretê, onde nenhuma mulher conseguiu se tornar líder geral ou líder comunitária. Apesar 
dessa realidade, a maioria das mulheres não tem se mobilizado para ocupar o cargo de liderança.

Entretanto, com a ajuda de algumas missionárias e pesquisadoras, aos poucos, algumas mulheres indígenas da região começam se destacar na luta pela igualdade entre os homens e as mulheres, tanto dentro da organização social de cada grupo como dentro do movimento indígena do rio Negro. As mulheres que lideram esse movimento são as que estudaram em colégios salesianos e do governo. Outras que se destacam são as que se graduam nas universidades e depois retornam para suas comunidades com novos conhecimentos, valores e princípios que se apropriam do mundo ocidental, e tentam mudar o curso da história e do papel da mulher indígena dentro de sua comunidade. Essa luta das mulheres não é tão fácil, pois quem determina a direção do povo nas comunidades são os homens, porque são os que detêm os conhecimentos tradicionais do grupo. Essa relação de convivência entre os homens e as mulheres, talvez seja a mais difícil de se mudar, porque se trata dos princípios tradicionais que regem um povo e não simplesmente uma comunidade. É um desafio interno que um dia os próprios indígenas terão que decidir se mudarão ou não o seu modo de ser.

Depois que a FOIRN foi criada, as mulheres passaram também a se organizar em associações e conquistar o seu espaço dentro do movimento indígena. Desde então, têm-se organizado e, em meados da década de 90, surgiram várias associações de mulheres com objetivo de mostrar sua importância a partir da constituição dos grupos e comunidades, como por exemplo: Associação das Mulheres Indígenas do Alto Rio Negro (AMARN, 1984), com sede em Manaus; Associação das Mulheres Indígenas de Taracuá do Rio Uaupés e Tiquié (AMITRUT, 1989), com sede em Taracuá; Associação das Mulheres Indígenas do Distrito de Iauaretê (AMIDI, 1995), em Iauaretê; Associação das Mulheres do Assunção do Içana (AMAI, 1992); União das Mulheres Indígenas do Rio Ayarí (UMIRA, 1999), com sede em Canadá. $^{57}$ São associações que fazem diferença na luta pela autonomia indígena. Essas organizações são até mais estruturadas do muitas outras associações dirigidas pelos homens, porque as mulheres são mais objetivas e administram os recursos financeiros que recebem da Federação quase sempre melhor do que do que aquerlas dirigidas pelos homens.

A força política das mulheres tem aumentado cada ano que passa. A prova disso é que em 2000, conseguiram eleger uma mulher para compor a Diretoria da FOIRN.$^{58}$ Depois dessa conquista, em 2002, criaram o Departamento de Mulheres Indígenas do Rio Negro e

\footnotetext{
${ }^{57}$ ISA - Instituto Socioambiental. Povos Indígenas no Brasil 1996/2000, p. 267-268.

${ }^{58}$ Ibidem.
} 
construiram a Casa de Produtos Indígenas do Rio Negro, denominada de "Wariró"59 . Esse departamento veio "atender a uma antiga demanda das mulheres rionegrinas que lutam para conseguir alcançar melhores condições tanto nas questões políticas como na da sobrevivência. A eleição de uma mulher para diretoria FOIRN, foi o primeiro passo para demonstrar o amadurecimento do movimento indígena no Rio Negro em relação à questão das mulheres".

As mulheres indígenas têm muita vontade de contribuir para a melhoria de suas comunidades, porém para manter o departamento ativo enfrentam o desafio de se tornar autônomo financeiramente. Com a autonomia financeira em relação à Federação o departamento estaria mais fortalecido. Por enquanto, os desafios do departamento são os mesmos enfrentados pelas associações do rio Negro, pois, dependem de projetos da FOIRN, que geralmente são de curta duração. ${ }^{60}$

\subsubsection{Os projetos}

Após a conquista da demarcação de terras, a FOIRN se fortaleceu em nível regional nacional e internacional como instituição política de luta pelos interesses das comunidades indígenas do rio Negro. Por essa razão, aumentou o interesse de ONGs e instituições governamentais em criar parcerias com a Federação com objetivos de desenvolver projetos sustentáveis para o "benefício das comunidades indígenas" e realizar pesquisas socioambientais.

Veja-se a seguir os principais projetos já executados pela FOIRN e seus parceiros, e outros que ainda estão em execução:

\section{a) Fiscalização das Terras Indígenas}

A demarcação física das cinco Terras Indígenas do Alto Rio Negro nos anos de 1997 a 1998, foi realizada pela FOIRN em parceria com o Instituto Socioambiental (ISA), “com apoio das associações filiadas, da FUNAI e recursos do Plano de Proteção e Fiscalização das Terras Indígenas do Alto e Médio Rio Negro I, II, Rio Téa e Apapóris". ${ }^{1}$

O processo de demarcação não resultou apenas na demarcação ambiental ou física, pois de acordo com as lideranças que participaram diretamente da demarcação, a atividade se

\footnotetext{
${ }^{59}$ ISA - Instituto Socioambiental. Povos Indígenas no Brasil 2001/2005, p. 281.

${ }^{60}$ FOIRN, op. cit., 2001-2004.

${ }^{61}$ Ibidem, 2001- 2004.
} 
delineou de forma inovadora tanto para a topografia brasileira como resultou em um banco de dados socioambiental:

Foi um processo inovador de demarcação, que incluiu atividades de mobilização, informação e produção de conhecimento, além de atividades obrigatórios de topografia. Resultou desse processo um banco de dados dando um perfil socioambiental da região baseadas em entrevistas por comunidades e ainda um conjunto de recomendações para construção de um Plano de Proteção e Fiscalização das terras indígenas ainda ser negociada com PPTAL/FUNAI. ${ }^{62}$

O Plano de Proteção e Vigilância das TIs do Alto Rio Negro e Apapóris foi elaborado pela FOIRN, e teve inicio em 2004 através da proteção e fiscalização das TIs. O plano tem os seguintes objetivos: ${ }^{63}$

O projeto vem para ampliar a visibilidade da demarcação para os não indígenas (colocando placas ou abrindo aldeias em pontos estratégicos) e desenvolver atividades para a proteção e a fiscalização dessas terras, através de parcerias com o governo ou instituições não governamentais. São as principais linhas de ação:

a) Expedições de fiscalizações para as áreas mais afastadas ou que ficam nas fronteiras com outros países para melhorar as sinalizações dos limites das terras indígenas.

b) Viajar para as áreas críticas, ou seja, aquelas muito isoladas ou aquelas que sofrem ameaças diretas de invasores, para coletar informações sobre as condições das famílias e também para equipar estas comunidades com bote, motor e outros pequenos projetos.

c) Fortalecer as comunidades onde ainda existem invasões (garimpeiros, coletores de peixes ornamentais, extratores de piaçaba, biopiratas etc.).

d) Informar as comunidades e estimular seus moradores para participar da fiscalização.

e) Criar uma rede das pessoas envolvidas no trabalho com as entidades governamentais e não governamentais do município, para criar e divulgar informações sobre invasões e exploração de recursos naturais.

Nesse aspecto, o esforço da equipe de fiscalização da FOIRN e seus parceiros tem obtido resultados positivos na região, porque se observarmos com mais atenção, entre as demais regiões do país, as comunidades do alto rio Negro não enfrentam conflitos diretos com os não-indígenas. É evidente que sempre há garimpeiros, exploradores clandestinos de

\footnotetext{
${ }^{62}$ Ibidem, 2001-2004.

${ }^{63}$ Ibidem, 2001-2004.
} 
recursos naturais, que vivem dentro das terras indígenas, porém são poucos. E quando há presença de estranhos, os próprios indígenas se mobilizam para resolver o problema de forma dialógica e pacífica ou comunicam diretamente para FOIRN e FUNAI que interferem nos casos. Depois de 1998, não tivemos confrontos físicos diretos entre indígenas e não-indígenas na região por disputas de Terras.

Entretanto, a parte mais crucial da fiscalização ocorre com relação à biopirataria, porque ninguém sabe quem são os biopiratas. Podemos levantar várias hipóteses de quem eles poderiam ser, por exemplo: podem ser os garimpeiros, que nem sempre buscam apenas o ouro, mas que também levam espécies da floresta amazônica para outros lugares. Mas poderiam ser também, os pesquisadores da sociedade envolvente, entre os quais a maioria são os profissionais das ONGs ou de instituições governamentais, que biopirateiam os conhecimentos tradicionais de populações indígenas sem a permissão expressa dos grupos? Poderiam ser também, os missionários de diferentes Igrejas que se instalam nas comunidades indígenas para evangelizar. Ou ainda poderiam ser os turistas que chegam na região. Alguns agentes de instituições parceiras são mais difíceis de serem controlados porque entram para assessorar as organizações e o movimento indígena, e se dizem parceiros, mas ninguém sabe de fato, quais são as suas verdadeiras intenções. Por enquanto, o que sabemos é que alguns têm a intenção de escrever suas dissertações, teses e artigos científicos para despontar como profissionais. Outros conseguem conviver entre os indígenas fazendo tudo isso, mas conseguem também contribuir na luta do movimento indígena.

\section{b) Na área de Sustentabilidade Econômica e Ambiental}

Os projetos de sustentabilidade econômica e ambiental das comunidades indígenas interessadas sempre foram e são elaborados e orientados pela FOIRN e o ISA. Ou seja, a comunidade propõe realizar um trabalho de sustentabilidade e a FOIRN/ISA decidem apoiar através de projetos com recursos financeiros e recursos humanos. Geralmente o recurso humano é constituído dos profissionais do ISA. Na prática são projetos desenvolvidos pelo ISA em caráter experimental, denominados de projetos piloto, por isso não atende todas as comunidades indígenas do rio Negro.

O objetivo da FOIRN é a partir desses projetos pilotos expandir para mais outras comunidades da região, porém depois de 20 anos de sua existência, os projetos econômicos não surtiram efeitos esperados para a melhoria das comunidades. Os projetos pilotos acabam se tornando balcões de experiências acadêmicas e sustento financeiro para as ONGs. Existem 
projetos de piscicultura, agricultura, avicultura, artesanato, etc., que são importantes para a sustentabilidade das comunidades indígenas do rio Negro, mas que precisam também, ser investidos em outros locais. ${ }^{64}$

Os projetos de piscicultura e artesanato "são os que estão mais desenvolvidos, pois a parceria com o ISA, permite a presença de técnicos de maneira mais constante nas comunidades". ${ }^{65}$ A piscicultura faz parte do projeto de "Manejo Sustentável de Recursos Naturais" implantado pela FOIRN/ISA, que foi executado em três localidades ${ }^{66}$ :

[...] no Rio Tiquié com apoio da ATRIART, em Yawareté com apoio da COIDI e no Içana, mais especificamente na comunidade da Escola Pamáali, com apoio da OIBI e da AEITU. As atividades do projeto são voltadas para implantar a piscicultura familiar de peixes nativos. $\mathrm{O}$ aracu, por ser da região e ser muito apreciado, é o que recebe destaque. Depois que o município de S. Gabriel não conseguiu sucesso com a experiência de fazer tanques de piscicultura com peixes que não são da região, como o tambaqui e jaraqui, o ISA está trabalhando com as associações de base para desenvolver uma piscicultura inovadora, adaptada às condições de cada região, e associadas ao manejo agroflorestal, ou seja, cuidando da parte da vegetação que permite a criação de alimento para os peixes e proteção das águas para a criação. É uma experiência única no contexto dos povos indígenas do Rio Negro e da Amazônia brasileira.

O objetivo destes projetos vem ao encontro com a questão da segurança alimentar em regiões relativamente pobres na oferta de animais e peixes e ainda com o solo pobre para agricultura.

Foi feita uma avaliação com consultores externos para observação dos resultados colhidos e as dificuldades enfrentadas. As conclusões foram muito favoráveis. Grande parte dos problemas deve-se ao prazo ainda curto de sua implantação e às dificuldades de acompanhamento e logística, devido às distâncias a serem percorridas. Por outro lado, o projeto conseguiu construir 28 viveiros no Alto Tiquié com bom aproveitamento. Os técnicos indígenas das estações Caruru (no Tiquié) e Yauaretê estão bem capacitados e conduzem por conta própria estas atividades, com supervisão da equipe do ISA. O mesmo pode ser dito com os alunos da escola Pamáali, que estão sendo treinados para a atividade e isto vai valer no currículo de sua formação no ensino médio.

São vários os desafios que a FOIRN precisa enfrentar para a aperfeiçoar a implantação dos projetos de piscicultura. Os principais são:

a) na questão técnica - a equipe técnica do ISA é muito reduzida; falta mais capacitação de técnicos indígenas para o monitoramento dos viveiros (eles precisam aperfeiçoar atividades como recolher dados quantitativos sobre a distribuição de alevinos, registrar as despesas e os gastos realizados etc);

b) na questão política - pouca discussão sobre a auto-suficiência financeira (no médio prazo) das estações de piscicultura; a concentração pela FOIRN dos projetos pilotos nessas áreas causou o crescimento desigual das associações; faltou

\footnotetext{
${ }^{64}$ Israel Fontes DUTRA, 2007

${ }^{65}$ FOIRN, 2001-2004.

${ }^{66}$ Ibidem.
} 
fazer parcerias também com o município e o Estado do AM para implementarem conjuntamente essa experiência.

O projeto "Arte Baniwa” é outro projeto desenvolvido com o apoio da FOIRN/ISA, na região do Içana. É uma iniciativa genuinamente indígena do Içana que buscam, através desse trabalho e venda de produtos, a melhoria de vida para o povo Baniwa. Com esse projeto, os Baniwa conseguiram avanços relevantes em várias áreas, porque produzem o artesanato e vendem diretamente sem passar pelo atravessador. Os seus artesanatos produzidos a partir de Warumã, (balaios, urutus, cestas ornados) estão espalhados por todo território nacional. ${ }^{67}$

A gerência do Projeto é feita pela Organização Indígena da Bacia do Içana (OIBI). A FOIRN e o ISA dão suporte logístico, assessoria técnica "e apoio comercial, identificação de mercado, e apoio para mobilização de recursos". ${ }^{68}$ Hoje, o projeto é uma referência nacional, porém apenas esse tipo de iniciativa não garante a autonomia econômica das comunidades, porque como o artesanato é produzido a partir de recursos naturais, explorado diretamente da floresta, fica sempre uma questão, pois, um dia os vegetais usados para a produção podem se esgotar. Os Baniwa, com certeza, já pensaram nessa possibilidade provável, mas levantamos esse questionamento porque a maioria dos indígenas tem uma cultura de apenas extrair recursos naturais para o seu sustento e não cultivar. Na região do alto rio Negro, há diversas plantas e vegetais frutíferas que os indígenas poderiam plantar nas roças ou ao redor de suas casas, no entanto preferem derrubar as árvores para colher os frutos e apenas extrair objetos naturais para a produção de artesanatos sem se preocupar com o que pode ocorrer no futuro.

Falar de arte Baniwa não significa afirmar que apenas os Baniwa produzem artesanato, no entanto existem outros povos da região que também produzem o mesmo tipo de artesanato. Por isso, a questão é como eventualmente poder-se-ia patentear estes produtos que não são exclusivos de um grupo. A partir dessa experiência econômica, o risco que temos é cada povo ou grupos de outras regiões começarem patentear produtos artesanais e conhecimentos milenares, por existe os dois lados que devemos pensar e analisar. De um lado sabemos que pode vir a ser uma experiência interessante e positiva, porque que em curto prazo poderia ajudar na melhoria das comunidades, mas por outro lado, pode gerar disputas de direitos dos conhecimentos tradicionais entre povos, como por exemplo, o cultivo e as espécies de pimentas, que não é exclusividade de um único povo.

\footnotetext{
${ }^{67}$ Ibidem.

${ }^{68}$ ISA. Povos Indígenas no Brasil 1996-2000, p. 280-281.
} 


\section{c) Projeto de Educação Escolar Indígena}

O projeto de Educação Escolar Indígena do rio Negro iniciou em 1998, depois que a Lei Municipal do Ensino foi aprovada e foram criadas as escolas municipais nas terras indígenas, como escolas indígenas. ${ }^{69}$

Para melhorar a qualidade de ensino, a Secretaria de Educação Municipal desenvolveu o programa de formação de 180 professores indígenas do município de São Gabriel da Cachoeira de diversos grupos em nível de magistério. Foi o marco inicial para o avanço e transformação da Educação Escolar Indígena do alto rio Negro, e, desde então mudanças positivas ocorrem, mas com isso também surgem maiores desafios de adaptação e conciliação de conhecimentos indígenas e não indígenas, e a falta de assessoria pedagógica qualificada e material didático específico para esse tipo de educação diferenciada. ${ }^{70}$

Diante da demanda que surgem todos os anos nas comunidades indígenas, onde novas escolas indígenas são criadas, principalmente no Ensino Fundamental, a FOIRN e o ISA criaram em 1998 um projeto de Educação para o rio Negro que chamam de "Projeto de Educação Indígena no Alto Rio Negro”. O objetivo desse projeto é: ${ }^{71}$

Colaborar com o processo de reestruturação da educação escolar indígena na região. O projeto tem como princípio a valorização das línguas e culturas dos povos indígenas da região, relacionando-as com os conhecimentos científicos acadêmicos ocidentais e tendo em vista a profissionalização em áreas que contribuam para o desenvolvimento regional indígena sustentável.

A execução do projeto foi iniciada em 1999 com experiências escolares inovadoras e profissionalizantes; formação continuada de professores indígenas; acompanhamento das políticas públicas; e intercâmbio nacional e internacional com outras escolas indígenas. As experiências escolares se fixaram nas seguintes comunidades: no médio rio Içana, a Escola Indígena Pamáali (Baniwa e Coripaco); no alto Tiquié, a Escola Indígena Uhtãpinõponõ (Tuyuka); no médio Tiquié, a Escola Indígena Yupuri (Tukano e outros povos); no alto rio Uaupés, a Escola Indígena Khumunó Wu'ú Kootiria (Wanano). Elas são escolas municipais de ensino fundamental. ${ }^{72}$

\footnotetext{
${ }^{69}$ FOIRN, op. cit., 2001-2004.

${ }^{70}$ Ibidem.

${ }^{71}$ Ibidem.

${ }^{72}$ ISA. Povos Indígenas no Brasil 2001/2005, p. 249.
} 
As características principais dessas escolas é que elas são geridas pelos próprios indígenas a partir da lógica do diálogo, da liberdade e autonomia de "decisões comunitárias na organização político-pedagógica" e pela prática do "ensino via pesquisa" a partir das pesquisas temáticas. Com isso, o objetivo é estimular os jovens indígenas para se tornarem pesquisadores e investigadores de sua própria cultura. De acordo com a Flora Dias CABALZAR (2005) ${ }^{73}$ : "Como boa parte dos projetos de educação escolar entre os povos indígenas, este também busca, nas mudanças, "criar novas referências" e alcançar maior "sensibilização das políticas públicas" para as realidades locais e suas experiências sóciohistóricas diversas".

Outra ação do projeto que destacamos é o intercâmbio de experiência com outras escolas indígenas da região, do país e de países vizinhos como a Venezuela, e principalmente da Colômbia, porque no território vizinho há parentes que foram divididos pela linha de fronteira e que compartilham os mesmos conhecimentos. Esse intercâmbio faz parte do processo de inovação da educação escolar indígena do alto rio Negro, porque contribui para as "políticas de parcerias, encontros e redes" de relações de convivência com outros povos. Ele fortalece também a organização da "política interna das escolas", contribui para a valorização das línguas paternas e corrobora as "políticas de vínculos geracionais e gestão de conhecimentos". 74

Para executar as propostas e projetos que surgem dentro das escolas indígenas, os gestores e a comunidade enfrentam diversos desafios, tais como:

conseguir autonomia para manter os recursos humanos, materiais e financeiros; conseguir mais apoio para a produção de materiais didáticos nas línguas indígenas; garantir mais formação específica para os professores indígenas; aprimorar o conhecimento do uso do português para melhor contato técnico com o mundo de fora; manter um sistema de acompanhamento constante do trabalho do professor; expandir a instalação de $5^{\mathrm{a}}$ a $8^{\mathrm{a}}$ série do ensino fundamental em mais comunidades a fim de interromper a migração de famílias para centros urbanos.

Em resumo, o que está em questão é a sustentabilidade dessas escolas, porque a cooperação norueguesa informa com muita ênfase que ela vai, no curto prazo, parar de subsidiar uma ação que é de responsabilidade do governo brasileiro, ou seja, a de oferecer o ensino básico para toda sua população, seja indígena ou não. ${ }^{75}$

\footnotetext{
${ }^{73}$ Ibidem, 2001/2004, p. 249.

${ }_{75}^{74}$ Ibidem, 2001/2005, p. 249-254.

${ }^{75}$ Ibidem.
} 
Os recursos financeiros que sustentavam as atividades das escolas indígenas apoiadas pelo FOIRN/ISA vinham de fontes internacionais, como por exemplo, a "Cooperação Norueguesa". A FOIRN e o ISA sabiam que mais cedo ou mais tarde a fonte se esgotaria, no entanto não se preveniram para garantir a autonomia indígena. Quando os recursos externos começaram ser cortados, as instituições parceiras tiveram que cobrar a responsabilidade do governo municipal para que apoiasse os projetos pilotos. Por isso, hoje, as Escolas Indígenas apoiadas pela FOIRN/ISA, também são apoiadas pela Secretaria de Educação Municipal SEMEC, porque na prática e legalmente são escolas municipais.

\section{d) O Projeto de Macrozoneamento}

É um projeto elaborado e executado pela FOIRN em parceria com o ISA. O objetivo é desenvolver a sustentabildidade das comunidades indígenas através do uso da terra, do solo. Para isso, a FOIRN e o ISA também contam com a parceria da Escola Agrotécnica Federal de São Gabriel da Cachoeira e, portanto, faz "pesquisa sobre o conhecimento que a população tem sobre as áreas que habitam: a diversidade dos solos, da fauna, da flora, os diferentes usos desses recursos naturais, a qualidade das terras para cultivo, as áreas de caça, etc" ${ }^{76}$

Por se tratar de uma extensão muito grande de terras indígenas, este projeto abre condições para que a FOIRN desenhe estratégias de ação que visam a proteção e a fiscalização das Terras Indígenas do Rio Negro através da implantação de projetos de sustentabilidade ambiental, econômica e cultural. O potencial positivo que um projeto deste trás é, por exemplo, subsidiar a Escola Agrotécnica de S. Gabriel na formulação de seus cursos, já que os conteúdos das aulas praticadas por essa escola são adequados a uma realidade ambiental que não é a da região onde está instalada a Escola. Com os conhecimentos recolhidos pelo Projeto do Macrozoneamento, seria possível a construção de um programa de formação e capacitação de técnicos indígenas preparados para responder aos anseios de suas comunidades de origem. ${ }^{77}$

Esse é um projeto importante para as comunidades indígenas, porque busca formular projetos a partir das realidades comunitárias. Procura também, subsidiar as políticas públicas locais e ao mesmo tempo ajudar o sistema de ensino da Escola Agrotécnica, que apesar de atuar em uma região onde a população indígena é aproximadamente $90 \%$, não consegue inovar seu método de ensino e adequar-se à realidade indígena. Enfim, através desse projeto de macrozoneamento os parceiros querem enfrentar o desafio de "manter o sistema de recolhimento e trocas de informações" entre indígenas e os pesquisadores "em relação às

\footnotetext{
${ }^{76}$ Ibidem.

${ }^{77}$ FOIRN, 2000-2004, p. 12.
} 
condições ambientais da região". Outro desafio que surge entre os indígenas das comunidades é como acreditar em novos pesquisadores se eles não se apropriarem de seus conhecimentos milenares, fato que passou a ocorrer com a execução do projeto. ${ }^{78}$

\section{e) Projetos de Telecentro e de Centro de Capacitação e Comercialização}

O Projeto de Telecentro da FOIRN foi concretizado em parceria com a IBM Brasil e o Ministério da Cultura. O seu objetivo é auxiliar os jovens indígenas em suas pesquisas escolares e acadêmicas e também auxiliar os trabalhos das Associações de base filiadas a FOIRN. ${ }^{79}$ O projeto é executado na sede da Federação, em São Gabriel da Cachoeira, por isso as pessoas que utilizam a sala de pesquisa pertencem a quase todos os grupos da região, com exceção dos Hupda, que ainda não tem acesso, porque como sempre aconteceu na história dos povos da região, estão esperando uma oportunidade para ter os mesmos direitos que outros povos.

O Centro de Capacitação e Comercialização é outro projeto ousado e inovador que a Federação propõe executar na região. O prédio do centro está em fase de construção e acabamento, e está sediado no centro da cidade de São Gabriel da Cachoeira. O projeto tem apoio do Governo do Estado e o recurso da União Européia (EU). O objetivo é capacitar recursos humanos indígenas locais.

Através desses projetos, a FOIRN e seus parceiros municipais, estaduais, federais e internacionais, buscam a autonomia indígena e se aproxima mais das associações de base. A luta pela melhoria da qualidade de vida e a autonomia indígena são alguns dos objetivos que a FOIRN propõe alcançar a curto e em longo prazo, porque conquistar esses objetivos exigirá do movimento indígena da região a colaboração de parceiros externos que realmente valorizem a luta indígena. "O aprimoramento dessa idéia vem ao encontro dos objetivos pelos quais as populações indígenas da região do Rio Negro pretendem lutar daqui para frente". 80

\section{f) As redes e as relações nacionais e internacionais}

A FOIRN faz parte da rede nacional das organizações indígenas do Brasil, que tem como objetivo "juntar os esforços de cada integrante para atuarem conjuntamente para pressionar as políticas públicas no Brasil para atuarem com mais força na educação indígena e

\footnotetext{
${ }^{78}$ Ibidem.

${ }^{79}$ Ibidem, 2001-2004.

${ }^{80}$ Ibidem, 2001-2004.
} 
no apoio a iniciativas para o desenvolvimento sustentável pelos projetos de manejo florestal, dos recursos naturais em geral". Essa rede chama-se "Rede de Cooperação Alternativa (RCA)", e, através dela os representantes das organizações indígenas fazem intercâmbios políticos, culturais, sociais e econômicos. Visitam outras áreas indígenas para conhecer os projetos que são executados na área de educação indígena e na área de manejo agroflorestal etc. As organizações indígenas e ONGs que fazem parte dessa rede são as seguintes: VytyCati, do povo Timbira, a Organização dos Professores Indígenas do Acre, a Associação Terra Indígena Xingu, o ISA, a Comissão Pró Índio do Acre, a comissão Pró-Yanomami e o Centro de Trabalho Indigenista. ${ }^{81}$

Outra rede relações internacionais que a FOIRN participa e se projeta como instituição indígena do rio Negro é a Cooperação e Aliança no Noroeste Amazônico (CANOA). A CANOA tem o como objetivo "unir povos indígenas do noroeste amazônico [...], da Colômbia, [...] Venezuela e do Brasil para discutirem aspectos e problemas comuns que enfrentam nas áreas de saúde e educação", e buscar soluções a curto e longo prazo. As experiências e os desafios que os parentes colombianos e venezuelanos vivenciam, são compartilhados em eventos anuais que ocorrem rotativamente nesses três países. Esse é mais um projeto político da FOIRN, que fortalece as relações internacionais dos povos indígenas e que também incomoda muito os militares brasileiros, que entendem que esses projetos trazem ameaça à soberania nacional. $\mathrm{O}$ objetivo do movimento indígena internacional dos três países (Brasil, Colômbia e Venezuela), é contribuir para a convivência amistosa de indígenas que vivem em diferentes países e mostrar que podem conviver além das fronteiras de forma internacional. $^{82}$

\subsubsection{A participação indígena na política partidária}

Desde que São Gabriel da Cachoeira se tornou município, entre 1962 e 2008, a política partidária no município sempre foi controlada e dominada pelos descendentes de portugueses e nordestinos. Os indígenas eram vistos como pessoas incapazes de administrar uma prefeitura, desorganizados, preguiçosos, cachaceiros etc. Por essas e outras razões, o comando dos partidos políticos também eram controlados pelos não-índios. Essa estratégia política impedia que os indígenas concorressem diretamente para cargos majoritários e proporcionais. Porém, chegou o dia 05 de outubro de 2008, quando essa página da história mudou, porque

\footnotetext{
${ }^{81}$ Ibidem, 2001-2004.

${ }^{82}$ Ibidem, 2001-2004.
} 
nesse dia um Tariano da comunidade de Iauretê se tornou o primeiro indígena prefeito de São Gabriel da Cachoeira; mas, para conquistarem essa vitória, os povos indígenas tiveram que lutar muito.

Ao longo desses anos de dominação, o 'coronelismo' e a 'ditadura' assumidos por autoridades não-indígenas, neste município, têm gerado perseguições políticas, ameaças aos cidadãos que opinam de forma diferente, compra de dignidade e honestidade das pessoas,

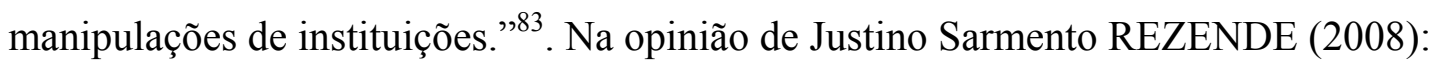

AS LUTAS DOS POVOS INDÍGENAS SEMPRE FORAM CONSTRUÍDAS EM MEIO ÀS AMEAÇAS, AGRESSÕES E MORTES. MUITOS LÍDERES INDÍGENAS JÁ MORRERAM POR CAUSA DA DEFESA DE SEUS IRMÃOS. QUE O SANGUE DERRAMADO PELOS LÍDERES INDÍGENAS DE DIVERSOS POVOS VENHA SOMAR COM A NOSSA LUTA, VENHA CORRER EM NOSSAS VEIAS PARA QUE POSSAMOS TER CORAGEM DE CONSTRUIR A NOSSA E NOVA HISTÓRIA!

A mudança da estrutura da política partidária montada pelos não-índios do município dependia da união e da força dos povos indígenas que sempre foram maioria, mas que até então, não tiveram forças suficientes para transformar o contexto político. Existe uma explicação do por que os indígenas, apesar de serem a maioria, não tinham conseguido ainda controlar a política partidária no município. É que os objetivos da FOIRN não priorizaram a discussão e a participação direta de lideranças indígenas na política partidária do município. $\mathrm{Na}$ teoria, a Federação nunca quis participar diretamente da política, porque os seus representantes alegavam que a instituição existia para apoiar as organizações indígenas de bases e não os políticos indígenas.

Entretanto, antes de criar a FOIRN, os Tukano de Pari-Cachoeira, juntamente com os indígenas de Taracuá e Iauaretê, tinham o objetivo de fortalecer a política do movimento indígena e a participação dos indígenas na política partidária do município. Foi com essa finalidade que criaram, no início da década de 80, o evento esportivo dos "Jogos do Triângulo", que coincide exatamente no ano das eleições municipais. Assim, independentemente da FOIRN, os "Jogos do Triângulo Tukano" servem para unir as populações indígenas da região do Uaupés. Portanto, os resultados e efeitos dessa articulação social e política não surgiram rapidamente, os indígenas tiveram que esperar quase três décadas para ocupar o cargo máximo da prefeitura.

\footnotetext{
${ }^{83}$ Justino Sarmento REZENDE, 25/07/2004.
} 
A relação de poder entre indígenas e não-índios, em São Gabriel da Cachoeira, sempre foi desigual, por diversos fatores, por exemplo, um dos principais foi a falta de recursos financeiros e humanos que sustentassem a participação. Nas relações de convivência social, os não-índios nunca gostaram da participação indígena na política partidária, porque sabiam que se um dia concorressem para os cargos majoritários e proporcionais, os não-índios perderiam o poder que sempre controlaram. Essa era a maior preocupação dos políticos nãoindígenas, que por essa razão, ao longo dessas décadas usaram os seus poderes econômicos para controlar os indígenas que vivem nas comunidades do interior e que são menos instruídos. Também conseguiram conquistar algumas lideranças indígenas para lutar ao seu lado, pelos seus interesses e, assim, manter o poder municipal em suas mãos. Por isso, alguns professores e lideranças indígenas ainda apóiam os políticos tradicionais, porque recebem bonificações financeiras e apoio político para satisfazerem seus interesses subjetivos. Assim como na sociedade envolvente, também há indígenas que pensa mais em si do que no bem comum das populações indígenas e sempre querem ter vantagens às custas dos outros. $\mathrm{Ou}$ seja, sabem o gosto de ter o poder em suas mãos. Nesses momentos, o dinheiro fala mais alto, e o interesse da coletividade fica em segundo plano.

Em todas as eleições municipais que antecederam a de 2008, os indígenas foram comprados para votar em candidatos não-indígenas. Os políticos não-índios, com o seu poder econômico distribuíam dinheiro, cestas básicas, motores de popas, motores de luz, cimento, telhas, alumínio, sandálias, panelas, redes, balas (bombons), gasolina, sal, etc., realizavam festas dançantes para distribuir bebidas alcoólicas, porque sabiam que com apenas esses materiais já conquistavam os votos indígenas. Faziam das comunidades indígenas seus verdadeiros currais eleitorais e locais sem lei. O ministério público e poder judiciário do município sempre se omitiram em punir os candidatos não-indígenas que praticavam e praticam atos ilegais durante as campanhas eleitorais. Ainda, hoje, fazem vista grossa e nunca punem nenhum político que comete atos ilícitos na época da campanha. Muitas vezes isso acontece porque o juiz e o promotor (a) são amigos (as) do prefeito e apadrinhados do candidato a prefeito.

Em todas eleições municipais, os candidatos não-indígenas, violam as normas eleitorais e nunca são punidos. Candidatam-ser e ganham as eleições e continuam ocupando os cargos de prefeitos e vereadores. Nesse aspecto, o município transformou-se em um lugar sem lei, porque quem deveria punir é amigo ou é amiga do prefeito e, portanto, nunca são condenados. São Gabriel da Cachoeira é um município, onde qualquer pessoa recém chegada pode tornar-se prefeito ou vereador. As pessoas desconhecem suas trajetórias de vida. 
Ninguém sabe de fato quem ele é. Outra coisa que observamos é que vários canbdidatos antes de se tornarem prefeitos eram pobres, mas, depois de quatro anos de mandato, aumentaram seus patrimônios acima do que o salário do prefeito do município permitira. Aos poucos, compram dezenas de lotes de terras, abrem lojas e ninguém sabe como em pouco tempo conseguiram enriquecer tão rápido. Enquanto isso, a população indígena e alguns não-índios não têm condições financeiras para sustentarem suas famílias e dependem da boa vontade do administrador municipal, que na maioria das vezes só enxerga o povo na véspera das eleições. Conforme REZENDE (2008) ${ }^{84}$ :

No campo da política partidária, que é diferente modelo de organização social, em nosso município os povos indígenas (eleitores) participaram ativamente votando num e noutro candidato não-indígena. Com o passar do tempo alguns indígenas filiados aos partidos políticos concorreram para assumir uma cadeira na Câmara Municipal, alguns deles: Paulino Vieira, Odilon Penha, Flávio Carvalho, Alberto Barbosa, José Maria de Lima (de Iauareté), Geminiano (de Taracuá), Pedro Machado, Henrique Vaz, José Protásio Castro e Hernani (de Pari-Cachoeira) e outros. O professor Tiago Cardoso em 1996 ganhou as eleições como vice-prefeito.

Em 2000, para tentar reverter a história da política municipal e para mostrar aos políticos tradicionais do município, os ex-dirigentes da Federação e lideranças de base começaram construir um projeto de união das forças políticas dos grupos indígenas do município. Denominada Comissão Indígena Supra Partidária era formada por três partidos políticos que eram presididos pelos indígenas: o Partido dos Trabalhadores (PT), o Partido Verde (PV) e o Partido Comunista do Brasil (PCdoB).

O PT era presidido por Pedro Garcia (Tariano), que representava a área do Triângulo Tukano, Uaupés; o PV era presidido por Camico (Baniwa), que representava a área do Içana e Xié; e o PC do B, comandado por Braz França (Baré), que representava o povo Baré. O objetivo da CISP era unir os povos indígenas da região para fortalecer a participação de candidatos indígenas e disputar as eleições municipais de 2004, com uma chapa indígena, ou seja, com prefeito e vice-prefeito indígenas. Para isso, um dos três teria que ser escolhido para concorrer o cargo majoritário e outro para vice. A escolha foi feita através de uma eleição extraordinária, que aconteceu na "maloca" da FOIRN. Um ano antes das eleições, a CISP convocou a população indígena para escolher quem seria o candidato indígena que concorreria para o cargo majoritário nas eleições municipais de 2004, e, o segundo mais votado, seria indicado para ser o vice-prefeito.

\footnotetext{
${ }^{84}$ REZENDE, 2008.
} 
O candidato escolhido para concorrer a cargo majoritário foi Pedro Garcia, do Triângulo Tukano e o vice Camico (Baniwa). Braz França ficou em terceiro lugar com o compromisso de apoiar a candidatura dos dois. Entretanto, naquele momento os representantes indígenas dos partidos políticos que disputavam esses cargos romperam os compromissos assumidos. O PC do B decidiu não apoiar os dois candidatos indicados e, optou pela aliança com um candidato não-indígena, com a intenção de obter benefícios, e, porque achavam que era o candidato mais forte naquele momento.

Essa atitude do presidente do PC do B demonstrou que alguns indígenas já estavam se apropriando das estratégias e das armadilhas da política partidária, ou seja, tinham aprendido a fazer política. A desarticulação da CISP continuou, pois, Camico que tinha sido escolhido para ser vice-prefeito de Pedro Garcia, na véspera das convenções partidárias resolveu desistir de ser candidato a vice-prefeito de Pedro Garcia para ser vice-prefeito de um outro candidato não-indígena. Mais uma vez, ficou evidente a disputa política entre as lideranças quando entram na política partidária, porque assimilam as mesmas práticas dos políticos nãoindígenas, que fazem o jogo da política para conquistar poder.

Assim, como o candidato indígena do PT tinha ficado sem o seu vice, fomos escolhidos para concorrer ao cargo de vice-prefeito. Porém, naquele momento o objetivo assumido pela CISP havia diluído e a derrota nas eleições municipais era praticamente certa. No final, nenhum candidato indígena ganhou as eleições. Todos perderam: o PT, o PV e o PC do B. Principalmente a população indígena foi derrotada, pois seus interesses não prevaleceram naquela eleição.

Nas eleições de 2004, os indígenas não tiveram apoio da maioria dos não-indígenas do município, porque os adversários políticos pregavam que um índio no comando da prefeitura seria uma irresponsabilidade da população, porque os índios não tinham experiência administrava, eram viciados em bebidas alcoólicas, não tinham dinheiro como os brancos e se ganhassem excluiriam os não-índios. Era a manifestação de uma visão totalmente preconceituosa e eficiente politicamente, que até os eleitores indígenas acharam que era verdade, por isso a maioria não votou nos candidatos indígenas. Contraditoriamente, a primeira candidatura de uma chapa composta só de indígenas não encontrou apoio nem da maioria dos indígenas, nem dos não-indígenas.

A campanha naquela eleição dos candidatos indígenas foi feita com apenas duas voadeiras de alumínio, com um motor de popa de $15 \mathrm{HP}$ e outro de $40 \mathrm{HP}$, cedidos gratuitamente pelos familiares dos candidatos. A gasolina receberam também doados pelos seus parentes e familiares. Tinha apenas duas músicas de campanha composta pelos próprios 
indígenas. Naquela eleição, nenhum comerciante não-indígena da cidade apoiou a candidatura indígena.

Apesar desses desafios e dificuldades, REZENDE $(2008)^{85}$ destacou que:

Como se pode ver esta história é viva. Em cada eleição municipal os indígenas de diferentes etnias disputam alguma vaga para Câmara Municipal de nosso município; alguns deles são indicados pelas organizações indígenas nas quais fazem parte.

No ano de 2004 surgiu uma candidatura indígena concorrendo para o cargo majoritário: Sr. Pedro Garcia (Tariano) e Israel Dutra (Tuyuka). Naquele ano não obtivemos vitória, perdemos, embora, o número da população do Município é formado por $90 \%$ de indígenas. Como já disse anteriormente o processo de luta para conquistar os diversos espaços da nossa sociedade não vai parar. [...]

Entretanto, a experiência da eleição municipal de 2004, serviu como uma lição de vida para os indígenas, porque essa mesma população que ajudpou a derrotar a primeira candidatura indígena para o cargo majoritário do município de São Gabriel da Cachoeira, em 2008, decidiu mudar o curso da história política do município.

A eleição de 05 de outubro de 2008 se tornou uma data histórica do município, porque primeiro os indígenas venceram os políticos tradicionais da cidade, inclusive alguns coronéis, que nunca aceitaram um candidato indígena para os cargos majoritários de seus partidos. Segundo porque a decisão popular foi decretada, pois, a partir de 2009 a prefeitura de São Gabriel da Cachoeira será finalmente comandada pelo indígena Pedro Garcia (Tariano do PT) e pelo vice-prefeito André (Baniwa do PV), que ganharam as eleições municipais com 51\% dos votos.

Diante do fato histórico da política municipal, REZENDE (2008) afirmou que:

Historicamente significa deslocamento de personalidades para ocupar os cargos públicos. Pela primeira vez os índios ocupam o cargo majoritário neste município. Os não-indígenas acostumados a ocupar o poder pela primeira vez têm que se calar e conformar com os resultados da última eleição. Desta vez os povos indígenas e não-indígenas insatisfeitos com todas estas décadas administrativamente malassumidas, disseram pelo voto que quem deve administrar os próximos anos deve ser uma coligação denominada ADMINISTRAÇÃO PARA TODOS, encabeçada por dois indígenas, um Tariano (Pedro - PT) e um Baniwa (André - PV).

\footnotetext{
${ }^{85}$ REZENDE, op. cit., 2008.
} 
Figura 1. A vitória indígena nas eleições municipais de SGC, em 2008.

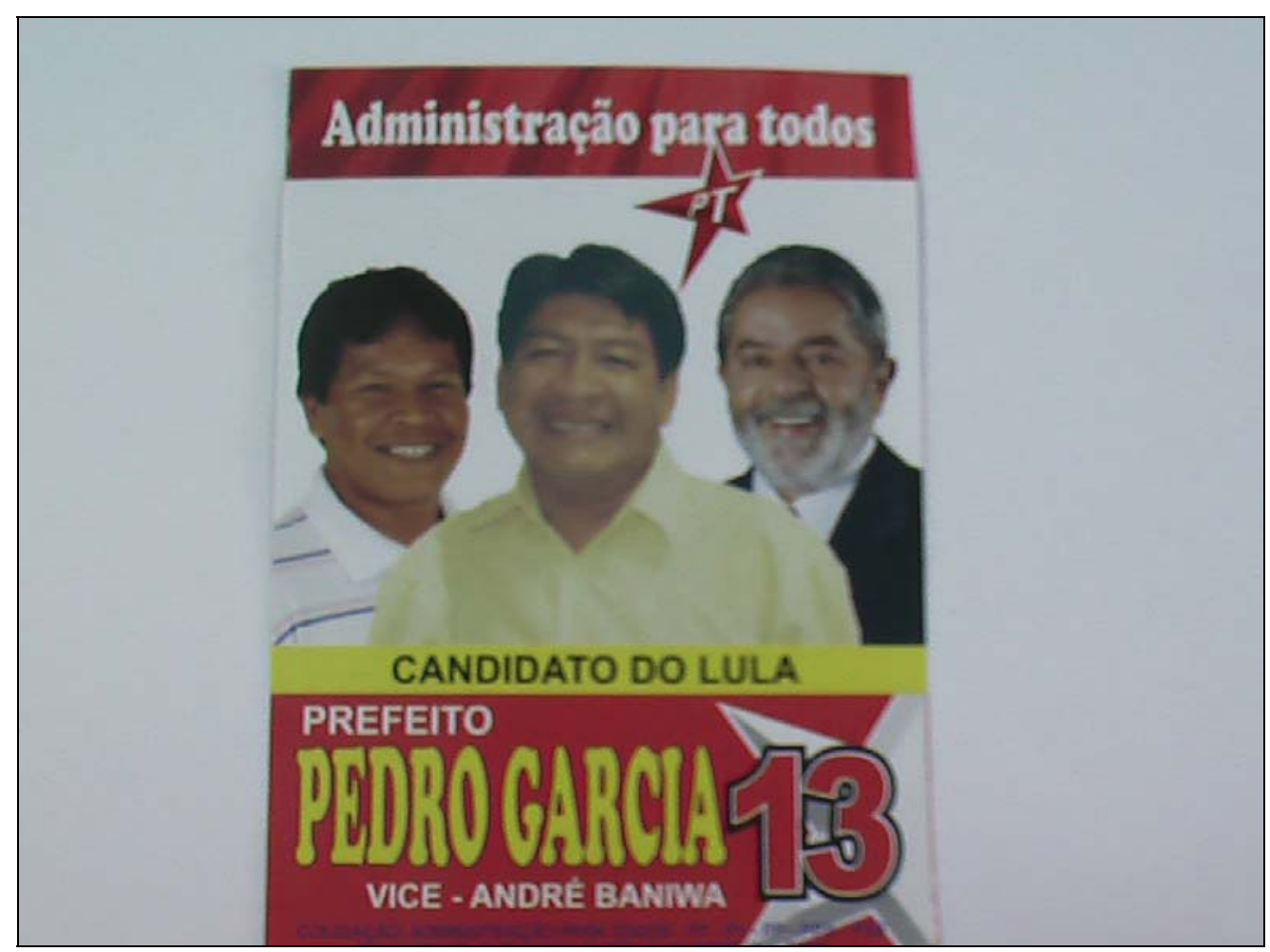

Fonte: Justino Sarmento REZENDE, 2008.

A partir de 2009, a prefeitura de São Gabriel da Cachoeira será assim, gerida pelos indígenas, por isso a cobrança será muito maior por parte dos não-indígenas, que poderão indiretamente tentar desequilibrar a imagem da participação política na administração da prefeitura. A história do movimento indígena já comprovou que a interferência de políticos locais sempre foi feita no sentido de prejudicar as ações dos representantes indígenas em instituições governamentais. Esta prática sempre visou a desmoralização da participação política dos representantes indígenas na vida política do município. É um risco que o novo prefeito indígena de São Gabriel da Cachoeira irá enfrentar. Agora, o caminho está traçado, resta apenas os dois indígenas mostrarem para os eleitores indígenas e não-indígenas a capacidade política que têm para administrar as instituições não-indígenas. Mas, uma coisa 
eles sabem, os adversários políticos não-indígenas de São Gabriel da Cachoeira sempre serão adversários políticos, e eles poderão agora, mostrar que os povos indígenas podem comcndar seus destinos, inclusive no plano da política. 


\section{AS CONCEPÇÕES NA VISÃO DE DIFERENTES AUTORES}

Neste capítulo dois, apresentaremos as noções e conceitos selecionados a partir de autores que reforçam a análise e reflexão do objeto de nosso estudo. Assim, como disse uma vez, o Prof. Ariovaldo Umbelino de Oliveira, durante a orientação do nosso trabalho, "não vamos inventar a roda mais vez, porque ela já existe". Por isso, escolhemos os principais conceitos utilizados ao longo da dissertação e, iniciamos com Marco Antônio BARBOSA (2001), que analisa e reflete sobre os conceitos de povo, comunidade e autodeterminação indígena, baseando-se no direito internacional.

Para BARBOSA $(2001)^{86}$ :

“...se não formos capazes de compreender a questão profunda da diversidade e valor das sociedades humanas - todas elas dignas de respeito dos individuos, dos Estados e das demais sociedades humanas; todas elas com iguais potencialidades intelectuais de seus membros e de arranjos e opções de organização social e jurídica, apenas e tão somente diferentes quanto aos modelos que adotaram e de forma alguma inferiores ou menos desenvolvidas do que qualquer outra -, não estaremos atos a admitir o direito dos povos tradicionais às suas terras, mas estaremos sempre lidando com a prioris etnocêntricos, evolucionistas ou paternalistas. ... Na medida em que alcancemos esta capacidade de ultrapassar nossos preconceitos e mesmo nossa ansiedade de dar-lhes um espaço delimitado, tanto sobre a terra como em nosso imaginário, teremos nos deparado com a pura realidade de que os grupos indigenas, esses povos tradicionais, existem e continuarão sempre a existir caso não sejam fisicamente exterminados ou tenham suas terras confiscadas. E que são tão evoluídos e desenvolvidos quanto as sociedades modernas, apenas diferentes, e que como toda sociedade humana têm o direito de existir; e como toda sociedade humana sua existência é importante para o resto da humanidade, por sua forma peculiar de ser e de seu conhecimentos."

Entre os estudiosos do conceito de fronteira, está o Prof. André Roberto MARTIN, da Universidade de São Paulo, e Claude Raffestin. São estudados por eles os conceitos de território e circulação, não-brasileiros e brasileiros. São também estudiosos da ciência política que discutem o poder e a liberdade, que constituirão a nossa fundamentação conceitual. Não vamos aprofundar o estudo de conceitos e noções, mas, utilizaremos muitos autores para fundamentar o nosso trabalho.

\footnotetext{
${ }^{86}$ Marcos Antônio BARBOSA, 2001, p. 392.
} 


\subsection{Povo e comunidade}

\subsubsection{Povo}

Em suas considerações preliminares, do livro "Autodeterminação: direito à diferença", Marcos Antônio BARBOSA (2001), o autor apresenta uma "luz" e um instrumento jurídico internacional, pois para ele os indígenas são, sim, reconhecidos como povos e, portanto, têm o direito à autodeterminação, assim como é reconhecida a todos os povos da Terra. Entretanto, ressalta que esse direito não significa, necessariamente, que venham a se separar dos países onde habitam. Reconhecer o direito à autodeterminação indígena significa "tratamento adequado de sua condição de povos com amplos direitos políticos e real autonomia para tratarem de seus assuntos próprios e reconhecimento de sua importância no conjunto da humanidade $[\ldots]$ ", pois eles podem contribuir para "uma nova relação da humanidade com a vida e com a Terra", e, portanto, é nesse sentido que "se evitará o fantasma da secessão e se criará um novo patamar nas relações entre as sociedades estatais e esses povos, até hoje tratados como de segunda categoria e inferiores aos demais". ${ }^{87}$

Para iniciar a nossa reflexão é necessário entender que "a idéia de povo implica sempre no seu plural". Ou seja, quando pensamos em povo, pensamos em diversidade, em multiplicidade de agrupamentos humanos diferentes entre si, de tal modo que o termo, esta noção nasce caracterizada como um conceito relacional". Desse modo, ela existe e se apresenta não como uma idéia total, unívoca, que se explique por si mesma, porém pelo contrário, a sua existência invoca algo maior que a simples unidade, por isso destaca BARBOSA (2001), "que mesmo que estejamos utilizando o termo precedido de artigo definido (o povo), inarredavelmente o estaremos pensando dentro da diversidade, sabedores da existência de outros povos". 88

A concepção de povo, inclusive no plural, implica também, ao mesmo tempo, na idéia de unidades constituídas por pluralidade de indivíduos que vivenciam e seguem padrões sociais comuns, mesmo que sejam diferentes entre si. Portanto, essa é a razão da existência de ser da noção. E a noção do povo nos remete a uma outra noção que é a de cultura-humana, "que por sua vez evoca a de sociedade-humana". As três noções (povo, cultura-humana e

\footnotetext{
${ }^{87}$ Ibidem, 2001, p. 18.

${ }^{88}$ Ibidem, 2001, p. 53.
} 
sociedade-humana) remetem a idéia de pluralidade e uniformidade dos conjuntos humanos, que mesmo que sejam conjuntos diferentes "todos são humanos". 89

Deste ponto de vista, a noção de povo é altamente complexa, porque falar de povo implica "automaticamente em todas essas idéias e nas realidades que essas idéias representam". 90

Pelo fato de possuir um significado plural, grupos de diferentes razões políticas, ideológicas e sistemas de governo aceitam ou rejeitam o uso "do termo povo em função de diferentes conveniências [...]"91. Para os indígenas "não importa que o Estado utilize os termos povos, etnias ou grupos, área, terra ou território indígena, pois eles têm consciência do que são e do que querem"92.

No campo sócio-político, segundo José ECHEVERIA “a nação como o povo são comunidades humanas caracterizadas pela participação num mesmo passado e pela vontade de construir um futuro" (apud Cassesse, dir., et al, 1978:95). ${ }^{93}$

Ainda, sempre de acordo com ECHEVERIA, BARBOSA (2001) escreveu que a nação reivindicaria a origem comum e povo a de "vontade de um futuro". E "a nação tende a se reproduzir, a repetir no presente o seu passado e o povo tende à mudança a inventar um futuro que escolhe livremente afirmado, na seqüência, nas suas decisões". ${ }^{94}$

Desse modo, a livre determinação é apenas atribuída ao povo e não à nação, porque pressupõe que a nação já a tem. A nação é titular do direito de soberania, por isso o povo reivindica o direito de autodeterminação, autonomia à ela, porque "o povo é uma comunidade carente" desses direitos.

ECHEVERIA pensa que:

o povo é a comunidade que se estabelece na pobreza relativamente a uma riqueza da qual se sabe despossuído, na impotência relaivamente a um poder de decisão do qual se tem a consciência de ser titular. Assim, pertencer a um povo, é um direito de demanda, de reivindicação, de ação e de luta contra os que se opõem a essa exigência (apud Jouve, 1992: 123). ${ }^{95}$

\footnotetext{
${ }^{89}$ Ibidem, 2001, p. 53.

${ }^{90}$ Ibidem, 2001, p. 53.

${ }^{91}$ Ibidem, 2001, p. 53

${ }^{92}$ Ivani Ferreira de FARIA, 1997, p. 274.

${ }^{93}$ José ECHEVERIA apud BARBOSA, 2001, p. 55.

${ }^{94}$ ECHEVERIA apud BARBOSA, op. cit., 2001, p. 55.

${ }^{95}$ ECHEVERIA apud BARBOSA, 2001, p. 55.
} 
No campo jurídico, H. Gros-Espiell definiu o povo como "toda forma particular de comunidade humana unida pela consciência e a vontade de constituir uma unidade capaz de agir em vista de um futuro comum" (apud Jouve, 1992: 123). ${ }^{96}$

Por sua vez, F. Demichel, ressaltou que a existência de um povo só pode ser comprovada dentro da dimensão histórica, na qual o papel da luta e da história implica na noção de um povo.

"A noção de povo só pode ser provada historicamente. Um povo não é, com efeito, se não pelo fato de se constituir como tal por seu combate histórico... donde o valor maior da guerra de liberação nacional. Essas guerras não são apenas, do ponto de vista jurídico, uma forma de luta válida para o direito internacional. Elas são, do ponto de vista sociológico e político, ao mesmo tempo demonstrativas e produtoras da existência de um povo" (apud Jouve, ibidem). ${ }^{97}$

Desse modo, até agora, percebe-se que enquanto que a noção de nação exprime algo completo e concluído, a idéia de povo "evoca a de processo", de transformação e mudança que culminaria em nação. Nesse sentido, segundo BARBOSA (2001):

poderíamos, talvez, dizer que o povo é uma comunidade humana caracterizada por um passado comum que the confere identidade particular, aglutinadora de seus indivíduos que têm a permanente disposição da continuidade futura demonstrada internamente pelo respeito à sua própria organização social e externamente pela reivindicação de respeito ao seu sistema organizativo e de governo. ${ }^{98}$

Conforme Carlos Frederico Marés de SOUZA FILHO (2005), os grupos indígenas não são reconhecidos como povos pela legislação brasileira e por outros países que não aprovam a Convenção 168 da OIT como lei nacional, porque o termo povo "tem conotação de autonomia, autodeterminação, guerra de independência, libertação nacional”. A Constituição de 1988 reconhece os índios como organização social e atualmente tramita no Congresso Nacional brasileiro uma lei que trata os povos indígenas como sociedades indígenas.

\footnotetext{
${ }^{96}$ BARBOSA, op.cit., 2001, p. 55.

${ }^{97}$ Ibidem, 2001, p. 55-56.

${ }^{98}$ Ibidem, 2001, p. 56.
} 
Entretanto, aos poucos essa visão vem mudando, porque vários juristas brasileiros começam perceber que o termo é mais adequado para se referir aos grupos indígenas, porque para os indígenas o termo povo não tem o mesmo significado que a dos não-índios. ${ }^{99}$

No campo antropológico, de acordo com Roberto Shirley citado por BARBOSA (2001), "Nação é um grupo de pessoas que tem uma língua em comum e uma cultura geralmente semelhante...", que pode existir sem um Estado. ${ }^{100}$

\begin{abstract}
"Podemos falar dos Cheynnes como nação, no sentido de que eles reconhecem sua própria unidade e cultura, porém é difícil identificar um Estado em suas intituições políticas. Há autoridade e liderança na vida política Cheyenne (The Cheyenne way), porém são poderes exercidos por cidadãos comuns como parte de seus deveres como membros da sociedade e não como uma corporação profissional. $\mathrm{Na}$ realidade eles estão sob o domínio, através da conquista militar, de um Estado que não é a sua nação - o governo dos Estados Unidos". ${ }^{101}$
\end{abstract}

Desse modo, no Brasil os políticos, militares, alguns estudiosos e governantes preferem não adotar o termo povo para se referir aos índios, porque tem medo que um dia os indígenas entendam a importância política da palavra e lutem pela independência e por libertação nacional. Enquanto isso, a maioria dos indígenas não imagina que o Estado brasileiro age assim em relação à política do movimento indígena, mesmo porque até agora nunca pensaram em lutar ou guerrear pela formação de um novo Estado na fronteira entre Brasil e Colômbia.

Nem as ONGs (ISA, IPOL, SSL, IBDS e outros), que assessoram as organizações indígenas do rio Negro na faixa de fronteira, que muitas vezes são vistas como uma ameaça à soberania nacional, porque incutem nas lideranças indígenas a lógica da autodeterminação trabalham para que os indígenas lutem para buscar a independência para formarem um outro Estado nacional. Pelo contrário, essas ONGs buscam executar projetos que beneficie as

\footnotetext{
${ }^{99}$ Carlos Frederico Marés de SOUZA FILHO, 2005, p. 154.

${ }^{100}$ BARBOSA, op. cit., 2001, p. 57.

${ }^{101}$ Ibidem, 2001: 57.
} 
comunidades indígenas onde o Estado brasileiro não tem investido, porque apesar de ser uma área de fronteira o Governo brasileiro não investe o necessário para melhorar a vida dos indígenas. Nesses últimos anos, o maior investimento feito na região fronteiriça da Amazônia foi a instalação de Organizações Militares (OMs) para defender a floresta amazônica e não para defender os interesses dos indígenas que vivem nessas terras há milhares anos.

\subsubsection{Comunidade}

Carlos Frederico Marés de Souza Filho (2005) escreveu que é recente a legislação brasileira que introduziu o conceito de comunidade indígena, pois, até 1973 o índio era considerado individualmente. $\mathrm{O}$ conceito de comunidade indígena ou grupo tribal só foi introduzido para assegurar direitos indígenas a partir da Lei 6.001/73 - Estatuto do Índio -, porque dizia que "é um conjunto de famílias ou comunidades índias, quer vivendo em estado de completo isolamento em relação aos outros setores da comunhão nacional, quer em

contatos intermitentes ou permanentes, sem, contudo estarem neles integrados" (art. $3^{\circ}$, II). ${ }^{102}$

Depois desse reconhecimento legal do Brasil, as comunidades indígenas, conquistaram a "titularidade de direitos de propriedade de bens móveis e imóveis", a qual estabelece que "as comunidades são titulares dos direitos sobre o patrimônio indígena (art.40), composto de vários bens e direitos". O Estatuto do Índio também garantiu o direito "aos grupos tribais ou comunidades indígenas para estarem em juízo na defesa de seus direitos (art. 37)”. ${ }^{103}$

A Constituição de 1998 reconheceu “a organização social dos índios [...] à legitimidade das comunidades indígenas para entrarem em juízo em defesa de seus direitos". $\mathrm{O}$ artigo 232, estabeleceu que "os índios, suas comunidades e organizações são partes legítimas para ingressar em juízo em defesa de seus direitos". ${ }^{104}$

Esta legitimação da Constituição brasileira se refere aos índios que podem ingressar em juízo em defesa de seus direitos coletivos, o patrimônio indígena e não para defender os direitos individuais ou o chamado patrimônio individual. Por isso, segundo SOUZA FILHO (2005), “este dispositivo constitucional é uma expressa autorização para o indivíduo índio, em

\footnotetext{
${ }^{102}$ SOUZA FILHO, op. cit., 2005, p. 153-154.

${ }^{103}$ Ibidem, 2005, p. 154.

${ }^{104}$ Ibidem, 2005, p. 154.
} 
nome próprio, postular direito coletivo, alheio da comunidade, sociedade ou povo a que pertença". 105

A legislação brasileira apresenta as organizações dos índios para se referir às “organizações não governamentais que atendem a defesa dos interesses e direitos indígenas". São organizações que têm registro no Cadastro Nacional de Pessoas Jurídicas (CNPJ) e têm seu nascimento e vida estabelecidos por lei. No Brasil existem muitos grupos indígenas que se organizam em associações e têm registro no CNPJ, porque assim são garantidos legalmente para postular em juízo e reivindicar seus direitos ${ }^{106}$. Para exemplificar, temos no rio Negro a Federação das Organizações Indígenas do Rio Negro (FOIRN) como uma organização não governamental formada e dirigida exclusivamente pelas lideranças indígenas.

$\mathrm{O}$ fato de que a legislação brasileira ter legitimado o conceito de comunidade indígena significou garantir a legitimidade ativa à comunidade como organização social indígena. Quando a lei reconhece comunidade indígena inclui também as organizações indígenas de povos que não tem contato direito com a sociedade envolvente e, portanto, são constituídas de costumes e tradições próprias que estabelecem as suas relações de convivência. ${ }^{107}$

Assim conta SOUZA FILHO (2005), que a outra característica da comunidade é a sua capacidade civil, a qual se reconhece legalmente aos índios o direito originário sobre as terras que tradicionalmente ocupam. Sobre estas terras existem direitos coletivos, do povo, do grupo indígena, da sociedade ali existente, e a propriedade comum, o que chamamos de patrimônio indígena. $^{108}$

Dentro das normas jurídicas brasileiras não existe nenhum dispositivo legal que define a natureza jurídica da comunidade. Isso evidencia, mais uma vez, o silêncio do Estado brasileiro com relação a natureza do ser indígena, isto porque, afirma SOUZA FILHO (2005), que:

Dentro da dogmática, não há titularidade de direitos sem sujeitos de direitos, que são pessoas, físicas ou jurídicas. As comunidades indígenas não o são, porque não são físicas, nem são criadas por lei ou ato jurídico. Curiosa situação que alguns juristas chamam de sociedade de fato, em que pese sua relevância constitucional. A aparência jurídica destas comunidades é de estados-membros ou municípios, porque não há outra classificação possível para as comunidades indígenas senão a de pessoas jurídicas de direito público interno, com existência reconhecida e preexistente qualquer ato. ${ }^{109}$

\footnotetext{
${ }^{105}$ Ibidem, 2005, p. 154.

${ }^{106}$ Ibidem, 2005, p. 154.

${ }^{107}$ Ibidem, 2005, p. 155.

${ }^{108}$ Ibidem, 2005, p. 156.

${ }^{109}$ Ibidem, 2005, p. 156.
} 
A situação jurídica dos povos indígenas no Brasil é complexa, porque tanto na teoria como na prática são populações que vivem sob o nome de comunidade ou grupo tribal e sob um Estado que não reconhece os grupos nativos como povos.

\subsection{Soberania e Autodeterminação}

A luta indígena pela autodeterminação e autonomia, muitas vezes é mais reconhecida no âmbito internacional do que mesmo no cenário legal dos Estados onde vivem. Há diversos fatores que impedem a compreensão do sentido de autodeterminação indígena. No Brasil, o que se vê entre os vários governantes e alguns juristas, é o julgamento da reivindicação indígena por autodeterminação a partir de conceitos e definições ocidentais sem se preocupar em querer entender a real compreensão indígena sobre a questão.

Nesses últimos anos, o Brasil acompanhou que a autodeterminação foi a principal bandeira de reivindicação dos povos indígenas tanto no plano internacional como no plano nacional. Se um dia conquistarem o reconhecimento legal do direito de autodeterminação dentro dos Estados onde vivem, poderão gerir seus próprios interesses. ${ }^{110}$ Entretanto, para conquistar essa vitória, os indígenas da Amazônia terão que lutar muito, porque a ideologia da soberania e segurança da Amazônia, a concepção "de integrar para não entregar"111 ainda exprimem o pensamento geopolítico de militares brasileiros.

A luta indígena pela autodeterminação se esbarra no conceito de soberania dos Estados onde vivem, principalmente os grupos que vivem nas áreas fronteiriças como é o caso particular no noroeste amazônico e em Roraima, onde a demarcação das terras indígenas são ferrenhamente contestadas pelos militares, fazendeiros, madeireiros, rizicultores e alguns políticos donos de empresas mineradoras ou pecuaristas etc. Muitas vezes a idéia de soberania nacional sobre a Amazônia brasileira é argumentada para justificar os interesses particulares de certos governantes do país.

No ponto de vista histórico, segundo BOBBIO citado por FARIA (1997):

o termo soberania apareceu juntamente com o de Estado no final do século XVI, para indicar o poder estatal, sujeito único e exclusivo da política. Um conceito jurídico-político que permitia ao Estado Moderno impor-se à organização medieval do poder [...] com o objetivo de reunir uma única instância o monopólio da força num determinado território e sobre uma determinada população $\left[\ldots . .{ }^{112}\right.$

\footnotetext{
${ }^{110}$ BARBOSA, op. cit., 2001, p. 313.

${ }^{111}$ Ariovaldo Umbelino de OLIVEIRA, 1987 e 1990.

112 BOBBIO apud FARIA, 1997, p. 131.
} 
O conceito de soberania, no campo jurídico e político, não tem a mesma definição, mas são complementares, por isso torna-se necessário diferenciar. No campo jurídico, soberania é definida como "o poder de decidir em última instância sobre a atributividade das normas, sobre a eficácia do direito (...) A soberania é um poder jurídico para fins jurídicos" $"$. Conforme FARIA (1997), “isso significa que não existiriam Estados fracos ou fortes, pois estariam no mesmo patamar com os mesmos direitos". 114

No campo político, soberania é entendida como "o poder incontrastável de querer coercitivamente e de fixar as competências" "115. É uma definição que revela a supremacia do poder mais forte, indiferentemente de ser legal ou não ${ }^{116}$.

De acordo com FARIA há a terceira concepção de soberania a partir de uma visão culturalista que concebe a soberania como uma expressão de poder dentro dos limites, que pode usar da coação para determinar suas imposições. Nesse sentido, Miguel REALE citado por FARIA (1997) definiu a soberania como "o poder de organizar-se juridicamente e de fazer valer dentro de se seu território a universalidade de suas decisões nos limites dos fins éticos de convivência" (REALE, 1996). ${ }^{117}$

FARIA sublinhou que existem algumas características que a maioria dos estudiosos de soberania concordam entre si, tais como:

Una, não se admite dentro do mesmo estado a existência de duas soberanias; Indivisivel, aplica-se a universalidade dos fatos ocorridos no Estado, não podendo separa-se; inalienável, pois quem a detém desaparece quando fica sem ela, imprescritivel, uma vez que não tem prazo certo de duração. Acrescenta-se a estas que a soberania é um poder: originário, nasceu no bojo do Estado Moderno; exclusivo, só o Estado o possui; incondicionado, só se encontra nos limites postos pelo próprio Estado e coativo, o Estado ordena e faz valer suas ordens coativamente. ${ }^{118}$

No Brasil, o conceito de soberania tem a forte expressão no pensamento militar, que concebe como o "poder máximo dentro do território nacional". Os militares brasileiros se baseiam na idéia de um poder estatal supremo. Segundo Mário PESSOA (1971):

[...] A soberania é a parte nobre da construção estatal. É a mente dessa instituição que atua em nome do Poder Nacional (...) nela se abriga o sentimento de posse e de domínio de todo um patrimônio (...) a soberania é forma específica do fenômeno genérico do Poder. E por isso é poder também. Quanto ao Estado, é como organização política, uma soberania na sua concretização estrutural. ${ }^{119}$

\footnotetext{
${ }^{113}$ Dalmo de Abreu DALLARI, 1991, p. 68 apud FARIA, 1997, p. 132.

${ }^{114}$ FARIA, op. cit., 1997, p. 132.

115 DALLARI apud FARIA, 1997, p. 132.

${ }^{116}$ FARIA, op. cit., 1997, p. 132.

${ }^{117}$ Ibidem, 1997: 132-134.

${ }^{118}$ DALLARI, op. cit., 1991, p. 69 apud FARIA, 1997, p. 133.

${ }^{119}$ Mário PESSOA, 1971.
} 
Para Lâm, apud Barbosa, a soberania deveria ser definida a partir de duas idéias distintas, porém conexas:

a) o direito inerente de um povo e, por extensão, do Estado que ele se dá, de não reconhecer nenhuma outra autoridade secular senão a sua sobre seu próprio território; b) a expressão desse direito na prática da autoridade política suprema. Para ela, um Estado soberano pode então continuar soberano mesmo decidindo exercer menos poder. Exemplificando através da prática corrente no mundo contemporâneo na qual Estados cedem algumas de suas prerrogativas e organismos internacionais ou simplesmente quando eles aceitam normas internacionais. A nível interno isto ocorre quando o Estado cede uma parte de seus poderes às unidades constituintes (províncias ou zonas autônomas). ${ }^{120}$

“[...], o exercício da soberania estará sempre ligado ao território, de modo que se ela representa domínio de um dos lados da fronteira, do outro, está reduzida à total impotência.

Adverte ainda a mesma autora que facilmente se esquece que, segundo a teoria política liberal sobre a qual se funda o Estado moderno, existe em cada território uma autoridade que prima sobre a do Estado, sobre a do povo e dos povos desse mesmo Estado, de modo que tal esquecimento leva a uma confusão dos conceitos de soberania e de Estado, muito bem demonstrado pela bem conhecida expressão: "soberania e integridade territorial dos Estados". 121

Maivân Clech Lâm no artigo La portée juridique de l'autodétermination (1996: 73) afirmou que o conceito de autodeterminação surgiu e evoluiu entre 1945 e 1980, "período em que toda a África, a Ásia e a Oceania se libertaram do colonialismo, adquirindo a plena independência política". ${ }^{122}$

O contexto da reivindicação indígena à autodeterminação difere das pretensões dos povos africanos e asiáticos, porque o sentido da autodeterminação reivindicada pelos indígenas, “[...] não constituiria uma secessão, na medida em que os seus territórios é que foram invadidos. $\mathrm{O}$ exercício da autodeterminação por eles nada mais seria do que o inerente poder da soberania ao qual jamais renunciaram (Morris, Glenn apud Lâm, ibidem, p. 86)". ${ }^{23}$

BARBOSA destaca um questionamento que incomoda os militares e alguns políticos brasileiros que não aceitam o direito a autodeterminação dos povos indígenas dentro do território brasileiro: “O direito de separação de um Estado existente estará sempre

\footnotetext{
${ }^{120}$ BARBOSA, op. cit., 2001, p. 314-315.

${ }^{121}$ Ibidem, 2001, p. 314-315.

122 Ibidem, 2001, p. 314.

${ }^{123}$ Rouland apud BARBOSA, 2001, p. 324.
} 
compreendido no de autodeterminação?" Para o autor, "A verdade é que grande parte dos Estados, possivelmente a maioria deles, inquieta-se com a reivindicação indígena de autodeterminação; isso revela, na prática que, ou querem negar tal direito a tais povos ou, se isso não for mais possível, querem limitar o alcance do instituto para tirar a possibilidade da separação ou secessão". 124

A noção que mais aproxima da concepção de autodeterminação do movimento indígena no Brasil e de grupos que têm vivência nas áreas de fronteira, na Amazônia é Rouland (1996: 449), o qual:

afirma que o direito à autodeterminação para os autóctones trata-se mais de um direito à coexistência pacífica no interior do Estado com o resto da população, com poder de decisão com as autoridades estatais concernentes ao seu destino através dos seus próprios representantes. Com essa colocação preliminar passa então a tratar de dois tipos de descolonização e que são a externa e a interna. ${ }^{125}$

Ainda segundo Rouland e outros estudiosos a descolonização interna significa que "os povos indígenas teriam um direito de auto-administração em questões que lhes dizem respeito especificamente; participação com o Estado nas decisões a eles relativas dentro do conjunto nacional e participação nas decisões e na vida política do Estado como um todo”. Entretanto, para BARBOSA, no direito internacional, existe um nome jurídico inconfundível: autodeterminação. A descolonização interna trata-se na verdade de autonomia que difere do sentido de autodeterminação. Essa descolonização interna se trata na verdade de autonomia e que nada tem a ver com a autodeterminação. ${ }^{126}$

Para Lâm (op. cit., p. 87), citado por BARBOSA, o termo autonomia significa “...conjunto de atividades governamentais as quais o Estado soberano delega a responsabilidade a uma entidade constituinte não soberana para ela se ocupe no interesse de seu melhor estar... trata-se da conferência de uma vasta liberdade a um subgrupo no seio de um Estado". ${ }^{127}$ Por isso, segundo BARBOSA (2001), autodeterminação e autonomia são dois conceitos fundamentalmente diferentes. ${ }^{128}$

Uma das maiores conquista indígena no âmbito do direito internacional, nesse início do século XXI, foi o fato da Assembléia Geral da Organização das Nações Unidas ter aprovado, no dia 13 de setembro de 2007, a Declaração dos direitos dos Povos Indígenas, na

\footnotetext{
${ }^{124}$ BARBOSA, op. cit, 2001, p. 325-326.

${ }^{125}$ Ibidem, 2001, p. 326.

${ }^{126}$ Ibidem, 2001, p. 326.

${ }^{127}$ Ibidem, 2001, p. 326.

${ }^{128}$ Ibidem, 2001, p. 327.
} 
qual "reconhece o autogoverno e a livre determinação dos povos". Para os indígenas essa declaração significa uma vitória, porque representa um instrumento legal de reivindicação da autodeterminação nos Estados onde vivem.

O Brasil votou a favor da Declaração. Isso mostra que o governo brasileiro, apesar de existirem diferenças internas de concepções de soberania, segurança nacional, fronteira está cada vez mais respeitando e valorizando os povos indígenas, mesmo que juridicamente não os reconheça como povos, o fato de ter votado a favor significa o reconhecimento dos direitos indígenas dentro do território brasileiro. O que surprende é o fato da Colômbia ter negado votar a favor dessa declaração, porque o trabalho que o governo faz para o benefício das comundiades indígenas é interessante, pois, de uma maneira geral as ações do governo são bem avaliados pelos indígenas colombianos. Talvez, a posição contrária do governo colombiano deixa um sinal de alerta aos demais países da América do Sul, que a Colômbia não decide mais por si só, porque a interferência norte-americana na política colombiana começou mostrar seus verdadeiros propósitos.

\subsection{Fronteira, território e circulação}

\subsubsection{Fronteira}

Todos os dias, por sermos seres que $\mathrm{v}$ ivem de relações, confrontamos com a idéia de limite, ou seja, marcamos limites ou tocamos em limites. $\mathrm{O}$ fato de sermos seres de relações com outros seres e objetos significa que traçamos limites ou entramos em conflito com limites. Todas as relações de convivência direta e indireta dependem do limite de um campo, de como elas se originam, se realizam e se esgotam. ${ }^{129}$

Para maioria das pessoas a palavra fronteira soa como algo negativo, porque a história traz lembrança de conflitos e muito sofrimento, de manutenção e destruição. Assim, conforme MARTIN (1992) ${ }^{130}$ :

[...] associamos quase mecanicamente à idéia de "fronteira" a de "guerra". Ou pelo menos desde o advento da "Revolução Francesa"e da elevação da "liberdade" como supremo valor social e político, as idéias de "cerceamento", "vigilância", "repressão", como se as "fronteiras" se constituíssem em artifícios monstruosos que ofendem a naturalidade da condição humana, seu espírito de locomoção e de aventura.

\footnotetext{
${ }^{129}$ Claude RAFFESTIN, 1993, p. 165.

${ }^{130}$ MARTIN, op. cit., 1992, p. 11.
} 
Entretanto, se atentarmos bem, poderemos responsabilizar justamente esse "desejo de liberdade" como sendo o responsável principal pela formação das "fronteiras", uma vez que é a partir de que se organizam os movimentos autonomistas que provocam a erupção de novos territórios, e portanto de novas fronteiras.[...]

Em uma visão mais verdadeira podemos definir “"fronteira' o espaço que 'separa dois povos". 131

Nesse sentido, os homens estarão sempre interligados com a natureza e com os próprios homens, por isso é necessário destacar "pelo menos três condicionamentos de ordem geral, que conduzem à permanente estruturação e reestruturação das 'fronteiras'". ${ }^{132}$

$\mathrm{O}$ primeiro [...] diz respeito à contradição entre o caráter relativamente fixo e estático do espaço terrestre, em oposição à natureza dinâmica e à mobilidade das populações. [...].

O segundo refere-se às discrepâncias em termos de "densidade de ocupação" observáveis na superfície do planeta. Quer se deva a condições naturais mais ou menos favoráveis, ou a níveis de desenvolvimento tecnológico diferenciados, encontramos populações com volumes e ritmos de crescimento demográfico bastante desiguais. [...] existem povos em expansão e povos em retração, e que um mesmo povo pode ocupar as duas posições, dependendo do mesmo histórico. [...], o fato é que a existência dessa dualidade entre povos que se expandem e outros que se retraem conduz à movimentação das fronteiras, tendência exatamente oposta àquela primeira que pretendia torná-las fixas.

Finalmente, derivada dessa "diferença de potencial" entre áreas mais ou menos densas, temos uma intrínseca rede de fluxos, na qual a ação de forças centrífugas e centrípetas interage de modo a tecer uma trama complexa de relações, cujo resultado final tende para um certo equilíbrio entre rigidez e a flexibilidade das fronteiras.

Em seu estudo, MARTIN (1992) destaca a existência de fronteiras na natureza: natureza orgânica e inorgânica. De acordo com autor, para Friedrich Ratzel:

[...] o que importava era avaliar como o meio natural influenciava o desenvolvimento das sociedades, [...]. Ele descreve na sua Antropogeografia que: "A fronteira é constituída pelos inumeráveis pontos sobre os quais um movimento orgânico é obrigado a parar".

[...] a origem da "fronteira" reside no movimento, que é próprio de cada "ser vivo" [...], e não implica uma zona de paragem duradoura, mas pelo contrário, uma paragem momentânea frente à falta de condições vitais necessárias à continuação

\footnotetext{
${ }^{131}$ Ibidem, 1992, p. 12.
}

132 Ibidem, 1992, p. 13. 
do movimento ou então, frente à resistência de outro movimento no sentido oposto.[...].

Dessa forma, MARTIN (1992), expõe que a fronteira está sempre ligada à "área de difusão" de vegetais, animais, das províncias rochosas, de relevo, de solo, climáticas, das "áreas" habitadas por grupos étnicos, lingüísticos, políticos, etc. Enfim, são áreas que se originam de tudo que tem movimento, o qual em certos eventos se vê obrigado a parar. ${ }^{133}$

No ponto de vista histórico e de origem "as fronteiras" sofrem mudanças em suas concepções e práticas.

A palavra "fronteira" deriva do antigo latim "fronteria" ou "frontaria", que designava a parte do território localizada "in fronte", ou seja, nas margens. As fronteiras do Império também foram denominadas de "limes", que significava "confim entre dois campos" e se referia à propriedade fundiária individual. ${ }^{134}$

Para os "primitivos" "135 o fato de delimitar território, significava garantir a reprodução biológica e cultural do grupo. As delimitações não eram feitas através de linhas rígidas, pelo contrário, eram feitas por meio de zonas mais ou menos fluídas que aceitavam até certo lugar, uma interpenetração. Apesar disso, essas fronteiras que na prática eram instáveis, fazia com que as comunidades procurassem por habitar territórios mais bem delimitados e protegidos. Essa vontade de viver dentro de territórios bem delimitados gerou o surgimento das fronteiras rígidas, características dos impérios, por exemplo, os Impérios da Antiguidade destacamos como o de Roma, o Chinês e dos Inca ${ }^{136}$

As fronteiras na Idade Média tiveram uma forte influência da Igreja Católica na unificação política e econômica da "Europa Ocidental”, que não passavam de ficção, "quando assim, um sentido religioso das fronteiras começou a se separar daquele políticoadministrativo, o que só se completaria bem mais tarde com o surgimento dos Estados modernos.[...]". 137

"Delineia-se, dessa forma, o desenvolvimento jurídico do conceito e a noção de que [...] as fronteiras resultam de um "contrato entre partes". Essa mudança ocorreu devido as "novas exigências do modo de produção mercantil”, que "instaurava uma contradição entre

\footnotetext{
${ }^{133}$ Ibidem, 1992, p. 16.

${ }^{134}$ Ibidem, 1992, p. 21.

${ }^{135}$ MARTIN (1992, p. 21) utiliza o termo "Primitivo", porque, segundo ele, "é forçoso admitir que a expressão "primitivos" contém uma dose bem menor de preconceito do que aquela outra popularmente utilizada de "selvagens", [...].

${ }^{136}$ Ibidem, 1992, p. 23-24.

${ }^{137}$ Ibidem, 1992, p. 30-35.
} 
dispersão geográfica e centralização política, o que provocou "a construção de um arcabouço institucional capaz de abarcar os conflitos surgidos". ${ }^{138}$

Conforme MARTIN (1992), depois que as fronteiras surgem dificilmente desaparecem. O que pode haver são algumas mudanças para este ou aquele povo, porém a sua existência nunca será anulada. A única coisa que resta aos homens é reconhecer a sua existência. $^{139}$

Para MARTIN (1992), [...] todas as fronteiras são construções humanas, na medida em que são os grupos humanos que atribuem a esse ou aquele acidente geográfico a condição de divisão entre um espaço conquistado e outro não. [...]. Desse modo, para os franceses prevaleceria a teoria da "fronteira espiritual" e para os alemães as "fronteiras naturais". ${ }^{140}$

Para evitar algumas confusões e distinções entre "fronteira"e "limite, "demarcação" e "delimitação", fronteira externa e interna, Martin faz afirmações fundamentais, pois, os conceitos de fronteira e limite são sinonímicos, porém um é diferente do outro, por isso requer a compreensão diferencial dessas duas palavras. Conforme André Roberto MARTIN (1992), “[...] hoje o 'limite' é reconhecido como linha, e não pode portanto ser habitada, ao contrário da 'fronteira' que, ocupando uma faixa, constitui uma zona, muitas vezes bastante povoada onde os habitantes de Estados vizinhos podem desenvolver intenso intercâmbio, em particular sob a forma de contrabando". ${ }^{141}$

Para A. E. MOODIE ${ }^{142}$, “[...] a 'fronteira' se distingue do 'limite' precisamente porque a primeira é 'natural' e remete portanto à geografia, enquanto a segunda é 'artificial' e remete diretamente ao Estado. [...]”. Assim, de acordo com MARTIN (1992):

[...] O limite de um Estado, então, aparece como uma linha puramente imaginária, marcada a superfície terrestre por objetos naturais ou artificiais. Pode-se, portanto, tentar acrescentar outro elemento, ao mesmo tempo distinto tanto do limite quanto da fronteira: trata-se da divisa, isto é, o aspecto visível do limite. Assim, o marco, a baliza, aparecerão como pontos fixos, erguidos pelo homem, os quais, alinhavados, expressam o limite de jurisdição dos Estados. A divisa por fim é o limite que se apóia geralmente em cursos d'água, cristas montanhosas, coordenadas geográficas ou outras linhas geodésicas. ${ }^{143}$

\footnotetext{
${ }^{138}$ Ibidem, 1992, p. 34-35.

${ }^{139}$ Ibidem, 1992, p. 36.

${ }^{140}$ Ibidem, 1992, p. 40-46.

${ }^{141}$ MARTIN, 1992, p. 47.

${ }^{142}$ MOODIE apud MARTIN op. cit., 1992, p. 47.

${ }^{143}$ MARTIN, op. cit., 1992, p. 48.
} 
Se há uma fronteira e um limite de Estado é porque um dia alguém demarcou e delimitou, daí é necessário distinguir os conceitos de demarcação e delimitação. Para MARTIN (1992: 49), “[...] por delimitação, entende-se o estabelecimento da linha de fronteira - isto é, do limite -, a qual é determinada a partir de um tratado assinado entre as partes envolvidas. Demarcação, por sua vez, é a locação da linha de fronteira no terreno - isto é, a construção da divisa - através do estabelecimento de marcos e balizas.[...]". ${ }^{144}$

Para Claude RAFFESTIN (1993), limites e fronteiras constituem "as quadrículas do poder" ${ }^{\prime 145}$, onde:

O limite, a fronteira a fortiori, seria [...] a expressão de uma interface biossocial, que não escapa à historicidade e que pode, por conseqüência, ser modificada ou até mesmo ultrapassa. De fato, desde que o homem surgiu, as noções de limites e de fronteira evoluíram consideravelmente, sem no entanto nunca desaparecerem. É evidente que os significados do limite variaram muito no decorrer da História. Não há porque se admirar, pois o limite é um sinal ou, mais exatamente, um sistema sêmico utilizado pelas coletividades para marcar o território: o da ação imediata ou da ação diferenciada. Toda propriedade ou apropriação é marcada por limites visíveis ou não, assinalados no próprio território ou numa representação do território: plano cadastral ou carta topográfica. Toda função é também marcada por limites frouxos ou rígidos que determinam sua área de extensão ou de ação. Nesse caso, os limites estão em estreitas relações com o trabalho, portanto com o poder. Limites de propriedade e limites funcionais podem coincidir, superpondo-se, ou, ao contrário, se recortarem. [...] na qualidade de sistema sêmico, os limites são utilizadas para manifestar os modos de produção, isto é, para torná-los espetaculares. O limite cristalizado se torna então ideológico, pois justifica territorialmente as relações de poder.

Toda quadrícula constitui a expressão de "um projeto social que resulta das relações de produção" e ideológicas, "presente em todas as relações humanas". Assim, "os limites aparecem como uma informação que estrutura o território". Nessa estrutura o limite é um conjunto onde a "fronteira é um subconjunto". Apesar de ser um subconjunto a fronteira tem maior relevância política, porque os Estados-nações absorveram-na como um sinal ideológico, no sentido pleno e próprio da palavra ${ }^{146}$. A fronteira é um sinal político e ideológico, porque o Estado moderno atingiu um controle territorial "absoluto" e tornou unívoca a mensagem fronteira = limite sagrado, que resultou do processo histórico de linearização da fronteira. O mapa é um dos instrumentos que mostra a mudança que ocorreu na história da humanidade. "É o instrumento ideal para definir, delimitar e demarca a

\footnotetext{
${ }^{144}$ Ibidem, 1992, p. 49

${ }^{145}$ RAFFESTIN, op. cit., 1993, p. 165-170.

${ }^{146}$ Apud GUICHONNET, P.; RAFFESTIN, C. 1974, p. 5.
} 
fronteira"147. Enfim, a linearização da fronteira é uma tendência do Estado moderno para controle e vigilância de seus territórios. ${ }^{148}$

A demarcação de uma fronteira implica a prática de três funções - legal, de controle e fiscal - que controlam as "relações de poder que se instaura ou que podem se instaurar entre os atores políticos por intermédio das fronteiras". A função legal "delimita uma área no interior da qual prevalece um conjunto de instituições jurídicas e normas que regulamentam a existência e as atividades de uma sociedade política". A função de controle "tem por dever inspecionar a circulação dos homens, dos bens e da informação de uma maneira geral". A função fiscal seria um instrumento de política econômica, "por meio de protecionismo". A diferença de significação entre as três funções é que a função legal "está sempre presente", enquanto que as funções "de controle e fiscal podem ser virtuais". ${ }^{149}$

A distinção entre o "externo" e "interno" acima tudo é uma questão política que diz respeito "aos limites espaciais dentro dos quais o Estado pode exercer sua autoridade. Um Estado soberano não está sujeito a nenhum outro poder, contrariamente a uma subunidade, que deve obediência a um nível superior de governo". Desse modo, segundo MARTIN $(1992)^{150}$ :

Parece que a evolução dos Estados percorre como que um "ciclo geopolítico", no qual num primeiro momento é a luta contra o inimigo externo a força propulsora da "união". Obtida a vitória, o Estado se expande, até o ponto em que o tamanho excessivo comece a gerar disfunções que estimulam a "divisão". Muda-se, porém, de escala, isto é, altera-se a intensidade e o conjunto de relações, assim que encerrado cada ciclo. [...].

\subsubsection{Território e Circulação}

Os indígenas do Uaupés acreditam que ter uma fronteira entre Brasil e Colômbia é uma estratégia política interessante tanto para eles como para outros brasileiros não-indígenas que vivem na região, porque se sentem e se dizem brasileiros de sangue e de coração. Além disso, existem fronteiras e delimitações geográficas construídas pelos seus antepassados e, hoje, são controladas por cada comunidade. ${ }^{151}$ A única coisa que não admitem é o fato de que

\footnotetext{
147 GUICHONNET ; RAFFESTIN, op. cit.

${ }^{148}$ RAFFESTIN, op. cit., 1993, p. 166-167.

${ }^{149}$ Ibidem, 1993, p. 167-168.

${ }^{150}$ MARTINS, op. cit., 1992, p. 52-55.

151 É óbvio que a concepção indígena de fronteira e limite não é a mesma, entretanto a ação de controlar e dominar são características próprias do poder, que também faz parte do ser indígena.
} 
um dia suas relações de convivência com seus parentes colombianos possam ser controladas pelos militares ou por quaisquer outros representantes do governo brasileiro e colombiano. A circulação, as visitas e os eventos festivos que ocorrem entre os parentes brasileiros e colombianos é uma forma de manter e fortalecer as relações de convivência, parentesco e familiar. Os indígenas estão dentro de suas terras tradicionais, por isso acreditam que têm autonomia para andar livremente onde quiserem, respeitando o limite territorial de cada comunidade.

Antes de avançar a nossa reflexão sobre a circulação vamos refletir o que seria uma terra indígena e um território na visão de alguns estudiosos: "Terra Indígena é o mesmo que território indígena?" Para Profa. Dominique Tilkins GALLOIS (2004): “A noção de "Terra Indígena" diz respeito ao processo político-jurídico conduzido sob a égide do Estado, enquanto a de 'território' remete à construção e à vivência, culturalmente variável, da relação entre uma sociedade específica e sua base territorial". ${ }^{152}$

No ponto de vista jurídico brasileiro "a terra indígena é propriedade da União, mas destinada à posse permanente dos índios, a quem cabe o usufruto exclusivo das riquezas do solo, dos rios e dos lagos nelas existentes”. O usufruto exclusivo significa que quaisquer resultados das atividades do grupo será comunitária. A Constituição de 1988 reconhece esse direito originário dos indígenas sobre as terras que habitam tradicionalmente e garantiu a reprodução física e cultural, de acordo com suas tradições milenares. Dentro do enfoque jurídico "o território é dos elementos formadores do Estado e, físicamente, o limite de seu poder". para muitos autores o conceito é ultrapassado, no entanto os Estados ainda tentam manter a noção de território a sua estreita ligação como o exercício da soberania. Ou seja, as palavras povo, território e soberania, soam tambores de guerra, de libertação e de independência, por essa razão sofre repulsa dos que se dizem nacionalistas e principalmente pelos militares. ${ }^{153}$

Segundo FARIA (1997):

A terra indígena, na visão do Estado, é um espaço homogêneo, meio de produção onde estão distribuídos recursos naturais. Na concepção indígena, terra é um mosaico de recursos materiais e espirituais; seu território, além de conter dimensões sócio-políticas, também contém uma ampla dimensão cosmológica, o que não ocorre na concepção de território do Estado. A importância do território está no seu significado, pois as nações indígenas do Alto Rio Negro constroem sua identidade por meio da relação mitológica que mantêm com o território,

${ }^{152}$ GALLOIS, Dominique Tilkin, 2004, p. 39.

${ }^{153}$ Carlos Frederico Marés de SOUZA FILHO, 2005, p. 119-136. 
considerando-o como sítio de criação do mundo. Trata-se de identidade criada em relação a uma geografia determinada. ${ }^{154}$

De acordo com RAFFESTIN (1993), o espaço é anterior ao território, portanto, o território se constitui a partir do espaço. O espaço é a "prisão original", enquanto que "o território é a prisão que os homens constroem para si”. "O espaço de certa forma é dado, "dado" como se fosse uma matéria-prima. Preexiste a qualquer ação. [...]. O território se apóia no espaço, mas não é o espaço. É uma produção, a partir do espaço. Ora, a produção, por causa de todas as relações que envolve [...] num campo de poder. Desse modo, "Falar de território é fazer uma referência implícita à noção de limite que, mesmo não sendo traçado, [...], exprime a relação que um grupo mantém com uma porção do espaço", onde se configuram as relações de produção e as relações de poder, enfim todas são relações de poder. $^{155}$

Para os povos indígenas existe apenas uma palavra para se referir o território, meio ambiente, superfície terrestre, natureza e para falar do espaço físico: terra (dihtá, em tuyuka; ditá, em tukano). Apesar dessa visão tradicional, atualmente existem duas concepções de terra: a tradicional e a visão do "devir".

A visão tradicional é sustentada e vivenciada pelos que detêm os conhecimentos como os rituais de pajelança e benzimento e músicas e danças tradicionais.

De acordo com a concepção tradicional de terra, ela é constituída de recursos animais, vegetais, minerais e animais, e, é uma das maiores riquezas dos povos indígenas. É nela que os indígenas circulam e andam para caçar e pescar, para buscar áreas férteis para derrubar e fazer as roças e cultivar manivas e plantas frutíveras (caju, ingá, pupunha, abacaxi, cará, batata, pimenta, cucura, banana, abiu, cubiu, cana, etc.), e para construir suas habitações para fortalecer suas relações sociais, culturais e políticas internas e externas. Segundo Tuyuka REZENDE (2007) ${ }^{156}$ :

A terra é a maior riqueza dos povos indígenas. Ela significa fonte e lugar da vida. Nela os povos indígenas vivem e trabalham para gerar os bens materiais que os sustentam. A terra, independentemente, do esforço humano, traz muitos frutos, animais, pássaros, animais que rastejam e que pulam nas árvores, etc. Nela, escondem-se muitos seres vivos que os indígenas, de acordo com os seus costumes e tradições, se alimentam.

\footnotetext{
${ }^{154}$ FARIA, op. cit., 1997, p. 16.

${ }^{155}$ RAFFESTIN, op. cit., 1993, p. 143-158.

${ }^{156}$ REZENDE, 2007, p. 67.
} 
Entretanto, atualmente a noção tradicional de terra não é mais unanimidade entre os povos indígenas da região, porque a apropriação da concepção de economia, de uso e produção capitalista mudou a nova forma de entender e ver o sentido da terra. A maioria dos indígenas do Uaupés não vê a terra como fonte espiritual, pelo contrário a terra é cada vez mais vista como uma fonte de riqueza, na qual podem explorar de forma racional para ganhar dinheiro e melhorar a qualidade de vida de seus familiares. No discurso de acadêmicos e algumas lideranças indígenas pode parecer que todos os indígenas têm a mesma visão tradicional de terra, mas na prática a história mudou, porque surgiram novos atores e novas lideranças indígenas que tem outros objetivos e vêem o mundo de maneira diferente. Têm uma visão de projeto, de construção da vida a partir de mecanismos e instrumentos da sociedade envolvente. Por isso, o conceito de terra não é mais o mesmo, pois "sofreu uma evolução e a ela foi acrescentando um novo sentido, o do amanhã, de planejar o devir que não existia antes". No entanto, "o significado e a importância da terra continua o mesmo, [...]"157. A terra sempre foi vista como uma riqueza não comercializável, porque os homens não criam e nem produzem terra. Por isso, os indígenas do Uaupés afirmam, com todas as letras, que nenhum ser humano é ou pode ser dono da terra, porque ninguém faz terra, logo não pode vender.

É a partir dessa visão que os indígenas defendem a circulação, a mobilidade e o trânsito de seus parentes na fronteira não pode ser impedido, porque estão dentro de seus territórios tradicionais. De acordo com Arsênio Vaz LOBO (2007), "Para nós, indígenas, nunca existiu fronteira ou qualquer outra coisa que limitasse ou impedisse a mobilidade e circulação de nossos irmãos. Nossos pais nunca criaram limites rígidos para impedir circulação de pessoas, porque todos eram parentes. Por isso, transitavam com liberdade para visitar seus familiares, realizar festas e participar de eventos tradicionais. Hoje, ainda, continuamos com essa visão" ${ }^{158}$.

Apesar de se considerarem parentes ou familiares, os indígenas do alto rio Negro delimitam seus territórios e controlam quem pode circular, usufruir e quem não pode. A antropóloga Dominique BUCHILLET (1993), citada por FARIA (1997), descreve mais ou menos como se constitui a delimitação de território entre os povos indígenas do alto rio Negro.

\footnotetext{
${ }^{157}$ FARIA, op.cit., 1997, p. 165-266.

${ }^{158}$ Entrevista concedida por Arsênio Vaz LOBO no dia 15 de março de 2007 em Pari-Cachoeira.
} 
O território é composto de mata e rio para explorarem a caça, a pesca e abrirem plantações de mandioca. Em cada povoado é delimitado por marcas naturais como curvas de rios, afloramentos rochosos e igarapés. A mata é repartida entre as diversas famílias nucleares para estabelecerem suas roças. O território para a caça e pesca não é limitado, podendo cada um pescar e caçar onde quiser, dentro dos limites do povoado. ${ }^{159}$

$\mathrm{Na}$ prática, cada comunidade, grupo ou família tem o seu território delimitado e controlado de forma rigorosa - porém não rígida - principalmente para o uso da terra. Os membros de uma comunidade têm um limite geográfico, no qual podem fazer roça, caçar e pescar sem ultrapassar o limite e o domínio de outra comunidade. Quando um desses limites é invadido, ocorrem conflitos, brigas e discussões entre as pessoas que controlam e invadem os territórios alheios. É evidente que no passado os conflitos eram mais intensos. Atualmente, os conflitos acontecem, porém não com a mesma intensidade que no passado. A única coisa inquestionável é a circulação livre de indígenas da região tanto pelos rios como pelo mato. Nesse caso nenhuma comunidade proíbe a mobilidade das pessoas.

A história de origem indígena do Uaupés evidencia que após sua emergência para a superfície terrestre, cada povo procurou se adaptar às condições ambientais e conquistar novas terras. Para conquistar as terras, os antepassados tiveram que migrar e circular em vários lugares do Uaupés. Por exemplo, o grupo Tuyuka (Dohkapuała) emergiu na cachoeira de Jurupari, alto Uaupés, localizada na Gran Resguardo del Vaupés, Colômbia. Daí, os Tuyuka migraram ao alto Papuri (Colômbia) e alto Tiquié (Brasil e Colômbia), onde estão instalados até hoje. Quando houve a divisão territorial entre Brasil e Colômbia, ficaram divididos em dois grupos com diferentes nacionalidades: brasileiros e colombianos (ver tabela 1).

Tabela 1. Informações gerais sobre o povo Tuyuka (Uhtãpinõponã) (2005/2007).

Nome Outro nome Países s Pajés Yaíwa Pajés Ba’asera População Ano

\begin{tabular}{|c|c|c|c|c|c|}
\hline Uhtãpinõponã & Tuyuka & Brasil- & 00 & 02 & 925 \\
\hline ou & & Colômbia & 01 & 03 & 570 \\
\hline
\end{tabular}

Dohkapuata

Fonte: adaptado por autor de DSEI/FOIRN e LevSGC2004 e Povos Indígenas no Brasil 2001 a 2005.

${ }^{159}$ BUCHILLET, 1993 apud FARIA, 1997. 
Dessa forma, desde antes da chegada de colonizadores a mobilidade indígena era de ordem política, social, cultural, religiosa e econômica. A circulação dos povos indígenas não se reduzia apenas em aspectos sociais, porque outras dimensões também influenciavam diretamente nas relações de convivência do grupo. Assim como quaisquer grupos humanos existentes, os indígenas enfrentavam desafios de todas as ordens, porque "desordem e ordem" nunca se separaram.

A dimensão familiar abrange constitui a base das relações de convivência indígena, na qual o aspecto político é um dos fatores que fortalece a convivência familiar e garante a circulação entre diferentes comunidades e povos da região. A troca matrimonial é outro ponto unificador das relações de convivência indígena, através da qual introduzem no grupo novos parentes. Assim, os membros familiares da mulher são deferidos como novos parentes do grupo. A mulher geralmente traz consigo novos valores, costumes, tradições e comportamentos, que depois são absolvidos pelo grupo do marido. "A introdução de um elemento numa região é suficiente para modificar um velho gênero de vida, para dar a ele um novo dinamismo" 160 . Por isso, afirmou SORRE (1952:110), "A introdução de elementos novos pode ocorrer também, por contaminação entre grupos vizinhos, e somente vai-se percebê-la depois de certo tempo [...]"161.

A circulação de grupos indígenas possibilita a apropriação e a partilha de novos conhecimentos, que gera transformações positivas e negativas, que se permeiam nas comunidades indígenas. SORRE (1952) destacou que a circulação faz surgir novos modos de viver.

Todas as mudanças nos gêneros de vida aparecem como ligadas à atividade da circulação. A circulação faz o grupo humano participar da vida mais geral. Trazendo-lhe os germes da renovação que vêm fecundar os antigos modos de existência. Ela faz nascer novos modos de existência portadores de sua marca e organizados com vistas a seus próprios fins. ${ }^{162}$

Para SORRE (1952), a circulação não significa meramente uma transformação ou mudança, mas é uma condição de estabilidade. E a estabilidade não significa imobilidade,

\footnotetext{
${ }^{160}$ Maximilien SORRE, 1952, p. 109.

${ }^{161}$ Ibidem, 1952, p. 110.

162 Ibidem, 1952, p. 110.
} 
mas é uma condição de existência dos gêneros de vida. Também a circulação é criadora de "novos gêneros de vida, ligados diretamente à sua existência [...]". ${ }^{163}$

Desse modo, conforme Friedrich RATZEL (1990) ${ }^{164}$ :

O homem é sem dúvida entre os seres vivos o que tem a organização mais completa. Ele possui os melhores meios para perceber tudo aquilo que vem de fora dele e um raciocínio muito superior ao de qualquer outro animal. Também os meios de que ele dispõe para se mover e para se fixar são muito eficazes [...]

A circulação, a mobilidade, como condição de existência tem a liberdade como princípio e direito natural do ser humano que se torna para os indígenas fronteiriços o "motor" que impulsiona a reivindicar a livre circulação. Por essa razão, “[...] a liberdade é um dos nomes da mobilidade" ${ }^{\text {165 }}$. Essa liberdade, muitas vezes, é restringida aos grupos fronteiriços, mesmo que estejam em seus territórios tradicionais.

VAINER (2005) em suas considerações finais sublinha o seguinte:

Vivemos numa conjuntura histórica em que só parece haver uma lei do próprio capital: a liberdade de circulação de capitais e mercadorias nos confins do planeta, onde nesse mundo poucos se privilegiam e milhões não podem gozá-las [...] No centro destes dois mundos, como ponto que unifica e separa, os estados nacionais, que muitos dizem estar desaparecendo, afirmam sua soberania e demarcam seus territórios. ${ }^{166}$

$\mathrm{O}$ fato de terem uma terra homologada na faixa de fronteira e a presença militar dentro de suas comunidades suscita diversas questões entre as lideranças indígenas do alto rio Negro, como por exemplo: como planejar e implementar políticas públicas dentro da área indígena? Como ampliar o intercâmbio cultural entre indígenas brasileiros e colombianos? Como possibilitar uma convivência sem conflitos com os militares? Como fortalecer a livre circulação de parentes colombianos que querem visitar seus familiares no território brasileiro? Por enquanto, são perguntas que na teoria têm muitas propostas, porém, na prática, ficam sem respostas concretas.

De acordo com Carlos Frederico Marés de SOUZA FILHO (2005), "Cada povo indígena tem, portanto, uma idéia própria de território, ou limite geográfico de seu império,

\footnotetext{
${ }^{163}$ Ibidem, 1952, p. 114-116.

${ }^{164}$ Friedrich RATZEL, 1990, p. 71.

${ }^{165}$ Carlos B. VAINER, 2005, p. 260.

${ }^{166}$ Ibidem, 2005, p. 272-273.
} 
elaborada por suas relações internas de povo e externas com os outros povos e na relação que estabelecem com a natureza onde lhes coube viver". ${ }^{167}$

Os indígenas não vivem a sós no planeta Terra. Fazem parte de um conjunto de relações humanas, onde "as redes e o poder" 168 são complementares. A circulação é uma das faces da mobilidade. Assim como a comunicação, está presente em todas as estratégias que os atores desencadeiam para dominar as superfícies e os pontos por meio da gestão e do controle das distâncias". Ela "engloba tudo o que é mobilizável”, ela é o significante. A rede, afirmou RAFFESTIN (1993), "faz e desfaz as prisões do espaço, tornado território, ou seja, tanto liberta como aprisiona. É o porquê de ela ser o "instrumento" por excelência do poder". 169

\subsection{Os paradoxos da política: poder e liberdade}

"Serás tão livre quanto os ventos das montanhas, basta apenas seguir as minhas ordens." (SHAKESPEARE, W. A tempestade, 1991).

Nesse item, a nossa idéia é discutir o Poder no sentido mais amplo, apesar dos autores que citaremos não sejam estudiosos dos povos indígenas, escolhemos apenas alguns que têm idéias afins à realidade indígena, porque, atualmente, os povos indígenas não estão isolados do mundo moderno e, além disso, o poder é algo familiar ao sistema hierárquico dos grupos do Uaupés. O poder é epicentro de qualquer povo, da comunidade, do Estado, da soberania, dos governantes, da fronteira e de qualquer ser humano, instituição ou disciplina. Por isso, torna-se necessário refletir as concepções de poder e liberdade como paradoxos da política. Os autores que escolhemos abordarão a idéia de poder de diferentes maneiras: o poder na individualidade; o poder na interação; o poder como um espaço autônomo que se fundamenta nas regras próprias, no Estado.

A descoberta de mim que vai levar a um tipo de desenvolvimento e vai levar a uma certa posição, face ao mundo, face ao eu, face ao outro, face aos outros, face à sociedade, a carne, a sexo, ao amor etc. Trata-se de instauração de novos valores na política, da liberdade individual, da liberdade que agora se faz de forma ardente. É nesse sentido que a idéia de

\footnotetext{
${ }^{167}$ SOUZA FILHO, op. cit., 2005: 44.

${ }^{168}$ RAFFESTIN, op. cit., 1993: 201-220.

${ }^{169}$ Ibidem, 1993: 200-2005.
} 
liberdade, de igualdade, constituem conceitos em permanente desenvolvimento, permanente complexidade, por que é na complexidade que o ser humano vive.

Talvez daqui a 20 ou 30 anos, teremos novas questões para colocar já em relação a liberdade. Hoje, por exemplo, os povos indígenas lutam pela autodeterminação, pela demarcação de suas terras e alguns, que vivem em áreas fronteiriças, reivindicam pela construção da autonomia em uma faixa de fronteira onde impera a idéia de soberania nacional. Então, a liberdade é reivindicação, é desejo, é algo a ser almejado. Tanto uma quanto a outra. Então, podemos dizer: Ela é concreta? Sim ela é concreta, porém é inconcreta. A liberdade está do lado e não está, é consenso e inconsenso, irrealização, em avanço, em desenvolvimento. É nesse sentido que nós podemos falar dessas questões paradoxais, dessas experiências paradoxais.

$\mathrm{Na}$ contemporaneidade que se vive não é possível visualizar apenas um conceito ou uma noção de política a partir de um grupo humano, povo ou de uma região. Aqui é necessário entendê-la a partir de questões como cruzamentos e organizações internacionais, de um estado transnacional, que ganha uma dimensão maior e da diversidade conceitual que ela nos traz. Assim, a política pode ser analisada a partir da perspectiva que se fundamenta no princípio de conflitos. São conflitos não-resolvidos, que se perpetuam na dinâmica de gerações humanas e que também fazem parte da vida dos povos indígenas do alto rio Negro e do mundo. Ou seja, o desaparecimento de tensões e conflitos significaria o desaparecimento da política.

Esses conflitos são meramente humanos, que estão no indivíduo, na pessoa, no grupo e na sociedade, isto é a política se fundamenta a partir do desentendimento dos homens. Segundo Jacques RANCIÈRE $(1996)^{170}$ o desentendimento é a chave para entendermos a luta pela palavra e pela razão, crucial em política.

Por desentendimento entenderemos [...] aquela em que um dos interlocutores ao mesmo tempo entende e não entende o que diz o outro. O desentendimento não é o conflito entre aquele que diz branco e aquele que diz preto. É o conflito entre aquele que diz branco e aquele que diz branco, mas não entende a mesma coisa, ou não entende de modo nenhum que o outro diz a mesma coisa com o nome de brancura. [...] O desentendimento não é de modo nenhum o desconhecimento. $\mathrm{O}$ conceito de desconhecimento pressupõe que um ou outro dos interlocutores ou os dois [...] não sabem o que diz ou o que diz o outro. Não é tampouco o malentendido produzido pela imprecisão das palavras [...].

[...] o desentendimento não diz respeito apenas às palavras. [...] O desentendimento não diz respeito à questão da heterogeneidade dos regimes de frases e da presença

\footnotetext{
${ }^{170}$ Jacques RANCIÈRE. O desentendimento: política e filosofia. Editora 34, SP, 1996.
} 
ou ausência de uma regra para julgar gêneros de discursos heterogêneos. Diz respeito menos à argumentação que ao argumentável, à presença ou ausência de um objeto comum entre um $\mathrm{X}$ e um $\mathrm{Y}$. Diz respeito à apresentação sensível desse comum, à própria qualidade dos interlocutores em apresentá-lo. [...] As estruturas de desentendimento são aquelas em que a discussão de um argumento remete ao litígio (pendência judicial, disputa) acerca do objeto da discussão e sobre a condição daqueles que o constituem como objeto.

Entretanto, a política não é apenas o conflito. O conflito é uma das dimensões e um dos elementos da política. A política é exercício do poder. Então, se há conflitos, o poder instaura "o campo da política". É nesse sentido que a idéia de política deve ser entendida. A idéia de poder sempre está ligada a uma tragédia, porém esse só pode ser visualizado a partir da polifonia de conflitos, que é exercido no âmbito do conflito. ${ }^{171}$

Então, se o poder é uma tragédia várias indagações podem ser feitas, por exemplo: $\mathrm{O}$ que é poder? Para que serve? Porque se instaura o campo da política?

É aqui que a política indígena também se enquadra, porque muitas vezes a política indígena não consegue dar a idéia de pertencimento a um movimento constituído de vários grupos. Há, sim, uma visão trágica e escandalosa dessa política. É essa visão trágica que coloca a política como exercício do poder na sua essência. Por isso, para Jacques RANCIÈRE (1996) " "...] O que torna a política um objeto escandaloso é que a política se torna atividade que tem por racionalidade própria, a racionalidade do desentendimento. [...]"172.

A liberdade é o valor que tem permanente desenvolvimento e complexidade. É uma liberdade totalmente interligada com o poder. Uma complexidade que vivenciamos todos os dias.

Para ROUSSEAU (1973), o homem nasceu livre para constatar que a independência natural do indivíduo é roubada quando ele entra em sociedade. Veja-se o paradoxo: o homem nasceu livre de Deus, mas essa liberdade é roubada quando entra na sociedade. Então, a sociedade, o poder instauram a liberdade? Se sim, em que condições ela poderá instaurar? O homem nasce livre na sociedade. Tem a liberdade dentro dele. Só que essa liberdade não se desenvolve, porque a sociedade o sufoca, a sociedade reprime, a sociedade impede essa liberdade. É da natureza humana, no entanto com a medida que a sociedade o envolve e se desenvolve no seu interior, perde sua liberdade. ${ }^{173}$

\footnotetext{
${ }^{171}$ Ibidem, 1996.

172 Ibidem, 1996.

${ }^{173}$ J-J ROSSEAU. Discurso sobre a origem e os fundamentos da desigualdade entre os homens, Abril cultural, SP, 1973.
} 
Então, qual é o esforço do liberalismo? O que é liberalismo? É um pensamento político que vai buscar regras, normas leis e instituições, portanto ideologia e prática para instaurar em uma sociedade os direitos naturais do homem. Então o que é que o liberalismo? É uma sociedade que reconhece que o homem perde e pode perder a liberdade e vai criar normas e leis para que essa liberdade da natureza possa sobreviver, possa ser expressa mesmo nas relações sociais. É esse o esforço que a modernidade devia ter. A mesma coisa a acontecer com todos os ismos: anarquismo etc.

A liberdade é agora o termo que a política se apropria da liberdade. Os liberais se dizem os defensores da liberdade. O pensamento radical de esquerda e de direita se diz também defensores de liberdade, só que na legalidade. Todas as correntes políticas sobrevivem, como ideologias, com as idéias de liberdade, não só os ismos (anarquismo), mas o próprio Estado também. Então o que o Estado vai afirmar? O Estado vai afirmar o seguinte: Olha! Eu é que defendo a liberdade de vocês, dos brasileiros, indígenas, negros, xiitas, bolivianos, iraquianos, etc., em nome da liberdade e da democracia.

Assim, a liberdade é agora apropriada. Ela, então, é submetida ao longo do tempo às mais diferentes experiências. A justiça, tempo e liberdade estão associados. Experimenta-se a possibilidade do gozo da liberdade. A história da civilização, a história de uma sociedade é uma história de experimentação da liberdade contra a opressão, contra o autoritarismo. Nas diversas experiências nesse andamento é que descobre esse paradoxo, quer dizer, o desejo da liberdade, a busca da liberdade, a proposta de liberdade ou as suas instituições ou as suas insuficiências.

A liberdade e igualdade é algo que se coloca no presente com o desdobramento no futuro. A liberdade que nós queremos, não é a que temos hoje. Nós, ainda queremos mais. É isso que os povos indígenas também querem. É isso que Shakespeare (1991) mostra em "A Tempestade" 174 . Ou seja, mostra que mesmo que eu não tenha liberdade dentro da sociedade eu busco e defendo o desejo da liberdade. Pego a minha voadeira e motor de popa para viajar pelo rio Negro ou quaisquer igarapés para passear ou pescar, pago imposto, viajo de canoa, viajo de barco, bebo e embriago, canto e danço, faço aquilo e outro, tudo em nome da liberdade. Portanto, a liberdade é realidade, é irrealidade, é desejo, é valor? É tudo isso.

É nesse sentido que a idéia de liberdade remete à idéia de utopia. Se quisermos é negação pela utopia. Nós buscamos a minha realização ou a realização do coletivo, de um desejo para o futuro. Então o gozo da liberdade e igualdade entre os homens será sempre

\footnotetext{
${ }^{174}$ W. SHAKESPEARE. A Tempestade. Relume Dumará: Rio de Janeiro, 1991.
} 
insuficiente. É isso que a história das idéias nos mostra. Agora, só que o gozo da liberdade e da igualdade por vários motivos pode reforçar as relações da sociedade ou pode reforçar o poder, pode ser entrave do outro ou dos outros. Existem entraves, dificuldades que impedem o gozo pleno, mas o fato de não ser realizado também gera novos amigos. Por que talvez essa idéia de viver em sociedade?

O conceito de HOBBES (1993) ${ }^{175}$ vai nos mostrar que mesmo que eu não tenha liberdade, condição de igualdade, todos têm uma esperança. A esperança é um elemento fundamental das ciências políticas. Ninguém vive em coletividade se não tivermos a esperança de amanhã ser melhor ou sermos felizes. Quando se fala de liberdade a idéia também remete o futuro. Hoje, não é o que eu quero, não é o que eu sou, mas talvez amanhã. Essa metáfora vai estar muito bem colocada na figura da Tempestade do Ariel: "Serás tão livre quanto os ventos da montanha....." ${ }^{176}$. Todo dia é isso. Serás livre, ... hoje, amanhã, depois de amanhã e assim vai. É isso que é política. Essa possibilidade de viver positivamente na esperança, dessa crença plena. Então, cada dia surge novos desejos, novas paixões, novas racionalidades novas propostas

O poder da modernidade ele é claramente um articulador da liberdade individual (Revolução Francesa). O que é liberalismo? Liberalismo é realizar no presente oportuno, eles estão pensando no futuro uma sociedade, um estado que tenha liberdade, igualdade e que tenha propriedade. O liberalismo defende até hoje que a liberdade é um treino da política do Estado. O discurso do totalitarismo não tem política. Na estrutura da política moderna não pode existir sem liberdade, igualdade e propriedade, sem qualquer ismo. A liberdade é fator essencial da política moderna. Aqui não vamos definir o que é liberdade, porque não existe uma definição exata de liberdade, o que existe é uma rede de definições. Por isso, vamos discutir sobre a liberdade e tentar entendê-la. A liberdade também não é definida por um povo, mas pelos pensadores. Aqui falamos da impossibilidade de gozo, em formulação da multiplicidade, em aproximações em diferenças, individual e coletivo, de social de político, de filosófico e teórico, de ético e religioso.

Hoje, as relações de convivência dos povos indígenas e sua luta pela autodeterminação, na prática, é um sonho de liberdade. É um sonho que se faz com que os indígenas enquanto seres vivos participem das relações interpessoais com diferentes sociedades e instituições para conquistar o poder e a liberdade.

\footnotetext{
175 T. HOBBES. Leviatã. Abril Cultural: São Paulo, 1973.

${ }^{176}$ SHAKESPEARE, op. cit., 1991.
} 
A partir daqui entramos na grande discussão de Jean-Paul Sartre, que é a da liberdade. E nós podemos perguntar: Quem é o homem para o Sartre? É o ser vivo. É a liberdade. O homem não é mais o indivíduo, agora é o ser. Ser é muito mais que o indivíduo. Aqui poderíamos entrar no campo da psicanálise, mas não é o nosso foco. Entretanto, é importante ressaltar que política e psicanálise são eminentemente interligadas, totalizadas. Por isso, não se pode pensar política sozinho. Quem pensa política tem que pensar com sexualidade, afetividade, economia, hierarquia social, cultura.

Isso significa que o homem só pode pensar a política a partir do mundo como todo. Nesse sentido que o ser e a liberdade se opõe do poder. Ou seja, o homem livre se opõe ao poder. É contra o poder.

Para SARTRE (1977), "nós estamos condenados ao processo de libertação ou não"177. É um processo que não termina. Portanto, é um processo e uma revolução permanente. Pois, não se alcança o final da revolução e não se goza o final da revolução. Quando se pensa que chegamos ao fim de uma revolução a outra começa. O homem jamais se satisfaz com os objetivos alcançados. Na ânsia de buscar novos objetivos provoca novas revoluções, novos conflitos e guerras. Esse é o processo permanente de libertação, a busca constante da liberdade de poder ser e ter. Por isso, ser consciente e ser inconsciente.

A definição do ser sartriano, pode ser compreendida na individualidade, peculiaridade, especificidade. Por que a angústia, o compromisso de liberdade é individual. A liberdade é uma discussão da vida humana e não de conceituações científicas. É uma experiência interna, humana, subjetiva, que é a micropolítica. Sartre não está preocupado com política do Estado. Ele está preocupado no ser como existência, na capacidade de poder individual. É a vontade de poder de Nietszche.

Por isso, de acordo com SARTRE (em verdade e existência) "a realidade humana não pode se desgarrar do mundo. Ou seja, o homem não pode ser compreendido fora do mundo. $\mathrm{O}$ homem só pode ser compreendido fora do mundo quando estiver consciente de sua existência".

No capítulo I, da Quarta Parte, Ser e Fazer, Sartre (1997) defende que a "condição primordial da ação é a liberdade" ${ }^{\prime 17}$. Essa ação é do ser. Portanto, pode gerar transformações no próprio ser, no mundo, no ser no mundo e na a sociedade. Isso significa estar ligado ao mundo. Essa ligação se faz na ação do ser. Um agir condicionado pela liberdade. Assim, conforme SARTRE (1997):

\footnotetext{
177 Jean-Paul SARTRE, 1977.

${ }^{178}$ SARTRE, op cit., 1997, p. 533.
} 
[...] agir é modificar a figura do mundo, é dispor com vistas a um fim, é produzir um complexo instrumental e organizado de tal ordem que por uma série de encadeamentos e conexões, a modificação efetuada em um dos elos acarrete modificações em toda a série e [...] produza um resultado previsto. Mas [...] convém observar, antes de tudo, que uma ação é por princípio intencional $[\ldots]^{179}$

Outro autor que ajuda a discutirmos sobre política como poder e liberdade é Michael FOUCAULT, que pensa a política não na perspectiva do indivíduo, mas na perspectiva do ser, da estrutura do poder. Em uma indefinição, difuso, algo que vai estar acima da localidade, da localização. A idéia de sujeito não é de individualidade, mas é do sujeito constituinte. Ele se preocupa na constituição do sujeito. Esse sujeito que é vivo e que produz. Para Foucault o poder e liberdade são complementares. Significa que só podemos pensar em poder se pensarmos em liberdade.

O poder e liberdade são entendidos em Foucault no plural: poderes, resistências e liberdades. A liberdade não é uma determinação física. Ela é resultado das relações de poder sobre as relações de resistências. Não existe grande recusa, grande liberdade, o grande lugar, mas as resistências que se inscrevem nas relações dessas redes, no confronto entre poder e resistência. Portanto, o poder não é algo que se dê, que se venda ou que se transfira. São malhas que circulam e exercem os efeitos sobre nós. O poder passa pelos homens, ultrapassa homens, fazendo transmissores ou receptores de sua ação.

Contra a idéia de que o poder está centrado no Estado, o Michael FUCOULT mostra que o próprio Estado aparece como conjunto e resultante de uma multiplicidade de engrenagem e focos que se situam de modo diferente e constituem por sua conta uma "Microfísica do Poder" 180 . Nesse caso, o Estado se situa nas relações de poder. O foco não está no Estado. Daí FOUCAULT ${ }^{181}$, ter afirmado que o exercício que era dado ao Estado de aprovar e controlar é da sociedade por causa da dispersão do poder, isto é, em vez de instituir, o Estado é instituído. Essa sociedade se define pela disciplina e pelo controle. A partir daí também se pode afirmar: onde há poder e coerção existe a resistência.

Para FOUCAULT o poder não é subordinado. O que existe ao contrário disso é a chamada rede. O poder está em todos os cantos da sociedade. Em todos os exercícios da sociedade. Não há subordinação do poder sobre o outro. Não há um poder soberano ou que se coloca sobre os outros. Em Foucault o poder não tem essência. O que tem é a operatoriedade.

\footnotetext{
${ }^{179}$ Ibidem, 1997, p. 536.

${ }^{180}$ Michel FOUCAULT. Micrifísica do Poder. 6 a Edição. Graal: Rio de Janeiro.

${ }^{181}$ Ibidem.
} 
Ele é relacional e opera sem essência nenhuma. É na prática que o poder adquire caracterizações específicas. O poder é produtor de modalidades, de verdades antes de produzir ideologias, reproduz saber antes de produzir violência. No estado liberal o poder é legal. É o que atende a um conjunto da sociedade. O poder também é propriedade, no entanto não é propriedade de ninguém. Eu possuo o poder. Eu exerço o poder. Eu estou exercendo o poder. O poder não é propriedade de ninguém, nem sua, nem minha, nem da classe, nem de um grupo social, nem de uma facção da sociedade. Ele é exercido e está a disposição. Ele é estratégia. Antes de ser propriedade ele é estratégia. Ele é uma forma de operação. ${ }^{182}$

Assim, FOUCAULT, na Microfísica do Poder, quer sondar como somos o sujeito no campo do saber, do poder, da moral problematizando o campo da verdade. Na Soberania e disciplina, FOUCAULT argumentou que:

Para caracterizar não o seu mecanismo, mas sua intensidade e constância, poderia dizer que somos obrigados pelo poder a produzir a verdade, somos obrigados ou condenados a confessar a verdade ou a encontrá-la. O poder não pára de nos interrogar, de indagar, registrar e institucionalizar a busca da verdade, profissionaliza-a e a recompensa. No fundo temos que nos produzir riquezas, ou melhor, tempos que produzir a verdade para poder produzir riquezas. ${ }^{183}$

Portanto, para FOUCAULT é nesse caminho que o sujeito está no jogo da verdade, da ética contra as relações de poder. É o caminho da prática da liberdade. E a ética como prática da reflexão da liberdade.

Por último apresentamos o E. M. CIORAN (1994) ${ }^{184}$, o filósofo romeno que se coloca como um cético da vida, da política e dos homens. Um cético niilista. Para ele em todo caso a utopia esparrama em todo campo político. Em Sartre não há uma idéia de utopia, mas de projeto. É um projeto que aponta para o futuro. Ou seja, nós fazemos escolhas, opções, vivenciamos a liberdade pensando no futuro. Não se trata de uma ficção política. Não se trata a idéia de utopia como tentativa coercitiva brutal. Quem realiza esse projeto é o indivíduo. É no projeto que o indivíduo, a sociedade está incluso Não se trata de fé, de imaginação diante desse projeto, de uma ordem e, sim, trata-se de um jogo que exercemos ouvindo o mundo, porque escolhemos ou fazemos opções ouvindo o mundo. É nesse sentido que o indivíduo se realiza.

Então, o que é a utopia? O que significa a utopia para Sartre? Autores como Sartre e Foucault poderão nos apresentar algumas pistas. A utopia é a negação da realidade. É a ruptura da ordem real. O projeto de futuro de Sartre é a partir dessa ordem, no interior dessa

\footnotetext{
${ }^{182}$ Ibidem.

${ }^{183}$ Ibidem, p. 180.

${ }^{184}$ E. M. CIORAN,1994.
} 
ordem. É assim que se realiza o projeto. Realiza-se o possível que ainda existe com a possibilidade dela vir existir. Possibilidade dela existir significa que ela nasce nas condições dadas. Não é um projeto fechado, mas um esboço. São atos a serem realizados constantemente. E FOUCAULT fala e entende da heteroutopia como um lugar no mundo, que é a construção e uma espécie de contestação ao mesmo tempo em que emite real dentro do espaço em que vivemos. Não há uma transformação total da heteroutopia. É um lugar no meio da totalidade. É a configuração da realidade a partir do sujeito.

É nessa discussão que se coloca o E. M. CIORAN (1994). Ele nos traz os paradoxos da liberdade e do poder e da política. Nós não conseguimos definir o que é liberdade e poder para CIORAN e nem o que é que é a política. Ele vai tratar das impossibilidades, das inviabilidades, desconstruindo o que foi dito até agora. Ele vai dizer também que a utopia é uma ilusão. É uma grande assassina. Mas, que não podemos viver sem a utopia. Ele traz a utopia como algo benéfico e maléfico, mas por outro lado não podemos viver sem a utopia. Nós vamos continuar convivendo com estas situações. ${ }^{185}$

Assim, o homem é aquele que está tentando realizar o absoluto. CIORAN reúne o homem, a política e vida. Ele não consegue pensar o indivíduo, a política, separado da vida ou da história. A vida é uma busca constante do indivíduo de realizar absolutamente por dinheiro, com desconfiança, e, não conseguindo tenta a realização no social. ${ }^{186}$

No social ele vai enfrentar outros homens que têm os mesmo desejos. Esse é o campo da inveja, da desconfiança. Nessa escola dos tiranos, para CIORAN (1994: 58):

Todos os homens são mais ou menos invejosos; os políticos o são completamente. Tornamo-nos invejosos quando já não suportamos mais ninguém nem ao lado nem acima de nós. Engajar-se em qualquer empreendimento, mesmo o mais insignificante, é pactuar com a inveja, prerrogativa suprema dos seres vivos, lei e mola dos atos. Se a inveja te abandona, és apenas um inseto, um nada, uma sombra. $\mathrm{E}$ um doente. Enquanto ela se sustenta, remedia as fraquezas do orgulho, vigia teus interesses, vence a apatia, opera vários milagres $[\ldots]^{187}$

O político é aquele invejoso, pois assume as armadilhas do poder. Segundo CIORAN, ninguém escapa do poder. Ninguém pode escapar do poder. Ele está em nós e fora de nós. $\mathrm{O}$ poder está dentro de nós. O homem diz: eu quero o poder. O poder é que movimenta a história. As relações de convivência e a construção da autodeterminação indígena também são pautadas no desejo pelo poder. A política indígena é constituída de políticos indígenas.

\footnotetext{
185 Ibidem, 1994.

${ }^{186}$ Ibidem, 1994.

${ }^{187}$ Ibidem, 1994, p. 58.
} 
O poder é o ápice de quase todos os políticos. Pode-se afirmar, que todo político e todo poder se movimenta entre autoritarismo e a democracia. É nesse espectro que o poder movimenta. Todo político tem um desejo secreto, ter o poder em suas mãos. Daí os autoritários se orgulham desse desejo e o expõe à adoração pública. Os democratas envergonham-se e o escondem, mas todos são tiranos. O mundo está sempre oscilando entre esses sistemas.

Fazer política, ou ser político, ou seja, a prática do poder implica a manipulação intensa da polarização entre "continuidade versus descontinuidade". A estrutura do poder implica ora a continuidade, mudando os limites, ora gerando a descontinuidade, "criando novos limites". [...]. É um circuito paradoxal, constante ${ }^{188}$.

Ao mesmo tempo, antes de se expandir e se esgotar, o poder se cristaliza em um lugar, ou em vários lugares onde deixa suas marcas de forma positiva e negativa: “[...], comunidades, lugares centrais, a partir dos quais tudo irradia e que quase sempre constituem locais simbólicos de uma unidade coletiva [...]”. ${ }^{189}$ É assim que o poder constitui a dialética da "ordem e desordem" $" 190$.

\footnotetext{
${ }^{188}$ Yves BAREL (1979) apud RAFFESTIN, op. cit., 1993.

${ }^{189}$ RAFFESTIN, op. cit., 1980, p. 186-187.

${ }^{190}$ BALANDIER, op. cit., 1997.
} 


\section{A CONVIVÊNCIA ENTRE INDÍGENAS E NÃO-INDÍGENAS NO UAUPÉS}

Neste capítulo três, refletiremos sobre as relações de convivência entre indígenas e não-indígenas na região do alto rio Negro, de modo especial com destaque para o "Triângulo Tukano", Uaupés. Primeiro apresentaremos como eram as relações de convivência indígena antes da chegada de missionários. Segundo apresentaremos como se deu a convivência entre indígenas e missionários salesianos no Uaupés e Trinidad (Colômbia), indígenas e miliatres e indígenas e ONGs antes e depois de 1998. No estudo, destacaremos a realidade das comunidades indígenas de Pari-Cachoeira (Brasil) e Trinidad (Colômbia), que constitui o objeto desta dissertação.

\subsection{Indígenas e missionários no Uaupés}

Começamos a reflexão apresentando como era a convivência entre os indígenas no interior de suas habitações tradicionais (Bahsawihseri) antes da chegada de missionários da Congregação Salesiana em 1923. Em seguida, apresentaremos as relações de convivência entre indígenas e missionários no período de 1923 a 1987. E, por fim, destacaremos a queda do poder da Igreja Católica diante da pressão política do Movimento Indígena do rio Negro em 1998.

Iniciaremos a reflexão com os missionários porque foram um dos os primeiros e principais ocidentais que se instalaram de forma permanente entre as comunidades indígenas do Uaupés e atuaram diretamente no processo de transformação social, cultural, política e religiosa dos povos do alto rio Negro.

Antes da chegada de missionários, os indígenas tinham como habitação tradicional denominada em Tuyuka de Bahsawi ou Bahsariwi, que significa casa de rituais, casa de danças, casa de festas tradicionais, casa de confraternização, casa de alegria, casa de vida, casa da criação de seres humanos. A Bahsawi era habitada por diversas famílias distribuídas de acordo com a hierarquia do grupo ou sib. O local da Bahsawi se chamava Mahkã (povoado) $^{191}$.

A casa tradicional recebeu a denominação de Bahsawi, porque o chefe tradicional se chamava Bayá (mestre de cerimônias, músicas e danças tradicionais). Ele era chefe

\footnotetext{
${ }^{191}$ Vicente DUTRA (2007). Era meu avô, faleceu no dia 05 de julho de 2006 aos 104 anos de idade, foi o último maior Bayá do povo Tuyuka, da geração que não freqüentou os internatos salesianos; ele não falava e nem entendia a língua portuguesa.
} 
responsável para comandar e promover a união das famílias de cada povo ou sib do alto rio Negro. Cabia ao Bayá coordenar o sustento das famílias indígenas que moravam na Bahsawi. Além de Bayá, existiam outras duas pessoas que sustentavam a força espiritual do chefe e de cada membro da habitação: Ba'asi e Yaí, ambos eram pajés, porém com diferentes funções, mas se complementavam. ${ }^{192}$

O Ba'asi era o principal responsável dos rituais de benzimento da habitação, do chão da casa, das bebidas, comidas, de adornos, de instrumentos musicais e de todos os membros que constituíam a Bahsawi. Ao realizar os rituais, o Ba'asi repetia o que Suniã Pãtãmĩ fez em Ohkó Diawi, antes de iniciar a criação de grupos indígenas do Uaupés. Além disso, o Ba'asi era o principal protetor de Bayá, o chefe da habitação. A segurança da vida de Bayá dependia da sabedoria e do conhecimento dos rituais de proteção de Ba'asi, se o Bahsawi não fosse muito bom, existiam outros chefes e pajés participantes de eventos tradicionais, que por rivalidade e inveja, poderiam por em risco a vida do chefe. Por isso, existia um $\mathrm{Ba}$ 'asi (pajé), o melhor da habitação, responsável pela vida do Bayá-chefe e da vida da habitação. ${ }^{193}$

O Yaí não era outro responsável pelos rituais de benzimentos das habitações, porém a sua função era outra, de curar e prevenir as doenças através dos rituais de pajelança. No entanto, alguns yaíwa conheciam os rituais de benzimento da Bahsawi, por isso também executavam os rituais de habitações. Assim, ao longo da vida cultural dos povos indígenas do Uaupés, até a chegada de missionários, o Bayá (chefe), Ba'asi e o Yaí constituíam as figuras mais importantes para a construção de mahkãtĩ (povoados), Bahsawihseri (das Casas Tradicionais) e para a vida dos grupos. ${ }^{194}$

Na região do Uaupés, as relações de convivência mais intensas ocorriam dentro das Casas Tradicionais (Bahsawihseri), que representavam a materialização do ser espiritual da Casa da Emergência de Ohkó Diawi e de Suniã Pãłãmĩ. ${ }^{195}$ A convivência entre as famílias era orientada pela lógica do poder, da organização social rigorosamente hierárquica. Por exemplo, as festas tradicionais com danças de Kapiwayá e com os rituais de Jurupari, organizadas pelos bayaroá (chefes) que possuíam as Bahsawihseri, tinham dois significados: o primeiro significava a partilha e a confraternização familiar, o segundo significava uma demonstração de poder.

\footnotetext{
${ }^{192}$ Entrevista concedida pelo Pajé Antônio BARRERA em Trinidad (Colômbia), no dia 08 de março de 2007 e documentada por autor.

${ }^{193}$ Entrevista concedida pelo meu pai Avelino DUTRA em Pari-Cachoeira, no dia 03 de abril de 2007, e documentada pelo autor.

194 Ibidem, 2007.

195 Ver item 1.1 do Capítulo 1 desta dissertação.
} 
O poder dos chefes tradicionais e dos pajés só durou até a chegada dos missionários católicos e de evangélicos, os quais atuaram para destruir as culturas do alto rio Negro e substituir as tradições milenares por princípios cristãos.

\subsubsection{A presença missionária antes de $1998{ }^{196}$}

Os missionários foram os que mais dominaram e destruíram as tradições culturais dos povos do Uaupés. Mas, apesar desta história "negra" de convivência com indígenas, elas também contribuíram para o desenvolvimento intelectual que fortaleceu a luta do movimento indígena do rio Negro. Eles foram os padres e as freiras da Congregação Salesiana. Os evangélicos não conseguiram instalar suas Igrejas nas comunidades indígenas do Uaupés, porque os católicos chegaram em primeiro lugar e praticamente dominaram e não deram nenhum espaço para essas Igrejas. Por essa razão não há nenhuma Igreja Evangélica na região.

Segundo GALVÃO (1979), os missionários que acompanhavam as tropas que cumpriam os "resgates" ou buscavam "drogas do sertão", aproveitavam as viagens para "transformar as aldeias indígenas, em núcleo permanentes sob controle secular e religioso do Reino [...]". O autor ainda destaca:

[...] os missionários, em seu zelo catequista e desejo de controle secular desse grande contingente humano, condenavam sumariamente as práticas religiosas indígenas. Com o intuito de desmoralizar as crenças e o ritual apropriavam-se de objetos de uso cerimonial e os exibiam em público quebrando tabus que proibiam às mulheres e jovens não iniciados a vista desses objetos (Coudreau, 1886-7:182). Proibiam festas, quebravam os potis de caxiri, impediam os funerais [...]

Para BRÜZZI (1962), a chegada dos salesianos (as), a partir de 1914, na região:

[...] inicia a nova era negra para as populações indígenas do alto rio Negro, quando foi confiada pelo Vaticano à Congregação Salesiana para continuar

com novo alento a evangelização das tribos indígenas dessa região. Mais uma vez os indígenas foram obrigados pelo governo brasileiro, pelas mãos dos salesianos, que em nome do céu e do inferno destruíram diversas aldeias e malocas para os aglomerar. Para isso construíram, dentro dos princípios evangélicos, os hospitais, ambulatórios, igrejas, mercearias, carpintarias, sapataria, olarias, tapeçarias, etc.

\footnotetext{
${ }^{196}$ Existem vários autores pehka 'asã (não-indígenas) que se destacam nos estudos da vida cultural e religiosa dos povos do Uaupés e alto rio Negro e que ajudam entender como aconteceu o processo de destruição de tradições indígenas, tais como: STRADELLI (1890, 1964); KOCH-GRÜNBERG (1903-1909); João BALZOLA (1916); RODON (1945); LAMUS (1959); MARCHESI [Boletin Salesiano, Ano XXIV, no 4 e Ano XXVI, nº 6 (1930, 1927)]; MARCHESI (1975); Lúcia Hussak Van VELTHEM (1975); Antônio GIACONE (1949); Sílvia Maria Schumuziger CARVALHO (1979); Eduardo GALVÃO (1979); Curt NIMUENDAJÚ (1982); Aloisio CABALZAR \& Carlos Alberto RICARDO (1989); Ana Gita de OLIVEIRA (1992); Berta G. RIBEIRO (1995); Renato ATHIAS (1995); Nilton Cezar DE PAULA (2005), Robin M. WRIGTH (2005) etc.
} 
O Pe. Antônio Giacone (1927), que escrevia para o Boletim Salesiano com finalidade de pedir ofertas e esmola aos leitores do mundo inteiro para as obras salesianas do rio Negro, dizia que se iniciava um novo processo de evangelização no meio dos povos indígenas do Brasil. Nesse ensejo ele asseverou que "Os Índios dessas regiões são indiferentes e frios para as cousas religiosas; não tem práticas nem cerimônias especiais"197.

Padre João Marchesi - que depois se tornou Dom João Marchesi, primeiro bispo da prelazia do Rio Negro - escreveu uma outra carta ao superior de sua congregação Rdmo. Sr. D. Felipe Rinaldi (1930), após realizar a viagem ao rio Uaupés, na qual contou como eram os índios dessa região e como eles (salesianos) $\operatorname{agiam}^{198}$ :

[...] acabo a construção da casa para receber um bom número de pequenos índios. Procuro devagar contacto com os adultos.

Estes já freqüentam a missão muito mais que antes e vão se deixando convencer a deixar os feios costumes que praticavam. Os que vivem perto são muito assíduos ao catecismo e às práticas religiosas.

O número de índios é considerável e aumenta sempre, também pela razão que os que formavam parte da Comissão Rondon, passaram para a nossa missão. Podemos assim afirmar que as nossas vilas agrupam todos os índios destes lugares, menos os poucos que vivem ainda nas florestas. São 28 vilas bem encaminhadas, o que facilita muito a evangelização.

[...] Pouco por vez os índios foram ficando nossos amigos e a nossa residência vê-se continuamente invadida por eles. [...] Nós aproveitamos destas disposições para impor-lhes um programa mínimo de civilização e de moral que consiste:

$1^{\circ}$ No abandonar a maloca, lugar que por sua natureza torna-se de corrupção, para que cada qual viva em casa própria.

$2^{\circ}$ no desistir das orgias periódicas com as inevitáveis bebedeiras.

$3^{\circ}$ no realizar o matrimônio sem o rapto violento da esposa, mas de comum acordo; $4^{\circ}$ no participar á missa dominical.

No Uaupés, os salesianos chegaram e construíram suas gigantescas sedes missionárias em Taracuá, Iauaretê e Pari-Cachoeira.

Na comunidade Tukano de Taracuá, os salesianos chegaram em $1923^{199}$, construíram a Igreja do Sagrado Coração de Jesus, que se tornou a sede da paróquia; construíram o prédio do internato masculino e feminino; a residência dos padres e das freiras, e o hospital Santa Casa; instalaram cursos profissionalizantes de tecelagem, sapataria, mecância, carpintaria marcenaria etc. Depois construíram centenas de capelas nas comunidades que constitui o

\footnotetext{
${ }^{197}$ A carta foi publicada no Boletim Salesiano. Órgão dos Cooperadores Salesianos. Um caso singular de modo indígena (diário de viagem do Pe. J. Marchesi). Ano XXIV, no 4, 1927, p. 122-125.

${ }^{198}$ A carta foi publicada no Boletim Salesiano. Órgão dos Cooperadores Salesianos. Um caso singular de modo indígena (diário de viagem do Pe. J. Marchesi). Ano XXVI, nº 6, 1930, p. 179-181.

${ }^{199}$ Aloisio CABALZAR; Carlos Alberto RICARDO, 2006, p. 91-98.
} 
Distrito, e, formaram centenas de capitães, catequistas que substituíram os bayaroá (chefes tradicionais), pajés (ba'asera e yaíwa). $\mathrm{Na}$ comunidade funcionou o primeiro internato salesiano do Uaupés, fundado em 1925, que abrigou milhares de adolescentes e jovens indígenas que chegavam de vários lugares da região, tais como: de Iauaretê, Pari-Cachoeira, São Gabriel da Cachoeira, Cucuí; da Colômbia, sendo que os meninos e meninas vinham de Trinidad (alto Tiquié), Puerto Colômbia (alto Tiquié), Bela Vista, Caño Inambu, etc.

Figura 2. Igreja Matriz "Sagrado Coração" da comunidade de Taracuá, Uaupés.

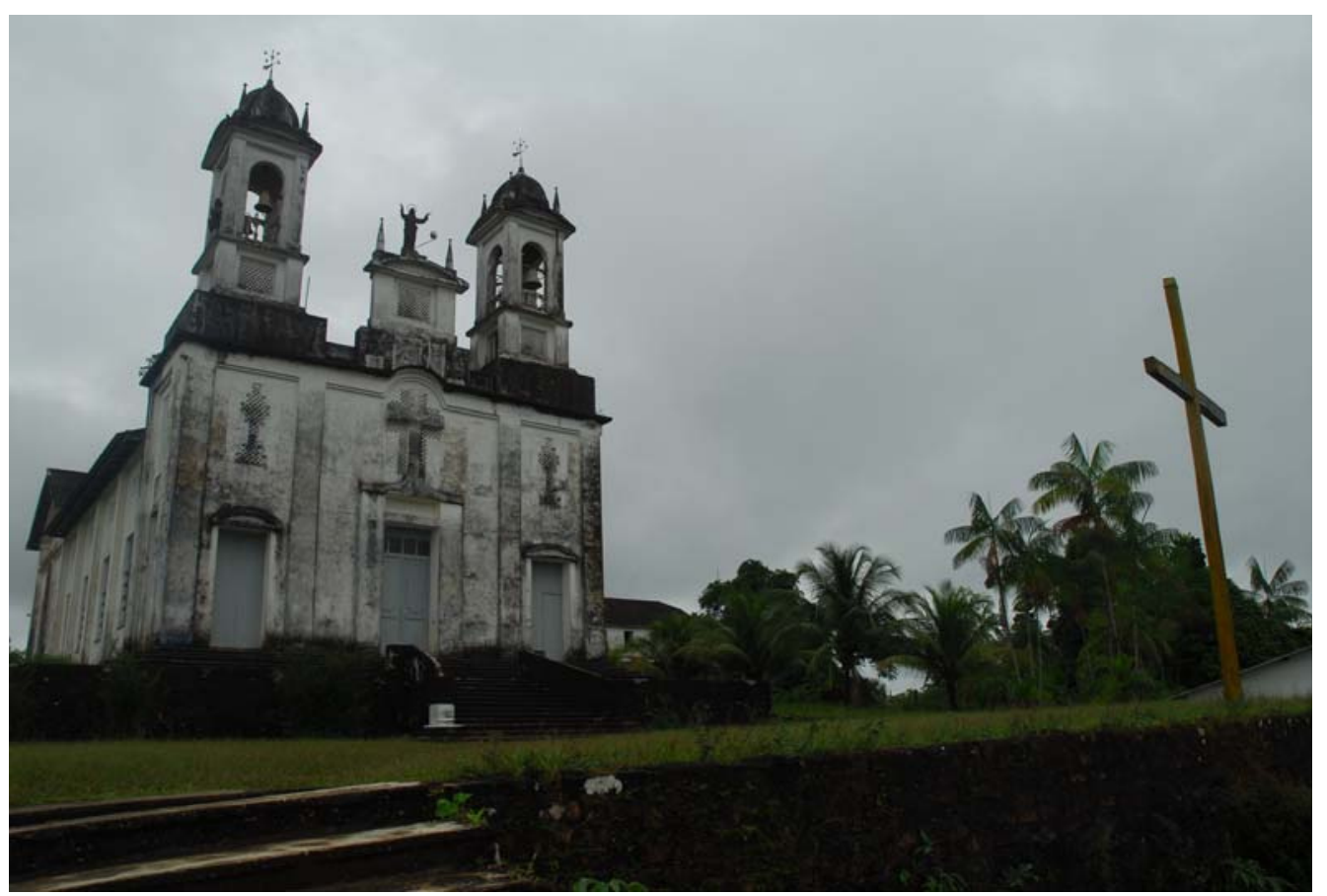

Fonte: Maurício Torres, 2007.

Figura 3. O antigo prédio de internato masculino, da Missão Salesiana de Taracuá.

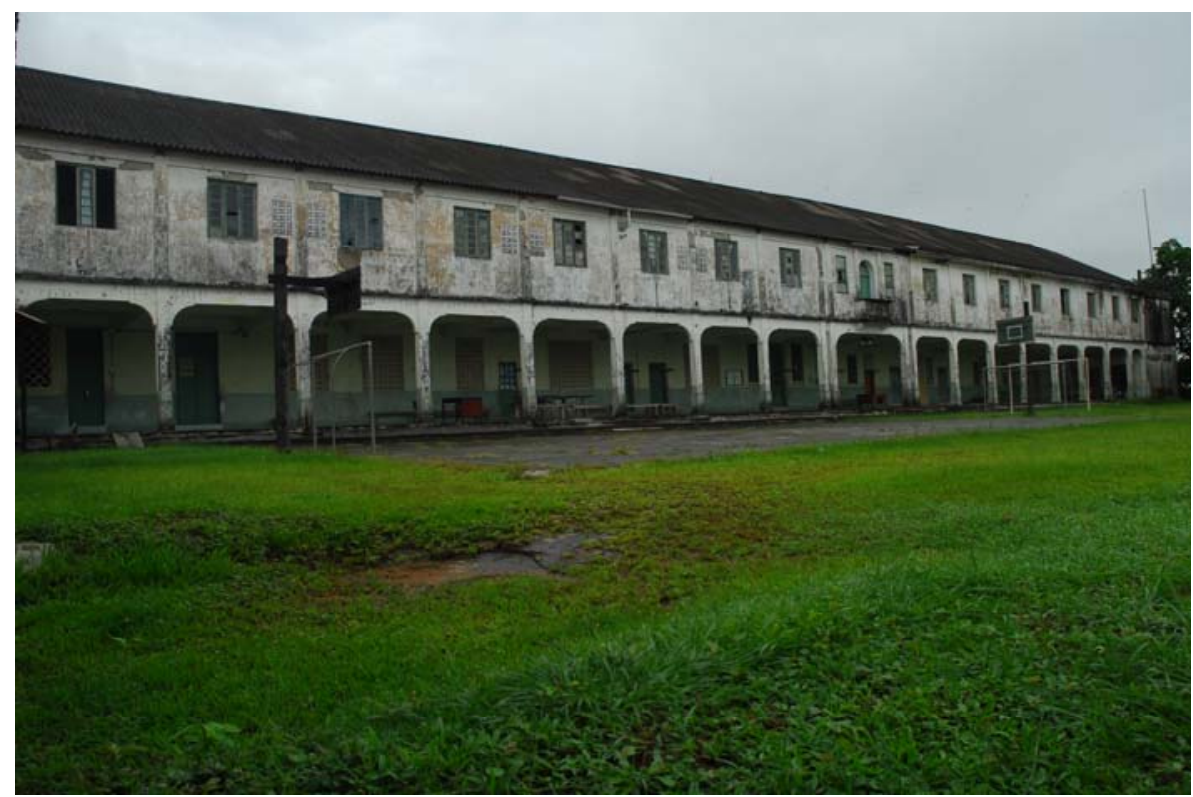

Fonte: Maurício Torres, 2007. 


\section{Para BÉKSTA (1988):}

[...] Dom João Marchesi - chamado de "Anchieta" do Uaupés - tinha como um dos propósitos transformar gradativamente as malocas: primeiro em uma série de choupanas e depois, em casinhas de madeira". A grande maloca é perigosa demais, tanto do lado moral, quanto do sanitário. Comece-se retirando dela os mais jovens para instruí-los no internato gratuito: é o primeiro passo para influir sobre os pais, Mons. Giordano conheceu bem demais a maloca com as danças orgiásticas que duravam dois dias e duas noites seguidas.

[...] para Mons. Pedro Massa, a maloca é também, como costumava dizer o zeloso Dom Bálzola, a "casa do diabo", pois ali se fazem as orgias infernais, maquinam-se as mais atrozes vinganças contra os brancos e contra os outros índios, na maloca transmitem-se os vícios de pais e filhos.

Continuando diz Massa (1928), [...] essa casa do índio, essa casa do diabo não existe mais em Taracuá: nós a desencantamos se substituímos por um discreto número de casinhas, cobertas de folhas de palmeira e com paredes de barro. Não se mostraram descontentes os índios por causa do arrasamento da maloca: antes ficaram satisfeitos reconhecendo a grande utilidade de cada família ter sua casinha, seu lar, especialmente para evitar o contágio. Foi-se, pois, a maloca dos Tukano!

Na comunidade Tukano e Tariano de Iauaretê, os salesianos chegaram em $1927^{200}$ onde construíram a sede da missão, Igreja Matriz "São Miguel”, construíram a Escola "São Miguel", o internato masculino e feminino, as residências dos padres e freiras, e o hospital Santa Casa. Instalaram também, cursos de carpintaria, corte e costura, mecânica, sapataria tecelagem e cantinas para comercializar produtos industrializados com os indígenas. As mesmas estratégias adotadas em Taracuá, com base no sistema preventivo de Dom Bosco, os salesianos eliminaram os chefes tradicionais e os pajés e, enfim, preparam os seus alunos e ex-alunos internos para se tornarem capitães e catequistas das comunidades.

${ }^{200}$ Ibidem, 2006, p. 91-96. 
Figura 4. Atual sede dos missionários salesianos em Iauaretê.

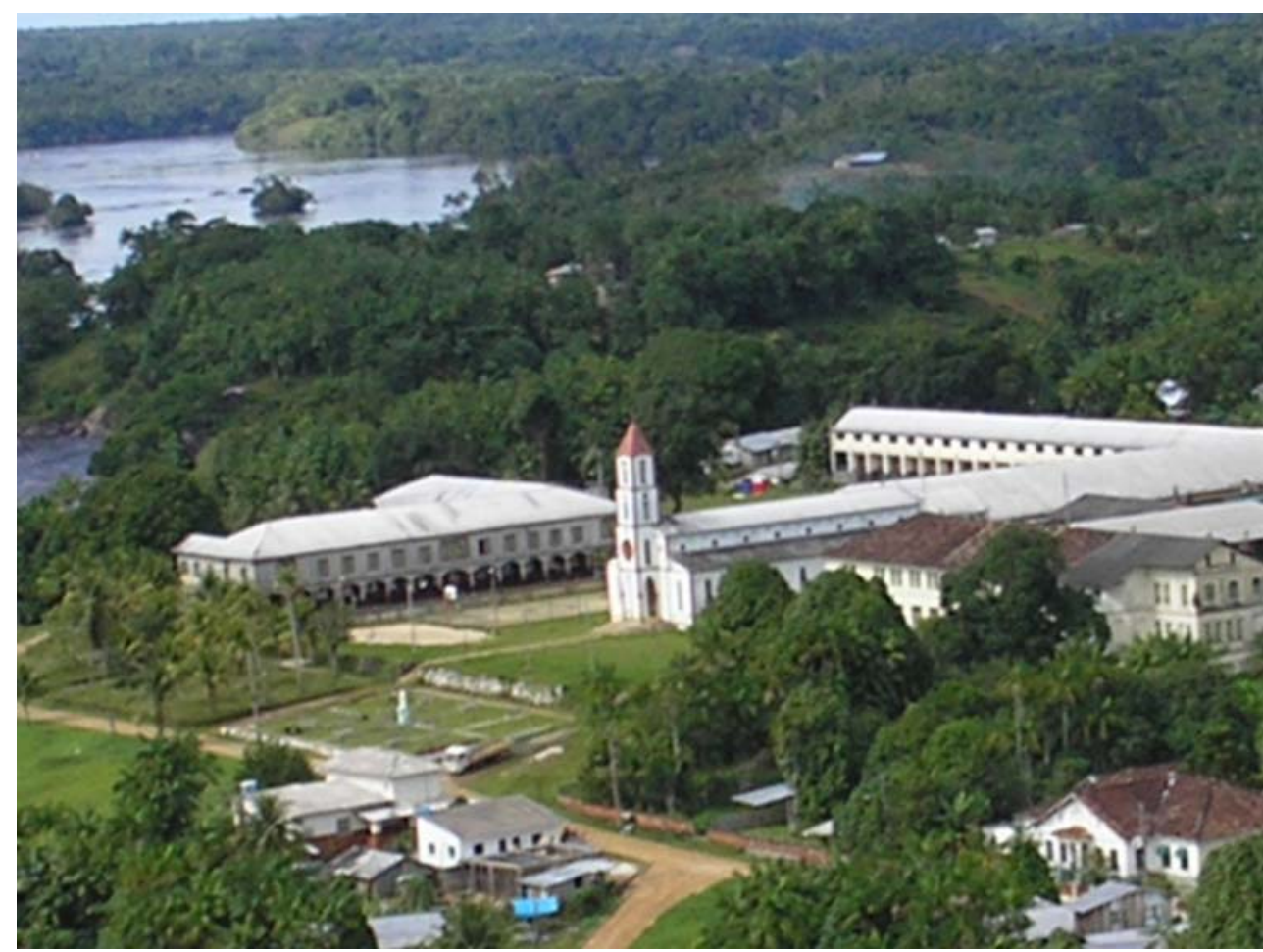

Fonte: Geraldo Veloso FERREIRA, 2007.

Na comunidade Tukano de Pari-Cachoeira, os salesianos chegaram em $1940^{201}$ e, seguida, "construíram a Igreja Dom Bosco, a Escola "Dom Pedro Massa", o internato masculino e feminino, hospital. Instalaram também, as cantinas (dos padres e das freiras) para comercializar com os indígenas, criaram cursos profissionalizantes de tecelagem, corte e costura, marcenaria, sapataria, carpintaria, mecânica, olaria etc"202;

Os salesianos trabalhavam em parceria com o Governo brasileiro, particularmente com os militares, por isso conseguiram construir o aeroporto de Pari-Cachoeira e os prédios da Missão, usando a mão-de-obra indígena do Tiquié. Eles mantiveram ativo o internato com a verba do Governo Federal, acolhiam os militares e as autoridades governamentais em suas residências; e, tinham cotas específicas para viagens de religiosos em aeronaves militares, e para o transporte aéreo de seus mantimentos. O internato de Pari-Cachoeira funcionou até $1987^{203}$. Nesse período, os missionários enviaram dezenas de jovens indígenas para os seus

\footnotetext{
${ }^{201}$ Ibidem, 2006, p. 91-96.

202 Essas informações foram transmitidas meu tio Laureano DUTRA, que foi um dos primeiro aluno interno da Missão Salesiana de Pari-Cachoeira. Entrevista concedida no dia 03 de abril de 2007 em Pari-Cachoeira.

${ }^{203}$ Eu, Israel Fontes Dutra, fui um dos últimos alunos interno da Missão Salesiana de Pari-Cahoeira. Na minha época a disciplina não era tão cruel assim com foi na década de 40 a 70 . Os padres já não proibiam tanto para que não falássemos as nossas línguas paternas, mas castigos ainda existiam. Lembro-me de uma vez que um padre que atirou em minha cabeça um pedaço seco e duro de estrume de gado, enquanto trabalha na horta, porque achava que estava com nojo de pegar no estrume de boi para misturar com outros adubos e terra. Esse padre era paulista. Não gostei da atitude dele, mas nada pude fazer. Se fosse um pouco mais velho, teríamos brigado ali mesmo. Sorte dele que era uma criança de 11 anos de idade.
} 
centros de formação religiosa, em Belém e Manaus, e várias moças para se tornarem empregadas de suas casas e de amigos militares. Enfím, a relação de convivência entre missionários salesianos e indígenas em Pari-Cachoeira foi tão polarizada que em 1980 um dos pioneiros do Movimento Indígena do Rio Negro, o Tukano, Álvaro Fernandes Sampaio testemunhou na acusação contra os salesianos da Prelazia do Rio Negro, AM, no IV Tribunal Bertrand Russel, na cidade de Rotterdan, Holanda, sobre os crimes de etnocídio e genocídio 204

Conforme REZENDE (2007) as relações de convivência dos povos indígenas do Uaupés e missionários evidenciam o processo histórico de forma contundente e incisiva:

A ação missionária dos primeiros anos profanou as malocas, suas tradições e seus líderes religiosos. No segundo momento eliminaram-nas, incentivando as casas particulares [...].

[...] a destruição da maloca era parte integrante da ação evangelizadora.

Diante de atitudes como está, o que os índios podiam fazer e falar? Não podiam. Era domínio salesiano [...]

$\mathrm{O}$ olhar dos salesianos era diferente do olhar indígena sobre a maloca. Para os indígenas ela significa, a vida, a origem e continuidade da vida. O próprio Béksta (1988) lembra que, destruindo a maloca, destruiu-se a comunidade, os pajés foram expulsos e desterrados [...]

Em Pari-Cachoeira, a história de convivência entre indígenas e missionários salesianos ficou marcada de aspectos positivos e negativos.

Por exemplo, entre os aspectos positivos destacamos os seguintes: os salesianos ajudaram os indígenas de Pari-Cachoeira a se organizarem em associações (UFAC, UCIRT, Associação de Mães), que deu origem o movimento indígena do rio Negro e que culminou na criação da Federação das Organizações Indígenas do Rio Negro (FOIRN); construiu a base intelectual indígena que despontaram e despontam como lideranças dentro e fora do movimento indígena; através da educação escolar prepararam indiretamente vários jovens para que lutassem pelos interesses do movimento indígena do rio Negro; construíram a base de educação escolar no alto rio Negro, propiciando os docentes indígenas se tornarem mais preparados para que um dia dirigissem e construíssem as escolas indígenas etc.

Os aspectos negativos que se destacaram na história da ação missionária no alto rio Negro e Uaupés, são: a destruição das Casas Tradicionais (Bahsawihseri), dos chefes tradicionais (bayaroa) e dos pajés (yaíwa e ba'asera); através dos internatos, dividiram famílias indígenas entre pais e filhos, impedindo o processo de educação indígena; proibiram os jovens indígenas dos internatos que falassem as línguas paternas e, portanto, provocaram a

\footnotetext{
${ }^{204}$ Álvaro Fernandes SAMPAIO, 1981, 1982 e 1983. Ver anexo 5.
} 
extinção de diversas línguas da região; expulsaram algumas famílias indígenas que se manifestavam contra a atuação missionária. ${ }^{205}$

A partir de 1987, depois que a FOIRN foi criada, com a interferência direta de ONGs, as lideranças decidiram excluir a participação da Igreja católica do movimento indígena. Em 1998, enquanto os indígenas e as ONGs comemoravam a vitória da demarcação das TIs do Alto Rio Negro, muitos missionários também comemoraram, no entanto outros ficaram preocupados com o futuro da Igreja dentro das áreas indígenas, porque sabiam que sob a motivação das ONGs, as comunidades indígenas reivindicariam maior autonomia para dirigir as escolas existentes em Pari-Cachoeira, Taracuá, Iauaretê, Assunção do Içana e até em São Gabriel da Cachoeira, que até então as irmãs salesianas dirigiam.

A nova forma da relação de convivência com os indígenas estava traçada e, portanto, seria outra, porque os indígenas teriam mais coragem e direito de ditar regras e normas de convivência, e de conduzir a sua vida social de acordo com seus princípios tradicionais sem a influência da Igreja. Por isso, existia o medo de alguns padres e freiras de perder o prestígio e o poder político e religioso. Os missionários que mais revelaram essas preocupações foram os não-indígenas, porque os padres e as freiras indígenas comemoraram juntos com seus parentes, porque para eles também era uma vitória, pois daí em diante seriam mais respeitados e valorizados pela Igreja do rio Negro, porque estariam dentro de suas terras com os seus familiares.

Na comunidade Tuyuka de Trinidad (Colômbia), os únicos missionários que chegaram foram os católicos da congregação Javeriana, em meados da década de 70, que segundo Álvaro Sampaio foram mais ferrenhos que os missionários salesianos no alto rio $\mathrm{Negro}^{206}$. Os evangélicos não chegaram na comunidade devido a presença da Igreja Católica, porque onde existia uma sede da missão católica, eles (os evangélicos) não tinham vez e nem voz, e viceversa.

Os católicos construíram em Trinidad uma Igreja Matriz, a sede da missão e uma escola de Ensino Fundamental. Depois iniciaram o processo de catequização, a formação de catequistas e capitães Tuyuka e Barás; e, enfim, conseguiram destruir os chefes e as habitações tradicionais e os pajés. Apesar da ação avassaladora, os Tuyuka conseguiram manter em pé algumas Casas Tradicionais para vivenciar seus rituais e danças, porém com menor intensidade, porque os padres e as freiras da missão proibiam os eventos.

\footnotetext{
${ }^{205}$ Laureano DUTRA, op.cit., 2007.

${ }^{206}$ Álvaro Fernandes SAMPAIO, op. cit., 1981.
} 
Entretanto, os missionários colombianos não tardaram em perceber a importância da cultura indígena e em seguida começaram respeitar, valorizar e motivar a prática das tradições Tuyuka. Por exemplo, em 1984, os Tuyuka do subgrupo Wehsé Dohkapuała, do Igarapé Cabari, fizeram um dabucuri de peixe surubin para os seu parentes de Trinidad. Nessa ocasião presenciamos as danças de kapiwayá, danças de cariço (perurigê) e mawaco e o consumo de kahpi. Durante o evento o que chamou a nossa atenção foi a coragem, vontade e o arrojo das irmãs da missão de Trinidad que dançavam e pulavam junto com os mestres de músicas e danças tradicionais. Os nossos pais ficaram felizes e curiosos com a participação das irmãs, e disseram o seguinte: essas, sim, são as verdadeiras irmãs, que vieram trabalhar conosco; tem que ser assim mesmo. No final as irmãs dançaram, beberam caxiri e participaram da festa com toda alegria, mas com moderação.

Essa fase da história de convivência entre indígenas e missionários no Uaupés pode ser considerada a fase negra e ao mesmo tempo, o período de consolidação e aprendizagem das lideranças indígenas, que tiveram suporte político para a luta do movimento indígena do rio Negro, por isso também conquistaram a demarcação de suas terras. E, hoje, tem uma das federações indígenas mais influente e importante do Brasil. Algumas das principais lideranças indígenas mais conscientes do processo histórico da ação missionária reconhecem que as conquistas políticas do movimento indígena do rio Negro se devem a atuação histórica de missionários, que apesar de aspectos negativos, contribuíram para a construção do movimento indígena.

\subsubsection{A presença missionária depois de 1998}

A partir de 1998, após a demarcação das Terras Indígenas (Tis) do Alto Rio Negro, a relação de convivência entre indígenas e missionários iniciou uma nova fase: a separação entre a Igreja e o movimento indígena. Outros agentes externos começaram dominar e interferir diretamente na política indígena do rio Negro. A Igreja Católica e as Igrejas Evangélicas, na prática, se tornaram adversárias da Federação das Organizações Indígenas.

Do ponto de vista histórico, a divisão entre o movimento indígena e a Igreja Católica iniciou-se nas décadas de 70 e 80 com o surgimento de novos líderes indígenas de PariCachoeira, depois se consolidou com a criação da FOIRN e, por fim, com as ONG, que sempre lutaram e agiram contra a atuação missionária no alto rio Negro. A Igreja Católica ainda é julgada pelos erros do passado, do período de internato, no entanto as pessoas que as julgam não querem ver que, hoje, os objetivos e os missionários da Igreja Católica do alto rio 
Negro não são mais os mesmos. Existem padres e freiras indígenas, padres e freias amazonenses e brasileiros que têm novas idéias e novas visões, porém, apesar disso, há lideranças indígenas, manipuladas pelas idéias de alguns agentes externos, que criam um “campo político" entre indígenas e missionários.

A posição excludente de algumas lideranças provoca reações dos padres e freiras indígenas, que acham que os seus próprios parentes querem excluí-los de suas participações em debates e discussões da comunidade, nas quais poderiam contribuir para a convivência comunitária e para o fortalecimento do movimento indígena do rio Negro. Os missionários indígenas acreditam que por serem indígenas e parentes têm os mesmos direitos de contribuir na luta pela autonomia indígena. Por isso, tentam participar mais ativamente de encontros comunitários, mas, muitas vezes, não são bem-vindos e bem vistos por algumas lideranças, que os vêem como representantes da Igreja Católica e não dos interesses das comunidades indígenas. $^{207}$

Na região do alto rio Negro, os missionários católicos estão presentes nas seguintes comunidades:

Tabela 2 - Presença católica nas comunidades indígenas do alto rio Negro, em 2008.

\section{COMUNIDADE \\ PADRES \\ FREIRAS \\ ESCOLA}

DIREÇÃO DA

\begin{tabular}{|c|c|c|c|c|}
\hline $\begin{array}{l}\text { Assunção do } \\
\text { Içana }\end{array}$ & Xaverianos & Salesianas & $\begin{array}{l}\text { Escola Indígena de Ensino } \\
\text { Fundamental e Médio }\end{array}$ & $\begin{array}{l}\text { Indígenas } \\
\text { Ind }\end{array}$ \\
\hline Cucuí & Xaverianos & - & Escola de Fundamental & Indígenas \\
\hline Iauaretê & Salesianos & Salesianas & $\begin{array}{l}\text { Escola Indígena de Ensino } \\
\text { Fundamental e Médio }\end{array}$ & Indígenas \\
\hline Maturacá & Salesianos & - & $\begin{array}{l}\text { Escola Indígena de Ensino } \\
\text { Fundamental }\end{array}$ & Salesianos \\
\hline Maiá & - & Salesianas & $\begin{array}{l}\text { Escola de Ensino } \\
\text { Fundamental }\end{array}$ & Salesianas \\
\hline Pari-Cachoeira & Diocesanos & Salesianas & $\begin{array}{l}\text { Escola Indígena de Ensino } \\
\text { Fundamental e Médio }\end{array}$ & Indígenas \\
\hline Taracuá & Diocesanos & Salesianas & $\begin{array}{l}\text { Escola Indígena de Ensino } \\
\text { Fundamental e Médio }\end{array}$ & Indígenas \\
\hline $\begin{array}{l}\text { São Gabriel da } \\
\text { Cachoeira }\end{array}$ & $\begin{array}{l}\text { Diocesanos, } \\
\text { Salesianos e } \\
\text { Sagrado Coração } \\
\text { de Jesus }\end{array}$ & $\begin{array}{l}\text { Salesianas e } \\
\text { Franciscanas }\end{array}$ & $\begin{array}{l}\text { Colégio Indígena de } \\
\text { Ensino Fundamental e } \\
\text { Médio }\end{array}$ & Salesianas \\
\hline
\end{tabular}

Fonte: acervo do autor, 2008.

Duas questões atuais se destacam no processo da perda de domínio católico sobre as comunidades indígenas após a demarcação das terras indígenas na região do alto rio Negro e Uaupés em 1998: a religiosa e educacional.

\footnotetext{
${ }^{207}$ Entrevista concedida pelo Tukano de Iauaretê, Geraldo Veloso FERREIRA, no dia 10 de maio 2007 em São Paulo e documentada por autor.
} 
$\mathrm{Na}$ questão religiosa ocorreram mudanças e chegadas de novas congregações católicas na diocese de São Gabriel da Cachoeira para tentar diversificar os carismas e reconquistar fiéis indígenas que estavam migrando para as Igrejas Evangélicas. Por exemplo, em 2000, os padres salesianos saíram de Pari-Cachoeira e foram substituídos pelos padres diocesanos; em 2003 e 2005, os padres salesianos saíram de Assunção do Içana e Taracuá, respectivamente. No caso de Assunção do Içana, os salesianos foram substituídos por javerianos; e em Taracuá por diocesanos; enfim, atualmente os padres salesianos somente estão presente em Iauaretê (alto Uaupés), na cidade de São Gabriel da Cachoeira e Maturacá, na área dos Yanomami. As irmãs salesianas, ainda estão presentes em Pari-Cachoeira, Taracuá, Iauaretê, Assunção do Içana, Maiá e em São Gabriel da Cachoeira, por enquanto elas, as freiras, resistem bravamente diante dos desafios das áreas demarcadas.

Talvez, um dos maiores desafios que a Igreja Católica do alto rio Negro enfrenta seja a falta de mais padres não-indígenas para atuarem nas comunidades indígenas e mais padres indígenas que dificilmente conseguem suportar as regras das congregações que engajam para formação religiosa e o celibato da Igreja Católica. Por exemplo, a Diocese de São Gabriel da Cachoeira tem apenas quatro padres não-indígenas diocesano, e quatro padres indígenas diocesanos: em Iauaretê são dois Tariano e um Wanano, e em Pari-Cachoeira tem apenas um Tukano. A Inspetoria Salesiana Missionária da Amazônia (ISMA) tem apenas um padre indígena, do povo Tuyuka e aproximadamente 5 padres não-indígenas no alto rio Negro. As freiras salesianas têm aproximadamente 10 freiras indígenas no alto rio Negro, porém elas (as indígenas) não têm a mesma formação acadêmica como as freiras não-indígenas para poder representar e interferir nas decisões religiosas da Visitadoria Santa Terezinha, AM, de forma eqüitativa e mais incisiva.

Por falta de padres e freiras, a diocese tenta colocar a maior responsabilidade das atividades catequéticas e as atividades das pastorais nas mãos de leigos, principalmente nas comunidades indígenas. As lideranças indígenas e catequistas, por exemplo, de PariCachoeira, Taracuá e Iauaretê, começam reagir diante disso, porque percebem que os padres e as freiras, que foram preparadas e enviadas para desenvolver as atividades pastorais nas comunidades, não cumprem com as suas responsabilidades de missionários, pois, em vez deles dirigirem, põem "toda" responsabilidade sobre os leigos. A menor contribuição na parte catequética da Igreja Católica no rio Negro é das irmãs salesianas, porque muitas são funcionárias do Governo estadual e trabalham nas Escolas como profissionais da educação. No final, sobram poucas freiras que se dedicam à catequese e para a evangelização. 
A relação de convivência entre indígenas e padres é diferente da relação entre indígenas e freiras. Os padres são mais participativos e abertos para inovações, por isso, os indígenas têm mais afinidade com eles. As freiras são mais fechadas, ficam mais resguardadas em suas residências, principalmente as mais velhas, que não aceitam facilmente as inovações culturais. Existem freiras mais novas, indígenas e não-indígenas, que tentam participar mais ativamente da vida da comunidade indígena e são bem aceitas pela comunidade, no entanto entram em conflito com a ala mais tradicional da própria instituição religiosa que não se abre para a inculturação do evangelho.

A segunda questão é a educacional, pois até o final de $2004^{208}$, as escolas de ensino Fundamental e Médio instaladas dentro da Terra Indígena Alto Rio Negro eram dirigidas pelas irmãs salesianas. O ano de 2004 marcou o início da perda do poder de controle da Igreja Católica sobre a direção das Escolas Estaduais situadas nas terras indígenas do alto rio Negro. Anteriormente, em nenhum momento os professores indígenas tiveram direito de se tornarem diretores e vice-diretores das escolas de Pari-Cachoeira, Taracuá, Iauaretê, Assunção do Içana, Maturacá e Colégio "São Gabriel”. As freiras e o bispo da diocese nunca quiseram ceder esse poder e o direito para os professores indígenas, porque acreditavam que só os missionários podiam ser diretores das escolas; porque os prédios das escolas eram propriedade da Igreja e o convênio para o funcionamento das escolas tinha sido legalizado entre a Diocese e a Secretaria de Educação do Estado do Amazonas (SEDUC). Por isso, quem escolhia o diretor ou a diretora da escola era o bispo da diocese, e, o único direito que os professores indígenas tinham era de serem coadjuvantes ou vice-diretores. Em fim, a Diocese de São Gabriel da Cachoeira nunca abriu esse espaço para participação nos cargos de direção das escolas.

Veja-se a seguir, a entrevista de Dom Song Sullivan (2004), Bispo da Diocese de São Gabriel da Cachoeira que expressa de forma clara a posição da Igreja Católica do rio Negro sobre a direção das escolas, baseando-se no evangelho de Jesus Cristo segundo João, capítulo $3,22-29:^{209}$

Queremos inspirar com o evangelho do dia [...]. Proclamação do Evangelho de Jesus Cristo, segundo São João.

Essa lição serve para todos nós, missionários e missionárias desde o papa até a criança que nasceu neste instante. Como a família cristã, todos nós devemos ser pregadores e evangelizadores do Senhor, mas pregar o Senhor e não nos colocar os Senhores, dominadores e exploradores do povo, isso chama-se desonestidade, incoerência, falsidade. Ninguém pode sair por aí lucrando, sair enriquecido.

\footnotetext{
${ }^{208}$ Conselho dos Professores Indígenas do Alto Rio Negro, COPIARN. Relatório 08 a 10 de 2004.

${ }^{209}$ Entrevista concedida na rádio "Nova Milênio" e na "Rede Vida" de televisão local, ambos dirigidos pela Diocese de São Gabriel da Cachoeira, n dia 03 de fevereiro de 2004.
} 
Infelizmente no Brasil, nós falamos, há pouco tempo, que há muitos falsos profetas [...]. Pensam que estão curando as doenças, mas na realidade não passam de farsas [...], teatrinho só para enganar o povo, dizendo: Olha aquele pastor está realmente fazendo milagres, prometendo curas rápidas e baratas [...]. Jesus já falou: Cuidado com falsos profetas. Estão vestidos com a pele de cordeiro, por fora bonitinhos, inocentes e por dentro maldoso, aproveitador e enganador.

Meus caros irmãos, quem está me acompanhando pela televisão, Rede Vida, canal 7, e quem está acompanhando pela nossa rádio "Novo Milênio" está sabendo que estou abordando com vocês, o tema da educação indígena e da escola indígena. Resumindo seria o seguinte: Já está aprovada a lei nova que todas as escolas, onde tem a população indígena, as escolas devem ser indígenas. Então, a Diocese aprova, não só aprova, já colaborou com os próprios missionários apoiando, orientando aqui em São Gabriel da Cachoeira - aqui nós temos até muitas irmãs apoiando e orientando, fazem parte da equipe dos líderes indígenas. Então, nesse sentido, a Diocese, a Igreja Católica do rio Negro é de pleno acordo, plena concordância com a legislação. Nós também queremos que as escolas sejam indígenas, diferenciadas, para que a dignidade e a identidade indígena seja muito esclarecida, seja defendida, garantida e assegurada, e não omissa como acontece às vezes. Já perdemos as etnias e as identidades de vários povos indígenas no Brasil. E nós não queremos que haja esse suicídio coletivo, aos poucos vão se extinguindo. Então, os missionários têm uma missão grande de preservar o que é de bom nas culturas, colocando o Evangelho, Jesus Cristo em primeiro lugar. Isso chama-se de inculturação. Inculturação sem Jesus, sem Deus é uma coisa falsa para o inglês ver, como diz o ditado.

Muito bem. O que está em polêmica é a direção da escola. [...] vejam bem que na nossa diocese temos dez ou onze escolas que pertencem a propriedade dos missionários, da missão ou da Diocese de São Gabriel da Cachoeira. Inclusive quem está me escutando ou me vendo pode ser que já colaborou a um padre para construir o nosso Colégio "São Gabriel", quem sabe, não é. Pois bem! São propriedades da diocese, então, nós somos responsáveis. Então, aqueles que estão com medo, ih!, vão embora as irmãs, vão embora os padres das escolas, não... Nós não temos essa pretensão, seria última análise, tinha que acontecer muita coisa grave para tirar essa decisão, mas graças a Deus, nós queremos ser até o final, fiéis, permanecentes e permanentes nessas escolas. Nós não queremos divisão, não queremos também luta de poder, que nós estamos aqui por dever, por amor, por carisma. As diretoras, os diretores que estão nas escolas nossas, não disputaram para poder depois entrar. São por pura obediência, todos eles são religiosos e religiosas salesianos. Não é que cada um faça política, uma campanha para entrar como diretor. Então, ninguém faz isso, quem fizesse isso seria falso diretor e falso diretora, e falso pastor ou profeta.

Os diretores e as diretoras que estão nas nossas escolas salesianas ou diocesanas, eles têm esta missão de continuar [...] seguindo o artigo 5 do nosso regimento escolar da Diocese de São Gabriel da Cachoeira, que é aprovada e assinada. Então, continuem diretores salesianos e diretoras salesianas. E também contamos com a colaboração de alguns colaboradores indígenas, vice-diretores. Aqui fala bem clarinho. Eu vou ler para vocês entenderem o espírito daquilo que estou falando: A direção das escolas é constituída pela diretoria e tem a vicediretoras legalmente habilitadas. A diretora é nomeada pela secretária do Estado de Educação do Amazonas, após indicação da entidade mantenedora, diocese de São Gabriel da Cachoeira, na pessoa do bispo diocesano, que o fará através da superiora da Visitadoria Santa Terezinha, até que perdure o contrato da locação feita com a mesma. A vice-diretora é escolhida pela diretora após a consulta a comunidade educativa e nomeada pelo secretário de Estado de cultura do Amazonas. As palavras são técnicas e difíceis de entender, mas traduzindo em miúdos seria o seguinte: Os diretores e as diretoras das escolas que pertencem a 
diocese são indicadas pelo bispo. Então, no caso, eu indico de acordo com a Visitadoria ou com a Inspetoria Salesiana do Amazonas, Manaus. Uma vez indicada pelo bispo, então é aprovado pela SEDUC e depois, então, é declarado oficial. Isso aí é sempre a responsabilidade da SEDUC e Diocese. Existe também uma pessoa chamada vice-diretora e colabora com a diretora. E também é indicada, veja bem, escolhida pela diretora, depois da consulta a comunidade educativa. O que é educativa? A comunidade educativa é constituída de irmãos e irmãs, padres ou também alunos, professores e pais, isso chama-se comunidade educativa, então, tem que consultar a população.

A questão é delicada, mas não é confusa como as pessoas podem imaginar. É muito simples: Nós queremos continuar. Não queremos largar. Não fiquem preocupados os que estão achando que os salesianos e as salesianas vão largar as escolas. Pelo contrário, vamos continuar colaborar nesse visual de uma escola indígena diferenciada. Então diretor que é salesiano e diretora que é salesiana, continua a direção, mas coadjuvado ou coadjuvada, ajudado pela colaboração de uma outra pessoa, que pode ser vice-diretor ou vice-diretora. Bom! Por que tudo isso? É que nós queremos garantir, o nível, a qualidade de ensino. Até agora, eu acho que todo mundo elogia. Há defeitos? Há defeitos, mas ninguém pode ninguém mérito dos nossos educadores salesianos que trabalharam desde 1923, isso nas escolas diocesanas, que faz mais de 80 anos os salesianos se dedicam a educação. Então, nós não vamos entregar, não vamos largar assim tão facilmente. Nosso sonho é poder continuar trabalhando. É como suponhamos, uma pessoa estudou para medicina para ser médico e você obriga a vender pipoca, não é. Claro, pode vender pipoca, não é. Não difícil vender pipoca, mas estudou para ser médico. Deixar de ser médico para ser vendedor de pipoca, não estou desprezando, mas é uma coisa muito triste, não muito inteligente. A mesma coisa, os salesianos estudaram para ser educadores. Que seria igualmente ridículo querer colocá-los para vender pipocas nas escolas, que nós fundamos, nós construímos [...], não tem lógica. Quem pretende totalmente a assumir a direção das escolas, das nossas escolas não tem lógica, seria um absurdo, não é. Nós gostamos de pensar e raciocinar, usar a nossa razão. Então, é importante ter idéias muito claras para não ficar brigando por coisas que já são tão óbvias. Naturalmente se um dia por parte dos religiosos salesianos SDB, das irmãs salesianas FMA, nós constatarmos a deficiência quantitativa; um dia suponhamos que não tem mais padres, não tem mais irmãs, não é; ou então, a deficiência qualitativa, não temos mais gente formado para isso, o que vai acontecer? Pode acontecer. Vamos ser primeiros muito honestos dizer para a população: Olha, infelizmente, não tenho padre para colocar nessa escola como diretor; não mais irmãs para colocar como diretora nessa escola, vocês têm que se virar, têm que procurar escolher as pessoas dignas. Quando acontecer esse dia, vou ser primeiro a procurar a população, SEDUC, o MEC, os professores para falar e fazer esse gesto que para mim é honesto. Não queremos enganar ninguém, [...], porém essa é uma hipótese. Por enquanto, pelo que vejo, não temos problemas, embora haja de fato falta de pessoal na direção, mas ainda temos pessoas suficientes quantitativamente e qualitativamente.

Portanto, nós queremos garantir que nossas escolas continuem sendo responsabilizadas pela diocese. No momento presente, nos encontramos, por tanto, numa situação muito privilegiada com uma quantidade invejada de religiosos. Confesso que a sua atuação tem sido merecedora de elogios e apreços sem nada que os desabone. [...]. Vou externar o pensamento da diocese. Se uma coisa está indo bem, porque trocarmos ou substituir por uma outra que talvez tão certa. Dizem que o time que joga bem não muda. Então, nós não temos motivos de mudar diretores e substituir por leigos, sem desprezar os leigos. Todo reino dividido se enfraquece. Toda entidade que luta pelo poder torna-a frágil. Nós, não estamos lutando pelo poder. Não estou com medo de perder as escolas da diocese, não. Estou com medo, sim, a escola na mão de gente que não tem qualidade e não tem 
também honestidade. Competência, não duvidamos, as vezes a motivação honesta, motivação por uma missão, carisma a gente tem que as vezes estar muito atentos para não confiar facilmente. Aqui não se trata de poder, de perder o prestígio. Pelo contrário, a diocese que eu estou representando dá o melhor de si. Veja que a maior parte das religiosas, aliás, as irmãs salesianas, totalmente estão dedicadas as escolas. Se vocês querem que elas vão embora, elas vão começar vender pipocas nas portas das escolas. Isso não é uma coisa que nós queremos não. Nós caros irmãos e caras irmãs, não visamos apenas uma educação parcial, ensinar as crianças ler, escrever, contar, cantar; não visamos apenas esse ensino parcial. Nosso objetivo é uma educação integral. Aí entra o elemento essencial e indispensável, o religioso. Nós, os missionários que mantemos as escolas, nós queremos através da educação também evangelizar.

Esse depoimento foi dado pelo bispo de São Gabriel da Cachoeira, depois que publicamos e enviamos a circular $\mathrm{n}^{\mathrm{o}} 01$ para os professores indígenas de Iauaretê, PariCachoeira, Taracuá, Assunção do Içana, Cucuí e São Gabriel da Cachoeira, em nome do Conselho dos Professores Indígenas do Alto Rio Negro (COPIARN), escrito no final de 2003, no qual escrevemos o seguinte: “[...] que os indígenas do alto rio Negro não precisavam mais da tutela de nenhuma instituição governamental, não-governamental e religiosa para construir seu projeto de autonomia cultural, principalmente para dirigir as escolas instaladas dentro de suas terras $[\ldots]^{\prime 210}$. Esse enunciado provou uma reação ferrenha por parte de alguns missionários, que se sentiram ameaçados para continuar na direção das escolas, principalmente as freiras salesianas. Muitas irmãs salesianas e os padres salesianos apoiaram o teor do circular, porém algumas irmãs não aceitaram o risco de perder o poder da direção das escolas situadas dentro das áreas indígenas.

Nos dias 08 a 10 de março de 2004, foi realizado o I Seminário de Ensino Médio Indígena, promovido pelo COPIARN com o apoio do MEC para discutir a educação escolar indígena do rio Negro, especialmente sobre o Ensino Médio Indígena. Nesse evento, os indígenas que sabiam o conteúdo do discurso do bispo, manifestaram contrários a posição da diocese em relação à direção das Escolas e diziam, de forma até dura, que há dezenas de décadas os missionários vinham destruindo as tradições milenares de seus povos e que agora chegava a hora deles, os indígenas, assumirem as escolas que estavam dentro de suas terras, suas comunidades; que dentro das terras demarcadas, quem mandava eram os indígenas e não o bispo, a madre inspetora, os padres e as freias; e que, se os missionários não gostassem da nova luta indígena, estavam livres para sair de suas comunidades. Além disso, os representantes indígenas disseram aos padres o seguinte: "Nós não estamos expulsando vocês,

\footnotetext{
${ }^{210}$ Escrita por mim, Israel Fontes Dutra, que na época era Coordenador recém empossado do Conselho dos Professores Indígenas do Alto Rio Negro, COPIARN, 2003.
} 
mas também não queremos prendê-los para que continuem entre nós, fiquem se quiserem, se não quiserem poder ir embora do jeito que chegaram, sem nada."211

O Seminário de Ensino Médio Indígena ocorrido em 2004 marcou o fim do domínio religioso na direção das escolas, que antes eram consideradas pelo bispo como propriedade da diocese. O discurso do bispo para defender os interesses da Igreja na área educacional não surtiu efeito, porque a Igreja aos poucos começou perder a direção de suas principais escolas sediadas dentro das áreas indígenas. Atualmente, quase todas as escolas são dirigidas pelos professores indígenas, mas para conquistar esse espaço alguns indígenas tiveram que ser considerados indiretamente como "falsos profetas".

Os missionários, hoje, antes protagonistas de todas as atividades religiosas, políticas, culturais e sociais, são apenas coadjuvantes dos povos indígenas. Estão na área apenas para executar as funções religiosas, sem direito de interferir diretamente na vida indígena. É assim que acontecem as relações de convivência entre os indígenas e missionários católicos no alto rio Negro e Uaupés.

A relação de convivência entre os indígenas e evangélicos é mais acentuada na região do Içana e Xié, onde as comunidades indígenas ainda são controladas pelos pastores de diferentes Igrejas: Assembléia de Deus, Missões Novas Tribos etc; Entretanto, o controle evangélico nessa região também caminha para maior autonomia indígena. Um dos fatores que mais contribui para o domínio de evangélicos na região é o fato das famílias indígenas possuírem baixo nível de escolaridade, que, além das Igrejas evangélicas, também são controladas pelos políticos não-indígenas, que consideram as comunidades dessa região seus currais eleitorais; e também, os regatões, que exploram e enganam os indígenas na hora de comercializar os produtos industrializados e indígenas.

Em seguida destacamos com mais detalhes a relação de convivência entre indígenas em Pari-Cachoeira e missionários, após a demarcação das terras indígenas, em 1998, e em Trinidad (Colômbia).

\subsubsection{A Missão Salesiana de Pari-Cachoeira depois de 1998}

Em Pari-Cachoeira, a força religiosa e política, de missionários salesianos, só durou até 1987 , no último ano de internato, depois que o internado fechou, os padres e as freiras perderam o poder de interferência entre os indígenas do Tiquié. Por isso, a partir de 1998

\footnotetext{
${ }^{211}$ Ver anexo 10.
} 
decidiram sair da comunidade, porque a sua presença não tinha muito significado para a comunidade indígena pelo fato das atividades religiosas só se resumirem em celebrações eucarísticas e em alguns finais de semana no "oratório Dom Bosco". Os indígenas queriam mais novidades que pudessem contribuir no crescimento da comunidade, mas os missionários que estavam na época não conseguiam responder as necessidades de Pari-Cachoeira, e, no final, foram embora.

Em 1999, os padres salesianos decidiram abandonar a missão, mas os indígenas não imaginavam que após cinco décadas de presença, os padres sairiam da missão. Em 2000, no lugar deles (dos salesianos) chegaram os missionários do Sagrado Coração de Jesus, que em 2004, também abandonaram a missão de Pari-Cachoeira. Depois, a Diocese de São Gabriel da Cachoeira assumiu a Paróquia "Dom Bosco", através de um padre indígena, do povo Tukano, que não é Tukano de Pari-Cahoeira e, sim, um Tukano de sib diferente. É um Tukano da comunidade Barreira, localizado no médio Tiquié.

A história da relação entre a comunidade de Pari-Cachoeira e missionários nunca foi de admirar, por isso, hoje, também não é diferente. Apesar de o atual padre ser um Tukano, sua convivência com os seus parentes é bastante conflituosa, por causa da rivalidade milenar de povos e sibs.

Os padres salesianos saíram de Pari-Cachoeira, mas as freiras salesianas não, elas permanecem até hoje. Vivem na comunidade, executam trabalho missionário especialmente entre os Macú, da comunidade de Nova Fundação, no médio Tiquié; em Pari-Cachoeira atuam mais na escola "Dom Pedro Massa" como profissionais da Educação e de vez em quando participam de festas comunitárias. É uma comunidade de freiras diferente de suas antecessoras, da época de internato, porque o trabalho missionário delas é silencioso, porém significativo para a vida de muitas famílias da região.

A presença das freiras salesianas entre os Macu de Pari-Cachoeira incomoda alguns membros de ONGs, que vêem nelas como adversárias e rivais para o controle das comunidades Macú. As freiras atuam entre esses grupos indígenas há décadas, e, as que trabalham na maioria são da nova geração que se esforçam em aprender as línguas da região e outras são freiras indígenas do Uaupés, que falam a língua Tukano e se comunicam perfeitamente com os membros do grupo e com outros do Tiquié. Assim, a relação entre as missionárias atuais e os indígenas facilita para a convivência e o trabalho missionário que se dinamiza de acordo com a vida indígena.

Um dos objetivos das missionárias salesianas é não deixar que outros grupos dominem os Macu. É outro fator que incomoda alguns indígenas não-Macu, porque sempre viram os 
Macu como pessoas que vieram para este mundo para serem seus servos, empregados ou pessoas para trabalhar para os seus interesses. Por causa do trabalho longo e árduo das irmãs salesianas, é que vários membros do grupo posicionam-se contrários a visão de outros povos em relação a sua existência na região. A educação é o caminho que as irmãs investem entre os Macu para que um dia, não muito distante, sejam autônomos em relação a outros grupos e sejam respeitados e valorizados, e lutem de igual para igual para conquistar seus objetivos, assim como os demais povos da região fazem atualmente.

Em seguida, apresentamos alguns depoimentos dos sujeitos sociais da nossa pesquisa que retratam como eles, os Tukano e outros indígenas de Pari-Cachoeira, convivem e vêem, hoje, a presença dos padres e as freiras que trabalham na comunidade.

\section{Para Umũpó, Arsênio Vaz LOBO (2007): $:^{212}$}

Nós sabemos que antigamente aqui trabalhavam os missionários não-indígenas, depois chegaram os indígenas. Hoje, temos o nosso irmão, o Pe, Josimar Marinho, o primeiro padre indígena que trabalha entre nós. Quando analiso o cenário atual da presença missionária aqui em Pari-Cachoeira, chego a seguinte conclusão: nós, indígenas, respeitávamos e valorizávamos muito mais os missionários não-indígenas, porém sabemos que a relação com eles também sempre foi turbulenta e conflituosa.

A convivência polarizada entre nós e os missionários, sempre existiu aqui em PariCachoeira, no entanto, hoje, está [...] pior do que antes, porque em vez de respeitarmos e valorizarmos os nossos parentes missionários, a gente preteri, fala mal, desrespeita e, muitas vezes, criamos um grau de inimizade como se fossem estranhos. É uma coisa difícil de entender, porque isso acontece. Em vez construirmos uma relação harmoniosa entre nós e o nosso padre indígena, em vez de reconhecermos que somos parentes, não existe a idéia que o padre é nosso parente e irmão e que por isso devemos caminhar em conjunto.

Sabemos que o padre é uma pessoa como nós, por isso também tem seus erros, mas alguns de nossos conterrâneos de Pari-Cachoeira não pensam assim, aliás são sempre os mesmos indivíduos que criam conflitos com outros indígenas reagem e criticam o padre; entretanto, há outros que querem o bem do padre, dizem para ele continuar trabalhando para sempre, com eles, porém sempre tem um grupinho que não gosta do padre. Assim é a relação de convivência com o padre. A relação de convivência com as freiras é mais pacífica, porque elas não são mais com as de antes, que interferiam mais na vida indígena, quando dirigiam a escola. As atuais ficam mais na dela, são mais simples e resguardadas em sua residência.

\section{De acordo com Afonso Lopes MACHADO (2007): ${ }^{213}$}

A relação entre os dirigentes da comunidade e o padre, aqui em Pari-Cachoeira, é pautada de não cumprimento de responsabilidades e compromissos assumidos diante da comunidade, de ambas as partes. Depois que o Pe. Josimar chegou houve a expectativa da comunidade que, pelo fato do padre ser indígena, o trabalho seria diferente dos padres não-indígenas, porque no início ele se envolveu com a paróquia, escola e comunidade; porém, não aconteceu o que esperamos. Por exemplo, ultimamente vários eventos políticos acabaram atrapalhando a nossa comunidade e, além disso, existem muitos pastorais na paróquia, tais como: pastoral de artesanato, pastoral da família, pastoral do batismo, pastoral da saúde etc., porém nenhuma pastoral funciona, porque ninguém cumpre os compromissos assumidos. A pastoral da criança era uma coisa muito

${ }^{212}$ Entrevista concedida no dia 15 de março de 2007 e documentada por autor. Umúpó é nome de benzimento indígena, do grupo Miriti-tapuia.

${ }^{213}$ Entrevista concedida no dia 14 de março de 2007 e documentada por autor. 
importante para a comunidade; o Pe. Ivo ${ }^{214}$, ainda dava apoio para o seu funcionamento, depois que ele saiu essa pastoral ficou praticamente abandonada. Você bem sabe que a Pastoral da Criança abrange muitas coisas, medicamentos e diversos materiais destinados para usar no trabalho em prol das crianças, para quem entende eram coisas importantes; entretanto, o único problema do padre é a falta de cumprimento com os compromissos.

A diferença entre os padres de Dom Bosco, do Sagrado Coração de Jesus e o atual padre indígena é o seguinte: os padres de Dom Bosco se envolviam demais na política partidária e política indígena, e até falavam nas celebrações eucarísticas, por isso mandamos embora da comunidade; os padres do Sagrado Coração de Jesus, como o Pe. Ivo eram bons, porque dirigiam a paróquia com participação mais significativa da comunidade, participavam na política da comunidade sempre lutando pelos nossos interesses e nos orientavam de forma objetiva e com respeito; e o padre atual também é bom [...], no entanto, não é tão zeloso com os trabalhos e materiais da paróquia. Parece que nós indígenas não temos muita responsabilidade.

\section{Segundo o Tukano, Leopoldino GENTIL (2007): $:^{215}$}

Depois que os padres salesianos foram embora, os seus sucessores foram diferentes, por isso se adaptaram rapidamente a realidade da comunidade e suas relações com os membros de Pari-Cachoeira se tornou até fácil e harmoniosa; alguns padres e freiras até participavam das festas comunitárias, bebiam as bebidas indígenas e dançavam; porém, esse modo diferente der ser de missionários provocou um susto e preconceito na comunidade, porque alguns indígenas começaram criticar os padres e as freiras que tinha essa conduta.

Agora, temos na nossa comunidade a presença de um padre indígena, que é nosso parente. Antes de ir embora, o Pe. Ivo disse o seguinte: depois de mim chegará um padre indígena que é o vosso parente, por isso vocês se relacionarão melhor que conosco, que não somos indígenas.

A nossa relação com o nosso padre indígena é boa, por que ele é Tukano e fala a nossa língua o que facilita a nossa relação de convivência. Algumas pessoas da comunidade acham que o seu trabalho não é bom, mas para outros é bom, para mim, ele é uma pessoa boa; tem seus erros, mas quem não erra? Quase todos os missionários que conheci e que trabalharam na nossa comunidade era bons, porém para alguns não tanto, por isso, os que não gostavam de padres e freiras faziam abaixo-assinados para expulsá-los.

Os padres não-indígenas diziam que estavam na missão para ajudar os indígenas em quaisquer coisas que necessitassem, mas quando a gente ia pedir ajuda, muitas vezes, negavam. Hoje, o nosso parente Pe. Josimar nos ajuda muito, principalmente, na área educacional, orienta os nossos filhos, mostra a importância do ser indígena na sociedade atual, reflete a importância dos estudos para o bem das nossas famílias e para a luta do movimento indígena. Segundo estudantes da escola, a sua presença é significativa para o processo de aprendizagem dos educandos, porque ele ajuda muito.

\section{Laureano Massa COSTA (2007) declarou o seguinte:}

Depois da demarcação da Terra Indígena Alto Rio Negro, A nossa relação de convivência com os missionários é boa, continua como antes, porque continua como era com os primeiros padres que chegaram aqui em Pari-Cachoeira. Não mudou muita coisa, por isso não dá para dizer muita coisa sobre eles, porque eles continuam tendo uma boa relação conosco. Sabemos que cada padre tem o seu modo diferente de trabalhar e de relacionar com as pessoas. Já convivemos com vários tipos de padres: os que gostavam de jogar bola e motivar a prática de esporte; os que só priorizavam o trabalho de campo; outros que eram alegres e bravos; alguns que só celebravam a missa e depois ficavam dormindo; existia até padre que não gostava de jogar bola e nem permitia que crianças ou jovens jogassem nos campos e quadras da missão, proibia todo mundo; tinha padre que adorava trabalhar com oratório de Dom Bosco e outro não tinha esse carisma; e, enfim,

${ }^{214}$ O Pe. Ivo é da Congregação do Sagrado Coração de Jesus, padre não-indígena que trabalhou em PariCachoeira no período de 2000 a 2004.

${ }^{215}$ Entrevista concedida no dia 16 de março de 2007 e documentada por autor. Laureano Costa é Tukano de PariCachoeira, líder comunitário da Vila Dom Bosco e meu cunhado, casado com a minha prima irmã (falecida em 2008). 
continua como antes. Não temos muitos conflitos entre a comunidade e os padres. As discussões mais conflituosas acontecem na área da Educação, quando os próprios indígenas querem dirigir a escola sem interferência da Igreja. É nesses momentos que os professores e algumas lideranças da comunidade criam atritos com os missionários.

Os depoimentos mostram como é na prática, hoje, a relação de convivência entre indígenas de Pari-Cachoeira e os Missionários. Não é uma relação totalmente harmoniosa, mas também não põe risco a boa convivência entre os dois lados, porque a maioria apóia, respeita e valoriza a presença dos missionários, desde que não interfiram diretamente na política da comunidade. Assim como em Pari-Cachoeira, a convivência entre os Tuyuka e Missionários, em Trinidad, não é tão diferente. Veja-se em seguida, a situação atual dessa relação.

\subsubsection{Missão Javeriana de Trinidad}

A missão religiosa de Trinidad (Colômbia) é católica, representada pelos missionários javerianos e lauritas, porém a história de convivência entre os indígenas colombianos e missionários católicos ultrapassou as fronteiras, pois vários sujeitos socais de nossa pesquisa declararam que estudaram em colégios salesianos, na região do Uaupés.

Hoje, a situação da comunidade de Trinidad, é resultado do trabalho da Igreja Católica que está presente na região há várias décadas. Ao longo desses anos, talvez, os missionários sabiam que chegaria o dia em que os indígenas se rebelariam politicamente contra eles, por isso, no início da década de 80, alguns missionários começaram respeitar e valorizar as tradições Tuyuka e Barás para tentar conviver de maneira mais harmoniosa. Nem todos agiam dessa forma, pois outros continuaram com estratégias missionárias que violavam os costumes e rituais milenares das populações indígenas.

\section{Segundo Tuyuka pajé Põntõ, Henrique Rodriguez BARRERA (2007): ${ }^{216}$}

$\mathrm{Na}$ época de internatos salesianos, centenas de adolescentes e jovens indígenas colombianos atravessaram a fronteira entre Brasil e Colômbia para estudar nas missões salesianas de Pari-Cachoeira, Taracuá, Iauaretê, São Gabriel da Cachoeira, Santa Isabel do Rio Negro e até de Barcelos. Nossos irmãos e eu que vivemos aqui, somos ex-alunos salesianos e exalunos javerianos. Nossos pais eram obrigados a nos internar nos internatos das missões católicas. No início, não entendíamos porque tínhamos que sair das nossas casas para estudar as coisas dos não-indígenas. Depois que éramos internos, os padres diziam que tínhamos que estudar para sermos civilizados e gentes como eles, essa era a razão de nós estudar, porém não diziam que com isso estavam destruindo os principais conhecimentos de nossos avós, as nossas Casas Tradicionais (Bahsawihserı) e os pajés (yaíwa e ba'asera) do nosso povo. Enquanto estávamos nos internatos salesianos, os nossos pais tentavam vivenciar as nossas tradições, mas não como antes, porque não estávamos mais com eles para receber os conhecimentos de nossos antepassados e

\footnotetext{
${ }^{216}$ Entrevista concedida no dia 08 de março de 2007, em Trinidad, Colômbia, e documentada por autor.
} 
para que transmitissem e formassem novos pajés e mestres de músicas e danças de kapiwayá, e rituais de Jurupari.

Por exemplo, quando retornamos para a nossa comunidade de Trinidad, não encontramos mais os pajés e nem os mestres de músicas, porque morreram. Morreram e levaram com eles todos os principais conhecimentos, por isso, hoje, não somos mais como os nossos antepassados; não conhecemos mais como eles. A culpa é dos missionários antigos que não contaram para nós, suas verdadeiras intenções. Os padres e as freiras de hoje não são mais como alguns padres antigos que eram ruins. Agora são outros, novos, acho que por isso tentam valorizar, cada vez mais, os nossos costumes, mas ainda não são totalmente compreensivos com a nossa diferença cultural.

Apesar da ação destruidora de missionários no passado, sempre respeitamos e valorizamos a presença deles aqui na nossa comunidade; nunca proibimos que participem em nossos eventos tradicionais, pelo contrário sempre gostamos que estejam ao nosso lado. Existem alguns rituais que não podem participar, como por exemplo, o ritual de Jurupari, que é próprio para os homens, nem as nossas mulheres indígenas e as crianças participam. Para mim, a nossa relação com o padre de hoje é boa. Somente as freiras que trabalhavam conosco foram embora da missão, por que ficaram chateadas conosco, porque os nossos filhos quase não participavam da catequese e das celebrações religiosas da Igreja. Diante disso, as freiras e o padre acharam que nós, os pais, que proibíamos os nossos filhos. Alguns até proibiram, sim, os seus filhos de participarem de eventos da missão, mas nem todos agiram dessa forma.

Nós, Tuyuka, temos as nossa maneira diferente de educar os nossos filhos. Depois que os nossos pajés e chefes tradicionais foram destruídos, o nosso objetivo, agora, é tentar reconstruir os nossos conhecimentos que herdamos de nossos pais. Por isso, muitas vezes, queremos que nossos filhos aprendam as nossas tradições, para não perdermos o pouco que ainda temos.

\section{O Tuyuka pajé Henrique BARRERA (2007) disse o seguinte: ${ }^{217}$}

A presença atual dos padres e freiras entre nós, não é muito boa, porque em 2005 as freiras brigaram com as lideranças da comunidade, depois foram embora. Há alguns atrás, tivemos a presença de um padre Barasano, que era o nosso parente, mas depois foi embora, porque o seu jeito de trabalhar conosco era diferente dos padres não-indígenas. Talvez, isso tenha incomodado algumas lideranças locais ou políticos da região, que se sentiam ameaçados com o modo de ele trabalhar conosco. Agora não sei onde está.

Nesses últimos anos, os padres e as freiras começaram interferir no nosso modo de ser Tuyuka e obrigar que participássemos de todas as celebrações eucarísticas e outros eventos que promoviam. Nós, Tuyuka, também temos os nossos momentos festivos, mas eles não queriam saber disso. Por exemplo, aqui na comunidade, os nossos filhos realizam as festas todos os finais de semana, de forma intercalada: uma vez dançam as nossas danças tradicionais e outra vez promovem festa com músicas não-indígenas e, assim, sucessivamente. Hoje, é assim que nós somos. No passado, os missionários já nos obrigaram a destruir o que tínhamos de mais importante: o ser pajé, mestre de músicas tradicionais e mestres dos rituais de Jurupari. Agora, ninguém pode nos obrigar a sermos o que não queremos ser.

Por causa dessa nossa maneira de ser que muitas vezes incomodamos os missionários que trabalham conosco, mas quem tem que se adaptar à comunidade não somos nós, são os de fora. Por isso, as freiras ficaram bravas conosco, mas não as expulsamos, foram porque não estavam maduras suficiente para entender o nosso jeito de ser. Alguns de nossos parentes brigaram com elas, mas não foram todos os Tuyuka e Barasano da comunidade. Elas acham que todos nós não gostamos delas, isso não é verdade. Quando retornarem, serão bem acolhidas. Teve uma época que até o padre foi embora, mas já retornou, está entre nós. A comunidade aceitou bem a volta dele, porque são pessoas que ajudam para que a nossa convivência interna seja mais harmoniosa. Quando tem reunião da comunidade, ele participa, dá conselhos, orienta-nos e explica as coisas dos não-indígenas que não entendemos etc. Isso é bom. Agora, estamos esperando a volta das freiras. O meu filho que é capitão dessa comunidade já foi conversar com a superiora delas para

${ }^{217}$ Entrevista concedida no dia 07 de março de 2008, em Trinidad, Colômbia, e documentada pelo autor. 
pedir a volta delas na nossa missão. Estamos aguardando o retorno das freiras na nossa comunidade. Ninguém as expulsou.

Agora, tem outro problema que surge na nossa comunidade. Temos alguns de nossos parentes Tuyuka que, por causa da briga que tiveram com as freiras e os padres da missão, viraram evangélicos, se tornaram amigos de crentes e querem construir uma Igreja de crentes dentro da nossa comunidade, mas não conseguirão, porque eles não são mais dirigentes daqui. Nós já temos os padres, não queremos mais outros, porque sabemos mais ou menos como os crentes trabalham e fizeram com outros nossos parentes do território colombiano e brasileiro.

A escola de ensino fundamental funciona na sede e faz parte do prédio da missão católica. O que chamou a nossa atenção foi que entre os professores da escola a maioria é não-indígena e indígena de grupos diferentes do Departamento Del Vaupés, no entanto, não tem nenhum Tuyuka ou Brasano de Trinidad. O diretor da escola é não-indígena, um gringo da cidade de Barranquilla, casado com uma indígena.. Perguntei às lideranças da comunidade, por que essa ausência se há décadas os missionários lá estavam e muitos deles são ex-alunos salesianos e javerianos? Para os Tuyuka da comunidade, a falta de professores Tuyuka e Brasano, é resultado de como os missionários trabalharam em Trinidad, porém, também reconhecem que os próprios Tuyuka não priorizaram os estudos dos não-indígenas, porque queriam se dedicar à transmissão de seus conhecimentos para os seus filhos. Isso também ajudou adiar a preparação de professores Tuyuka de Trinidad, talvez daqui a quatro ou cinco anos estariam retornando alguns professores Tuyuka e Barasano, que estudam nos centros urbanos colombianos.

É assim que os Tuyuka de Trinidad convivem com os missionários da Igreja Católica em Trinidad, Colômbia. Não é uma relação tão harmoniosa, mas isso mostra que os indígenas não são mais os mesmos da época de internato, quando os padres podiam dominar e controlar com mais facilidade. Hoje, eles, os indígenas sabem o que querem, lutam pelos seus próprios interesses comunitários e não aceitam mais a interferência da Igreja Católica ou Evangélica na estrutura social, política e cultural de seus grupos. Querem, sim, continuar a convivência com os missionários, porém se os missionários não se adaptarem à vida indígena, deixam livres para que os padres e as freiras decidam o seu novo rumo, ou seja, podem ir embora a qualquer hora sem levar ou vender nada do que construíram dentro das comunidades e áreas indígenas.

Em seguida apresentaremos como se dá a relação de convivência entre indígenas e militares no alto rio Negro e Uaupés, principalmente em Pari-Cachoeira e Trinidad. 


\subsection{Indígenas e militares no alto rio Negro}

Os militares na região do alto rio Negro e Uaupés, até o final da década de 80, sempre trabalharem em conjunto com os missionários, com os mesmo ideais que se complementavam: "civilizar e integrar os indígenas à sociedade nacional". A separação quase total entre os dois só ocorreu, depois que os internatos salesianos se desmantelaram, mas apesar disso alguns missionários mantiveram boas relações com os militares, porque, na acepção indígena, são parentes da mesma sociedade ocidental. ${ }^{218}$

Em seguida, apresentaremos como era a relação entre indígenas e militares antes de 1998 e, analisaremos com mais detalhes como é a convivência após a demarcação das Terras Indígenas do alto rio Negro, e, além disso, mostraremos pontos positivos e negativos dessa relação - e principalmente em Pari-Cachoeira (Brasil) e Trinidad (Colômbia).

\subsubsection{A presença militar antes de 1998}

A presença militar na região do alto rio Negro, antes de 1998, fez-se através de projetos de ocupação, segurança e desenvolvimento da região fronteiriça da Amazônia com o objetivo de defender a soberania nacional, tais como: Projeto Radambrasil, construção da Perimetral Norte, Projeto Calha Norte (PCN) e Sivam.

Na década de 60, segundo Aziz Nacib AB'SABER (2004) ${ }^{219}$ :

Por dezenas de anos, a partir da década de 60, a Amazônia foi apresentada ao mundo ocidental como uma região uniforme e monótona, pouco compartimentada e desprovida de diversidade fisiográfica e ecológica. Enfim, um espaço sem gente e sem história, passível de qualquer manipulação por meio de planejamentos feitos a distância, ou sujeito a propostas de obras faraônicas, vinculadas a um muito falso conceito de desenvolvimento.

O AB'SABER (2004) destaca diversos fracassos das políticas públicas dos governos desse período - destinados à Amazônia - que foram "sucessivos e irreversíveis".

Fracasso nas políticas agropecuárias. Fracassos na política indigenista. Incompetência e permissivismo na política de terras. Ausência total de criatividade na busca de modelos auto-sustentados e não predatórios de utilização econômica [...] ocorreu total desprezo pelo destino das populações tradicionais, dependentes da floresta e dos igarapés: índios, seringueiros, castanheiros, beiradeiros. A política hidroelétrica [...] acarretou enormes gastos [...] baixo rendimento econômico e social em relação a uma grande área a elas relacionada ([...]) [...] implantações de rodovias no coração das selvas, com inteira ausência de previsão de impactos

\footnotetext{
${ }^{218}$ SAMPAIO, Op. cit. 1980. Ver anexo 5.
}

219 Aziz Nacib AB'SABER, 2004, 131. 
físicos, ecológicos, sociais e fundiários [...] Imprevisão e omissão em relação à proteção das águas de rios, riozinhos e igarapés [...] Tolerância e estímulos assimétricos para a grande e pequena mineração, sem qualquer preocupação com a cadeia de conseqüências a elas relacionadas [...] desenvolveu-se uma criminosa permissividade e tolerância para com a invasão de reservas indígenas, por meio de aliciamento maciço de ingênuos trabalhadores braçais, sob rígido controle de aviadores enriquecidos e truculentos proprietários de barrancos e cavas. Insensibilidade humana e cultural das autoridades e das classes dominantes em relação aos contatos étnicos e altamente nocivos [...].

Assim, quase todos os projetos militares desenvolvidos na Amazônia faliram, porque assim como ocorre em quaisquer instituições governamentais e não-governamentais, existiram desvios de recursos destinados ao desenvolvimento da Amazônia. ${ }^{220}$ Por isso, os principais projetos citados a seguir tiveram um único fim: a falência.

\subsubsection{Projeto RADAMBRASIL}

O Projeto RADAMBRASIL foi desenvolvido no período de 1971 a 1986 durante os governos militares: Garrastazu Médici (1969-1974), Ernesto Geisel (1974-1979), João Figueiredo (1979-1985) e até os primeiros dois anos do Governo José Sarney (1985-1990). Do ponto de vista geopolítico foi estratégico para o domínio territorial brasileiro. ${ }^{221}$

Esse projeto teve os dois lados positivo e negativo. Primeiro, foi um projeto que possibilitou o levantamento dos aspectos físico-ambientais do Brasil, principalmente da Amazônia que era até então, a área mais desconhecida pelos brasileiros não-indígenas. Contribuiu para o ordenamento de dados e informações de estudos ambientais de pesquisadores brasileiros e estrangeiros, através de imagens de Radar, de imagens de satélite Landsat. Ajudou o Brasil para no levantamento e sistematização de informações cartográficas na escala regional onde era difícil de se obter imagens de satélite, como é o caso da Amazônia. E os aspectos "negativos" do projeto foram os fundamentos políticos e a visão estratégica que continha, que não respeitava a autonomia territorial de populações indígenas. $^{222}$

Na década de 70, o Brasil vivia sob a ditadura militar e o projeto RADAMBRASIL "tinha como objetivos principais o levantamento de recursos naturais para a exploração

\footnotetext{
${ }^{220}$ CEDI. Deputado denuncia corrupção na Funai. Folha da Tarde, São Paulo, 12/05/87. Povos Indígenas no Brasil.; CEDI. COSTA, Sebastião Amâncio da. CMA investiga corrup̧̧ão. Jornal do Comércio, Manaus, AM, 09/05/87, p. 24; CEDI. Investigação apura: documento some nas dependências da Funai. A Crítica, Manaus, AM, 09/05/87, p. 3.

${ }^{221}$ Ivani Ferreira de FARIA, 1997.

${ }^{222}$ Ibidem, 1997.
} 
econômica, ocupação das áreas florestadas da Amazônia e controle político territorial”. Esta ocupação acabou contribuindo para causar enormes danos ambientais. Por exemplo, o estudo do potencial dos solos da Amazônia, "favoreceu diversas distorções e degradação das florestas Tropicais" ${ }^{223}$ e o loteamento da Amazônia para atividade minerária, que resultaram em "processos incidentes em Terra Indígena na Amazônia Legal brasileira", "interesses minerários incidentes em Terra Indígena, por Empresas de Mineração" 224 e a invasão de garimpeiros.

\subsubsection{Perimetral Norte}

A rodovia federal BR-210, também conhecida como Perimetral Norte, fez parte do Plano de Integração Nacional (PIN), do período da ditadura militar, na década de 70 e 80, projetada no auge do desenvolvimento econômico do regime para cortar toda a Amazônia brasileira.

$\mathrm{O}$ traçado dessa rodovia passava por diversos territórios indígenas. Na Amazônia, um dos povos indígenas que "mais" se submeteu e sofreu conseqüências catastróficas com os projetos de desenvolvimento do Estado brasileiro foi o povo Yanomami. Em 1970, centenas de Yawarip (subgrupo do povo Yanomami) se tornaram mendigos ao longo da estrada. Entre 1973 a 1978 os Yanomami dos vales dos rios Ajari e Catrimani perderam metade de sua população com as epidemias de sarampo. Com os projetos de colonização do Governo, pessoas não-indígenas se instalaram na região e, em contato com os indígenas, introduziram doenças letais nas comunidades indígenas. ${ }^{225}$ Segundo Bruce ALBERT (1999):

Nas décadas de 1970 e 1980, os projetos de desenvolvimento do Estado começaram a submeter os Yanomami a formas de contato maciço com a fronteira econômica regional em expansão, principalmente no oeste de Roraima: estradas, projetos de colonização, fazendas, serrarias, canteiros de obras e primeiros garimpos. Esses contatos provocaram um choque epidemiológico de grande magnitude, causando altas perdas demográficas, uma degradação sanitária generalizada e, em algumas áreas.

Nesse mesmo período, declara ALBERT (1999):

[...] o projeto de levantamento dos recursos amazônicos RADAM (1975) detectou a existência de importantes jazidas minerais na região. A publicidade dada ao potencial mineral do território Yanomami desencadeou um movimento progressivo

\footnotetext{
${ }^{223}$ Ibidem, 1997.

${ }^{224}$ INSTITUTO SOCIOAMBIENTAL, 2005.

${ }^{225}$ FARIA, op. cit., 1997.
} 
de invasão garimpeira, que acabou agravando-se no final dos anos 1980 e tomou a forma, a partir de 1987, de uma verdadeira corrida do ouro.

Em São Gabriel da Cachoeira, a partir de 1974, chegaram diversas empresas construtoras da rodovia, a saber: EIT, Queiroz Galvão, Camargo Correia, LASA, DENE e um corpo de engenharia militar (o $\left.1^{\circ} \mathrm{BEC}\right) .^{226}$

Com a chegada das empresas também chegavam os administradores com suas famílias e muitos homens não-indígenas solteiros para trabalhos braçais, que na região eram chamados de "peões", e os militares do $1^{\circ}$ BEC. Quase todos os dias, no porto de Camanaus, a $25 \mathrm{~km}$ da cidade de São Gabriel da Cachoeira aportavam barcos e balsas carregados de maquinarias de “todos os tipos e tamanhos". Além disso, também chegavam mulheres não-indígenas vindas de Manaus para ganhar dinheiro através da prostituição. O movimento na cidade era tão grande que atraiu a curiosidade dos povos indígenas da comunidade. ${ }^{227}$

O projeto de construção da Perimetral Norte em São Gabriel da Cachoeira (AM) atingiu brutalmente as populações indígenas do alto rio Negro, porque segundo Álvaro Tukano (1981): ${ }^{.28}$

Em poucos dias a cidade ficou movimentada de gente e dinheiro. Os finais de semanas eram agitados, os clubes, as danceterias estavam lotados de trabalhadores de empresas curtindo suas folgas com as mulheres indígenas e não-indígenas prostitutas. E os rapazes indígenas entravam em conflitos com os peões que muitas vezes os matavam a facada, peixeirada (peixeira é pexeira, terçado ou facão), a paulada ou a tiro.

A maioria dos indígenas que morava na cidade de São Gabriel da Cachoeira era migrante de Pari-Cachoeira, Taracuá, Iauaretê, Assunção do Içana, Cucuí e de povoados das margens do alto rio Negro. Segundo Álvaro Fernandes Sampaio (1981), “Até no ano de 1968 a cidade de São Gabriel da Cachoeira conheceu a paz [...]”, porque depois que as empresas chegaram na região, a violência, as doenças sexualmente transmissíveis, a prostituição e o alcoolismo se expandiram entre os indígenas. As palavras seguintes de Álvaro Tukano resumem como os indígenas se sentiam diante da realidade social que vivenciaram nas décadas de 60 a $80:^{229}$

\section{$[\ldots]$}

\footnotetext{
${ }^{226}$ SAMPAIO, op. cit. 1983.

${ }^{227}$ Ibidem, 1983.

${ }^{228}$ Ibidem, 1983.

${ }^{229}$ SAMPAIO, op. cit. 1981.
} 
É triste eu dizer essas coisas depois que só foram feitas as propagandas de coisas agradáveis, por exemplo, filme sobre os índios do rio Negro. Mas assim é a vida do povo que pertenço. Digo com profunda tristeza, após tanta violência, facadas mortais que eliminaram algumas pessoas [...] Hoje, a cidade de São Gabriel da Cachoeira é marcada pela história da invasão, as testemunhas são as mulheres indígenas e abandonadas com seus filhos, são as lembranças do progresso.

\section{$[\ldots]$}

Mesmo assim continua o $1^{\circ}$ BEC com seus recrutas abalando a cidade na tranqüilidade das mocinhas indígenas, violando-as para o uso sexual de 20 a 30 homens, ato sexual que nenhuma filha de sargento, tenente ou coronel, dos comerciantes e de muitos brancos sofre, a não ser as indígenas. Nenhum dos indígenas nunca deu geral nas filhas dos brancos, infelizmente, só ódio devido muito abuso e racismo. Enquanto isso os nossos povoados sente a falta de jovens para animar a festa.

\section{$[\ldots]$}

A estrada trouxe também malária, muitos abortos criminais, curetagem com mortes, anticoncepcionais [...] a vergonha para as indígenas não voltarem para suas aldeias, prisões para homens, as injustiças, discriminações, isto é, o indígena é chamado MAKU - palavra ofensiva e de baixo teor que possa existir [...].

\section{$[\ldots]$}

O império da invasão durou pouco tempo em São Gabriel da Cachoeira - 2 a 4 anos. São Gabriel parece que volta para sossego da vida. A primeira empresa que sai é a Queiroz Galvão que se instalara em São Felipe. Fizera uma construção boa um aeroporto e $14 \mathrm{~km}$ de estrada, centenas de casas. Seria a estrada que ligaria a Mitú, Colômbia. A estrada parou porque a quantidade de lama e igapó foram as defesas da Reserva Florestal do rio Negro. A empresa fora derrotada pela arma da natureza Amazônica e mandou a firma de volta para o Nordeste. Muitos peões ficaram desempregados e foram procurar outros empregos na Venezuela ou na Colômbia, outros ficaram em São Gabriel da Cachoeira. Muitos acompanharam o retorno da empresa e desceram nas balsas com todas as máquinas com destino à Manaus.

Enfim, as empresas não construíram a Perimetral Norte, porque não suportaram os desafios da selva amazônica, o dinheiro do projeto foi desviado pelos administradores e, assim, a única certeza que os indígenas têm, é que não foram eles e nem a floresta amazônica os beneficiários. $\mathrm{O} 1^{\circ} \mathrm{BEC}$ foi a única unidade que permaneceu, e, nesses últimos anos não tem tido muitos serviços para executar na região. Por isso, os militares já pensam em transferi-lo para outra região do país. 


\subsubsection{Projeto Calha Norte (PCN)}

Na década de 60 a 70, período do regime militar, "a Amazônia brasileira passou a ser objeto de uma agressiva política de ocupação demográfica e de desenvolvimento econômico, enquadrada numa estratégia geopolítica de integração nacional [...]”. 230

$\mathrm{Na}$ década de 80, “o peso da dívida externa brasileira contribuiu para acentuar drasticamente o papel da região amazônica como fonte de recursos primários para exportação e implementação de projetos de desenvolvimento que atraísse um fluxo de empréstimos internacionais". O Projeto Calha Norte (PCN), além de outros projetos de desenvolvimento do Estado brasileiro para a Amazônia (Operação Amazônia, Plano de Integração Nacional, POLONOROESTE, POLAMAZÔNIA, ZONA FRANCA DE MANAUS), foi mais um dos projetos dos militares brasileiros "originalmente sigiloso, elaborado por um grupo coordenado pela Secretaria-Geral do Conselho de Segurança Nacional e concluído em 1985";231

Para Ronaldo Brasiliense (1992), o PCN foi idealizado no governo José Sarney ministro-chefe do Gabinete Militar e Secretário-Geral do Conselho de Segurança Nacional, general Ruben Bayma Denys, através do qual “construíram estradas, pistas de pouso, escolas, postos de saúde e implantaram pelotões especiais ao longo da fronteira do Brasil com Colômbia e Venezuela". O projeto visava preencher "os espaços vazios numa das mais inóspitas regiões do país, principalmente na área conhecida como Cabeça do Cachorro”, onde circulavam "contrabandistas de armas, narcotraficantes e grupos guerrilheiros colombianos". 232

O PCN, também chamado de "Desenvolvimento e Segurança desenvolvido a partir da região ao norte das Calhas dos Rios Solimões e Amazonas foi concluído em 1985”, no início do Governo José Sarney. Segundo DINIZ (1994):

O Projeto Calha Norte (doravante PCN) foi apresentado ao Presidente da República em 1985 pelo então Secretário-Geral do Conselho de Segurança Nacional (CSN), General de Brigada Rubem Bayma Denis. Oficialmente, seu nome é Desenvolvimento e Segurança ao norte das Calhas dos Rios Solimões e Amazonas - Projeto Calha Norte, segundo consta do relatório final do Grupo de Trabalho Interministerial - GTI, integrado por representantes do Ministério das Relações Exteriores - MRE, Ministério do Interior - MINTER, e da própria Secretaria Geral (SG) do CSN, além de contribuições dos militares e do Ministério da Fazenda.

\footnotetext{
${ }^{230}$ Bruce ALBERT, 1991.

${ }^{231}$ Eugênio DINIZ, 1994.

${ }^{232}$ Ronaldo BRASILIENSE, 13 de abril de 1992.
} 
O PCN criou muitas dúvidas e incertezas na sociedade brasileira, mas pricnipalmente para a sociedade civil, os parlamentares amazonenses que tiveram dúvidas sobre os seus objetivos, principalmente em relação à política indígena, que de acordo com o deputado amazonense Raimundo Reis (1987), líder do PSB, no Legislativo estadual, o PCN não era um "projeto sério", porque "a maneira como o projeto foi elaborado "nos gabinetes refrigerados de Brasília sem a participação mínima das lideranças amazônicas, inclusive, dos povos indígenas", as comunidades indígenas seriam os mais prejudicados. ${ }^{233}$

Segundo FARIA (1997):

Por tratar-se de um projeto sigiloso e confidencial, foi mantido fora do alcance das entidades civis e de certos escalões do governo, que só tomaram conhecimento em 1987, quando da CPI que investigava o inquérito sobre as difamações praticadas contra o CIMI, acusado de conspiração contra o Brasil. Segundo o Jornal "O Estado de São Paulo", o CIMI incentivava a constituição de um Estado Yanomami independente do Brasil, governado por religiosos financiados por empresas mineradoras internacionais.

[...] o Governo entrou com sua parte [...] sem perguntar o que é que nós desejamos, o que é que o público nacional acha desse projeto. Então, agora é hora nós cobrarmos dele e pedirmos explicações pedirmos as vantagens que o índio vai ter. E ao mesmo tempo através das vantagens que o índio vai ter, nós vamos saber quais são as desvantagens que ele vai ter. Automaticamente a questão de terra vai entrar. A questão de terra é de prioridade [...] porque se nós não batalharmos pelo direito de demarcação de terra nós não estaremos fazendo uma boa negociação com o Governo. Tem que haver demarcação. Após demarcação de terra, aí sim, o governo poderá criar os quartéis. Poderá fazer o que ele melhor achar. Mas desde que as terras dos índios sejam demarcadas.

Pedro Fernandes MACHADO (durante):

Meus conterrâneos! Nesta assembléia vamos colocar uma pauta bem concreta. Vamos buscar a demarcação de terra. $O$ índio não sentou na mesa do congresso para escrever pautas da lei deste país. Tão pouco, nenhum parlamentar se dirigiu ao índio para perguntar quais são seus desejos. Nunca vi guerra no alto rio Negro. Nunca vi guerrilha penetrando no nosso país. No rio Tiquié, fronteira BrasilColômbia nunca vi o marco com quartel.

Álvaro Sampaio (1987) (durante):

Nós estamos enfrentando, hoje, as empresas, o governo, os quartéis. Nós temos esta responsabilidade. Ou eles pensam que nós estamos inventando a guerrilha. Vocês não são guerrilheiros. Somos e mulheres que sempre lutamos pela paz. Somos homens que sempre reivindicamos nossas terras. Outros pensam que nós estamos vivendo de cocaína, porque cocaína dá muito dinheiro. O branco sempre

${ }^{233}$ Denys ARAÚJO, 23 de abril de 87. 
vive de dinheiro. Nós aqui vivemos de terra, de roça, de nossos encontros e visitas. Isso nós vamos manter. Tem mais pobreza no mundo dos brancos do que na nossa. Então, nós não iremos cair nessa. Ficaremos aqui, pois esse é o nosso mundo.

\section{Benedito Fernandes Machado (durante):}

O Projeto Calha Norte foi colocado na opinião pública como um projeto aterrorizante e monstruoso. Até eu, particularmente falando, profissionalmente falando, fui taxado publicamente de pelego da FUNAI, que eu era o puxa saco do Governo, que eu era um safado e vendilhão, que estava a serviço do Governo brasileiro. É claro! Eu me considero brasileiro. Eu considero índio brasileiro. Índio que pertence a nação brasileira. É justo que eu tenha que defender o bem estar social e o benefício social para minha sociedade. Então, eu, na minha posição de assessor, agente do Governo e membro da comunidade indígena, eu coloquei que Projeto Calha Norte beneficiaria em vários sentidos. Que ela mudaria um pouco ou minimizaria os problemas indígenas. Eu acredito que o direito de defender as fronteiras é da atuação e competência do Governo. Mas, uma coisa tenhamos que esclarecer que nós sempre vivemos em fronteira. Nós sempre defendemos o interesse nacional em termos de fronteira. Em termos aqui do rio Negro podemos dizer que não houve invasões estrangeiras aqui para que haja uma necessidade imperiosa de colocar, de vim forçar em termos de fronteira. Outra coisa que teremos que ver é que com a presença constituída do Governo no meio de nós, das populações indígenas, nós vamos poder reivindicar diretamente com o Governo, nós vamos poder dialogar diretamente com o Governo brasileiro. É ele que tem a infra-estrutura. É ele que tem condições de nos dar apoio. O que fica dificultoso para nós, da sociedade indígena, é que as autoridades promovem projetos, e uma entidade diferente acha que é aterrorizante. E nós não temos tido informações corretas. E ficamos no meio do tiro. De um lado projetos do Governo, de outro lado outras entidades. E nós ficamos no meio sem saber em quem acreditar, se acreditamos no Governo ou se acreditamos pra cá. Eles que são entendidos já estão se degladiando entre si! E nós que somos simples como é que ficamos nessa situação? Então, para nós é triste e lamentável essa posição. Ou eles nos dão orientações práticas, até onde é benéfico e até onde começa situações não benéficas à comunidade. Ninguém explica. Então justamente aqui nós vamos discutir isso. Eu sei que maioria de vocês não conhece o Projeto chamado Calha Norte. Eu conheço um pouco. Então para melhor conhecimento nosso, nós vamos convidar [...] o Coronel Teixeira, que [...] conhece. [...] Ele vai nos dar uma exposição geral do projeto como todo. [...]

Em seguida posicionou-se na tribuna o Coronel Teixeira ${ }^{234}$ para explicar aos líderes indígenas, o que era o PCN e como seria executado.

Então, um dos trabalhos desenvolvidos foi em torno da área ao norte do rio Solimões e Amazonas. Exatamente, por isso, o projeto recebeu o nome de Projeto Calha Norte. $\mathrm{E}$ as grandes preocupações que reinavam no momento era o imenso vazio que representava a nossa fronteira e que onde vocês vivem, vivem outros brasileiros não-índios, mas vivem outros brasileiros como vocês. Então, o projeto ele não especifica exatamente a comunidade indígena, apesar de que a maioria das

${ }^{234}$ Coronel Teixeira era uma Autoridade ligada ao PCN, membro do Conselho de Segurança Nacional, assessor direto do gabinete militar. 
críticas e os ataques voltados ao projeto tem sido, exatamente, como disse o Benedito, em termos de extermínio das populações indígenas. Eu tenho a sorte de perguntar aqui quantos índios já foram exterminados desde que o projeto começou. Ele existe desde 1985, eu acredito que nenhum de vocês tem o conhecimento disso. A preocupação com a fronteira é uma preocupação que o Brasil sempre teve, o Brasil como nação, como país. Muitas vezes os países são obrigados a estabelecer suas fronteiras para que se relacione bem com seus vizinhos. Da mesma forma que vocês, nas suas tribos, nas suas comunidades têm os seus limites. Cada um sabe até onde o outro atua e onde é que vive a outra família, onde é que vive o outro povo. E os países também estabelecem os seus limites. E os protegem. É um direito da nação proteger sua fronteira. Tradicionalmente essa fronteira é protegida pelos contingentes populacionais que existem nela, não exatamente forças armadas, os contingentes populacionais. Ora, nessa nossa fronteira, o que se caracteriza é exatamente a pouca quantidade de brasileiros que aí reside, os poucos grupos populacionais que aí existem. Em conseqüência esse projeto, ele teve uma predominância, ou seja, ele foi utilizado fundamentalmente com o apoio das forças armadas, onde se destacam o Exército e a Aeronáutica e o Ministério do Interior. Evidentemente temos a participação do Itamaraty, que é o nosso Ministério de Relações Exteriores, tratando a parte da demarcação da fronteira e do limite de convivência com outros povos. E o Ministério da Marinha também tem uma participação limitada com ação deles nos rios. Mas o forte da atuação do Projeto Calha Norte cabe ao Ministério do Exército com a implantação de alguns Pelotões de Fronteira que vocês conhecem e a maioria conviveu em alguns lugares como Ipiranga, Vila Bitencourt, Cucuí e aqui mesmo em São Gabriel da Cachoeira. A força aérea, a aeronáutica, que tradicionalmente mantêm as linhas de apoio, não pode ser em quantidade adequada às necessidades de vocês, mas é aquilo que se pode fazer. Em conseqüência uma série de vinte campos de pouso foram previstos para serem abertos. Desses vinte campos, nós podemos seguramente dizer que todos estão de alguma maneira ligados a área indígena. Uns diretamente ligados para os Pelotões do Exército como é o caso de São Joaquim, Como é o caso de Querari, como é o caso de Iauaretê. Mas, onde vivem as populações indígenas em conseqüência o benefício é para os dois tanto para o pelotão do Exército como para a comunidade indígena que ali existe. Então são cerca de vinte campos de pouso. São cerca de oito pelotões estão sendo implantados numa fronteira de mais de $6.000 \mathrm{~km}$, nada representa em termos militares, mas apenas em termos de presença do Governo brasileiro na área. Uma parte da atuação destinada ao fortalecimento da FUNAI. E, exatamente nesse ponto que eu tenho observado, tenho lido nos jornais reside a maior parte das críticas ao projeto. Nunca vi uma crítica à instalação de um pelotão para defender uma fronteira, porque seria considerado antinacionalista. Mas as críticas que se levantam é exatamente no sentido de ameaçar e que isso provocaria a dizimação das comunidades indígenas. Ora se nós olharmos com cuidado a parte que afeta o Ministério do Interior e a FUNAI, nós vamos ver que dentro do Projeto Calha Norte os recursos são destinados, em princípio para manutenção de Casa do Índio, contratação de pessoal especializado, apoio aos projetos comunitários, demarcação de áreas indígenas. E eu não vejo exatamente nisso aí nenhum risco à sobrevivência das populações indígenas. Ao contrário, isso aí se constitui no fator de garantia das populações indígenas. Esse, então, é o todo do projeto. Lógico, o projeto para ser mais completo, ele abrange para áreas que se voltam para o transporte, para energia, para colonização em algumas áreas. No entanto, nós temos a certeza de que esses dados ainda não são bastante fortes para nós, em termos de decidir como fazer. $\mathrm{E}$ isso tanto que é verdade, que hoje em dia nós acompanhamos com muita atenção um trabalho que é desenvolvido pela SEPLAM, é que se chama projeto ao apoio das comunidades indígenas e meio ambiente. [...]. Então, prosseguindo, o passo seguinte do projeto em termos de estradas, em termos de energia, em termos de assistência básica, em 
termos de colonização ainda não está definido, exatamente porque nós não temos todos os dados necessários para isso. No momento o Projeto Calha Norte, ele se volta para essas áreas. É o fortalecimento da segurança das fronteiras. E isso é feito através de ministérios militares. $\mathrm{E}$ o atendimento da comunidade indígena, que é uma população considerável nessa fronteira através do Ministério do Interior. [...]

Com o dinheiro do $\mathrm{PCN}$, os militares construíram vários hospitais que mais tarde serviram como bases hospitalares de militares e civis, entre esses o Hospital de Guarnição (HGu SGC), em São Gabriel da Cachoeira; o Hospital de Pari-Cachoeira; e o Hospital de Iauaretê. Entretanto, até em meados da década de 90 todos os hospitais do Uaupés ficaram abandonados $^{235}$ até que as próprias lideranças locais pressionaram os militares para que fizessem funcionar. Alguns só começaram funcionar depois que as equipes do Distrito Sanitário Indígena foram instaladas nas comunidades, porém outros continuaram abandonados.

Figura 5. Hospital de Guarnição de São Gabriel da Cachoeira, AM.

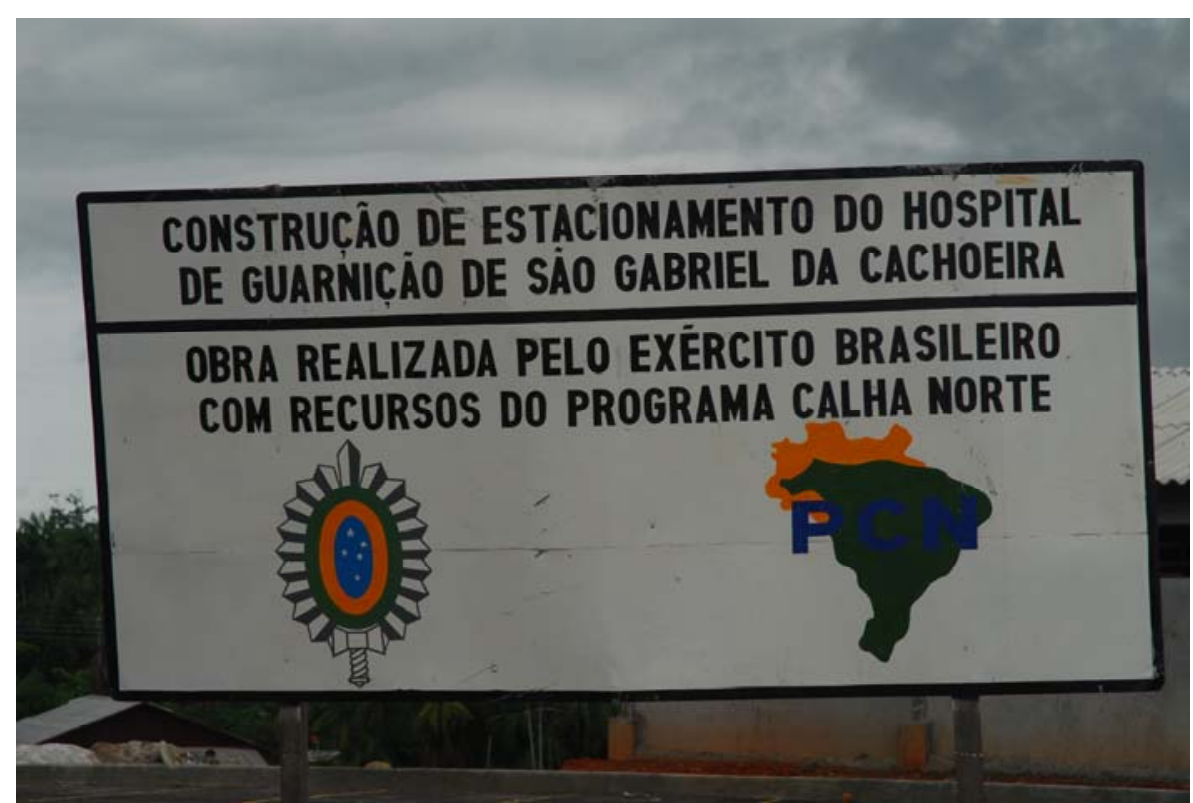

Fonte: Maurício Torres, 2007.

${ }^{235}$ CEDI. Fronteira. A notícia, Insituto Socioambiental, 06/07/92. 
Figura 6.Hospital de Guarnição de São Gabriel da Cachoeira.

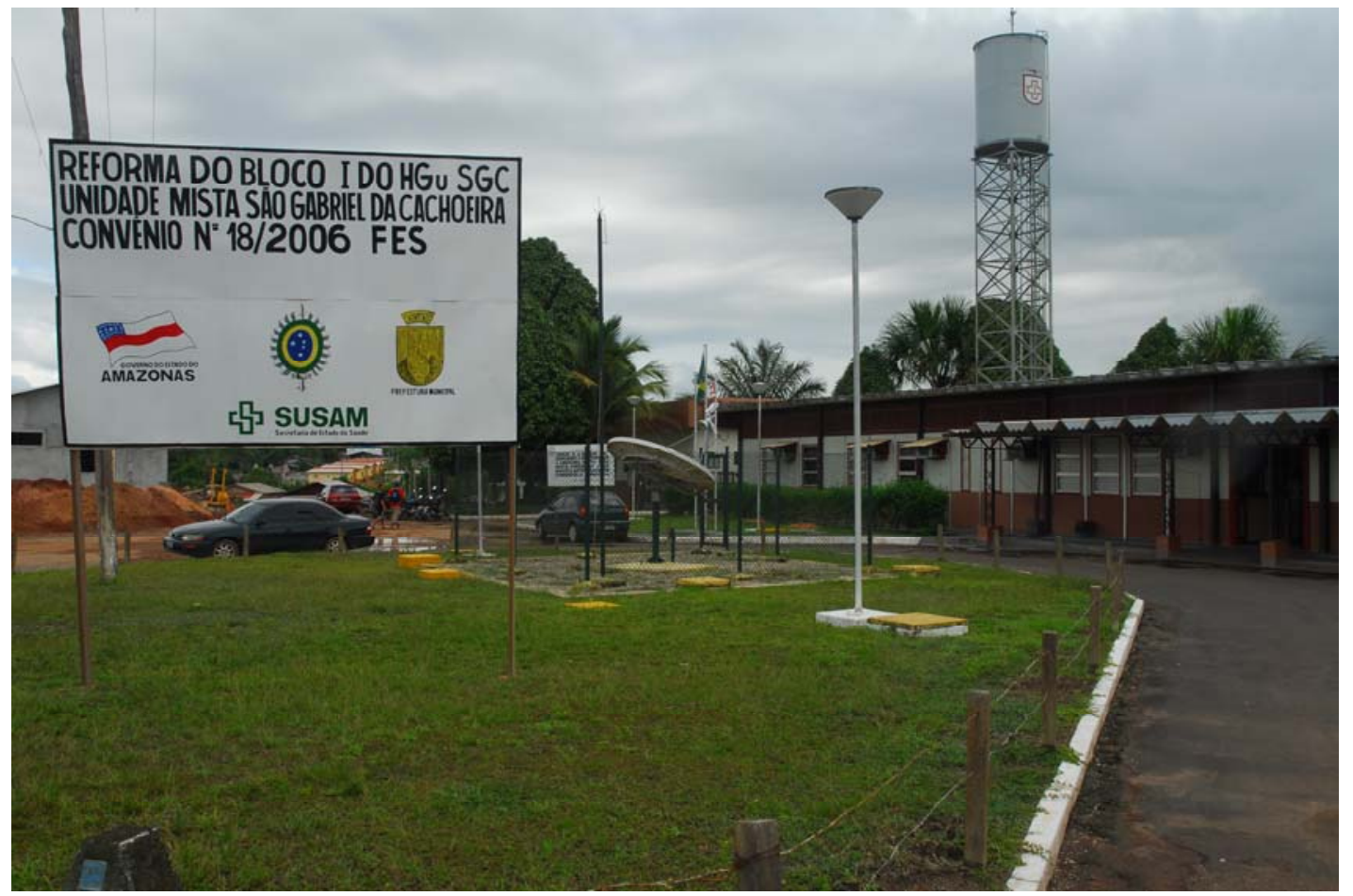

Fonte: Maurício Torres, 2007.

Figura 7. Hospital do Projeto Calha Norte de Iauaretê.

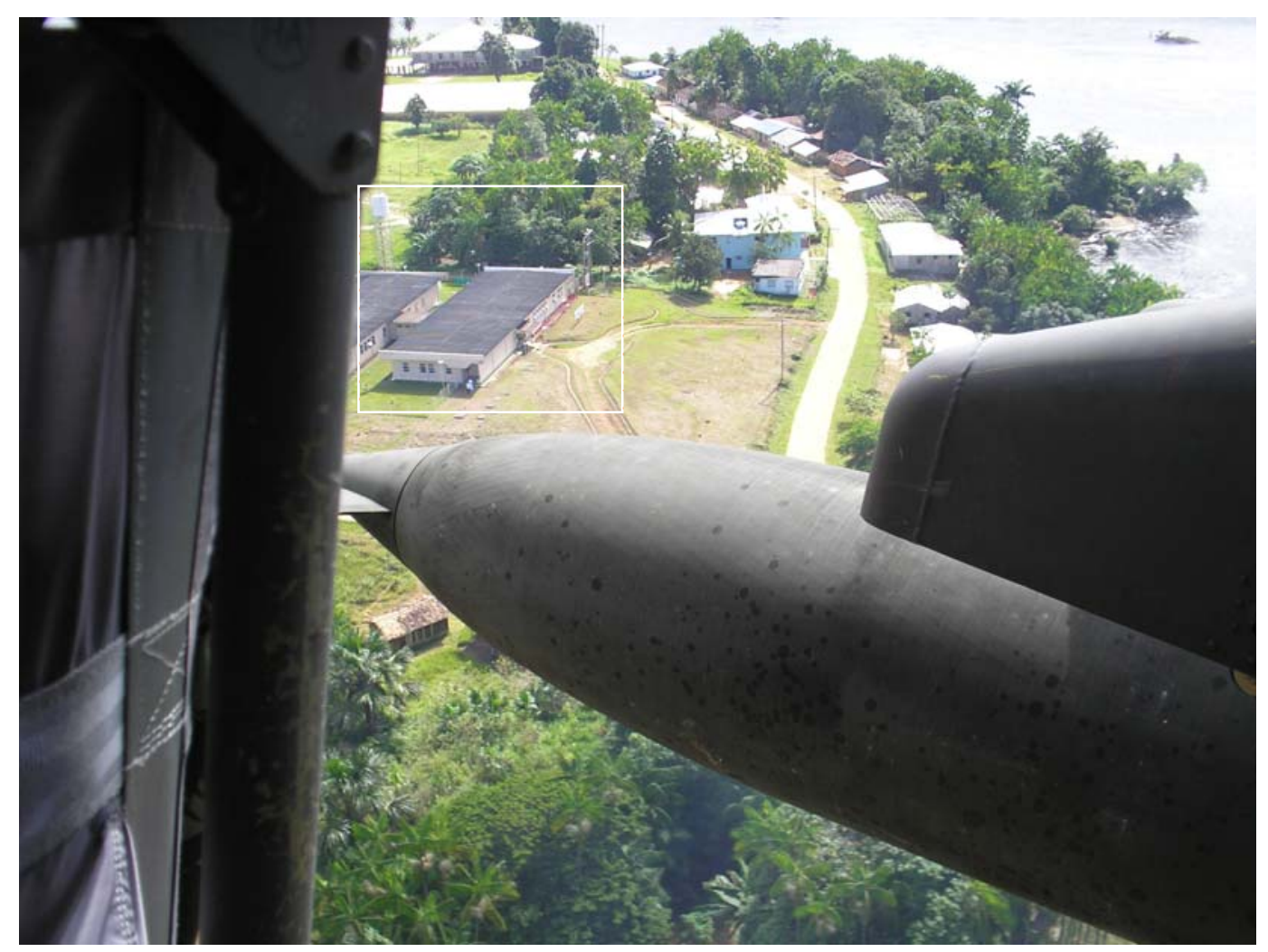

Fonte: adaptado de Geraldo Veloso Ferreira, 2007. 
Os hospitais que foram construídos e depois abandonados se transformaram em residências de ratos, baratas, morcegos e de outros bichos da Amazônia, como por exemplo: o hospital da comunidade de Colina, baixo Tiquié (ver figura a seguir).

Figura 8. Hosp. do Projeto Calha Norte da comunidade indígena de Colina, Tiquié.

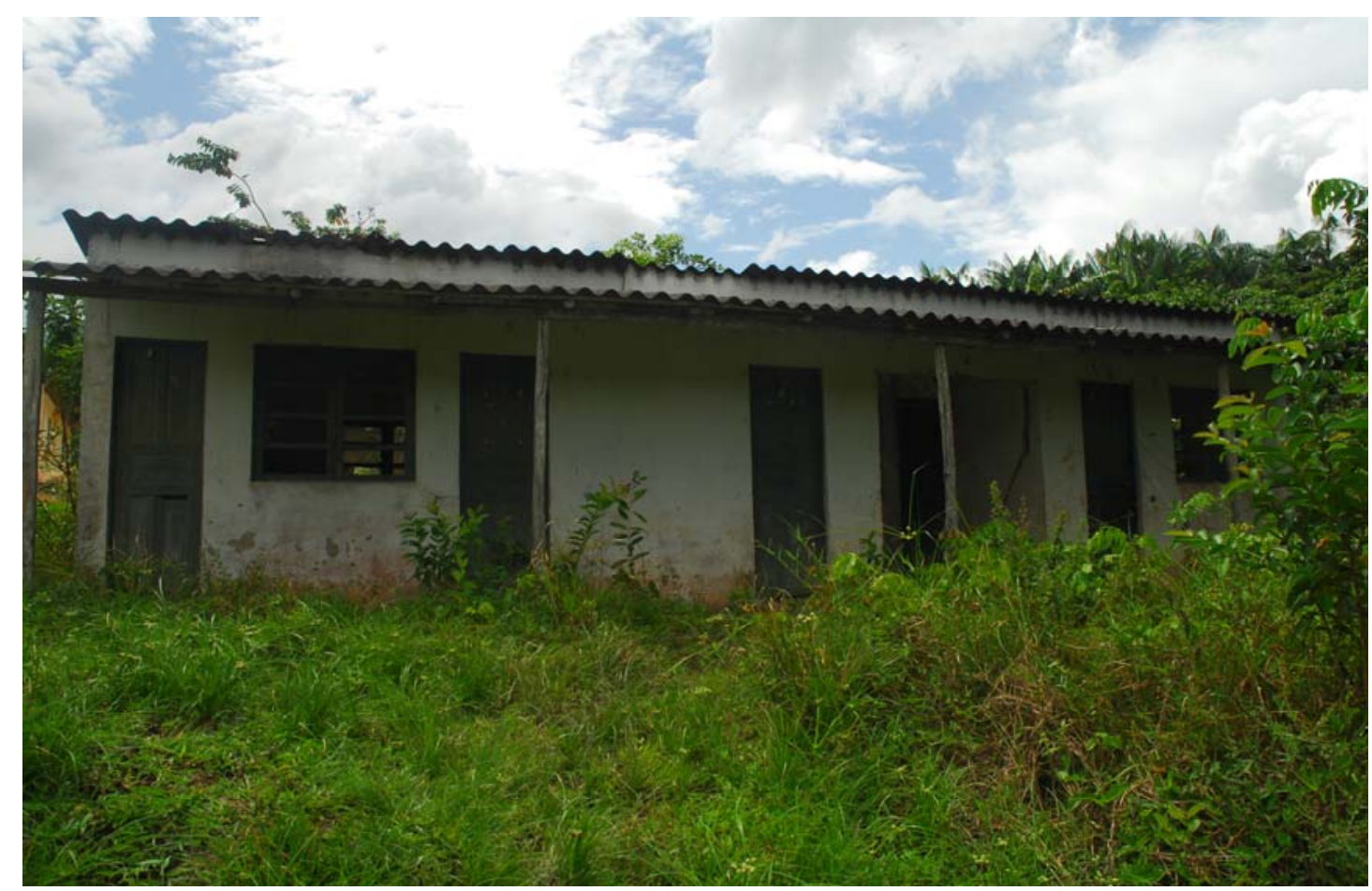

Fonte: Maurício Torres, 2007.

Além de hospitais, o PCN construiu escolas em várias comunidades indígenas, mas nunca contratou professores para trabalhar; possuía um barco saúde, chamado Barco "Calha Norte" que enquanto o projeto funcionava, ainda servia para o atendimento médico das comunidades indígenas. Depois que o projeto faliu o barco quebrou e se afundou no porto Queiroz Galvão, na cidade de São Gabriel da Cachoeira, servindo apenas como residência de cascudos, sarapós, acarás e camarões.

No ano de 1955 a 1987, em Pari-Cachoeira, ocorreram constantes manobras militares [Exército e Polícia Federal (PF)] para “combater" o narcotráfico, tentar intimidar a guerrilha colombiana e os povos indígenas. Diversas vezes presenciamos tropas do Exército que chegavam ao aeroporto da comunidade em quaisquer dias ou horas com aproximadamente 100 soldados e depois realizavam operações militares nas comunidades próximas de PariCachoeira, como em Bela Vista (médio Tiquié), São Sebastião e Jandu Cachoeira (Umari Igarapé), Coração de Maria e Mercês (igarapé Cabari), São Domingos, Fronteira (alto Tiquié, acima de Pari-Cachoeira) etc. 
Ao presenciar as operações militares, os indígenas se perguntavam o seguinte: Como esses militares chegaram até aqui? Será que vieram pelo mato, porque ninguém ouviu ou viu nenhum avião chegando ao aeroporto? Os militares acham que estamos produzindo cocaína? Perguntas como essas eram constantes nas conversas dos indígenas. Durante as operações, os militares transitavam nos mesmos caminhos que os indígenas andavam para irem e virem entre suas comunidades e Pari-Cachoeira. A presença deles provocava medo nas pessoas, porque os indígenas se sentiam confinados e vigiados, pois os mesmos poderiam estar no caminho da roça, da caça ou na beira de um igarapé olhando enquanto buscava seu sustento. ${ }^{236}$

Ainda em 1985, os militares do Exército enquanto estavam no aeroporto de PariCachoeira, prenderam um avião estrangeiro que passava pelo espaço aéreo brasileiro. $\mathrm{O}$ avião era de cor branca e com listras vermelhas; alguns indígenas diziam que a aeronave era do Peru, mas no final ninguém sabia; os militares nunca expunham os detalhes de suas operações. Os tripulantes (homens e mulheres) da aeronave foram presos e obrigados a permanecer no avião sob a guarda de vários homens do Exército durante uma semana; os civis somente saiam do avião sob os olhares de militares.

A ação da Polícia Federal foi mais incisiva no combate ao narcotráfico na região do Uaupés. Esses, sim, foram decididos para destruir as roças dos indígenas do território brasileiro, onde existiam plantações de ipadu. A PF supunha que os indígenas do Uaupés estariam produzindo cocaína e comercializando com os colombianos ou com outros brasileiros, por isso resolveram queimar as roças de ipadu. Alguns velhos indígenas cultivavam, sim, grande quantidade de ipadu, no entanto, nenhum velho ou pajé das comunidades do Uaupés produzia cocaína. O ipadu servia apenas para o consumo exclusivo dos pajés e benzedores, porém os policiais federais não entenderam isso, porque não sabiam como era a vida indígena do Uaupés.

Toda vez que as operações militares (Exército e PF) eram realizadas intensificava de forma agressiva e o Projeto Calha Norte se tornava um pesadelo para as populações indígenas, porque muitos indígenas só assistiam suas roças e casas tradicionais ser destruída sem justificativa nenhuma. ${ }^{237}$

Em Pari-Cachoeira durante vários meses de operações dezenas de helicópteros da PF, com homens e mulheres armados, pousavam no aeroporto e no campo de futebol da

\footnotetext{
${ }^{236}$ CEDI. Exército contesta que 30 mil índios estejam confinados e vigiados. Jornal do Brasil, 09/06/89, Povos indígenas no Brasil.

${ }^{237}$ Povos Indígenas no Brasil 1987/88/89/90 e 1991-1995. Ver anexos 6, 7 e 8.
} 
comunidade. Depois seguiam suas operações em todas as comunidades do Tiquié, onde obrigavam alguns indígenas que o levassem até as roças para queimarem as plantações de $\operatorname{Ipadu}^{238}$.

Durante essas operações, os velhos, os pajés e benzedores foram mais atingidos, porque o ipadu era o principal elemento para a prática dos rituais de pajelança e benzimento. Muitos entraram em desespero, choravam de tristeza e, em seguida, alguns morreram. Não só os velhos morreram, soubemos que depois que encerram as operações, cinco policiais federais que participaram da destruição das roças de ipadu dos velhos também morreram. Os indígenas acreditam que foram os velhos que se vingaram através de seus rituais de malzimentos. ${ }^{239}$

Entre diversas ações praticadas por militares, há fatos de agressão que marcaram suas atuações durante a tentativa de execução do Projeto Calha Norte no alto rio Negro, como por exemplo: transferência forçada de famílias indígenas de suas habitações como ocorreu na comunidade indígena de Iauaretêt ${ }^{240}$; agressões e torturas a índios e os não-índios, prisões etc. $^{241}$

Nesse período de execução do PCN na faixa de fronteira amazônica existiram fatos que ilustram como os militares não protegeram a região e sua população, porque como conseqüência do mesmo, ocorreu a dominação do narcotráfico, as constantes depredações ambientais e violações de povos que habitavam a região, como por exemplo: ${ }^{242}$

[...] saque aos minérios, o desrespeito aos direitos humanos e a devastação das florestas [...] o genocídio dos Yanomami, a submersão de parte da floresta pelos lagos da Usina de Balbina, a quantidade de mercúrio jogada nos rios pelos garimpeiros, invasões de terras indígenas do Vale do Javari por madeireiras e no Alto Rio Negro por garimpeiros e a abertura pelos garimpeiros e traficantes de cerca 63 pistas clandestinas de pouso sem o conhecimento das Forças Armadas $[\ldots]$.

Em meados da década de 90, o PCN se encontrava engavetado e sem recursos, mas em 1995, ressurgiu através de uma Comissão Especial do Congresso sob a liderança do senador Romeu Tuma/SP, "que aproveitou o escândalo do Sistema de Vigilância da Amazônia (SIVAM)", ressaltando que o PCN era fundamental para a segurança da Amazônia. ${ }^{243}$

\footnotetext{
${ }^{238}$ História contada pelo meu tio Laureano Dutra em 1987. Ele participou das operações da PF como guia dos policiais, conduzia os federais até as roças de alguns Tukano de Pari-Cachoeira.

${ }^{239}$ Ibidem.

${ }^{240}$ Povos Indígenas no Brasil 1987/88/89/90. Ver anexo 9.

${ }^{241}$ Ver anexos 10 e 11.

${ }^{242}$ FARIA, op. cit., 1997, p. 159.

${ }^{243}$ Ibidem, 1997, p. 160.
} 
Para os militares foi mais uma oportunidade para atrair recursos da União com alegação que seriam usados para atender as necessidades básicas das comunidades locais e o Projeto SIVAM, que tem uma base em São Gabriel da Cachoeira - teve o apoio do presidente Fernando Henrique Cardoso, que o denominou de "projeto social". No entanto, o objetivo principal de militares era fortalecer o seu eterno objetivo: "presença brasileira na Amazônia, mantendo a soberania sobre a região". 244

\subsubsection{Projeto do Sistema de Vigilância da Amazônia (SIVAM)}

"O SIVAM é a infra-estrutura para o vasto conceito do Sistema Interagência Brasileiro para a Proteção da Amazônia, SIPAM." ${ }^{245}$ Nesse caso, a atuação do Sistema de Proteção da Amazônia não se reduziria apenas à Amazônia brasileira, porque de acordo com a secretáriageral da OTCA, Rosália Arteaga SERRANO (2006):

os oito países-membros da OTCA - Organização do Tratado de Cooperação Amazônica - Brasil, Bolívia, Colômbia, Equador, Guiana, Peru, Suriname e Venezuela - planejam integrar seus programas nacionais de monitoramento da floresta, tendo como base a tecnologia desenvolvida pelo Sipam - Sistema de Proteção da Amazônia. Nós estamos falando do suporte técnico que o sistema brasileiro pode oferecer, além de uma complementaridade com os sistemas de informação dos outros países. ${ }^{246}$

Desde a década de 80 , os militares brasileiros "sonhavam" com um sistema de rastreamento aéreo na Amazônia para guarnecer e fortalecer a extensa região que para eles estava desguarnecida, ${ }^{247}$ devido "a instabilidade política na Venezuela e Colômbia"248, a instalação de bases militares norte-americanas e as constantes "manobras militares norteamericana em países vizinhos e a pressão internacional para controlar a reserva florestal”, fundamentados no medo de perder a "soberania sobre a Amazônia". 249

Com esse projeto, o objetivo dos militares não era simplesmente rastrear o espaço aéreo da Amazônia, mas a intenção consistia: “[...] em uma base de dados, com recursos suficientes para deter queimadas, analisar a ocupação do solo, controlar o espaço aéreo, vigiar reservas indígenas, estimativas metereológicas, contaminação da água e ar, combater o

\footnotetext{
${ }^{244}$ Ibidem, 1997, p. 160.

245 Ibidem.

${ }^{246}$ Ver Anexo 12.

${ }^{247}$ Ver Anexo 13

${ }^{248}$ FARIA, op.cit. 1997.

${ }^{249}$ Ibidem. 1997, p. 160-161. Para maiores informações e detalhes ver anexos 14,15 e 16
} 
contrabando e o tráfego de drogas"; ${ }^{250}$ mostrar ao mundo que a Amazônia brasileira é do Brasil e pertence à soberania nacional, portanto nenhum país estrangeiro poderá tentar ingerir nas questões internas que diz respeito sobre a ocupação da Amazônia e a exploração de seus recursos naturais. ${ }^{251}$

O projeto previa a obtenção e o apoio tecnológico de:

87 estações meteorológicas, 19 radares fixos e móveis, 32 unidades de vigilância e telecomunicações, três esquadrões de aviões Tucano, mais oito aparelhos de sensoreamento, sensores térmicos, etc. E tudo isso ligado a satélites e outras tecnologias de ponta, capazes depermitir o controle seguro do tráfego aéreo, o conhecimento do subsolo, o monitoramento do clima e dos recursos hídricos, a proteção da biodiversidade e a fiscalização de queimadas e desmatamento, entre outras possibilidades. ${ }^{252}$

Antes da aprovação do Projeto pelo Congresso era necessário que a sociedade brasileira refletisse sobre os possíveis efeitos positivos e negativos que o projeto causaria à nação. Por exemplo, algumas questões deveriam ser discutidas, tais como:

[....] De posse de todas as informações, que poderão fazer os órgãos governamentais para impedir, por exemplo, as queimadas e o desmatamento ilegais? Em que estrutura de repressão se pensa? [...] ficaremos limitados a assistir a desmatamentos e queimadas via satélite, já que o Brasil não dispõe de um só avião para combater os incêndios e o número de fiscais em terra é quase insignificante? Num sistema capaz de disponibilizar tantas informações estratégicas e comerciais, quem terá o controle dos acessos? Quem terá o poder de dizer que informações entram no sistema e quem pode ter acesso ao que entrar em seu banco de dados? O que será feito dessas informações? Quem terá acesso a elas? Como? $?^{253}$

Apesar de defender a soberania nacional sobre a Amazônia, os militares brasileiros não consultaram nem à sociedade brasileira e nem aos especialistas brasileiros sobre o uso da tecnologia nacional e cederam os interesses externos para gerenciar a vigilância da região, quando houve a contratação da ESKA sem licitação e, no final, explodiram "os escândalos ocorridos durante a instalação do SIVAM". ${ }^{254}$

Depois que o SIVAM foi aprovado pelo Governo brasileiro, os militares da aeronáutica tinham três propostas pontuais para São Gabriel da Cachoeira: a construção de uma pequena central elétrica $(\mathrm{PCH})$, a construção de uma base da aeronáutica e instalação de radares dentro de algumas comunidades indígenas do alto rio Negro.

\footnotetext{
${ }^{250}$ Ibidem, 1997, p. 161.

251 Para fortalecer a guarnição da Amazônia, o Governo brasileiro iniciou a consolidação da instalação de Organizações Militares na Amazônia, construindo bases, brigadas e pelotões, aeroportos, manobras e operações de treinamento de guerrra etc. Ver anexos 17, 118, 19, 20, 21 e 22.

${ }^{252}$ Washigton NOVAES, 12/06/98.

${ }^{253}$ Ibidem, 12/06/98.

${ }^{254}$ FARIA, op. cit., 1997.
} 
A primeira, a construção de "uma pequena central hidroelétrica $(\mathrm{PCH})$ com capacidade de 2,6 MW de energia no Igarapé Miuá, afluente da margem esquerda do rio Negro, localizado na área indígena Médio Rio Negro ([...])”, que substituiria a Central Termoelétrica da cidade e abasteceria os radares do SIVAM. Em contrapartida os indígenas reivindicaram e condicionaram a assinatura do convênio em troca da demarcação e homologação da Terra Indígena Médio Rio Negro. Diante da pressão indígena, os militares “comprometeram em agilizar o processo de homologação da TI [...] se dispuseram a criar postos de saúde nas comunidades indígenas mais próximas, realizar exames para admissão de operários da construção civil, manter uma equipe médica permanente na obra e a construir uma guarita a fim de permitir somente a entrada de pessoas autorizadas". 255

Dos compromissos assumidos durante a reunião no dia 20 de março de 1995, na sede da FOIRN, os militares cumpriram com alguns, porém, outras promessas não foram cumpridas. Por exemplo, foi cumprida a promessa de agilizar a homologação da área indígena, que foi a mais importante; também foi cumprida a construção da guarita para coibir a entrada de pessoas não-autorizadas. No entanto, os postos de saúdes foram construídos, mas não têm remédios e nem quaisquer profíssionais de saúde. O projeto de construção da hidroelétrica começou, mas, logo em seguida o projeto faliu.

Sabemos que o Governo Federal investiu no Sistema de Vigilância da Amazônia US\$ 1,395 bilhões de dólares, deste montante, US\$ 1,285 bilhões para compra e instalação de equipamentos e serviços, e US\$ 110 milhões para executar projetos sociais. "O sistema é integrado de radares, estações meteorológicas, aeronaves de vigilância, monitoração de comunicações e sensoriamento remoto, apoiados por uma rede de rádio e telefonia por satélite $[\ldots]^{\prime 2} \cdot{ }^{256}$

Conforme previsto pelos militares no projeto, o uso da tecnologia para monitorar e vigiar a Amazônia brasileira, o SIVAM funciona da seguinte forma: "Os computadores de três centros operacionais (Belém, Manaus e Porto Velho) interagem os dados de 860 localidades enviado-os para o Centro de Coordenação Geral em Brasília" ${ }^{257}$ (ver mapa 03). Inclusive, na cidade de São Gabriel da Cachoeira, AM, foi instalado um radar do Sistema de Vigilância da Amazônia.

\footnotetext{
${ }^{255}$ Ibid, 1997, p. 163.

${ }^{256}$ MAIA, op. cit., 2004.

${ }^{257}$ Ibidem, 2004.
} 
Mapa 3. Sistema Integrado de Vigilância da Amazônia, SIVAM ${ }^{258}$.

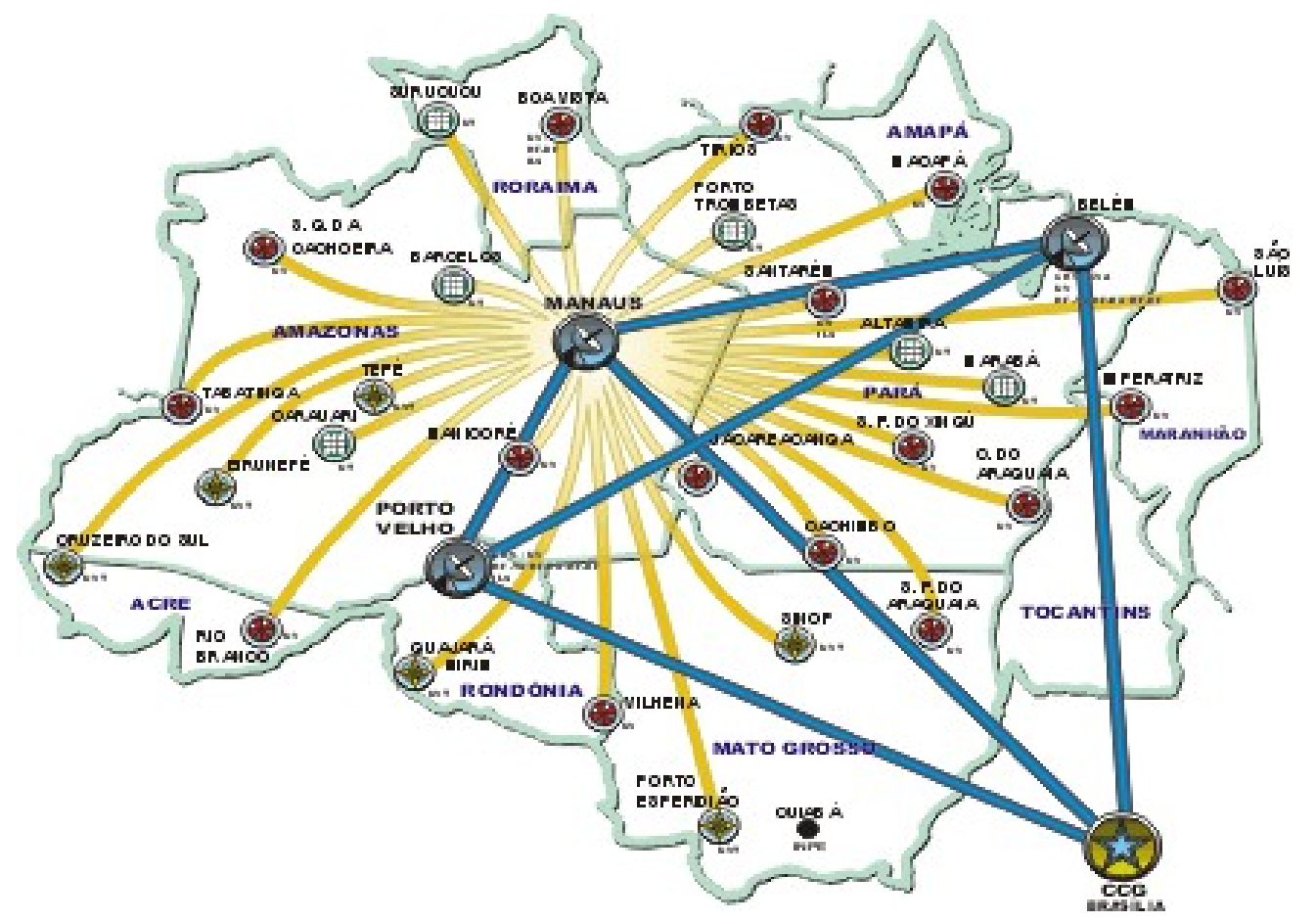

Um dos principais problemas que o Governo brasileiro teve que resolver imediatamente foi proteger a Amazônia contra os narcotraficantes que invadiam o espaço aéreo brasileiro com aviões bimotores. A principal proposta seria abater os invasores aéreos. Esse problema "foi resolvido em outubro de 2004, com a votação e aprovação da 'Lei do Tiro de Destruição' ou Lei do Abate', que entrou em vigor no dia 17 de outubro de 2004"259. O Brasil esperou muito tempo para tomar essa decisão, porque na Colômbia essa prática é comum desde a década de 80 . Nesse período, dezenas de pequenos aviões brasileiros, comandados por traficantes e garimpeiros brasileiros que invadiram o espaço aéreo colombiano foram abatidos ${ }^{260}$.

Para expandir sua ação de proteção da Amazônia, a Aeronáutica tentou instalar um radar na comunidade de Iauaretê, em 2003, porém se esbarrou na força política de lideranças da comunidade que não aceitaram a instalação do radar numa área residencial e de controle da comunidade. Revoltado com a posição contrária dos indígenas, um dos representantes da Aeronáutica disse o seguinte: "Se vocês não quiserem a instalação do radar no local que escolhemos, que seria em um monte de pedra, um dos pontos mais altos da comunidade, podemos construir até em cima da água, no meio do rio Uaupés, pois nós brancos temos

\footnotetext{
${ }^{258}$ Fonte: http://www.sivam.gov.br/INDEX.HTM. Acessado em: 04 nov. 2008.

${ }^{259}$ MAIA, op. cit., 2004.

${ }^{260}$ Ver anexo 23.
} 
tecnologia para isso". Falaram isso, somente para mostrar que eram poderosos, no entanto até agora não construíram nem na terra e nem no rio. ${ }^{261}$

Em seguida, apresentaremos com mais detalhes a relação de convivência entre os indígenas e militares no alto rio Negro e Uaupés com destaque as comunidades de PariCachoeira (Brasil) e Trinidad (Colômbia) depois de 1998.

\subsubsection{Indígenas e Militares depois de 1998}

Os militares instalados na região fronteiriça do alto rio Negro e Uaupés fazem parte do contingente militar que está sob o "Comando Militar da Amazônia (CMA), que tem sob sua responsabilidade cerca de $60 \%$ do território nacional ${ }^{\prime 262}$ para tentarem proteger a Amazônia brasileira "contra as ameaças de ingerência" de países interessados.

A região do alto rio Negro faz parte da fronteira entre Brasil-Colômbia, que tem "uma extensão de $1.644,2 \mathrm{~km}$ e uma fronteira terrestre que possui $15.700 \mathrm{~km}$ de extensão",263. Para proteger a Amazônia, o "CMA dispõe de três tipos de Organização Militar (OM) especiais de fronteira - o Destacamento, o Pelotão e a Companhia"264:

O Destacamento Especial de Fronteira é o núcleo inicial de um futuro Pelotão ou Companhia. Seus homens permanecem em instalações provisórias, sem familiares. O efetivo varia entre 10 e 20 homens. [...].

O Pelotão Especial de Fronteira (PEF) é uma Organização Militar (OM) com características verdadeiramente diferenciadas, uma vez que nele o Comandante tem responsabilidades que ultrapassam as lides normais da caserna.

Ali a liderança é uma ferramenta essencial, apoiada em um adequado conhecimento da natureza humana. Além desse aspecto, um PEF materializa a Estratégia da Presença na Amazônia, fundamental para a preservação da Região Norte do território brasileiro, [...].

[...] o PEF propriamente dito, com 66 homens comandados por um Tenente e todas as instalações comuns a qualquer aquartelamento: alojamentos, próprios nacionais residenciais, salas de instrução etc. Além dessas, há outras instalações peculiares, como carpintaria, padaria, horta, currais, pomares, igreja; enfim, tudo aquilo que é necessário para a sobrevivência de uma pequena comunidade. Nele vivem em média, 15 dependentes de militares. O CMA possui $28 \mathrm{PEF}$.

[...] as Companhias Especiais de Fronteira (CEF), comandadas por capitães que já concluíram a Escola de Aperfeiçoamento de Oficiais. O CMA possui duas CEP, cada uma delas com um efetivo de cerca de 250 homens, que ocupam instalações maiores e em maior número do que aquelas destinadas aos pelotões. [...].

\footnotetext{
${ }^{261}$ Entrevista concedida por Geraldo Veloso FERREIRA, no dia 17 de setembro de 2006, em São Paulo e documentada pelo autor.

${ }^{262}$ Centro de Comunicação Social do Exército, 2006, p. 40

${ }^{263}$ MAIA, op. cit., 2004.

${ }^{264}$ Centro de Comunicação Social do Exército, 2006, p. 40-42.
} 
Nesses últimos anos, a presença militar na região do alto rio Negro intensificou por ser uma região fronteiriça. Entre as forças militares brasileiras, que mais atuam na região do alto rio Negro destaca-se o Exército, que tem como sede o $5^{\circ}$ BIS de Infantaria de Selva, Cmdo da $2^{\text {a }}$ Brigada de Infantaria de Selva e cinco PEF dentro das áreas indígenas, "com o apoio da força Aérea Brasileira e da Aviação do Exército para atender as suas necessidades, principalmente as de apoio logístico" ${ }^{\text {265 }}$.

$\mathrm{Na}$ Terra Indígena Alto Rio Negro, estão instalados quatro Pelotões de Fronteira (PF): $1^{\circ}$ PEF em Iauareté, o $2^{\circ}$ PEF em Querari (alto Uaupés), o $3^{\circ}$ PEF em S. Joaquim (alto Içana) e o $6^{\circ}$ PEF em Pari-Cachoeira (alto Tiquié). Um quinto pelotão está sendo construído em Tunuí (alto Içana)”. Em outras áreas de abrangência da FOIRN, estão instalados o $4^{\circ} \mathrm{PF}$ em Cucuí (alto rio Negro, na fronteira tríplice Brasil-Colômbia-Venezuela), o quartel-sede do $5^{\circ}$ BIS, em São Gabriel da Cachoeira e o $5^{\circ}$ PEF de Maturacá, situado na Terra Yanomami. Além desses pelotões, há previsão de instalação de novas Organizações Militares (OMs) do Exército em Barcelos, Santa Isabel e Taracuá (Uaupés).

A estratégia que o Exército utiliza para instalar suas OMs no alto rio Negro é construir sempre onde há uma comunidade indígena e um aeroporto. Não existe nenhuma OM instalada fora da comunidade indígena, em lugares não habitados da Amazônia. Ao em vez de guarnecer áreas inabitadas, onde a guerrilha colombiana e narcotraficantes circulam com mais intensidade e nos limite da linha de fronteira, os militares constroem as OMs sempre atrás das comunidades indígenas. De acordo com Geraldo Veloso FERRERIA (2006), "na prática, quem guarnece os pelotões são as comunidades indígenas"266.

Também estão presente na região do alto rio Negro, com menor efetivo, a Aeronáutica e a Polícia Federal instalados na cidade de São Gabriel da Cachoeira (ver figuras 9 e 10).

\footnotetext{
${ }^{265}$ Ibidem, 2006.

${ }^{266}$ FERREIRA, op. cit., 2006.
} 
Figura 9. Sede do Comando da Aeronáutica, em São Gabriel da Cachoeira, AM.

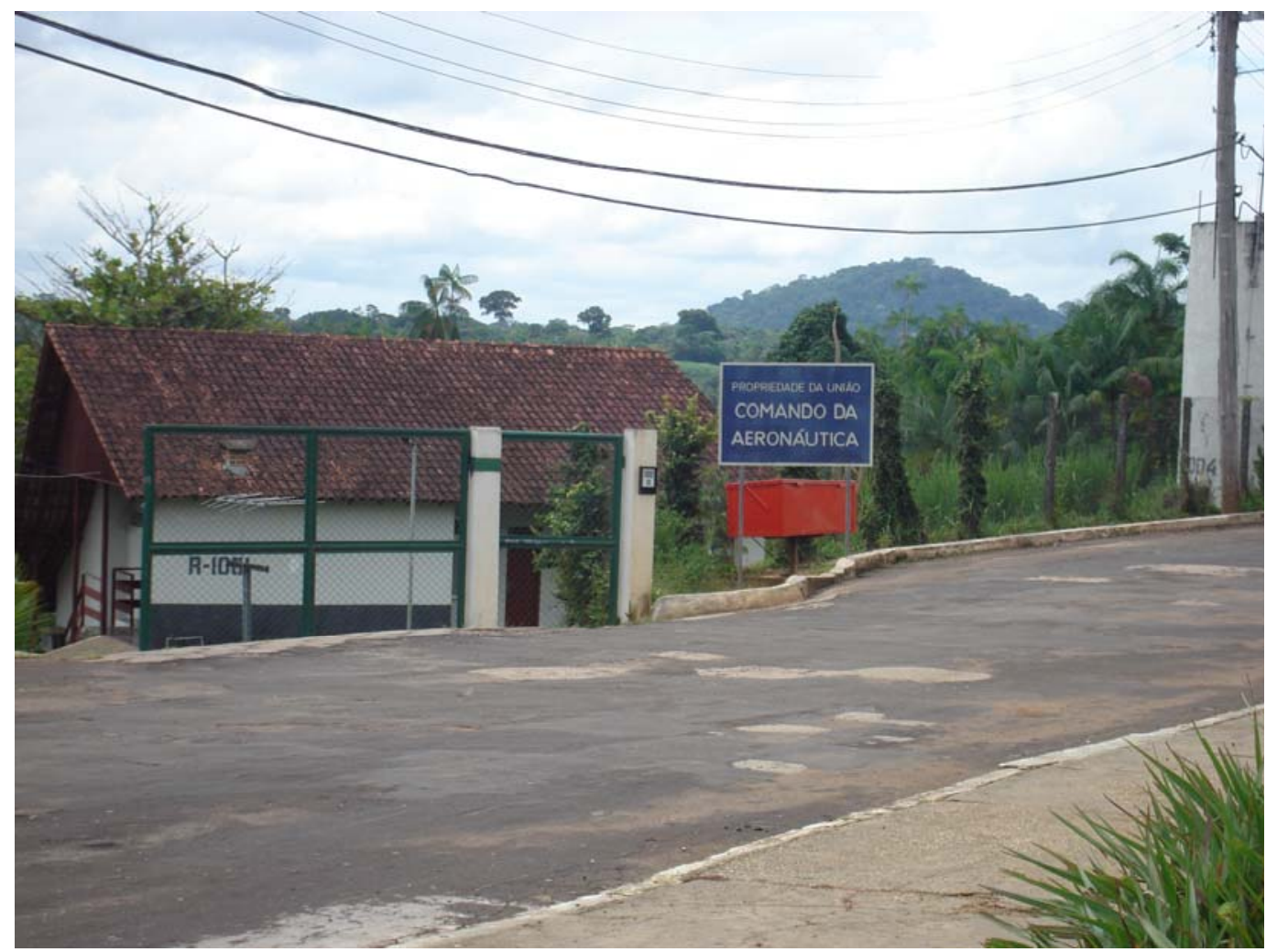

Fonte: acervo do autor, 2007.

Figura 10. Sede da Polícia Federal em São Gabriel da Cachoeira, AM.

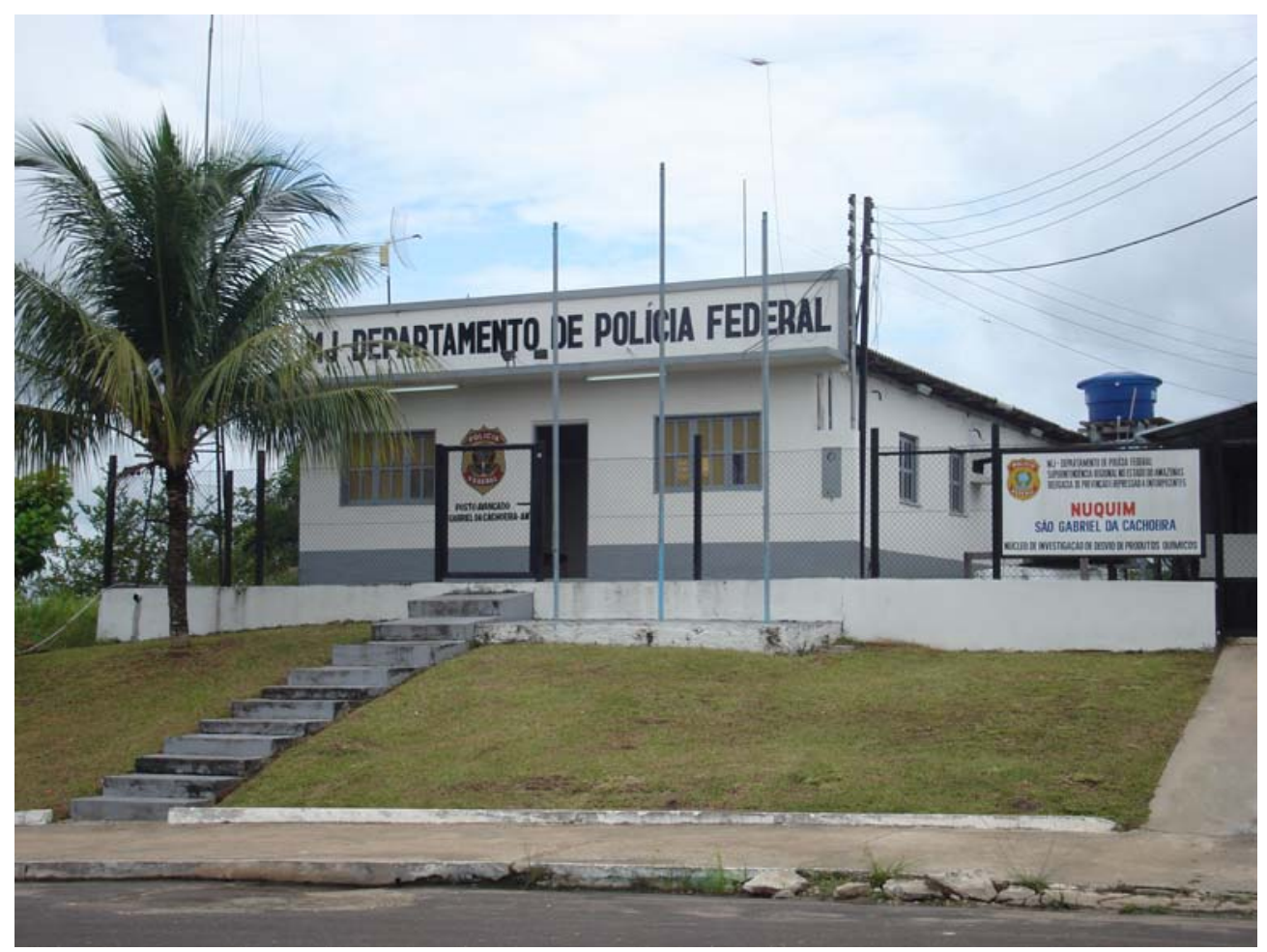

Fonte: acervo do autor, 2007. 
A atuação da Aeronáutica e da PF não interfere muito nas relações de convivência entre os indígenas e militares por duas razões: primeira porque não estão diretamente presentes nas comunidades indígenas; segunda porque não se envolvem muito com os problemas das comunidades indígenas. Por isso, as relações de convivência com os indígenas são consideradas mais tranqüilas, sem conflitos.

O Exército brasileiro é o que tem mais envolvimento com as comunidades indígenas, porque seus pelotões estão instalados dentro das comunidades indígenas, o que possibilita maior contato e convivência com as comunidades e, além disso, o maior efetivo de soldados é indígena. $^{267}$

\subsubsection{Indígenas e militares no alto rio Negro e Uaupés: acontecimentos e notícias}

A instalação de Pelotões Especiais de Fronteira no alto rio Negro, provocou transformações positivas e negativas nas relações interpessoais das comunidades indígenas, principalmente em Pari-Cachoeira, Iauaretê, Querari, São Joaquim, Maturacá e Tunui.

A história da convivência é marcada de aspectos negativos, conflitos, brigas, agressões físicas; e, porém, as relações construtivas também constituem a convivência entre indígenas e militares, tais como: amizade, ajuda mútua, assistência médica e apoio logístico de militares às comunidades consolidam a sua presença na região. ${ }^{268}$

Os eventos em destaques que ocorrem na região, geralmente são notícias publicadas nos jornais, livros etc. Neste item, destacaremos alguns dos principais acontecimentos que ocorreram no alto rio Negro como conseqüência da presença militar e da relação de convivência entre indígenas e militares, após a demarcação das Terras Indígenas do Alto Rio Negro (1998), nas quais as populações indígenas começaram ter mais autonomia para decidir suas próprias organizações sociais respaldadas pela Constituição Federal de 1988, porém vivem inseguros, principalmente com a presença das Farc em território brasileiro.

Veja-se a seguir os principais acontecimentos e noticiários da região após 1998: os noticiários de jornais e documentos de publicações indígenas.

\footnotetext{
${ }^{267}$ ISA, Povos Indígenas no Brasil 1996/2000, p. 251.

268 Roberto Stuckert FILHO. Índios gostam do trabalho, mas sobretudo do salário. O Globo, Rio de Janeiro, 06 de dezembro 1998, p. 15. Para maiores informações ver anexos 24, 25, 26 e 27.
} 


\section{a. Os noticiários de jornais}

a.1 Colombianos se refugiam em S. Gabriel. [...] A maioria dos refugiados são índios que procuram seus parentes no Brasil com medo da guerrilha. (A Crítica, 14/11/1998). ${ }^{269}$

a.2 Índios querem se engajar no Exército. Em vez de trazer de outras regiões o efetivo necessário para a vigilância da fronteira, o Exército prefere dar instrução militar aos moradores da região. No $5^{\circ} \mathrm{BIS}, 85,3 \%$ dos soldados incorporados em 97 são índios - 150 das tribos tukano, macu, dessano, cubeo, baré, piratapuia e baniwa. [...] (O Globo, 06/12/98). ${ }^{270}$

a.3 Ministério quer mais pelotões. O Governo vai aumentar a presença militar na Amazônia, a partir do próximo ano. [...]. (A Crítica, 06/12/98). ${ }^{271}$

a.4 Índios gostam do trabalho, mas sobretudo do salário. Comandante defende o recrutamento por causa da habilidade com fogo, vegetação, abrigos na floresta, caça e pesca. (O País, $06 / 12 / 1998) .{ }^{272}$

a.5 Zona perigosa de fronteira está desguarnecida. Exército, Polícia Federal e Ibama são pouco presentes na Cabeça do Cachorro, região dominada pelo tráfico colombiano. ( $O$ País, $06 / 12 / 98) .{ }^{273}$

a.6 FAB evita transportar índios. Depois que a Polícia Federal encontrou cocaína em um avião da Força Aérea Brasileira (FAB) as caronas nas aeronaves foram proibidas. [...]. [...], os pilotos passaram a evitá-los, temendo que, sem saber, os índios fossem usados pelos traficantes para levar drogas à capital. Sem a carona, os aposentados têm que gastar quase R\$ 60 em transporte. ( $O$ Dia, 07/10/99). ${ }^{274}$

a.7 Índias movem 157 ações contra soldados. Mulheres indígenas entram na Justiça com pedidos de pensão alimentícia pra filhos que tem com militares. (FSP, 23/12/2000). ${ }^{275}$

a.8 Colombianos ameaçam índios no Brasil. O Comando Militar da Amazônia (CMA) confirmou ontem oficialmente que está investigando a incursão de um grupo armado colombiano possivelmente guerrilheiros faz Farc - contra uma aldeia dos índios macus à margem do rio Apaporis, no Amazonas. Cerca de 2000 índios, entre eles sententa crianças, chegaram há uma semana ao PEF de Vila Bittecourt, relatando que foram ameaçados de morte pelos colombianos se informassem ao Exército a invasão. [...]. (OESP, 07/03/02).

a.9 FUNAI confirma. A Funai confirmou a permanência de pouco mais de cem indígenas da etnia macu em Vila Bittencourt. Eles fazem parte da tribo da Aldeia São José, que há quase um mês fugiu de lá por medo de represálias de guerrilheiros colombianos. [...]. (A Crítica, 12/03/02).

a.10 FOIRN apresenta documento para o diálogo de Manaus. No encerramento da segunda rodada do Diálogo de Manaus, que visou a elaboração de um termo de convivência cooperativa entre índios e militares, houve consenso quanto à criação de um GT Interministerial, com a participação de integrantes do exército, de organizações indígenas e de instituições de apoio, para continuar a discussão de um termo de convivência. [...]. (ISA, 26/02/03). ${ }^{276}$

\footnotetext{
${ }^{269}$ Povos Indígenas no Brasil 1996/2000.

${ }^{270}$ Ibidem, 1996/2000.

${ }^{271}$ Ibidem.

${ }^{272}$ Roberto Stuckert FILHO, 1998.

${ }^{273}$ Rodrigo França TAVES, 1998.

${ }^{274}$ Ibidem., 1998.

${ }^{275}$ Kátia BRASIL, 2000.

${ }^{276}$ Povos Indígenas no Brasil, 2001/2005: 288.
} 
a.11 PF Identifica Base das FARC. A Polícia Federal brasileira identificou um acampamento das Farc a 20 quilômetros da fronteira com o Brasil, próximo à aldeia dos índios tucanos, em Melo Franco, no Amazonas. Segundo a PF e o Exército, os guerrilheiros estão tentando aliciar índios exsoldados para reforçar suas tropas. De acordo com autoridades brasileiras, até crianças de oito anos foram procuradas pelos guerrilheiros para transportar armas na selva. [...]. (Oesp, 29/04/03). ${ }^{277}$

a.12 Governo cria brigada em área ameaçada pelas Farc. Mais de 2.500 homens fiscalizarão fronteira com a Colômbia. (O Globo, 18/09/2003). ${ }^{278}$

a.13 Fronteira com a Colômbia terá reforço militar. [...]. A idéia é enviar cerca de 2.500 soldados, reforçando assim o atual batalhão do Exército instalado no município de São Gabriel da Cachoeira (AM). (OESP, 19/09/2003). ${ }^{279}$

a.14 Exército manda mais 3 mil homens à Amazônia em 2004. Tropa ajudará a proteger o país de traficantes e guerrilheiros.. (OESP, 21/09/2003). ${ }^{280}$

a.15 Farc recrutam índios brasileiros. Na fronteira com a Colômbia, guerrilheiros são acusados de cooptar crianças de 8 anos. Ameaçados pelas Farc, índios deixam vilarejo de Acaricuara. $(J B, 04 / 10 / 2003)$.

a.16 FARC: PF investiga aliciamento. (O Globo, 04/10/2003).

a. 17 Índios recrutados pelas Farc. A Polícia Federal brasileira está acusando o grupo guerrilheiro Forças Armadas Revolucionárias da Colômbia (Farc) de recrutar índios brasileiros na Amazônia. [...]. (CB, 04/10/2003).

a.18 Escolta. Policiais Federais passam perto do barco de uma índia que viaja com seu filho, em Santa marcelina (AM), próximo à fronteira com a Colômbia; a PF investiga denúncias de que as Farc estariam recrutando índios brasileiros para a guerrilha. (FSP, 04/10/2003). ${ }^{281}$

a.15 Questão Indígena. Militares são acusados de torturar índios. Denúncia foi feita por entidades e vítimas dizem que agressões são comuns. (OESP, 02/11/2003). ${ }^{282}$

a.19 Começa terça-feira mega operação de combate ao narcotráfico na Amazônia. A Polícia Federal e a Aeronáutica realizam, na próxima terça-feira, a "Princesa dos Pampas", uma mega operação de combate ao narcotráfico, no município de São Gabriel da Cachoeira, no Amazonas. [...]. (Ambiente Brasil, 02/11/2003).

a.20 Tortura. MP investiga militares. (CB, 02/11/2003).

a.21 Militares do Exército são acusados de agredir índios. Fato teria ocorrido em PariCachoeira, no alto rio Negro. (Diário do Amazonas, 03/11/2003). ${ }^{283}$

a.22 FAB bombardeia pista. Aviões da FAB bombardearam ontem a chamada pista de pouso do Caparro, [...], na fronteira com a Colômbia. [...]. (FSP, 06/11/03).

\footnotetext{
${ }^{277}$ Ibidem., 2001/2005: 288.

278 Jailton de CARVALHO, 2003.

${ }^{279}$ Demétrio WEBER (2003); Denise CRISPIM (2003).

${ }^{280}$ Roberto GODOY, 2003.

${ }^{281}$ Patrícia SANTOS, 2003.

${ }^{282}$ Mariângela Gallucci, 2003.

${ }^{283}$ Márcio NORONHA, 2003.
} 
a. 23 Farc rondam a pacata Tunuí, no Amazonas. Forças Armadas e PF preparam ocupação da vila, onde índios viram guerrilheiros. "Temos medo. 'Eles podem aparecer a qualquer hora"'. (OESP, 25/11/2003). ${ }^{284}$

a.24 Operação Colbra. Manobra marca estréia dos Super Tucanos na defesa aérea. Brasil e Colômbia farão ação conjunta. (FSP, 19/05/2005). ${ }^{285}$

\section{b. As publicações indígenas} $1998 .^{286}$

b.1 Tukano denuncia violência de soldados em Pari-Cachoeira. Brasília, 30 de outubro de

b.2 FOIRN quer definição de procedimentos. Em cocumento entregue ao presidente da FUNAI. Dr. Carlos Marés, indicando dez linhas básicas que deveriam compor um Programa Regional de Desenvolvimento Indígena Sustentável do Alto e Médio Rio Negro, a Foirn incluiu uma recomendação ao Ministério da Defesa: definir e difundir um conjunto de procedimentos de convivência entre militares e indígenas a serem adotados nas terras indígenas da região. [...]. (ISA, $a$ partir de documento da Foirn à Funai em 10/12/99). ${ }^{287}$

b.3 Baniwa não quer Pelotão em Tunuí. Em carta dirigida ao Comandante do Exército, ao ministro da Justiça, ao presidente da Funai e do Ibama, ao CMA de Manaus e ao comandante do $\mathrm{V}^{\mathrm{o}}$ BIS em São Gabriel, lideranças Baniwa solicitam que o pelotão previsto para ser construído defronte a comunidade de Tunuí Cachoeira, localizada no alto Içana, seja transferido para outro local. Os Baniwa prevêem impactos culturais e ambientais indesejáveis [...]. (ISA, com base na carta enviada pela Foirn/Oibi/Acira/Unibi, de São Gabriel da Cachoeira, em 25/07/00). ${ }^{288}$

b.3 Lideranças de Iauaretê avaliam realacionamento. Em carta dirigida ao CMA de Manaus, lideranças indígenas de Iauaretê, reunidas em Assembléia Geral realizada entre 31 de julho e 4 de agosto de 2000 , fizeram uma revisão de pontos críticos no relacionamento com os militares do pelotão de fronteira ali instalado. [...]. Expressam também seu descontentamento pelo fato de um militar do pelotão ter introduzido entre os jovens a prática da capoeira o que, acrescido ao hábito de consumir bebidas alcoólicas em festas, tem estimulado a violência. (ISA, com base na carta ao CMA, assinada representantes de 16 associações indígenas locais, em 04/08/00). ${ }^{289}$

b.4 ADR quer apoio do comando para controlar bebidas. Ofício dirigido pelo administrador regional da Funai de S. Gabriel da Cachoeira (AM) ao comandante do $5^{\circ}$ BIS, registra que tem recebido informações verbais de indígenas e profissionais de saúde de que militares dos pelotões de fronteira - especialmente em Pari-Cacahoeira, Iauaretê e Maturacá - estão levando bebidas alcoólicas, promovendo festas e estimulando jovens a consumi-las. [...]. (ISA, com base no Ofício n $^{\circ}$ 121/ERA/SGC/AM, de 07/08/00. ${ }^{290}$

b.5 Aeronáutica quer despejo. O chefe do Estado Maior do VII Comando Aéreo Regional, de Manaus, cel. av. Fernando Taca de Andrade, notificou moradores e proprietários rurais das imediações do aeroporto da cidade de S. Gabriel da Cachoeira, incluindo 24 sítios e três comunidades indígenas situadas nas margens da estrada que liga o aeroporto/porto de Camanaus à cidadeSegundo o

\footnotetext{
${ }^{284}$ Edson LUIZ, 2003.

${ }^{285}$ BRASIL, 2005.

${ }^{286}$ Povos Indígenas no Brasil, 1996/2000, p. 287.

${ }^{287}$ Ibidem, 1996/2000, p. 287.

${ }^{288}$ Povos Indígenas no Brasil 1999/2000.

${ }^{289}$ Ibidem, 1999/2000.

${ }^{290}$ Ibidem, 1999/2000.
} 
VII Comar essas pessoas estão situadas na gleba Tombo AM 015-000, de uso exclusivo da Aeronáutica, e deveriam desocupá-lo em 15 dias. A Foirn enviou ofício ao diretor de Assuntos Fundiários da Funai em Brasília alertando sobre o fato e pedindo esclarecimento. $(I S A, 28 / 08 / 00) .{ }^{291}$

b.6 PF e FUNAI destroem garimpo na serra do Caparro. Moradores de comundiades baniwa, TI Alto Rio Negro, denunciaram a presença de garimpeiros na região conhecida como Serra do Caparro, localizada no rio Cuiari, afluente do rio Içana. Uma equipe composta por 14 policiais federais e representante da Funai se deslocaram para região a fim de averiguar as denúncias e destruir uma possível pista clandestina que estava sendo utilizada pelos garimpeiros para transportar minério tantalita. [...]. (Baseado no relatório da Funai de 31/07/02/ERA-SGC). ${ }^{292}$

\subsection{4 "Normas de Conduta em Terras Indígenas na Faixa de Fronteira"}

A relação de convivência entre indígenas e militares na região do alto Rio Negro e Uaupés é intermediada pela Federação das Organizações Indígenas do Rio Negro (FOIRN), que desde 1996 constrói um diálogo com os militares brasileiros para que a convivência entre indígenas e militares se torne um ambiente mais respeitoso entre ambas as partes. ${ }^{293}$

Para fortalecer a construção de uma convivência ordenada e harmoniosa entre indígenas e militares no alto rio Negro, a FOIRN traçou estratégias de diálogo com a cúpula do Exército em Brasília, no final de 2002, depois um encontro no CMA, em Manaus, para criar regras de condutas para militares na faixa de fronteira. "A FOIRN mobilizou lideranças da região do alto e médio Rio Negro para tratar desse assunto e contribuir com sugestões para a elaboração de regras de convivência". Depois de discutir e refletir com as lideranças de base, antes de dialogar com os militares, a Federação formalizou as seguintes sugestões, que seriam apresentados durante as reuniões com os militares: primeira sugestão, que deve existir mais diálogo, e esclarecimento de tudo sobre a construção de um PEF; segunda, antes da instalação do PEF, a comunidade deve ser avisada, quem são as pessoas que trabalharão na construção para que a comunidade esteja ciente das pessoas não-indígenas que chegarão; terceira, o efetivo militar que ocuparão os PEF, "seja dada preferência a soldados indígenas voluntários da região e que sejam enviados oficiais casados, acompanhados de seus familiares. Nossa experiência é que isso diminui os conflitos, além do fato de que soldados indígenas recrutados nas comunidades conhecem o terreno e os nossos costumes"; quarta, "nas manobras e treinamentos militares, [...] gostaríamos de saber quais são as regras. Nossas

\footnotetext{
${ }^{291}$ Ibidem, 1999/2000.

${ }^{292}$ Povos Indígenas no Brasil 2001/2005.

${ }^{293}$ FOIRN, op. cit., 2001-2004
} 
lideranças deveriam ser informadas com [...] antecedência sobre o que vai acontecer, para prevenir as comunidades e garantir a sua segurança". ${ }^{294}$

Outras demandas apresentadas pela FOIRN para reforçar a razão do porquê da urgência de construir regras de convivência foram as seguintes:

$\mathrm{Na}$ convivência quotidiana tem havido muitos problemas. Alguns serviços públicos (correio, escola, atendimento de saúde, comunicação), às vezes estão localizados dentro da área cercada pelas instalações militares, o que dificulta o acesso e causa constrangimentos aos usuários. Nos dias de folga, especialmente nos finais de semana, os militares convivem com o pessoal das comunidades, participam de eventos e festas e nem sempre respeitam nossos costumes e nossas autoridades. Tem havido muitos casos de paternidade irresponsável, sem que os militares envolvidos cumpram com suas obrigações legais; além do fato de que filhos com pais brancos não podem receber os nomes tradicionais e ficam marginalizados para sempre. Quando acontecem relações sexuais de militares com menores de 14 anos e nós queremos punições severas para esses casos, porque sabemos que a legislação brasileira os considera crime de estupro. Aqui na comarca de S. Gabriel da Cachoeira há muitos casos registrados de reconhecimento de paternidade, porém quase todos são de fatos ocorridos na cidade. Os fatos que acontecem nas comunidades próximas dos pelotões e longe da cidade quase nunca chegam ao conhecimento das autoridades e da Justiça. Nós sugerimos que os comandantes de cada unidade militar deveriam receber instruções superiores para garantir a observação de algumas normas de comportamento social fora do perímetro das instalações militares, de comum acordo com as autoridades indígenas locais. Essas normas deveriam incluir: relações de troca de bens e mercadorias, pagamento de serviços, acesso a festas, eventos sociais, roças, locais de pesca, caça e coleta; proibição de uso e facilitação de acesso a bebidas alcoólicas e drogas; todas as formas de constrangimento e discriminação. Sugerimos que na rotina dos comandantes locais deveria estar incluída a obrigatoriedade de reuniões periódicas com as autoridades locais, para avaliar o cumprimento dessas regras. Sugerimos ainda que a Justiça encontre meios de chegar até as comunidades próximas dos pelotões pelo menos uma vez por ano, para ouvir as comunidades e registrar suas queixas. ${ }^{295}$

A criação das normas de conduta para militares em Terras Indígenas na faixa de fronteira foi resultado de muitas discussões entre lideranças indígenas e cúpulas militares, que resultou nas Portaria $N^{0} 020$ - EME (02/04/03), que Aprova a Diretriz para o relacionamento do Exército Brasileiro com as comunidades indígenas; e a Portaria $\mathrm{N}^{\circ} 983$ DPE/SPEAI/MD (19/10/03), que Aprova a Diretriz para o relacionamento das forças armadas com as comunidades indígenas. ${ }^{296}$

\footnotetext{
${ }^{294}$ Ibidem, 2001-2004.

${ }^{295}$ Ibidem. Ver anexo 28.

${ }^{296}$ Povos Indígenas no Brasil 2001/2005, p. 225-232. Ver anexo 29.
} 


\subsection{5 $6^{0}$ Pelotão Especial de Fronteira de Pari-Cachoeira}

O $6^{\circ}$ PEF de Pari-Cachoeira, localizado no alto Tiquié, tem efetivo de aproximadamente 60 homens entre soldados e oficiais do Exército. O efetivo é composto de maioria indígena sob o comando de um Tenente (ver figuras 11, 12 e 13).

Figura 11. Sede do $6^{\circ}$ PEF de Pari-Cachoeira.

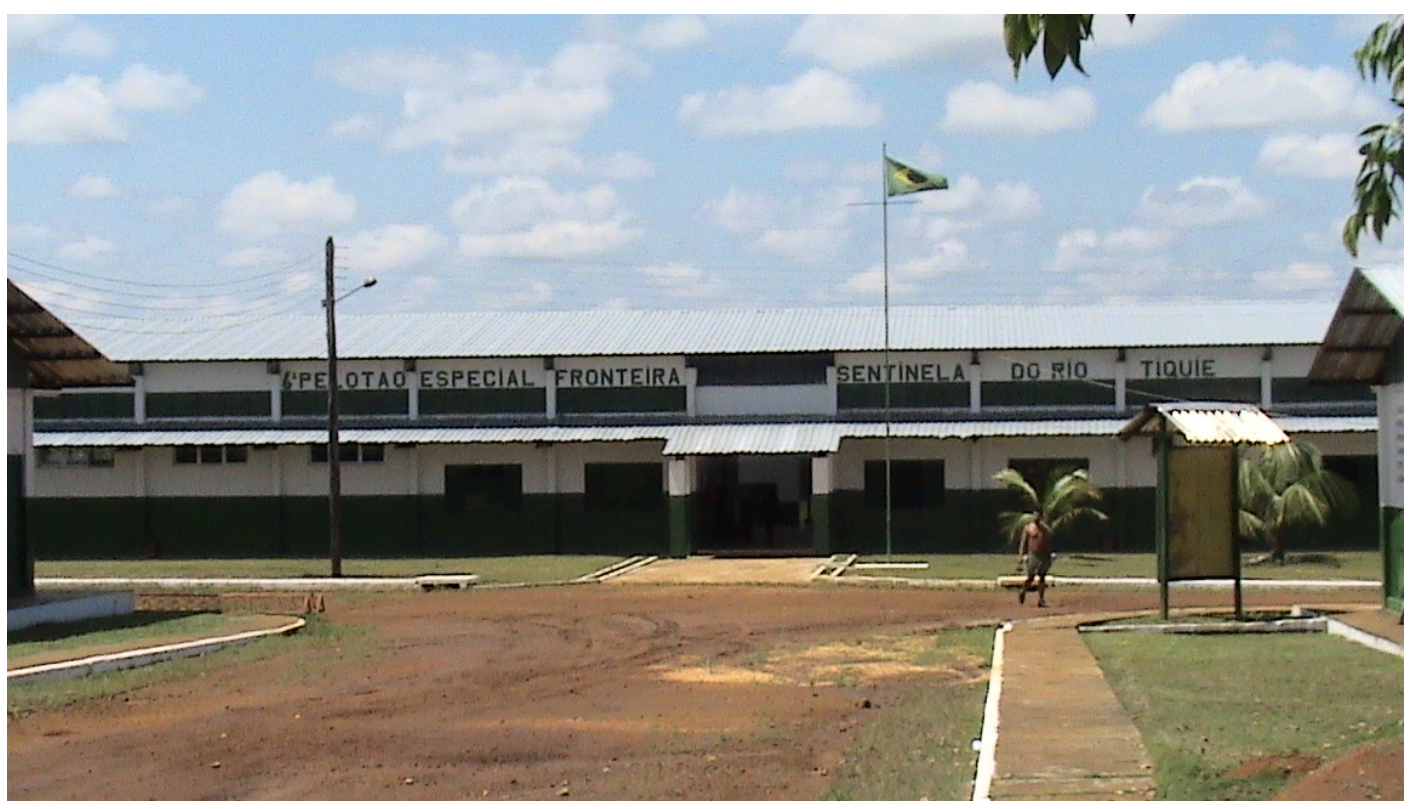

Fonte: acervo do autor, 2007.

Figura 12. Soldado indígena do povo Tukano.

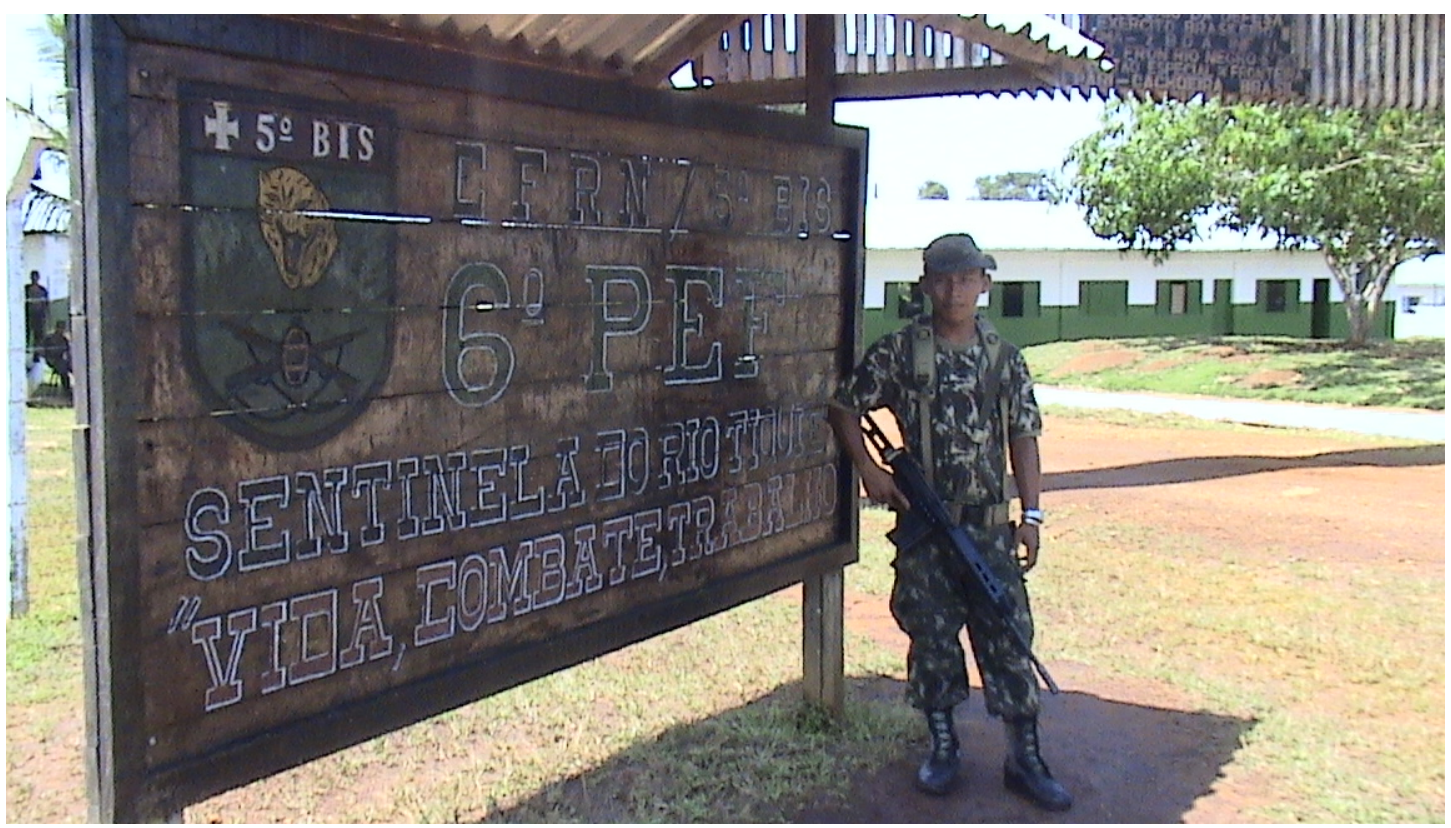

Fonte: acervo do autor, 2007. 
Figura 13. Vista parcial do $6^{\circ} \mathrm{PEF}$ de Pari-Cachoeira.

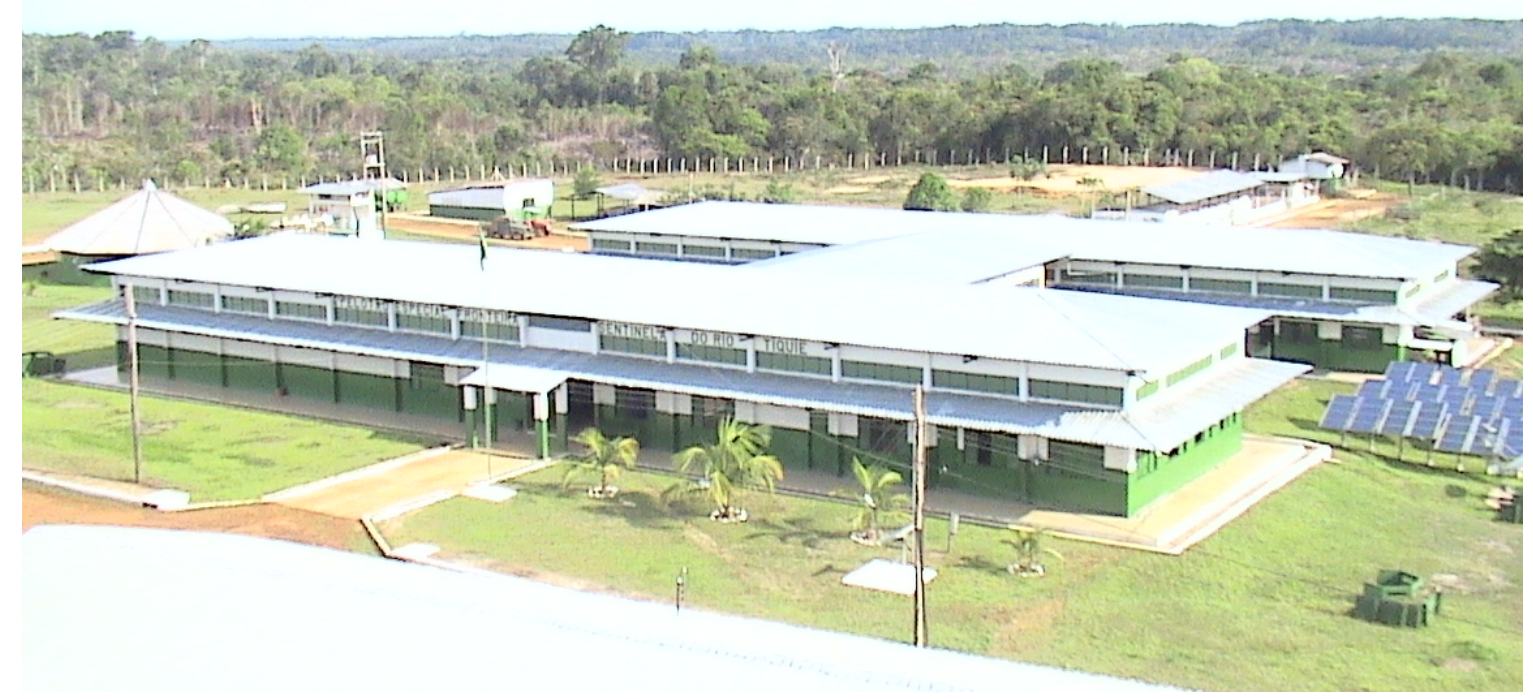

Fonte: acervo do autor, 2007.

Em Pari-Cachoeira, segundo as lideranças locais as normas de conduta não são observadas por alguns militares, principalmente por soldados durante as festas quando não respeitam a organização de cada vila. Entretanto, indiretamente regras de conduta têm contribuído, sim, para melhorar a relação de convivência entre militares e indígenas da comunidade. Talvez, a maioria dos indígenas não tenha noção do que sejam as normas de conduta em áreas indígenas, porque esse tipo de informação não chega ao conhecimento de indígenas que não são lideranças. Na comunidade, um dos principais conflitos é desencadeado devido à disputa entre os rapazes indígenas e militares solteiros para conquistar as moças indígenas.

De acordo com as moças de Pari-Cachoeira, quem começa as brigas são os rapazes indígenas enciumados, sempre quando estão embriagados, porque quando não estão nem parecem que são valentões, pois, são tímidos. Ainda, de acordo com as meninas indígenas, os meninos indígenas só se aproximam para conversar com elas e tentar conquistá-las somente quando estão bêbados, e, ao contrário, quando não estão no estado de embriaguez, não têm coragem nem de dizer: "Oi! Como vai você". Quando percebem que alguns militares se aproximam para conversar com elas, já ficam enciumados e querem bater. 
Figura 14. Moças indígenas de Pari-Cachoeira que foram entrevistadas. ${ }^{297}$

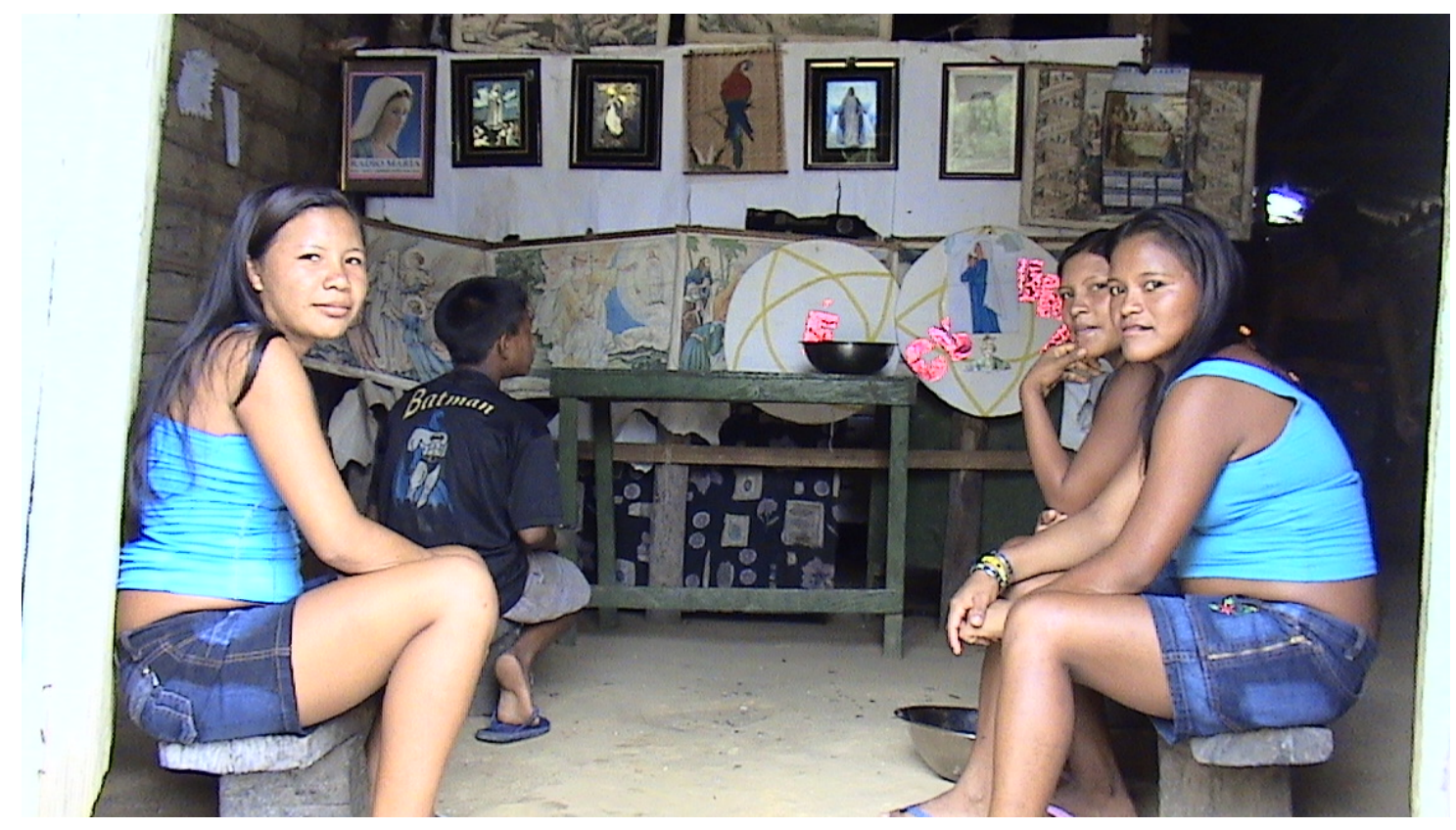

Fonte: acervo do autor, 2007.

Veja-se em seguida os depoimentos de outros indígenas de Pari-Cachoeira sobre a presença militar na comunidade e suas relações de convivência.

\section{Para Tukana, Franciene CASTRO (2007): ${ }^{298}$}

Muitas vezes, as brigas ocorrem durante as festas, porque os meninos indígenas ficam com ciúme de militares que participam das festas e puxam as meninas para dançar. Os militares puxam as meninas para dançar, porque percebem que os rapazes indígenas não têm coragem de puxá-las. Quando os meninos daqui convidam as meninas para dançar, elas dançam bem e com disposição, mas os meninos são pessoas que só tem coragem de puxar as meninas quando estão embriagados. Esse é motivo principal que gera as brigas. Geralmente são os meninos que começam as brigas por causa das meninas.

Outra coisa que acontece aqui são os casamentos entre as moças indígenas e militares, onde a maioria das moças casa com militares.

\section{Para indígena, Leonarda BARBOSA, (2007): $:^{299}$}

Vou falar o meu ponto de vista de como vejo a relação entre nós indígenas e os militares. Antes da chegada de militares a nossa convivência interna era mais tranqüila e harmoniosa. Depois que eles chegaram, os conflitos se sucedeu com mais intensidade, porque as mulheres daqui começaram dar preferência aos homens militares e desprezar os homens indígenas, por

\footnotetext{
${ }^{297}$ A entrevista concedida na língua Tukano, no dia 13 de março de 2007 em Pari-Cachoeira e documentada pelo autor.

${ }^{298}$ Ibidem, 2007. Franciene Castro é tukana da família tradicional de Pari-Cachoeira, 18 anos, casada com outro Tukano, soldado. Esse tipo de casamento é raro acontecer entre os grupos indígenas, porque quase os povos do Uaupés são patrilineares e não deveriam casar entre os membros de mesmo grupo. Nesses últimos, o povo que mais contrariou as regras tradicionais foi, exatamente, o grupo Tukano, porém são mudanças que também pode ocorrer com outros grupos, inclusive há pessoas de outros povos que também se casaram com membros de mesmo grupo.

${ }^{299}$ Ibidem, 2007. Leonarda é casada com um soldado Dessano, tem 22 anos de idade
} 
isso, ocorrem brigas. Quando os meninos daqui querem conversar com as meninas, elas os desprezam e nem ligam para eles, aí começam as brigas.

Outro motivo das brigas é que os meninos indígenas se revoltam com a maneira que as suas parentas ou as moças que pretendiam casar são tratadas pelos militares, que no começo fazem de tudo para conquistá-las, dão coisas, ficam com elas e no final as engravidam, e largam com filhos no colo. Por isso, eles se revoltam e brigam com eles.

\section{Segundo Tukana, Cleomira da Silva GOMES (2007): ${ }^{300}$}

A nossa convivência com os militares não-índios é marcada por momentos bons e ruins. Os militares não são pessoas tão más como muitos dizem. Eles se tornam agressivos quando são provocados pelos rapazes daqui. Aliás, as brigas que ocorrem são provocadas mais pelos rapazes de comunidades vizinhas que estudam aqui em Pari-Cachoeira. Já presencie brigas que chegaram até cortar e esfaquear alguns militares. Os meninos que participaram das brigas não foram os daqui do centro de Pari-Cachoeira, mas quem leva a fama sempre são de Pari-Cachoeira.

Em rerlação a instalação do $6^{\circ}$ PEF e a convivência entre militares e indígenas, Arsênio Vaz LOBO (2007) $)^{301}$ declarou o seguinte:

No começo, nem todos aceitaram a presença do Exército em Pari-Cachoeira, alguns eram a favor e outros a maioria era contra. Para convencer os indígenas, os militares argumentaram que se o pelotão fosse construído, ajudariam a comunidade na área de saúde, educação, transporte etc. No final, os militares convenceram as principais lideranças Tukano de Pari-Cachoeira e conseguiram construir o PEF na comunidade. Por isso, quando há discussões e desentendimento entre indígenas que são contra e outros a favor da presença militar, existe aqui na comunidade, alguns Tukano que dizem o seguinte: nós que pedimos que instalassem aqui; nós deixamos eles para que ficassem na comunidade. No meio dessas conversas internas, surgem outros problemas, brigas, que são resultados da convivência entre nossos parentes e militares. Geralmente, quem participa dessas brigas são os soldados e não os oficiais, porém todos levam a fama como se os oficiais motivassem os conflitos com a comunidade. Às vezes, chega comandante que ele próprio comanda seus soldados para fazer confusões e intrigas com os membros da comunidade indígena, no entanto chega outro que não se envolve com as confusões, porque é mais reservado e mais respeitoso.

Durante as festas, quando há brigas não são os militares que começam provocar, são os nossos próprios parentes que começam. Quando não tem festa não existe briga, só há brigas quando tem festa.

Das coisas que prometeram aos indígenas, nem tudo eles cumprem, mas tem algumas coisas que ajudam os indígenas de acordo com as suas condições, por que ele também não todas coisas que nós precisamos, por exemplo, : quando tem doentes graves fazem resgate; trabalham em parceria com o Distrito Sanitário Indígena (DISEI/RN); quando o pessoal do DISEI não está no pólo, os militares que dão assistência à comunidade etc. Nesse ponto eles ajudam muito.

$$
\text { Para Afonso Machado (2007) }{ }^{302} \text { : }
$$

As razões que nos levou a pedir a presença de militares aqui em Pari-Cachoeira foram os seguintes: primeiro ver este Hospital de Calha Norte funcionando com a equipe de saúde de militares para dar assistência sanitária todo o rio Tiquié. $\mathrm{Na}$ área de educação não precisávamos, porque os missionários já atuavam nessa área.

\footnotetext{
${ }^{300}$ Ibidem, 2007. Cleomira da Silva Gomes é do povo Tukano, casada.

${ }^{301}$ Entrevista concedida no dia 15 de março de 2007 em Pari-Cachoeira.

${ }^{302}$ Entrevista concedida no dia 14 de março de 2007 em Pari-Cachoeira.
} 
$[\ldots]$

As promessas que os chefes militares foram os seguintes: apoio de transporte via aeronave e via fluvial, centro de informática que funcionaria dentro do pelotão. Em contrapartida, fiz o seguinte discurso: Nós solicitamos este pelotão querendo ver nossos filhos serem comandantes; enquanto os nossos filhos estiverem se preparando academicamente, os comandantes ainda serão não-indígenas, depois queremos que nossos filhos se tornem comandantes de pelotões. Por isso, quero pedir 12 bolsas de estudo para nossos filhos estudarem no colégio militar. Aí me responderam que é possível, pediram que encaminhassem um documento para Funai, depois a Funai direcionaria para o CMA.

Outra coisa que orientaram foi que se houvesse qualquer bagunça e alteração, conflito entre comunidade e militares que ligássemos no 1104 , no telefone do $5^{\circ} \mathrm{BIS}$, mas antes de ligar para esse número peça o comandante do PEF que puna os militares envolvidos nos conflitos, se o comandante não cumprir o pedido, aí sim, pode ligar para o $5^{\circ}$ BIS, porque aí punirei o comandante e os militares envolvidos. Depois que instalaram o pelotão, já tivemos várias confusões, não sei se as atuais lideranças seguiram essa orientação, porque a iniciativa de ligar para esse número quando há confusões depende delas.

Os militares ajudam muito na parte de saúde, em quaisquer momentos se dispõe para socorrer os pacientes. Nesse ponto, eles ajudam muito. O único problema são as brigas que ocorrem durante as festas, não porque os militares que incitam, é mais porque os nossos parentes jovens também não os respeitam. O que falta para melhorar a nossa convivência é a nossa liderança que estão na linha de frente estarem ao par com o chefe maior de militares. Para fortalecer a nossa relação de convivência pensamos em colocar umas normas; normas que vigorassem, como por exemplo: se a gente disser que os soldados podem vir participar das festas comunitária, podem vim; se a gente disser, hoje não podem vir, eles não podem.

Outra coisa que acontece aqui é o transporte de bebidas alcoólicas, os próprios militares transportam cachaça (sibioké). Já presenciamos um comandante promovendo festa na praia com bebidas alcoólicas. Parece que o comandante atual não é assim, mas quando chega um que bebe, a gente só vê festas com geradores de luz, som e tudo no porto daqui, onde tem praia.

A relação de convivência entre militares e indígenas é como se fosse uma relação de "cão e gato". Os indígenas brigam e discutem com os militares, mas quando precisam de alguma ajuda ou apoio logístico, muitas vezes, recorrem ao comandante do pelotão, que quando tem o que os indígenas necessitam se dispõe sem negar a ajuda. Por exemplo, quando os líderes de vilas precisam de combustível para ligar o motor de luz para festas ou para o barco da comunidade e quando precisam de trator para transportar materiais da comunidade recorrem ao pelotão.

\subsubsection{Indígenas e Militares em Trinidad (Colômbia)}

Em Trinidad não há presença física de militares do Governo colombiano, porque a comunidade está situada numa área controlada pelas FARC. Por isso, o nosso estudo se concentrou na relação entre indígenas e a guerrilha colombiana.

Os Tuyuka e Barás que residem em Trinidad, situada na Área de Gran Resguardo Indigena del Vaupés, Departamento Del Vaupés, Colômbia, estão interligados culturalmente 
com grupos de outros Resguardos Indígenas em La Amazonía Colombiana. ${ }^{303}$ Culturalmente porque tem parentes, primos, cunhados, filhos espalhados na cidade de Mitu e outros centros colombianos. Naturalmente porque a comunidade possui varadouros e igarapés que dão acesso a diversas comunidades da região, inclusive algumas vias dão acesso até às comunidades indígenas do Brasil. A guerrilha colombiana aproveita esses acessos para transitar na área.

A relação de convivência entre indígenas e as Farc se constitui de forma indireta. De acordo com os Tuyuka de Trinidad, os guerrilheiros nunca entraram na comunidade para invadir e raptar garotos e garotas como fazem em várias outras povoações indígenas, no entanto, rondam nas suas proximidades, fato que cria um clima de medo nos indígenas.

Desde a década de 60, assim como os demais povos da região, os tuyuka de Trinidad vivem cercados pelas ações da guerrilha colombiana que rapta meninos e meninas indígenas de 11 anos ou mais para recrutar. Na Colômbia, essa é a prática comum das Farc. Alguns jovens indígenas entram na guerrilha por livre espontânea vontade por razões familiares. Por exemplo, os jovens que não vêem perspectiva de uma vida melhor na comunidade e jovens que brigaram com os seus familiares, geralmente são os que decidem entrar na guerrilha e depois nunca mais sair. Significa que nem sempre a guerrilha que raptam os jovens, os jovens indígenas que decidem ir com eles.

A relação de indígenas com as Farc é uma relação de medo. ${ }^{304}$ Segundo o pajé Tuyuka, Antônio Barreira $(2007)^{305}$, as Farc ameaçam matar todos os pajés da área controlada por eles ou recrutá-los para guerrilha. Ameaçam matar, porque acham que os pajés impedem com os rituais de pajelança e benzimento que os guerrilheiros entrem nas comunidades indígenas, principalmente onde residem pajés. Querem recrutar forçadamente para que o pajé trabalhe e lute com eles, servindo a guerrilha com os rituais de pajelança e benzimento para protegê-los de inimigos. ${ }^{306}$

Essa é uma realidade que os indígenas colombianos procuram não expor, porque têm medo que os guerrilheiros matem seus familiares. Por esses motivos muitas famílias indígenas migram para as cidades brasileiras, onde há seus parentes. Inclusive, o pajé Antônio BARREIRA (2007) declarou que estava decidindo abandonar Trinidad para ir à Santa Isabel do Rio Negro, rio Negro, Brasil, porque no Brasil a sua família estaria protegida. ${ }^{307}$

\footnotetext{
${ }^{303}$ Ver anexo 28.

${ }^{304}$ Ver anexo 39.

${ }^{305}$ Entrevista concedida no dia 09 de março de 2007 e documentada por autor.

${ }^{306}$ DUTRA, op. cit., 2007.

${ }^{307}$ Entrevista concedida no 09 de março de 2007 em Trinidad.
} 
O medo por guerrilheiros das Farc não é só coisa de indígenas colombianos, os indígenas brasileiros que vivem nas pequenas comunidades do Tiquié, Papuri e Uaupés também vivem com medo, porque os guerrilheiros transitam livremente dentro do território brasileiro. Como a região é muito extensa, os militares brasileiros não conseguem guarnecer todos os lugares e povoados. Muitas vezes quem se depara com guerrilheiros são os próprios indígenas.

Por exemplo, as Farc circulam na área de Pari-Cachoeira, porque existem muitos varadouros que interligam Pari-Cachoeira com as comunidades indígenas do território colombiano; e porque também há guerrilheiros que nasceram na área de Pari-Cachoeira, por isso conhecem bem a região, ou seja, os indígenas guerrilheiros que conduzem os grupos que rondam a região; existe caminho que liga Pari-Cacchoeira e Monfort (Colômbia), PariCachoeira a Iauaretê, Pari-Cachoeira a Jandiá, localizada próximo a Serra Ibaca, onde vivem os Macu do Igarapé Cabari etc. Enfim, são caminhos que interligam direto entre as comunidades brasileiras e colombianas, onde a guerrilha usa para circular e refugiar de incursões e operações militares do Governo colombiano. Entretanto, as guerrilhas das Farc que transitam na área de Pari-Cachoeira nunca invadiram ou atacaram nenhuma comunidade indígena; e também não se tem notícia que eles raptaram crianças, jovens indígenas dentro do território brasileiro. Por enquanto, esse tipo de prática se reduz apenas dentro do território colombiano. A única coisa que os guerrilheiros atacam no território brasileiro são as roças dos indígenas, quando tem frutas fazem arrastões para se alimentarem. ${ }^{308}$

\subsection{A relação de convivência entre indígenas e ONGs}

$\mathrm{Na}$ região do alto rio Negro, as principais ONGs presentes são: Instituto Socioambiental (ISA), Instituto Brasileiro pelo Desenvolvimento Sanitário (IBDS), Saúde Sem Limites (SSL), Instituto de Investigação e Desenvolvimento em Política Lingüística (IPOL) e ProAmazônia.

O ISA “foi fundado em 1994 para propor soluções integradas a questões sociais e ambientais [...], tem como objetivo defender bens e direitos sociais, coletivos e difusos, relativos ao meio ambiente, ao patrimônio cultural, aos direitos humanos e dos povos". ${ }^{309}$ É o principal parceiro que assessora a Federação das Organizações Indígenas do Rio Negro.

\footnotetext{
${ }^{308}$ Existem muitas histórias contadas pelos indígenas sobre a presença das Farc dentro do território brasileiro. Nesta dissertação, não detalharemos sobre essa questão. O que podemos afirmar é que a guerrilha colombiana circula no território brasileiro, muitas vezes, sem que os militares brasileiros percebam.

${ }^{309}$ ISA, 1994-2004: 2.
} 
Figura 15. Residência e sede do Instituto Socioambiental do rio Negro em São Gabriel da Cachoeira.

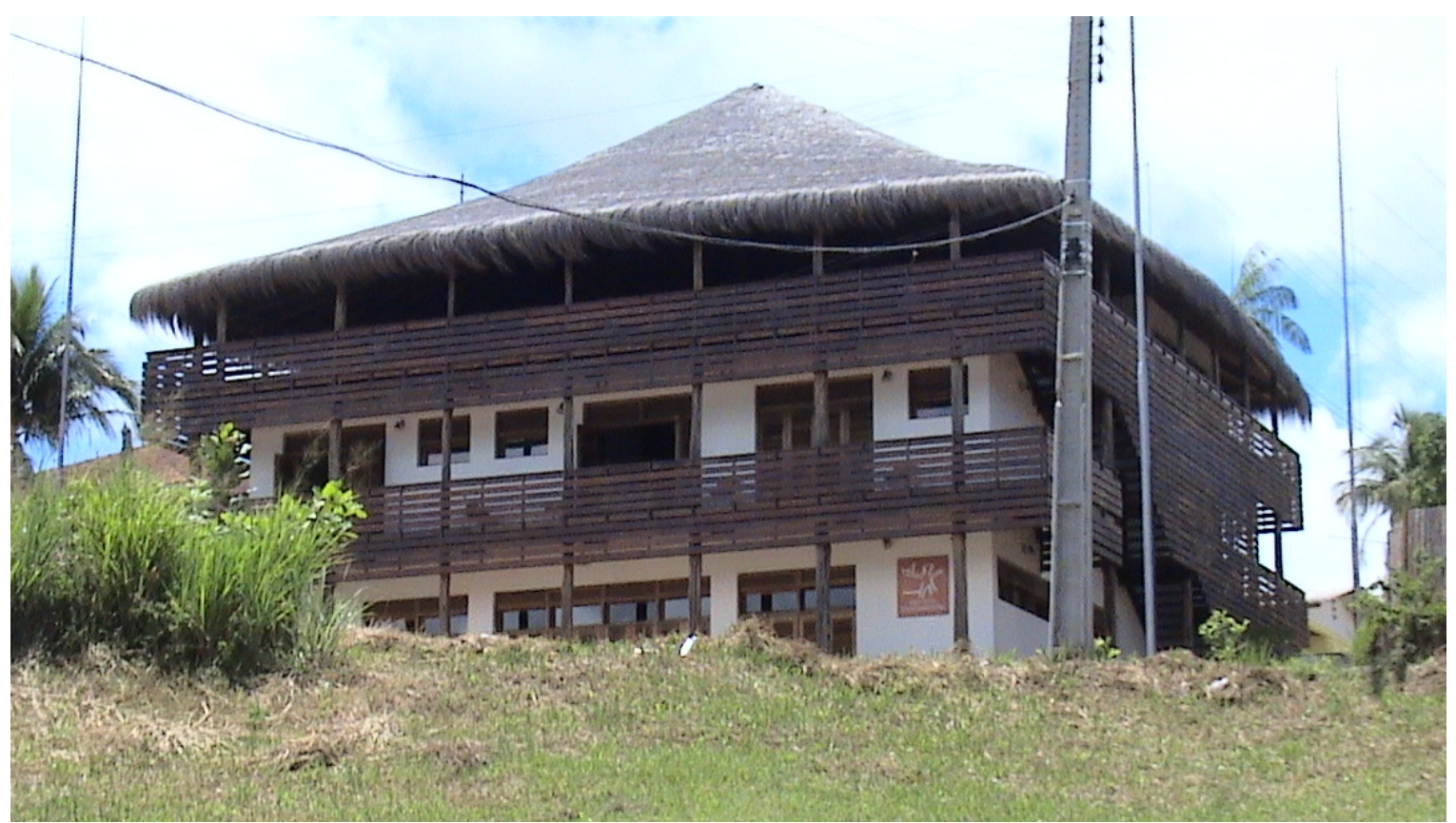

Fonte: acervo do autor, 2007.

Figura 16. Sede da Saúde Sem Limites em São Gabriel da Cachoeira.

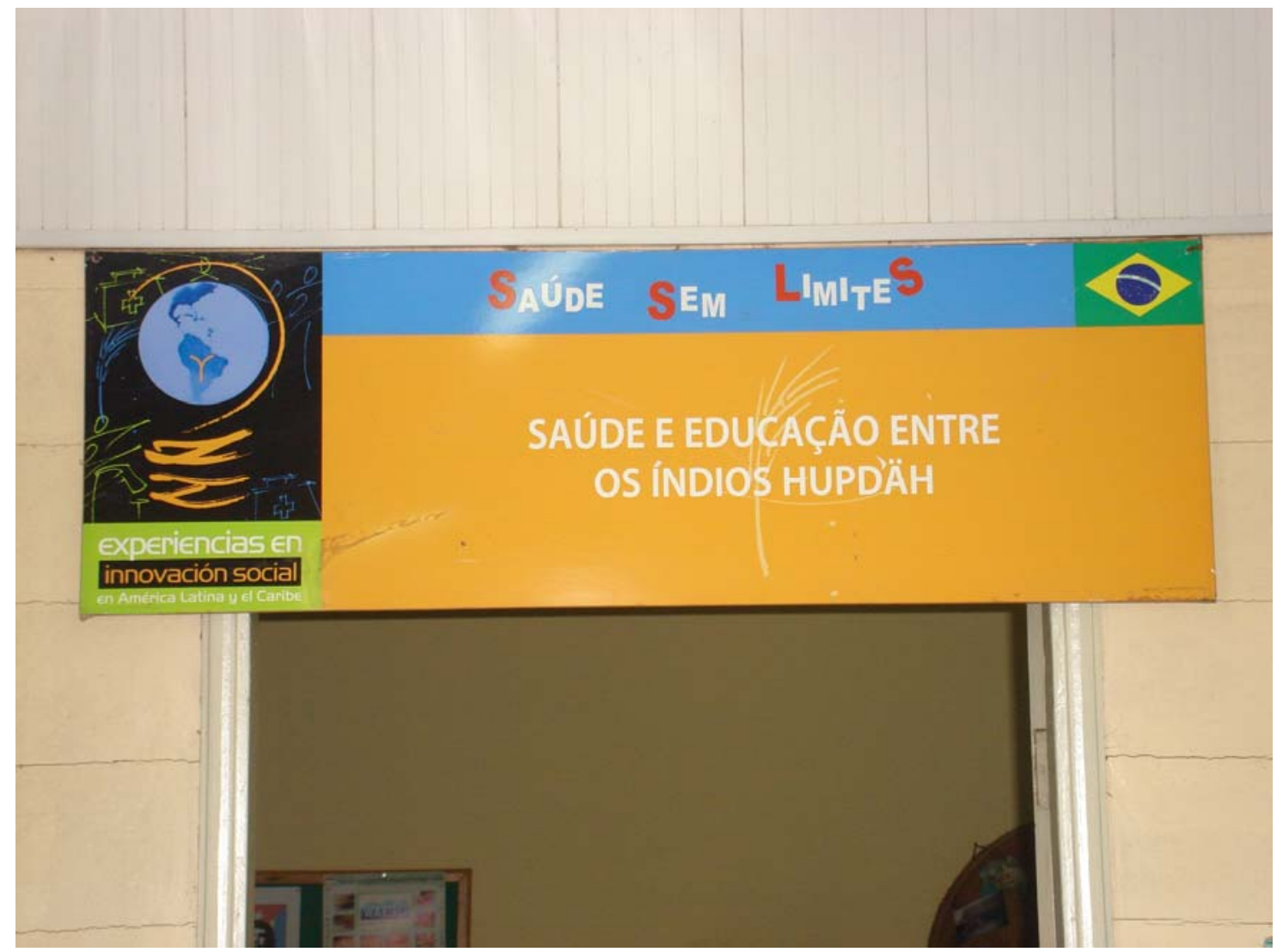

Fonte: acervo do autor, 2007. 
O IBDS não é um parceiro direto da FOIRN, porém trabalha na área de saúde com os Yanomami. Seus profissionais graduados são pessoas todos de fora e o corpo de técnicos de enfermagem é constituído por profissionais da área.

O SSL é outra Ong que trabalha na área de saúde e educação com os Macu da comunidade de Barreira, Taracuá Igarapé e Nova Fundação, no médio Tiquié. É um parceiro da FOIRN, mas não interfere diretamente no rumo do Movimento Indígena assim como o ISA.

O IPOL não tem muita presença significativa no rio Negro, porque não é uma Ong bem estruturada, não conta com um quadro de profissionais permanentes na região que atuem entre as comunidades indígenas.

A Ong Pró-Amazônia é a mais recente que chegou no alto rio Negro para trabalhar entre os Macu do baixo Tiquié.

Sobre a presença dessa Ong, o Tukano, Anazildo (2007), da comunidade de Matapi, baixo Tiquié, declaraou o seguinte: $:^{310}$

A gente conversa com os membros dessa Ong, mas não sabemos quais são as suas verdadeiras intenções. Chegaram entre os Macu dessa para trabalhar na área de Educação, mas aos poucos, de acordo com os Macu, estão querendo construir uma Igreja que seria a sede de muitas outras que pretende construir na área. Eles enganam os Macu dando materiais como anzóis, linhas de pescas, sal, redes, fósforos coisas que os Macu necessitam no seu dia a dia. A FOIRN sabe o modo de atuação e as pretensões dessa Ong, mas não quer tirar, não sei porquê. $O$ presidente da Federação sabe dessa história, mas até agora ainda não tomou nenhuma providência. [...]

Assim como a história da atuação de missionários e militares no alto rio negro, a presença de ONGs tem aspectos positivo e negativo.

Os aspectos positivos que constituem as atividades das ONGs são: a contribuição direta para a política de sustentabilidade da FOIRN; os projetos pilotos de Psicultura e Educação Escolar Indígena, executados em algumas comunidades indígenas, especialmente na Escola Tuyuka (alto Tiquié), Escola Pamali (alto Içana), Escola Tariano (alto Uaupés), Escola Wanano (alto Uaupés), Escola Tukano Yupuli (baixo Tiquié); as pesquisas científicas que contribuem para o conhecimento técnico da região. O fortalecimento da FOIRN como instituição indígena se deve em parte pelo apoio e assessoria das ONGs, principalmente do ISA, que é parceiro desde a criação da FOIRN em 1987. Essas ações contribuem para a transformação de mentalidade e mudanças de estratégias de desenvolvimento sustentável do movimento indígena do rio Negro. Entre esses e muitos outros trabalhos destacamos sobre as atividades de Educação Escolar Indígena do rio Negro, que tem uma grande parcela de

\footnotetext{
${ }^{310}$ Entrevista concedida no dia 20 de fevereiro de 2007 na comunidade indígena de Matapi, baixo Tiquié.
} 
colaboração das ONGs, porque elas ajudaram os indígenas a pensarem numa nova forma de Educação que respeita e valoriza o modo de ser indígena. Foi através das experiências pilotos das ONGs que a Educação Escolar Indígena no rio Negro e no Brasil teve avanços e inovações significativas, que conseqüentemente foram criadas e aprovadas leis tanto nas esferas municipais, estaduais e federais; hoje, as ONgs, principalmente o ISA, apóia diretamente no fortalecimento das redes de relações internacionais e intercâmbios dos povos indígenas do alto rio Negro e indígenas colombianos e venezuelanos. Em São Gabriel da Cachoeira uma das maiores contribuições das ONGs foi o reconhecimento e a aprovação das línguas Tukano Baniwa e Ñhengatu como línguas co-oficiais do município.

Os aspectos negativos que constituem de acordo com a visão indígena são: assim como a Antropóloga Dominique Buchillet escreveu o artigo "Pari-Cachoeira: o laboratório Tukano do projeto Calha Norte" em 1990, atualmente, depois de 1998, o rio Negro está se transformando o laboratório do projeto das ONGs. Existem diversas razões que corroboram com essa tese, por exemplo, o mais evidente é que após 20 anos da existência da FOIRN, a parceria entre a Federação e as ONGs não dá sinais de que os indígenas estejam caminhando para a autonomia que tanto lutam e buscam para melhorar a qualidade de vida das comunidades indígenas; em vários setores, a Federação ainda é totalmente dependente de seus parceiros ONGs, principalmente quando se trata de recursos humanos indígenas. Outra questão negativa da atuação das ONGs é que elas não trabalham em parceria com a Igreja Católica e não fazem nenhum esforço para criar um ambiente de diálogo com os membros da Igreja para executar projetos em parceria nas comunidades indígenas. Por isso, depois da demarcação das terras em 1998 a Igreja Católica é posta de lado quando se trata do movimento indígena, porque as ONGs evitam o envolvimento da Igreja em seus projetos e impedem que atuem mais uma vez na política do movimento indígena.

A FOIRN também é uma Ong, porém uma Ong diferenciada, uma organização genuinamente indígena. No Relatório Geral 2000, da FOIRN deixa evidente que é uma organização dos índios, e que toma suas próprias decisões.

[...] sabemos que temos nossas dificuldades, avanços e conquistas. Na firmeza de construir uma política e organização indígena no meio político de ONGs e do governo, buscando através de sua política original de que a organização indígena não é uma ONG a mais, mas sim tem uma característica própria de administração e gestão, tanto para a sociedade indígena que representa como para mostrar para a sociedade não indígena que a organização é dos índios combinada com tecnologia atualizada que valoriza a cultura milenar dos povos indígenas do Rio Negro, contribuindo assim para uma política indígena em nível regional, nacional e internacional. Também de promover, administrar e acompanhar projetos pilotos desenvolvidos nas comunidades pelas associações de base que na política de o movimento indígena é um caminho 
para se chegar num objetivo mais esperado, defendendo a autonomia da população indígena. ${ }^{311}$

A relação de convivência entre os profissionais das ONGs e indígenas ocorre mais entre profissionais indígenas que trabalham na sede da FOIRN e indígenas das comunidades onde existem projetos pilotos. Nas comunidades onde não há projetos pilotos, os indígenas desconhecem quem são os membros das ONGs e nem sabem o que fazem na região.

Por exemplo, por enquanto o ISA não atua em todo o rio Negro ou na maioria das comunidades indígenas da região e nem nas maiores comunidades localizadas dentro das terras demarcadas, talvez no futuro expanda para outras comunidades, por exemplo: em Taracuá não há nenhum trabalho das ONGs; em Iauaretê, agora que o ISA começa realizar pesquisas sobre as tradições milenares com os velhos Tariano e Tukano da comunidade e as atividades de Psicultura com as famílias; em Assunção do Içana também não temos nenhum trabalho executado ou em execução; em Querari também não existe; em Cucuí também não tem.

Em Pari-Cachoeira a maioria dos indígenas não conhece o que é ISA, SSL, IBDS, IPOL, etc., nem mesmo as lideranças da comunidade. Veja-se a seguir os depoimentos de algumas lideranças e outros indígenas de Pari-Cachoeira :

\section{Para Afonso Machado (2007): ${ }^{312}$}

Pelo meu ponto de vista, a presença de ONGs na região do Tiquié, não fez melhorar nada a qualidade de vida indígena. $\mathrm{O}$ mal do índio é que só trabalha bem quando há assessoria dos brancos, quando eles dizem agora trabalhem sozinhos, a gente não consegue dar continuidade. Nós, indígenas, somos assim.

Outra coisa que percebo é que os não-índios, que assessoram o movimento indígena do rio Negro, não querem que sejamos sábios como eles para dominar o computador e outros meios tecnológicos. [...]. O que a gente vê é apenas o pessoal interno que trabalha na FOIRN se capacitando. Agora, a FOIRN em parceria com o Governo estadual está construindo um prédio de $\mathrm{R} \$ 1.000 .000,00$ de reais, que será um Centro de Capacitação de Lideranças, ...., não sei como vai ser. Quem será capacitado, não sei, porque pessoas como nós, que moram nas comunidades do interior não é capacitado.

Conforme Miriti-tapuia, Arsênio Vaz Lobo (2007), líder geral do distrito de PariCachoeira, CIPAC: ${ }^{313}$

Aqui na comunidade de Pari-Cachoeira não há presença de nenhuma ONG.

No início, o ISA se comprometeu de trabalhar em todo o Tiquié na parte de psicultura, disseram que realizariam todos os tipos de trabalhos, por isso a Funai parou executar projetos do Governo [...]. Aqui no CIPAC, em Pari-Cachoeira, eles passam direto. Os únicos trabalhos que executam é

${ }^{311}$ Federação das Organizações Indígenas do Rio Negro, FOIRN. Relatório Geral 2000. Terra e Cultura. São Gabriel da Cachoeira/AM, janeiro de 2001.p. 12.

${ }^{312}$ Entrevista concedida no dia 14 de março de 2007 em Pari-Cachoeira.

${ }^{313}$ Entrevista concedida no dia 15 de março de 2007 em Pari-Cachoeira. 
na comunidade de Caruru (com psicultura) e nas comunidades que constituem a Escola Tuyuka em São Pedro. [...]

Depois que a terra foi demarcada em 1998, o ISA não executou nenhum trabalho na comunidade e nem a FOIRN. [...] Já faz quase oito anos que a gente não tem apoio da FOIRN, porque os seu dirigentes dizem que não tem mais recursos para aprovar nossos projetos, que nunca são aprovados. Talvez isso acontece, porque o CIPAC não tem o seu Estatuto legalmente aprovado. A gente acha que seja isso, não sei se é isso mesmo.

A Saúde Sem Limite trabalha mais com os Macu. Uma vez fui visitar a comunidade Macu de Nova Fundação (baixo Tiquié), encontrei freiras que trabalham com os Macu. Quando cheguei diziam que o pessoal de Saúde Sem Limite não chegava na comunidade [...]. Os membros dessa ONG trabalham mais com os Macu da comunidade de Barreira, Taracuá Igarapé e Nova Fundação. Segundo os Macu, eles ficam duas vezes por ano durante 30 dias ou mais, depois vão embora e não voltam nunca mais. Quando a gente vê com mais atenção de como funciona o trabalho dessa $\mathrm{ONG}$, percebemos que não funciona muito bem.

O Tukano, Afonso Rezende Arantes (2007), vice-líder geral da CIPAC, disse o seguinte: ${ }^{314}$

Aqui em Pari-Cachoeira não vejo nenhuma ONG. Pelo menos aqui não tem nenhum trabalho deles. A gente só se ouve falar de ONG quando nossos parentes contam para nós, que passaram gente de ONGs pela cachoeira de Pari-Cachoeira. Além disso, ninguém sabe mais nada, ninguém sabe quem são eles, porque não param na comunidade. Eles não conversam conosco.Se eles conversassem conosco estaríamos disposto para pedir apoio de sustentabilidade e seriam bem-vindos, mas eles não param aqui.

O Tuyuka, Waldemiro Maranhão Rezende (2007), líder comunitário da Vila São Domingo Sávio, vê da seguinte maneira: ${ }^{315}$

Aqui na nossa comunidade de Pari-Cachoeira não tem nenhum trabalho do ISA. Eles têm só tem trabalhos na estação Caruru. Uma vez conversamos com o presidente da FOIRN, que aqui, entre nós, não tem nenhuma Ong como ISA. Quando o pessoal do ISA chega aqui passa direto, nem encostam para conversar conosco.

Se alguma ONG estivesse presente entre nós, respeitaríamos e valorizaríamos o trabalho deles. Como não atuam entre nós, a gente fica bravo e desconfiado. Se estivessem nos ajudando ficaríamos felizes e agradeceríamos com festas. Como eles não fazem nada para a melhoria da nossa vida, a gente também não os acolhe, não damos atenção e nem importamos se passaram aqui ou não, deixamos de lado.

Em Trinidad (Colômbia), não há atuação de nenhuma ONG, aliás a Fundação Gaia já atuou na comunidade. Os Tuyuka não gostaram com a forma de trabalho dos membros dessa ONG, decidiram expulsá-los. Por isso, não tem mais nenhuma ONG na região e os Tuyuka também não querem mais ver nenhuma entre eles, pois disseram que as ONGs só querem formalizar os conhecimentos tradicionais do grupo e vão embora sem dar satisfação e nem retorno para a comunidade.

\footnotetext{
${ }^{314}$ Entrevista concedida no dia 16 de março de 2007 em Pari-Cachoeira.

${ }^{315}$ Entrevista concedida no dia 20 de março de 2007 em Pari-Cachoeira.
} 


\section{A FRONTEIRA "VIVA": CONVIVÊNCIA ENTR TUKANO E TUYUKA}

Depois de ter analisado a situação da convivência de parcerias e de conflitos entre os indígenas e agentes da sociedade envolvente no capítulo três, nosso objetivo neste capítulo quatro é apresentar a parte da fronteira "viva" composta pela convivência entre os indígenas Tukano de Pari-Cachoeira (Brasil) e Tuyuka de Trinidad (Colômbia).

\subsection{Pari-Cachoeira: a comunidade de domínio Tukano}

Figura 17. Cachoeira de Pari-Cahoeira.

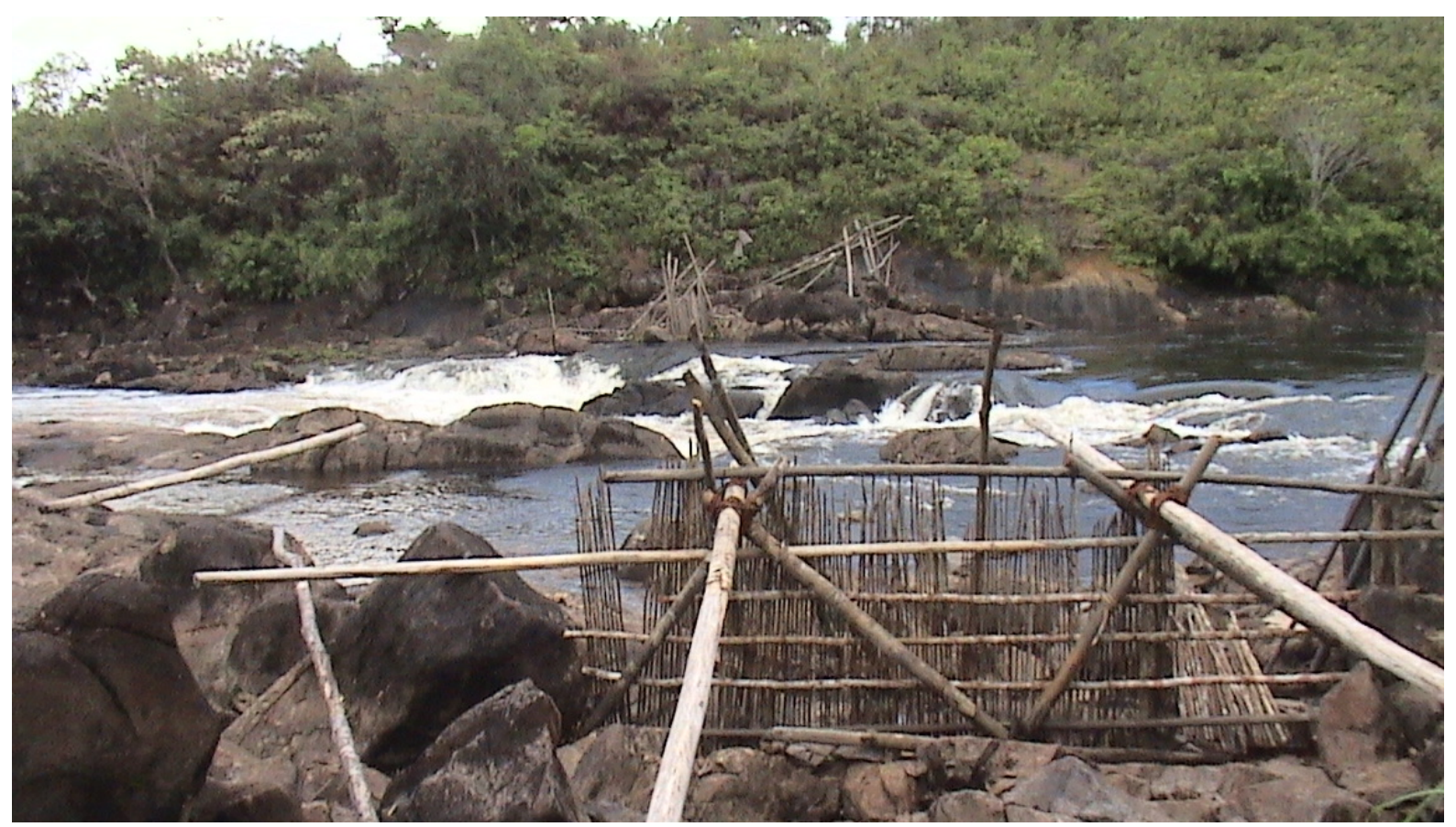

Fonte: acervo do autor, 2007.

A palavra pari vem do Tupi que significa "armadilha feita de talas e varas com que se apanha peixe nos rios"316; cachoeira, porque em frente a comunidade há duas cachoeiras, onde os Tukano preparam armadilhas para pegar peixes durante o ano; daí foi denominado pelos missionários de Pari-Cachoeira (ver figura 01). Nas línguas Tuyuka e Tukano é chamada de Imikahsapá [em Tuyuka (TY)] e Imisapá [em Tukano (TK)], ou Buhsapoeá (em TY) e Busapoeá (em TK), ou Siririá (TY) e Siripá (TK). A comunidade está localizada no alto rio Tiquié, na região do Uaupés, dentro da Terra Indígena (TI) Alto Rio Negro (ver mapa 02), extremo noroeste do estado do Amazonas, Brasil (ver figuras 02 a 06).

\footnotetext{
${ }^{316}$ FERREIRA, Aurélio Buarque de Holanda, 2004, p. 1496.
} 
Pari-Cachoeira é a comunidade dos Tukano (Dahseá) de subgrupo intermediário Palésipõtã (filhos de Palẽsi, também chamados de Batitorotã), ou seja, não são considerados chefes do povo Tukano. São Patẽsipõtã porque o avó deles se chamava Patẽsi. Além deles, residem algumas famílias Tuyuka, principalmente dos subgrupos Béroa, Ohkokahperiá, Wehsé Dohkapuała, Dahsiá Pahkała e Dessano; há a presença de padres diocesanos e irmãs salesianas; e o $6^{\circ}$ Pelotão Especial do Exército Brasileiro ( $6^{\circ}$ PEF do rio Tiquié) composta da maioria de soldados indígenas e oficiais não-indígenas.

Segundo João Costa $(2007)^{317}$ “os Tukano de Pari-Cachoeira são descendente de único pai e única mãe. Os salesianos chegaram, dividiram as famílias colocando sobrenomes diferentes, depois disso, hoje, parece que as famílias descendem de diferentes subgrupos e brigam entre si para controlar a comunidade com se fossem adversários”. Essa divisão gerou forte hierarquização entre os Tukano de Pari-Cachoeira e, hoje, é usado como justificativa pelos irmãos maiores, que se consideram chefes dominarem os irmãos menores. A ordem da hierarquia social Tukano de Pari-Cachoeira é constituída dos seguintes sobrenomes: Machado, Abreu, Brandão Gentil, Costa, Arantes, Maranhão, Fontes, Reis e Castros.

Os membros da família Machado se consideram os chefes dos demais Tukano de PariCachoeira, porque descendem do primeiro filho de Palési. Por isso, ao longo da história de convivência interna e de contato com a sociedade envolvente se destacaram como chefes de Pari-Cachoeira e, atualmente, ainda se impõem diante da comunidade como chefes natos, e procuram sempre atuar como líderes da comunidade. $\mathrm{O}$ evento político que mais enalteceu os membros da família Machado foi o fato de eles terem liderado a origem do movimento indígena do rio Negro e a Fundação da Federação das Organizações Indígenas do Rio Negro (FOIRN), os quais são considerados os "pioneiros", junto com o Álvaro Fernandes Sampaio (mais conhecido como Álvaro Tukano, o pai do movimento indígena do rio Negro). Os Machados que mais se destacaram na história de Pari-Cachoeira no cenário regional e nacional foram os seguintes: Pedro Machado, Benedito Machado, Carlos Machado e Cecília Machado, todos irmãos. Eles representam os pilares do marco histórico que mudou a organização política dos povos indígenas do rio Negro.

Pari-Cachoeira é constituída de cinco vilas: Aparecida, Dom Bosco, Domingo Sávio, São Miguel (localizadas na margem esquerda), e São José (localizada na margem direita do Tiquié).

\footnotetext{
${ }^{317}$ Entrevista concedida no dia 20 de março de 2007 em Pari-Cachoeira. O Sr. João Costa é um dos últimos moradores mais velhos de Pari-Cachoeira, que pertence a família Costa. Vive na vila Dom Bosco. É benzedor e conhecedor das principais histórias do povo Tukano.
} 
a) Vila Aparecida

Figura 18. Vista da vila Aparecida.

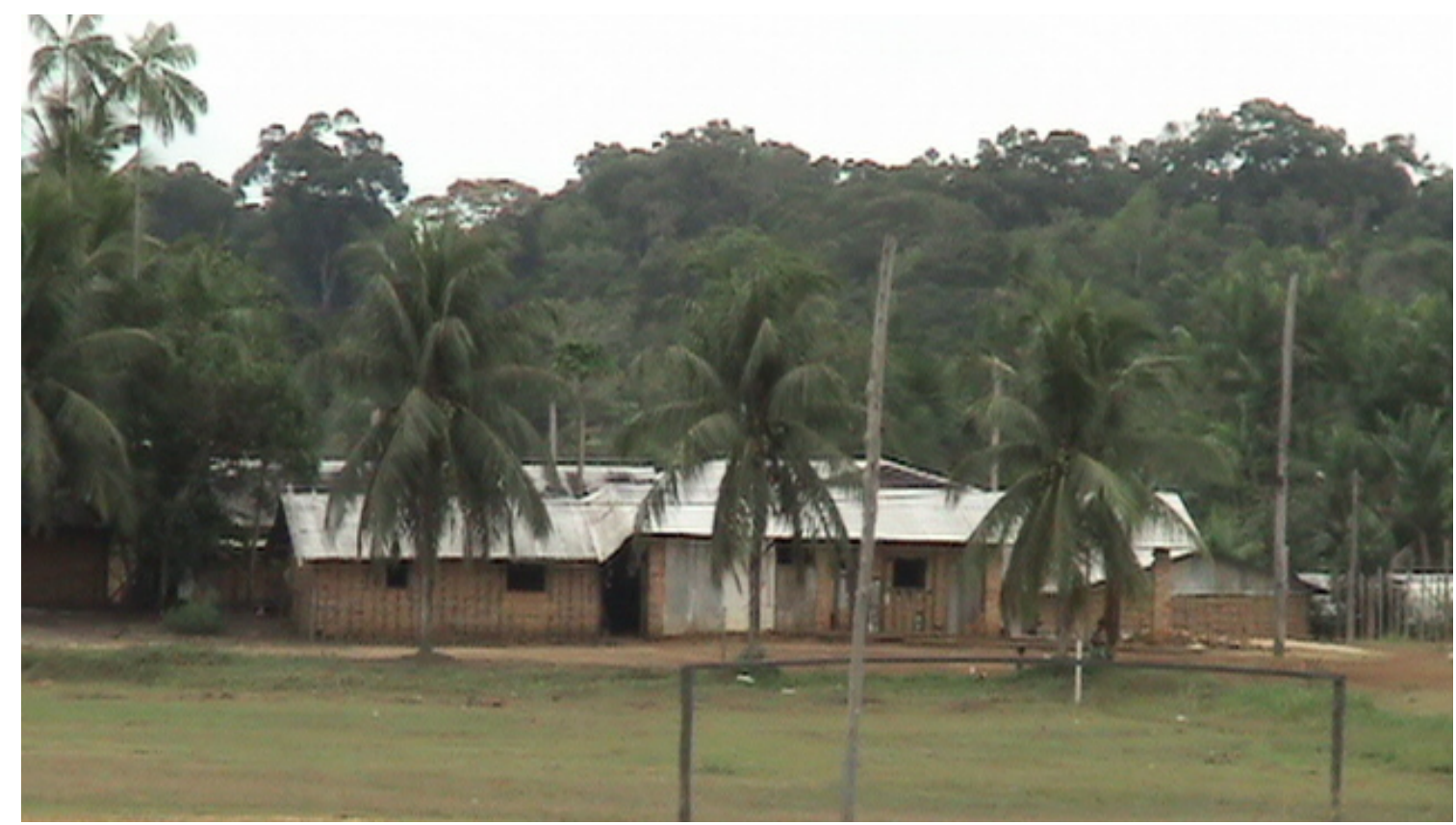

Fonte: acervo do autor, 2007.

A vila Aparecida é habitada exclusivamente pelos Tukano que se consideram os mais tradicionais de Pari-Cachoeira das seguintes famílias: Machado, Brandão, Gentil, Fontes e Castro. Na vila está instalada a antiga Missão Salesiana, construída no início da década 40. A Missão é constituída da Igreja Dom Bosco (ver figura 19), os dois prédios gigantescos, localizados nas laterais da Igreja, que funcionou até 1987 como internato masculino; a escola indígena "Dom Pedro Massa" e residências de missionários (padres e freiras) (ver figura 20) e a Santa Casa, atualmente desativada (ver figura 21).

A Escola Estadual "Dom Pedro Massa" (ver figura 22), onde funciona Ensino Fundamental e Médio, em 2004 foi transformada em uma escola indígena e no mesmo ano, a escola que foi dirigida durante 64 anos pelos padres e freiras da congregação salesiana, a direção da escola foi assumida pelos próprios indígenas de Pari-Cachoeira. Na vila, há outra escola municipal de ensino fundamental que se chama Escola Municipal 12 Tribos (ver figura 23) .

Também na mesma vila, em meados da década de 80, o Exército brasileiro construiu o Hospital Calha Norte que até em 1998 nunca funcionou (ver figura 24). Há anos esse hospital serviu apenas como habitat de baratas e ratos. Somente após duas décadas de abandono, o hospital foi reassumido pelo Exército do $6^{\circ} \mathrm{PEF}$, no entanto em 1998, foi entregue para o Distrito Sanitário Especial Indígena do Rio Negro (DISEI/RN), que hoje dá assistência à saúde indígena do Tiquié e utiliza o prédio como sede e local de atendimento aos doentes em 
parceria com o Exército. Os Tukano dessa vila são casados com tuyukas e dessanas. $\mathrm{O}$ atual líder comunitário chama-se Celestino Castro. O curioso é que nessa vila só residem as famílias tradicionais Tukano de Pari-Cachoeira, talvez isso signifique uma demonstração de poder.

Figura 19. Igreja Dom Bosco.

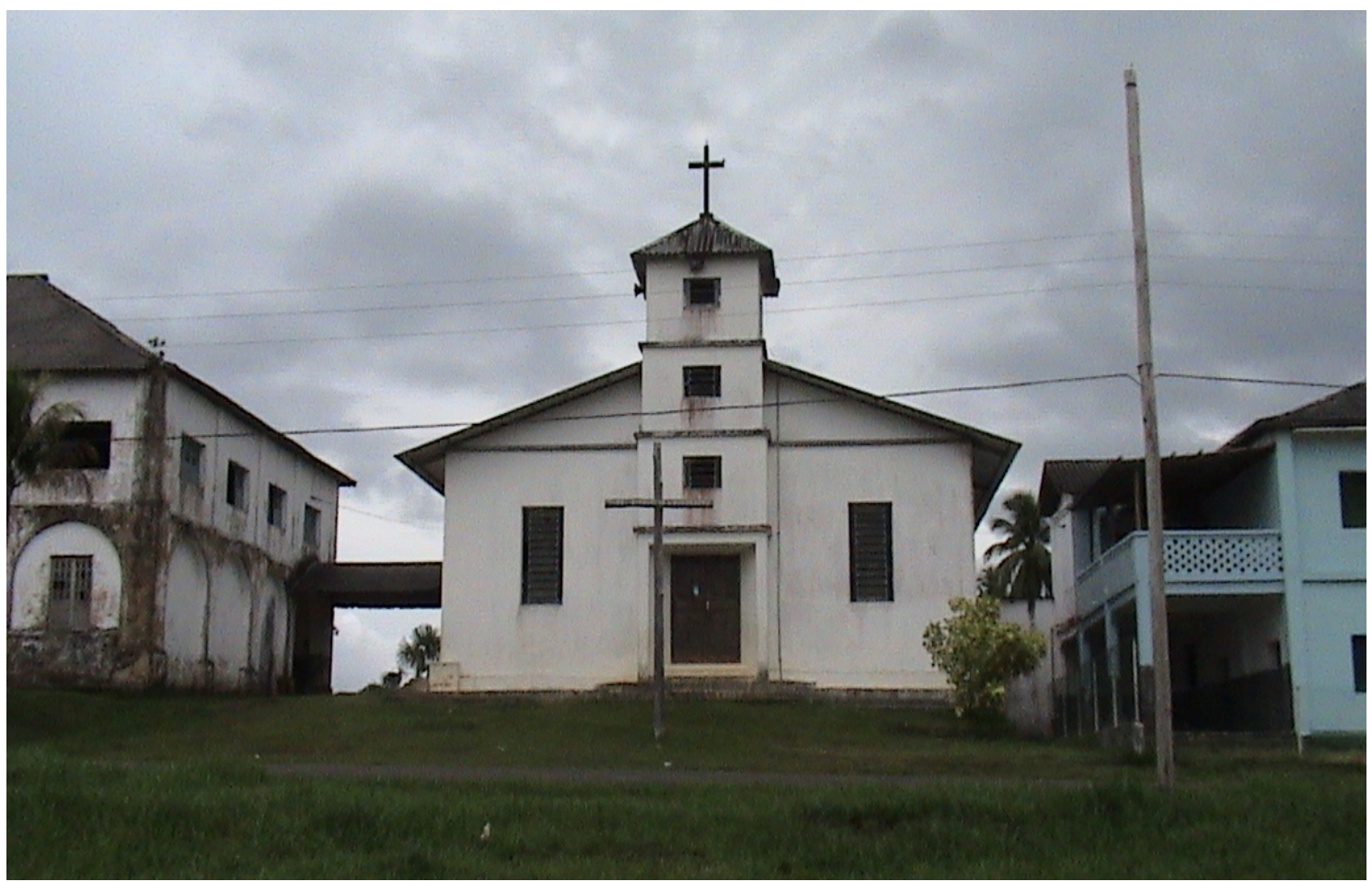

Fonte: acervo do autor, 2007.

Figura 20. Vista geral da Missão Salesiana.

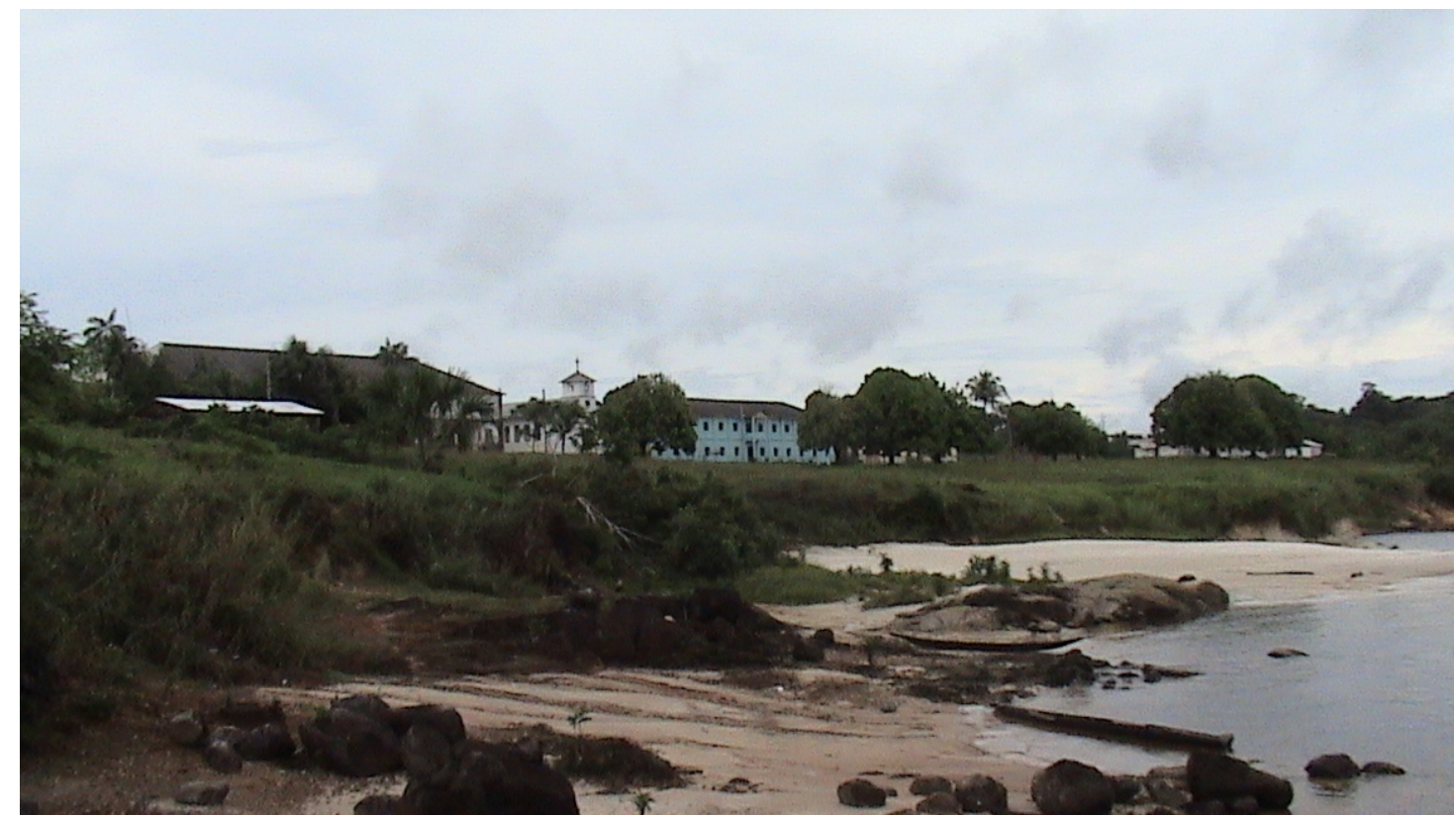

Fonte: acervo do autor, 2007. 
Figura 21. Santa Casa de Pari-Cachoeira.

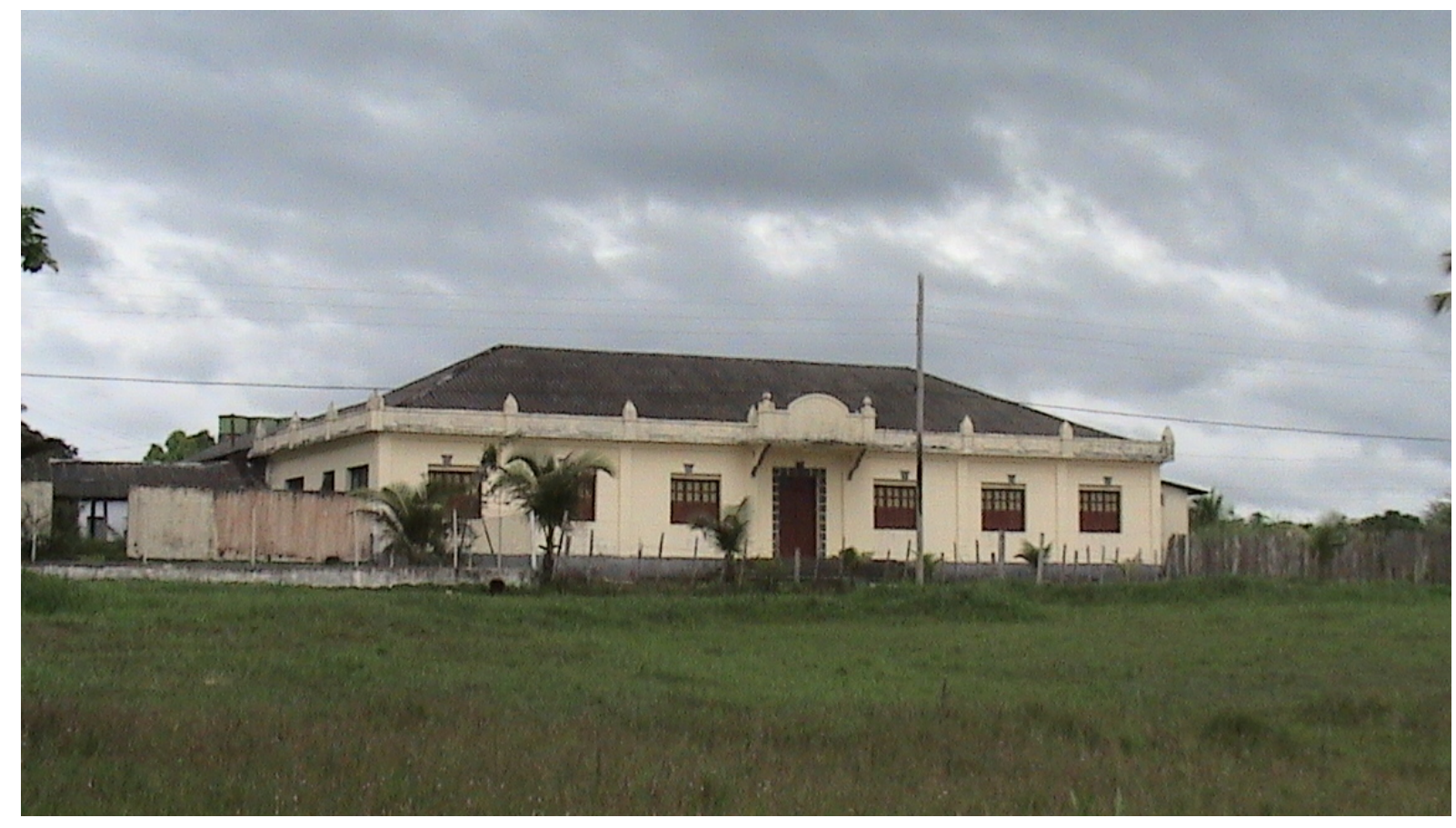

Fonte: acervo do autor, 2007.

Figura 22. Escola Indígena "Dom Pedro Massa".

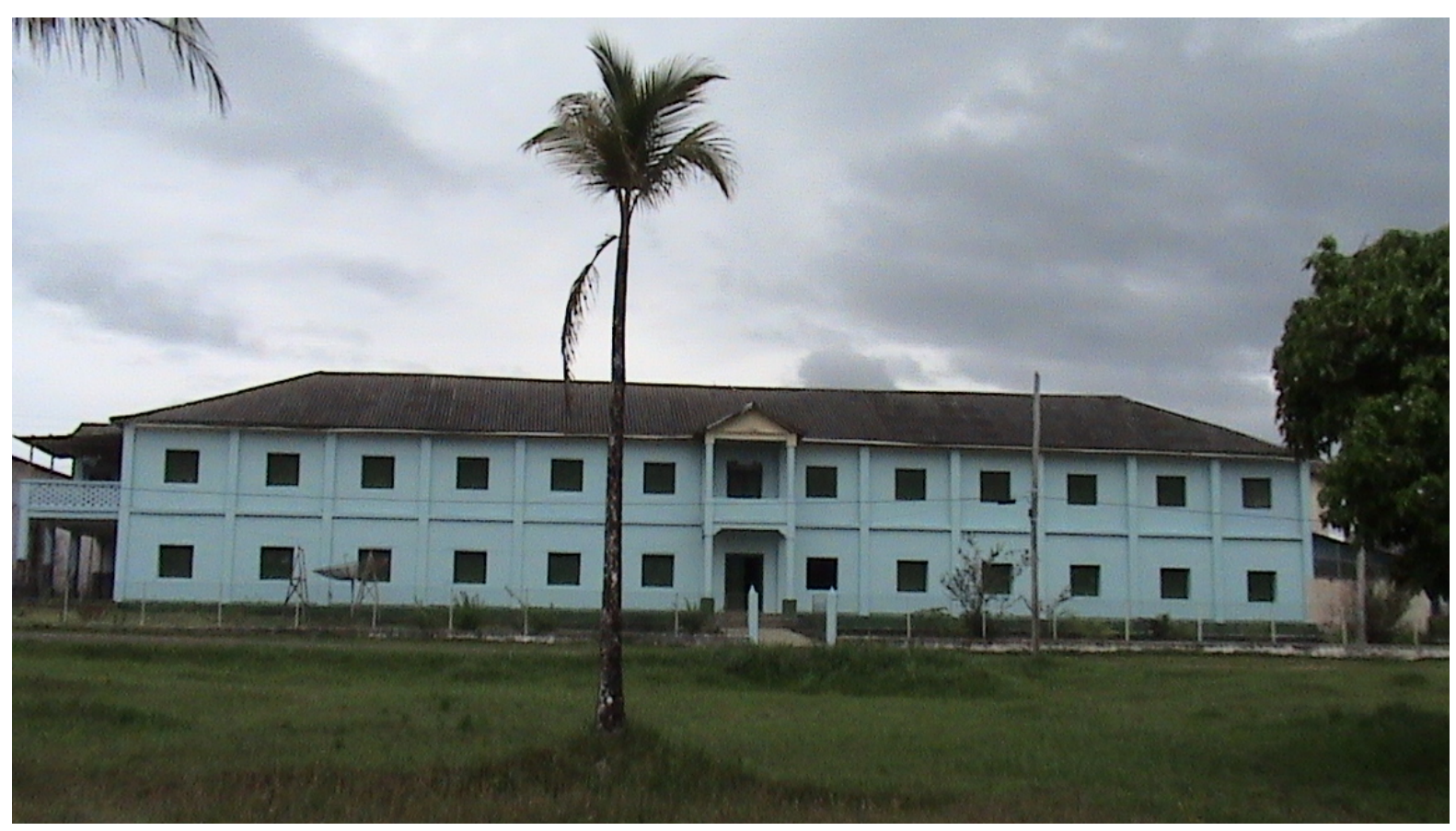

Fonte: acervo do autor, 2007. 
Figura 23. Escola Municipal de Ensino Fundamental 12 Tribos de Pari-Cachoeira.

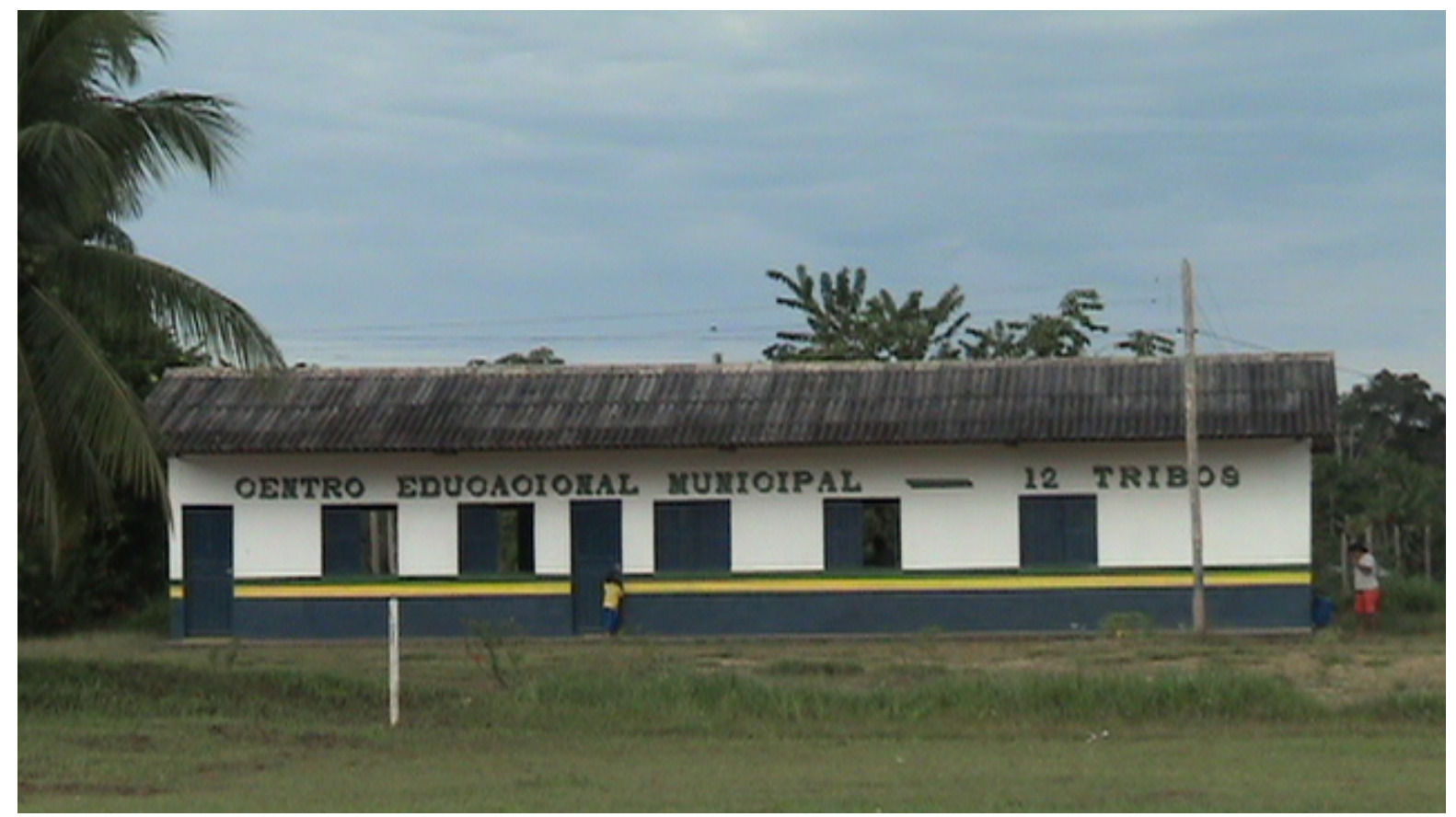

Fonte: acervo do autor, 2007.

Figura 24. Antigo Hospital Calha Norte de Pari-Cachoeira.

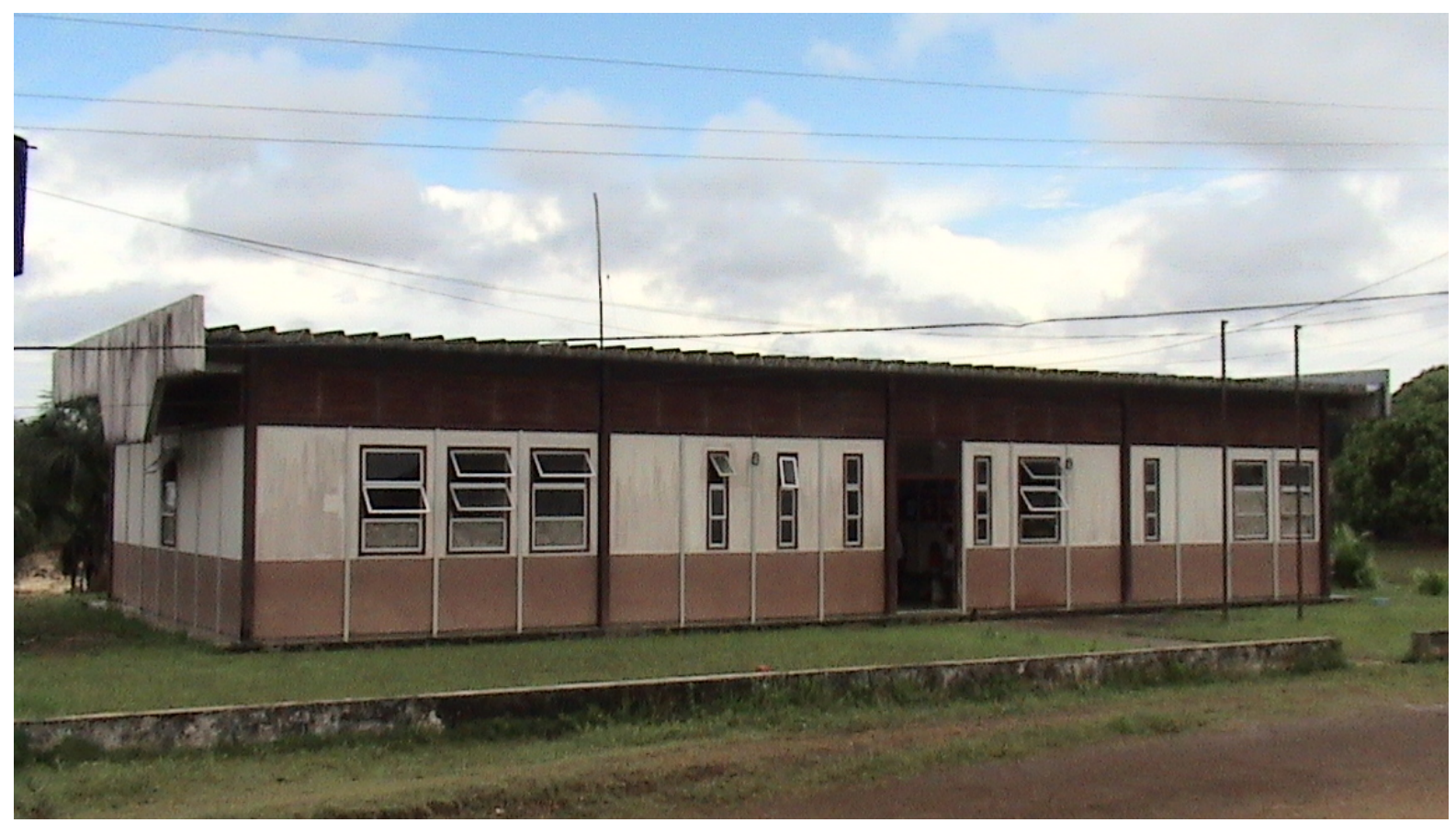

Fonte: acervo do autor, 2007. 
Figura 25. Residências dos Tukano.

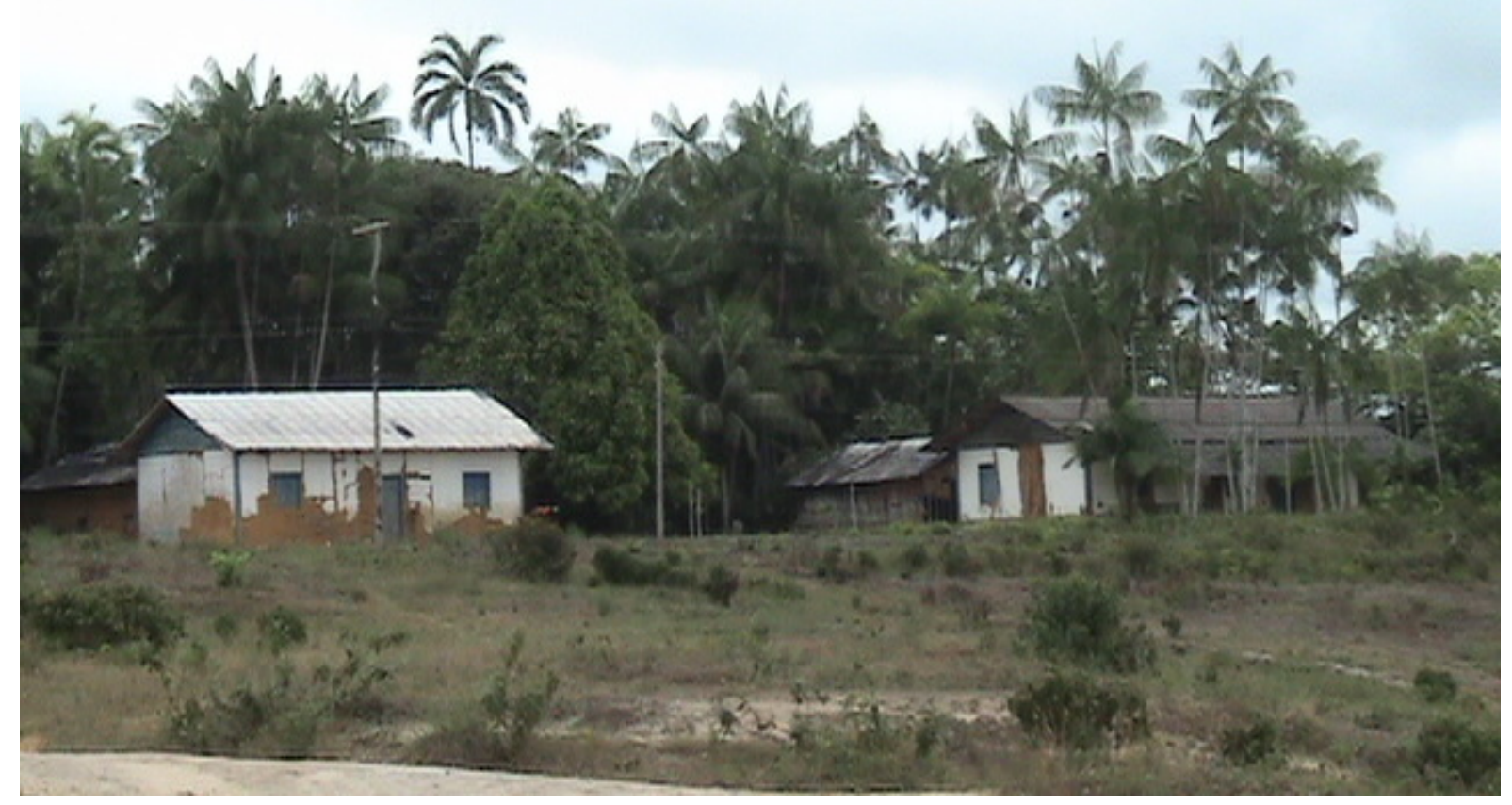

Fonte: acervo do autor, 2007.

A Vila Dom Bosco fica localizada próximo ao aeroporto (ver figura 26) - o aeroporto foi construído na década de 40 pelos indígenas sob o comando de padres salesianos que serviam ao Estado brasileiro. Essa vila é mais heterogênea, pois além dos Tukano tradicionais de Pari-Cachoeira, de famílias Machado, Brandão, Costa e Fontes, residem famílias de outros grupos - e principalmente os Tuyuka. Os Tukanos dessa vila são casados com tuyukas (ver figura 10), dessanas e tarianas. E os Tuyuka são casados com tukanas e desanas. Nas proximidades dessa vila está instalado também o $6^{\circ} \mathrm{PEF}$ do Tiquié com aproximadamente 66 homens entre soldados e oficiais do Exército. O atual líder comunitário chama-se Domingos Brandão. 
Figura 26. Aeroporto e residências de militares de Pari-Cachoeira.

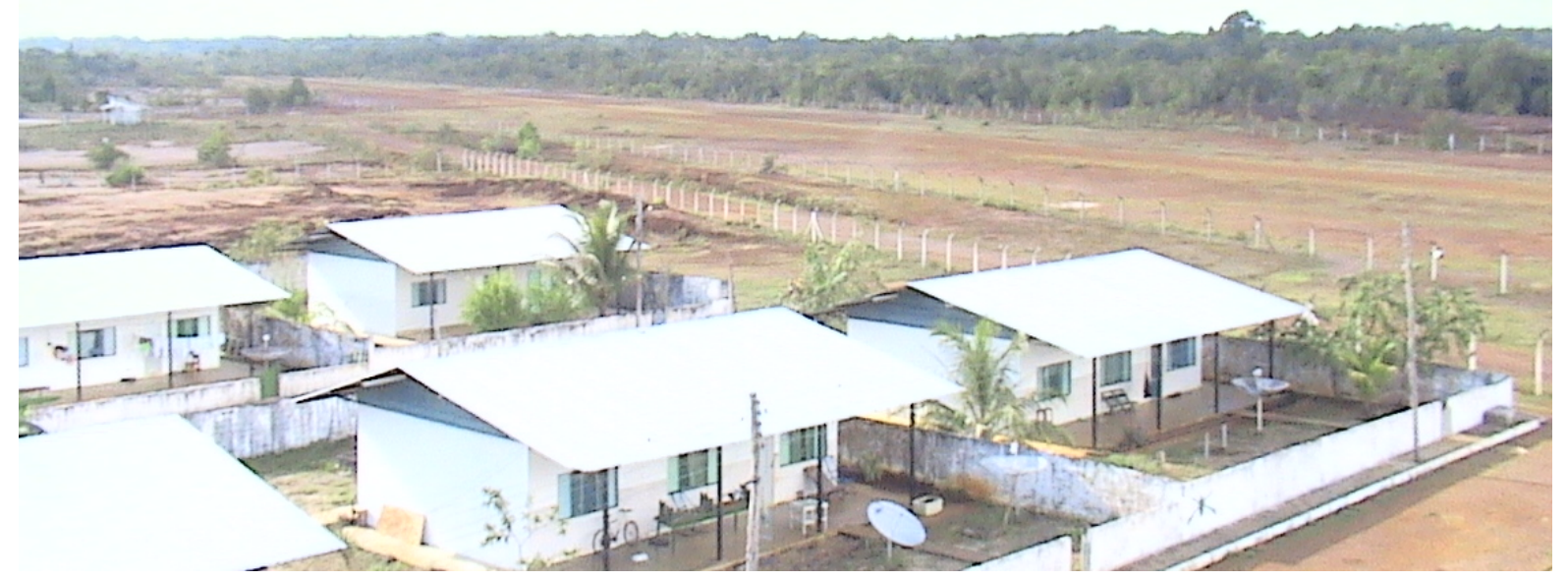

Fonte: acervo do autor, 2007.

Figura 27. Família do Tukano Laureano Massa Costa.

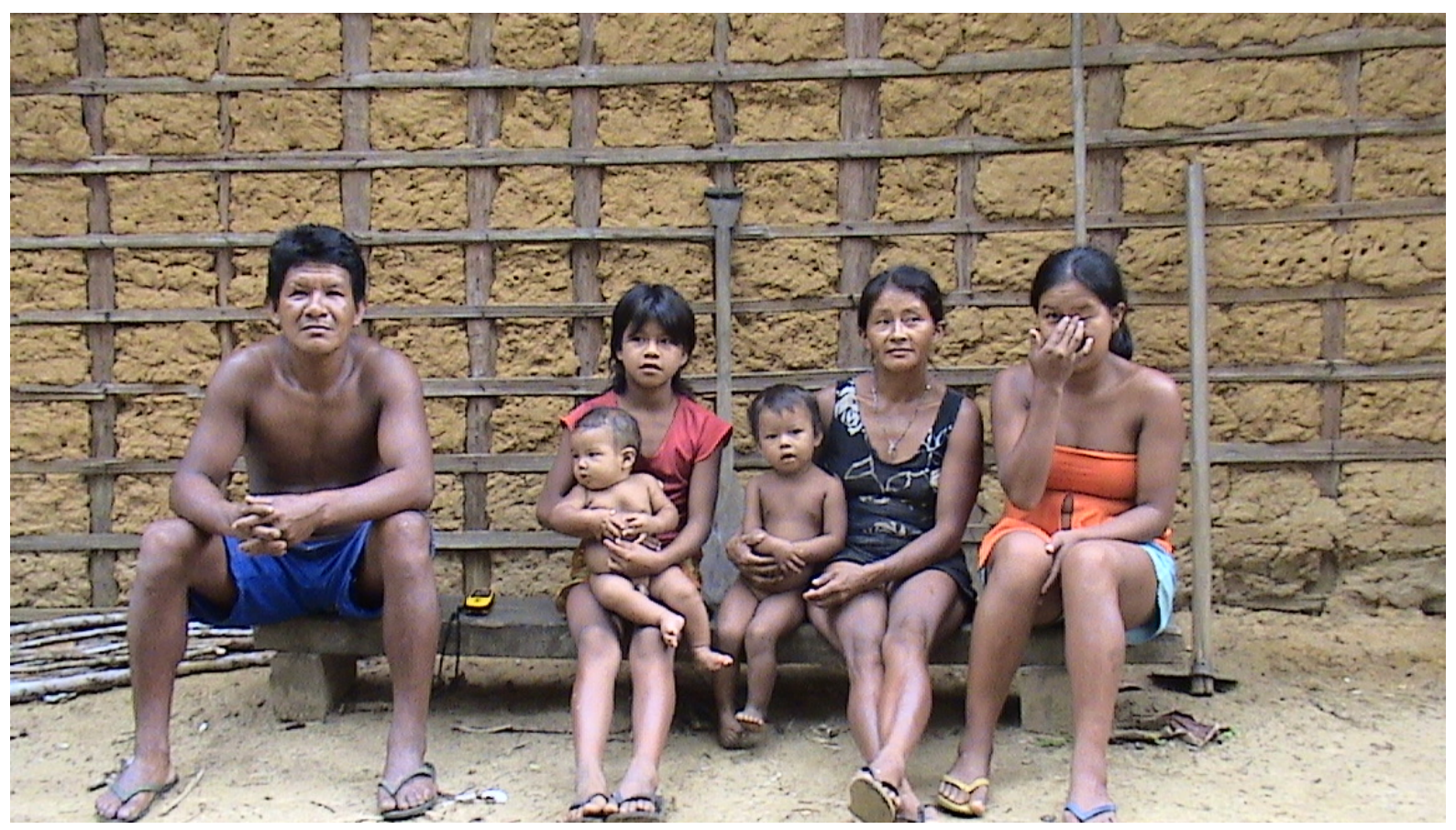

Fonte: acervo do autor, 2007. 


\section{c) Vila São Domingos Sávio}

Figura 28: Família do Tukano Afonso Rezende Arantes.

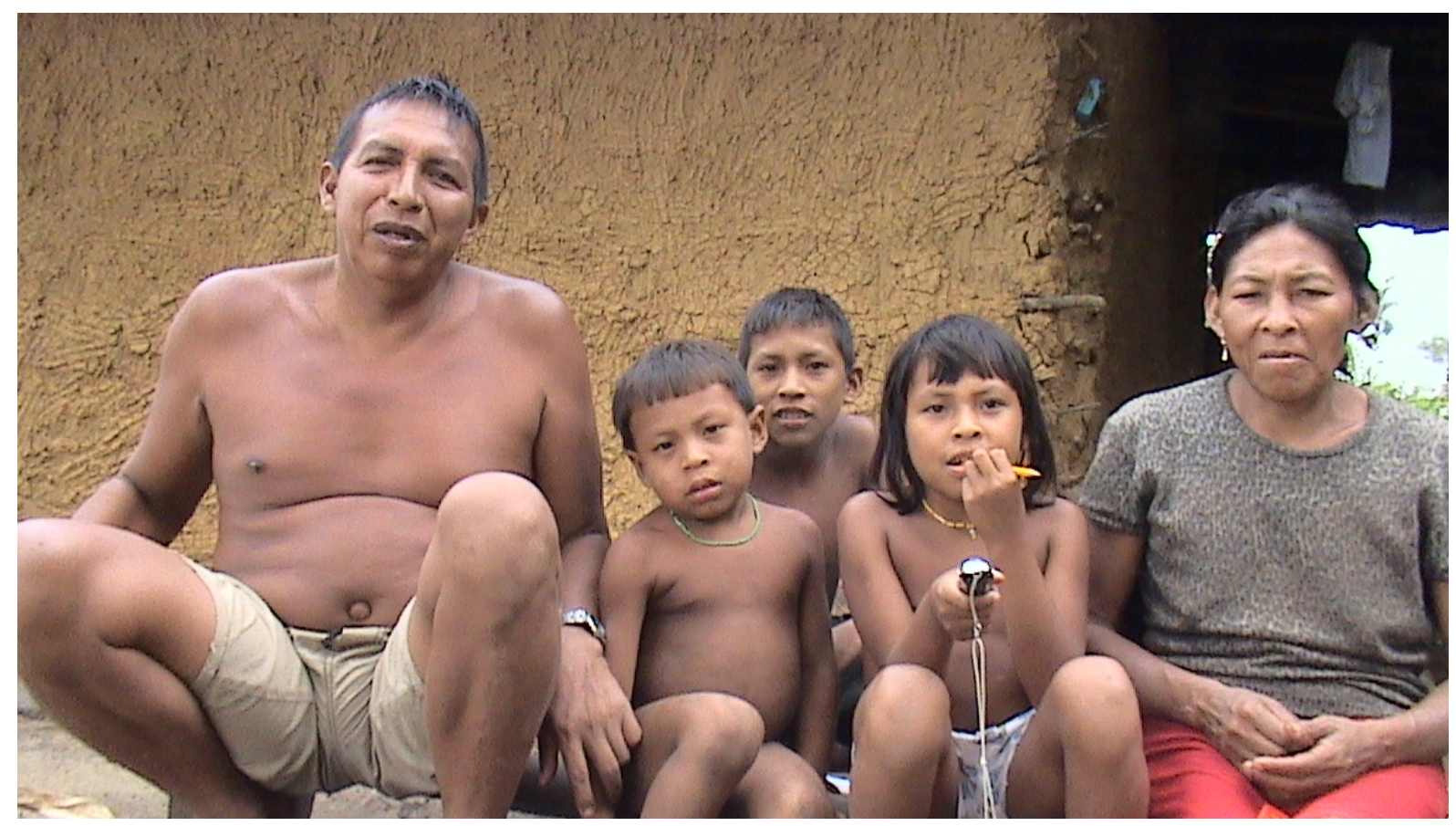

Fonte: acervo do autor, 2007.

A Vila Domingos Sávio é onde há porto de embarque e desembarque de passageiros que viajam de barco o rio abaixo para Taracuá, Iauaretê, São Gabriel da Cachoeira etc. A vila é heterogênea, pois, além das famílias tradicionais Tukano de famílias Arantes (ver figura 28) e Maranhão, vivem os Tukano de outros sibs e comunidades, os Tuyuka e Desanos. Inclusive, o atual líder comunitário é um tuyuka, que se chama Waldemiro Rezende (ver figura 29). Assim como a vila tem denominação de um santo da congregação salesiana, São Domingos Sávio, o centro comunitário também tem a mesma denominação (ver figura 30). 
Figura 29. Líder comunitário da vila São domingos Sávio e suas sobrinhas.

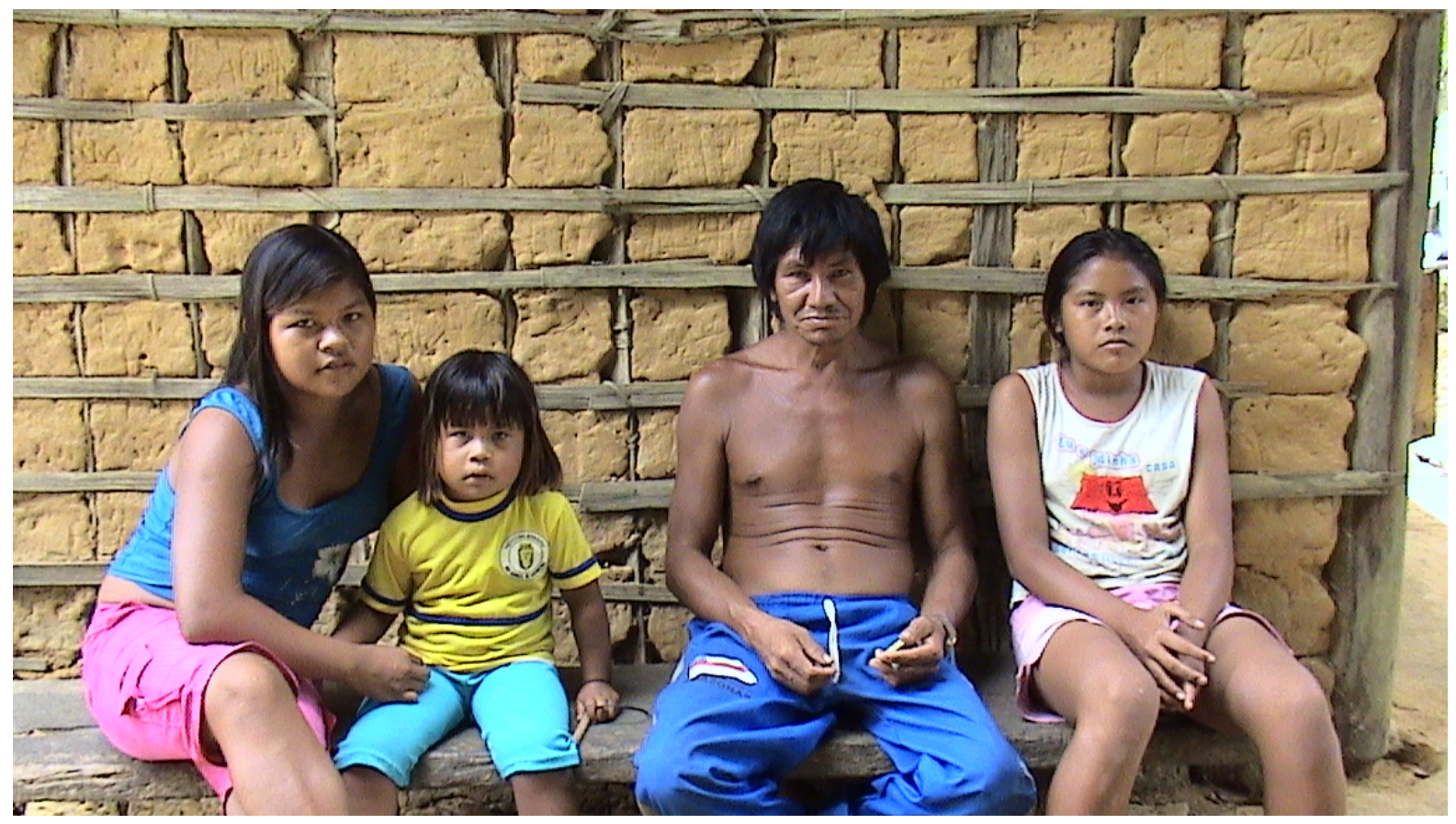

Fonte: acervo do autor, 2007.

Figura 30. Centro comunitário da vila São Domingos Sávio.

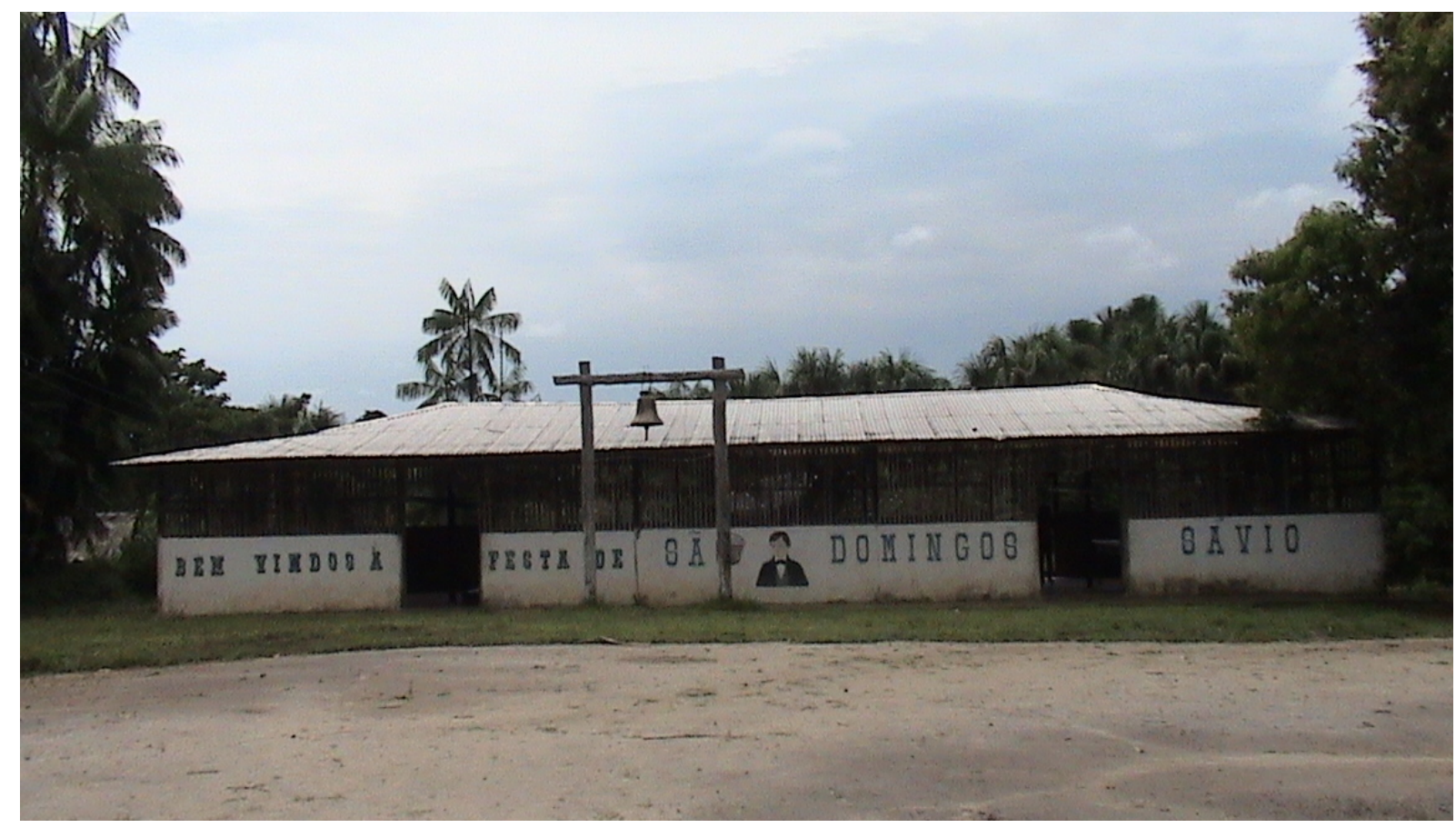

Fonte: acervo do autor, 2007. 


\section{d) Vila São Miguel}

Figura 31. Família Dessano do Umari Igarapé.

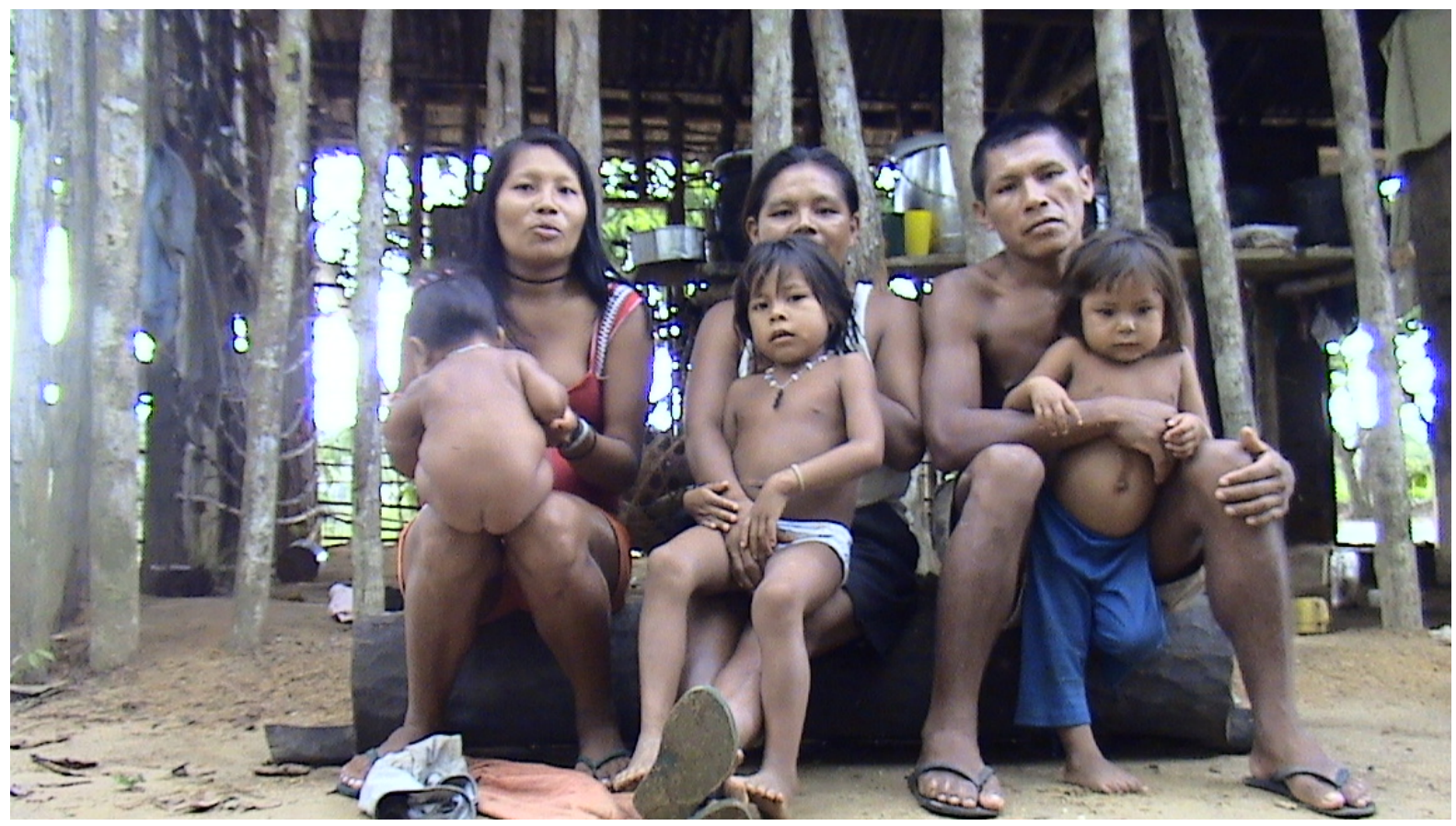

Fonte: acervo do autor, 2007.

A Vila São Miguel é constituída temporariamente (no período do ano letivo) por famílias de comunidades Dessana e Tukano do Umari Igarapé (ver figura 31), afluente do Tiquié; e as famílias de vários povos das comunidades do médio Tiquié, que chegam e constroem suas casas para acompanhar os filhos que estudam na Escola Estadual Indígena "Dom Pedro Massa". O atual líder comunitário é Miriti-tapuio, Arsênio Vaz Lobo, que também é líder geral de Pari-Cachoeira, da Coordenação Indígena de Pari-Cachoeira (CIPAC) (ver figura 32). Nessa vila não mora nenhuma família Tukana considerada tradicional. 
Figura 32. Arsênio Lobo, atual Líder Geral do CIPAC.

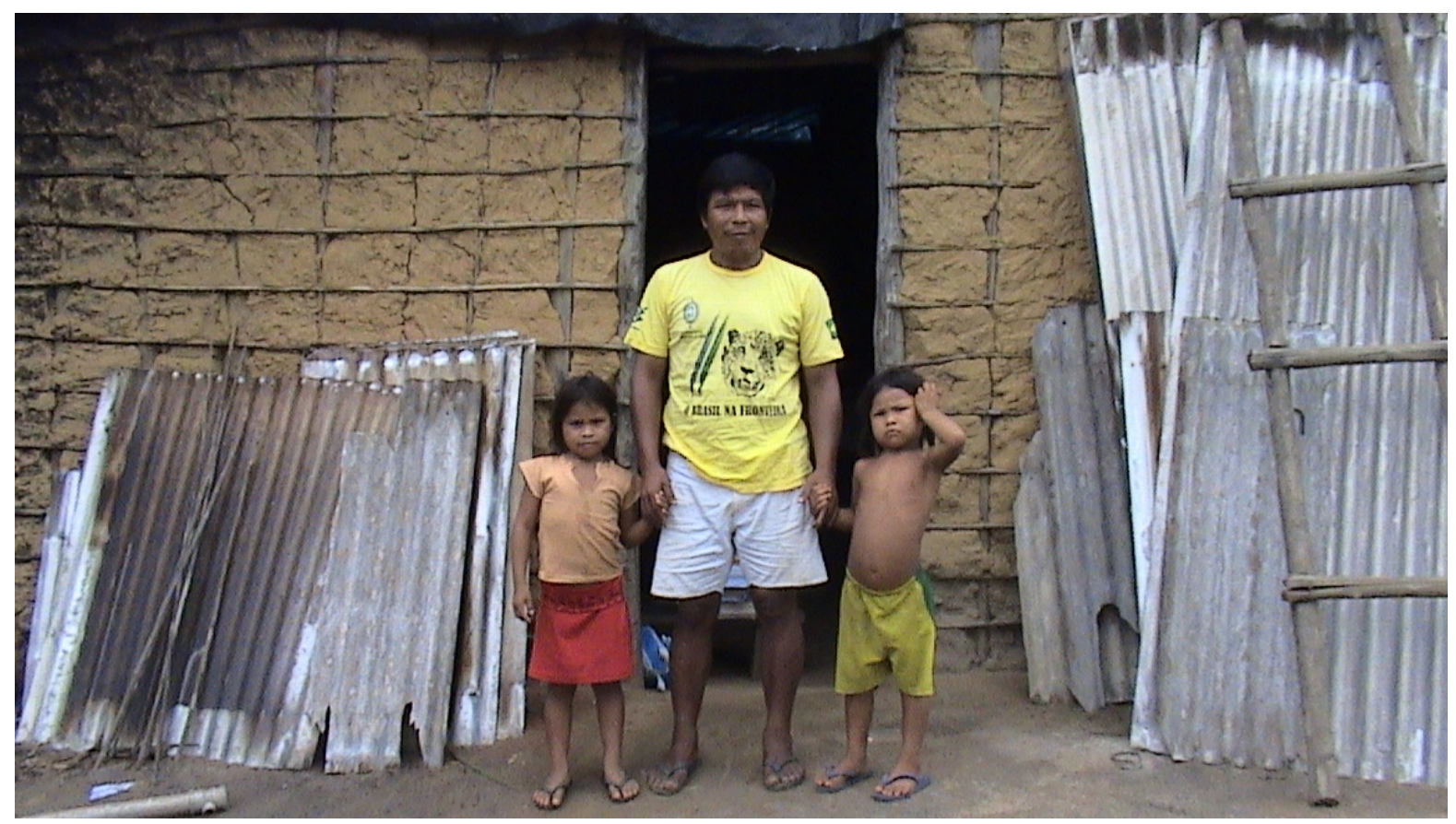

Fonte: acervo do autor, 2007.

e) Vila São José

A Vila São José é formada por seguintes famílias tukanas: Machado, Costa e Gentil. É a única vila de Pari-Cachoeira, onde a maioria de mulheres dos Tukano são tuyukas, e o atual líder comunitário chama-se Leopoldino Gentil, casado com uma Tuyuka. Essa vila tem um marco histórico muito importante para os atuais Tukano, porque foi aí que se instalaram e residiram os seus primeiros ancestrais que migraram do rio Papuri (ver item 4.1.1).

Os Tukano, Tuyuka, Desano, Miriti-tapuio, etc., que residem em Pari-Cahoeira são os que migraram de outras regiões do Uaupés, ou seja, nenhuma família que, hoje, reside em Pari-Cachoeira são moradores a ponto de serem reconhecidos como habitantes que vivem desde os tempos imemoriais. Isso vale para "todos os demais grupos" que vivem nas margens e afluentes do Tiquié; exceto os Maku que são habitantes milenares e imemoriais. Por essa razão, a história de convivência entre os indígenas da comunidade de Pari-Cachoeira e os demais povos do Tiquié, do território brasileiro, é marcada por conflitos políticos. De um lado, os Tukano de Pari-Cachoeira defendem que são descendentes dos primeiros ancestrais Tukano que migraram e se instalaram na comunidade; do outro lado, todos os outros povos o Tiquié contestam essa versão dos Tukano de Pari-CAchoeira, principalmente os Dessano das comunidades de São Sebastião e Tukano de Jandu, situados nas margens direita do igarapé 
Umari, afluente do Tiquié, porque argumentam que os pais dos atuais Tukano de PariCachoeira chegaram depois deles.

Veja em seguida, quem são os Tukano de Pari-Cachoeira e as versões polarizadas de nossos sujeitos da pesquisa.

\subsubsection{Quem são os Tukano de Pari-Cachoeira?}

Atualmente, de maneira mais intensa, há um motivo histórico que está gerando o desentendimento político e social mais agudo na convivência entre os indígenas de PariCachoeira, a questão é: quem chegou primeiro na comunidade e no Tiquié, e como chegou. Essa é uma discussão dual, onde de um lado há pessoas que sustentam pontos de vistas para tentar manter o domínio político local e do Tiquié; e, por outro lado, existem pessoas que não aceitam o domínio dos Tukano de Pari-Cachoeria e tentam mostrar o outro lado da história de migração, que parece ser mais real, porque é sustentada por todos os outros grupos do Uaupés, inclusive pelos Tukano que moram no território colombiano.

Veja a seguir a polarização de versões da história de migração dos Tukano de PariCachoeira, que é o motivo de tensão na relação comunitária. Primeiro apresentamos a versão resumida comungada e defendida pelos Tukano de Pari-Cachoeira e que foi relatada por um dos principais líderes da comunidade; segundo destacamos alguns sujeitos da pesquisa que mostram outra versão defendida por todos os demais grupos do Uaupés, inclusive pelos Tukano colombianos. Para obter respostas de nossos sujeitos da pesquisa,fizemos os seguintes questionamentos: Quem eram os primeiros habitantes do Tiquié e de Pari-Cachoeira? Quando e como chegaram os primeiros Tukano de Pari-Cachoeira no Tiquié?

De acordo com o Tukano Yupuli (nome de benzimento), Afonso Machado ${ }^{318}$ :

Quando o nosso avó adentrou no rio Tiquié, encontrou os seguintes povos: Wayała, Waupołã, Detuałã, Pãłẽłoã, Muhteã, Buhpumahsã, Yahpiamhsã, Ẽmoãmahsã, Oá (Sẽrã). Esses indígenas eram valentes e guerreiros.

Os não-indígenas, a turma de Manduca Albuquerque no final do século XIX, que chegaram no Tiquié prenderam e recrutaram os homens desses grupos para o trabalho escravo nos piaçabais do alto, médio e baixo rio Negro. Com isso espantaram os demais grupos para outras regiões do Tiquié, os quais muitos fugiram com medo de serem pegos.

O nosso avô era um mestre de músicas tradicionais Tukano (Bayâ). Segundo as nossas tradições Tukano, dentro da nossa hierarquia, nós, Tukano de Pari-Cachoeira, fazemos parte de uma classe nobre; no entanto, acima da gente há outros subgrupos mais nobres, como por exemplo, Wauloa etc.

Desde o começo, o nosso subgrupo não teve muita prole, talvez, porque éramos os filhos mais próximos do criador, depois também porque os nossos ancestrais priorizavam à prática dos

\footnotetext{
${ }^{318}$ Entrevista concedida pelo Sr. Afonso MACHADO, no dia 14 de março de 2007, na sede do CIPAC, vila Aparecida, Pari-Cachoeira
} 
rituais de danças e músicas. Na época, o nosso avô tinha uma filha que casou com um tariano. Esse tariano (o genro do velho), segundo meu tio Manuel Machado, foi empregado dos primeiros não-indígenas que andaram recrutando os índios do Tiquié. Nas viagens ao Tiquié percebeu que existiam muitos peixes e, além disso, viu uma cachoeira muito bonita. Depois que casou com a filha do nosso avô, contou-lhe as maravilhas do Tiquié e propôs que o sogro migrasse para esse rio, onde tinha uma cachoeira muito bonita e muitos peixes.

E disse o seguinte: vai para o Tiquié, porque lá é um lugar maravilhoso. Aqui você está sofrendo demais e ninguém te respeita.

Em seguida, o velho decidiu migrar para o Tiquié. A rota de sua viagem se deu pelo rio Uaupés. Antes de chegar na cachoeira de Pari-Cachoeira, tentou construir duas comunidades: um no baixo Tiquié e outro no médio Tiquié, onde hoje é a comunidade de São José. Enquanto estava em São José, resolveu visitar a cachoeira, onde hoje é Pari-Cachoeira, quando chegou pela primeira vez encontrou a ilha separada por duas cachoeiras. A ilha guardava marcas de guerras e dizimação de humanos; estava toda cercada de estacas, construída e armadas pelos indígenas para guerrear com os não-índios. Dentro da cerca havia muitas caveiras e restos mortais de grupos indígenas que tentaram resistir a invasão dos agentes externos, mas que foram mortos. Vários indígenas do Uaupés guerrearam ao lado dos não-índios para matar, prender e expulsar os índios do Tique. O lugar era assombroso.

$\mathrm{O}$ nosso avô adentrou pelo Tiquié como se o rio fosse dele. Ele se sentia o dono desse lugar, porque foi o primeiro indígena do Uaupés que chegou aqui. Os demais chegaram depois; alguns migraram via terrestre, pela floresta; o nosso avô migrou pelo Uaupés e depois entrou no rio Tiquié.

Os Tukano do Umari Igarapé têm outra versão. Quando participei do seminário promovido por eles em São Sebastião, disse-lhes o seguinte: nós, Tukano de Pari-Cachoeira, constituímos um grande grupo; somos netos de um só avô, no entanto acabamos discriminando um ao outro e criamos divisões internas, devido os sobrenomes diferentes que geram discriminações; esse fato se tornou um problema e um desafio para nossa convivência, que hoje tentamos resolver. Falei que no Tiquié, há vários subgrupos Tukano, por isso, cada família deve conservar o que seus antepassados transmitiram sobre as tradições e as histórias de migrações.

A seguir temos a segunda versão da história de migração dos Tukano de PariCachoeira, narrada por Dessano Henrique Pimentel Paz e a guerra entre os indígenas do Tiquié contra os não-indígenas que invadiram a região:

$$
\text { Wahati (nome de benzimento) Henrique Pimentel Vaz }(2007)^{319} \text { relatou o seguinte: }
$$

Os nossos pais e avó Dessano, do subgrupo do qual pertenço, migraram do rio Papuri ao Umari Igarapé e depois de muitos anos viajando pelo mato chegaram ao Tiquié. O motivo que levou a migração foi a falta de comida, que foi provocada pela escassez de peixes e de caça na região do Papuri. Outro fator que provocou a mobilização dos meus pais foi a disputa pelo domínio de caranazais entre os próprios Dessano. Cansados de brigas e conflitos internos, os meus avós decidiram migrar para essas regiões do Tiquié.

Para chegar no Umari Igarapé, os nossos pais passaram dezenas de anos atravessando a floresta. Ao longo do caminho construíram várias Casas Tradicionais (Bahsawiserı), onde viviam por vários anos. Como quaisquer seres humanos que vivem em grupos, nos dias que promoviam festas brigavam entre si e alguns membros se separavam. Devido os conflitos, os Dessano que se separavam construíam outras novas habitações em diferentes lugares, sempre em direção ao Tiquié. Passaram anos e anos por essa caminhada, onde em cada habitação construíam Casas Tradicionais (Bahsawihserı) e faziam roças para plantar maniva e plantas frutíferas.

Após dezenas de anos que meus avós construíram uma habitação próximo cabeceira do Umari Igarapé, os Tukano do Papuri chegaram para pedir a filha do nosso avô para que casasse

${ }^{319}$ Entrevista concedida por Sr. Henrique Pimentel VAZ, no dia 15 de março de 2007 em Pari-Cachoeira. O Sr. Henrique Pimentel Vaz é sogro do Sr. Arsênio Lobo, líder geral de Pari-Cachoeira. 
com o filho deles que seria o futuro avô desta minha mulher. O ambiente onde estávamos morando ficava no meio da selva entre Umari Igarapés e Papuri. Depois que casou com a nossa parenta dessana, pediu aos seus sogros para viver perto deles, que eram os meus pais. Os Tukano do subgrupo Bu'upõłã, o qual a minha esposa pertence, souberam que o filho havia decidido viajar para morar definitivamente com os seus sogros. Por isso, com medo de perder o filho, os pais Tukano também decidiram morar junto com os Dessano. Aí começaria a migração do primeiro subgrupo Tukano ao Tiquié. Antes de quaisquer subgrupos Tukano, nós, Desano, chegamos primeiro no Umari Igarapé, no entanto, o subgrupo Tukano da minha esposa foi o primeiro que chegou ao Tiquié.

Os Desano só descobriram o Umari Igarapé, porque um de nossos avôs que era chefe e comandava a Casa Tradicional resolveu procurar rios onde pudesse pescar para conseguir alimentos para o sustento de seus familiares, porque o número de seus membros havia aumentado com o passar de anos. Por causa desse aumento começou faltar alimento para os membros da habitação. Após alguns dias andando na mata encontrou o Umari Igarapé, onde encontrou muitos peixes. Na volta à habitação o velho contou aos seus familiares que encontrou um rio onde havia muitos peixes, depois da descoberta o grupo decidiu migrar para a cabeceira do Umari Igarapé. E os Tukano Bu'upõłã acompanhavam o nosso avô.

Depois que se instalaram na cabeceira do Umari Igarapé, os avôs desta minha mulher, os Tukano Bu'upõłã, descobriram o Tiquié e esta cachoeira de Pari-Cachoeira. Não foram nem os meus pais Dessano que descobriram o Tiquié, foram os Tukano Bu’upõłã. Depois que encontraram o Tiquié, decidiram migrar para esta localidade. O genro Tukano falou o seguinte para o seu sogro Dessano: descobri um rio grande e uma cachoeira muito bonita. Os meus pais e eu viajaremos para morar lá, vamos esperar vocês por lá. E o velho concordou. Assim, deixaram os seus sogros, na cabeceira do Umari, vieram embora para o Tiquié. Segundo meu pai, que já faleceu, a primeira Casa Tradicional Tukano foi construída onde hoje é a residência do Tancredo Brandão (Tukano de Pari-Cachoeira) e o centro comunitário da vila Aparecida (ver figura 33). Por isso, digo que os primeiros Tukano que chegaram aqui em Pari-Cachoeira foram do subgrupo Tukano de minha esposa: os Tukano Bu'upõłã.

Enquanto os nossos cunhados se instalavam aqui, nesta comunidade, os meus pais ainda viviam na cabeceira do Umari Igarapé. Os nossos pais Desano não chegaram a se instalar no Tiquié, apenas preferiram permanecer no Umari. Somente depois de vários anos que migraram onde hoje é a comunidade de São Sebastião.

Figura 33. Centro Comunitário da Vila Aparecida, Pari-Cachoeira.

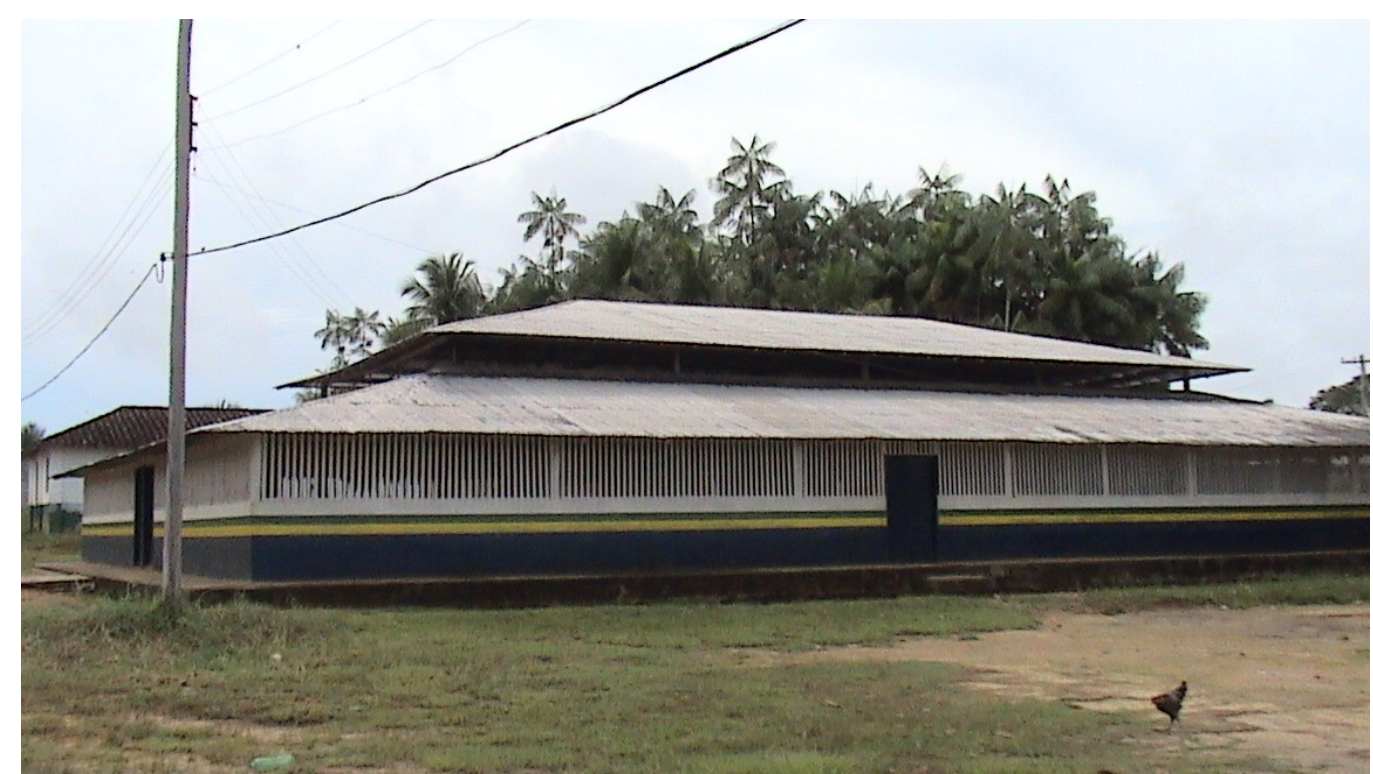

Fonte: acervo do autor, 2007.

Nessa época, os atuais habitantes Tukano de Pari-Cachoeira moravam em Piracuara, no alto Papuri (Colômbia). Esses Tukano ainda não moravam aqui. 
Quando os Tukano Bu'upõłã chegaram aqui, nesta cachoeira, já viviam outros indígenas que se chamavam Wayirã (em Desano) ou Wayała (em Tukano). Hoje, ainda há marcas dessa presença indígena. Por exemplo, nas margens do caminho que liga Pari-Cachoeira e a comunidade de São Sebastião existem capoeiras que eram deles, que são resquícios de suas habitações e roças. Eles não moravam aqui nessa margem. Só desciam para este rio para pescar. Agora, de acordo com nossa história da emergência esse rio é deles, os donos desta cachoeira são os Wayirã.O meu avô foi quem transmitiu essa história para o meu pai; e o meu pai transmitiu esse conhecimento para mim. Eu ainda cheguei a ver alguns esteios fincados pelos Wayirã. Agora, não têm mais, apodreceram.

Um dos meus avos se chamava Joanico, era policial de Manduca e sabia de tudo que existia e acontecia aqui na área do Tiquié porque viajava com Manduca para prender e matar os índios do Tiquié. Antes de ser policial, trabalhava em seringais de Manduca na área de Manaus. Depois de vários anos trabalhando com os portugueses, foi nomeado policial que serviria ao Manduca no rio Negro. Quando recebia ordens para pegar ou matar indígenas e não-indígenas apenas cumpria, ou seja, na verdade era o capitão do mato.

O português Manduca Albuquerque ${ }^{320}$, foi quem espantou exterminou os Wayirã com a ajuda de outros indígenas do rio Negro. Segundo os nossos pais, Pari-Cachoeira foi o lugar de muitas guerras entre indígenas e os homens do Manduca. O Manduca perseguiu e prendeu quase todos os membros Wayirã dentro de jaulas de madeiras e os exterminou. Você vê que aqui em Pari-Cachoeira, além dessas duas cachoeiras, tem uma ilha rodeada de corredeiras. É nessa ilha que Manduca prendeu, surrou e matou os Wayirã.

Outros povos que viviam no Tiquié se revoltaram contra o Manduca, porque não aceitavam que seus parentes fossem exterminados daquela forma, por isso decidiram se unir para guerrear contra o português sanguinário. Os indígenas se armaram com cercas de madeira para contra-atacar os invasores. Flecharam e mataram muitos homens de Manduca, porém não conseguiram expulsá-los porque as suas armas não eram tão potentes com a de Manduca. Enfim, os indígenas se renderam, alguns conseguiram fugir, outros foram presos e mortos dentro da cerca que existia nessa ilha. Assim, o Tiquié foi dominado pelo Manduca

Durante e após a guerra, alguns os grupos que moravam desde os tempos imemoriais, conseguiram fugir, outros foram completamente dizimados. Os que conseguiram fugir das matanças de Manduca e seus irmãos, hoje, devem viver no território colombiano ou em outras regiões da Amazônia. De vez em quando, a gente ouve notícias que eles querem de volta os seus antigos territórios.

Foi somente depois que os donos desse rio Tiquié foram expulsos pelo Manduca, que os atuais Tukano de Pari-Cachoeira, os descendentes de Pałẽsi, que também são denominados de Batitorołã, migraram de Piracuara à Pari-Cachoeira, onde se instalaram para dominar o rio Tiquié.

O avô desses Tukano não tinha um pai declarado, nasceu de uma mãe solteira, mas era Tukano. Segundo os Tukano de Piracuara, o provável pai do menino pertencia de um subgrupo considerado servo. Talvez, apenas por consideração e respeito, atualmente os Tukano Bu'upõłã consideram os seus parentes de Pari-Cachoeira como seus irmãos maiores. Na verdade não são, porque os seus próprios familiares de Piracuara dizem que eles são assim.

Os pais desses Tukano, durante os anos que moraram em Piracuara provocaram muitos conflitos e estragos entre seus parentes, por essa razão foram expulsos da comunidade pelos seus próprios parentes. Foi assim que eles migraram para o Tiquié, também pelo mato, pois sabiam que aqui moravam seus outros parentes Tukano Bu'upõłã. Quando chegaram aqui, os ancestrais da minha esposa, os Tukano Bu'upõłã já moravam aqui em Pari-Cachoeira. Depois que os seus parentes chegaram, pediram para que construíssem suas habitações na outra margem do Tiquié, na margem direita, onde atualmente é Vila São José. Aí é a terra "tradicional" desses Tukano. Neste lado, na margem esquerda só moravam os Bu’upõłã, porque os avós da minha esposa não queriam que os seus novos parentes morassem junto com eles, devido a fama negativa deles. $\mathrm{O}$ primeiro chefe, o pai, o avô dos atuais Tukano se chamava Metiri.

O chefe dos Bu'upõłã foi o primeiro quem recebeu os missionários em Pari-Cachoeira. Ele queria que os padres construíssem a missão na margem esquerda, por isso quis que os Tukano recém chegados morassem na outra margem do rio. No entanto, não demorou muito tempo que os

${ }^{320}$ Manduca Albuquerque era português que morou em Bela Vista, no baixo Uaupés, no final do século XIX; era agente do Serviço de Proteção ao Îndio (SPI) (Álvaro Fernandes SAMPAIO, 1983). 
Tukano que moravam na margem direita ficaram doentes, pois foram atingidos por uma epidemia de diarréia. Com o medo que a situação piorasse, alguns começaram atravessar para a margem esquerda, onde aos poucos foram dominando e controlando a comunidade. Agora estão aqui até hoje.

Os seus avós não vieram pelo Uaupés e nem adentraram pelo Tiquié.

Essa história não é aceita, principalmente, pelos Tukano desta comunidade. Se você entender o contexto atual, essa história contradiz a versão deles. Somente as pessoas mais antigas que compreenderão a verdadeira história, porque ela contém informações que podem ferir a moral dos que defendem outra versão, mas isso que é o importante de uma história, a contradição. A única coisa que exige das pessoas interessadas é saber escutar a versão do outro ou da maioria; é saber ser humilde para reconhecer que a sua história pode não ser verdadeira e aceitar a verdade. Se as partes não se esforçarem para entender ao outro pode gerar muitos conflitos. É o que ocorre aqui nesta comunidade.

Se a gente for aprofundar nessa questão de sermos ou não sermos os primeiros habitantes do Tiquié, perceberemos que nenhum grupo indígena que aqui vive é descendente dos primeiros habitantes, pois todos somos estrangeiros, todos migramos das regiões do Uaupés, do Papuri ao Tiquié. Alguns vieram pelo rio, outros, como os, Tukano Bu'upõãa, os Tukano de Pari-Cachoeira, os da comunidade de São José (situada na margem direita do Tiquié, Baixo Tiquié) migraram via terrestre. Como eu disse, os verdadeiros habitantes tradicionais foram expulsos por Manduca e devem estar espalhados por aí.

Podemos observar que os Tukano (Dahseá), Dessano, Tuyuka, etc., do Tiquié não são habitantes dos tempos imemoriais. Os primeiros povos que emergiram no Tiquié, de acordo com a história de origem dos povos indígenas do Uaupés, são outros grupos, tais como: Tatuyo, Maku, Bará, Barasano, Kubeu etc (Avelino Dutra e Laureano Dutra/2007 ${ }^{321}$ ). Estes, sim, são considerados habitantes desde os tempos imemoriais e sua emergência é reconhecida pelos demais povos da região.

Atualmente, vários conhecimentos tradicionais do Uaupés são transmitidos e discutidos nas escolas e em algumas Assembléias comunitárias, que reavivam a prática de seus ancestrais. Em Pari-Cachoeira, os indígenas também vivenciar suas tradições milenares. Entre os diversos conhecimentos transmitidos aos seus filhos e aos alunos da Escola Indígena "Dom Pedro Massa" são as histórias de migração dos Tukano de Pari-Cachoeira e de outros povos do Tiquié, porém estão gerando muitas tensões na convivência interna, porque toca no ponto fraco das pessoas que querem manter o domínio político do Tiquié e revelam quem são ou pelos menos quem deveriam ser os verdadeiros habitantes milenares e donos do Tiquié. Esses conhecimentos e discussões interferem nas relações de convivência intertribal dos indígenas de Pari-Cachoeira. Veja-se a seguir como elas interferem.

\footnotetext{
${ }^{321}$ Avelino Dutra é meu pai e Laureano Dutra é meu tio, ambos são irmãos, hoje considerandos uns dos principais pajés Tuyuka do Uaupés. A informação foi documentada na foz do rio Tiquié, no dia 27/02/2007.
} 


\subsubsection{A convivência entre os indígenas de Pari-Cachoeira}

A convivência entre os indígenas de Pari-Cachoeira é marcada por conflitos. A principal razão do embate talvez seja o medo que os Tukano têm em perder o controle e o domínio político de Pari-Cachoeira para os demais grupos que aos poucos tentam se instalar na comunidade. Para sustentar o seu predomínio na comunidade, controlam ferrenhamente duas coisas fundamentais que envolvem a sobrevivência de famílias procedentes de outras comunidades, tais como: o controle de terras cultiváveis e os terrenos dentro da comunidade, onde outras famílias poderiam construir suas residências.

No futuro próximo, o que acontece em Iauaretê, também poderá ocorrer em PariCachoeira, onde enquanto alguns Tukano de Iauaretê que se consideram os moradores tradicionais se isolam, quem movimenta e se destaca como comerciantes e líderes do distrito são membros do povo Tariano e Wanano. Em Iauaretê a concepção tradicional de ser chefe ou não ser só existe na teoria, porque na prática essa visão está sendo superada aos poucos a partir do momento que a comunidade é composta de maioria da população procedente de comunidades vizinhas. Com o aumento de famílias que vem das pequenas comunidades, os antigos moradores Tukano e Tariano são obrigados a dividirem suas terras com novas famílias que se instalam na comunidade.

Em Iauaretê, as mudanças de concepções ocorreram porque o sentimento de parentesco falou mais alto, mas isso, não significa que anulou a idéia de ser morador tradicional ou não de Iauaretê, porque essas conversas existem, sim, principalmente nos dias de festas, alguns Tukano e Tariano quando brigam tentam falar que são os chefes de Iauaretê; porém não é tanto como em Pari-Cahoeira e Taracuá. "Sempre que alguém tenta levantar sobre essa questão, as próprias lideranças comunitárias abortam esse discurso e, portanto, não deixam que essas idéias antigas poluam o ambiente comunitário" (Geraldo Veloso Ferreira, $2007)^{322}$.

Os Tukano de Pari-Cachoeira têm medo que ocorra o que acontece em Iauaretê, por isso se fecham para não dar espaço aos demais povos ocuparem espaço dentro da comunidade, pois sabem que essa mudança mais cedo ou mais tarde ocorrerá. Enquanto puderem controlar esse processo tentam manter a ordem predominante sob controle.

Até hoje, na prática, não aceitam que o líder geral seja de comunidades vizinhas ou de outros povos, porque acreditam que quem deve ser chefe da comunidade de Pari-Cachoeira é

\footnotetext{
${ }^{322}$ Entrevista concedida por Geraldo Veloso FERREIRA no dia 20 de outubro de 2006 em São Paulo.
} 
um Tukano que nasceu em Pari-Cachoeira e não de outras comunidades. Se de repente numa disputa eleitoral para líder geral ou líder comunitário ganha um não-Tukano de Pari-Cahoeira, imediatamente procuram desequilibrar o mandato de nova liderança. O novo líder geral e comunitário enfrenta direta ou indiretamente o desrespeito e a desconsideração por parte de alguns membros de famílias Machado, Abreu, Brandão Gentil, Costa, Arantes, Maranhão Arantes, Fontes, Reis e Castros.

Essa visão retrógrada é que permeia na organização política e social dessa comunidade e que sustenta temporariamente o domínio Tukano em Pari-Cachoeira. É por essa razão que Pari-Cachoeira, hoje, encontra-se no estado de decadência política, social e cultural.

Os conflitos das relações de convivência entre os indígenas se agravam, cada vez mais, porque a nova geração indígena do Tiquié não aceita mais esse tipo de domínio cultural, por isso reagem. A reação de alguns jovens e adultos que gera mudança de mentalidade e também brigas (verbais e físicas). Os "muros" de poder político, cultural, social e político criado ao longo de dezenas de décadas pelos Tukano de Pari-Cachoeira, aos poucos são desmoronados, porque outras pessoas que residem na área do Tiquié, começam discutir e refletir sobre o direito de igualdade entre os povos da região. Isso mexe e incomoda os que se consideram chefes, tanto os tukanos de Pari-Cachoeira como os demais "chefes" de outros grupos da região.

Na comunidade de Pari-Cachoeira, o conflito é tão evidente que o desentendimento político se delineia entre os próprios membros Tukano. Ou seja, a briga pela disputa do poder local se dá entre os próprios membros de famílias Machado, Abreu, Brandão Gentil, Costa, Arantes, Maranhão Arantes, Fontes, Reis e Castros, que querem comandar a comunidade. Nesse meio estão outros indígenas que aí residem, mas que não "podem” e nem querem ser líderes com medo de serem desrespeitados fisicamente e moralmente. Apesar disso, alguns indígenas enfrentam com coragem o desafio de se tornarem líderes, porém a maioria prefere coadjuvar os "majoritários".

Uma outra forma de demonstração e controle de poder dos Tukano de Pari-Cachoeira é com relação o controle das áreas de terras cultiváveis, situadas próximo à comunidade. Há extensas áreas cultiváveis que são controladas por poucas famílias Tukano que não se dispõem em compartilhar e dividir com outros povos. Esse é um dos principais motivos que leva as famílias desistirem de morar no centro, porque não têm como manter suas famílias sem roças e mandioca para produzirem farinha e beiju, alimentos básicos para a sobrevivência indígena. Alguns Tukano não aceitam que as famílias de outras comunidades se instalem nas vilas de Pari-Cachoeira, porque se uma família constrói uma residência numa área das vilas 
acham que estão perdendo terrenos que eram tradicionalmente de seus antepassados.

Diante dessa situação, os indígenas de outros povos - e principalmente os homens não-Tukano (tanto adultos como os jovens) perdem paciência e partem para confrontos diretos com os Tukano; os conflitos são mais agudos nos dias de festas, quando estão embriagados. Com isso, a convivência entre os Tukano da comunidade de Pari-Cachoeira e famílias de outros grupos vai se transformando em ambiente polarizado e tenso.

Segundo Edmar Barreto $(2007)^{323}$, alguns Tukano de Pari-Cachoeira só revelam suas diferenças e preconceitos somente quando estão embriagados.

Atokhãłã Dahseá keałãpł diaku mãłinohõłë yãtuá tuti, kẽsirirã wemuhamã. Nã keałó waterołe nã deró nĩsĩrĩrõ, nã deró tutisĩrĩrõ, nã deró pasĩrĩrã pakã wemã atołé. Mãłinohõ tohó tłokã ô tohó keõkã wekãłẽ, małinõhõłẽ tohó nipekãsĩrĩmã atohokãłã. Teré kałibuhtirã ãhperã ató nisĩrĩmikãłã, ahpeyé mahkãłipł wa'awamã. Atokahãłã dahsea nã tohó nisetikãtã ati mahkã siapemerã buhutidihawałowé. Até nã bahsitá, nã ahkawererã merãtá ãmẽrĩ ãmẽkẽ kuñãmã atołé, ãmẽrĩ dusasókuñã wemã, wiuguwa'aseré. Yałokuhupu wiogu sahãkamã nẽ wiopehsá yãtimã. Nõ ni’iku sahãmãkamã nisamãna: ató kuhu mehtá ni’i muã ató duhti weakuhu; uhsãpé ni’i ató duhtirãnohõ; muya mahkãpu wa'a wehti duhtiwayá; yoałókahała nã duhtinohorãmehtá ni’i uhsã. Tuhtuagu nirõ ni’i ató.

Alguns Tukano de Pari-Cachoeira só se aproximam da gente, que somos de outras comunidades, para xingar ou bater. Quando estão bêbados falam o que querem, sem medir palavras; se quiserem xingar, xingam; se quiserem bater, também batem. Se a pessoa não reagir, aí que se sentem superiores, porque sabem que podem continuar humilhando até a pessoa desistir de morar nesta comunidade. Algumas famílias não agüentam as ameaças constantes, por isso preferem retornar para as suas comunidades ou migrar para outras cidades brasileiras e colombianas. A arrogância dos Tukano de Pari-Cachoeira faz com que a comunidade se torne num ambiente morto, sem dinamismo social e político, ou seja, ao em vez de progredir e desenvolver, Pari-Cachoeira está no processo de regressão. Além disso, até entre eles (os próprios Tukano) vivem em disputa pelo poder, medindo forças políticas para ver quem manda mais na comunidade. Essa situação gera uma tensão interna que desequilibra a harmonia da convivência comunitária. Se de repente uma pessoa de outra comunidade é escolhida para ser líder geral ou comunitário, aqui ninguém respeita. Acham que somente eles podem ser chefes de Pari-Cachoeira e não outrem que não sejam da comunidade. Para manifestar suas insatisfações, dizem o seguinte: você não é daqui para ser nosso chefe; nós que devemos ser os chefes de Pari-Cachoeira; volta para sua comunidade e vá ser chefe de seus familiares; não nascemos para sermos chefiados por outras pessoas que não sejam daqui de Pari-Cachoeira.

Parar morar aqui em Pari-Cachoeira a pessoa tem que ser forte e não pode baixar a cabeça para os Tukano daqui.

Outra coisa que gera o desentendimento político é em relação ao controle do comércio interno. O motivo é sempre o mesmo, de a pessoa ou o comerciante ser ou não ser de PariCachoeira. A maioria dos Tukano não aceita que empreendedores indígenas de outras

\footnotetext{
${ }^{323}$ Entrevista informal concedida no 03 de abril de 2007 em Pari-Cachoeira Edmar Barreto é indígena do grupo Tukano, da comunidade de São Domingos, localizada acima de Pari-Cachoeira, Tiquié. Atualmente é docente da Escola Indígena "Dom Pedro Massa". O seu depoimento não foi documento formalmente, porque ele desabafou o seu sentimento numa conversa informal, quando estive na residência de seus pais em Par-Cachoeira.
} 
comunidades abram seus pontos comerciais (tabernas, lojas, etc.) nas vilas para vender os produtos industrializados, porque se sentem humilhados e rebaixados.

Quando os Tukano vêem que um indígena de outra comunidade instala um ponto comercial numa vila, que movimente mais que os seus já ficam com inveja. Alguns fazem de tudo para comprar fiado as mercadorias, com pretexto de bater e xingar o comerciante, se caso ele não venda fiado, por isso os indígenas de outras comunidades que tentaram montar pequenos estabelecimentos comerciais em Pari-Cachoeira, ou foram à falência, ou migraram para a cidade de São Gabriel da Cachoeira. São poucos que agüentam a pressão e agressões dos Tukano da comunidade.

A disputa pelo domínio da comunidade é tão intensa que entre os próprios Tukano há brigas por causa do comércio. Os mais fortes, ou que têm mais filhos homens e familiares, conseguem permanecer na comunidade; os Tukano mais fracos, que não têm muitos familiares para se defender, não agüentam a pressão, abandonam a comunidade.

Dessa forma, a comunidade caminha, cada vez mais, para o "fundo do poço", porque os Tukano não se conformam quando outros indígenas da região tenham uma qualidade de vida melhor que a deles. Para o contexto de Pari-Cachoeira, o "fundo do poço" significa que a comunidade não tem uma dinâmica social; o atual ambiente comunitário não proporciona uma convivência harmoniosa; não há lideranças capazes de unir as famílias que constituem a comunidade; as lideranças não promovem mais debates, encontros e assembléias que sejam capazes de provocar transformações sociais para a melhoria da qualidade de vida das famílias; não promovem festas comunitárias que ajudem a unir as pessoas; as intrigas intertribais dominam o ambiente da comunidade; e a comunidade ficou estagnada no tempo, porque as atuais lideranças Tukano não conseguem proporcionar um ambiente familiar. Esse cenário interfere diretamente na vida das pessoas que lutam para sobreviver numa área onde não há mais caça e nem peixes. Os próprios Tukano enfrentam essas dificuldades, mas ainda são fechados para compartilhar a vida com outros povos do Tiquié.

Entretanto, a convivência indígena não é constituída apenas por conflitos e tensões. Diante da situação atual que se encontra a comunidade, há e surgem novas lideranças jovens Tukano que demonstram interesse em mudar o rumo da comunidade. Existem Tukano que buscam construir uma relação harmoniosa de convivência entre os diferentes grupos do Tiquié; sonham com uma comunidade, onde as relações interpessoais estejam fundadas na lógica familiar; tentam promover a união das pessoas e discutir a autosustentabilidade de seus parentes. Essa é uma luta constante que põe a comunidade na perspectiva da construção de 
convivência harmoniosa de seus membros. As transformações positivas ocorrem, porque há vários Tukano de Pari-Cachoeira que são pessoas que tem o bom senso familiar.

\subsubsection{A perspectiva da relação de convivência entre os indígenas de Pari-Cachoeira}

Os indígenas de Pari-Cachoeira têm certeza de uma coisa: os conflitos e as tensões comunitárias existirão na comunidade, porém não dominarão, porque são superáveis. Por isso, para que os princípios de familiaridade permeiem entre os membros da comunidade, há tukanos e não-tukanos que se esforçam para unir cada vez mais seus outros parentes.

Até o final da década de 80, Pari-Cachoeira vivia o seu auge político, porque havia transformado num centro de discussões sobre a política indígena do rio Negro. Entre todas as comunidades indígenas do alto rio Negro se destacava como a referência da política indígena. Os líderes Tukano da década de 80 promoviam encontros periódicos para debater e discutir questões referentes aos problemas comunitários do distrito de Pari-Cachoeira. Os capitães de comunidades vizinhas eram convidados para participar desses eventos. Eram eventos que fortaleciam a convivência indígena e a luta pela demarcação de suas terras.

A construção da convivência familiar foi interrompida no início da década de 90 , quando os que organizavam as assembléias gerais migraram para outras cidades brasileiras para se tornarem representantes indígenas em instituições governamentais. As novas lideranças que permaneceram ou surgiram na comunidade não souberam conduzir a população do distrito, que ao em vez de unir as comunidades contribuíram mais para gerar desavenças, brigas e divisões.

Depois disso, muitos indígenas que moravam nas vilas de Pari-Cachoeira destruíram e abandonaram suas residências alguns retornarem em suas comunidades de origem e outros migraram para a cidade de São Gabriel da Cachoeira, AM. Aos poucos, Pari-Cachoeira foi se transformando em um ambiente sem movimento de pessoas e comércio, ficou vazia de pessoas que davam vida à comunidade. Só permaneceram alguns Tukano de famílias tradicionais, porque a maioria deles não agüentou o ambiente tenso, abandonaram PariCachoeira. Por exemplo, as famílias Tukano que mais saíram da comunidade foram os de família: Reis, Abreu, Maranhão, Fontes, Machado, Costa e Gentil. Atualmente quem domina a comunidade é a família Castro, pois são os únicos que resistem e interferir diretamente na vida comunitária de Pari-Cachoeira.

No início da década de 90 , outro fato que ocorreu foi a retirada quase total de famílias Tuyuka que residiam em Pari-Cachoeira. Os Tuyuka retiraram todos os seus filhos que 
estudavam em na Escola "Com Pedro Massa" por quatro motivos: primeiro porque perceberam que os seus filhos só falavam a língua Tukano e não mais a língua do grupo, por isso o povo Tuyuka corria o risco de perder a sua língua paterna; segundo porque os Tukano de Pari-Cachoeira não compartilhavam as terras para que os Tuyuka derrubassem as roças para plantar maniva, que serviriam para o sustento de suas famílias; terceiro porque não aceitavam o domínio quase ditatorial dos Tukano; quarto porque tinha um projeto de uma escola indígena genuinamente Tuyuka, com objetivo de educar seus filhos com base em princípios tradicionais do grupo.

Não foram somente os Tuyuka que abandonaram Pari-Cachoeira, outros grupos também saíram da comunidade, por exemplo, os Dessano do Umari Igarapé, afluente do Tiquié. Veja-se a seguir o relato do Sr. Henrique Pimentel Vaz $(2007)^{324}$ do porquê os Desano, que residiam em uma das vilas de Pari-Cachoeira até o final da década 80, decidiram abandonar e atualmente tentam retornar de novo, porém ainda com desconfiança, porque não dá para confiar muito em Tukano que os convidaram, pois em quaisquer momentos podem dizer que os Dessano não são daí.

No final da década de 80, depois que acabou internato dos padres salesianos, nós, Desano do Umari, decidimos retornar para a nossa comunidade de Sebastião, no Umari Igarapé, porque os Tukano de Pari-Cachoeira brigavam com os nossos pais por causa da terra; não queriam que a gente construísse as nossas residências e nem roças dentro da área da comunidade, por isso, cansados de viver em conflitos intensos com eles, retornamos para nossa comunidade. Entre nós, Dessano, dizíamos o seguinte: esses Tukano não querem dar terra para nós, pensam que vão morrer com ela.

No início, quando chegamos aqui tentamos instalar as nossas residências e formar uma vila, onde hoje é vila São Miguel, no entanto percebemos que a nossa relação com os Tukano somente piorava, devido a isso preferimos abandonar e retornar para a nossa comunidade.

Recentemente, os Tukano Afonso Machado, Domingos Brandão e outros nos convidaram e propuseram para que construíssemos, mais uma vez, as nossas residências para morar aqui em Pari-Cachoeira, porém resolvemos não retornar. Esse convite foi feito, porque os Tukano perceberam que a comunidade estava abandonada por outros povos e, e com isso, a Escola Indígena "Dom Pedro Massa" ficou com poucos alunos. Por isso, agora tentam nos convidar para morar aqui, a gente sabe que quando não estão embriagados são ótimas pessoas, mas quando estão bêbados são agressivos e já começam gritar e tentar nos agredir fisicamente, pois alegam que não somos daqui. Isso atrapalha para que nós, povos de outras comunidades, tenhamos vontade de morar aqui.

Hoje, apesar da dificuldade de relações entre os Tukano daqui, há famílias de outras comunidades que começaram retornar, não porque querem morar, mas é mais porque vem aqui por causa de seus filhos que tem que estudar Ensino Médio. A dificuldade de mobilizar até a cidade de São Gabriel e sobreviver na cidade faz com que muitos pais de alunos decidam acompanhar seus filhos aqui mesmo, em Pari-Cachoeira. Por isso, estão aqui.

\footnotetext{
${ }^{324}$ Entrevista concedida pelo Sr. Henrique Pimentel Vaz, no dia 15 de março de 2007 em Pari-Cachoeira.
} 
Depois de aproximadamente 14 anos abandonados por outros grupos, devido a sua arrogância, os Tukano de Pari-Cachoeira perceberam que o seu orgulho e o seu sentimento de superioridade não ajudou para o crescimento da comunidade. Atualmente, tentam corrigir o erro do passado com objetivo de ver uma comunidade mais unida e forte no ponto de vista político. Daqui a diante, a luta é para que Pari-Cachoeira rume para uma convivência mais harmoniosa e familiar.

Com a vontade de mudar a situação atual da comunidade que os Tukano de PariCachoeira começam ceder espaço para lideranças de outras comunidades ocuparem cargos de chefia do distrito. No dia 01 de maio de 2006, elegeram o primeiro líder geral não-Tukano de Pari-Cachoeira: Arsênio Vaz Lobo, do povo Miriti-Tapuia. Foi um marco histórico que mexeu com o domínio de poder de alguns Tukano da comunidade, que não cederam de forma tranqüila, mas já demonstra mudança de mentalidade. A maioria de indígenas que residem na comunidade querem construir um ambiente de vida familiar e de convivência plural, os próprios Tukano começam ceder esse espaço de convivência.

Veja em seguida a declaração do atual líder geral Sr. Arsênio Vaz Lobo (2007), de como ele conseguiu ser eleito líder geral do distrito de Pari-Cachoeira, sendo de outra comunidade e quais são as mudanças positivas que ocorrem na comunidade:

Os moradores da vila São Miguel viviam sob a liderança dos Tukano da Vila São Domingos Sávio, que nem sempre tratavam com cordialidade. Por causa da relação tensa que a gente vivia com eles, propus aos moradores da vila São Miguel para que saíssemos dessa dependência. A partir daí, decidimos organizar uma nova vila com as famílias de outras comunidades que residiam na vila São Miguel, na qual pertenço. Foi nessa ocasião que fui eleito como líder comunitário.

Enquanto, nós, moradores da vila São Miguel, organizávamos a nossa vila, surgiu novo problema aqui em Pari-Cachoeira: a briga e a disputa política entre os próprios Tukano, por causa do barco da comunidade que estava sob o comando de Pedro Machado, irmão maior dos Tukano de Pari-Cachoeira. Apesar de serem irmãos, algumas lideranças locais acusaram o irmão deles (o Pedro Machado) de estar se beneficiando ilicitamente com o lucro do barco. Você sabe como são nossos parentes, que só enxergam as coisas erradas e nunca querem ver as coisas boas que a pessoa faz. Foi isso que aconteceu com Pedro Machado, que foi vítima da inveja. Na verdade, os seus irmãos queriam tomar de volta o barco para eles comandarem.

No meio dessa confusão "caseira", as lideranças de todas as vilas da comunidade se reuniram para escolher novo líder geral de Pari-Cachoeira através de uma eleição com votos secretos. Antes da Assembléia Geral que escolheria o novo líder geral, alguns amigos que cursam Ensino Médio comigo, propuseram formar uma chapa para disputar a eleição. Nesses dias não participei da reunião, pois estava com os meus familiares, na comunidade de Iraiti, Médio Tiquié. Convidaram para participar da chapa formada apenas por alunos da escola, porque era líder de do corpo discente da escola.

Tudo isso aconteceu sem a minha presença. Só me contaram quando retornei da minha comunidade que tinham formado uma chapa para disputar a eleição e que eu tinha sido indicado para fazer parte. A decisão de formar uma nova chapa, demonstrou a coragem e a vontade de mudança dos estudantes da escola. Chegava a hora de escolher quem seria o candidato majoritário da chapa, ninguém queria ser; no final fui escolhido pelo grupo para ser candidato a líder geral. Percebi que ninguém tinha coragem de ser líder geral. Diante do impasse que havia 
aceitei enfrentar o desafio de concorrer para o cargo de líder geral. Foi um grande desafio, porque pela primeira vez um não-Tukano se candidatava para ser líder de todos os grupos do distrito de Pari-Cachoeira, que até então só tinha sido liderado por Tukano da comunidade que se consideram os chefes de Pari-Cachoeira.

No dia 01 de maio de 2006, a eleição aconteceu e nossa chapa acabou ganhando. A chapa era formada por seguintes componentes: eu, Miriti-tapuio, Arsênio Vaz Lobo (Presidente); o Tukano, Afonso Rezende Arantes (Vice-Presidente), o Tukano, Rafael Castro (Secretário) e o Tukano, Danilo Castro (Tesoureiro). Daí a diante, assumimos o CIPAC.

A primeira coisa que estudamos foi o estatuto e o funcionamento do estatuto que foi elaborado pelos nossos antecessores. Constatamos duas coisas: a primeira, o estatuto não estava legalizado; segundo, o estatuto regia que o mandado de líder geral seria de dois anos, porém a antiga diretoria tinha violado, porque ultrapassou o tempo de dois anos de mandato; ninguém sabia disso e, se sabiam, não tiveram coragem de encarar os Tukano que se consideram chefes nato.

Atualmente, como líder geral, acabei assumindo a responsabilidade de legalizar esse estatuto, que já era para ter feito antes; por razões pessoais, os membros da antiga diretoria conseguiram adiar sem justificativa convincente.

Assumi a direção do CIPAC com duas principais responsabilidades: legalizar o estatuto e reativar o funcionamento do barco. Além dessas responsabilidades, não prometi para a comunidade coisas que não pudesse realizar. Claro que tenho como objetivo tentar elaborar projetos para a melhoria da comunidade, mas esse é o passo que será dado após a legalização do estatuto.

Agora que sou o líder geral da comunidade a minha relação com alguns Tukano de PariCachoeira se constitui de pontos positivos e pontos negativos. No dia de minha posse, fiz o seguinte discurso: hoje, vocês me escolheram para ser vosso líder geral, mas também estou ciente que algumas pessoas desta comunidade não aceitam a derrota para uma pessoa que vocês dizem que é de "fora", por isso não me considerarão e nem respeitarão como chefe. Agora, o fato é que sou chefe. Atualmente, não podemos mais aceitar que as idéias de domínio, de ser daqui ou não ser impere entre nós. Por causa dessas visões medíocres que a nossa comunidade de PariCachoeira está nesta situação de "desordem" e, ao em vez de desenvolver, está cada vez pior, sem movimento e sem novidade; a comunidade parece que está morta. Se até agora não tivéssemos alimentado e herdado os princípios culturais retrógrados, os nossos parentes que migraram para outras regiões estariam morando conosco; estariam nos ajudando a construir novas escolas. Por causa de algumas pessoas daqui que dizem que quem manda aqui somos nós, que a comunidade chegou ao estado que está agora. Enquanto que outras comunidades como Iauaretê cresce em todos os aspectos da vida, nós, de Pari-Cachoeira, estamos em decadência aguda, desunidos e em constante conflito que só empurra para a decadência da comunidade.

Falei que não continuassem mais com esse tipo de visão.

Ainda, disse o seguinte: essas conversas sempre existirão, porque somos pessoas, mas não podemos ceder que dominem a nossa convivência. Vocês sabem que essas conversas só aparecem quando estamos bêbados; enquanto estamos no estado normal, a nossa convivência é irmanal. Por exemplo, hoje, vocês me escolheram para ser vosso chefe, nem por isso serei chefe pelo resto da minha vida; depois de dois anos de mandato, sairei da presidência; aí entrará outro. É assim que funciona a forma de organização dos não-indígenas, que adotamos. Não se pode brigar constantemente pelo controle do poder só porque perdeu o poder por dois anos; todos aqui são estudados e ouviram falar de democracia; hoje, lutamos para vivenciarmos os princípios da democracia, no entanto só conseguiremos realizar em prática se cada um que está aqui entender a importância desses valores. Se continuarmos defendendo os nossos interesses culturais para tentar dominar os demais, a nossa comunidade não irá para frente.

Com essas minhas preocupações e manifestações travo discussões e debates para mostrar como podemos construir conjuntamente uma Pari-Cachoeira permeada de valores familiares. Percebo que, atualmente, comparando com o passado remoto, a visão arcaica dos Tukano vem diminuindo, mas ainda tem cabeças que sustentam essa visão.

Outra coisa que provoca tensão entre nós, de Pari-Cachoeira, é o uso da terra dentro da área dominada por Tukano. Há muitas críticas e conflitos verbais quanto ao uso dessas terras por pessoas de outras comunidades, que tentam fazer roças para plantar maniva. Muitas vezes, os Tukano daqui reclamam que nós, "de fora”, fazemos roças dentro de suas áreas. 
Diante dessa situação, como líder geral que sou, falo o seguinte: como é que as pessoas que vem de outras comunidades participar de eventos festivos e comunitários que vocês promovem? Vocês dizem para a gente compartilhar com a vida comunitária das vilas, convidam para participar das festas etc; se não temos um pedaço de terra para derrubar roça e plantar mandioca, como podemos compartilhar como vocês? Se não querem dar terra para a gente plantar, não convidem para morar aqui e nem para participar da vida comunitária das vilas.

Essas brigas e tensões existem, sim, aqui em Pari-Cachoeira, mas percebo que a nossa convivência está melhorando.

\subsection{Trinidad: a comunidade de domínio Tuyuka}

A comunidade de Trinidad [também chamada Miñõbutó ou Bubibutó (em Tuyuka) e Miõbua (em Tukano)] está situada no alto Tiquié, Gran Resguardo Indígena del Vaupés, Colômbia (ver mapa 01).

Trinidad é a comunidade dos Tuyuka (Uhtãpinõponã) do subgrupo Buabiponã. De acordo com a hierarquia social Tuyuka, os membros desse subgrupo não são considerados chefes, entretanto pertencem ao conjunto de membros servos de chefes maiores Tuyuka, que se chamam Béroa.

$\mathrm{Na}$ comunidade, também moram alguns membros do povo Barás e os missionários católicos (ver figura 18). Os Barás constituem os principais cunhados dos Tuyuka e residem em Trinidad. Assim, a comunidade é constituída de Tuyuka, Barás e missionários católicos, porém quem comanda a comunidade são Tuyuka.

Veja a seguir como esses Tuyuka se organizam, como convivem entre si e como é o aspecto físico da comunidade.

\subsubsection{Quem são os Tuyuka de Trinidad?}

Os Tuyuka (Dohkapuała) de Trinidad são os que mais vivenciam as tradições do grupo e que, ao mesmo tempo que mantêm suas tradições, também se apropriam constantemente de costumes e valores do mundo ocidental. Assim como os Tuyuka que vivem no território brasileiro, os de Trinidad e de outros territórios colombiano se declaram Tuyuka colombianos.

$\mathrm{Na}$ comunidade há duas malocas (ver figuras 35 e 36), onde praticam constantemente rituais de pajelança, benzimento, ritual de Jurupari e realizam danças de músicas e danças tradicionais (kapiwayá); além de suas Casas Tradicionais, os Tuyuka construíram um centro comunitário, onde tocam e dançam merengue, forró e até brega. Na comunidade vive o único 
yaí [(pajé) ver figura 37) Tuyuka e um kũmũ [(também pajé) ver figura 38]. No centro da comunidade existe um aeroporto e a sua margem direita um presídio (ver foto 39), sem policiais. Os próprios indígenas construíram o presídio para prender e punir os desordeiros da comunidade. Quando há indivíduos que cometem graves delitos, as lideranças locais que se encarregam de prendê-los até a segunda ordem da comunidade.

Figura 34. Sede da Missão Católica, Trinidad.

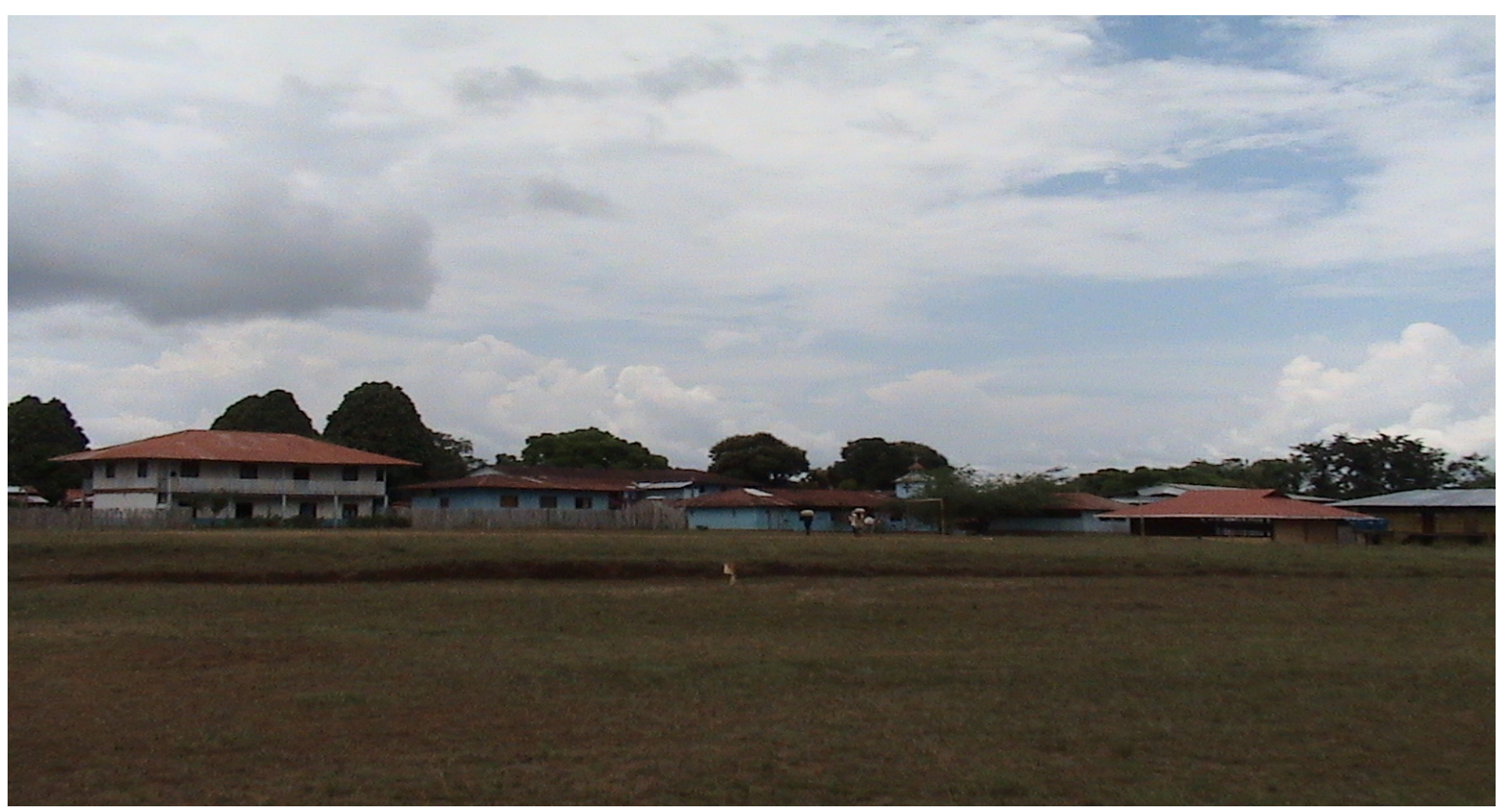

Fonte: acervo do autor, 2007.

Figura 35. A Casa Tradicional (Bahsawi) do Sr. Marcos Barrera, Trinidad, alto Tiquié.

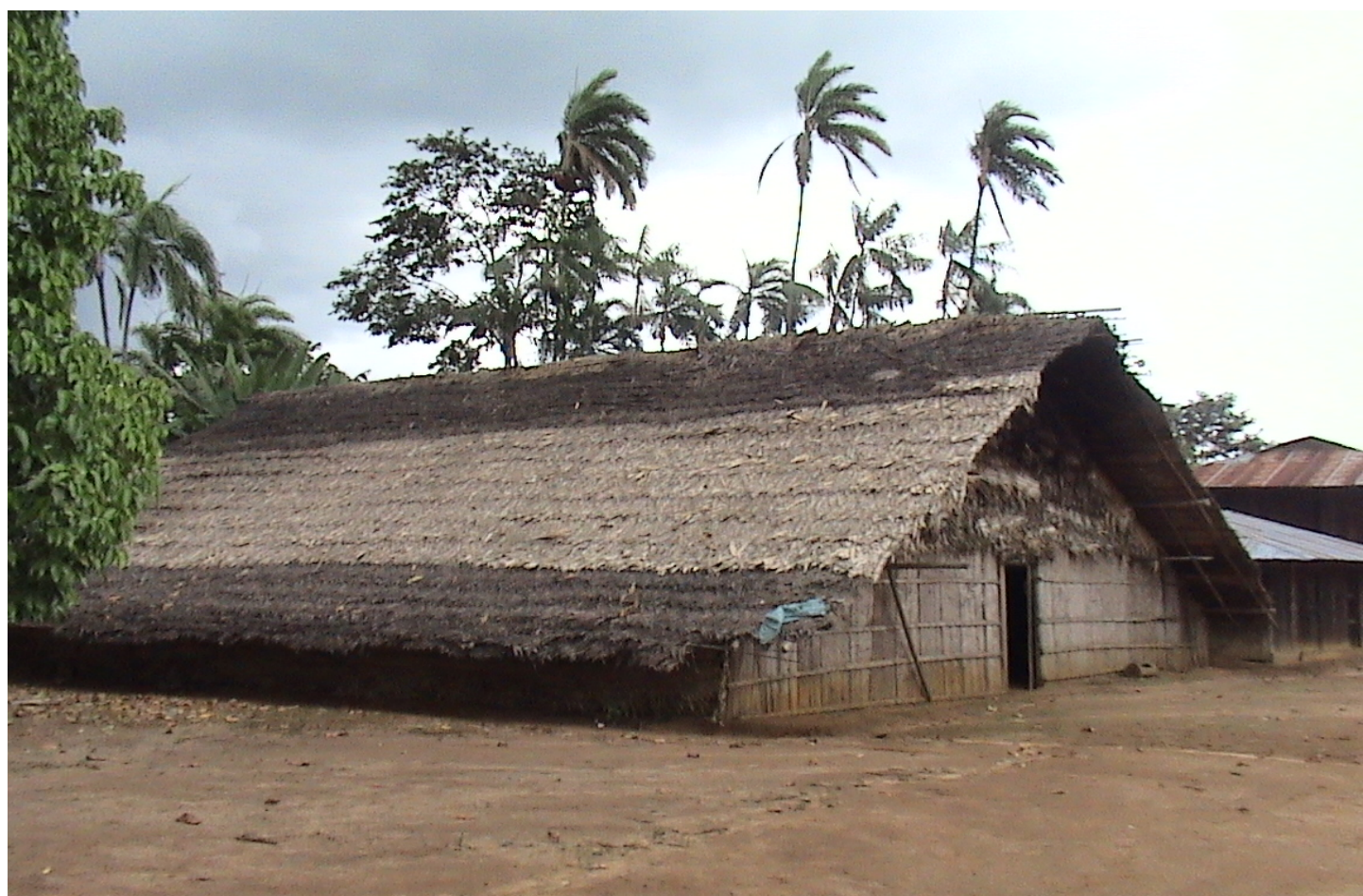

Fonte: acervo do autor, 2007. 
Figura 36. A Casa Tradicional (Bahsawi) do Sr. Severiano Barrera, Trinidad, alto Tiquié.

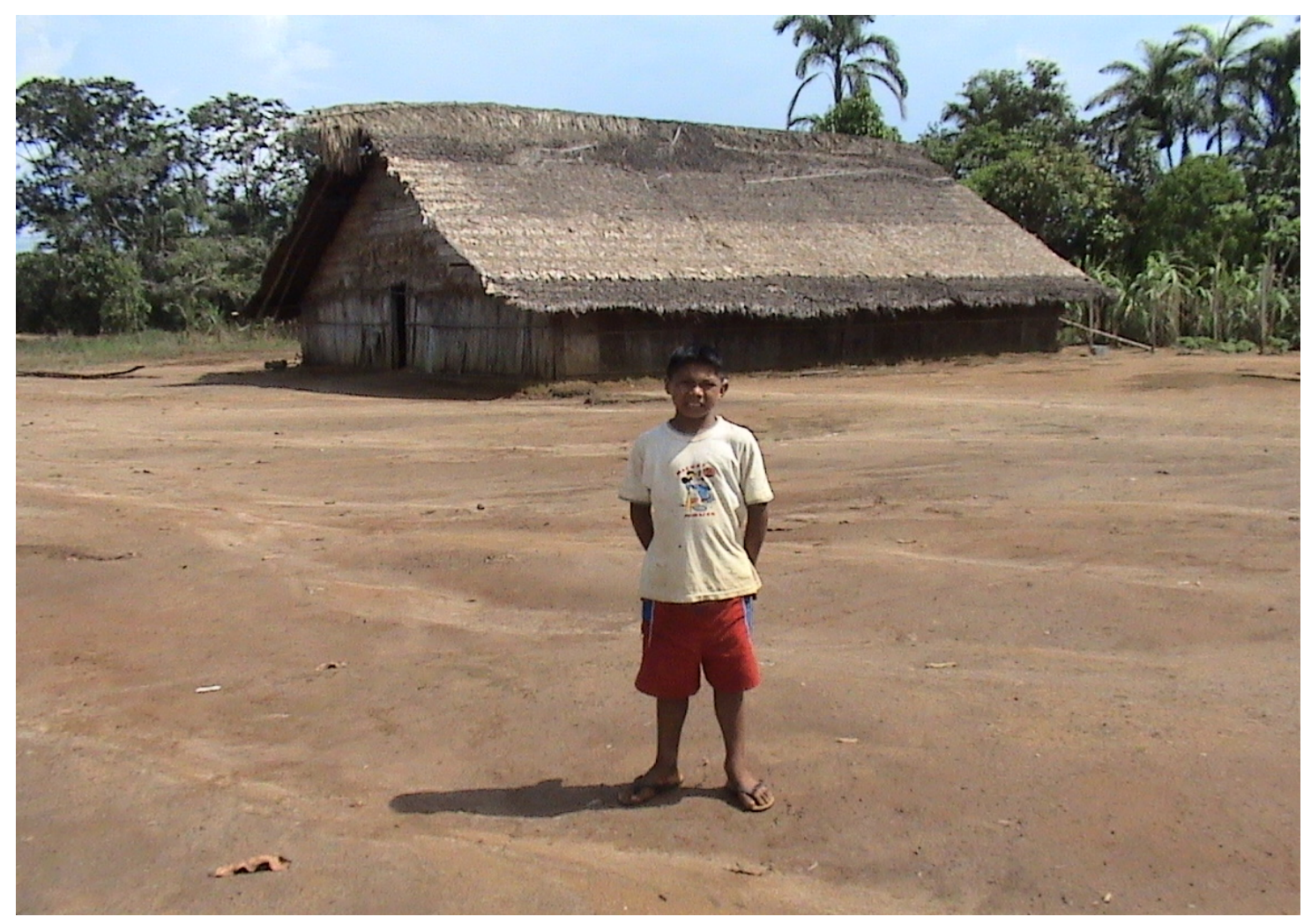

Fonte: acervo do autor, 2007.

Figura 37. O yai Tuyuka em frente a sua residência, Trinidad.

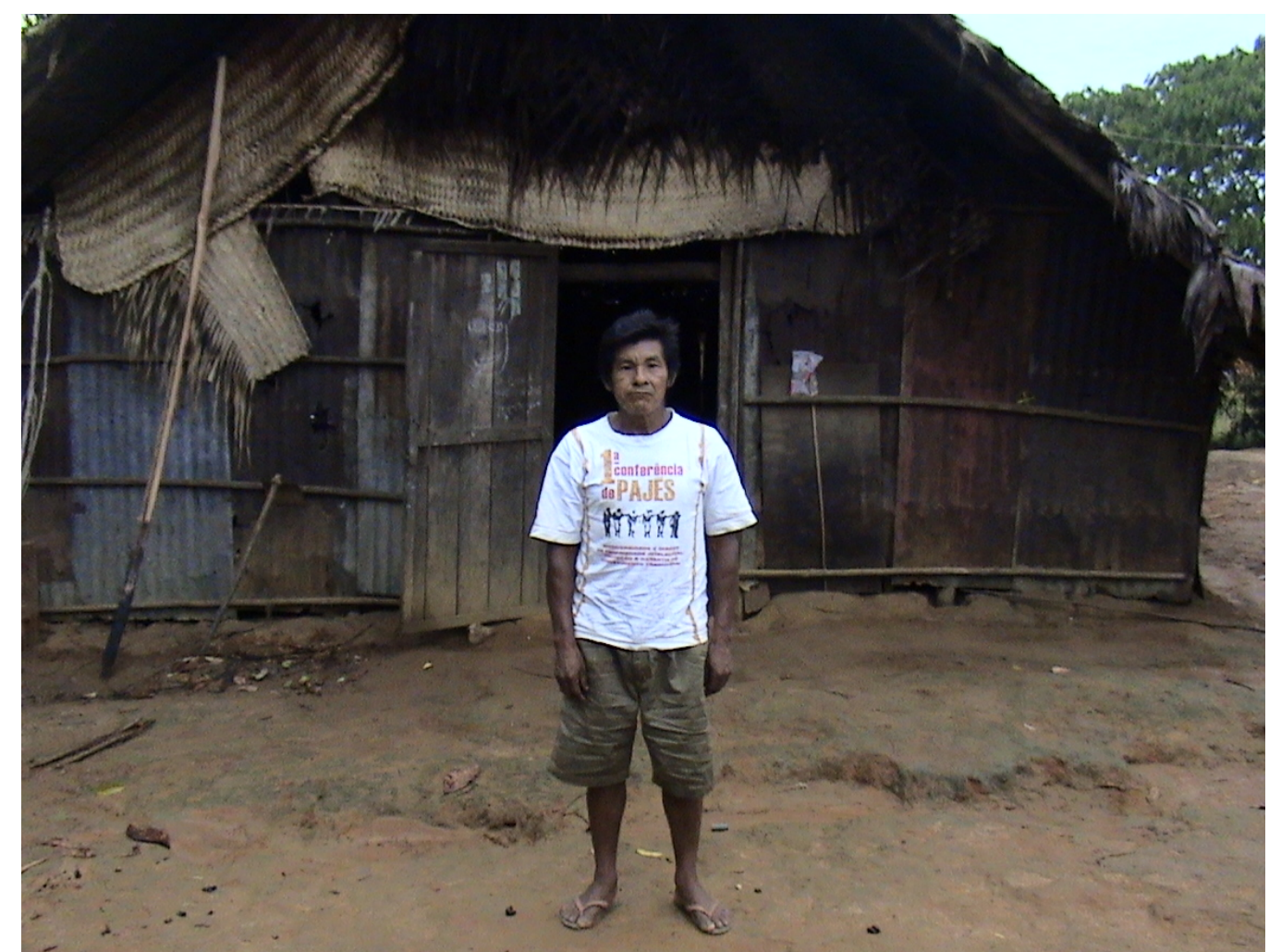

Fonte: acervo do autor, 2007. 
Figura 38. O kũmũ (pajé), Antônio Barrera,Trinidad.

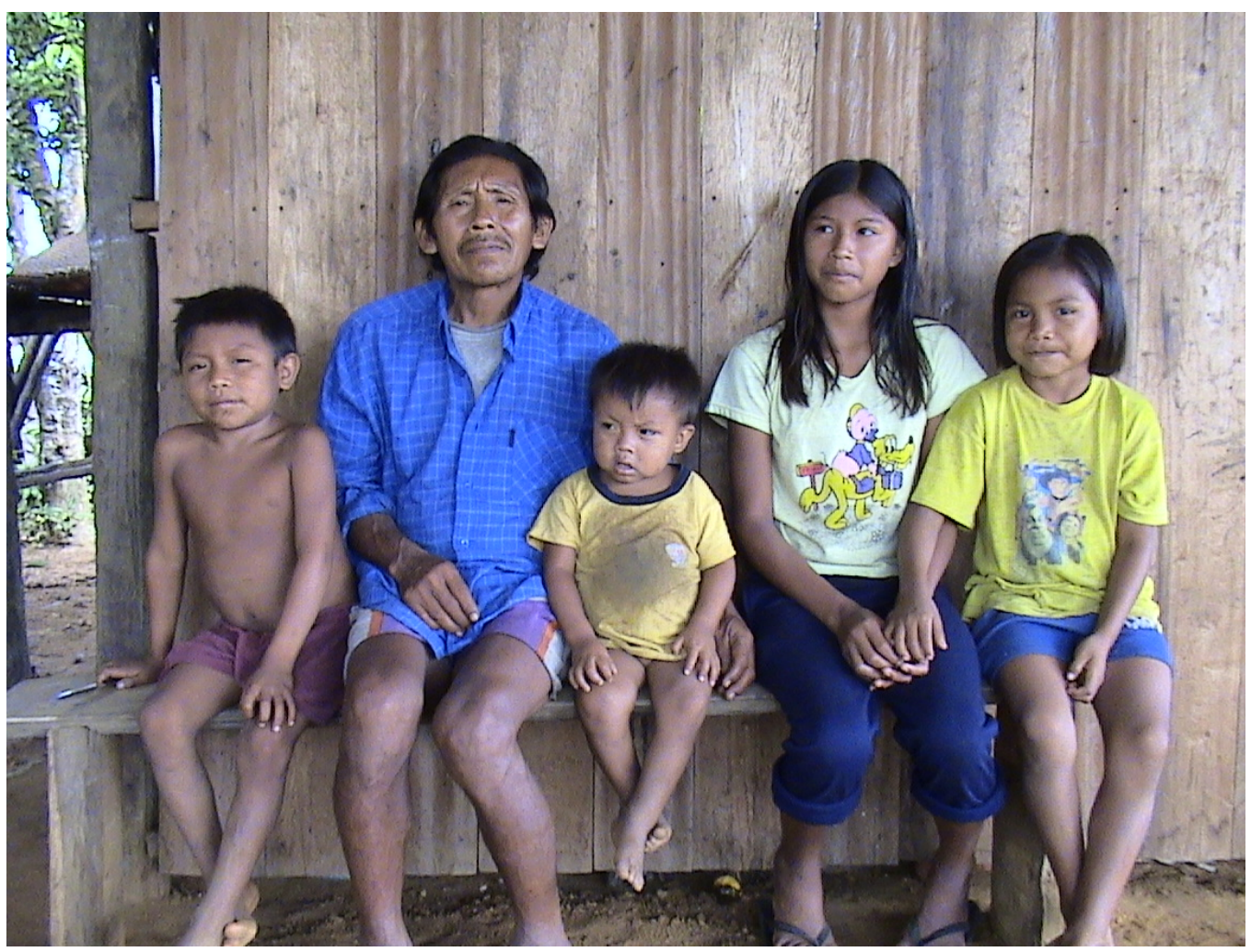

Fonte: acervo do autor, 2007.

Figura 39 Casa de presídio Tuyuka, Trinidad.

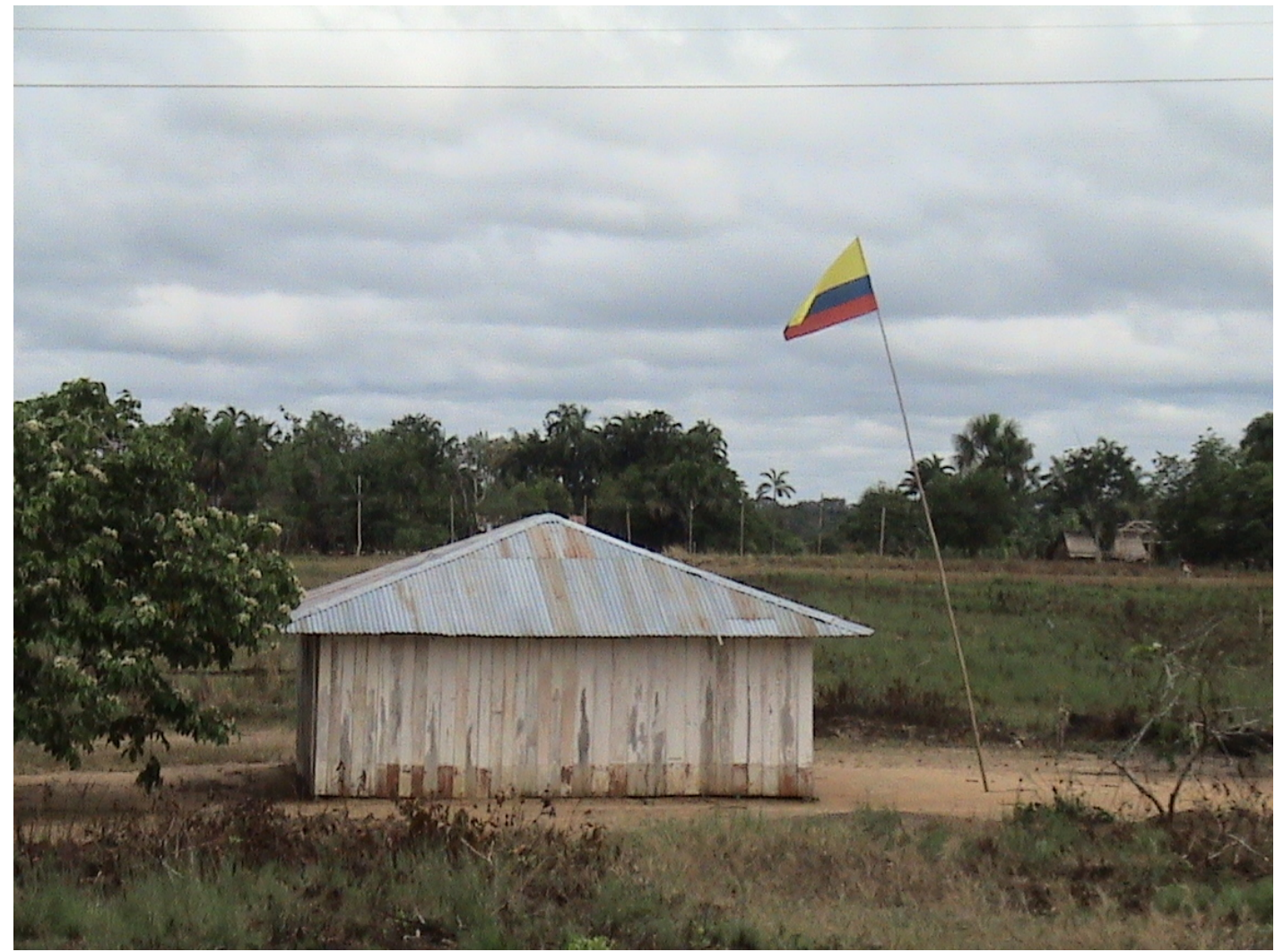

Fonte: acervo do autor, 2007. 
A convivência entre os Tuyuka e os Barás se fortalece cada vez mais devido a troca de relações matrimoniais. Essa relação que dá o sentido maior para a convivência familiar da comunidade. Diferente da relação tensa que ocorre em Pari-Cachoeira, os indígenas de Trinidad se mostram mais sintonizadas e unidas. Têm seus conflitos internos, porém não tão complexos quanto os de Pari-Cachoeira.

O principal fator que contribui o equilíbrio da convivência familiar é a vivência das tradições milenares. Os pais Tuyuka educam os seus filhos de acordo com os princípios culturais do povo. Todas as crianças Tuyuka falam a língua Tuyuka; todas as crianças Barás falam a língua de seu povo; ou seja, nesse aspecto os Tuyuka não interferem na autonomia de outros povos. Assim, os indígenas que vivem aí, compartilham os seus valores culturais, pois os Tuyuka se apropriam os conhecimentos de outros grupos e vice-versa.

Outra coisa fundamental para a união da comunidade é o fato de todas as famílias que residem em Trinidad possuírem seu pedaço de terras para fazer a sua roça e, assim, sustentar, os seus filhos durante o ano letivo. Não há conflitos por terra.

Apesar de possuírem uma terra extensa, os habitantes de Trinidad enfrentam com a escassez de caça e peixes. Pelo fato de habitarem na cabeceira do Tiquié, além de outros fatores ambientais e crescimento demográfico, a comunidade está situada numa região isolada das principais cidades colombianas e brasileiras, o acesso é difícil. Nem os guerrilheiros circulam constantemente na área de Trinidad, porque é longe e não tem muita comida. $\mathrm{O}$ único meio para se chegar até a comunidade, inclusive para transportar produtos de consumo é via aérea ou pelo rio Tiquié levando alguns produtos brasileiros. Os aviões que pousam no aeroporto da comunidade são avionetas, aviões pequenos, que só chegam uma vez por mês. As condições do aeroporto também não contribuem para o pouso de aviões maiores.

As condições precárias de vida aumentam o sofrimento daquele povo, que muitas vezes, dependem de alguns indígenas comerciantes de Pari-Cachoeira para abastecer a comunidade com produtos alimentícios, que mesmo assim, só compram quem é funcionário do Governo e tem dinheiro e quem não tem dinheiro passa fome. Por exemplo, produtos como sal, açúcar, arroz, feijão, sardinha, sandália havaiana; outros produtos como cimento, são comprados em Pari-Cachoeira. Esse é o maior desafio da comunidade, que o Governo colombiano não consegue resolver.

Em comparação com os indígenas brasileiros, os parentes colombianos recebem mais assistência do Governo colombiano na área de saúde, educação e meio ambiente.

$\mathrm{Na}$ área da educação, os educadores indígenas recebem apoio e benefícios necessários para o sustento de suas famílias. Por exemplo, quando um professor (a) casado é indicado 
para ministrar aulas numa escola distante de sua comunidade de origem recebe casa e assistência alimentícia suficiente para se manter com sua esposa e filhos; além disso, segundo os Tuyuka de Trinidad o salário dos professores colombianos é o dobro do salário pago no Brasil, isto é, se o salário médio de professores brasileiros é R \$1.000,00 reais, na Colômbia equivale a $\mathrm{R} \$ 2.000,00$ reais. Os sujeitos da pesquisa ainda declararam que na Colômbia a educação é prioridade; o Governo investe pesado para que todos os colombianos tenham uma educação de qualidade.

A saúde também é outra área que o Governo colombiano investe em peso para dar assistência não só às comunidades indígenas, mas para todos os colombianos. Conforme declarou o pajé Henrique Barrera (2007), quando um indígena de Trinidad fica muito doente, imediatamente o capitão e o enfermeiro da comunidade ligam para a Secretaria de Saúde de Mitú, que no mesmo instante providencia um avioneta e envia para a comunidade indígena para o resgate; levam direto para um dos hospitais do Governo em Mitú; se o doente necessitar de cuidados maiores envia diretamente para a cidade Bogotá, onde as condições de tratamento são melhores.

Outra coisa interessante que ocorre nas comunidades indígenas do território colombiano é o fato do Governo do país condições de materiais para construir uma casa e formar uma família. Todos os recém-casados são cadastrados pelo governo para receber gratuitamente folhas de alumínio, tábuas, caixas d'água, placas solares, baterias, fios de eletricidade, botas, terçado e machados. Por exemplo, na comunidade de Trinidad existe uma casa só de materiais de construção das casas, a espera de um casal novo e de alguma família que precise trocar o telhado ou materiais de trabalho.

O Governo colombiano, de acordo com a constituição de 1991, dá condições legais necessários que garantem para o caminho das Entidades Territoriais Indígenas (ETI's) na Amazônia colombiana para que se organizem e administrem seus territórios. A partir de 1993, garantidos pelo decreto 1088 do Governo colombiano, as lideranças indígenas de diferentes departamentos a Amazônia colombiana, começaram se organizar em associações, que são denominados de Asociaciones de Autoridads Tradicionales Indígenas (AATI's). Os indígneas de Trinidad fazem parte do Departamento Del Vaupés, onde existe o Consejo Regional Indígena Del Vaupés (CRIVA), com sede na cidade de Mitú (capital do departamento). A associação que aglomera as comunidades colombianas do alto Tiquié se chama Asociación de Autoridades Tradicionales Indígenas de la Zona Del Tiquié (AATIZOT). ${ }^{325}$

\footnotetext{
${ }^{325}$ María Camila RIVERA; Silvia GÓMEZ (ed.). Povos Indígenas no Brasil 2001/2005: 254-256. Ver anexo 30.
} 


\subsubsection{A fronteira: os marcos que dividem Pari-Cachoeira e Trinidad}

As duas comunidades (Pari-Cachoeira e Trinidad) são simbolicamente divididas por dois marcos que indicam o limite territorial entre Brasil e Colômbia (ver figuras 40 a 41), situados nas margens direita e esquerda do Tiquié, ELEV: $142 \mathrm{~m}, \mathrm{~N} \mathrm{00}{ }^{\circ} 15^{\prime} 35.0^{\prime \prime} \mathrm{e} \mathrm{W}$ $070^{\circ} 02^{\prime} 44.3^{\prime \prime 326}$.

$\mathrm{Na}$ margem esquerda do Tiquié fica localizada a comunidade Tuyuka, que se chama Fronteira (ver figura 42), também denominada em Tuyuka de Ihkisiriá ou Kaíra Tałó, onde vivem os Tuyuka brasileiros do subgrupo Niñã Dohkapuała. É uma comunidade situada do lado brasileiro.

O velho Tuyuka de nome $\tilde{\boldsymbol{N}} \boldsymbol{o} \boldsymbol{t} \tilde{\boldsymbol{o}}$, morador atual da Fronteira Brasil-Colômbia, no alto Tiquié, contou como a fronteira foi vigiada pelos dois Estado, depois que foram instalados os marcos divisórios.

Antigamente, no outro lado do rio (na margem direita), viviam os militares colombianos para vigiar a fronteira colombiana. Os militares brasileiros nunca chegaram a instalar posto de segurança. Os militares colombianos, sim, possuíam uma residência fixa. No posto de segurança ficavam dois, três ou mais militares. Enquanto estavam no posto, os militares colombianos não deixavam passar nenhum brasileiro (não-indígena) para o território colombiano; apenas os indígenas brasileiros que passavam, porém, mesmo assim, passavam após uma rígida inspeção.

Depois de vários anos vigiando a fronteira, foram embora, nunca mais retornaram.

Hoje, os marcos que marcam a fronteira entre o Brasil e a Colômbia estão dominados pela floresta. Ninguém limpa ao redor desses marcos, o mato toma conta. Nesse trecho do rio e do limite internacional, não há controle de saída e nem de entrada de indígenas brasileiros e colombianos. Para os indígenas, na prática, essa fronteira não interfere em suas relações de parentesco; não impede o uso da terra para o cultivo de mandioca; não impede que cacem e pesquem no território colombiano. Por exemplo, os Tuyuka dessa comunidade têm o seu domínio territorial tanto do lado brasileiro como do lado colombiano, possuem suas roças nos dois territórios, porque já viviam nessa área antes da divisão de fronteira. Por isso, transitam de maneira livre e com autoridade. Como disse o velho Tuyuka $\tilde{N} \tilde{o} t \tilde{o}$ : “fronteira é coisa dos não-indíos".

\footnotetext{
${ }^{326}$ Dados do GPS etrex GARMIN coletados por autor no dia 05/032007.
} 
Figura 40. Marco que indica o limite entre Brasil e Colômbia, alto Tiquié, AM.

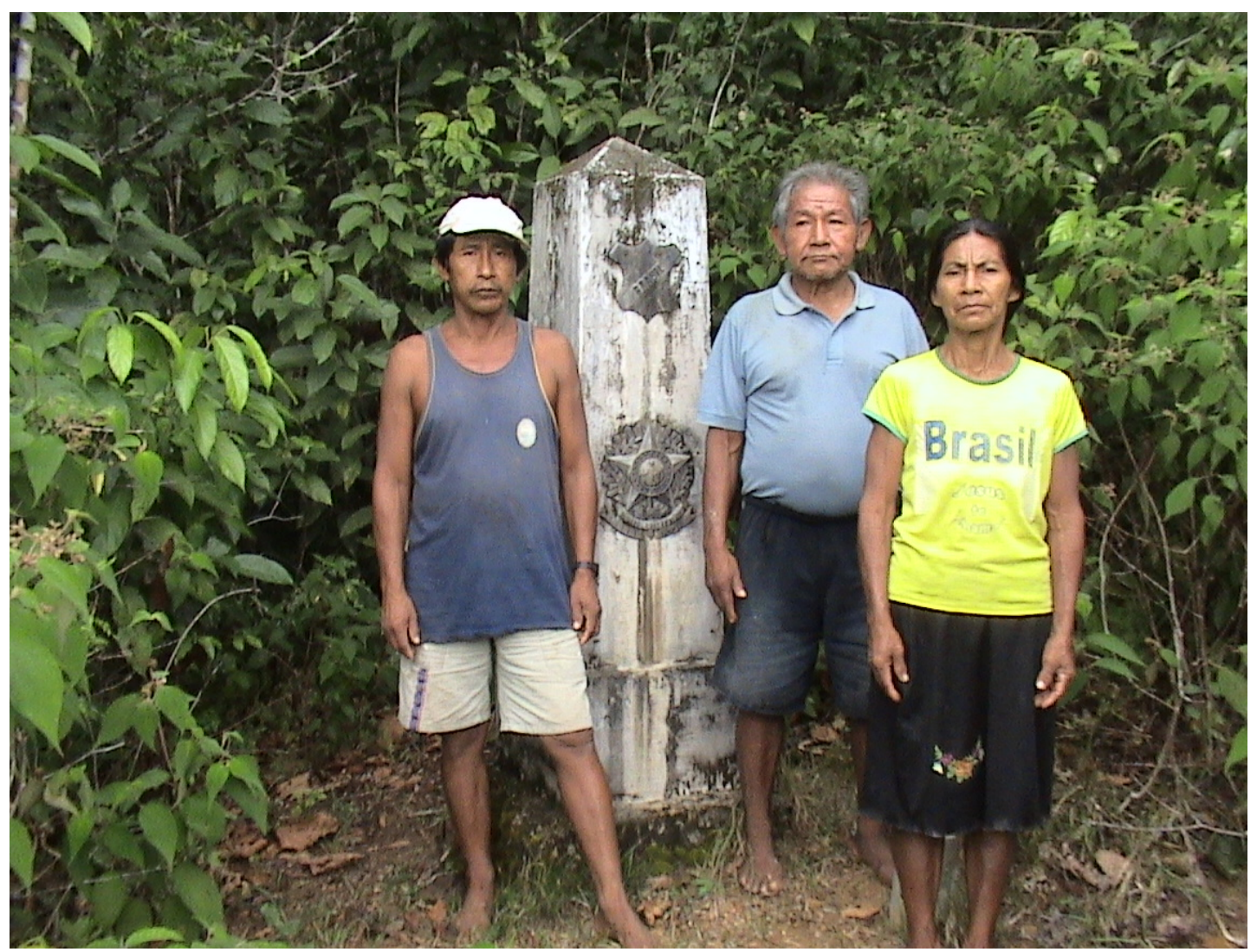

Fonte: acervo do autor, 2007.

Figura 41. As coordenadas do marco.

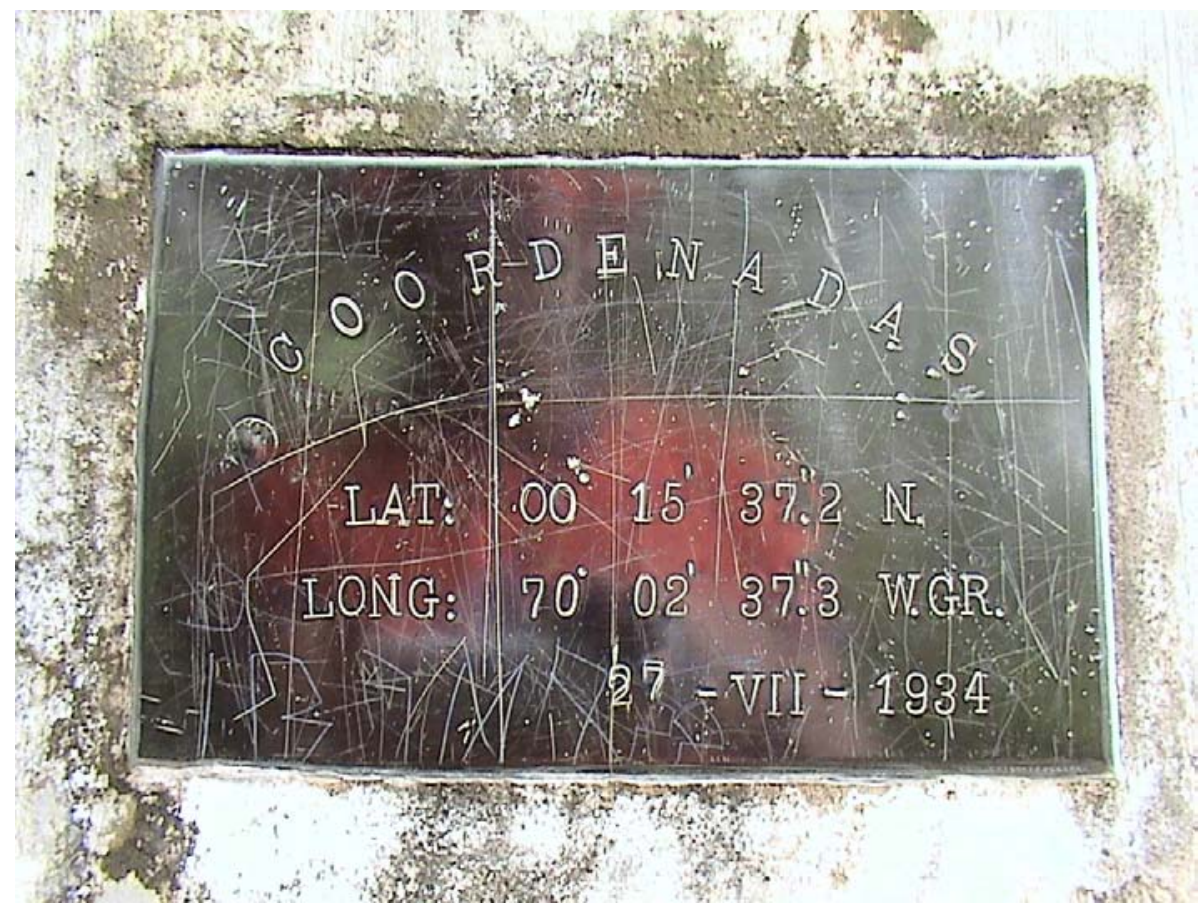

Fonte: acervo do autor, 2007.

O significado de parentesco, de familiaridade entre os indígenas de Trinidad e

Pari-Cachoeira ultrapassa a linha de fronteira criada pelos não-indíos. Depois que foram 
separados pela fronteira, os que nasceram e vivem no território colombiano se declaram colombianos e os que nasceram e vivem no território brasileiro se declaram brasileiros. Assim temos na região, Tukano e Tuyuka brasileiros; Tuyuka e Tukano colombianos; no entanto, acima de tudo, são Tuyuka e Tukano. Apesar de serem de nacionalidades diferentes, reconhecem culturalmente que cada povo constitui uma família, não importa em qual país estejam.

Depois da demarcação das Terras Indígenas do Alto Rio Negro (1998), os indígenas da Colômbia enfrentaram a contraposição de militares brasileiros, do $6^{\circ}$ Pelotão de Fronteira de Pari-Cachoeira, que no início tentaram controlar a entrada e a saída de indígenas colombianos para o território brasileiro.

No próximo item, apresentamos a atual onda de migração de indígenas colombianos para o território brasileiro, que fogem de ameaças das Forças Revolucionárias da Colômbia (FARC).

Figura 42. Bahsawi Tuyuka da comunidade de Fronteira.

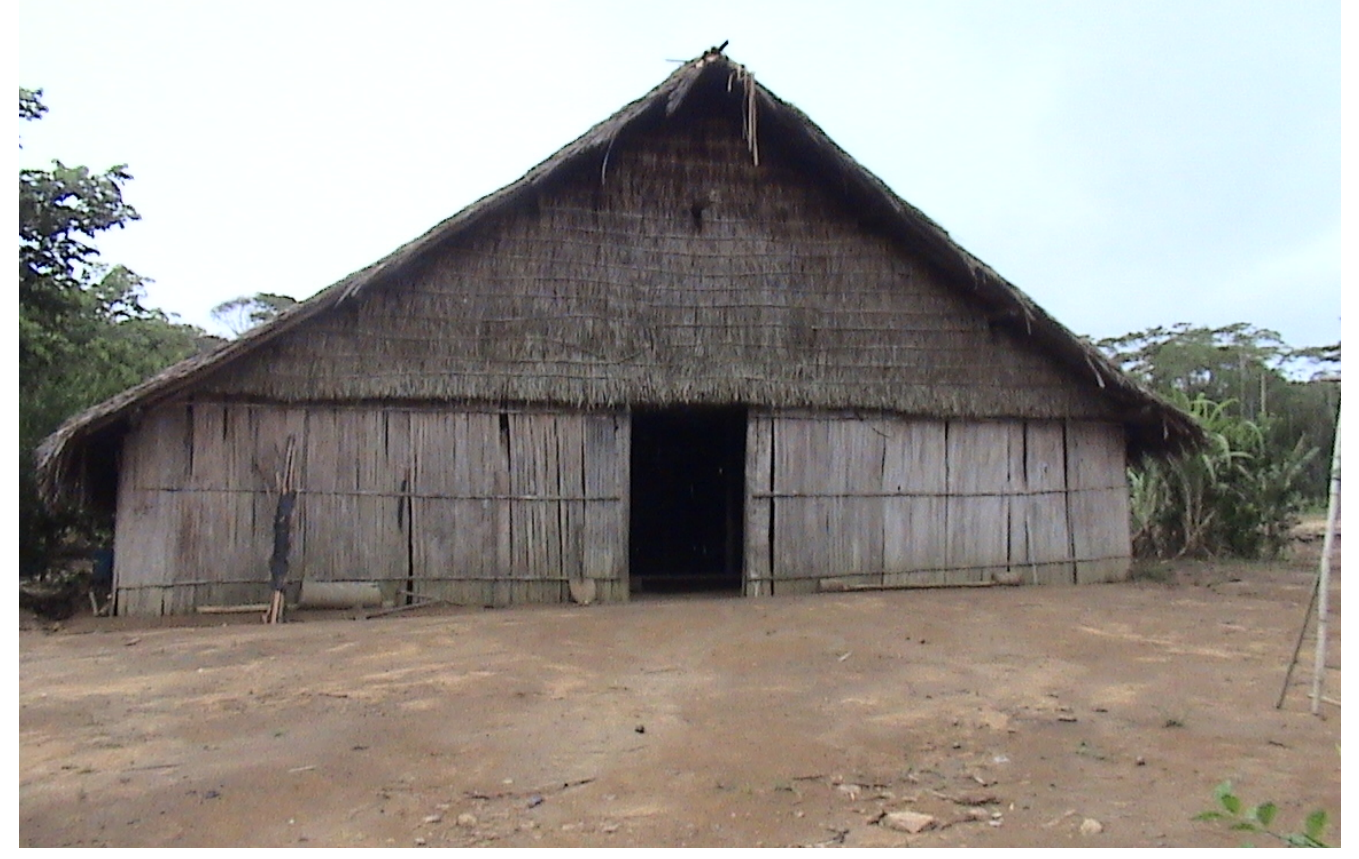

Fonte: acervo do autor, 2007. 


\subsection{A importância e o desafio da convivência indígena na fronteira}

Segundo a Organização Internacional de Trabalho (OIT 169), a convivência entre os indígenas em uma área de fronteira não impede o trânsito desses povos, como por exemplo, seria o caso entre brasileiros e colombianos e de outras nações. A própria lei internacional prevê que a fronteira tenha um trânsito permitido, desde que não venha contrariar as legalidades de cada nação envolvida.

A razão histórica da relação de convivência entre os indígenas brasileiros e colombianos se deve ao fato da lógica de familiaridade reger entre eles. Essa relação de convivência tem sido construída, desde antes da divisão de fronteira entre Brasil e Colômbia, antes da chegada de militares e da demarcação da Terra Indígena Alto Rio Negro.

Hoje, os indígenas que vivem na fronteira constituem e se consideram os guardiões da pátria, tanto do lado colombiano como do lado brasileiro. Todas as relações internacionais que envolvem os indígenas do Estado brasileiro e colombiano se dão numa relação de intercâmbio de comunicação intensa. Quando ocorrem eventos festivos ou revolucionários, do lado colombiano, os parentes colombianos rapidamente comunicam para os parentes brasileiros a situação do conflito e o risco de circulação. Isso significa que, de certo modo, durante os conflitos no território colombiano, muitas famílias indígenas se refugiam no território brasileiro, onde vivem os seus familiares.

Existem outras coisas que atraem e aproximam os indígenas colombianos para o Brasil, como por exemplo, os benefícios de aposentadoria, bolsa família, auxílio maternidade, auxílio doença, etc., coisas que não existem na Colômbia, mas que no Brasil apesar de ser uma ajuda mínima contribui para a melhoria das condições da vida indígena; outra razão que motiva a migração colombiana é pelo fato do Brasil ser um país de paz, sem guerra civil e sem guerrilha como as Farc.

Os indígenas brasileiros que migraram para a Colômbia no período da década de 50 a 80, no auge da extração de caucho e a produção livre de cocaína, hoje, começam retornar para o Brasil com medo da guerra civil colombiano e das Farc. Esses problemas fazem com que as muitas famílias indígenas da Colômbia, que têm parentes no Brasil, venham para cá. Ou seja, além de eles fugirem da invasão das FARC, vêm também porque não encontram um meio de sobrevivência no país de origem. 
De acordo com Henrique VAZ $(2007)^{327}$, muitos parentes colombianos chegam na sede da FUNAI em São Gabriel da Cachoeira falando o seguinte:

Aqui vocês vivem bem. Lá na Colômbia vivemos todo tempo preocupados se vai haver briga, se vai haver matança e ninguém consegue dormir, aqui vocês vivem bem; lá a gente morre de fome; aqui não, aqui vocês vendem a farinha de vocês, vendem as frutas, com isso vocês ganham dinheiro para comprar comida para os seus filhos; no porto de Camanaus, toda semana chega barco, quando vocês podem carregar e descarregar produtos para ganhar dinheiro; na Colômbia não existe nada disso.

Devido a tudo isso, muitos indígenas que fugiram das FARC se fixam aqui na cidade de São Gabriel da Cachoeira.

A migração dos indígenas colombianos para o Brasil cria um certo problema para a FUNAI, ou seja, para o Governo brasileiro por questões jurídicas. Até o momento a legislação brasileira não permite que esses indígenas sejam legalizados. O que dificulta a vida deles no Brasil é o fato de eles, os indígenas colombianos, não conseguirem obter documentações como cidadãos brasileiros. Para resolver esse impasse legal, a FUNAI estuda como resolver esse problema e melhorar a situação deles. ${ }^{328}$

O movimento indígena do rio Negro, junto com a Coordenação das Organizações Indígenas da Amazônia Brasileira (COIAB) pressiona a FUNAI intensamente para que esse problema seja resolvido. Para os indígenas do rio Negro, a chegada de seus familiares colombianos no Brasil não se constitui como problema, porque são seus parentes e seus irmãos, pelo contrário, fortalece a luta para a construção da autonomia indígena na região. ${ }^{329}$

Conforme Henrique VAZ (2007): ${ }^{330}$

Inclusive os indígenas brasileiros que se fixaram na Colômbia por muito tempo e que já retornaram para o Brasil com filhos adultos e mulheres colombianas, chegaram com toda a documentação colombiana. Nesses casos a gente sabe que eles são brasileiros, mas o fato de eles possuírem documentos colombianos provoca o impasse jurídico. Aqui no Brasil a lei não permite que sejam legalizados. Apesar da questão jurídica, nós nunca tivemos problema de convivência, pelo contrário, sempre tivemos uma relação de convivência muito pacífica e até fraternal em relação aos povos colombianos e brasileiros.

A situação da fronteira, depois da demarcação da Terra Indígena, ficou um pouco complicado para a relação de convivência entre os povos indígenas brasileiros e colombianos, porque existe uma lei que os militares brasileiros e a própria lei da demarcação coloca algumas restrições para entrada de indígenas e não-indígenas dentro das terras indígenas demarcadas. Por exemplo, para entrar nas áreas indígenas do rio Negro, você tem que pedir autorização da FUNAI e da FOIRN e tem que ter a autorização do líder geral da comunidade local. Essa norma também vale para os próprios indígenas colombianos e, então, eles fazem essa restrição.

A FUNAI está tentando brigar para que a Convenção 169 seja cumprida no país, porque entre os povos indígenas não deve ter restrições para circular na faixa de fronteira, porque vivem

\footnotetext{
${ }^{327}$ Entrevista concedida por Henrique VAZ, no dia 28 de fevereiro de 2007 em São Gabriel da Cachoeira.

Atualmente é Administrador Regional da FUNAI de São Gabriel da Cachoeira

${ }^{328}$ Ibidem., 2007.

${ }^{329}$ Ibidem., 2007.

${ }^{330}$ Ibidem., 2007.
} 
dentro de suas terras, entre seus parentes; a não ser para os não-indígenas que conhecem a legislação, que a lei tem que ser mais rígida; as suas entradas deveriam ser mais controladas e as suas saídas muito mais inspecionadas. Apesar das restrições existentes no Brasil os indígenas transitam na fronteira livremente.

Outro exemplo, relatado pelo Henrique VAZ $(2007)^{331}$, foi a atuação rígida de militares como os indígenas colombianos na fronteira, no alto Tiquié, que segundo ele:

Depois da demarcação da Terra Indígena do Alto Rio Negro (1998), a relação de convivência entre os indígenas da área de Pari-Cachoeira e os nossos parentes da área de Trinidad esfriou um pouco, porque os militares começaram fiscalizar e muitas vezes os obrigavam retornar para a Colômbia. Com medo de serem vistos como ameaça à soberania nacional, os indígenas de Trinidad pararam de transitar e visitar os seus parentes no território brasileiro.

O que une e fortalece os diferentes povos para uma convivência transfronteiriça entre Brasil e Colômbia é a observação e a vivência de seus valores tradicionais que compartilham entre seus parentes de diferentes povos da região. Um dos eventos mais importantes que demonstra a construção da relação de convivência transfronteiriça entre os indígenas de Trinidad e Pari-Cachoeira, e com outros grupos da região é o evento esportivo dos Jogos do Triângulo Tukano, que acontece de dois em dois em Pari-Cachoeira, Iauaretê e Taracuá, Uaupés, Brasil. Nesse evento esportivo, os parentes colombianos são convidados para participarem com suas delegações. É o evento que aproxima os familiares que vivem em territórios diferentes e fortalece a luta indígena pela autonomia territorial.

\subsection{Jogos do Triângulo Tukano: o fortalecimento da relação de convivência indígena}

O Triângulo Tukano é uma área indígena, localizada na bacia do Uaupés, região do alto rio Negro, Amazonas, Brasil. Recebe esta denominação devido as três comunidades indígenas (Iauaretê, Pari-Cachoeira e Taracuá) que formam triângulo devido as suas posições geográficas (ver mapa 04).

- Pari-Cachoeira é a comunidade com aspecto urbano e a população exclusivamente indígena, hoje, com aproximadamente 600 pessoas.

- Taracuá também chamada de Merẽ wasá ${ }^{332}$, situada a margem esquerda do rio Uaupés, ELEV: 92m, N 0007'52.9” e W 068³2’32.6”333, baixo Uaupés; é a comunidade

\footnotetext{
${ }^{331}$ Ibidem, 2007.

${ }^{332}$ Merẽwasá em Tukano significa casa das formigas.

${ }^{333}$ Fonte: GPS etrex, dados obtidos na pesquisa de campo do autor, 20007.
} 
Tukano, tem aspecto urbano e população exclusivamente indígena, com aproximadamente 500 pessoas (ver foto 27 ).

- Iauaretê é também denominada de Yaí Poeá (em Tukano, que significa cachoeira da Onça), situada na foz do rio Papuri, nas duas margens do Uaupés. Hoje, a comunidade é chamada de "cidade indígena", com uma população de aproximadamente quatro mil habitantes (ver figura 29). A comunidade é dominada pelos Tukano e Tariano.

O reconhecimento de cidade indígena não é por acaso, pois ela talvez seja a maior comunidade indígena do continente americano. No aspecto da organização política comunitária é uma referência para outras comunidades indígenas da região do alto rio Negro, porque o poder político é compartilhado entre todos os grupos que constituem a "cidade".

Figura 43. A comunidade indígena de Taracuá.

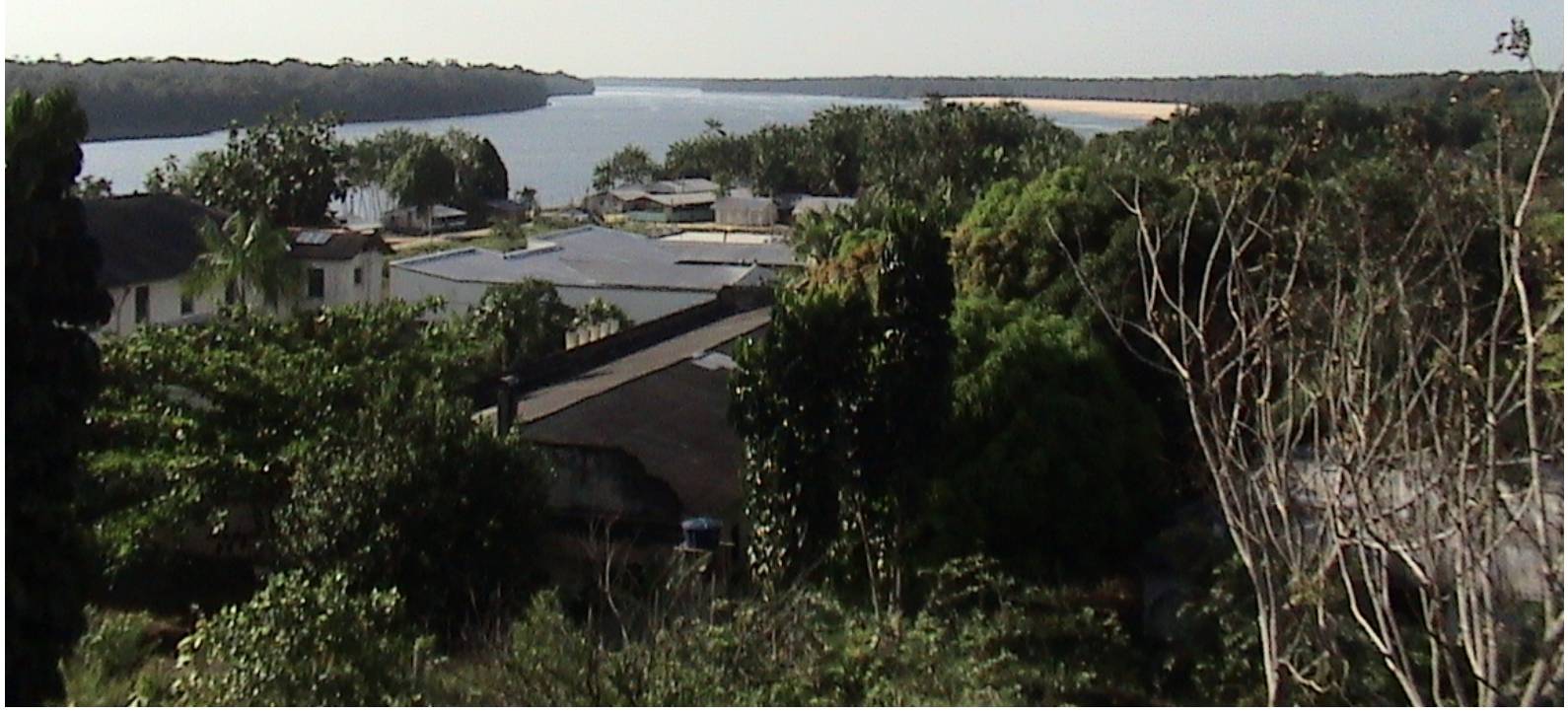

Fonte: acervo do autor, 2007. 
Figura 44. Vista parcial da vila Dom Pedro Massa, Iauaretê, AM.

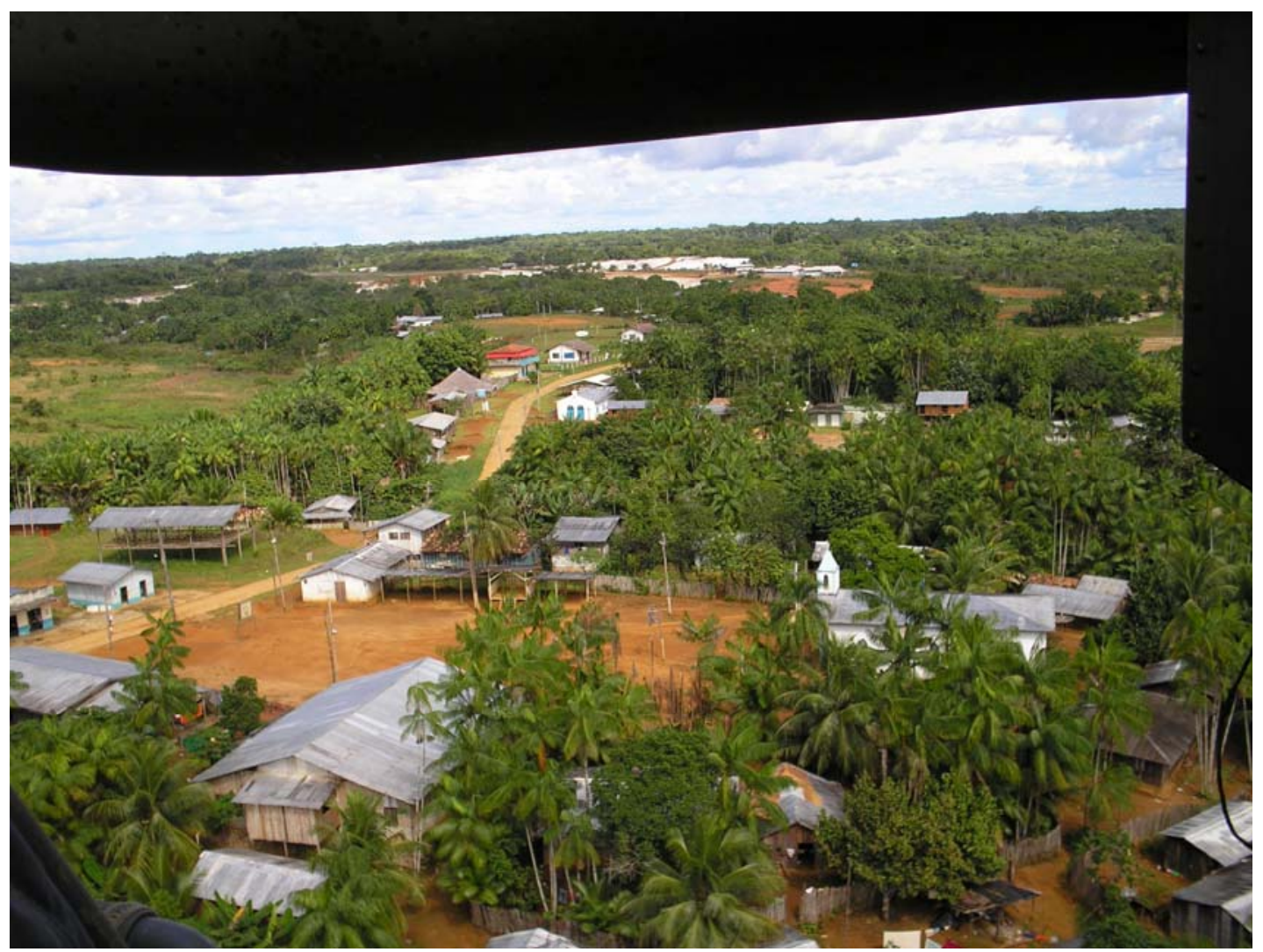

Fonte: Geraldo Veloso FERREIRA, 2004.

Figura 45. Pelotão do Exército em Iauaretê.

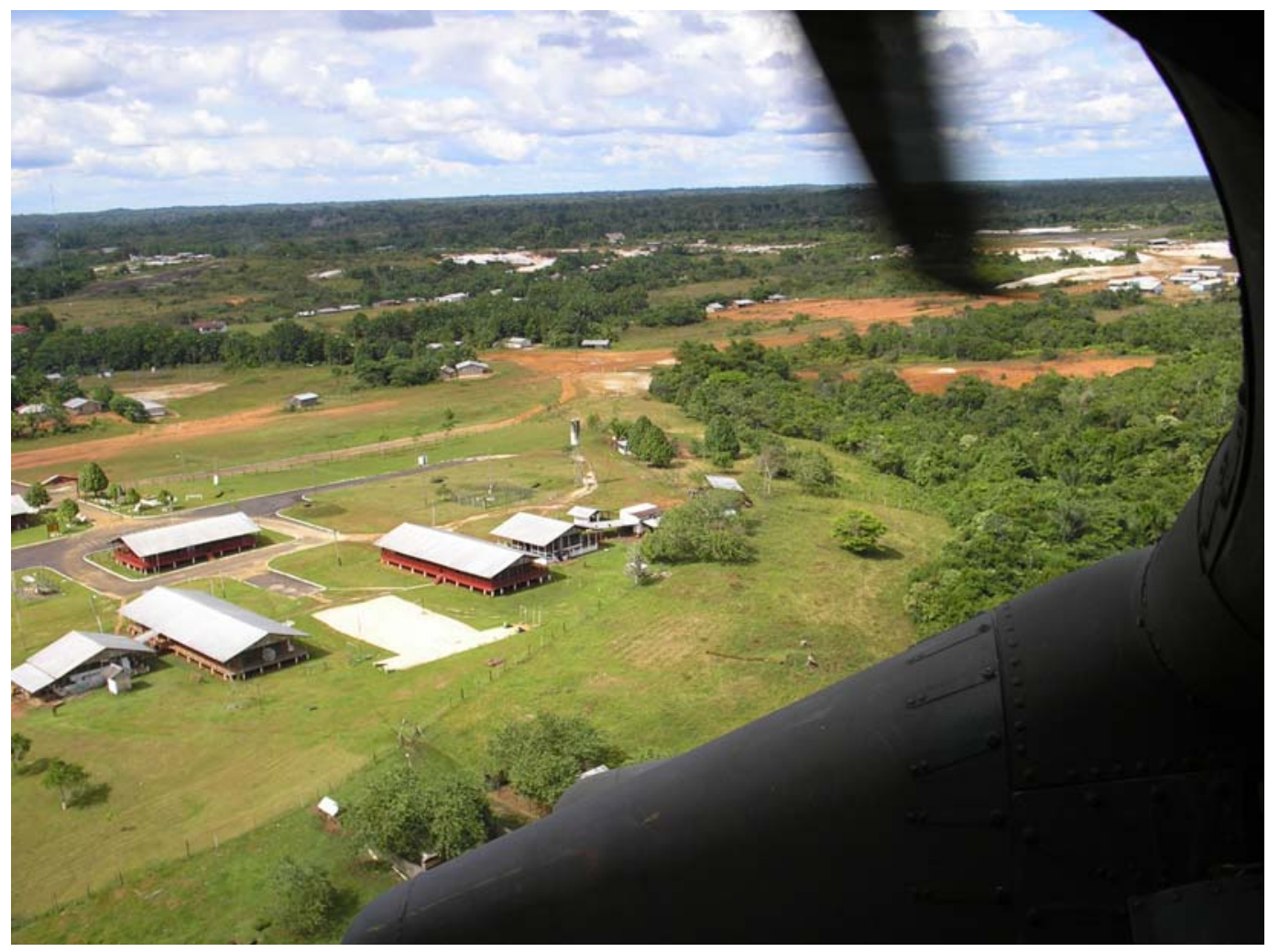

Fonte: Geraldo Veloso FERREIRA, 2004. 
Mapa 4. Comunidades indígenas que formam o Triângulo Tukano: Pari-Cachoeira, Iauaretê e Taracuá.

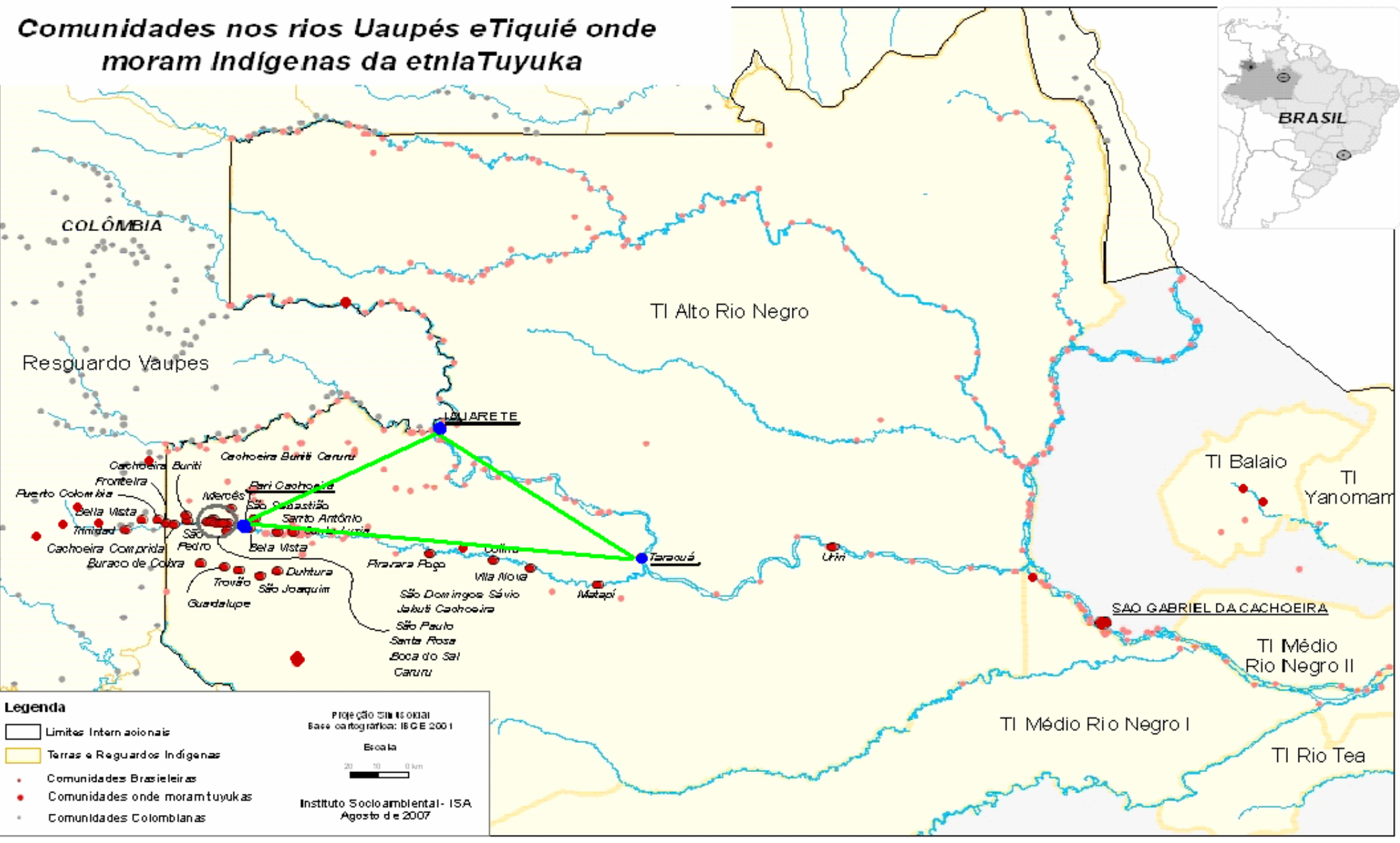

Fonte: adaptado por autor do Instituto Socioambiental, 2008. Os dados da presença Tuyuka, em diversas comunidades do alto rio Negro é do autor, 2007. 
O Triângulo Tukano é habitado por 19 (vinte) povos indígenas regidos por princípios patrilineares e exogâmicos. Segundo os estudos antropológicos e lingüísticos, os vinte povos são de três troncos lingüísticos: Arwak, Maku e Tukano Oriental. Em seguida, apresentamos os povos dos três troncos: do tronco lingüístico Maku - Hupda, Yuhupe; do tronco lingüístico Tukano - Arapaso, Bará, Barasano, Desano, Karapanã, Kubeo, Makuna, Miriti-Tapuya, Pira-Tapuya, Siriano, Taiwano, Tatuyo, Tukano, Tuyuka, Wanano, Yuruti; do tronco lingüístico Arwak - Tariano.

Segundo a história de origem dos povos indígenas do Uaupés, são grupos originários da Casa da Emergência de Ohkó Diawi, localizado no Baixo Uaupés. Por essa razão histórica, constituem uma única família e não diferentes como foram divididos por alguns estudiosos não-indígenas.

Esses povos foram separados em diferentes territórios, por causa da divisão de fronteira entre os dos Estados nacionais (Brasil e Colômbia). A partir daí tiveram que se adequar à jurisdição de cada país. As normas legais de cada nação geraram o distanciamento de parentes e familiares, porque de um lado, os indígenas que ficaram no território colombiano se tornaram colombianos; do outro lado, os indígenas que permaneceram no território brasileiro se tornaram cidadãos brasileiros.

A partir da década de 80, as lideranças de Pari-Cachoeira, sentiram a necessidade de promover eventos transfronteiriços para tentar reatar e reaproximar suas relações de convivência com seus parentes colombianos. O meio inicial para promover essa relação foi através de eventos esportivos. Foi por meio desses eventos que os indígenas de Pari-Cachoeira iniciaram a convivência mais intensa com os indígenas de Iauaretê e Taracuá que, até então, também não existia.

O evento esportivo do Triângulo Tukano fortaleceu as relações matrimonias; a organização da política indígena; a participação indígena na política partidária do município de São Gabriel da Cachoeira; e, enfim, muitos indígenas, de ambas as nacionalidades que não conheciam os seus parentes descobriram novos familiares.

\subsubsection{A história de origem dos Jogos do Triângulo Tukano}

O reinício da caminhada de reaproximação da relação de convivência entre os indígenas do Uaupés brasileiro e colombiano começou na década de 80. A primeira iniciativa foi dada pelos Tukano de Pari-Cachoeira, através de eventos esportivos, que culminou nos Jogos do Triângulo Tukano.

Em 1980, o Desano Henrique VAZ foi o primeiro Presidente da Liga Esportiva de PariCachoeira (LEP), que impulsionou as relações mais intensas entre os indígenas brasileiros e colombianos. Henrique Vaz (2007) contou o seguinte:

O movimento esportivo iniciou em Pari-Cachoeira, no ano de 1980. No início, os jogos eram realizados apenas internamente, sempre na semana da pátria. Primeiro convidávamos os parentes de 
comunidades mais próximas, tais como: os Desano de São Sebastião (Umari Igarapé), os Tukano de Jandu (Umari Igarapé) e Bela Vista (baixo Uaupés). Todos os finais de semana a gente fazia torneio de futebol de campo e futsal em Pari-Cachoeira.

Em 1980, após o torneio, realizou-se uma eleição para escolher o primeiro Presidente da Liga Esportiva de Pari-Cachoeira, foi aí que fui eleito como o primeiro Presidente da Liga. Daí em diante, o evento começou de forma mais organizada e ampliada, pois no dia 25 de setembro, depois de sete de setembro, organizamos um debate no qual concluímos que tínhamos que expandir e pensar além de São Sebastião e Bela Vista, e convidar outros parentes tanto os brasileiros de Iauaretê e Taracuá como os colombianos de Trinidad e Monfort.

Daí a diante, tivemos que nos organizar pensando em como envolver os nossos parentes colombianos. $\mathrm{Na}$ época, nós que fomos primeiro à Trinidad para participar de jogos. Antes de ir à Colômbia, vim para São Gabriel da Cachoeira atrás do finado Prefeito Dagoberto para pedir equipamentos, bolas etc., que seriam utilizados no evento esportivo em Trinidad e, enfim, consegui.

Em Trinidad, eles gostaram muito com a nossa presença, porque lá têm muitos nossos parentes que casaram com os Tuyuka de lá, que vivem na comunidade. Foi uma festa de confraternização muito boa. Nós, de Pari-Cachoeira, também gostamos e voltamos muito animados. No retorno treinamos de novo e, em seguida, fomos para o Monfort. Para chegar na comunidade de Monfort fomos pelo varadouro que liga PariCachoeira a Monfort na Colômbia. Durante a viagem andamos um dia inteiro no meio do mato. Rapaz, lá também foi muito bom.

Depois desses dois eventos que aconteceu em 1981, decidimos convidar os parentes dessas duas comunidades colombianas, dessa vez para participar em Pari-Cachoeira para a festividade do dia sete de setembro e o torneio que seria realizado. Eles vieram e a gente começou fazer esse torneio.

Em 1982, em uma avaliação que fizemos, dissemos: Puxa! Já que estamos conseguindo trazer o pessoal da Colômbia, porque não incluir o pessoal de Taracuá e Iauaretê? Aí que veio essa idéia do Triângulo Tukano. A idéia surgiu porque estávamos com o objetivo de criar os jogos entre os indígenas falantes da língua Tukana e, além disso, era uma oportunidade para criar um ambiente de troca de idéias sobre a política indígena, sobre a demarcação da terra e a discussão do Projeto Calha Norte, que já envolviam diretamente as comunidades do Tiquié. Então, a gente tinha que envolver mais comunidades do Uaupés para esses jogos.

O objetivo principal mesmo era trazer trocas de idéias, conhecimento das famílias distantes, tanto do território brasileiro (Iauaretê e Taracuá) como do território colombiano. Ficou mais fácil esse relacionamento de conhecimento e boa convivência com os outros. Então, em 1983, foi oficializado esse Triângulo Tukano. A partir desse ano, o evento seria de dois em dois, com participação de todos os nossos parentes da Colômbia e envolvendo as comunidades de Pari, Iauaretê e Taracuá.

No final de 1983, saí da coordenação da liga esportiva de Pari-Cachoeira. Depois entrou o Afonso Machado e, assim, continuamos... O movimento da liga esportiva, além de trazer vários benefícios para a população indígena, para os parentes se conhecerem, além de ajudar na luta política, surtiu efeito bom para reaproximar os parentes brasileiros e colombianos.

Como os jogos coincidiam com a política partidária do município, ou seja, com o período da campanha eleitoral, pensamos conciliar também com a política do município. Na época se discutia ou se ouvia falar que Iauaretê seria município, por isso os de Iauaretê queriam o apoio de outros distritos. Diante dessa possibilidade e notícia, nós, de Pari-Cachoeira tínhamos interesse para ocupar o poder da futura sede do município. Assim, o objetivo era escolher o Prefeito de Iauretê, o Vice seria de Pari-Cachoeira e o Presidente da Câmara de Vereadores seria de Taracuá e os demais seriam vereadores. Naquela época, essa foi a discussão que tivemos. Só que no final não aconteceu nada, Iauaretê não se tornou município. Depois surgiu outra questão, que ficou até hoje: a discussão sobre o Território Indígena.

No final, percebi que com essa mobilização esportiva e política, os indígenas se envolveram mais com a prática do esporte, principalmente os jovens; o relacionamento e a convivência de uma comunidade com a outra facilitou fortaleceu a troca de casamento; inclusive muita gente levou mulheres para casar, conheceram do lugar, as meninas colombianas acabaram se casando com os brasileiros e foi assim que aconteceu, e, hoje, alguns de nossos objetivos foram alcançados.

\section{De acordo com Afonso MACHADO (2007): ${ }^{334}$}

\footnotetext{
${ }^{334}$ Entrevista concedida no dia 14 de março de 2007 em Pari-Cachoeira e documentada por autor.
} 
Para se tornar Jogos do Triângulo, o primeiro evento foi realizado em Taracuá, em maio de 1982 com apoio do Prefeito Dagoberto Pinder de Albuquerque. O evento foi denominado de Torneio Interdistrital (Iauaretê, Pari-Cachoeira, São Gabriel da Cachoeira e Taracuá).

No final do encontro, o prefeito propôs que continuássemos promovendo esse tipo de evento. Essa proposta era mais uma motivação de uma idéia que a gente já tinha, mas não tínhamos condições financeiras para sediar jogos em Pari-Cachoeira. Diante dessa impossibilidade, chegamos a um acordo que, após quatro anos, em 1986, Iauaretê seria a sede do I Jogos Esportivos do Triângulo Tukano. Iauaretê foi escolhida por ter mais condições estruturais para acolher atletas e para promover jogos. Ainda em Taracuá ficou decidido que o evento aconteceria de dois em dois.

Quando projetamos realizar os jogos de dois em dois, tivemos os seguintes objetivos: 1) fortalecer a nossa política indígena; 2) fortalecer a participação indígena na política partidária do município de São Gabriel da Cachoeira, com interesse de eleger indígenas para cargos majoritários e proporcionais; 3) fortalecer as relações de casamento entre os indígenas de Iauaretê, Pari-Cachoeira, Taracuá e os parentes colombianos. Enfim, o nosso sonho era fortalecer social, econômica e politicamente o Triângulo Tukano.

As comunidades que participam do evento são: do Brasil - Pari-Cachoeira, Taracuá e Iauaretê; da Colômbia - Trinidad e Bela Vista, do alto Tiquié; Acariquara, Wainambi, Monfort, Terezita (da região do Papuri) e Ibacaba, do alto Uaupés. Outros parentes brasileiros, das comunidades de Marabitana, Balaio e Camanaus foram convidados, no entanto nem todos chegaram a participar, apenas uma vez o pessoal de Camanaus participaram. Quando convidamos outras comunidades foi porque achávamos que assim poderíamos ter mais parentes convivendo conosco, porém nem sempre deu certo.

Apesar de algumas delegações não conseguirem participar do evento, por condições financeiras ou porque acontecem imprevistos, como quebra de barcos, foi o que aconteceu com o pessoal de Marabitana, aos poucos a idéia é convidar mais parentes da região.

Outra questão é a participação de militares não-indígenas no evento. Nunca preterimos a participação de militares na seleção dos times de nossos parentes, porém alguns levam vantagens porque nem todas as comunidades têm a presença de Pelotões de Fronteira, por exemplo Taracuá e todas as comunidades colombianas que participam do evento não possuem militares em suas comunidades. Além disso, a participação de militares como juízes de partidas prejudica os times de comunidades que não têm milicos.

Por essa razão, os Jogos do Triângulo Tukano é o evento esportivo que estreita as relações de parentesco entre os grupos do território brasileiro e colombiano. A relação de parentesco constitui o fundamento da interação familiar, que ultrapassa o limite dos territórios nacionais. Para alguns políticos e militares brasileiros e colombianos que não aceitam a presença indígena na faixa de fronteira por razões de soberania, afirmamos que esse movimento esportivo não interfere e nem viola a soberania nacional, porque em nenhum momento os indígenas discutiram ou discutem sobre a possibilidade de um dia constituírem um território independente; o interesse maior que os indígenas têm é de uma convivência familiar sem interferência de agentes externos, todavia respeitando a jurisdição de cada nação; por isso, até hoje, mesmo sendo parentes cada um se identifica como brasileiros e colombianos, e cumprem a legislação de seus países de origem. 


\section{CONSIDERAÇÕES FINAIS}

Este trabalho, que projetou descrever sobre as relações de convivência e construção da autodeterminação indígena dos povos indígenas de Pari-Cachoeira (Brasil) e Trinidad (Colômbia), do alto Tquié, região do Uaupés, Amazonas, porporcionou uma experiência agradável e ao mesmo tempo, com isso, pudemos viajar e conviver diretamente com os indígenas do Tiquié.

No final deste estudo, é possível dizer que nem todos os problemas foram respondidos, porque alguns pontos foram levantados e sucintamente discutidos. Precisam ser aprofundados, no entanto o processo analítico produziu algumas considerações finais importantes de como vivenciam os povos indígenas na fronteira entre Brasil e Colômbias no dinâmico processo de mudança das relações internacionais; como se dá as relações de convivência entre indígenas, missionários, militares e ONGs; e como os indígenas representam uma estratégia política para a segurança da Amazônia, sem por em risco a soberania dos Estados onde vivem.

O estudo da convivência e construção da autodeterminação indígena do alto Tiquié, aqui constituída em quatro capítulos e analisados em sua dimensão histórico-cosmológica, permitiu maior aprofundamento do estudo e, conseqüentemente, um melhor entendimento sobre o movimento indígena atual; as concepções de autodeterminação, poder e liberdade; a convivência entre indígenas e não-indígenas (missionários, militares e ONGs) após a demarcação de suas terras em 1998; e, efim, visualizou a fronteira "viva" constituída pelo nosso objeto de pesquisa.

Sobre a dimensão histórica-cosmológica dos povos do Uaupés e o movimento indígena do alto rio Negro, estamos, portanto, diante de três questões. Em relação as concepções alguns termos usados (povo, comunidade, fronteira, território e circulação estamos, então, face a um paradoxo da política: poder e liberdade. A respeito das relações de convivência entre indígenas e não-indígienas no Uaupés, estamos, perante as três tipos de relações: indígenas e missionários, indígenas e militares, indígenas e ONGs. Por último, estamos frente a fronteira "viva" na área de Pari-Cachoeira e Trinidad, alto Tiquié. Dedico uma parte das considerações finais a destacar sinteticamente, que questões, que bases tradicionais e que concepções são estas e o que eles representam para os indígena do Uaupés.

$\mathrm{Na}$ dimensão histórica-cosmológica dos indígenas do Uaupés e o movimento indígena do rio Negro, temos informções e análise da história origem dos povos do Uaupés, segundo Avelino DUTRA (2007), os indígena dessa rgião foram criados por Pamutĩ Pinõ (também é chamado de Suniã Pãłãmĩ) e por Yałebo (irmão menor de Suniã Pãłãmĩ) na Casa da Emergência de Ohkó Diawi, médio Uaupés, Amazonas. As histórias como essas, segundo Avelino DUTRA (2007) são as "Histórias verdadeiras" (ELIADE, 1963) 335 . São verdadeiras, porque guardam fatos verídicos que ocorreram há milhares de anos, isto é, não são meramente mitos ou contos. Para vários autores não-indígenas, as

\footnotetext{
${ }^{335}$ ELIADE, Mircea, 1963: 23.
} 
histórias que os indígenas narraram e transmitem de geração em geração são mitos, acontecimentos imaginários, pensamentos sem lógica. Entretanto, os indígenas - e principalmente - os pajés (yaíwa e ba'asera), não se importam o que alguns estudiosos não-índios pensam sobre o que eles têm certeza de que é história verdadeira. Ao mesmo tempo, por exemplo, não querem saber se a Bíblia é sagrada ou não, não questionam se o que está escrito no Alcorão é verdade ou é falso. A única coisa que querem é continuar vivenciando aquilo que acreditam e procurar reviver o ritual de criação que ocorreu na Casa da Emergência de Ohkó Diawi. Isso não significa que ninguém mais possa questionar ou refletir sobre os conhecimentos tradicionais indígenas, pelo contrário, agora que os próprios indígenas do Uaupés iniciaram o processo de formalização de seus conhecimentos, que levará às análises mais aprofundadas de seus conhecimentos tradicionais e suas histórias.

A luta do movimento indígena, muitas vezes, fundamenta-se nessas histórias para reivindicar a demarcação de suas terras, porque argumentam que eles são descendentes dos que foram criados naquele território, por essa razão a terra é deles. A criação da Federação das Organizações Indígenas do Rio Negro (FOIRN), baseou-se nesse princípio histórico da criação para conquistar a homologação de suas terras em 1998 e, hoje, reivinidcam a autodeterminação política para ver melhoria de vida de suas comunidades. Por estarem na área de fronteira são temidos por militares, políticos, empresas mineradores e comerciantes não-indígenas do município de São Gabriel da Cachoeira, que vêem na luta indígena uma ameaça à soberania nacional e à segurança da Amzônia. Na verdade, esse "medo" é movido por interesses estratégicos, políticos, pessoais, porque os indígenas constituem uma barreira para exploração e devastação de recursos animais, vegetais e minerais da Amazônia.

Percebemos que o movimento indígena do rio Negro, que teve origem no início da década de 70, com os Tukano de Pari-Cachoeira, alto Tiquié, hoje, constitui uma Federação bem mais estruturada do país. Para chegar a esse patamar a FOIRN não caminhou sozinho, ela contou com a parceria de instituições internacionais que "injetaram" recursos financeiros para executar centenas de projetos pilotos e projetos sutentáveis em várias comundiades indígenas da região. Além de recursos financeiros externo, o movimento indígena contou com o Instituto Socioambiental, que desde a sua fundação é principal parceira. Talvez, sem a assessoria, em quase todos os aspectos, a Federação não seria o que é hoje: uma instituição indígena reconhecida nacional e internacionalmente pela sua luta por interesses indígenas do rio Negro.

A participação indígena na política partidária no município de São Gabriel da Cachoeira, AM, é resultado da própria articulação do movimento indígena do rio Negro. Os partidos políticos existentes no município são controlados por políticos não-indígenas, que muitas vezes usam os partidos como se fossem suas propriedades privadas. Essa forma de controlar os partidos políticos que na década de 70, 80 e 90 impediu o protagonismo indígena dentro dos partidos, porque os não indígenas nunca aceitaram que um indígena comandasse a prefeitura do município. A não aceitação significava 
discriminação, pois políticos diziam que os brancos não nasceram para serem mandados por índios irresponsáveis, cachaceiros e sem experiência administrava. Inclusive os próprios indígenas diziam que: um índio quando entra no poder, não quer saber mais de seus parentes; o índio não tem dinheiro para ser prefeito; somente os brancos que têm dinheiro, por isso eles devem ser prefeitos, deputado, senadores etc; o índio político, quando vê dinheiro, também rouba como os brancos, por isso ninguém vota.

Apesar dos desafios da imagem indígena enntre os não-indígenas e comunidades indígenas, algumas lideranças do movimento indígena começaram se filiar em vários partidos políticos [PSB, PFL (PD), PMDB, PDT, PL, PSDB, PT, PV, PCdo B, etc,.]. Cansados de serem apenas coadjuvantes de políticos não-indígenas, os ex-dirigentes da FOIRN começaram articular a participação mais efetiva dos indígenas na política partidária. Assim, no ano de 2000, criaram a Comissão Indígena Suprapartidári, que envolvia o Partido dos Trabalhadores (PT), Partido Verde (PV) e Partido Comunista do Brasil (PCdoB). O PT era dirigido pelos indígenas do Triângulo Tukano, Uupés; o PV, foi até denominado de Partido dos Baniwa, porque a a direção do partido era constituído de lideranças Baniwa, portanto, representava a área do Içana e Xié; o PCdoB era dirigido por representantes do povo Baré.

Antes das eleições municipais de de 2004, nunca um índio havia se candidatado para cargo majoritário, sempre tiveram vereadores e um vice-prefeito. Em 2004, tentaram concorrer para cargo majoritário, no entato perderam as eleições por conflitos internos provocado pelos dirigintes dos partidos (PT, PV e PCdoB) e, conseqüentemente, nas urnas. Apesar de os indígenas representarem 90 \% da população do município não conseguiram eleger um prefeito indígena. Nas eleições municipais de 2008, mais uma vez lançaram uma candidatura indígena e, enfim, ganharam as eleições. Para a história do movimento indígena do rio Negro e para a polítida partidária do município foi um feito histórico, porque até então os não indígenas achavam que dominavam a política do município. Essa vitória só aconteceu, porque o próprio movimento indígena possibilitou indiretamente a articulação política para que algumas de suas lideranças participassem da politica partidária do município.

Outra coisa que percebemos na política indígena do rio Negro é a participação mais intensa de mulheres indígenas. Elas começam reividicar e ocupar cargos de comando na Federação. As mulheres não receberam esses espaços pela boa vontade dos homens, tiverma que lutar contra a resistência dos homens. Apesar da resistência da maioria dos homens, aos pouvos elas vêm conquistando seu espaço político dentro do movimento indígena. Para a vida e a luta indígena a participação direta de mulheres dentro do movimento representa um ponto positivo, porque elas têm uma nova visão e compreensão de luta que reforçam a dinâmcia do movimento indígena.

Os conceitos como de povo, comunidade, fronteira, autodeterminação, poder e liberddade, que destacamos são termos reconhecidos pelo direito internacional, que como quaisquer outros povos da 
Terra têm direitos reconhecidos. Assim como afirma FARIA (1997), para os indígenas o Estado brasileiro pode chamar de povo, etnia, grupo sociedade indígea ou quaisquer outros termos de respeito, que não se importa, porque suas concepções são diferentes. Para se referir ao lugar onde habitam os indígenas denominam de terra. Os não-indígenas já criam outros termos e definições para controlar seus interesses privados e estatais. Por esse motivo, hoje, os indígenas brasileiros que vivem principalmente em áreas de fronteira internacional da Amazônia enfrentam oposições de alguns políticos, juristas, acadêmicos, militares, arrozeiros, madeireiros, mineradoras, brasileiros, quando reividicam a demarcação de suas terras, a autodeterminação e lutam para serem reconhecidos como povos, porque são povos.

Um exemplo concreto da atual luta indígena na Amazônais é o caso do conflito entre indígenas e não-indígenas sobre a demarcação da Reserva Indígena Raposa Serra do Sol, em Roraima, onde a causa da briga constitui os interesses de ambas as partes. No entanto, os indígenas lutam por uma coisa que sempre foi deles, a terra que herdaram de seus antepassados desde antes da chegada de quaisquer pessoas da sociedade envovlente. Os grupos indígenas brsileiros reivindicam a autodeterminação para garantirem a continuidade de suas geraçãos sob a segurança do Estado brasileiro. Em nenhum momento da história dos movimentos indígenas da Amazônia de outras regiões do país, as lidderanças colocaram em suas pautas de discussões e como prioridade a independância de seus territórios após a homologação de suas terras, aliás nunca discutiram sobre essa possibilidade. Os indígenas sempre se orgulharam por serem brasileiros, por isso nenhuma instituição não-governamental, nenhuma instituição religiosa ou quaisquer agentes estrangeiros conseguiram e conseguirão incutir nos indígenas a idéia de independância territorial, porque os grupos indígenas sabem quem são e o que querem: quem vive no Brasil serão sempre brasileiros; quem vive na Colômbia semrpe serão colombianos, etc.

Os sujeitos que supõe ou acusam que os indígenas das áreas fronteiriças representam uma ameça para a soberania nacional e que o Governo brasileiro está entregando a Amazônia para os novos proprietários não entenderam os objetivos da luta indígena pela autodeterminaão territorial, aliás não querem entender, porque é mais um pretexto de políticos e outros agentes para explorar os recursos naturais da Amazônia em nome para ganhar dinheiro. Aqui entram as garras do poder econômico, o Brasil é um país que prioriza o crescimento enconômico, através de exportação, onde os melhores produtos são feitos para os países ricos, enquanto que para o povo brasileiro (indígena e não-indígena) são oferecidos os produtos segunda qualidade. Por isso, para os representantes do desenvolvimento econômico do Brasil, demarcar terra indígena na Amazônia significa atrapalhar o avanço enconômico. A luta entre indígenas e não-indígenas constitui o verdadeiro paradoxo da política, onde de um lado há os que detêm o poder político e econômico que lutam para conquistar novos territórios e, por outro lado, existem os indígenas que reivindicam a autodeterminação, ou seja lutam por uma liberdade 
cultural. Entretanto, como tem menos força política dentro do Estado brasileiro dependem do bom senso do Supremo Tribunal, porque no Brasil a assinatura parece que não tem muito valor.

Em relação a convivência entre indígenas e não-indígenas (missionários, militares e ONGs) no alto rio Negro, principalmente nas comunidades de Pari-Cachoeira (Brasil) e Trinidade (Colômbia), que formam o objeto de nosso estudo, concluimos que: os indígenas reconhecem que os missionários da Igreja Católica tentaram destruir totalmente seus costumes e tradições, mas não conseguiram, porque que a essência do ser indígena é maior que qualquer ameaça externa; apesar da ação destruidora da Igreja Católica do rio Negro, existiram alguns padres e algumas freiras que lutaram ao dos indígenas e ajudaram criar o movimento indígena do rio Negro; a educação escolar salesiana contribuiu direta e indiretamente para que novas lideranças surgissem para enfrentar novos desafios e conquistarem vitórias, como por exemplo, a homologação das cinco Terras Indígenas do alto rio Negro em 1998 e ajudou para que a partir de 2004 assumissem a direção das escolas estaduais que até então eram dirigidas e controladas pela Diocese de São Gabriel da Cachoeira, AM.

Sobre a presença de militares em suas comunidades, os indígenas reconhecem que: os militares não cumprem com todas as promessas que apresentaram aos indígenas antes de instalar suas Organizações Militares (OMs), no entanto afirmam que os militares ajudam muito na parte de saúde. Constatamos também que os militares são os que socorrem as comundiades indígenas quando as mesmas precisam de um trator para transportar o material comunitário, o combustível para os barcos e motores de luz. Vimos também que os conflitos, as brigas entre os jovens indígenas e militares (soldados) ocorrem por causa das moças indígenas. Algumas moças indígenas preferem ficar com militares não-indígenas e outras cansadas de esperar que algum rapaz indígena a conquiste acabam namorando e casando com soldados. Diante disso, os rapazes se sentem excluídos e, por isso, ficam enciumados, e no final brigam com soldados do Exército. As brigas só acontecem nos dias de festas, porque segundo as própiras moças entrevistadas os indígenas só têm coragem de bater nos militares quando estão embriagados e quando não estão não têm coragem nem de conquistar as moças e nem de brigar com militares. Por isso, segundo as moças muitas vezes quem começa a briga são os indígenas e não os soldados do Exército.

Em Pari-Cachoeira e Trinidad não existe nenhuma ONG, logo, de acordo os sujeitos da nossa pesquisa não tem nenhum trabalho executado e muito menos em execução. Por isso, concluimos que a maioria de indígenas dessas duas comunidades não sabe o que é Instituto Socioambiental (ISA), Saúde Sem Limites (SSL), Fundação GAIA, etc. Para os sujeitos da nossa pesquisa se as ONGs quiserem trabalhar com eles, em Pari-Cachoeira, seriam bem acolhidos para desenvolver os projetos pilotos, mas como eles não param nem para dar um bom dia para os moradores dessas comunidades, os indígenas também não dão atenção. Enfim, em Pari-Cachoerira não existe nenhum trabalho das ONGs. 
Por último, apresentamos a fronteira "viva", onde convivem os indígenas de Pari-Cachoeira e Trinidad de acordo com seus costumes e tradições, e compartilham os conhecimentos tradicionais. Concluimos que os Tukano, Tuyuka, Dessano e alguns outros grupos do Tiquié não são habitantes de tempos imemoriais, porque migraram do rio Uaupés para o Tiquié. Os primeiros povos que habitaram o Tiquié são outros, por exemplo, Wayała, Waupołã, Detuałã, Pãłẽłoã, Muhteã, Buhpumahsã, Yahpiamhsã, Ẽmoãmahsã, Oá (Sẽrã, Tatuyu). Por essas razões históricas, a atual convivência interna em Pari-Cachoeira é tensa, porque os autais Tukano de Pari-Cachoeira acham que chegaram primeiro no Tiquíe, porém para todos os outros grupos indígenas do Tiquié, inclusive para os Tukano que vivem na Colômbia, os esses Tukano não chegaram primeiro no Tiquié. Os Dessano do Umari Igarapé, afluente do Tiquié, os primeiros Tukano que chegaram em Pari-Cachoeira foram do subgrupo Búupõã.

Apesar de viverem em Estados diferentes os indígenas dessas duas comundiades estão interligados pela lógica familiar, por isso acreditam que para eles não pode existir uma fronteira rígida que limite a livre circulação de seus parentes. Para fortalecer suas relações internacionais os indígenas criaram os jogos do Triângulo como um meio de manter contatos constantes entre seus parentes colombianos e brasileiros. Os jogos são protagonizados pelos indígenas brasileiros de Pari-Cachoeira, Taracuá e Iauaretê. Os objetivos dos jogos são: foralecer as trocas matrimonias; conhecer novos parentes colombianos e brasileiros; realizar as trocas matrimoniais e fortalecer a política indígena e partidária.

Com este estudo notamos que, a construção da autodeterminação indígena na fronteira entre Brasil e Colômbia, não ameaça a soberania dos dois Estados, porque o único interesse do movimento indígena do rio Negro é lutar pela melhoria das condições de vida de suas comundiades e garantir a existência futura de sua geração sob a proteção dos Estados onde vivem. Além disso, a presença indígena na área de fronteira representa uma estratégia geopolítica para a segurança da Amazônia brasileira e colombiana. 


\section{REFERÊNCIAS}

AB'SABER, Aziz Nacib. A Amazônia: Do Discurso à Práxis. - 2. ed. - São Paulo: Editora da Universidade de São Paulo, 2004.

ADOLFO, Mário; BARBOZA, Cláudio; DIAS, Carlos. Índios mostram democracia adulta: do silêncio da floresta, a esperança de liberdade. A Crítica, Manaus, $\mathrm{N}^{\mathrm{o}} 1$ julho de 1987, $16 \mathrm{p}$.

AEITU; FOIRN; ISA. Wiseri Makañe Niromakañe - (Casa de Transformação: origem da vida ritual Utapinopona Tuyuka). Histórias contadas por membros da AEITU, Associação Escola Indígena Utapinopona Tuyuka. São Gabriel da Cachoeira, AM; São Paulo, SP, 2005.

ALBERT, Bruce. O Tempo do "desenvolvimento" e o Perimetral Norte. Povos Indígenas no Brasil, 1991. Disponível em:

http://www.socioambiental.org/pib/epi/yanomami/ desenvolv.shtm. Acesso em: 12 out. 2007.

ANDRELLO, Geraldo. Área indígena do alto rio negro renasce das cinzas. In: ISA. Povos indígenas no Brasil 1991/1995. São Paulo: Instituto Socioambiental 1996.

ARAÚJO, Denys. Godoy explica o projeto. Jornal do Comércio, 23 abril 1987, p. 6. CEDI: Povos Indígenas no Brasil 1987/88/89/90.

ASSEMBLÉIA Geral dos Povos Indígenas do Alto Rio Negro (2ª: 1987: São Gabriel da Cachoeira, AM). Documento final. São Gabriel da Cachoeira-AM: s.ed., 30 de 1987, 21 p.

ASSEMBLÉIA Geral dos Povos Indígenas do Alto Rio Negro (2ª 1987: São Gabriel da Cachoeira, AM). Recortes de jornais, 1987.

ATHIAS, Renato. Contribuições a etnografia dos grupos Maku do Uaupés: as relações entre Hupdë-Makú e Tukano: a origem das desigualdades. Université de Paris x Nanterre, 1995.

BALANDIER, Georges. A desordem: elogio do movimento. Tradução de Suzana Martins. Rio de Janeiro: Bertrand Brasil, 1997.

BALZOLA, Giovanni. A prefeitura Apostólica do Rio Negro. In: Boletim Salesiano, N. 4 julho/agosto, 1916 (Ano XV - Vol. VII). Torino: Itália, 1916.

BARBOSA, Marco Antônio. Autodeterminação: direito à diferença. Série: Pluralismo Jurídico. São Paulo: Plêiade: Fapesp, 2001. 452 p. 
BAREL, Yves. Le paradoxe et le système, essai sur le fantastique social. Gernoble, PUG, 1979.

BÉKSTA, Kasys Jurgis. A maloca Tukano-Dessana e seu simbolismo. Manaus: Secretaria de Estado da Educação e Cultura, SEDUC, 1988.

BOLETIM Salesiano. Órgão dos Cooperadores Salesianos. Um caso singular de modo indígena (diário de viagem do Pe. J. Marchesi). Ano XXIV, nº 4, 1927, p. 122-125.

BOLETIM Salesiano. Órgão dos Cooperadores Salesianos. Um caso singular de modo indígena (diário de viagem do Pe. J. Marchesi). Ano XXVI, nº 6, 1930.

BRASIL, Kátia. Brasil e Colômbia farão ação conjunta. Folha de S. Paulo, São Paulo, 19 maio 2005, p. A16.

BRASIL, Kátia. Índias movem 157 ações contra soldados. Folha de S. Paulo, São Paulo, 23 dezembro 2000, p. A8.

BRASILIENSE, Ronaldo. Exército abre estrada em parque ecológico. Jornal do Brasil, 13 de abril 1992, p.06.

BUCHILlETI, Dominique. Pari-Cachoeira: o laboratório Tukano do Projeto Calha Norte. In: CEDI. Povos indígenas no Brasil 87/88/89/90. São Paulo: CEDI 1991.

CABALZAR, Aloisio; RICARDO, Beto. Povos Indígenas do alto e médio rio Negro: uma introdução à diversidade cultural e ambiental do noroeste da Amazônia brasileira. $3^{\text {a }}$ edição atualizada. São Paulo: São Gabriel da Cachoeira, ISA/FOIRN, 2006.

CABALZAR, Aloisio; RICARDO, Beto. "Cabeça do Cachorro" é "área cultural" de povos indígenas. Terras Indígenas \& Unidades de Conservação da natureza: os desafios das sobreposições. Fany Ricardo (Org.). - São Paulo: Instituto Socioambiental, 2004.

CARVALHO, Sílvia Maria Schumuziger de. Jurupari: estudos de mitologia brasileira. São Paulo: Ática, 1979.

CARVALHO, Jailton de. Governo cria brigada em área ameaçada pelas Farc. $O$ Globo, Rio de Janeiro, 18 de setembro 2003, p. 14. 
CHAGAS, Dorvalino S. J. V. Cosmologia, Mitos e História: o Mundo dos Pamulin Mahsã Waikhana do Rio Papuri - Amazonas. Dissertação (Mestrado em Antropologia)-Uiversidade Federal de Pernambuco, Recife, 2001.

CIORAN, E. M. História e Utopia. Rocco Ed., Rio de Janeiro, 1994.

DAMASCENO, Felisberto Ascenção. Organização Indígena e a Representação Nacional. Manaus: CIMI, 1992.

DE PAULA, Nilton Cezar. A ação Missionária do Catolicismo e os Povos Indígenas do Rio Negro: evangelização $X$ autodeterminação e sobrevivência cultural. Dissertaacão (Mestrado em Antropologia)-Universidade Federal de Pernambuco, UFPE, 2005.

DINIZ, Eugênio. O Projeto Calha Norte: antecedentes políticos. 203 f. Dissertação (Mestrado em Ciência Política)-Universidade de São Paulo, São Paulo, 1994.

DUTRA, Israel Fontes. I Seminário dos Povos Indígenas no alto e médio rio Negro e a Educação Escolar: construindo um ensino médio específico. São Gabriel da Cachoeira: COPIARN, 2004.

DUTRA, Israel Fontes. II Seminário dos Povos Indígenas e Sustentabilidade: saberes e práticas na Universidade. Reflexão sobre as parcerias da Federação das Organizações Indígenas do Rio Negro e as Universidades frente os Desafios da Sustentabilidade Indígena. Universidade Católica Do Bosco: Rede de Saberes, 2007.

DUTRA, Israel Fontes. Xamanismo Tuyuka. Universidade Católica Dom Bosco: Rede de Saberes, 2007.

EXÉRCITO BRASILEIRO. Centro de Comunicação Social do Exército. Amazônia - Pelotões Especiais de Fronteira. Ano XXXIII, Nº 189. Brasília - DF: Jul/Ago/Set 2006.

FARIA, Ivani Ferreira de. Território Indígena: direito imemorial e o devir. 359 f. Dissertação (Mestrado em Geografia Humana)-Universidade de São Paulo, São Paulo, 1997.

${ }^{*}$. Território e Territorialidades Indígenas do Alto Rio Negro. EDUA, Manaus, 2003.

FILHO, Roberto Stuckert. Índios gostam do trabalho, mas sobretudo do salário. $O$ Globo, Rio de Janeiro, 06 de dezembro 1998, p. 15.

FEDERAÇÃO das Organizações Indígenas do Rio Negro. Relatório Geral 2000. Terra e Cultura. São Gabriel da Cachoeira/AM: janeiro de 2001, p. 12. Relatório. 
FEDERAÇÃO das Organizações Indígenas do Rio Negro. Relatório Institucional 2001 a 2004. São Gabriel da Cachoeira/AM, janeiro de 2001, p. 19. Relatório.

FEDERAÇÃO das Organizações Indígenas do Rio Negro. VI Assembléia Geral Eletiva da Foirn. São Gabriel da Cachoeira/AM, 28 a 30 de outubro de 2004. p. 41. Relatório.

FERREIRA, Aurélio Buarque de Holanda. Dicionário Aurélio. 2004.

FULOP, Marcos. Aspectos de la Cultura Tukana: mitologia. In: Revista Colombiana de Antropologia. Instituto Colombiano de Antropologia. Volume V, p. 338-373. Bogotá, 1956.

FOUCAULT, Michael. Microfísica do Poder. Graal, Rio de Janeiro.

GALLUCCI, Mariângela. Militares são acusados de torturar índios. O Estado de São Paulo, São Paulo, 02 de novembro 2003, p. A18.

GALVÃO, Eduardo. Encontro de sociedades tribal e nacional no Rio Negro. In E. Schaden (org.), Leituras de Etnologia Brasileira. São Paulo: Companhia Editora Nacional, 1979.

GARCIA, Pedro (org.). Upíperi kalísi: histórias de antigamente - histórias dos antigos TaliaseriPhukurana. UNIRVA/FOIRN, 2000 (Coleção: Narradores Indígenas do Rio Negro - Vol. 4).

GEERTZ, Clifford. A interpretação das culturas. Rio de Janeiro: Zahar editores, 1978.

GENTIL, Gabriel dos Santos. Mito Tukano: quatro Tempos de Antiguidades - histórias proibidas do Começo do Mundo e dos Primeiros Seres. Tomo I, Wadgut, 2000.

GIACONE, Antônio. Os Tucanos e outras tribos do rio Uaupés afluente do Negro, Amazonas. Notas etnográficas e folclóricas de um missionário salesiano. São Paulo 1949. XI, p 190.

GODOY, Roberto. Exército manda mais de 3 mil homens à Amazônia em 2004. O Estado de São Paulo, São Paulo, 21 de setembro 2003, p. A13.

GUICHONNET, P.; RAFFESTIN, Claude. Géographie des frontières. Paris: PUF, 1974.

HIRANO, Sedi (Org.). Pesquisa Social: projeto e planejamento. Volume 1. São Paulo, 2004.

HOBBES, Thomas. Leviatã ou Matéria, forma e poder de um estado eclesiástico e civil.Tradução de João Paulo Monteiro e Maria Beatriz Nizza da Silva. - 2. ed. - São Paulo: Abril Cultural, São Paulo, 1979 (Os pensadores). 
INSTITUTO Socioambiental. Povos Indígenas no Brasil 1987/88/89/90. São Paulo, 1990.

INSTITUTO Socioambiental. Povos Indígenas no Brasil 1991-1995. São Paulo, 1996.

INSTITUTO Socioambiental. Povos Indígenas no Brasil 1996-2000. São Paulo, 2001.

INSTITUTO Socioambiental. Povos Indígenas no Brasil 2001-2001. São Paulo, 2006.

INSTITUTO Socioambiental. 10 anos 1994-2004. São Paulo, 2005.

JUREMA, Jefferson. Universo mítico ritual do povo tukano. Manaus: Editora Valer, 2001.

KẼHÍRI, Tõrãmt. Antes o mundo não existia: mitologia dos antigos Desana-Kẽhíripõrã. $2^{\mathrm{a}}$ Edição. Coleção Narradores Indígenas do Rio Negro, v. 1. São João Batista do Rio Tiquié: UNIRT; São Gabriel da Cachoeira: FOIRN, 1995. 264 p.

KISIBI (Dorvalino Moura Fernandes). Mitologia sagrada dos antigos desana do grupo wari dihputiro põrã. São Gabriel da Cachoeira: UNIRT/FOIRN, 1996 (Coleção: Narradores Indígenas do Rio Negro - Vol. 2).

KOCH-GRÜNBER, Theodor. Zwei jahre unter den indianer. Reisen ind Nordewest-Brasilien, 1903/1905. I ${ }^{\text {, }}$ Berlin 1909, 359 p.

KOCH-GRÜNBERG, Theodor. Dois anos entre os indígenas: viagens no noroeste do Brasil (19031905). Manaus: EDUA/FSDB, 2005.

KONDER Leandro et alii. O que é dialética. Primeiros Passos. Editora Brasiliense, S.A. São Paulo, 1981.

LANA, Luís Gomes. Vamos conhecer retrospecto e descobri novos caminhos. São João: UNIRT, 1993.

LASMAR, Cristiane. De volta ao lago de leite: gênero e transformação no alto Rio Negro. São Paulo: Editora UNESP: ISA; Rio de Janeiro: NUTI, 2005.

LUIZ, Edson. Farc rondam a pacata Tunuí, no Amazonas. O Estado de São Paulo, São Paulo 25 de novembro 2003, p. A8. 
MACHADO, Benedito Fernandes. Ata da I Assembléia Geral dos Líderes Indígenas do Alto Rio Negro. São Gabriel da Cachoeira, 1984. Ata.

MACHADO, Benedito Fernandes. Ata da II Assembléia Geral dos Líderes Indígenas do Alto Rio Negro. São Gabriel da Cachoeira, 1987. Ata.

MAIA, Luiz Alves Brigido. Fronteira Brasil-Colômbia: formação, vigilância e vivificação. 169 f. Dissertação (Mestrado em Geografia Política)-Universidade de São Paulo, São Paulo, 2004.

MARCHESI, Giovanni. Tra fiume e Forest. Vol. I, Roma Esse-Gi-Esse, 1975.

MARTIN, André Roberto. Fronteiras e nações. São Paulo: Contexto, 1992, 91 pp.

NIMUENDAJÚ, Curt. Textos indigenistas: relatórios, monografias, cartas. Coleção missão aberta; São Paulo: Ed. Loyola, 1982.

NORONHA, Márcio. Militares do Exército são acusados de agredir índios. Diário do Amazonas, Manaus, 03 de novembro de 2003, p. 2.

NOVAES, Washington. A Amazônia e a Informação. Povos Indígenas no Brasil 1999/2000. São Paulo: Instituto Socioambiental, 2000.

OLIVEIRA, Ana Gita de. $O$ mundo transformado: um estudo da "cultura de fronteira" no alto rio Negro. Tese (Doutorado de Antropologia Social)-Universidade de Brasília, Brasília, 1992.

OLIVEIRA, Ariovaldo Umbelino de. Amazônia: monopólio, expropriação e conflitos. Campinas: Papirus, 1987.

*. Integrar para não entregar. Campinas: Papirus, 1990.

PESSOA, Mário. O direito da Segurança nacional. Rio de Janeiro: BIBLIEX, 1971.

RAMIREZ, Henri. A fala tukano dos Ye'pâ-masa (Tomo II: Dicionário). Manaus: Centro de Documentação Etnográfica e Missionária (CEDEM), Iauaretê, 1997.

RANCIÈRE, Jacques. O desentendimento: política e filososfia. Editora 34. São Paulo, 1996. 
RAFFESTIN, Claude [1980]. Por uma geografia do poder. Tradução de Maria Cecília França. São Paulo: Editora Ática, 1980.

RATZEL, Friedrich. Politisch Geographie. Berlin: Ed. Oldenburg, 1903.

REZENDE, Justino Sarmento. Escola Indígena Municipal Uhtãpinõponã - Tuyuka e a construção da Identidade Tuyuka. Dissertação (Mestrado em Educação)-Universidade Católica Dosco, Campo Grande, 2007.

REZENDE, Justino Sarmento. Indígenas na Prefeitura de São Gabriel da Cachoeira-AM: Pedro Garcia (Tariano - PT) e André (Baniwa - PV). Iauaretê: Missão Salesiana de Iauaretê, 2008.

RIBEIRO, Berta G. Os índios das águas pretas: modo de produção e equipamento produtivo. São Paulo: Companhia das Letras: Editora da Universidade de São Paulo, 1995.

RICARDO, Fany (Org.). Terras Indígenas \& Unidades de Conservação da natureza: os desafios das sobreposições. São Paulo: Instituto Socioambiental, 2004.

RIVERA, Maria Camila; GÓMEZ, Silvia. El Camino de las Entidades Territoriales Indígenas (ETI's) em la Amazonía Colombiana. Povos Indígenas no Brasil 2001/2005. São Paulo: Instituto Socioambiental, 2006.

RONDON, Frederico. Uaupés: hidrografia, demografia e geopolítica. Rio de Janeiro, 1945, 258 p.

ROUSSEAU, Jean-Jacques. Discurso sobre a origem e os fundamentos da desigualdade entre os homens. São Paulo: Abril Cultural, 1973.

SAMPAIO, Álvaro Fernandes. A região do Noroeste Amazônico: histórico, atuação salesiana, etnocídio e atuação da FUNAI. Brasília, 1981.

SAMPAIO, Álvaro Fernandes. A Linguagem e a Resistência do Índio Tukano. São Paulo, 1983.

SANTOS, Patrícia. Escolta. Folha de São Paulo, São Paulo, 04 de outubro 2003, p. A6.

SARTRE, Jean Paul. O ser e o nada. Ensaio de Ontologia fenomenológica. Petrópolis: Editora Vozes, 1977.

SARTRE, Jean Paul. Verdade e existência. São Paulo: Nova Fronteira (Coleção Os Pensadores. Abril Cultural). 
SERRANO, Rosália Arteaga. Sipam será base de monitoramento internacional da Amazônia. Disponível em:

http://www.ambientebrasil.com.br/noticias/index.php3?action=ler\&id=25058. Acesso em: 03 nov. 2006.

SHAKESPEARE, W. A Tempestade. Rio de Janeiro: Relume Dumará, 1991.

SORRE, Maximilien. "A noção de gênero de vida e sua evolução". In Os fundamentos da geografia humana [1952]. In Max. Sorre. (Organizador: Januário Francisco Megale). São Paulo: Ática, 1984.

SOUZA FILHO, Carlos Frederico Marés de. O Renascer dos Povos Indígenas para o Brasil. $1^{\mathrm{a}}$ Edição (ano 1998), $4^{\mathrm{a}}$ tiragem/ Curitiba: Juruá Editora, 2005.

SAÚDE Sem Limites. Pamiri-Masa: a origem do nosso mundo: revitalizando as culturas indígenas dos rios Uaupés e Papuri. São Paulo, 2004.

STRADELLI, E. Leggenda dell’Jurupary. B. Sociologia: Geografia Italiana, nº 27, 1890.

STRADELLI, Ermano. Leggenda dell'Jurupary e Outras lendas Amazônicas. Caderno n ${ }^{0}$ 4. São Paulo: Instituto Cultural Ítalo-Brasileiro de São Paulo,1964.

TAVES, Rodrigo França. Zona perigosa de fronteira está desguarnecida. O Globo, Rio de Janeiro, 06 de dezembro 1998, p. 14.

UNIÃO das Comunidades Indígenas do Rio Tiquié. 11 ${ }^{\mathrm{a}}$ Assembléia Geral da UCIRT. PariCachoeira, 1986. Relatório.

VAINER, Carlos. "Reflexões sobre o poder de mobilizar e imobilizar na contemporaneidade". In Póvoa Neto, Hélion (org.), Cruzando fronteiras disciplinares: um panorama dos estudos migratórios. Rio de Janeiro: Revan, 2005.

VELTHEM, Lúcia Hussak Van. Plumária Tukano. Tentativa de análise. In: Boletim do Museu Paraense Emílio goeldi. N.S., Antropologia Nº 57. Belém do Pará, 1975.

WEBER, Demétrio; CRISPIM, Denise. Fronteira com a Colômbia terá reforço militar. O Estado de São Paulo, São Paulo, 19 de setembro 2003, p. A6.

WRIGHT, Robin M. História indígena e do indigenismo no alto rio Negro. Campinas: Mercado de Letras; São Paulo, Instituto Socioambiental - ISA, 2005. 


\section{GLOSSÁRIO}

ãhsĩpoã ñehkt: segundo irmão mais velho de Suniã Pãtãmĩ, tão sábio quanto ele; foi escolhido e enviado para as regiões andinas, onde criou e povoou diferentes povos indígenas.

ba'asei: é pajé, também é chamado de kũmũ. Para ser ba'asi é necessário passar três a quatro meses de formação tradicional sob a orientação e acompanhamento de mestre-ba'asi, que dita regras rígidas de abstinência alimentar.

ba'asi: é pajé, também é chamado de kũmũ. Para ser ba'asi é necessário passar três a quatro meses de formação tradicional sob a orientação e acompanhamento de mestre- $b a$ 'asi, que dita regras rígidas de abstinência alimentar.

ba'asera: é a palavra no plural que deriva de $b a$ 'asei; significa pajés.

bahsawi: casa tradicional dos povos indígenas do Uaupés.

bahsariwi: casa tradicional dos povos indígenas do Uaupés; casa de danças e festas.

bahsegu: benzedor comum; não é pajé; conhece apenas alguns rituais de benzimentos considerados básicos, como por exemplo, alguns rituais do parto etc.

bahsei: benzedor comum; não é pajé; conhece apenas alguns rituais de benzimentos considerados básicos, como por exemplo, alguns rituais do parto etc.

bahserá: benzedor comum; não é pajé; conhece apenas alguns rituais de benzimentos considerados básicos, como por exemplo, alguns rituais do parto etc.

bahseré: rituais de benzimento, que podem ser realizados tanto por ba'asera como por bahserá, e até por yaíwa.

bahseré wãmẽ: bahseré significa benzimento; e wãmẽ significa nome; portanto, nome (es) de benzimento (os).

bahsoká: pessoas; gentes; seres humanos; pessoas humanas.

bairó: irmã menor, minha irmã menor.

bairó mahkõ: filha da irmã menor.

bairó mahku: filho da irmã menor.

bayá: antigo e principal chefe tradicional de casas tradicionais dos indígenas do Uaupés. Mestre dos cânticos e danças de kapiwayá.

bayaroa: plural da palavra bayá.

béroa: sib Tuyuka que é considerado o mais alto dentro da estrutura hierárquica do grupo. A palavra pode ser usada também para se referir aos membros desse sib.

bołi: doenças, tristezas, as coisas más.

bołi bahsoká: seres espirituais geradores de doenças, também chamados de Waí-Mahsã.

boli wihseri: casas de seres espirituais chamados Waí-Mahsã ; significa casa de doenças, de tristezas.

bugó: tia.

bugó'okó: refere-se à tia mais velha de idade.

bugukн: refere-se aos tios mais velhos de idade.

bugt: tio.

buhkt: meu esposo, meu velho.

buhkuó: minha esposa, minha velha.

buhpó: trovão.

buhpó ñehkt: refere-se a Deus Supremo; o termo significa Avô do Trovão.

buhtoá: velhos, ancestrais, antepassados.

bu'tkt: refere-se aos tios mais velhos de idade.ou (se forem tios mais velhos);

bułekó ñehkt: refere-se a Deus, que significa Deus do Universo, Deus do Tempo.

diá: rio.

diá kahsá: rio Tiquié.

diasihti mahkãwi: primeira Casa da Emergência, também chamada de Casa da Emergência do Sul, situada no litoral do Estado de São Paulo, Brasil. 
dihtá: terra, território, país, estado.

doále: são rituais de malzimento ou "sopros".

dohkapuala: refere-se ao povo Tuyuka; dohká significa pilar e socar; puała significa cravar, fincar-se; logo, dohkapuała significa gente que soca e crava. A palavra é uma cognominação e não um nome tradicional do grupo.

duhpu: cabeça, chefe, líder.

kahpi: "cipó da família das malpighiáceas (Banisteria caapi)" (Dicionário Aurélio), do qual os pajés do Uaupés usam para misturar com outras substâncias de origem vegetal que o torna alucinógeno.

kahpirt: pote de barra, onde se guarda a bebida kahpi.

kahpi suniã: ser espiritual que se chamava Kahpi Suniã e é considerado pelos pajés como pai de kahpi. No ritual da criação dos humanos na Casa da Emergência de Ohkó Diawi, foi transformado em um pé de kahpi, do qual Suniã Pãtãmĩ todas as partes de seu corpo para dividir aos chefes de cada grupo indígena. As partes do corpo desse ser espiritual representavam um tipo de kahpi.

kahpi suniã mahkõ: filha de Kahpi Suniã; foi a primeira mulher criada na Casa da Emergência de Ohkó Diawi, por Suniã Pãłãmĩ; foi a mulher que fez o primeiro parto que antecedeu todos os demais partos que seriam realizados por outras mulheres indígena, que com o sangue de seu parto transformou em bebida de kahpi, que inundou a Ohkó Diawi para que as novas criaturas humanas e os pajés pudessem beber e se embriagar.

kapiwayá: são músicas e danças tradicionais cantadas por bayaroa; essas músicas são compartilhadas por todos os grupos indígenas do Uaupés, que foram criados na Casa da Emergência de Ohkó Diawi.

koãmahku: Deus.

kũmũãłe: rituais de benzimento praticados apenas por um ba'asi ou kũmũ.

kũmũãlõ: banco de sentar.

kũmũduhkałi: cochos de caxiri.

mahkã: povoado, comunidade, aldeia, cidade, lugar habitado por pessoas.

mahkõ: filha, sobrinha, neta.

mahkt: filho, sobrinho, neto.

mahsã: pessoas; gentes; seres humanos; pessoas humanas.

mahsãkula: seres espirituais dos rituais de Jurupari.

mahsãkula yaí: pajés dos rituais de Jurupari.

mehkõ: tia, sogra.

mehku: tio, sogro.

miniã yaí: pajé e mestre dos rituais de jurupari.

miñõbułó: refere-se à comunidade Tuyuka de Trinidad, situada no alto Tiquié, Colômbia.

muĩpũlĩ: caraná.

muĩpũłĩ pinõ: o irmão caçula de Suniã Pãłãmĩ, ser espiritual dos rituais de habitação; representou o lado negro do projeto de criação dos grupos humanos deste novo continente; literalmente significa cobra de caraná e palha.

munõ: tabaco.

ñehku'tku: avô.

ñehkt: avô.

pahkt: pai, avô.

páhkt: refere-se apenas ao pai.

pahkó: mãe, avó

páhkó: refere-se apenas à mãe.

pahkó'okó: avó.

pahkt'tkt: avô.

pamulĩ wihseri: Casas da Emergência.

pamulĩ sohpé: Portão da Emergência.

pamulĩ yohkosoró: Canoa da Emergência dos povos indígenas do Uaupés.

pehka'asã: refere-se aos não-indígenas. 
peołá: maku, servos, membros de um sib mais baixo da hierarquia social dos povos do Uaupés; referese também aos membros dos povos hupda, nadeb etc.

pẽõłã: maku, servos,

peyuru: caxiri.

piñ̃: cobra.

ponã: filhos, descendentes, prole.

ñehkõ'õókó: avó.

ñehkõ: avó

numiõ: menina, mulher.

numiõ mahkõ: filha da irmã.

numiõ mahkt: filho da irmã.

ohpé: breu preto.

ohkó: água.

pãlãmeõ: neta.

pãlãmĩ: neto.

pamutĩ pinõ: é outra denominação para se referir ao Suniã Pãłãmĩ; o termo significa literalmente que emergiu ou que fez emergir.

patu: ipadu.

poeá: cachoeira; refere-se também à cidade de São Gabriel da Cachoeira, Amazonas, Brasil.

siririá: refere-se à comunidade Tukana de Pari-Cachoeira.

sõwõ: irmã maior.

sõwt: irmão maior.

suniã: Deus.

suniã ñehkt: refere-se a Deus Supremo.

suniã pãlãmĩ: suniã refere-se a Deus Supremo; os dois termos significam neto de Deus.

suniã poeá: refere-se à cachoeira de Jurupari, onde há a Casa da Emergência do Povo Tuyuka, localizada no alto Uaupés, Colômbia

uhtã: pedra.

uhtã ñehkt: refere-se a Deus dos povos indígenas do Uaupés, que em uma tradução literária significa Avô das Pedras.

uhtã piñ̃: cobra de pedra.

uhtãpinõmahkt: significa filho de Uhtã Pinõ; tuyuka.

uhtã tuhtu mahkãwi: uhtã significa pedra; tuhtu significa touco; mahkã, nesse caso é advérbio de lugar; wi significa casa: portanto, significa Casa da Emergência de Touco de Pedra, situada em Belém, Pará.

waí-mahsã: seres espirituais das Casas da Emergência, que no início eram grupos humanos, mas que se perderam no Portão da Emergência de Diasihti Mahkãwi, quando se tornaram seres espirituais, considerados pelos pajés como nossos principais adversários e geradores de doenças. Existem vários tipos deles, tais como: wai-mahsã das casas espirituais da terra; Wai-Mahsã das casas espirituais das árvores; Waí-Mahsã das casas espirituais dos rios; Wai-Mahsã das casas espirituais das serras e montanhas etc. Waí-mahsã , em tukano, significa peixes-gentes, respectivamente.

waí: peixe (s).

waikałi: substância de origem vegetal usada durante a formação de pajés.

wãmẽ: nome, denominação, nominação.

wehté: breu preto.

wi: casa.

wihseri: casas, habitações.

wihseri yaí: pajé (ba'asi ou kũmũ) que conhece os rituais de benzimento das habitações, das casas tradicionais (Bahsawihseri).

wiõ: substância alucinógena usada durante a formação de pajés (yaíwa e ba'asera).

wihõ: refere-se ao mesmo wiõ.

wehsé: roça. 
wehseri: roças.

wehseri yaí: pajé (ba'asi ou $\boldsymbol{k} \tilde{u} m \tilde{u}$ ) que conhece os rituais de benzimentos das roças; especialista em benzimento de maniva e tudo que é cultivado em uma roça.

wehteri yaí: pajé (ba'asi ou kũmũ) que conhece os rituais de benzimento com breu.

yaí: pajé que passou quatro anos em formação sob a orientação de um mestre-yaí. É o único que realiza o ritual de pajelança (ohkó sihtałe e hułe).

yaíwa: plural de yaí, pajés.

yałebo: terceiro irmão de Suniã Pãłãmĩ; ser espiritual que construiu todas as Casas da Emergência; ser espiritual considerado criador de alimentos.

yehpá: chão, terra, espaço ambiental.

yehpałi: chãos, terras, espaços ambientais

yehpałi yaí: pajé especialista em rituais de habitação e chão.

yohkosoró: canoa.

yeriponã: coração, alma.

yeriponã bahseré: ritual (s) de benzimento do coração.

yé tudi: yé significa garça; tzdi significa barranco, parede; que, portanto, significa barranco de garça.

yu bayió: $y z$ significa meu (s), minha (s); bayió significa irmã menor. A junção dos dois termos significa minha irmã menor. 


\title{
ANEXOS
}

\section{ANEXO 1 - Vamos conhecer retrospecto e descobrir novos caminhos.}

\section{VAMOS CONHECER RETROSPECTO E DESCOBRIR NOVOS CAMINHOS}

\author{
Luiz Gomes Lana \\ Presidente da UNIRT com sede e São João Batista, Tiquié.
}

Na década de 1940, 50, 60 e 70 a Pari-Cachoeira viveu numa fase de instrução educativa pelos valorosos missionários salesianos que nestes trinta anos tivemos o silêncio de nossa autodeterminação perante os órgãos públicos mas sempre ansiosos para o destino do futuro recebendo orientações e posteriormente descobrindo um mundo diferente dos nossos antepassados. Os primeiros jovens que receberam a educação de saber ler e escrever, também formaram profissionais de carpintaria, alfaiataria, mecânica e serviços gerais. Isto foi o princípio de participação para o desenvolvimento econômico na produção destes, para justamente nela obter possibilidade de bem-estar social.

Na década de 1970 surgiu nova era; nos dias 16 de agosto foi fundada pelos moradores de PariCachoeira, pelo incentivo da Irmã Dirce uma organização com sigla "UFAC"União Familiar Animadora Cristã, com estatuto feito pelo Pe. Antônio Scolaro. Em 16 de agosto de 1972 foi aprovada com título de Centro Social Educacional "UFAC" de Pari-Cachoeira sendo presidente o Sr. Firmiano Alves Castro. Em 1974 foi eleito o Sr. Henrique Alves Castro com o mandato de 3 anos inclusive eu Luís Gomes Lana fui eleito como tesoureiro. Em 1982 o Sr. Benedito Fernandes Machado, no dia 4 de abril de 1983 ele extinguiu o estatuto do Centro Social Educacional UFAC e criou a UCIRT (União das comunidades indígenas do Rio Tiquié) com estatuto próprio. Se criou também a AIPAC (Associação dos Indígenas da Pari-Cachoeira) liderados por Américo Maranhão do qual fui vice-presidente o seu estatuto porém não chegou a funcionar. Em 1985 foi eleito o Sr. Afonso Lopes Machado do qual participei como conselheiro, ao completar um ano e meio o presidente renuunicou-se subsituindo provisoriamente o Sr. Lúcio Miguel Fontes até 1987, nas eleições deste ano houve a vitória do Alfredo Miguel Fontes que renunciou o cargo de presidente sem exercer atividades (dentre de três meses) passando o cargo ao vice-presidente Carlos Eugênio F. Machado sendo ele o presidente nesta diretoria eu Luís Gomes Lana fui conselheiro, no segundo semestre de 1989 eu criei uma chapa com o lema "A LUTA CONTRA OPRESSORES DO POVO" para concorrer nas eleições do dia 26 de dezembro/89 ao cargo de presidente da UCIRT, os meus adversários entraram com política violenta contra minha candidatura, demonstrando assim a ditadura diante da organização democrática como se entende na sigla e no estatuto, então a vitória foi do Benedito F. Machado. Em $1^{\circ}$ de janeiro de 1990 juntamente com povo da comunidade de Sto. Antônio discutimos em criar outra organização na vila de São João Batista com sigla UNIRT (União das Nações Indígenas do Rio Tiquié). Em fevereiro/90 estive em Manaus para filiar com a Coordenação das Organizações Indígenas da Amazônia Brasileira em Manaus (COIA) em nome da diretoria provisória. Em abril/90 mediante a sigla UNIRT fui participar a II Assembléia Geral dos povos das Organizações Indígenas da Amazônia Brasileira em Manaus local Maromba nos dias 16 a 19 de julho de 1990. No dia 26 a 27 de maio foi realizada a I Assembléia Geral da UNIRT e foram nomeados a diretoria da nova organização totalizando 274 sócios inscritos com suas próprias assinaturas. Coube assim Luís Gomes Lana a ser presidente nomeado nesta ocasião do dia 10 de julho de 1990. A ata da assembléia da UNIRT foi reconhecida no Cartório Municipal de São Gabriel da Cachoeira. No dia 20 de setembro de 1990 foi extraído o estatuto da UNIRT aprovado pelo advogado Dr. Felisberto Damaceno, o extrato do estatuto foi entregue ao deputado estadual Manoel Diz para ser publicado no diário oficial do Estado do Amazonas depois seria registrado no cartório de São Gabriel da Cachoeira e será adquirida $0 \mathrm{n}^{0}$ do CGC no mês de dezembro. Portanto no mês de janeiro/91 a UNIRT realizará a II Assembléia Geral e a data será marcada em dezembro. A organização UNIRT tem como seu principal objetivo de lutar a demarcação das terras indígenas em área contínua conforme reza o artigo 231 da nova constituição brasileira. Pedimos a colaboração de você que não faz parte da nossa luta, participe nesta organização cheia de objetivos e venha fazer inscrição quanto mais gente nós poderemos tornar fortes na luta pelos nossos direitos.

Muito obrigado! 


\section{ANEXO 2- Relatório da I Assembléia Geral dos Líderes Indígenas do alto rio Negro.}

\section{ASSEMBLÉIA GERAL DOS LÍDERES INDÍGENAS DO ALTO RIO NEGRO}

A reunião da I Assembléia Geral dos Líderes Indígenas do Alto Rio Negro teve sua abertura no dia 30 de abril de 1984 e até dia 4 de maio do ano em curso.

O plenário foi presidido pelo Sr. Pedro Fernandes Machado e Benedito Fernandes machado, Presidente e Secretário, respectivamente do seminário.

Para início da abertura, o Presidente da Comissão Organizadora, convidou autoridades convidadas presentes para compor a mesa de honra que ficou assim constituída: $\operatorname{Exm}^{\circ}$ Sr. Comandante da $1^{\mathrm{a}}$ Companhia do $1^{\circ}$ Batalhão de Engenharia e Construção, representado pelo Tenente Veronildo Lemos de Oliveira; Bispo Diocesano Dom Miguel Alagna, representado pelo Padre Valdecir Vieira; Prefeito Municipal de São Gabriel da Cachoeira, Sr. Antônio Evangelista Batista da Silva; Chefe da FUNAI, Sr. José Ribamar Caldas Lima Filho; Presidente da Câmara Municipal, Sr. Manoel Soares; Diretor de Campus Avançados do Projeto Rondon, Dr. Fernando Mota; Agente do IBDF, vereador Rodolfo Otéro Gonçalves e Sr. Jaime Edward Curts, Chefe das Missões Novas Tribos. Constituída a Mesa, foi entoado o Hino Nacional Brasileiro.

Dando abertura, propriamente dita, o Presidente da Assembléia, explanou sobre os objetivos do evento que são: expor na reunião os problemas que afligem o povo indígena da área do Município de São Gabriel da Cachoeira para que juntos, unidos encontrar soluções; saídas para melhor progredirmos, seja, na vida social, econômica, política indígena nacional para irmanarmos humanamente, sem choques, com a civilização da Sociedade Branca. Fazermos juntos nossos estudos, nossas reivindicações coerentes e conscientes perante as autoridades constituídas para conquistarmos o nosso progresso. Não vamos só pedir, cobrar, exigir, porém cooperar, retribuir, estudar juntos com a autoridades para chegarmos ao único objetivo que é: a promoção humana do povo indígena ao Alto Rio Negro e suas adjascências.

A presença pioneira da Congregação Salesiana na nossa região tem promovido grandes desenvolvimentos, pois estão na região desde 1914. A presença da FUNAI tem facilitado auxílios diretos e indiretos em todos os setores das necessidades, mas a imensidão da área e pouco recursos econômicos e materiais tem dificultado sua ação de trabalho. A chegada do $1^{\circ} \mathrm{BEC}$ tem facilitado imensamente na integração nacional da juventude com acesso nas fileiras do exército. A Prefeitura Municipal tem se esforçado em auxiliar a população de seu município, porém as grandes distâncias e dificuldades de acesso às diversas localidades e escassos recursos financeiros não tem permitido melhor atendimento. O projeto Rondon com tempo no nosso meio, vem demonstrando os eu esforço e boa vontade no auxílio das organizações de nossas comunidades e também, outras instituições existentes na nossa área tem esforçado em promover a nossa evolução, contudo, a falta de conhecimento de nossos problemas reais não tem garantido a aplicação de sua boa vontade. Agora, cabe a nós, índios, unirmos entre nós, para em conjunto com as instituições estudarmos os nossos problemas e buscarmos soluções viáveis para entramos no Mundo da Civilizado Branco em sintonia com a nossa Civilização Indígena.

O chefe da FUNAI, Sr. José Ribamar Caldas Lima Filho, convidado a dirigir sua mensagem, agradeceu a presença das autoridades e dos líderes indígenas reunidos e disse que tinha plena liberdade de discutir todos os problemas , seja: educação, saúde, problemas de terra, agricultura, política e outros assuntos de interesse comunitários para poder preparar documento de reivindicações para entregar às autoridades competentes e ver a possibilidade de atendimento. Conforme os pedidos, poderão ser atendidos aqui mesmo, em São Gabriel, se não der, serão enviados aos órgãos competentes.

O Sr. Prefeito Municipal, Antônio Evangelista, dirigindo a sua mensagem, agradeceu a presença das autoridades e dos líderes indígenas de todas as áreas do Alto Rio Negro. Os 90 mil quilômetros quadrados do município não permitia melhor controle da administração da Prefeitura, mas esforços e boa vontade não lhe faltavam. Foi pensando no bom atendimento e melhor controle administrativo é que, junto com os irmãos Machado e a FUNAI, organizaram a realização da I Assembléia Geral dos Líderes Indígenas do Alto Rio Negro, para que assim, juntos, unidos conhecer e estudar os problemas e procuramos encontrar soluções satisfatórios. Os recursos não dependem da Prefeitura e sim de outros órgãos superiores; por isso a administração é de todos. Disse que os líderes indígenas estavam reunidos para discutir seus problemas e demonstrar soluções e não só exigir por exigir.

O Presidente da Câmara Municipal, Sr. Manoel Soares, agradeceu o convite recebido da I Assembléia Geral dos Líderes Indígenas do Alto Rio Negro e desejou sucesso nos seus trabalhos e a realização de outras assembléias. 
O Padre Valdecir Vieira, disse estar honrado de poder participar da I Assembléia Geral dos Líderes Indígenas do Alto Rio Negro. Afirmou que não existe barreira entre civilização indígena e branca, pois cada uma, tinha suas próprias riquezas e características. O que importa é a complementação de uma com a outra.

Prosseguindo a reunião, o Presidente da Comissão Organizadora, agradeceu as mensagens de estímulo das autoridades e estava ciente que, saindo da Assembléia, todos levariam algo proveitoso para as suas comunidades e esperava que encontrássemos algumas soluções, se não for todas, para os problemas que afligem as comunidades indígenas. Logo a seguir foi dada palavra franca.

Desta feita, um dos Líderes do rio Içana, Sr. Valdomiro Firmo, aproveitou para agradecer a mensagem de estímulo das autoridades e acreditava que desta Assembléia levaria soluções de progresso para seu povo e que no futuro próximo veríamos os frutos da I Assembléia Geral dos Líderes Indígenas do Alto Rio Negro e sua posteridade agradeceria por esta iniciativa nossa que é de marco importante na história da Sociedade Indígena do Alto Rio Negro.

Continuando, o Presidente da Assembléia, convidou todas as autoridades para prestigiarem com suas presenças o encerramento da reunião que seria no dia 4 de maio do ano em curso, porém quem quisesse participar a seqüência do plenário tinha total liberdade e seria benvindo.

O Chefe da FUNAI aproveitou para avisar que foi enviado convite para o Presidente da FUNAI e seus assessores; deputado Cacique Mário Juruna e outras autoridades federais e estaduais.

Terminado esta informação, o Presidente da I Assembléia Geral dos Líderes Indígenas do Alto Rio Negro considerou encerada a sessão.

São Gabriel da Cachoeira/AM, 30 de abril de 1984.

Pedro Fernandes Machado - Tukano PRESIDENTE DA FUNAI

Benedito Fernandes Machado - Tukano SECRETÁRIO Da ASSEMBLÉIA

Carlos Antônio Fernandes Machado - Tukano

COORDENADOR

Marcos Fernandes Moura - Tukano

ASSESSOR ADJUNTO

ANEXO 3 - FOIRN e associações filiadas.

FOIRN E ASSOCIAÇÕES FILIADAS

Fonte: Livro-Mapa: Povos Indígenas do Alto e Médio Rio Negro, 2006, p. 107.

FOIRN (1987) - Federação das Organizações Indígenas do Rio Negro

AAISARN (1996) - Associação dos Agentes Indígenas de Saúde do Alto Rio Negro

Alto Rio Negro e Xié

ACIRNE (1988) - Associação das Comunidades Indígenas do Rio Negro

ACIRX (1989) - Associação das Comunidades Indígenas do Rio Xié.

AIP (1989) - Associação Indígena Potyra-Kapuano.

AINBAL (1991) - Associação Indígena do Balaio

\section{Médio Rio Negro}

ACIBRN (1990) - Associação das Comunidades Indígenas do baixo Rio Negro

CACIR (1993) - Comissão de Articulação das Comunidades Indígenas e Ribeirinhas

ACIMRN (1995) - Associação das Comunidades Indígenas do Médio Rio Negro 
ACIRI (1988) - Associação das Comunidades Indígenas do Rio Içana AMAI (1990) - Associação das Mulheres de Assunção do Içana

OIBI (1992) - Organização Indígena da Bacia do Içana

ACIRA (1995) - Associação das Comunidades indígenas do Rio Aiari

UNIBI (1997) - União das Nações Indígenas do Baixo Içana

Baixo Rio Uaupés e Tiquié

ACITRUT (1986) - Associação das Comunidades Indígenas de Taracuá, Rios Uaupés e

Tiquié

AMITRUT (1989) - Associação das Mulheres Indígenas de Taracuá, Rio Uaupés e Tiquié

UNIRT (1990) - União das Nações Indígenas do Rio Tiquié.

ACIRU (1991) - Associação das Comunidades Indígenas do Rio Umari

CRETIART (1992) - Conselho Regional das Tribos Indígenas do Alto Rio Tiquié

CIPAC (1995) - Coordenação ${ }^{336}$ Indígena de Pari-Cachoeira

OIBV (1996) - Organização Indígena de Bela Vista

\section{Alto Rio Uaupés e Papuri}

UNIDI (1988) - União das Nações Indígenas do Distrito de Iuaretê

AMIDI (1994) - Associação das Mulheres Indígenas do Distrito de Iauaretê

ONIMRP (1994) - Organizações Indígenas do Médio Rio Papuri

UNIARP (1994) - União das Organizações Indígenas do Alto Rio Papuri

UNIRVA (1996) - União das Nações Indígenas do Rio Vaupés Acima

OICI (1997) - Organização Indígena do Centro de Iauaretê

ATIDI (1997) - Associação dos Trabalhadores Indígenas do Distrito de Iauaretê

COIDI (1997) - Coordenadoria das Organizações Indígenas do Distrito de Iauaretê
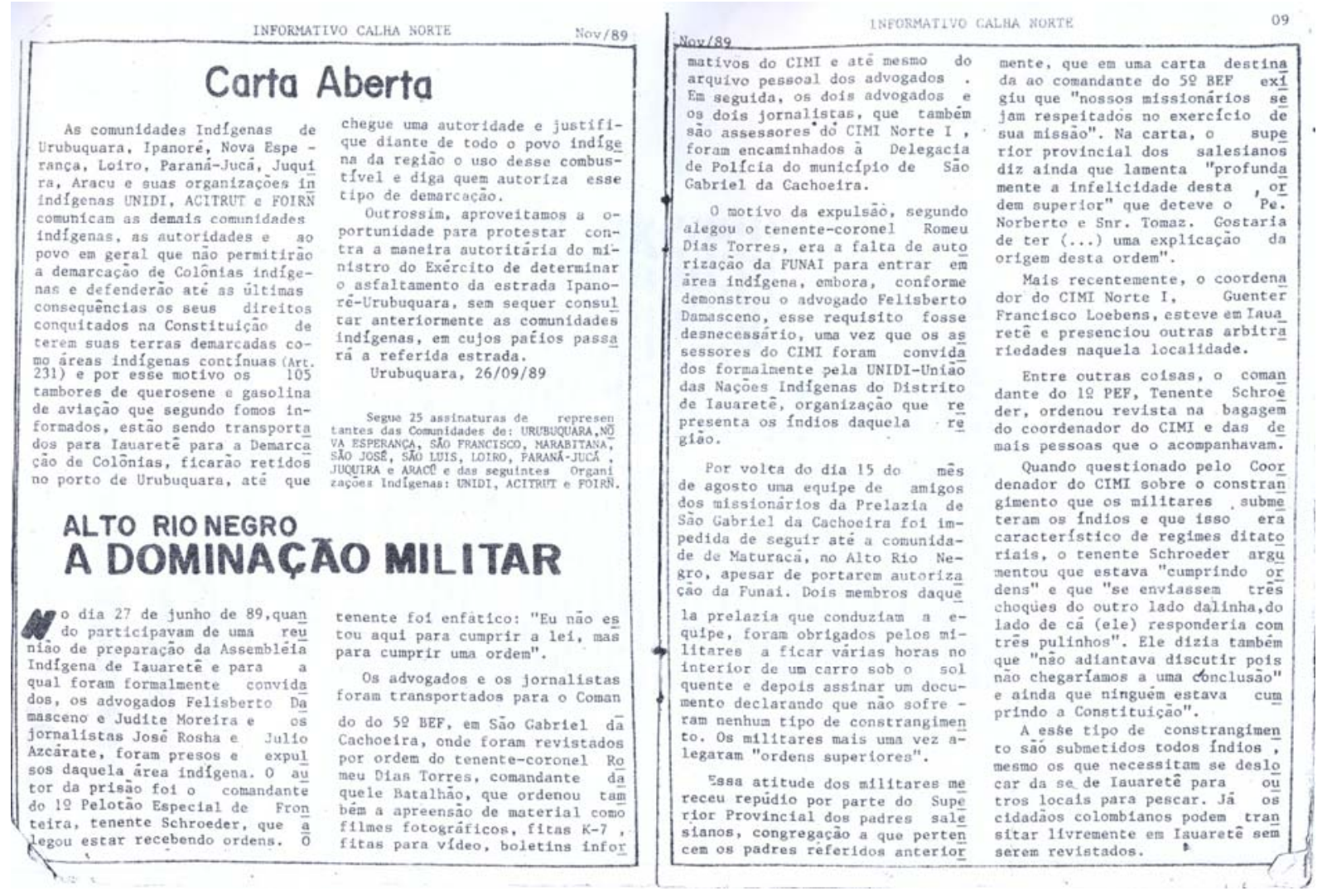

${ }^{336} \mathrm{O}$ termo Comunidade foi substituído por Coordenação. 


\title{
ANEXO 4 - Letras de Músicas usadas por indígenas nas eleições municipais de 2004 em São
} Gabriel da Cachoeira, AM.

Eleições Municipais de 2004

COLIGAÇÃO: Agora é a hora

Letra e Música: Israel Fontes Dutra - Tuyuka

Interpretação: Israel Fontes Dutra

\author{
Chegou a hora \\ Agora é a hora de mudar a nossa história \\ Vamos votar em Pedro Garcia para ser nosso prefeito \\ É a nossa vez de confiar na nossa gente no nosso sangue. \\ Chegou a hora \\ Agora é a hora de assumir a nossa história \\ Vamos votar em Pedro Garcia para ser nosso prefeito \\ É a nossa vez de comandar a nossa terra a nossa casa. \\ Chegou a hora \\ Agora é a hora de construir a nossa história \\ Chega de senhores, de ilusões, sermos mandados por tanto tempo \\ É nossa vez de acreditar em nosso irmão em nosso parente. \\ Mudança tem que acontecer para viver em paz \\ Mudança tem que acontecer com inteligência \\ Mudança tem que acontecer para humanizar \\ Mudança tem que acontecer com muito respeito.
}

\section{Letra e Música: Israel Fontes Dutra \\ Interpretação: Israel Fontes Dutra \\ Tradução: Israel Fontes Dutra}

Yu ahkawererã, $Y u$ ahkawererã, mãłĩ yá numu heałowesató.

Hoasãłĩ ntmษ Heałowesató,

$\mathrm{Y} \sharp$ ahkawererã, $Y \sharp$ ahkawererã,

\section{Mãlĩ ahkawerẽrãłẽ hosãłã}

prefeitua wakã, prefeitua wakã.

Poterikahałã nã duhti duhikã,

ati ditalé, ati ditałé. (2x)

$Y_{\sharp}$ ahkawererã, $Y \sharp$ ahkawererã, hoasã peołãbá, hoasãpeołãbá, Mãłĩ ahkawererãłe hoasãłã prefeitua wakã, prefeitua wakã.

Yu ahkawererã, Yu ahkawererã, poterikahałã, pehkasãkaba, Hoasãpeokãłã wuiro mãłĩrõ, ahkaweriré, ahkaweriré

Meus irmãos, meus irmãos, o nosso dia está se aproximando, O dia de votação está chegando, Meus parentes, parentes, 


\section{Vamos votar em nossos parentes \\ para prefeitos, para prefeitos. \\ Para que os índios comandem \\ esta terra, esta terra.}

Meus irmãos, meus irmãos,

vamos votar, vamos votar,

Vamos votam em nossos parentes

para prefeitos, para prefeitos

Meus irmãos, meus irmãos,

indígenas e não-indígenas,

Vamos votar sem medo,

em nossos parentes, em nossos parentes.

ANEXO 5 - Abril a outubro de 1980, em São Francisco, rio Tiquié - alto rio Negro -

AM.

ABRIL A OUTUBRO DE 1980, EM SÃO FRANCISCO, RIO TIQUIÉ, ALTO RIO NEGRO, AM.

\section{Álvaro Tukano \\ Doéthiro: Sëori-nigë (chefe)}

Após o carnaval, em São Gabriel da Cachoeira, peguei o avião Búfalo e fui para Pari-Cachoeira. Logo, quando cheguei em casa de minha prima, passei visitar o diretor. Mas, a conversa saiu fora do caminho, porque o Padre Norberto logo me agrediu em termos da religião, e começou a fazer críticas ao Porantim, ao Renato, ao Egídio Shwade e outros bispos que eram contra o governo, segundo ele.

Defendeu os militares da FAB dizendo que os missionários, junto com o bispo Dom Miguel Alagna estavam civilizando os índios, para que no futuro pudessem defender o Brasil como verdadeiros brasileiros. Ele me disse: "Nós, os missionários, estamos trabalhando com governo, sempre conseguimos o que queremos junto dele, e tanto é que os salesianos estrangeiros entra com facilidade no Brasil, porque nós temos amigos militar, como por exemplo, o Brigadeiro Protásio que fala diretamente com o governo. Desde no tempo de Dom Bosco quando os missionários de outras congregações eram perseguidos na Itália pelo governo, a nossa congregação nunca procurou brigas, e nós mantemos essa linha no Brasil e somos elogiados. Nós, ajudamos o governo a desenvolver o país, evangelizados e construímos escolas para o melhor assegurar a nação Brasileira..."

E como eu estava voltando de uma civilização de brancos, não quis ouvir muita cerimônia, porque os diretores e diretoras dos colégios sempre derrubaram os índios impondo uma ordem através de religião.

Fui obrigado responder numa altura exata, e logo o padre Norberto ficou brabo ainda mais, e começou puxar o breviário e leu o evangelho de São João: O BOM PASTOR. "Nós fazemos o que o bispo manda, porque somos boas ovelhas, e obedecemos ao papa e não aso comunistas como Dom Pedro Casaldáliga, Dom Tomás Balduino e tantos outros. Nós salvamos almas e pregamos o evangelho de Nosso Senhor Jesus Cristo..."

Nesse momento eu disse que não adiantava salvar só alma, também a cultura, a terra, enfim a vida da juventude. Que não adianta ser uma ovelha ou pastor para ouvir ou mentir através de imposições dos militares, porque os brancos sempre acabaram os índios através dos missionários. Por exemplo, os salesianos são inimigos dos futuros índios.

Ao ouvir essa coisa o padre ficou bateu contra mesa, e ficou todo nervoso e disse: "Álvaro, vossos pais, eram pagãos, não conheciam deus e que sempre viveram em estado de orgia. Eles praticavam a religião de diabo, eram atrasados, e os missionários transformaram-nos gente civilizada. Você é um deles que aprendeu nas escolas, e agora fala contre os seus benfeitores...".

Álvaro - Benfeitores seriam se toda o alto rio negro fosse demarcada. Para mim, não há beneficença se continuar com tantos erros, e vocês mandarem boas notícias que só engrandecem aos seus benfeitores. Você não vê a constante destribalização, a grande prostituição em São Gabriel ou em Manaus. Como os padres e freiras podem dizer que estão nos abrasileirando? Como? 
Norberto - Nós, somos missionários, e nos preocupamos com evangelho e não com questões sociais. Nós fazemos o que o governo colaborar, e mantemos grande amizade, e Deus sempre ouviu as nossas súplicas.

Álvaro - Bem Norberto, eu conheço os lugares de progresso, de grande civilização de Manaus, Recife, de São Luís e de outros lugares. No progresso do branco existem pequenos e grandes bares, os restaurantes caros, puteiros de luxo onde se encontram mulheres bonitas e caras, enfim todo tipo de pobreza ao redor dos ricos. Se quiser nos salvar tão cedo, então que nos traga os melhores cabarés e outros vícios. Assim vocês terão o papel consumado, e todos vamos compartilhar desse progresso. Não acha melhor assim?

Norberto - Vocês são contra o governo, contra os padres. Deus há de castigar-lhes. Bem, o mundo é grande. Se vocês não nos querem mais, nós, vamos embora. Aí sim que muitos brancos virão, e pisarão em cima de vocês e ninguém lhes protegerá. Então, sereis pobres, tristes, como tantos outros índios, e o governo não terá pena de vocês. O que é que vocês querem? E se não quiserem só basta avisar ao Dom Miguel que nós vamos embora.

Bem a $1^{\text {a }}$ primeira briga foi feio, mas que saí muito corajoso, porque terminei falando mais do que o padre. Antes, eles, sempre nos dominaram com humilhações públicas. E no corredor onde se encontravam as salas de aulas vi muitos jornais do meu artigo, todo sublinhado, para que o povo ficassem com raiva de mim. $\mathrm{Na}$ verdade, houve muitos comentários, toda confusão pesou em cima do Quintino Gentil, do Sebastião de Abreu, ambos de Pari-Cachoeira que estiveram no encontro. Os filhos deles não puderam ser aceitos no colégio, porque segundo os padres eram filhos das pessoas que não queriam ser civilizados. Portanto, os padres salesianos acharam que os filhos destes, ficassem sem estudo para melhor viver no mundo dos índios.

Outra coisa, o índio Henrique Castro sempre foi pessoa ambígua, astuto e sempre apoiado pelos padres. Mas sempre falou contra os padres, e do qual comecei a ter uma nova visão sobre os referidos missionários. Viveu por mais 20 anos como ditador entre os próprios índios, e sempre gritou e ganhou nas questões. Então, vendo a imagem traiçoeira, e porque enganou muita gente tive que falar verdade numa ocasião que houve a reunião de capitães em Pari-Cachoeira. quer dizer, em pouco tempo, ganhei a confiança do povo. Assim, quando me dirigia para meu sítio visitei os sítios vizinhos e dei o conhecimento a todos moradores, e busquei e consegui aliados.

Durante a semana santa, após a primeira reunião que realizei no meu povoado, houve grande surto de sarampo. Morreram muita gente, e outros ficaram chacados e abatidos, e houve desequilíbrio na comunidade. Tal fato deu a entender que a mina comunidade fora castigada por Deus por eu ter falado contra Deus e padres. Quer dizer, que qualquer cousa que acontecesse com os índios era o castigo do $\mathrm{Sr}$.

Deixei a coisa passar, e voltei da Páscoa para meu sítio, porque durante a Missa solene o Norberto me criticou diante de umas 3 mil pessoas, enfim terminou fazendo um grande ato público contra as lideranças indígenas. Falei ao povo, mas fiquei sem jeito, até aí o povo não tinha abrido seus olhos.

No povoado encontrei muita gente morrendo, e tudo passou mal. No fim do sarampo, uma mulher do sítio vizinho levou um corte de caititu, máquina de ralar mandioca. E como não tinha condições para socorrê-la levei-a para Missão. Foi uma semana depois da Páscoa, quando falei com Padre Norberto. O povo estava triste, porque os meus parentes alunos secundaristas que estudavam em São Gabriel não foram aceitos pelo Dom Miguel Alagna por causa do meu artigo contra o Protásio.

Desse jeito piorou mais para meu lado, porque muitos diziam que os padres iriam embora. O Padre Norberto, me disse que eu deveria falar diretamente com o Dom Miguel. Então, diante de minha discriminação dos missionários e do povo em geral, sem estar na lista dos passageiros fui falar com o comandante do avião para poder viajar até São Gabriel da Cachoeira. Não esperava de encontrar outra tristeza.

Quando pousamos na missão de Iauaretê, encontrei um salesiano ditador que trabalha muitos anos por aquela região. Era Sr. Guilherme Adamele, tcheco; portanto um comunista estrangeiro no meio dos índios inocentes e frágeis às suas exigências. Logo que desci do avião ele me perguntou donde eu era e como se chamava. Respondi-lhe, que era de Pari-Cachoeira, e que me chamava de Álvaro Fernandes Sampaio. E ele ficou brabo comigo, e disse:

Guilherme - Foram vocês que escreveram artigo contra Dom Miguel Alagna, contra o Sr. Brigadeiro Protásio e que falaram contra os padres. Que te educou e te fêz gente? Com quem que foram educados, quem lhes dá a roupa, sal, o fósforo? Quem lhes construiu escolas? Foram índios? Vocês são bugres e infelizes... E quando vão ser gente?

Quando se aproximou de mim pegou nas minhas orelhas e puxou-as, e quase chorei diante dos militares e dos índios que se encontravam no aeroporto. Eu fui agredido, e ele gritou na minha cara com toda soberba e outros ficaram conhecendo quem o era.

Esse salesiano me ofendeu tão grande, e seu que disso nunca vou esquecer até que não seja revelado ao público. Depoi, após uns 10 min de ter puxado a minha orelha, gritando me pediu para que pedisse desculpas ao 
Protásio, ao Dom Miguel e aos missionários. Nesse dia eu não falei nada, mas fiquei com muita raiva, e em vez de pedir desculpas me deu a vontade de brigar ainda mais.

Assim, nesse dia segui para São Gabriel, e no aeroporto pequei a carona do Sr. Tomás Hanlys, secretário do Dom Miguel Alagna que trabalhou 12 anos em Taracuá. Era salesiano com que trabalhei durante três anos no magistério.

Marquei audiência para o dia seguinte com Dom Miguel Alagna, e logo vi que não era tão pesado.

Assim, durante os três dias consecutivos, às tardes, falei com Dom Miguel e tudo nos esclarecemos como seriam os trabalhos:

- melhorar o nível de formação pessoal

- melhorar as comunidades de base

- promover serrarias em Pari-Cachoeira e Iauaretê

- promover as roças comunitárias, etc.

Assim, após 10 dias voltei para minha comunidade, e logo promovi outra grande reunião. Dessa vez, para trabalhar de acordo com as necessidades do povo, pois o Dom Miguel já me havia convencido.

Porém, aconteceu que o Padre Norberto continuava pregando sobre minha pessoa por onde passava. Outro padre, Luciano Chiappini, italiano sempre jogava charadas a mim, e os outros líderes sempre eram tentados pelos padres.

A resistência para isso foi fácil:

- $2^{\circ}$ domingo de maio - Dia das Mães fiz grande reunião na minha aldeia.

- festas juninas - novos encontros

- 7 de setembro, grande encontro na minha comunidade, assim conquistei espaço político dentre os parentes.

- enfim, terminei uma casa para comunidade, nessa última reunião fiquei doente de estômago e tive que parar no Hospital da missão de Pari-Cachoeira, porque fiquei em coma durante três dias.

\section{OUTUBRO DE 1980, ÚLTIMA GRANDE EM SÃO FRANCISCO E DESPEDIDA PARA TODOS OS CAPITÃES DA COMUNIDADE}

Durante a minha permanência dentre os meus parentes sempre estudei as matérias para o vestibular de janeiro que eu faria em Manaus. Também sempre mantive em contato com Renato Athias - Porantim - CIMI Manaus-AM.

Quando passei os dias com minha família sempre houve festas, e até brigas entre nós, mas que foram todas bem resolvidas e reconhecidas os erros.

Quando cheguei em Pari-Cahoeira, recebi uma carta de Deocleciano de Souza, através da francesa Dominique Buchillet que ficou trabalhando em São João, em dessano Luís Lana, o autor do livro Antes o Mundo não Existia.

Era uma carta que disse, que seria bom se eu fosse servir de testemunha na acusação contra os salesianos da Prelazia do Rio Negro - AM sobre os crimes de etnocídio e genocídio.

O acusador seria Márcio Souza, amigo do Luís Lana, do Renato Athias e do João Bessa, todos os que tinham acesso ao Porantim. Na verdade, quando não havia problemas, eu sempre confiei nesses sujeitos, e por isso que acreditei no conteúdo da carta de Deocleciano. Na carta ele dizia, que eu deveria baixar para Manaus na primeira oportunidade ou se não, eles pagariam uma passagem pela TABA (Transporte Aéreo da Bacia Amazônica) de São Gabriel para capital.

Mas quando sai da casa, eu não pensei de encrencar mais a minha vida ou mesmo encontrar fraqueza nos meus companheiros brancos. Eu vinha para Manaus a fim de prestar vestibular para medicina, porém acontece que, as inscrições já haviam sido fechadas.

Quando cheguei em São Gabriel falei com meu primo, Pedro Fernandes Machado, mas esse camarada ficou meio assustado quando ouviu a referida notícia. Mas, que tudo correu bem, e até que no dia vim para Manaus. Em Sana Isabel encontrei o Padre Casimiro Béksta, salesiano que não é bem aceito pelas freiras e Dom Miguel, e também falei com Padre Bento que vinha para Barcelos. Em meio o barulho do avião falamos um pouco sobre a violência cultural que o Padre Norberto vinha fazendo em Pari-Cachoeira, quando escrevia circulares para acabar com os papéis de pajés e do KUMU.

Mas, eu não disse nada sobre a minha participação para IV Tribunal Bertrand Russell que haveria de se realizar na Holanda, na cidade de Rotterdan; mas o meu espírito não teve nenhum medo, e cheguei em Manaus. No mesmo dia fui me encontrar com Renato Athias do CIMI, e logo começou chover um pouco. Logo, 
compareceu o irmão do Márcio Souza, o Deocleciano, e com estes fiquei conversando por mais de 30 min, e relatei como esta acontecendo na minha região.

Mas, quando comecei a falar, e disse, que iria para julgamento na Holanda o Renato me disse:

Renato - Rapaz! Oh Álvaro! Você tem coragem para isso? Olha lá meu amigo, que vai ser duro.

Com toda firmeza respondi-lhe:

Álvaro - Eu tenho coragem, eu sou tem amigo, e confio nos amigos, e chegou a hora de quebrar o tabu dos padres que nunca souberam respeitar as nossas cerimônias e ritos.

Depois, ficamos falando sobre o padre Alcionilio Bruzzi, um salesiano que ajudou matar muita gente na itália, durante a II Guerra Mundial, porque esse missionário é louco e racista e neofacista. É por isso, que esse missionário tem publicado muita coisa pejorativa sobre os índios do Alto Rio Negro-AM. Também era amigo íntimo do Brigadeiro Protásio Lopes de Oliveira - gerente da empresa Brasileira de Aeronáutica - EMBRAER,, também homem que demonstra preconceito com índios, um dos militares, que segundo o Padre Casimiro é Espírita, então o maior inimigo dos (as) missionários (as), mas, que só que as freira consideravam-no como "benfeitor".

Essas coisas que afirmo, podem ser comprovadas através de grandes retratos que se encontram no Museu de Î́ndio-Manaus ou mesmo no Colégio Sta. Terezinha, nos colégios das freiras nas missões do alto rio Negro e no Instituo Histórico e Geográfico do AM.

As freiras que mais tiveram amizade estranha com esse brigadeiro e que indicaram mais índias a trabalharem com os aviadores foram:

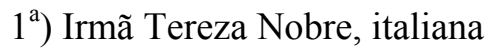

$2^{a}$ ) Irmã Elza Ramos, brasileira

$3^{\mathrm{a})}$ ) Irmã Olga Tenório, brasileira

$4^{\mathrm{a})}$ ) Irmã Irene Melo, brasileira de PE

$\left.5^{\mathrm{a}}\right)$ Irmã Anunciata, italiana

$6^{\mathrm{a}}$ ) Irmã Terezinnha A. Ribeiro, brasileira de MAO, e algumas outras freiras que sempre fizeram comidas para banquetes das comitivas.

$\mathrm{Na}$ verdade, quem foi culpado sobre o julgamento do Bispo do Rio Negro, foram as freiras, porque elas fazem mais gastos quando embelezam os seus colégios, elas quem manobram sobre os artesanatos, elas quem controlam o bispo, elas quem alienam mais alunos indígenas, elas que não querem saber sobre a autodeterminação dos índios do Alto Rio Negro, enfim elas quem controlam índios e até mesmo a lista dos passageiros no avião da $\mathrm{FAB}$ ou que influenciam sobre as pessoas trabalham nesses setores. Os padres estão debaixo dos pés das freiras, e me parecem que não foram criados ou enviados para serem "ovelhas" porque simplesmente são as "ovelhas" das freiras. Não há machismo ou moral nos padres, porque a maioria dos missionários são estrangeiros, e na verdade têm medo dos brasileiros, mas não dos índios. Por outro lado, por serem homens, eles dão palavras as freiras, e pessoa como eu, nunca se tem apoio moral. Por exemplo, o diretor de Pari-Cachoeira, padre Norberto não celebrava missa sem aprovação da Irmã Ana, porque era essa que escolhia cantos ou mesmo até o tema para pregação e ao mesmo namora com ela. Os capitães de minha comunidade São Francisco, Maracajá, Santo Antônio, Santa Luzia, Cucura, e mesmo de Barreira e Cunuri, diziam que esse padre só cumpria as determinações das freiras, e era mesmo.

Outras coisas que não posso dizer, porque seria demais, já dá para imaginar como são as coisas entre os índios do Alto Rio Negro. Tais processos que violam o direito de permanência de viver como índios, buscar uma integração mais justa e não compulsória.

Assim, logo me preocupei obter passaporte, difícil, mas consegui com a ajuda do advogado Dr. Hidebrand Dias, vinculado à Ordem dos Advogados do Brasil - $\mathrm{OAB}$, porque a Polícia Federal queria me enganar mais só porque eu era índio. Eles me diziam: vem amanhã; depois da amanhã, ou não seu e mais outras coisinhas que me desagradavam.

Durante o período, analisei a acusação do Márcio Souza, e vendo a falata de outras coisas fui obrigado acrescentar mais 20 laudas. Saiu com português, errado, mas que deu para imaginar, e vim para Brasília - DF.

Quem pagou a minha viagem de Manaus para Brasília foi o Deocleciano Souza. E quando por volta das 14:00 hs eu me encontrava no aeroporto, às 17:00 hs já estava em Brasília. Fiquei brabo quando vi jornalistas que me esperavam, porque na verdade, que eles iriam prejudicar a minha posição, e assim aconteceu. A FUNAI caiu em cima de mim, principalmente o Cel. João Carlos Nobre da Veiga, inimigo declarado contra os índios.

Foi assim que conheci o Egídio Shwadz, que também partia para mesmo destino. No Rio encontrei outra jornalista - Memélia Moreira - da Folha de São Paulo, e me pareceu gente boa, mas logo deve ter percebido a minha desconfiança. Também foi o começo do problema, porque logo fiquei perdido. O Egídio viajou no outro avião, eu e Memélia no outro. Voamos com destino a New York, levando 9 horas de vôo. 
Chegando em New York fiquei mais perdido, passei fome, falta de comunicação com a ditadura dos capitalistas, e fiquei numa sala de isolamento durante 12 horas, e tive que passar por uns dez computadores. Depois, com muita fome e raiva, fui o último a embarcar num avião árabe com destino a Amsterdam - Holanda, e chegamos às 7 horas. Logo, veio televisão, os jornalistas, chegaram muitos índios das Américas, e parecia uma festa. Enquanto isso, no Brasil o cacique Mário Juruna brigava e ganhava a questão na FUNAI, mas na abertura eu li uma carta que ele me mandou. Foi bom, porque lá era um momento (de oportunidade) para revelar as sensuras da FUNAI.

No dia 24 de novembro servi de testemunha na acusação de Márcio Souza, e também foi nesse dia que conheci o ex-salesiano Bernardo Strik que trabalhou no Rio Madeira - Humaitá e Porto Velho, em Barcelos no Rio Negro. Eles ficaram espantados quando ouviram o meu depoimento, porque pareceu forte demais, e por isso que logo se compareceu o padre Antônio Rasera - ex-inspetor provincial da Amazônia de missionários salesianos.

Na casa do Padre Bernardo Strik tivemos uma conversa dura com esse salesiano, até o padre Bernardo Strik entrou a meu favor, e o padre Egídio Shwade foi testemunha dessa confusão. Essa parada aconteceu no dia 2/12/80, numa noite de muito frio. Quando era menos de se esperar outras novidades o ex-inspetor saiu de casa um pouco triste, mas provável quis desmentir a minha acusação, e não conseguiu.

Na ocasião, o Bernardo Strik prometeu de ajudar a mim, através do Porantim, e até disse que assim eu poderia prosseguir a luta. Mais tarde, depois que o Renato Athias saiu de Manaus, o sucessor dele, o ricardo Parente mostrou a carta desse padre, uma coisa que o próprio Ranato Athias não quis me mostrar. E foi desde aí que desconfiei nas pessoas do CIMI - Manaus-AM, porque no fundo eles só me prejudicaram até hoje.

Hoje, não vejo a promessa do Renato Athias, e praticamente foi esse que interferiu nas promessas do Bernardo Strik, e mais uma vez, que o Egidio Shwade é testemunha disso que aconteceu comigo.

Muitas vezes passei isso ao Renato Athias, mas infelizmente não se deu para entender, e me deixou sozinho na briga, e assim fizeram outros companheiros, menos um que foi o Paulão - Paulo Monte, pois foi a única pessoa que comprovou como verdadeiro amigo, e nas horas de super fome ou mesmo de necessidade para transporte eu sempre obtive fé. Mesmo a mãe dele - D. Dora sempre me tratou como se eu fosse filho, mas a quanto o resto do pessoal só me utilizaram para se "vangloriar".

Também, o único padre de minha confiança era o Casimiro Béksta, salesiano que foi professor na minha infância, e por estudar os costumes do meu povo, a pedido de freiras exploradoras foi expulso por sua Excelência e Revdmo. Dom Miguel Alagna. Foi com esse padre que tenho obtido conselhos de muita cautela, e que também me disse que as pessoas do CIMI-Manaus só estavam me explorando. De tanto ser vítima desse papel, não deu para mim perceber, a não ser mais tarde quando a barriga roncou ou mesmo quando os procurei inutilmente.

Eu creio, que esse tipo de vida sá cabe às pessoas que sabem valorizar a luta e viver por ela, porque assim conheci novas formas de resistência ou a realização de "ser verdadeiro índio".

Para prosseguir, durante o IV Tribunal Bertand Russel conheci muitos índios de outros países, e passei receber correspondências e convites. Mas, na volta fiz uma entrevista coletiva, recebi reposta dos meus únicos inimigos políticos do governo e da oposição (PMDB) que defendiam os missionários. Eu como os índios SateréMauvé tinham um programa, passei assistir e participar co encerramento de inconsciência indígena, porque depois que tivemos reunião em Manaus, em janeiro de 1980, eles disseram que fariam um encontro. Então, pela primeira vez, os próprios índios do Pará e Amapá, de Roraima e até missionários, [...].

Essa reunião foi realizada entre 10 a 12 de dezembro de 1980, no rio Andirá, no município de Barreirinha-AM. Durante o encontro transmiti-lhes o fato que acabava de ocorrer no mundo - sobre o IV Tribunal B. Russel.

Foi assim que entre definindo a minha posição na luta indígena, e percebemos que isso é necessário. ANEXO 6 - Militarização da Amazônia: Calha Norte: Um pesadelo para os povos indígenas do
rio Negro. Fonte: Jornal da Manhã, 13 de julho de 1989.

\section{ANEXO 7 - Tukanos ingressam na justiça com uma ação contra o CMA. Fonte: Jornal do Brasil, 23 de maio de 1991.}

ANEXO 8 - CMA nada sabe sobre pedido de indenização. Fonte: Jornal $\boldsymbol{A}$ Crítica, 25

de maio de 1991. 
ANEXO 9 - Calha Norte já transfere os indígenas.

ANEXO 10 - Carta Aberta: alto rio Negro e dominação militar. Informativo Calha Norte Nov/89.

ANEXO 11 - Militares prendem e torturam índio Baniwa.

ANEXO 12 - Amazônia: Sipam será base para monitoramento internacional da Amazônia.

Fonte: http://www.ambientebrasil.com.br/noticias/index.php3?action=ler\&id=25058

Acessada no dia 06/06/2006.

\section{Amazônia}

Sipam será base para monitoramento internacional da Amazônia

Os oito países-membros da OTCA - Organização do Tratado de Cooperação Amazônica - Brasil, Bolívia, Colômbia, Equador, Guiana, Peru, Suriname e Venezuela - planejam integrar seus programas nacionais de monitoramento da floresta, tendo como base a tecnologia desenvolvida pelo Sipam - Sistema de Proteção da Amazônia. "Nós estamos falando do suporte técnico que o sistema brasileiro pode oferecer, além de uma complementaridade com os sistemas de informação dos outros países", disse nesta terça-feira (6) à Radiobrás a secretária-geral da OTCA, Rosalía Arteaga Serrano.

De acordo com ela, os termos gerais do acordo de cooperação entre a OTCA e o Sipam já foram acertados, mas não há prazo definido para que ele seja assinado. "Já fizemos nossa revisão e estamos agora esperando que o Sipam e a Casa Civil façam suas observações, para aperfeiçoar o convênio."

A primeira etapa do acordo, que começará a ser posto em prática por meio de planos de trabalho bilaterais entre o Brasil e os demais países, será a transferência de tecnologia. "A capacidade técnica do Brasil é maior do que a dos outros países. Precisamos de cooperação técnica para unificar a linguagem das diferentes instituições", explicou Rosalía.

Para ela, a troca de tecnologia e informações será essencial para efetivar a missão institucional comum da OTCA e do Sipam: a gestão integrada dos recursos naturais da Amazônia. Como a natureza não respeita fronteiras políticas - a água é um exemplo clássico disso - é preciso que os países compartilhem dados e planejem conjuntamente sua política ambiental para a região.

"Isso auxiliará na fiscalização da floresta, principalmente de ilícitos, como as queimadas, o tráfico de biodiversidade, a retirada ilegal de madeiras preciosas", lembrou a secretária. "São problemas que não acabam de um dia para outro, então é preciso que nosso projeto de cooperação seja de longo prazo, mas aconteça por etapas."

Rosalía Arteaga, que já ocupou o cargo de vice-presidente (em 1996) e de presidente constitucional do Equador (em 1997), explicou que a OTCA funciona como um grande guarda-chuva, acelerando as parcerias entre os países amazônicos. "Quando o acordo de cooperação com o Sipam for assinado, ele não terá que passar pelo Congresso do Equador, por exemplo. Como já existe o Tratado de Cooperação Amazônica, basta apenas que o Poder Executivo ratifique esse convênio."

A OTCA foi criada em 1995, reunindo os oitos países que em 1978 assinaram o acordo para a promoção de ações conjuntas visando ao desenvolvimento sustentável da Bacia Amazônica. O secretário-executivo da entidade, Francisco Ruiz, explicou que a Guiana Francesa não faz parte da OTCA porque é um departamento francês, não uma nação. (Thaís Brianezi/ Agência Brasil)

\footnotetext{
ANEXO 13 - Zona perigosa de fronteira está desguarnecida. Fonte: $O$ Globo, 06 de dezembro de 1998.
} 
ANEXO 14 - EUA redesenham sua estratégia militar. Fonte: Folha de São Paulo, 22 de junho de 2003.

\section{ANEXO 15 - Globalização, militarismo norte-americano e Amazônia. Brasília 01 de setembro de 2004.}

http://www.pstu.org.br/cont/\%7B3A5E4A14-947C-47B9-87D64EE085824AD5\%7D 2006 artigo Gilson militarismo.doc

Acesso: 21/11/2006

\section{Globalização, militarismo norte-americano e Amazônia}

Não é mais possível separar globalização ${ }^{337}$ de militarismo norte-americano, e para vários estudiosos, os Estados Unidos estão tentando resolver ou encaminhar seus problemas econômicos através da militarização do processo de globalização. Ou, nos termos de Serfati, "se a mundialização não procede de maneira alguma da 'mão invisível' do mercado, como afirmam os neoliberais, ela dispõe, na virada do século, de um sólido braço

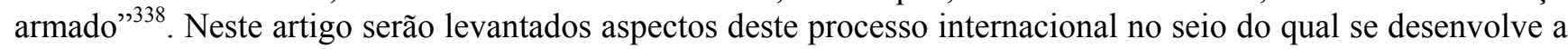
cobiça e a pressão atual sobre a Amazônia.

O complexo militar-industrial tornou-se um setor importantíssimo para o capital industrial dos Estados Unidos e para a sua política expansionista; ao mesmo tempo, em que se trata de um processo que se desenvolve associado à multiplicação exponencial do capital financeiro: são movimentos inseparáveis.

Essa escalada, que vem assumindo grande porte, dá indícios de que não tende a arrefecer. A corrida militar da Inglaterra e da Espanha, os dois países europeus que mais investem em ciência e tecnologia (C\&T) de natureza militar e cujas burguesias são as que precisamente mais se articulam com os Estados Unidos (que investem 5 vezes mais que a União Européia em C\&T militar), são dados apontando nessa mesma direção.

Os gastos militares norte-americanos já superaram os patamares mais elevados da era Reagan: chegaram a U\$ 350 bilhões naquele período, sendo que, em 2003, sofreram sua maior elevação em 21 anos, ultrapassando os 350 bilhões de dólares (chegaram a U\$ 375). Se forem computados os gastos com veteranos de guerra e outras despesas (como segurança civil e afins), o orçamento militar para o próprio ano fiscal de 2003 ultrapassa os 470 bilhões de dólares, segundo cálculos do economista Jurgen Brauer ${ }^{339}$. Isto significa gastos militares, ano passado, de quase meio trilhão de dólares! A previsão orçamentária oficial de W. Bush para 2005 é de U\$ 402 bilhões ${ }^{340}$; de toda forma, espera-se, para 2005, que os Estados Unidos adotem o maior orçamento de defesa nacional desde a II Guerra Mundial ${ }^{341}$. Ao mesmo tempo, assistimos a uma campanha eleitoral para presidente dos Estados Unidos, completamente envolvida pelo militarismo, defesa nacional, Estado policial e "guerra preventiva" contra o 'terror internacional'. Para o próprio Paul Krugman, um notório economista da ordem, estamos diante de uma "orçamento de destruição maciça"342.

Esse ascenso militarista, onde ganha destaque a ocupação do Iraque, tem tudo a ver com uma séria crise econômica e política do capitalismo mundial, com uma grande instabilidade que envolve seu funcionamento financeirizado atual. O empreendimento ao qual se lança a administração $\mathrm{W}$. Bush, de impor uma hegemonia incontrastável sobre os demais Estados (nos planos comercial, financeiro e de controle das reservas de petróleo e riquezas naturais), além de ser gerador de mais desordem, mal consegue ocultar um dado crucial em todo esse

\footnotetext{
${ }^{337}$ Expressão que ficaria mais bem posta como mundialização do capital (Ver François Chesnais, A mundialização do capital, São Paulo, Xamã, 1996).

${ }_{338}$ Claude Serfati, O braço armado da mundialização, revista Outubro, n. 6, 2002, São Paulo, Instituto de Estudos Socialistas, p.47-65, p.49.

339 Jurgen Brauer, United States military expenditure, 8 june 2004. Disponível em: www.aug.edu/ $/$ sbajmb/paperBrunswick.pdf. Acessado em 2/8/04.

${ }^{340}$ Bush favorece gastos com segurança, Gazeta Mercantil 3 fevereiro 2004.

341 Godoy, El presupuesto norte-americano y las nuevas victimas de George W. Bush, 6/2/2004. Disponível em www.rebelion.org, Acessado em 4/3/2004.

342 Mampaey, Luc, L'hysterie sécuritaire, moteur de la relance américaine, 10 février 2004. Disponível em www.grip.org.bdg. Acessado em 6/3/2004.
} 
processo: "a economia capitalista global não conseguiu sair da 'larga fase descendente' que começou com a primeira crise importante do pós-guerra, nos anos 1973-1974; e o boom americano dos anos 1990 não se mostrou ser mais que um falso despertar",343.

As políticas monetárias dos Estados Unidos não surtem efeito, e sua política fiscal se concentra em gastos militares, um bumerangue que implica em pressão sobre os mercados de capitais que pode levar a altas taxas de juros e mais estrangulamento sobre a economia real mundial; e isso numa fase histórica em que vieram abaixo os modelos capitalistas mais incensados: Japão, tigres asiáticos e a supostamente promissora nova economia norte-americana dos anos 90 .

A atual ofensiva militarista dos Estados Unidos não pode ser entendida satisfatoriamente fora desse quadro global (cujo exame nos remeteria para reflexões teóricas demasiado extensas para os limites deste espaço ${ }^{344}$ ) e este artigo pretende chamar a atenção para um dado empírico que merece destaque pelo que representa em termos de grave sintoma e de tendência política concreta do militarismo norte-americano, ou da globalização militarista: a expansão das bases militares norte-americanas em países e regiões cuja soberania fiscal, monetária e econômica vêm sendo reduzidas a pó. E os riscos que isso implica para a Amazônia brasileira, como veremos a seguir.

Trata-se de um dado concreto dos últimos anos, esse mesmo período em que crescem os gastos militares dos Estados Unidos: novas bases militares foram abertas na América Latina, Ásia e África. Equador, Bolívia, Turquistão, Tadjiquistão, Afeganistão, Arábia Saudita, Qatar, Kuwait, Kosovo, Aruba e Filipinas estão nessa lista de novas bases militares sobre zonas estratégicas, processo que tem a ver - embora se trate de uma política de alcance bem maior - com a agudização da luta pelo controle de recursos naturais mundiais.

Há denúncias de que o Pentágono planeja instalar um novo "comando" (à semelhança do Comando Sul, sediado em Miami) na Ilha de São Tomé para proteger a sua exploração de petróleo em Angola, Gabão e Nigéria ${ }^{345}$.

Nos dois últimos anos, essa foi uma tendência dominante na política norte-americana: o uso da força militar para controlar - contra seus rivais globais - regiões e recursos estratégicos, especialmente o petróleo: bases militares dos Estados Unidos foram instaladas na Ásia Central, Afeganistão, em redor da China e, agora, o Iraque (segunda reserva mundial de petróleo cru) tornou-se um protetorado militar norte-americano. A linha de política externa dos Estados Unidos, acentuada depois do 11 de setembro a pretexto de guerra contra o terror, passou a ser aquela de "inimigo público número um do planeta": minha soberania é inviolável, a sua não, e há duas regras, uma para nós, os Estados Unidos, outra para o resto do mundo ${ }^{346}$.

No caso específico da América Latina, lado a lado com a ofensiva norte-americana pela Alca (Associação de Livre Comércio da América Latina), passou a haver um aumento importante dos gastos militares dos Estados Unidos, tendo como foco o nosso continente. Como argumenta Petras, o Plano Colômbia, a Iniciativa Andina e os gastos relacionados com a militarização das fronteiras do Equador com a Colômbia e do Panamá com a Colômbia, implicam em mais de 1,5 bilhão de dólares e incluem centenas de agentes militares dos Estados Unidos $^{347}$.

Pompeu chega a mencionar 20 bases em volta da Amazônia $^{348}$. Essa rede de bases militares se espalha na América Latina a partir da coordenação militar do Comando Sul (norte-americano) sediado na Flórida, com subsede em Porto Rico. Há bases militares dos Estados Unidos nas Antilhas Holandesas, em Manta, El Salvador, Honduras (Soto Cono), Aruba-Curaçao e outros pontos da região; a partir delas, os Estados Unidos penetram no

\footnotetext{
${ }^{343}$ Alex Callinicos, Crisis de rentabilidad de larga duración y desajuste entre potencia militar y potencia econômica. Lo que subyace em la política guerrerista de los Estados Unidos, inverno 2003, revista Herramienta n.23. Disponível em www.herramienta.com.ar. Acessado em 2/1/2004.

${ }^{344}$ Ver, a respeito, Serfati (2002), Gill (1996), Chesnais (1996), Coggiola (2002), Mészàros (2003), Campos 2001) e outros, além do estudo de Letizia, A terceira oportunidade imperial americana, mimeo, 2002.

345 Rui Namorado Rosa, Com que armas são feitas as guerras e para quê, 7 março 2004. Disponível em www.resistir.info. Acessado em 4/4/2004.

${ }^{346}$ Namorado Rosa, op.cit. Ver também as análises de Donahoe, Myrna, Fernández, Raúl, González, Gilbert, 2003. Crisis general y militarización del império ianqui, 12 janero 2003. Disponível em: www.rebelion.org. Acessado em janeiro 2004.

${ }^{347}$ James Petras, Império e políticas revolucionárias na América Latina, 2002, São Paulo, Xamã, p.101.

${ }^{348}$ Renato Pompeu, O retrato assustador do novo imperialismo, 2003, Caros Amigos-Especial, n.17, junho 2003, p. 4-7.
} 
espaço aéreo de vários países da América Latina. Isso sem mencionarmos o processo de terceirização de vários exércitos periféricos que "agem de forma complementar à política militar do Pentágono ${ }^{349 " .}$

Evidentemente, recursos não-renováveis estão na mira dessa ofensiva geopolítica e militar. Há uma conjuntura política internacional, uma estratégia militar norte-americana e aquela profunda crise econômica dos Estados Unidos e do conjunto do sistema, que empurram na mesma direção: o mais poderoso Império militar de que se tem notícia, está disposto a tudo para garantir os recursos naturais que mantêm os padrões de consumo da civilização do desperdício; recursos esses que estão não apenas no Iraque, mas também na Amazônia (e alguns deles em terras indígenas ${ }^{350}$ ).

Conflitos como o de índios e garimpeiros por diamantes, embates com a guerrilha na fronteira com a Colômbia ou similares, podem, perfeitamente, ser usados como álibi para uma intervenção militar na Amazônia a partir daquela rede de bases militares de alta tecnologia que vem sendo instalada recentemente na região pelos Estados Unidos. Não se pode deixar de considerar que um Estado delinqüente (Rogue State) - na expressão de Pascal Boniface $^{351}$ - não precisa de qualquer mandato para organizar uma operação militar, sempre que encontre uma relação de forças favorável e governos locais colonizados e de espinha dorsal suficientemente flexível ${ }^{352}$.

Há fortes indícios de que esteja sendo preparada uma intervenção militar respaldada pelos Estados Unidos contra a Colômbia. Um exemplo: a cúpula de presidentes latino-americanos (Grupo Rio) reunida em Cuzco, Lula incluído, apelou à ONU para intervir e desarmar as FARC, caso contrário "se buscaria outras alternativas". A declaração do presidente Uribe, da Colômbia, foi mais longe: se a guerrilha rejeitar a mediação da ONU, ela "deverá ser derrotada militarmente com apoio internacional" (o presidente Chávez, da Venezuela, criticou esse pronunciamento). Os chanceleres do G-8, reunidos na França no mesmo dia, respaldaram de forma incondicional a "ação do presidente Uribe (...) em favor do fortalecimento da autonomia do Estado". Condolezza Rice, secretária de Segurança Nacional dos Estados Unidos declarou que "os Estados Unidos são contrários à negociação com os terroristas (colombianos)". Ao mesmo tempo, Uribe vem procurando envolver Brasil e Argentina nessa operação militar e Kirchner não reagiu negativamente ao pedido do presidente colombiano.

O objetivo não é o que parece ser (o "narcoterrorismo"). O que está em jogo é bem mais o interesse de controlar uma área - a Colômbia - que funciona como porta de entrada para a Amazônia (a maior reserva de água doce do planeta), os Andes e a Venezuela, através de um país que fica numa posição geográfica privilegiada entre o Pacífico e o Caribe. Não se deve deixar de levar em conta que na zona conhecida como das "cinco fronteiras" (Colômbia, Equador, Peru, Brasil e Venezuela) existe um gigantesco lençol de petróleo parcialmente explorado por esses cinco países ${ }^{353}$.

De uma vez por todas, vale reiterar: o processo político deflagrado pelos Estados Unidos, em sua condição de potência militar, midiática e financeira, inclui, além de outros objetivos - como assegurar a cobrança da dívida externa -, uma busca de controle das reservas naturais que decidem (petróleo, gás, minerais essenciais, biodiversidade genética e água), e num processo dessa natureza, evidentemente, a Amazônia ocupará um papel central.

Há pressões dos Estados Unidos pela instalação de bases norte-americanas na Patagônia em troca de rearranjos na dívida externa. Coggiola argumenta que a proposta de exercício militar conjunto dos Estados Unidos e mais sete países da América Latina (inclusive o Brasil), a chamada "Operação Aguila III" com duração de 14 dias, é parte da pressão norte-americana pela implantação de tais bases na Argentina e que seriam integradas ao plano do "escudo antimíssil" das Forças Armadas dos Estados Unidos. Com o acordo Brasil-Estados Unidos para

\footnotetext{
${ }^{349}$ Osvaldo Coggiola, O capital contra a história: gênese e estrutura da crise contemporânea, São Paulo, Xamã/Pulsar, 2002.

${ }^{350}$ A respeito da Amazônia e os riscos que pairam sobre ela, pode-se consultar os escritos de Gelio Fregapani, em especial seu livro Amazônia, a grande cobiça internacional, Brasília, Thesaurus, 2000.

${ }^{351}$ P. Boniface, Etats-Unis: shérif ou bandit?, Le Monde, 20/3/1999.

352 Enviar tropas brasileiras para sustentar a ação norte-americana no Haiti e, ao mesmo tempo, uma atitude de complacência para uma intervenção militar imperialista ao lado de Uribe, na Colômbia podem ser expressão dessa postura. É a política de Lula neste momento.

353 Plan Colombia: papel de las petroleras, Allende La Paz, 07 mayo 2004. Disponível em: www.rebelion.org; Acessado em: 22/4/2004.
} 
implantação da Alca, "abre-se a porta para um vasto plano de colonização econômica, política e militar da América Latina pelos Estados Unidos, sob a forma de um 'Tratado de Livre Ocupação da América Latina ${ }^{354, "}$

Dessa forma, a mão armada da globalização pode se ver tentada a arrematar a obra que sucessivos governos entreguistas e neoliberais da região têm levado a cabo contra suas Nações. Certamente se esse processo não for detido, a metrópole imperialista pode se lançar em campo aberto a tentar controlar, manu militari seus tradicionais objetos do desejo, no caso da chantagem da dívida externa não se mostrar um recurso de pressão suficiente. As bases para isso (sem trocadilho) já estão sendo montadas.

Brasília 1/9/04

Gilson Dantas.

\section{ANEXO 16 - A Amazônia ameaçada.}

Fonte: http://br.monografias.com/trabalhos/amazonia-ameacada/amazonia-ameacada.shtml - Acessado no dia $03 / 11 / 2006$.

\section{Amazônia ameaçada}

\section{Introdução}

Em outubro de 2004 o comandante e general-de-brigada Marco Aurélio Costa Vieira recebeu o jornalista Javier Godinho para uma discussão:

\section{A Internacionalização da Amazônia.}

O General Marco Aurélio demonstrou através de documentos, imagens, e informações do exército brasileiro que confirmam plenamente que o Brasil corre o risco de perder $56 \%$ de seu território, e justamente a maior riqueza intacta mineral, petrolífera, fauna e flora e principalmente água potável que será o grande problema mundial daqui alguns anos.

Da água potável ainda existente no planeta, $11 \%$ corre nos 23 mil quilômetros de rios navegáveis da maior bacia hidrográfica do mundo, responsável por dois terços do potencial hidrelelétrico do Brasil.

\section{Como seria o Brasil sem a Amazônia ? Veja os números...}

O general Marco Aurélio demonstrou um mapa mostrando como seria o Brasil sem a Amazônia. Já pensarem nisso algum dia?

Então veja: de um lado 5,1 milhões de quilômetros quadrados perdidos, o mais promissor do presente e o mais rico do futuro desse país, atualmente semi-abandonados pelos governos e pela população, com apenas 4 habitantes por quilômetro quadrado, $12 \%$ da representação política e US\$2.059,00 de renda per capita. Do outro, horrível no formato, os 3,4 milhões de quilômetros quadrados que nos sobrariam, com 40 habitantes por quilômetro quadrado, $88 \%$ da representação política e US\$ 4.955,00 de renda per capita.

Dentro da Amazônia brasileira cabem nada mais nada menos de 17 paises europeus dentre eles - Bélgica, Alemanha, Eslováquia, Áustria, Albânia, Portugal, Itália, Bósnia, Inglaterra, França, Espanha, República Tcheca Holanda e a Suíça.

Com certeza, grupos suspeitos, cada vez maiores, de várias dessas nações já se estabelecera, se movimentando e realizando ações escusas no território amazônico.

\section{"Eles Levam Nossas Riquezas"}

O general Marco Aurélio, que viveu 5 anos no Comando Militar da Amazônia, não acredita ainda que exista mesmo um movimento organizado para tomar a Amazônia. Mas destaca que há grandes interesses de potências econômicas, pois já atuam individualmente. Há grande número de estrangeiros dentro de nossa Amazônia. São mais de 600, entre ONGs, instituições religiosas, cientificas e culturais.

Este levantamento foi feito pelo exercito brasileiro. Tais instituições atuam entre a população branca pobre e os índios. E o mais grave: estão levando nossa riqueza de todo o tipo.

È inacreditável que estão nos cercando 20 bases militares dos Estados Unidos, a título de combater o narcotráfico e a guerrilha.

Depois desta reportagem você acredita que estão combatendo mesmo o narcotráfico ou estão de olho nesta região?

354 Coggiola, Osvaldo, 2003. A política externa do governo Lula e a Alca, 14 jul 2003. Disponível: www.brasilnews.com.br. Acessado: 6/6/2004. 
Na operação Timbó, realizada pelas forças armadas, foi detectado um contrabando de mogno realizado por representantes de empresas estrangeiras, que para tanto, usam caboclos e índios brasileiros para marcar as melhores árvores, e a seguir arrancadas por tratores as arrastavam para o território peruano.

Um dado importante mostra sem dúvida a presença marcante de estrangeiros no nosso território: $O$ governo da Guiana Francesa paga um salário por criança nascido no Brasil, que ali seja registrada, para retornar ao nosso país, mas com cidadania daquele departamento ultramarino da França.

O general destaca o trabalho dos pelotões de fronteira, praticamente única presença brasileira na área.

Essas unidades militares são procuradas por índios e caboclos em busca de assistência de todo tipo, inclusive médica.

\section{O Brasil Inteiro Contra o Mundo}

O general Marco Aurélio busca com muita apreensão despertar a consciência nacional para a necessidade de ocupação racional, de fato, pelos brasileiros, da Amazônia, onde a cobiça estrangeira cada vez mais estende seus tentáculos.

Do seus documentos, imagens e de sua experiência como Comandante Militar da Amazônia por 5 anos, contam opiniões manifestadas por vários "donos do mundo" que passaram pelas nações mais ricas da Terra sobre a posse da Amazônia pelo Brasil.

Vejamos tais declarações dos "donos do mundo":

Margareth Thatcher, primeira ministra do Reino Unido (Inglaterra) em 1983:

"Se os países subdesenvolvidos não conseguem pagar suas dividas externas, que vendam suas riquezas, seus territórios e suas fábricas."

John Major, Primeiro ministro sucessor de Thatcher, líder do Partido Conservador inglês, em 1992:

" As nações desenvolvidas devem estender o domínio da lei ao que é comum de todos no mundo. As campanhas ecológicas sobre a região amazônica estão deixando a fase propagandista para dar inicio a uma fase operativa, que pode definitivamente engajar intervenções militares sobre a região."

François Mitterrand, primeiro socialista presidente da França em 1989:

"O Brasil precisa aceitar uma soberania relativa sobre a Amazônia".

Mikhail Gobachev, estadista que liderou o fim do regime comunista e a volta do mundo socialista à economia de mercado:

"O Brasil deve delegar parte de seus direitos sobre a Amazônia aos organismos internacionais competentes."

Patrice Hugles, chefe do órgão central de informações das Forças Armadas Americanas:

"Caso o Brasil resolva fazer um uso da Amazônia que ponha risco o meio ambiente nos

Estados Unidos, temos de estar prontos para interromper esse processo imediatamente".

Al Gore, vice presidente Americano:

"A Amazônia não é dos brasileiros".

A CIA - Agência de Investigação Criminal Americana - Está na Região desde 1996

A opinião dos Estados Unidos pode ser encontrada nesta fala de Henry Kissinger, diplomata que foi assessor da Casa Branca e secretário de Estado, prêmio Nobel da Paz em 1973:

"Os paises industrializados não poderão viver da maneira como existiram até hoje se não tiverem à sua disposição os recursos naturais não renováveis do planeta. Terão que montar um sistema de pressões $e$ constrangimentos garantidores da consecução de seus direitos".

Em 1996, Madaleine Albright, secretária de Estado dos Estados Unidos, revelou:

"Atualmente, avançamos em uma ampla gama de políticas, negociações, e tratados, em colaboração com programas da ONU, diplomacia bilateral e regional, distribuição de ajuda humanitária aos países necessitados e crescente participação da CIA em atividades de inteligência ambiental"

Ao bom entendedor já está claro que a CIA está na Amazônia, onde as ONGs e tantas outras instituições com rótulos de cientificas e culturais e defensoras do meio ambiente atuam de mil e uma maneiras.

\section{A História Não Deixa Mentir}

No começo do século 20 a então poderosa Alemanha comunicou ao Barão de Rio Branco:

"Seria conveniente que o Brasil não privasse o mundo das riquezas naturais da Amazônia"

A competência desse diplomata brasileiro extraordinário e patriota maior ainda abortou as tentativas de invasões estrangeiras, disfarçadas sob o argumento de que o Brasil não teria condições de explora-la e a humanidade não poderia se privar dde desfrutar da Amazônia.

O Brasil já repeliu a tentativa do Hudson Institute de junta as águas dos maiores rios do mundo para formar o Grande Lago Amazônico.

O Racista notório americano general James Watson Webb, ministro de Washington, elaborou um plano para que a Amazônia fosse destinada aos negros norte-americanos, evitando que se repetissem as condições sócioeconômicas que levaram o pais à Guerra de Secessão. 
A companhia Amazon River Corporation tinha a finalidade de colonizar a Amazônia.

No principio do século 20, o Presidente Epitácio Pessoa ouviu, estarrecido, em Genebra a proposição do presidente americano Wilson um plano de Internacionlização da Amazônia.

No Japão vicejou a tese de que filhos de soldados americanos com japonesas durante a $2^{\text {a }}$ guerra mundial deveriam ser mandados para a Amazônia.

O presidente Eurico Gaspar Dutra rechaçou as propostas norte americanas de enviar para a Amazônia excedentes populacionais de Porto Rico e 200 mil refugiados árabe da palestina.

O general Juarez Távora denunciou as escandalosas concessões pretendidas pela Amazon Corporation of Delaware e a The CnadianAmazon Corporation Co. de extrair as riquezas nacionais amazônicas.

Em 1993 o ex presidente José Sarney denunciava a concentração de tropas norte americanas na Guiana, no Suriname e na Venezuela. Hoje, é público e notória a presença de militares dos EUA no Equador, Peru, Paraguai e na Colômbia, a título de combater o narcotráfico e a guerrilha.

É um cinturão de 20 bases que se encomprida e se alarga, fechando o cerco.

E quem pensa que essa ambição internacional é típica dos governo, da qual estão isentas as instituições que afirmam agir na Terra em nome dos Céus, oferecemos mais um quadro, o Conselho Mundial de Igrejas Cristãs, que em 1981, manifestou o seguinte em Genebra:

"A Amazônia é u patrimônio da humanidade. A posse dessa área pelo Brasil, Venezuela, Equador e Colômbia, é meramente circunstancial".

Pior do isso só o cartão muitas vezes encontrado até em forma de guardanapo de papel em restaurantes em Londres, cuja tradução do inglês é esta:

"Lute pela floresta. Torre um brasileiro."

Conclusão

Diante do quadro que acabamos de colocar a disposição de qualquer um cidadão brasileiro para refletir sobre a verdade que ocorre na questão da ocupação da Amazônia, ficamos estarrecidos com a reportagem que saiu no DM.

Como educador e biólogo não posso de a partir de agora levar aos meus alunos esta questão para refletirem sobre a soberania nacional.

Também gostaria de deixar bem claro que este tipo de matéria deveria estar em destaque em todos meios de comunicação para o livre pensar de cada cidadão sobre a nossa riqueza que está na Amazônia.

Assim sendo, espero que um dia não só os educadores que tiverem acesso a este documento, mas que os verdadeiros políticos que honram este País, possam ter mais vontade política de acabar com essa idéia de ocupação, desenfreada da Amazônia e que esses inescrupulosos "donos do mundo" possam estar mais preocupados em fazer uma política mais humana, sustentável e também estar preocupados com a melhoria da qualidade de vida de cada habitante deste planeta..

Neivaldo Lúcio Rosa de Oliveira

é educador e biólogo. Atua nas escolas públicas da rede oficial de ensino municipal e estadual em

Goiânia/Goiás.

Contato: gostaria de saber uma opinião a respeito deste assunto.

neivaldo-oliveira@ig.com.br

\section{ANEXO 17 - América sitiada.}

Fonte: http://www.social.org.br/artigos/artigo001.htm -

Acessado no dia 03/11/2006.

\section{AMÉRICA SITIADA}

Encontro hemisférico reúne representantes de 27 países que se posicionam oficialmente contra a política hegemônica militarista dos Estados Unidos

Por Maria Luisa Mendonça, de San Cristóbal de las Casas (México)

O I Encontro Hemisférico Contra a Militarização reuniu mais de 900 representantes de 215 organizações sociais, entre os dias 6 e 9 de maio, em San Cristóbal de las Casas, México. Participaram organizações de Honduras, Guatemala, Costa Rica, El Salvador, Nicarágua, Haití, Porto Rico, Panamá, Cuba, Peru, Equador, República Dominicana, Brasil, Bolivia, Chile, Argentina, Colômbia, Canadá, Estados Unidos, Itália, Inglaterra, Espanha, França, Grécia, Filipinas, Palestina e Nigéria.

O tema principal do Encontro foi o poderio econômico e militar dos Estados Unidos e seu desrespeito a tratados internacionais, como a Convenção sobre Armas Biológicas, o Tratado sobre Mísseis Antibalísticos, a 
Convenção da ONU sobre Tortura e o Tratado Contra Testes Nucleares, além de ignorar completamente o direito internacional com seu conceito de "guerra preventiva".

A professora Ana Esther Ceceña, da Universidade Nacional do México, observou que, após os atentados de 11 de setembro, o governo dos Estados Unidos "procurou criar um consenso sobre sua superioridade", com o objetivo de "asegurar acesso incondicional ‘a recursos naturais estratégicos". Esse controle inclui território e monopólio do espaço aéreo, através do desenvolvimento de tecnologia espacial e de comunicação.

Especialistas mostraram claramente que as intervenções militares estadunidenses estão diretamente ligadas a interesses econômicos e ao controle de recursos naturais, principalmente petróleo, água e biodiversidade. $\mathrm{Na}$ América Latina, as bases e as ocupações militares estão situadas principalmente na Amazônia, na região do Plano Puebla Panamá (abrangendo o sul do México e toda a América Central) e no sul do Continente (na região da Tríplice Fronteira e na Terra do Fogo).

\section{BASES MILITARES}

Nos últimos anos, os EUA intensificam sua intervenção na América Latina através da instalação de bases militares como no caso de Manta (Equador), Três Esquinas e Letícia (Colômbia), Iquitos (Peru), Rainha Beatrix (Aruba) e Hato (Curaçao). Essas bases complementam o cerco dos EUA no Continente, que também possui bases militares em Porto Rico (Vieques), Cuba (Guantánamo) e Honduras (Soto de Cano). Os EUA pretendem ainda construir bases militares em El Salvador e na Argentina. No Brasil, o objetivo era controlar a base de Alcântara, mas o governo Lula tem indicado que irá cancelar o acordo de Salvaguardas Tecnológicas com os Estados Unidos.

O acordo estabelece diversas obrigações para o Brasil e nenhuma para os Estados Unidos, além de ferir a soberania nacional em diversos aspectos. Por exemplo, Os EUA poderiam delimitar áreas restritas, onde só haveria acesso livre para oficiais norte-americanos; o governo brasileiro seria proibido de verificar o conteúdo dos materiais recebidos ou enviados pelos EUA e, em caso de acidente, o governo brasileiro não poderia inspecionar o material recolhido. Mas a questão fundamental em relação ao acordo diz respeito a tentativa de expansão do controle militar dos Estados Unidos na região amazônica.

\section{PLANO COLÔMBIA}

O economista colombiano Hector Mondragón explicou que, em preparação para o Plano Colômbia, o governo concedeu contratos de exploração de petróleo a empresas norte-americanas em grandes reservas, como na região de Putumayo, que hoje é controlada por grupos paramilitares. Ele denunciou os interesses de empresas multinacionais no Plano Colômbia, como no caso da Phillip Morris, que hoje controla a produção de café no país. As políticas de "livre comercio" e a destruição do Pacto Mundial do Café, imposta pelos EUA, destruiram a agricultura colombiana, estimulando a plantação da folha de coca.

Essas políticas têm gerado um forte movimento contra o governo de Alvaro Uribe. Esse ano, as manifestações de 1 de maio levaram cerca de 200 mil manifestantes 'as ruas de Bogotá. As principais reivindicações são trabalho e manutenção de direitos. A dívida externa colombiana consome $82 \%$ dos impostos arrecadados, os quais tiveram um grande aumento com a reforma tributária que criou o "imposto de guerra". Portanto, o caso colombiano torna evidente a ligação entre políticas neoliberais e processos de militarização.

Em Aruba e Curaçao, as bases militares são utilizadas para garantir que a Shell mantenha a exploração de grandes reservas de petróleo. No México, os EUA pretendem forçar a privatização da indústria petrolera, como condição para aprovar um tratado migratório com os mexicanos.

\section{REPRESSÃO NOS ESTADOS UNIDOS}

O Encontro Continental Contra a Militarização contou com a presença de muitos militantes estadunidenses que denunciaram a repressão em seu país. Ted Lewis, da Global Exchange, citou como exemplo a aprovação do "Tratado Patriótico", uma lei que permite a prisão de imigrantes sem justificativa e sem direito `a defesa jurídica. Essa lei, com cerca de 1200 páginas, foi aprovada poucos dias após os atentados de 11 de setembro-o que indica que ela já exitia e que o governo Bush só estava esperando um bom pretexto para colocá-la em prática. Ele lembrou ainda que o governo proibiu que a população de Nova Yorque se manifestasse contra a guerra no Iraque. Apesar disso, cerca de 200 mil pessoas saíram às ruas daquela cidade, nos históricos protestos de 15 de fevereiro.

Representantes da organização School of the Americas Watch, que lutam pelo fechamento da Escola das Américas, denunciaram a repressão da polícia contra manifestantes. Somente esse ano, 86 pessoas foram presas por protestar contra o treinamento de militares latino-americanos na chamada "Escola dos Assassinos". Desde o período das ditaduras militares na América Latina, essa instituição treinou cerca de 80.000 oficiais, especialmente em práticas de tortura, espionagem e repressão a movimentos políticos e sociais.

A cerimônia de encerramento incluiu uma palestra de Adolfo Perez Esquivel, militante argentino que recebeu o Prêmio Nobel da Paz em 1980. Para ele, a dominação cultural é tão perigosa quanto o domínio militar, pois 
assegura a hegemonia do pensamento único, fazendo com que "povos se tornem mercados, cidadãos se tornem consumidores e relações humanas se tornem competições mercantis".

Ele prestou homenagem ao Bispo Samuel Ruiz, que teve um papel muito importante na defesa das reivindicações do movimento Zapatista, como exemplo de "compromisso, carinho, resistência, luz e esperança". E lembrou as inúmeras "guerras silenciosas", como no caso das 35 mil crianças que, a cada dia, morrem de fome no mundo, em conseqüência da pobreza e da desigualdade social. Durante o Encontro, Adolfo Perez Esquivel concedeu uma entrevista exclusiva 'a Sem Fronteiras:

\section{SF: Por que esse Encontro é importante?}

É a primeira oportunidade de refletirmos juntos sobre a militarização na América Latina. Não é um caso isolado, mas uma etapa das políticas hegemônicas dos Estados Unidos, com suas vertentes econômicas, políticas e culturais, que inclui a ALCA, a dívida externa e também o controle dos governos através do FMI e do Banco Mundial. Essa estratégia prevê que os conflitos sociais devem aumentar. Portanto, em um cenário de guerra, os inimigos são as organizações sociais. É uma continuação do que foi a Doutrina da Segurança Nacional, que não desapareceu. Hoje o inimigo é o próprio povo, através da guerra contra o narcotráfico e contra a subversão. Essa reunião é importante para trocarmos experiências e construirmos políticas conjuntas.

\section{SF: Qual a relação entre militarização e neoliberalismo?}

As empresas norte-americanas se beneficiam das políticas hegemônicas dos Estados Unidos para anexar as economias e as indústrias latino-americanas, assim como para controlar recursos naturais. Isso requer a repressão social na América Latina, como no caso das Operações Cabañas na Argentina, onde militares estadunidenses treinaram soldados latino-americanos. O objetivo é manter as Forças Armadas latino-americanas subordinadas aos Estados Unidos, o que significa a perda da soberania e a recolonização.

SF: Como esse processo de militarização acontece na Argentina?

A Argentina possui grandes recursos energéticos, minas de ouro e biodiversidade. Uma base norte-americana na Argentina pode garantir o controle total do Continente, do México 'a Terra do Fogo. Além do Canal do Panamá, os Estados Unidos têm interesse em controlar o Estreito de Magalhães. Os grandes eixos dessa estratégia são o Plano Colômbia, Plano Puebla Panamá, a Tríplice Fronteira e a região da Patagônia. A base de Manta no Equador, uma das maiores da região, serve ao Plano Colômbia mas também ao controle hemisférico. Se os Estados Unidos conseguirem envolver outros países no conflito da Colômbia, significaria um outro Vietnã, com conseqüências imprevisíveis. A pressão dos Estados Unidos para derrubar o governo de Hugo Chavez na Venezuela também faz parte dessa estratégia.

\section{SF: Como o Sr. vê o papel dos governos latino-americanos?}

O domínio dos Estados Unidos não seria possível sem a cumplicidade de nossos governos. Eles abrem a porta para que venham nos saquear. Originalmente, as Forças Armadas tinham como objetivo a libertação dos povos. Hoje elas reprimem seu próprio povo. Infelizmente, somente os Estados Unidos têm hoje um projeto para a América Latina.

SF: Em que base deveríamos construir a unidade da América Latina?

É preciso mudar o conceito de desenvolvimento. Os povos indígenas não falam em desenvolvimento e sim em "equilíbrio" com o planeta. A dominação começa pela via cultural, não pela economia. É preciso gerar novos espaços políticos de participação, de controle social—o que significa uma verdadeira democracia. Se o povo é soberano e delega seu mandato, os governantes devem cumpri-lo.

SF: Que mensagem o Sr. enviaria ao presidente Lula?

Conheço o companheiro Lula desde o tempo em que ele era dirigente sindical. O PT ainda não existia. Hoje, eu diria que 'as vezes as heranças são pesadas, mas espero que Lula não se esqueça da participação popular e da consciência crítica em seu governo. Ele deve garantir a unidade regional e construir novos espaços de liberdade.

\section{ANEXO 18 - "Cinturão militar" em volta do Brasil.}

Fonte: http://www.radiobras.gov.br/materia_i_2004.php?materia=253250\&editoria= Acessado no dia 03/11/2006.

\section{Brasil Agora}

(C) Agência Brasil - Todas as matérias poderão ser reproduzidas desde que citada a fonte Professor Moniz Bandeira diz que EUA têm "cinturão militar" em volta do Brasil

\section{8:02}

André Deak e Bianca Paiva

Da Agência Brasil 
Brasília - Há mais de 50 anos o professor Luiz Alberto Moniz Bandeira tem como objeto de estudo os Estados Unidos da América. Em entrevista à Agência Brasil, ele fala sobre os "cerca de 6.300 militares americanos [que] estiveram baseados ou realizaram operações na região da Amazônia entre 2001 e 2002", conforme revela no livro Formação do Império Americano. Da guerra contra a Espanha à guerra do Iraque.

Leia, abaixo, a entrevista concedida no escritório de seu amigo, o secretário-geral do Ministério de Relações Exteriores, Samuel Pinheiro Guimarães.

Agência Brasil: O que o senhor diz da presença dos Estados Unidos na América do Sul?

Moniz Bandeira: Os Estados Unidos estão realmente criando, já há muitos anos, um cinturão em volta do Brasil.

ABr: De bases militares?

Moniz Bandeira: De bases militares sim. Base de Manta, no Equador, e outras, no Peru, na Bolívia. Algumas são permanentes, outras são para ocupação ocasional. Como essa do Paraguai, que não é propriamente uma base: eles têm uma pista construída desde a década de 80, maior do que a pista do Galeão (no Rio de Janeiro, a maior pista de pouso do Brasil, com 4.240 metros de extensão). Agora a notícia é de terão 400 soldados (norteamericanos, no Paraguai). Fazem exercícios conjuntos, juntam grupos para fazer exercícios perto da fronteira do Brasil ou em outros pontos. O mais curioso nisso tudo, e aí sim levanta muita suspeita: primeiro, a concessão de imunidade aos soldados americanos; segundo, a visita de Donald Rumsfeld (secretário de Defesa dos EUA) a Assunção, capital do país; terceiro, o fato de que Dick Cheney (vice-presidente norte-americano) recebeu nos Estados Unidos o presidente do Paraguai. O que representa o Paraguai para os Estados Unidos? Isso é só uma forma de perturbar o Mercosul.

ABr: Analistas dizem que hoje o Paraguai cumpre a função de aliado dos EUA, que um dia cumpriu a Argentina, com o presidente Carlos Menem, e depois o Uruguai, com Jorge Battle.

Moniz Bandeira: É o que eles tentam, primeiro a Argentina de Menen, depois o Uruguai de Battle, agora querem manipular o Paraguai. É uma situação delicada. O Paraguai não tem peso. Inclusive, se o Brasil fiscalizar a fronteira, acaba o Paraguai, porque a maior parte das exportações do Paraguai é contrabando para o Brasil. O Paraguai, oficialmente, destina ao Brasil mais de $30 \%$ de suas exportações. Se considerar o contrabando, sobe para mais de $60 \%$. E mesmo para exportar para outros países depende substancialmente do Brasil, dos corredores de exportação que levam para os portos de Santos, Paranaguá e Rio Grande. O Paraguai é um país com muitas dificuldades, se superestima, e não cai na realidade. Cada país tem que ver suas limitações, relações reais de poder. O Paraguai é inviável sem o Brasil e a Argentina. A Argentina está solidária com o Brasil, não tem interesse no Paraguai como instrumento dos Estados Unidos para ferir o Mercosul.

ABr: Onde estão, especificamente, os militares norte-americanos que formam esse "cinturão" ao redor do Brasil?

Moniz Bandeira: Eles se estendem desde a Guiana, passam pela Colômbia... Sobretudo não são militares fardados, mas empresas militares privadas, que executam uma série de serviços terceirizados para os Estados Unidos. O Pentágono está terceirizando a guerra. Eles criaram, já há algum tempo, desde o início dos anos 90 as Military Company Corporations [Companhias Militares Privadas, em inglês], que executam os serviços militares justamente para fugir às restrições impostas pelo Congresso americano. Pilotam aviões no Iraque, por exemplo. As companhias militares privadas estão fazendo tudo, até torturando. Com isso, escamoteiam as restrições impostas.

ABr: Existem também operações secretas?

Moniz Bandeira: Sim, mas isso é outra coisa. Sabemos dessas informações. Se você ler os jornais, verá, às vezes, que foi interceptado um avião americano no Brasil que voava da Bolívia para o Paraguai clandestinamente. Essas informações estão espalhadas em vários lugares.

ABr: Qual a razão desses militares norte-americanos na América do Sul?

Moniz Bandeira: Diversos fatores. As bases permitem a manutenção de grandes orçamentos para o Pentágono. Por causa da indústria bélica, do complexo industrial militar nos EUA, eles precisam gastar seus equipamentos militares para novas encomendas. É um círculo vicioso. E qual é o mercado para o consumo dos armamentos? A guerra. Os EUA têm interesse na guerra porque a sua economia depende em larga medida do complexo bélico, para inclusive manter empregos. Há certas regiões dos EUA dominadas totalmente pelo interesse dessas indústrias. Há uma simbiose entre o estado e a indústria bélica. $\mathrm{O}$ estado financia a indústria bélica e a indústria bélica necessita do estado para dar vazão aos seus armamentos e a sua produção.

ABr: Existe alguma razão estratégica do ponto de vista dos recursos naturais?

Moniz Bandeira: Os países andinos são responsáveis por mais de $25 \%$ do petróleo consumido nos Estados Unidos. Só a Venezuela é responsável por cerca 15\% desse consumo. De um lado querem derrubar o (presidente 
venezuelano Hugo) Chávez, de outro sabem que uma guerra civil ali levaria o preço do petróleo a mais de US\$ 200 o barril.

ANEXO 19 - Militares planejam defesa da Amazônia. 05 de maio de 2002.

Fonte: http://www.oliberal.com.br/arquivo/notícia/painel/n05052002index2.htm

\begin{tabular}{|c|c|}
\hline $\begin{array}{l}\text { Nicaragua } \\
\text { Costa/ } \\
\text { Rica } \\
\text { Ecunama }\end{array}$ & $\begin{array}{l}\text { Diante da nova agressividade do } \\
\text { imperialismo, especialmente após a } \\
\text { eleição de Bush, as Forças Armadas do } \\
\text { Brasil estão a adotar procedimentos } \\
\text { preventivos para o caso de haver uma } \\
\text { intervenção militar estrangeira na } \\
\text { Amazônia. A preocupação com a } \\
\text { defesa da Amazônia permeia toda a } \\
\text { instituição militar brasileira, inclusive } \\
\text { entre oficiais de formação } \\
\text { conservadora. A possibilidade de "uma } \\
\text { potência tecnologicamente superior" } \\
\text { (sic) tentar a ocupação militar da } \\
\text { Amazónia é levada muito a sério. }\end{array}$ \\
\hline $\begin{array}{l}\text { Hoje há consenso de que a defesa da região e do } \\
\text { povo brasileiro. Assim, o Exército, a Marinha e a } \\
\text { militar na fronteira da Amazónia brasileira (P } \\
\text { começam a pôr em prática uma estratégia de } \\
\text { sociedade civil. Com esse objectivo foram rea } \\
\text { "Estratégia de Resistência e Mobilização da Vont } \\
\text { Boa Vista e em Manaus. O terceiro simpósio se } \\
\text { desses simpósios representantes da sociedade civil } \\
\text { Comandante Militar da Amazónia, Gen. Valdésio } \\
\text { A entrevista abaixo foi concedida pelo Gen. İtal } \\
\text { Militar, ao jornal "O Liberal" . As suas declar } \\
\text { mostram o nível de consciência já adquirido pe } \\
\text { latentes que pesam sobre a região amazónica. As } \\
\text { Frank Siqueira, daquele jornal (manteve-se a orto } \\
\text { Resistir.info }\end{array}$ & $\begin{array}{l}\text { cabe não só aos militares como a todo o } \\
\text { náutica procuram fortalecer a presença } \\
\text { cto Calha Norte) e, ao mesmo tempo, } \\
\text { stência que envolve a participação da } \\
\text { os recentemente dois simpósios sobre } \\
\text { Vacional em Defesa da Amazônia" , em } \\
\text { entro em breve, em Belém. Participam } \\
\text { ciais generais das três armas, inclusive o } \\
\text { herme de Figueiredo. } \\
\text { ortes Avena, Comandante da } 8^{\text {a Região }} \\
\text { s são extremamente interessantes. Elas } \\
\text { nilitares brasileiros quanto às ameaças } \\
\text { guntas foram formuladas pelo repórter } \\
\text { la brasileira). }\end{array}$ \\
\hline
\end{tabular}

Qual é a visão que o comando militar do país tem hoje sobre as ações em defesa da Amazônia e da soberania nacional sobre a região, em caso de agressão externa?

O principal enfoque que nós vamos dar à questão da defesa da Amazônia, inclusive no simpósio que vamos realizar em Belém, é o de que a defesa não se restringe apenas à atuação das Forças Armadas. A atuação das Forças Armadas é fundamental, obviamente, mas é preciso haver também o que nós chamamos de uma vontade nacional, principalmente por parte dos amazônidas, na defesa deste riquíssimo território. Então, esta é a nossa visão, a visão de um trabalho conjunto em que toda a sociedade brasileira deverá estar irmanada na consecução dos seus objetivos. A Amazônia pode ser considerada uma região ímpar no mundo, já que abriga extensas áreas de floresta, enormes riquezas minerais, a mais rica biodiversidade do planeta e as maiores reservas de água doce, um bem estratégico de valor econômico que vai se tornando dramaticamente escasso.

Dentre todos esses bens, bens é possível distinguir quais aqueles que mais despertam a cobiça internacional?

Você citou praticamente tudo que pode despertar e realmente desperta a cobiça internacional sobre a Amazônia. Disso não há dúvida alguma, e nós não podemos tapar os ouvidos ou simplesmente fechar os olhos em relação ao que ocorre no mundo. Mas também é preciso salientar que, por enquanto, não existe nenhuma ameaça concreta, não existe uma ameaça de governo. O que existe são apenas algumas manifestações, boatos que surgem na imprensa e que vêm sendo insistentemente difundidos pela internet. A rigor, porém, repito que não existe nenhuma ameaça concreta.

Considerando, entretanto, a possibilidade de uma agressão, nós temos que estar preparados para a defesa e por isso estamos trabalhando nessa estratégia. Trata-se, como eu já disse, de uma estratégia que envolve não só os militares, mas toda a sociedade brasileira, principalmente os que estão aqui na Amazônia, e nós estamos 
difundindo isso para que todos tomem conhecimento, passem a se preocupar e que assim possa haver o fortalecimento da vontade nacional em relação à defesa do nosso território.

Esse sentimento em defesa da Amazônia deve ter um cunho regionalista ou o senhor acredita que ele possa resultar numa tomada ampla de consciência de toda a sociedade brasileira, em defesa não apenas de uma região específica, mas da própria nação e de sua soberania?

Sem dúvida alguma este será um sentimento de todos os brasileiros. A Amazônia é um patrimônio do Brasil, um patrimônio da nação brasileira. Então essa preocupação não pode se restringir apenas a quem mora aqui. Tem que ser de todos nós.

Na hipótese de uma agressão externa os militares obviamente estarão à frente das ações bélicas de defesa. Sendo assim, de que forma poderá ser útil o envolvimento nessas ações também por parte da sociedade civil? A presença dos civis será importante?

É muito importante esta pergunta porque a estratégia nossa, digamos assim, frente a uma potência tecnologicamente superior, ela não pode ser de enfrentamento direto. Ela tem que ser uma estratégia como foi feita lá no Vietnam, recentemente, ou como aconteceu no tempo dos Guararapes, pelos próprios brasileiros, enfrentando um inimigo potencialmente superior. Na hipótese de uma agressão, nós estaremos num terreno nosso, e nós somos donos desse terreno, nós conhecemos perfeitamente esse terreno e somos imbatíveis nesse terreno. Mas, de qualquer maneira, não poderá haver um confronto direto. Será um confronto em que nós estaremos lutando de maneira invisível, atuando em todos os pontos, fazendo com que o inimigo fique inquieto o tempo todo. Eles não vão ter paz enquanto estiverem aqui dentro do nosso território. E, para isso, é fundamental o apoio da população, porque nós temos que receber provisões, nós temos que receber esse apoio logístico da população, e a população tem que nos apoiar, tem que nos ajudar, tem que estar conosco.

O comando militar pretende levar também para o interior essa mobilização da vontade nacional para a estratégia de resistência ou esse trabalho ficará restrito às capitais?

Por enquanto nós estamos fazendo nas grandes capitais da Amazônia. A idéia, porém, é que esse simpósio venha a ser feito também em capitais de outros Estados de fora da Amazônia. Entretanto, temos a convicção de que, sem nenhuma dúvida, o nosso interior da Amazônia será alcançado pelas idéias que surgirem. Nós estamos convidando os prefeitos, nós estamos convidando autoridades do interior do Estado e pretendemos também ir ao interior do Estado para difundir as nossas idéias. Isso é para nós é fundamental.

Como fica a questão indígena na estratégia de defesa da região?

O índio é brasileiro, o índio é um grupo étnico que faz parte dessa miscelânea étnica que nós temos no nosso país. Então nós consideramos o índio como brasileiro, ele faz parte do nosso povo. Aliás, há mesmo a tradição de uma ligação muito estreita das Forças Armadas, principalmente do Exército, com os índios, com o nosso índio, e nós não vemos de forma alguma o índio como uma ameaça. Nós temos inclusive trânsito livre em todas as reservas indígenas. Como bom brasileiro, o índio é nosso aliado, e jamais uma ameaça.

Mas é inegável que muitas organizações estrangeiras procuram se aproximar das comunidades indígenas da Amazônia, chegando mesmo ao ponto de defender aqui o que elas chamam de "nações indígenas". Isso não preocupa os militares?

Nós temos que, dentro desse processo de fortalecimento da vontade nacional, a primeira coisa é não admitir que se chame de nações indígenas. Não podemos admitir isso de forma alguma. Como eu já disse, nós temos que cada vez mais acreditar que, por mais que eles tentem, eles jamais vão poder mudar a cabeça do nosso índio.

E com relação às ONGs, as estrangeiras sobretudo, que agem dentro da Amazônia: elas chegam a causar preocupação? Os militares fazem algum tipo de acompanhamento e vigilância sobre essas organizações?

Isso deve ser uma preocupação maior de toda a nação brasileira, do governo brasileiro. O governo brasileiro tem uma política para as organizações não governamentais, então nós não podemos interferir nessa política. Logicamente que exercemos o acompanhamento de algumas ações - o que aliás é de conhecimento geral -, mas até hoje nada há de grande vulto que possa nos preocupar. As Forças Armadas dispõem na região de recursos humanos, materiais e tecnológicos suficientes para fazer frente a uma eventual agressão externa?

Eu falei, no início, que a nossa estratégia é voltada exatamente para a nossa atuação num terreno nosso, num terreno que nós conhecemos muito bem. Então, o nosso equipamento e o armamento que temos são adequados para esse tipo de combate aqui na Amazônia. Nós continuamos estudando e aperfeiçoando, não só as nossas táticas da estratégia de resistência, como também testando equipamentos, testando apoio logístico, alimentação, os meios de transporte. Nós estamos trabalhando nisso e consideramos que dentro do nosso terreno ninguém o conhece melhor do que nós. E mais: temos perfeita noção disso e a certeza absoluta de que aqui dentro nós somos imbatíveis. 
Além da cobiça de potências estrangeiras, a Amazônia convive com outras situações de risco, como o narcotráfico e a presença de grupos guerrilheiros ativos em países vizinhos da nossa fronteira ocidental. Há algum plano para fortalecer ainda mais a presença militar nas fronteiras da Amazônia?

O Exército sempre se preocupou. Historicamente, o Exército teve e continua tendo uma presença efetiva aqui na Amazônia, embora devamos admitir que, ultimamente, a Amazônia tem sido de fato a nossa prioridade maior. Nós estamos deslocando continuamente tropas para cá, nós estamos mobiliando a fronteira, dentro do Projeto Calha Norte, e já foram implantados inúmeros pelotões de fronteira. Nós temos já cerca de vinte pelotões de fronteira implantados em toda a área, e logicamente as nossas ações fronteiriças são executadas de acordo com a política do governo brasileiro. Nós estamos agindo de acordo com as determinações do presidente da República, que é o nosso comandante maior, e de acordo com as diretrizes emanadas do Ministério Defesa e do comando do Exército.

Que papel vai desenvolver na estratégia de defesa da região o Sistema de Vigilância da Amazônia, o Sivam?

O Sipam, que é o Sistema de Proteção da Amazônia, e do qual o Sivam é parte muito importante, como sistema de vigilância, ele é fundamental, porque ele destina-se exatamente a detectar todos esses focos que surgirem. Na parte de informações, por exemplo, ele vai nos dar uma capacidade muito grande de saber em tempo real tudo o que está acontecendo na Região Amazônica. Então, para nós esse é um projeto fundamental.

Publicado em O Liberal , jornal de Belém do Pará, Brasil, edição 05/Mai/02.

ANEXO 20 - Governo cria brigada em área ameaçada pelas Farc: mais 2.500 homens fiscalizarão fronteira com a Colômbia.

ANEXO 21 - Fronteira com a Colômbia terá reforço militar.

ANEXO 22 - Exército manda mais 3 mil homens à Amazônia em 2004.

ANEXO 23 - 'Economist': Brasil quer minar domínio dos EUA.

NEXO 24 - Operação Colbra. Manobra marca estréia dos Super tucanos na defesa aérea. Brasil e Colômbia farão ação conjunta.

ANEXO 25 - Milicos na Amazônia: Brasil se reafirma por mais peso na América Latina, diz "El País".

ANEXO 26 - Índias movem 157 ações contra soldados.

ANEXO 27 - Militares do Exército são acusados de agredir índios.

ANEXO 28 - Indígenas del Vaupés fortalecen sus procesos organizativos.

Indígenas del Vaupés fortalecen sus procesos organizativos

http://colombia.indymedia.org/news/2005/04/23810.php

Bogota - Colombia

Junio 13 de 2003

Christian Díaz

Redactor Actualidad Étnica

Foto Hemera

Con sus $65.268 \mathrm{Km} 2$ de selva, el departamento de Vaupés, nororiente colombiano, cuenta con una gran riqueza cultural, plasmada en la diversidad étnica de una región que deslumbra por su exuberancia y exotismo. Aproximadamente el $90 \%$ de la

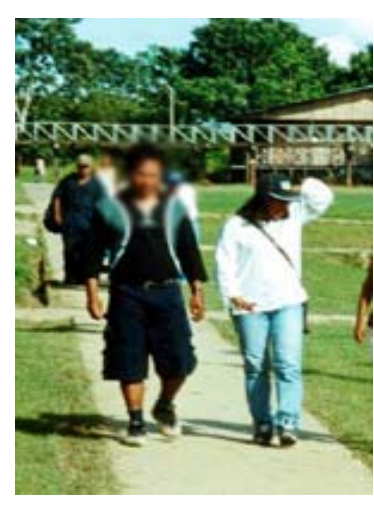
población total es nativa. Sus tierras son bañadas por los ríos Guaviare, Inírida, Guainía, Vaupés y Apaporis, siendo éstos las principales fuentes de subsistencia y transporte para todos sus habitantes.

Su economía está sustentada en la horticultura, acotando que en toda la región del Amazonas se carece de modelos de desarrollo adecuados al contexto sociocultural. Los cultivos siguen el esquema de roza, quema y siembra, en áreas donde predomina el cultivo de yuca, ñame, chontaduro, banano, ají, caimo, aguacate, piña, papaya, calabaza, lulo, marañón, dieta alimenticia que se complementa con actividades de caza, pesca y recolección de frutos silvestres. 
En este departamento, los 23 pueblos indígenas existentes se han organizado a través del Consejo Regional Indígena del Vaupés (CRIVA). Actualidad Étnica entrevisto a Mateo Estrada, indígena Sirano y quien se desempeña como Secretario General de la organización. En su diálogo destacó la gran fortaleza y unidad que las comunidades han construido, pese a los problemas de orden publico que los aquejan.

\section{¿Cuál es el panorama o la realidad que en estos momentos viven las comunidades indígenas del Vaupés?}

En sentido general el Vaupés tiene grandes cosas buenas y también cosas mala. Lo bueno es que los pueblos indígenas hemos logrado la unidad frente al Estado. Somos 23 pueblos, 14 organizaciones, pero hacia fuera sólo estamos representados por el CRIVA. Es una unidad que nosotros hemos logrado mantener a pesar de los diferentes problemas que hay, y eso nos ha servio tanto para defender la institución frente a la guerrilla como frente a todos los entes que afectan en forma negativa los intereses de los pueblos indígenas. Hay cosas negativas también, por ejemplo, no hemos podido superar el proceso organizativo, basado en un sistema antiguo, un sistema parecido al sindical obrero; estamos buscando un nueva forma de organización que responda a la problemática actual. Puede ser un Consejo, un Parlamento indígena, pero estamos en búsqueda de una unidad más grande, para proyectarla y que pueda enfrentar los grandes retos que hay en la actualidad. Eso nos permitiría buscar un nuevo derrotero frente a los actores armados y también frente al narcotráfico. Esto es lo que nosotros pensamos y lo vamos ha hacer. Muy seguramente será el 8 de diciembre, cuando se realice el Congreso de los Pueblos Indígenas del Vaupés en sus 30 años de existencia.

\section{¿Qué procesos se destacan dentro de la organización indígena?}

La unidad y la erradicación voluntaria de cultivos ilícitos sin ayuda nacional o internacional, el cual se realizó entre los años 1982 y 1986. Otro gran logro es el de haber constituido el segundo resguardos indígenas más grande del país, que es el Gran Resguardo Indígena del Vaupés. Otro de los procesos interesantes ha sido el trabajo político electoral; hemos tenido uno de los primeros alcaldes mayores en Mitú, Maximiliano Veloz García (1992) y hemos logrado sostenerla. Nosotros hemos creado un sistema de gobierno a través del CRIVA. El CRIVA es como el gobierno central y las 14 organizaciones restantes son como la parte seccional.

En materia de etnoeducación y salud indígena ¿qué nos puede contar?

En materia de etnoeducación ha sido difícil, no es como en otras partes del país, porque somos 23 pueblos con 23 lenguas distintas, y en este caso no se puede utilizar el bilingüismo, tendría que ser multilinguística, lo que es muy difícil que funcione. En materia de administración educativa, a partir del Congreso anterior (agosto de 2001), estamos planteando al Ministerio de Educación Nacional que se nos entregue la administración del trabajo educativo. En materia de salud ha sido un desastre para nosotros. A nivel nacional, en el Congreso de la ONIC, todos los pueblos dijeron: no a la ley 100 y a las EPS. No obstante, muchas comunidades se acomodaron a la ley y los únicos que quedamos por fuera fuimos nosotros. Hasta el año 2001 nos afiliamos a un sistema, pero hasta la fecha el mismo no ha respondido a las expectativas nuestras, porque solamente responde a las necesidades primarias. Entonces, hemos venido diciendo que a finales de este año nosotros no vamos a firmar los convenios de la Consulta para el Régimen Subsidiado, así la gente tenga que morirse; tendrán que haber sacrificados, pero queremos que la salud y los recursos nos lleguen directamente, y que los beneficios sean para los indígenas. Esto es lo que hemos planteado, y desde la semana pasada, todas las entidades y los indígenas del Vaupés estamos en paro por salud.

\section{¿Cómo son las relaciones de los indígenas del Vaupés con el Gobierno Central?}

El Estado no nos ha puesto ni nos pondrá cuidado, porque nosotros no le interesamos al Estado. En muchos casos hemos manifestado y denunciado la construcción de una carretera por parte de la guerrilla en la parte de Mitú, cuyo objetivo es conectar con el Brasil. Se ha manifestado ese problema y no nos han puesto cuidado, y el problema es que los que están trabajando en esa gran obra son lo propios indígenas, yo diría casi en calidad de esclavos. Nosotros advertimos hace dos años al entonces presidente Andrés Pastrana de que se estaban nuevamente iniciando los cultivos de coca. En la actualidad, se han comenzado a ver grandes sembrados de coca en diferentes partes del Vaupés, son de 10,15, 30 hectáreas y nosotros esperamos que el Gobierno pueda algún día resolver eso. De lo contrario, el único responsable será el presidente, porque él esta advertido, pero en una carta nos respondió diciendo: <<gracias indios por eso >>, y de esto se ha dejado constancia por escrito. 


\section{¿Cuál es el mensaje que Usted quiere dejar a las comunidades?}

Que sigamos en nuestro proceso de construcción de unidad para que de esta forma podamos fortalecernos y poder resistir desde la organización a todos los intereses mezquinos que habitan en la cabeza de algunos. También quisiera manifestar que existen muchas instituciones, ONGs, algunos funcionarios del Estado y ,sobre todo, la cooperación internacional, que han querido trabajar con nuestros pueblos, apoyando y fortaleciendo el trabajo desde las bases, eso es fundamental. Es el reclamo que hago, que estos intentos positivos para fortalecer los pueblos indígenas aterricen desde las bases para fortalecer una nueva propuesta para las regiones y para la atención de los pueblos indígenas de Colombia.

ANEXO 29 - Comunidades indígenas y campesinas del Vaupés confinadas por

combates.

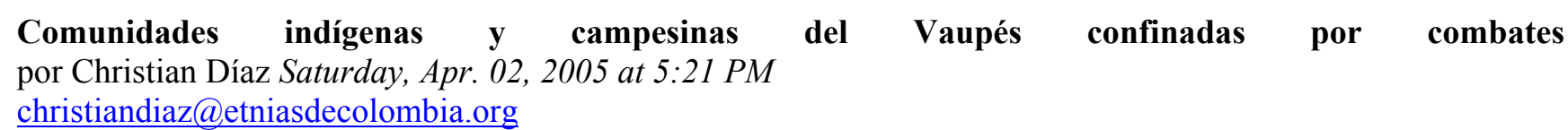

Las comunidades indígenas y organizaciones sociales ubicadas dentro del Gran Resguardo Oriental del departamento de Vaupés, amazonía colombiana, denunciaron que desde el año 2004 se han incrementado las acciones bélicas entre Fuerza Pública y las FARC en sus territorios, además de la siembra indiscriminada de minas antipersonales, agravando aún más la crisis humanitaria por la que atraviesan.

En la región de Mitú y Carurú se encuentran ubicadas 17 comunidades, unas 800 familias de 24 etnias indígenas, además de la población campesina y afrocolombiana.

Tradicionalmente el departamento ha sido controlado por la guerrilla de las FARC, situación que generó vulnerabilidad a los derechos de dichas comunidades. "Pero la presencia de un solo grupo armado era tolerable", sostienen voceros comunitarios.

Sin embargo, de un año para acá, con la llegada de la Fuerza Pública (Ejército y Policía) a la región, -en cumplimiento a la política de "Seguridad Democrática" impulsada por el gobierno del presidente Álvaro Uribe-, se han presentado intensos y reiterados enfrentamientos con las FARC, quedando las comunidades en medio del fuego cruzado.

"El problema se agrava con la siembra indiscriminada de minas antipersonales en nuestros territorios". Esta mortífera estrategia de guerra se implementa para detener el avance de la Fuerza Pública, quedando en riesgo inminente todos los pobladores. "Ya no podemos salir a nuestras chagras a trabajar con seguridad, porque estamos rodeados de muerte". Algunas minas han estallado, aseguran los voceros, sin que hasta el momento hayan víctimas fatales."Pero, cuántas faltan por explotar, cuál de ellas no iremos a pisar", se preguntan Cubeos, Sirianos, Wananos, Desanos, y la comunidad campesina.

Las comunidades, víctimas pacíficas en la guerra, han rechazado la presencia de la Fuerza Pública dentro de los cascos urbanos de Mitú y Carurú, situación que ha puesto en riesgo sus vidas porque los enfrentamientos armados y ataques de las FARC a la Fuerza Pública y la respuesta de éstos, no siempre dan en sus objetivos y se ven involucrados los habitantes, las infraestructuras, colegios, casas, entre otras. "No entendemos cómo la Policía y el Ejército se acantonaron en medio de la población civil, exponiéndonos vitalmente a los enfrentamientos, a la lluvia de cilindros bombas".

La salud, educación, economía, vivienda, todo se ha visto afectado. Los controles de bando y bando a la circulación de alimentos, mercancías, combustibles en ríos, carreteras y municipios son permanentes.

El parte que da la Defensoría del Pueblo Regional asegura que: "Las acciones de la Fuerza Pública para recuperar militarmente el territorio y las restricciones y controles que se han implementado sobre el ingreso, salida y circulación de las personas, la carnetización de la población, el registro de quienes entran o salen del casco urbano de la capital de Mitú, las restricciones y controles a la circulación de bienes y víveres indispensables, y el severo control sobre los combustibles para combatir las actividades relacionadas con el procesamiento de coca, han resentido el control social que venía ejerciendo las FARC en la región".

Las LLUVIAS DE GLIFOSATO también llegaron con la Fuerza Pública. Los cultivos, los ríos, los animales, las cosechas han sido fumigadas. La salud de las comunidades se deteriora con el avance de a estrategia gubernamental de recuperar ese territorio del país, frontera con Brasil.

"Sin embargo, el Estado nos mantiene abandonados con proyectos de desarrollo social. Estamos apartados y olvidados de la inversión gubernamental, pero si quieren llegar con más violencia tratando de conseguir una seguridad democrática". 
Para la Defensoría Regional: "La situación que viven las comunidades indígenas y no indígenas que habitan el departamento del Vaupés podría definirse como un "confinamiento forzado" tanto por efectos del conflicto que les impide atender sus labores agrícolas por el minado de las áreas rurales, como también por el aislamiento a que históricamente han estado respecto al desarrollo económico, social y político del país, situación especialmente evidenciada en la carencia absoluta de vías de comunicación terrestre que permitan la comunicación de esta región con el centro del país o con los diferentes polos de desarrollo económicos del mismo. La situación de confinamiento se ve agravada por el encarecimiento (hasta de más del cien por ciento) en los alimentos y artículos de primera necesidad dados los altos costos que implica su trasporte por vía aérea.

Esta alarmante situación ha sido denunciada pero muy poco escuchada. Por eso, las comunidades y autoridades tradicionales de la región quieren hacer visible esta problemática, generar estrategias de cambio y comprometer al gobierno nacional en la verdadera seguridad y desarrollo para el departamento.

Para esto, han programado para el próximo mes de junio, un Encuentro regional étnico: "Por la recuperación del Territorio Tradicional y la reactivación socioeconómica", que permita voltear los ojos de la comunidad nacional e internacional, a esta apartada y olvidada región inmersa en la selva amazónica colombiana.

Copyright $($ C Fundación Hemera

\title{
ANEXO 30 - Do outro lado da fronteira: El Camino de las Entidades Territoriales Indígenas (ETI's) em la Amazonía Colombiana.
}

\section{GOVERNANÇA: EL CAMINO DE LAS ENTIDADES TERRITORIALES INDÍGENAS (ETI's) EN LA AMAZONÍA COLOMBIANA}

\author{
Autores: Maria Camila Rivera; Silvia Gómez
}

Fonte: Povos Indigenas no Brasil 2001-2005, p. 254-256 - Instituto Socioambiental.

\begin{abstract}
COM A CONSTITUIÇÃO DE 1991, OS POVOS INDÍGENAS DA COLÔMBIA ENCONTRARAM CONDIÇÕES PARA SE ORGANIZAR E GERIR SEUS TERRITÓRIOS
\end{abstract}

La Carta Política de 1991 es uma apuesta democrática por reinventar las formas de articulación de diversos grupos poblacionales al Estado y la sociedad mayor, de modo que se establezcan relacione más inclusivas, equitativas y respetuosas de las diferencias. Muestra de ello es que hoy nos definamos como una nación pluriétnica, multicultural y territorialmente diversa, alejada de las consideraciones homogenizantes y univocas del discurso de nación que nos acompañó más de un siglo (desde la C. P. de 1886): una sola raza (la mestiza en proyección a lo blanco), lengua (español) y Dios (Católico).

Dajo la nueva perspectiva constitucional se intenta transformar la organización política, social, económica y administrativa del país, a partir del otorgamiento de derechos colectivos, políticos, sociales, culturales y territoriales a los grupos étnicos. Para el caso indígenas encontramos, entre otros, el reconocimiento de los resguardos como propiedad colectiva de las comunidades indígenas con carácter inalienable, imprescritible e inembargable; la creación de la Circunscripción especial Indígena del Congreso de la República (encargada de brindar 2 curules en Senado y 1 en Cámara) y la Jurisdicción especial Indígena (derecho a administrar justicia en sus territorios conforme a sus usos y costumbres); y, la posibilidad de crear Entidades Territoriales Indígenas - ETI's.

Las ETI's son una figura político administrativa que reconoce a los indígenas del gobierno de sus territorios por parte de sus autoridades, y a su vez, les permite definir jurisdicciones territoriales equiparables a las entidades existentes - municipios o departamentos - , de modo que puedan gozar de plena autonomia en la gestión de sus intereses, la administración de los recursos, el establecimiento de tributos para el cumplimiento de sus funciones y la plena participación en las rentas nacionales. En otras palabras, com las ETI's se brinda la posibilidad a las comunidades indígenas de organizarse para ser incluidos como nuevas y diferenciadas formas de entidades territoriales, en la estructura político administrativa del Estado Colombiano.

Ante el desafio indígena de formar las ETI's, há sido fundamental emprender un paulatino processo de organizacíon política que permita consolidar los procesos de gobierno propio. Trabajo que varios pueblos indígenas han adelantado mediante la construcción y el fortalecimiento de sus Asociaciones de Autoridades 
Tradicionales Indígenas (AATI's): entidades públicas de carácter especial, que se constituyen en los antecedentes organizativos y políticos más importantes de las ETI's.

\section{DE AATI'S A ETI'S}

Si bien es cierto que la figura de ETI no ha logrado ensamblarse dentro de la estructura politico administrativa de nuestro país, ${ }^{355}$ también es cierto que la Carta Política de 1991 previó una herramienta para impulsar la organización política de los territorios indígenas al establecer, en su artículo 56 transitorio que "mientras se expide la ley a la que se refiere el artículo 329, el Gobierno podrá dictar normas fiscales necesarias y las demás relativas al funcionamiento de los territorios indígenas y su coordinación con las demás entidades territoriales".

Con base en tal artículo, el gobierno expidió en 1993 el decreto 1088 donde se abre la posibilidad a las autoridades indígenas de organizarse a través de Asociaciones de caráter público con una jurisdicción territorial definida, las cuales son conocidas actualmente como AATI's (Asociaciones de Autoridades Tradicionales Indígenas). Dicho decreto, además de definir la naturaleza jurídica de las Asociaciones y el procedimiento para su conformación y registro ante la Dirección de Etnias del Ministerio del Interior, ${ }^{356}$ ha permitido que desde mediados de los 1990's se conformen numerosas AATI's por todo el país (en especial en los departamentos de la región amazónica). Asociaciones que en la practica se constituyen en los antecedentes políticos y organizativos más importantes de las ETI's.

Además del fortalecimiento alcanzado por algunas AATI's en el processo organizativos e político en su trabajo interno, hay dos elementos que han potenciado su consolidación. Esto es, el reconocimiento de los resguardos como territorios de propiedad colectiva de las comunidades de las comunidades indígenas y la ampliación e implementación de la legislación indígena en diversas áreas (salud, educación, medio ambiente etc.). Por un lado, ser propietarios colectivos de sus territorios permite a los pueblos indígenas mayor estabilidad, congruencia, poder y alcance a sus procesos de gobierno propio. Por otro lado, la ampliación e implementación e la legislación indígena fortalece los procesos organizativos, al permitir en la práctica desarrollar programas, proyectos e actividades en materia de educación, salud, medio ambiente etc., de manera diferenciada y de acuerdo a sus planes de vida, ${ }^{357}$ de los resguardos en los recursos de la Nación a través del sistema General de Particiones (SGP). ${ }^{358}$

\footnotetext{
${ }^{355}$ Las ETI's no han logrado instituirse dentro de la estructura político administrativa de nuestro país, debido a que la Carta Politica de 1991 en su artículo 329 ordena que la conformación de las ETI’s se sjete a la expedición de la Ley Orgánica de Ordenamiento Territoriale (LOOT). Norma que hata el dia de hoy no a logrado expedirse, debido a los innumerables intereses políticos que pueden ser agredidos a la hora de transformar el mapa político administrativo de nuestro país, ya que en otras, esto significa alterar el mapa electoral y con ello mover de lugar los votos de los políticos tradicionales. Situación a la cual no quieren verse enfrentados los congresistas colombianos.

${ }^{356}$ Decreto 1088 de 1993. Artículo 2. Naturaleza Jurídica. Las asociaciones de que trata el presente Decreto, son entidades de Derecho Público de carácter especial, con personería jurídica, patrimonio propio ay autonomía administrativa. Artículo 5. Constitución. La constitución de las asociaciones e que trata este Decreto o la vinculación a las mismas, se hará con la manifestación escrita del Cabildo o Autoridad Tradicional Indígena, previo concepto favorable de los miembros de la comunidad de conformidad con sus y costumbres. Artículo 11. Registro de la Asociación. Una vez conformada la asociación, deberán registrarse en la Dirección General de Asuntos Indígenas de 1 Ministerio de Gobierno, para que pueda empezar a desarrollar sus actividades. Parágrafo. Para efecto de coordinación con las entidades territoriales, la Dirección General de Asuntos Indígenas deberá informar a las respectivas autoridades locales o regionales sobre el registro de las asociaciones de que trata el presente Decreto.

${ }^{357}$ El Estado colombiano transfiere recursos de la nación a los resguardos a través del Sistema General de Participaciones SGP - para salud, educación, vivienda, agua potable y desarrollo agropecuario (artículos 356 y 357) de la Constitución Política). Estos recursos tienen una función específica e non contemplan la posibilidad de financiar el proceso organizativo interno de los pueblos indígenas que supone la transición hacia modelos de gobernabilidad pluriculturales. Es acá donde la cooperación internacional y el acompañamiento continuo de la Fundación Gaia Amazonas juegan un papel importante en 1 apoyo que requiere la definición y consolidación de las estructuras político-administrativas de gobierno indígena y su articulación con las demás entidades territoriales del Estado.

${ }^{358}$ Plan de Ordenamiento Territorial o Plan de Vida: son planes de Desarrollo Integral ajustados a las características de cada pueblo indígena, el cual debe ser adoptado por sus miembros. Este Plan de Desarrollo tiene en cuenta los aspectos económicos, sociales, ambientales, geográficos y políticos, conforme a los usos, costumbres y cosmovisiones de cada pueblo.
} 
Igualmente, el vacío legal dejado en los departamentos de Amazonas, Vaupés y Guiana, al desaparecer las figuras político administrativas de corregimientos departamentales, ${ }^{359}$ hace que las AATI's de tales territorios, sean las únicas autoridades publicas de carácter local, que adelantan importantes procesos de gobernabilidad. En otras palabras, las AATI's aprovechan y dinamizan herramientas legales y coyunturas políticas, permitiendo que la realidad organizativa de los pueblos indígenas supere en la práctica las limitaciones jurídicas y políticas.

\section{APUNTES SOBRE LOS PROCESOS ORGANIZATIVOS EN LA AMAZONÍA COLOMBIANA}

En la Amazonía Colombiana, el proceso de organización política y territorial iniciado con la conformación y el trabajo de las AATI's presenta diferentes matices según los antecedentes históricos, las características de los movimientos indígenas y los niveles de intervención del estado en los diferentes departamentos.

Por un lado, en el caso del Departamento del Amazonas, las AATI's fueron estructurando propuestas concretas de salud y educación, aprovechando la debilidad institucional y la poca presencia del gobierno departamental en sus territorios. Con el tiempo, se fue consolidando una unidad regional que permitió ir abriendo canales de comunicación y negociación con el Estado, para avanzar en la descentralización efectiva de recursos y la puesta en marcha de sus propuestas. De esa manera, las AATI's de este departamento han iniciado un proceso de articulación de los gobiernos locales indígenas con las instancias de gobierno departamental por medio de la creación, en el 2002, de la Mesa Permanente de Coordinación Interadministrativa (MPCI).

Dicha instancia de interlocución, entre las AATI's y la Gobernación del Departamento del Amazonas, se reúne 2 veces al año para analizar y definir conjuntamente los disintos planes y programas a desarrollar en los territorios indígenas. La MPCI se ha consolidado como un proceso de descentralización concertada a través del cual ha sido posible establecer mecanismo efectivos de colaboración y coordinación permanente entre autoridades públicas indígenas y departamentales, desarrollando un esquema de gobernabilidad acorde con las particularidades socio-culturales y ambientales de la región.

En el Departamento de Guainía y a diferencia del Departamento de Amazonas, los indígenas mantienen una estructura organizativa regional alrededor del Consejo Regional de Guainía CIRGUA, el cual mantienen una estructura vertical y centralista que distancia las autoridades de base de la toma de decisiones en Puerto Inirida (capital del Departamento). En la actualidad, existen três AATI's ubicadas en la frontera con Venezuela y Brasil, las cuales comienzan a focalizar sus esfuerzos en retomar directamente los proyectos de educación propia iniciados durante la década de los noventa.

Por último, en el Departamento del Vaupés y al igual que el Departamento de Guainía, existe un Consejo Regional Indígena del Vaupés - CRIVA, creado hace más 30 años, el cual trabajaba con organizaciones zonales conformadas sobre los principales ríos de forma centralizada desde Mitú (capital del departamento). Esta estructura organizativa no es reconocida por el Estado como una entidad pública, otorgándole el carácter de organización no gubernamental, lo cual diferencia su naturaleza a la de las AATI's y limita su ámbito de aplicación con relación a la gestión y administración de intereses y recursos públicos. Tal situación y la creciente demanda de las autoridades locales en las diferentes zonales del Vaupés, genero un movimiento de constitución de AATI's a partir del año 2004, donde las autoridades locales comenzaron a reivindicar su derecho de administrar y ejecutar directamente los recursos asignados a las comunidades por el SGP. Lo que a su vez, cuestionó la función de la organización regional CRIVA y estimulo la reorganización política de las autoridades indígena en el departamento, donde las AATI's han adquirido mayor representatividad. Es probable que en esta coyuntura se perfile un nuevo esquema organizativo más descentralizado y orientado a la conformación de estructuras federativas que mantengan y articulen las autonomías de las nuevas asociaciones. A diferencia del departamento de Amazonas y Guainía donde las AATI's han concentrado sus esfuerzos principalmente en los temas de educación y salud, en e Vaupés, las AATI's comienzan a proyectar su trabajo en temas como manejo ambiental, unidad territorial y conocimientos tradicionales.

A pesar de que los avances organizativos son evidentes, es importante reconocer que es necesario continuar trabajando en el fortalecimiento de las estructuras internas de gobierno indígena y sobre todo en la consolidación de los canales de articulación entre las autoridades indígenas y demás autoridades publicas del país. En este sentido la Fundación Gaia Amazonas seguirá acompañando los procesos locales como las AATI's y las instancias regionales de interlocución, tales como la Mesa Permanente de Coordinación Interadministrativa como escenario para la interlocución y reflexión conjunta de los diversos modelos de adminstración y gestión territorial. (maio/2006).

\footnotetext{
${ }^{359}$ Figura que fue declarada inconstitucional por la Corte en la sentencia C-141 de 2001.
} 